\title{
Plume-Lithosphere Interaction: Geochemical Evidence from Upper Mantle and Lower Crustal Xenoliths from the Kerguelen Islands
}

\author{
by
}

Deborah Renee Hassler

B.S. University of Kansas, 1989

Submitted to the Joint Program in Oceanography in partial fulfillment of the requirements for the degree of

Doctor of Philosophy

at the

\section{MASSACHUSETTS INSTITUTE OF TECHNOLOGY and the}

\section{WOODS HOLE OCEANOGRAPHIC INSTITUTION}

June 1999

(C1999 Deborah Renee Hassler. All rights reserved.

The author hereby grants to MIT and to WHOI permission to reproduce paper and electronic copies of this thesis in whole or in part and to distribute them publicly.
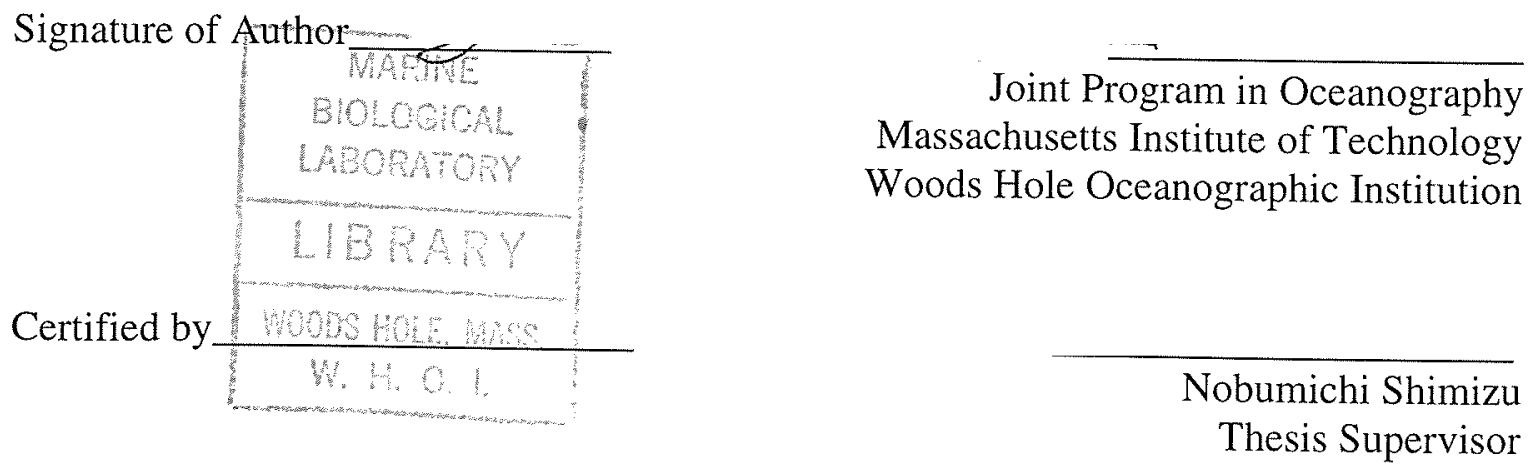

Accepted by

Deborah Smith

Chair, Joint Committee for Marine Geology and Geophysics

Massachusetts Institute of Technology

Woods Hole Oceanographic Institution 


\title{
Plume-Lithosphere Interaction: Geochemical Evidence from Upper Mantle and Lower Crustal Xenoliths from the Kerguelen Islands
}

\author{
by \\ Deborah Renee Hassler \\ Submitted in partial fulfillment of the requirements for the degree of \\ Doctor of Philosophy at the Massachusetts Institute of Technology and the Woods Hole \\ Oceanographic Institution
}

\begin{abstract}
This study is a geochemical investigation of the evolution of the Kerguelen plume, on the basis of upper mantle and lower crustal xenoliths. Ultramafic xenoliths include harzburgites (predominant), a lherzolite, dunites and pyroxenites, whereas lower crustal xenoliths are cumulate gabbros recrystallized under granulite facies conditions. On the basis of the whole rock major element characteristics and trace element abundance patterns in clinopyroxenes, the harzburgites were found to be residues of extensive melting at high pressures within the Kerguelen plume. These were then recrystallized at low pressures and metasomatized by plume generated melts. Details of the metasomatic process were determined from trace element variations in clinopyroxene in connection to texture. This demonstrated that meltrock reaction and the precipitation of new clinopyroxenes occurred by metasomatic carbonatitic melts.

It was also found that some of the harzburgites had distinctly unradiogenic Os isotopic compositions and were identified as originating from the sub-Gondwanaland lithosphere. On the basis of major and trace element compositions, the granulite xenoliths were found to be originally gabbroic cumulates formed from plume-derived basaltic melts emplaced at the base of the crust by underplating and subsequently recrystallized isobarically under granulite conditions. The $\mathrm{Sr}, \mathrm{Nd}$ and $\mathrm{Os}$ isotopic compositions of the peridotite and granulite xenoliths demonstrate that the Kerguelen plume is isotopically heterogeneous and displays a temporal progression toward more enriched $\mathrm{Sr}$ and $\mathrm{Nd}$ isotopic compositions from the Ninetyeast Ridge to granulite xenoliths to Kerguelen basalts and Heard Island basalts.
\end{abstract}




\section{Acknowledgments}

This research was supported by the National Geographic Society (4629-91), the National Science Foundation (EAR-9219158 and OPP-9417806), and William Van Alan Clark Senior Scientist Chair to Nobu Shimizu. I was also supported by a Cecil and Ida Green Fellowship and a Education Graduate Research Fellowship. These are all gratefully acknowledged. The Kerguelen xenolith samples were collected during the 1992 to 1993 austral field season. Thanks go to A. Giret, F. Frey, D. Weis, and J.-Y. Cottin for assistance in sampling.

First I would like to thank Nobu Shimizu for being my advisor. Working with him has been one of the best things about coming to WHOI. He allowed me complete academic freedom as well as the freedom to experience the many different opportunities that being a graduate student at MIT and WHOI have to offer. Over the years he has been my teacher, my mentor, my friend, and my therapist. I appreciate his boundless generosity, with his time, spirit and money. He has taught me how to think with the patience of a Zen Master. I have only the highest regards. Thanks Nobu.

I also thank my committee members Sam Bowring, Fred Frey, Stan Hart, and Steve Shirey for reading thesis drafts at short notice, for traveling to committee meetings and for advice. In addition to the previous, thanks to Mark Kurz for serving as Chair.

In the Education office, Jake Pierson, Julia Westwater, Marcey Simon, Stella Callagee, Stacey Frangos have offered patient help for all administrative details. I would like to thank them all for their kindness and compassion during the difficult months of writing my thesis. Thanks to John Farrington for making sure I had financial support in order to finish my degree.

Many people have influenced me in my graduate education, and I would like to mention them here.

Thanks to Fred Frey for serving as my advisor at MIT, taking an interest in and keeping a meticulous eye on my science.

Thanks to Stan Hart for suggestions on various things I have written and allowing access to his labs with no restrictions. It is truly generous and allows one to learn the techniques of the trade for oneself. Its been an honor to work with NIMA-B, cranky as she may be at times.

Greg Ravizza and Bernhard Peucker-Ehrenbrink spent many hours on numerous discussions on mass spectrometry and all things Os, and let me take the lead in developing sparging. Henry Dick led some great field trips, hosted fabulous gourmet dinners, and is always a strong student advocate. Peter Kelemen and Roberta Rudnick have both taken an interest in and supported me and my work since my early days of grad school. I look forward to working with them both in the future. The WHOI geochem group has been an excellent forum for trying out ideas, and exposure to a wide variety of scientific thought. I appreciate everyone's efforts.

Many people helped me with the technical aspects of this thesis: Mike Jercinovic and Neel Chatterjee at the MIT electron probe; Nobu Shimizu, Ken Burhuss, Graham Layne and Peter Landry with the ion probe; Lary Ball with the ICP-MS; Stan Hart, Greg Ravizza, 
Bernhard Peucker-Ehrenbrink and Jurek Blusztajn with clean lab protocol, chemistry development, NTIMS and ICP-MS; and B. L. Owens and K Brown with Macintosh advice. I couldn't have done it without all of their help. In the course of working together many of these people became my friends as well. Thanks to Nadine Mattielli for many discussions on Kerguelen xenoliths.

I have had the opportunity to work with a lot of great grad students; all have helped make MIT and WHOI interesting places to work. At MIT the various incarnations of the $11^{\text {th }}$ and $12^{\text {th }}$ floors included Glenn Gaetani, Eiichi Takazawa, Huai-Jen Yang, Kirsten Nicolaysen, Jim van Orman, Steve Parman, officemates Anke Friedrich and Audrey Huerta, Martha House, Mark Schmitz, and Meg Coleman.

At WHOI Jen Georgen, Kirsten Laarkamp, Carrie Tuit, and Allegra Hosford organized Girls nights out and in for much needed distraction. Lihini Aluwihare and Bill Shaw took me along on a sailing adventure at a time when such a get away was most needed, and made Woods Hole generally a fun place to be. Bob Greaves, Kelsey Jordahl Jamie Pringle, Jay Austin, Steve Jayne, Payal Parekh, and Tim Kenna provided good company (and many nice dinners Kels, Jay and Jamie) over the years. More recently, Anne Cohen and Estelle Rose have been great to have in the lab.

I also like to acknowledge my roommates in the West Falmouth house. They helped to make for a nice household: Sandra Werner, Gorka Sancho, Dan Torres (and Zoe) Juan Pablo Canales (and Suzanne Thomas) and Tad Snow (and Kathy Barbeau).

Thanks to Drew and Sharla Coleman, Jean Tangeman, and Kathy Andrew for their long standing friendships and cheering on during the time I have been in grad school here.

Special thanks go to Alberto Saal, Tad Snow, Ken Koga, Lucinda Gathercole and Kelsey Jordahl. Alberto provided many passionate discussions, the topic didn't matter and a loyal friendship. Tad and I suffered through the finishing of our theses together, and I truly appreciate his friendship and encouragement. Ken was a great officemate, always ready to help with Matlab code, last minute figures at 3 am and ignored my crankiness on bad days. Lucinda looked out for my well being: my mental health and making sure I had dinner to eat. Kels helped with Matlab codes, typing, and interesting diversions. Thanks Kels for your support and your companionship.

And especially thanks to my family. They never doubted that I could do it and supported me throughout, both morally and financially. Their strong belief in the power of education rubbed off: My grandparents Neva and Chalmers Hassler, Gertrude and Deloy Heath, my aunts and uncles: Ellen and Dave Boles, Helen and Les Schmidt, Deanne and John Korsak, my brothers and sister in law: Scott Hassler and Greg and Carol Hassler, my stepmother Juanita Hassler, and especially my mom and dad, who told me from the beginning I could be whatever I wanted to be when I grew up: Barbara Hassler and Sam Hassler. 


\section{Dedication}

I dedicate this thesis to my mother Barbara Lyn Heath Hassler, and to the memory of my father, Carl Samuel Hassler. 


\section{Table of Contents}

$\begin{array}{llr}\text { Chapter } 1 & \text { Introduction } & 15\end{array}$

1.1 The Kerguelen plume and the scope of the thesis 18

1.2 References Cited 25

1.3 Figures 29

Chapter 2 The Geochemistry of Peridotite Xenoliths from the Courbet Peninsula, Northern Kerguelen Islands

$2.1 \quad$ Introduction 31

$2.2 \quad$ Sample description 33

$2.3 \quad$ Analytical Methods

$2.4 \quad$ Results and Discussion 39

2.4.1. Whole rock compositions 39

Whole rock geochemistry and the "oceanic trend" 40

Trace element mass balance between whole-rocks and clinopyroxenes 44

2.4.2. Mineral compositions 46

Major Elements $\quad 46$

Trace elements 48

2.4.3. Isotopic compositions of $\mathrm{Sr}, \mathrm{Nd}$ and $\mathrm{Os} \quad 57$

$\begin{array}{ll}\mathrm{Sr} \text { and } \mathrm{Nd} \text { isotopes } & 57\end{array}$

Os isotopes $\quad 61$

2.5 Summary 63

$2.6 \quad$ References Cited 65

2.7 Tables 70

2.8 Figures 96

Chapter 3 Osmium Isotopic Evidence for Ancient Subcontinental Lithospheric Mantle Beneath the Kerguelen Islands, Southern Indian Ocean

3.1 Abstract 141

3.2 Os evidence for subcontinental lithosphere 141

$3.3 \quad$ References and Notes $\quad 147$

3.4 Tables 150

3.5 Figures 151

Chapter 4 Trace Element and Sr, Nd and Os Isotopic Composition of Mafic Granulite Xenoliths from the Courbet Peninsula, Kerguelen Islands 155
4.1 Introduction
155
$4.2 \quad$ Tectonic Setting 158
4.3 Sample Description $\quad 160$
4.4 Analytical Methods 161 
4.5 Results and Discussion $\quad 164$

4.5.1. Major Element Compositions 164

$\begin{array}{ll}\text { 4.5.2. These xenoliths are metamorphic rocks } & 167\end{array}$

$\begin{array}{ll}\text { Evidence for metamorphism } & 167\end{array}$

Conditions of Metamorphism 170

$\begin{array}{lr}\text { 4.5.3. Comparison to other oceanic cumulates } & 171\end{array}$

4.5.4. Trace Element compositions 173

4.5.5. Did the granulite protoliths contain an intercumulus melt? 177

4.5.6. Granulite Protolith Parent Melts 180

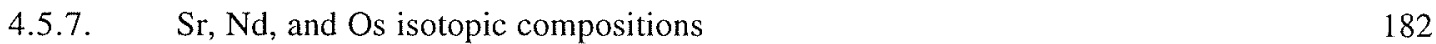

Comparison to isotopic compositions of other lower crustal rocks $\quad 185$

$\begin{array}{lr}\text { Origin of the isotopic signatures } & 188\end{array}$

$\begin{array}{ll}\text { 4.5.8. } & 194\end{array}$

4.5.9. What is the ${ }^{187} \mathrm{Os} /{ }^{188} \mathrm{Os}$ of the EM I component? 197

4.5.10. What is the mineral host for Re and Os? 198

$\begin{array}{llr}4.6 & \text { Summary } & 199\end{array}$

$\begin{array}{llr}4.7 & \text { References Cited } & 204\end{array}$

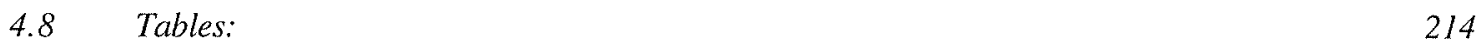

$\begin{array}{llr}4.9 & \text { Figures } & 234\end{array}$

$\begin{array}{lll}\text { Chapter } 5 & \text { Summary of Results and Conclusions } & 277\end{array}$

$\begin{array}{lll}5.1 & \text { Upper mantle xenoliths } & 277\end{array}$

$\begin{array}{lll}5.2 & \text { Lower crustal xenoliths } & 280\end{array}$

5.3 Evolution of the Kerguelen plume: a brief synthesis 282

$\begin{array}{lll}5.4 & \text { References Cited } & 286\end{array}$

$\begin{array}{llr}5.5 & \text { Figures } & 289\end{array}$

$\begin{array}{lrr}\text { Appendix 1. } & 293\end{array}$

$\begin{array}{llr}\text { Appendix 2. } & \mathbf{3 4 5}\end{array}$ 


\section{Table of Figures}

Figure 1-1. Map of the Indian Ocean (after Coffin, 1992). 29

Figure 2-1. Examples of peridotite textures and mineralogy. 96

Figure 2-2. Whole rock geochemistry of Kerguelen peridotites classified according to the IUGS system (Streckheisen, 1973). 101

Figure 2-4. Comparison of REE clinopyroxenes and whole rocks for selected samples, illustrating the trace element mass balance. 102

Figure 2-5. Spinel Cr\# v. Mg\#. 105

Figure 2-6. Range of clinopyroxene REE compositions from the Lac Superieur locality.

106

Figure 2-7. Range of clinopyroxene REE compositions from the Mt. Trapeze locality.

Figure 2-8. Normalized REE patterns of harzburgites with heterogeneous REE $\begin{array}{ll}\text { abundances. } & 108\end{array}$

Figure 2-9. Normalized REE patterns of LREE enriched harzburgites. $\quad 110$

Figure 2-10. Spidergrams of samples with high REE abundances and negative relative Ti and $\mathrm{Zr}$ anomalies.

Figure 2-11. Chondrite-normalized REE abundances of melts in equilibrium with clinopyroxenes from lherzolite OB93-52 and from the wehrlitic-dunites. 118 Figure 2-12. REE patterns of hypothetical melts that are similar to REE abundances observed in carbonatites (gray field; Nelson et al., 1988). 119

Figure 2-13. Summary of trace element abundances of LREE depleted samples. $\quad 120$

Figure 2-14. Trace element abundances of clinopyroxenes from LREE depleted harzburgites.

Figure 2-15. Normalized REE patterns of clinopyroxenes from depleted harzburgites.

Figure 2-16. Normalized REE patterns of the lherzolite.

Figure 2-17. Normalized REE abundances of the wehrlitic-dunites.

Figure 2-18. Normalized REE patterns of clinopyroxenes from the REE enriched harzburgites.

Figure 2-19. Normalized REE abundance patterns of clinopyroxenes from pyroxenites.

Figure 2-20. Nd v. Sr isotopic diagram of clinopyroxenes and host basalt from the

Kerguelen xenolith suite.

135

Figure 2-21. Whole rock Os isotopic compositions v. whole rock $\mathrm{Al}_{2} \mathrm{O}_{3}$ (upper panel) and clinopyroxene $[\mathrm{La} / \mathrm{Yb}]_{\mathrm{N}}$ (lower panel). $\quad 140$

Figure 3-1. Map of the Indian Ocean and Kerguelen Islands. 151

Figure 3-2. Histogram of the Os isotopic composition of the Kerguelen Islands peridotite xenoliths by location.

153

Figure 4-1. Examples of granulite textures and mineralogy. 234

Figure 4-2. Major element bulk-rock variation diagrams. 238

Figure 4-3. Bulk rock major element compositions ( $\mathrm{Mg \#} \mathrm{v.} \mathrm{SiO}_{2}$ wt.\%) of Courbet

Peninsula granulites compared to those from the Southeastern Province 239 
Figure 4-4. Whole rock geochemistry of Kerguelen granulites classified according to the IUGS system (Streckheisen, 1973).

Figure 4-5. Granulite clinopyroxene major element compositions compared to those from other oceanic cumulate rocks.

Figure 4-6. Granulite orthopyroxene major element compositions compared to orthopyroxene compositions from other oceanic cumulate rocks.

Figure 4-7. Cr\# v. Mg\# diagram of spinels from granulites.

Figure 4-8. Pressure -temperature diagram for mafic composition granulite-facies metamorphism (after Ringwood, 1975; Christy, 1989).

Figure 4-9. Whole rock major element compositions in comparison to oceanic gabbros and continental granulite xenoliths.

Figure 4-10. Semi-log plot of granulite whole rock trace element contents normalized to $\mathrm{C} 1$ chondrites.

251

Figure 4-11. C1 chondrite normalized REE abundances of clinopyroxenes and bulk rocks.

Figure 4-12. Whole rock abundances of transition metals (Cr, Ni, V, Sc) v. MgO wt.\%.

Granulites are shown as filled squares.

256

Figure 4-13. Granulite whole rock $\mathrm{Sr} / \mathrm{Sr}^{*}$ v Eu/Eu*.

258

Figure 4-14. Strontium isotopic composition v. [Sr] (ppm).

259

Figure 4-15. Normalized REE compositions of equilibrium melts calculated from whole rock trace element contents

260

Figure 4-16. Normalized REE content of melts in equilibrium with granulite clinopyroxenes.

Figure 4-17. Sr v. Nd isotopic diagram of bulk rock granulite compositions.

264

Figure 4-18. ${ }^{187} \mathrm{Os} /{ }^{188} \mathrm{Os} \mathrm{v}$. [Os] (ppt) upper panel, and ${ }^{187} \mathrm{Os} /{ }^{188} \mathrm{Os} \mathrm{v} .{ }^{187} \mathrm{Re} /{ }^{188} \mathrm{Os}$, lower panel, of granulite whole rocks (filled squares) and Kerguelen plume related basalts (open and gray circles; Reisberg et al., 1993; Barling et al., 1997; Yang et al., 1998). 266 Figure 4-19. Nd v. Sr isotopic compositions of continental granulites (after Rudnick, 1992).

Figure 4-20. Comparison of the present day values of the ${ }^{187} \mathrm{Os} /{ }^{188} \mathrm{Os}$ and ${ }^{187} \mathrm{Re} /{ }^{188} \mathrm{Os}$ of all lower crustal xenoliths analyzed to date.

Figure 4-21. Os v. Sr (upper panel) and v. Nd (lower panel) isotopic compositions of Kerguelen plume rocks.

Figure 4-22. Granulite whole rock abundances (filled squares) of the chalcophile element $(\mathrm{Ni}, \mathrm{Zn}, \mathrm{Pb}, \mathrm{Cu}) \mathrm{v}$. Re and Os concentrations.

Figure 5-1. Nd v. Sr isotopic diagram of peridotite clinopyroxenes, bulk rock granulite compositions, and the host basalt from the Kerguelen xenolith suite

Figure 5-2. Os v. Sr (upper panel) and v. Nd (lower panel) isotopic compositions of

Kerguelen plume rocks. 


\section{Table of Tables}

Table 2-1. List of samples. $\quad 70$

Table 2-2. Bulk rock major and trace element compositions of selected xenoliths. 71

Table 2-3. Calculated modes.

Table 2-4. Clinopyroxene major element compositions. 75

Table 2-5. Orthopyroxene major element compositions. 78

Table 2-6. Olivine major element compositions. $\quad 80$

Table 2-7. Spinel major element compositions.

Table 2-8. Clinopyroxene trace element compositions. 86

Table 2-9. Sr and Nd isotopic compositions. 94

Table 2-10. Re-Os isotopic compositions (from Hassler and Shimizu, 1998). 95

Table 3-1. Rhenium and osmium isotopic results from Kerguelen Islands peridotite xenoliths.

Table 4-1. Petrographic characteristics of the granulite xenolith suite.

Table 4 2. Major element and trace element comprantion and modes of granulite whole rocks.

Table 4-3. Representative clinopyroxene major element compositions.

Table 4-4. Representative orthopyroxene major element compositions.

Table 4-5. Representative plagioclase major element compositions.

Table 4-6. Olivine major element compositions.

Table 4-7. Representative spinel major element compositions.

Table 4-8. Metamorphic equilibration temperatures estimated with the two pyroxene thermometer of Wells (1977).

Table 4-9. Representative trace element compositions of clinopyroxenes. 


\section{Chapter 1 Introduction}

Mantle plumes are a significant means of heat and mass transfer from the earth's deep interior and result in hotspot volcanism on the earth's surface. Since the recognition of their importance in understanding plate tectonics (e.g. Wilson, 1963; Morgan, 1972), geochemical studies of plume-derived ocean island basalts (OIB) have established important insights into mechanisms for creating geochemical heterogeneities in the mantle via recycling (e.g. White and Hofmann, 1982; Allègre, 1982; Zindler and Hart, 1986) and spatial and temporal scales of mantle convection (e.g. Stein and Hofmann, 1994;

Hofmann, 1997 and many others). Radiogenic isotopes in OIB reflect time-integrated parent/daughter elemental ratios and characterize the geochemical history of the plume mantle source. On the basis of the isotopic compositions of $\mathrm{Sr}, \mathrm{Nd}$ and $\mathrm{Pb}$ in oceanic basalts, Hart and colleagues identified four "endmember" mantle components and showed that individual plume systems (as manifested by individual islands or island chains) form quasi-linear mixing arrays involving some of the components (e.g. Zindler and Hart, 1986; Hart and Zindler, 1989; Hart et al., 1992). That the asthenospheric mantle is not implicated as a common mixing endmember for the plume mixing arrays led Hart et al. (1992) to postulate that entrainment of the lower mantle could be an important process in determining the isotopic variations of OIB.

As a plume rises to the base of the oceanic lithosphere and plume-derived melts migrate through the lithosphere, interactions between the two could occur and modify the geochemical and isotopic compositions of both the melts and the lithosphere. The precise nature and extent of the interaction can vary on spatial and temporal scales, depending on physical and chemical conditions. 
In the case of plume-derived melt interacting with lithospheric peridotites, the isotopic compositions of incompatible trace elements such as $\mathrm{Sr}, \mathrm{Nd}$ and $\mathrm{Pb}$ of the melt would not generally be modified significantly. This is because of the low mineral-melt partition coefficients for these elements and the contrast in their concentrations between melt and mantle (i.e. high in the melt relative to the mantle). In contrast, the isotopic compositions of compatible elements such as Os in a plume-derived melt could easily and significantly be modified even in interactions that occur over a short length scale (for theoretical discussions, see Hauri, 1997). It follows then that isotopic heterogeneities for $\mathrm{Sr}, \mathrm{Nd}$ and $\mathrm{Pb}$ observed in coeval basalts of a given plume system can be attributed to time-integrated heterogeneities with respect to parent/daughter elemental ratios of the plume, but that the Os isotopic composition could represent that of the lithosphere. When a plume is considered to have been positioned beneath a mid-ocean ridge at some time in its evolutionary past, the interpretations of isotopic heterogeneities in plume-related basalts tend to focus on the mixing of plume and MORB source components. Isotopic heterogeneities that may be "indigenous" to the plume itself may thus be overlooked. It is well established that a plume can affect the geochemical and isotopic compositions of nearby ridge melts because the plume mantle flows toward ridges as a result of thermal and rheological gradients (Schilling, 1991; Small, 1995; Ribe, 1996; Yale and Phipps Morgan, 1998). However, when one invokes the effects of the MORB source on plume-related melts, some physical justification is needed, especially for a distal plume-ridge interaction.

A different aspect of the plume-lithosphere interaction can be studied with lithospheric xenoliths that are brought to the surface by plume-derived magmas. Plume-derived melts react with the lithosphere during melt migration, and modify the geochemistry and mineralogy of the lithospheric peridotites. The mechanisms for this process can be diverse: 1.) the mineralogy (the minerals and their modal abundances) remains unchanged, but the 
mineral chemistry is modified through elemental change at the interface, and through subsequent diffusion; 2.) new mineral phase(s) crystallize directly from the infiltrating melt; or 3.) the mineralogy and chemistry of the peridotite are modified through dissolution of pre-existing minerals and the precipitation of new ones. These processes represent what is generally termed mantle metasomatism and have been a subject of study for many years. A book was dedicated to the topic (Menzies and Hawkesworth, 1987). A general terminology of "cryptic" and "modal" metasomatism (e.g. Dawson and Kornprobst, 1984; Erlank et al., 1987; Harte et al., 1983) is inadequate in cases where a newly-precipitated mineral is one of the pre-existing species (for instance, the precipitation of diopside in lherzolite). The petrographic appearance of a rock that has been cryptically metasomatized may be the same as a rock that has not been metasomatized at all. If in fact new clinopyroxene was added to the rock, microbeam-based observations could play crucial roles in discerning this.

The understanding of mantle metasomatism has improved considerably over the past decade through theoretical work and by the modeling of trace element variations in rocks and minerals (Navon and Stolper, 1987; Bodinier et al., 1990; Takazawa et al., 1992; Sen et al., 1993; Bedini et al., 1997; Yang et al., 1998b). It is commonly observed that meltperidotite interaction modifies trace element abundance patterns of minerals (notably clinopyroxene, an important repository of many trace elements in peridotitic systems) to various extents in a given lithosphere-melt system. For instance, Takazawa et al. (1992) and Yang et al. (1998b) demonstrated that smoothly light REE-depleted original patterns in clinopyroxenes were gradually modified toward light REE-enriched "equilibrium" patterns, with sharply inflected (at Nd) or "spoon-shaped" patterns as intermediate stages of interaction. As discussed by Navon and Stolper (1987) and others, modification of REE patterns in peridotitic clinopyroxenes proceeds in a chromatographic manner, beginning with an increase in more incompatible LREE and moving towards less incompatible HREE. 
There are many instances where rocks (e.g. a suite of peridotite xenoliths from a single locality) display a wide range of "degrees" of metasomatism, indicating large local-scale variations in melt-rock ratios and perhaps short durations of interaction. Because of low clinopyroxene-melt partition coefficients, $\mathrm{Sr}$ and $\mathrm{Nd}$ abundances in highly depleted peridotite clinopyroxenes are susceptible to even incipient metasomatism. Hence, the original $\mathrm{Sr}$ and $\mathrm{Nd}$ isotopic compositions of the clinopyroxene can easily be erased.

\subsection{The Kerguelen plume and the scope of the thesis}

The Kerguelen plume is unique among mantle plumes because it is known to be especially long-lived. It became active at least $115 \mathrm{Ma}$ ago, and possibly as long as $130 \mathrm{Ma}$ agocoincident with the breakup of Gondwanaland (Whitechurch et al., 1992; Storey et al., 1989). This plume is responsible for enormous amounts of volcanism in the eastern Indian Ocean, including the Ninetyeast Ridge, Broken Ridge, and the Kerguelen Plateau, the second largest of the oceanic plateaus after the Ontong Java Plateau (Coffin and Eldholm, 1994). The Kerguelen plume may be a carrier of the DUPAL isotopic anomalies that are characteristic of the basalts that are erupted in the southern hemisphere (Hart, 1984), and the interaction of this plume with the Indian Ocean lithosphere has potentially affected the geochemistry of the entire southeastern Indian Ocean (Davies et al., 1989; Storey et al., 1989; Mahoney et al., 1989).

The Kerguelen Plateau, located in the southern Indian Ocean (Figure 1-1), is one of the large igneous provinces described by Coffin and Eldholm (Coffin and Eldholm, 1994). It is the second largest of the oceanic plateaus, covering an area greater than $2 \times 10^{6} \mathrm{~km}^{2}$, and extending over $2000 \mathrm{~km}$ in a northwest-southeast direction. The plateau is divided into two structural units on the basis of their separate tectonic and volcanic histories at 
approximately $54^{\circ} \mathrm{S}$ (Houtz et al., 1977; Coffin et al., 1986). In the northern province, the plateau is $4 \mathrm{~km}$ above the surrounding ocean floor, is submerged under less than $1 \mathrm{~km}$ of water. It decreases to $2 \mathrm{~km}$ of relief and $2.5 \mathrm{~km}$ water depth southward. Several Ocean Drilling Program (ODP) drill-holes (legs 119, 120 and most recently 183; Barron et al., 1991; Wise et al., 1992) and dredges recovered tholeiitic to transitional basement basalts from the Plateau (Leclaire et al., 1987). The Kerguelen Plateau was emplaced in a subaerial to shallow water environment (Coffin, 1992; Schlich, 1982), but little is known of the rocks that make up its volume.

Plate tectonic reconstructions (e.g. McKenzie and Sclater, 1971; Royer and Sandwell, 1989) indicate the Bunbury basalts and Rajmahal Traps, the Naturaliste Plateau and the southern Kerguelen Plateau all formed during the initial phase of magmatism attributed to the Kerguelen plume, and may have been coincident with the breakup of Gondwanaland (Royer and Sandwell, 1989). From $115 \mathrm{Ma}$ to $43 \mathrm{Ma}$, the northern Kerguelen Plateau, Broken Ridge and the Ninetyeast Ridge formed while sea-floor spreading between India and Antarctica-Australia began and India moved northward. At approximately $43 \mathrm{Ma}$, Broken Ridge rifted from the Kerguelen Plateau at the southeast Indian Ridge. Since as long as $43 \mathrm{Ma}$ until the present, the northern Kerguelen Plateau and the Kerguelen Islands formed. The most recent known activity of the plume was $40 \mathrm{ka}$ at Ross Volcano, in the southern Kerguelen Islands (Nougier et al., 1983).

Hypotheses for the origin of the Kerguelen Plateau have included a continental fragment, excessive mid-ocean ridge magmatism, an uplifted block of oceanic crust, or a hotspot (cf. Recq and Charvis, 1986). The most controversial of these has been the suggestion that the plateau is a continental fragment left behind after the breakup of Gondwanaland. Geological and geochemical studies (e.g. Watkins et al., 1974; Dosso et al., 1979; Gautier et al., 1990; Yang et al., 1998a) found no evidence of continental crust 
in rocks from the Kerguelen Islands, and seismic studies in the northern Kerguelen Plateau indicated a thickened oceanic crust (approximately $17 \mathrm{~km}$; Recq and Charvis, 1986). However, basalts from the southern Kerguelen Plateau exhibit geochemical characteristics of continental affinity (Alibert, 1991; Mahoney et al., 1994), and this part of the plateau has a seismic structure that is similar to that of a volcanic passive margin with a thinned continental crust overlain by basaltic lava flows (Recq and Charvis, 1986; Operto and Charvis, 1995). Moreover, Coffin et al. (1994) argued that the southern plateau is a mixture of structural elements, including crustal uplifts and continental fragments.

The Kerguelen Islands, located on the northern Kerguelen Plateau, are an archipelago consisting of 400 islands across an area of $4000 \mathrm{~km}^{2}$ (Watkins et al., 1974). More than $80 \%$ of the exposed rocks are transitional to highly alkaline plateau basalts (Giret and Lameyre, 1983; Gautier et al., 1990). The remaining 20\% are intrusive rocks: a tholeiitic to transitional series, and two alkaline differentiation series, including gabbro-syenite-alkaline granite, and gabbro-nepheline syenite. The rocks of this study are from two (Lac Superieur and Mt. Trapeze) of four xenolith localities on the Courbet Peninsula (Figure 1-1) that were discovered during the 1992-93 austral field season. The xenoliths are included in relatively young alkaline dikes that cross-cut the 24.5 Ma plateau basalts (Nicolaysen et al., 1999) that make up the Courbet Peninsula. The Lac Superieur xenolith suite contains harzburgites, rare lherzolites, dunites, pyroxenites and mafic granulites, but the Mt. Trapeze locality has only harzburgitic peridotite xenoliths.

The main purpose of this study is to investigate the geochemical evolution and interaction between the Kerguelen plume and the lithospheric mantle. As mentioned above, the Kerguelen plume is unique in that it has encountered various geodynamic conditions, from continental breakup to oceanic rift, and to the present-day intra-plate conditions. This 
thesis attempts to decipher how the diverse geodynamic environments have affected the geochemical evolution of the plume.

An approach taken here is an integrated petrological and geochemical study of lower crustal and upper mantle xenoliths brought to the surface by Kerguelen plume magmas. As discussed above, geochemical signatures of plume-lithosphere interaction processes were varied, and details of the interaction can be investigated based on characteristic trace element signatures of the mechanisms and the types of melt involved. Textures of rocks under which melt-rock interaction is recognized are also important in distinguishing between newly-formed metasomatic minerals and those that were present when the interaction occurred.

Given that the Kerguelen plume has encountered diverse geodynamic environments, the upper mantle xenoliths in this study can be any one of the following: 1.) pieces of young oceanic lithosphere upon which the Kerguelen plume impinged;2.) pieces of the plume mantle itself, either as unmelted source mantle or as residues of melting; 3.) pieces of lithosphere that delaminated from the Gondwanaland subcontinental lithosphere when the Kerguelen plume began its activity. All of these varieties could have pristine geochemistry or be in modified forms due to interaction with plume-derived melts.

In their pristine form, pieces of the oceanic lithosphere can be depleted harzburgites with clinopyroxene trace element characteristics like those in abyssal peridotites (e.g. Johnson et al., 1990) and with $\mathrm{Sr}$ and $\mathrm{Nd}$ isotopic compositions similar to that of the Indian Ocean MORB. However, these peridotites are extremely susceptible to interaction with plume-derived melts with respect to incompatible trace elements, and $\mathrm{Sr}$ and $\mathrm{Nd}$ isotopes, and the chances for sampling pristine oceanic lithosphere could be slim. 
In the case of plume mantle residues, the end products could be diverse. If melting proceeds beyond the garnet-out or the clinopyroxene-out phase boundaries due to high temperatures, the plume residue could also be highly depleted harzburgite. Since the melting of mantle plumes begin in the presence of garnet, garnet-bearing residues could be produced. However, they may well be recrystallized to a lower pressure assemblage during the adiabatic upwelling. In plume melting at pressures greater than $3 \mathrm{GPa}$, the clinopyroxenes are subcalcic. Upon recrystallization at lower pressures, high-Ca clinopyroxenes are formed, and the direct application of high-Ca pyroxene melt partition coefficients in such a case can not be made to produce meaningful results. However, these rocks could still contain high-Ca clinopyroxenes upon recrystallization due to the relative large $\mathrm{CaO}$ contents of high-temperature orthopyroxenes.

In their pristine form, these type of harzburgites may not be distinguishable from an unmetasomatized oceanic lithosphere, but $\mathrm{Sr}$ and $\mathrm{Nd}$ isotopic characteristics can be used to identify them. If these high pressure residual harzburgites were later metasomatized, they could be very similar geochemically to metasomatized oceanic mantle lithosphere. The Os isotopic compositions could be the only criterion by which their provenance can be distinguished, provided that Os isotopes in peridotites are insensitive to metasomatic reactions. The Os isotopic compositions would also reveal peridotites derived from subGondwanaland lithosphere by their unradiogenic ${ }^{187} \mathrm{Os} /{ }^{188} \mathrm{Os}$. This is because subcontinental lithospheric roots are known to possess unradiogenic Os compositions due to ancient melt extraction (Re depletion) events (e.g. Walker et al., 1989; Pearson et al., 1995; Carlson and Irving, 1994).

From the point of view of mantle metasomatism, the peridotite xenolith suites of this study provide opportunities for carrying out detailed geochemical studies using in-situ trace element compositions and isotopic data obtained for minerals and whole-rocks. Diversity in 
plume-derived melt compositions in terms of their trace elements and isotopes would be imprinted in peridotite xenoliths during melt-lithosphere interaction, and would be revealed.

The lower crustal xenoliths studied here are granulite facies rocks with gabbroic precursors. As noted before, the occurrence of granulite facies xenoliths in OIB was documented for the first time in the Kerguelen samples (Grègoire et al., 1994) including the first occurrence of sapphirine from the oceanic environment. However, their provenance (continental v. oceanic) must be carefully evaluated because of the complex evolutionary history of the Kerguelen plume. This history involves the possibility that delaminated lower crust from Gondwanaland may be present within the Kerguelen Plateau. If the granulite xenoliths are identified as part of the Kerguelen plume magmatism, they also provide an important opportunity for obtaining geochemical data on a part of the magmatism that may not have erupted as basalts on the surface. The origin of the granulites is also connected to the geodynamic evolution of the Kerguelen plume. If their precursors were to be identified as typical ocean-ridge gabbros, then they must have been incorporated into the Kerguelen plume system when the plume was ridge-centered. However, the recrystallization under granulite facies conditions would require significant thickening of crust (Grègoire et al., 1998), which may not be plausible. Alternatively, if their provenance was found to be the Kerguelen plume, the gabbroic precursors could represent pieces of lower crust formed by underplating, providing material evidence in support of geophysical inference based on thickened crust for many oceanic islands (e.g. ten Brink and Brocher, 1987; Caress et al., 1995).

The Kerguelen Islands provide an ideal setting to examine plume interaction with the lithosphere of different tectonic environments. This research presented an opportunity to use a diverse population of xenoliths to attempt to unravel the complexities of materials and processes associated with a mantle plume that had a varied tectonic history. 


\subsection{References Cited}

Alibert C. (1991) Mineralogy and geochemistry of a basalt from site 738: implications for the tectonic history of the southernmost part of the Kerguelen Plateau. In Proceedings of the Ocean Drilling Program, Scientific Results, Vol. 119 (ed. J. Barron, B. Larsen, and et al.), pp. 293-298. Ocean Drilling Program.

Allègre C. J. (1982) Chemical Geodynamics. Tectonophys. 81, 109-132.

Barron J., Larsen B., and et al. (1991) Proceedings of the Ocean Drilling Program, Scientific Results, Vol. 119. College Station, TX (Ocean Drilling Program).

Bedini R. M., Bodinier J. L., Dautria J. M., and Morten L. (1997) Evolution of LILEenriched small melt fractions in the lithospheric mantle; a case study from the East African Rift. Earth Planet. Sci. Lett. 153, 67-83.

Bodinier J. L., Vasseur G., Vernieres J., Dupuy C., and Fabries J. (1990) Mechanisms of mantle metasomatism: geochemical evidence from the Lherz orogenic peridotite. $J$. Petrol. 31, 597-628.

Caress D. W., McNutt M. K., Detrick R. S., and Mutter J. C. (1995) Seismic imaging of hotspot-related crustal underplating beneath the Marquesas Islands. Nature 373, 600603.

Carlson R. W. and Irving A. J. (1994) Depletion and enrichment history of subcontinental lithospheric mantle: $\mathrm{An} \mathrm{Os}, \mathrm{Sr}, \mathrm{Nd}$ and $\mathrm{Pb}$ isotopic study of ultramafic xenoliths from the northwestern Wyoming Craton. Earth Planet. Sci. Lett. 126, 457-472.

Coffin M. F. (1992) Emplacement and subsidence of Indian Ocean plateaus and submarine ridges. In Synthesis of Results from Scientific Drilling in the Indian Ocean, Vol. Geophysical Monograph 70 (ed. R. A. Duncan, D. K. Rea, and et al.), pp. 115-125. American Geophysical Union.

Coffin M. F., Davies H. L., and Haxby W. F. (1986) Structure of the Kerguelen Plateau province from SEASAT altimetry and seismic reflection data. Nature 324, 134-136.

Coffin M. F. and Eldholm O. (1994) Large igneous provinces: Crustal structure, dimensions, and external consequences. Rev. Geophys. 32, 1-36.

Davies H. L., Sun S.-s., Frey F. A., Gautier I., McCulloch M. T., Price R. C., Bassias Y., Klotwijk C. T., and Leclaire L. (1989) Basalt basement from the Kerguelen Plateau and the trail of Dupal plume. Contrib. Mineral. Petrol. 103, 457-469.

Dawson J. B. and Kornprobst J. e. (1984) Contrasting types of upper-mantle metasomatism?

Kimberlites; II, The mantle and crust-mantle relationships

Developments in petrology. In Third international kimberlite conference, Vol. 11B, pp. 289-294.

Dosso L., Vidal P., Cantagrel J. M., Lameyre J., Marot A., and Zimine S. (1979) "Kerguelen: continental fragment or oceanic island?": Petrology and isotopic geochemistry. Earth Planet. Sci. Lett. 43, 46-60.

Duncan R. A. (1978) Geochronology of basalts from the Ninetyeast Ridge and continental dispersion in the eastern Indian Ocean. J. Volcan. Geotherm. Res. 4, 283-305.

Duncan R. A. (1991) Age distribution of volcanism along aseismic ridges in the eastern Indian Ocean. In Proc. of the Ocean Drilling Program, Sci. Res., Vol. 121 (ed. J. Weissel, J. Pierce, E. Taylor, J. Alt, and et al.), pp. 507-517. Ocean Drilling Project. 
Duncan R. A. and Storey M. (1992) The life cycle of Indian Ocean hotspots. In Synthesis of Results from Scientific Drilling in the Indian Ocean, Vol. AGU Monograph 70 (ed. R. A. Duncan, D. K. Rea, R. B. Kidd, U. von Rad, and J. K. Weissel). American Geophysical Union.

Erlank A. J., Waters F. G., Hawkesworth C. J., Haggerty S. E., Allsopp H. L., Rickard R. S., Menzies M. A., Menzies M. A. e., and Hawkesworth C. J. e. (1987) Evidence for mantle metasomatism in peridotite nodules from the Kimberley Pipes, South Africa

Mantle metasomatism. , 221-311.

Gautier I., Weis D., Mennessier J.-P., Vidal P., Giret A., and Loubet M. (1990)

Petrology and geochemistry of the Kerguelen Archipelago basalts (South Indian Ocean): evolution of the mantle sources from ridge to intraplate position. Earth Planet. Sci. Lett. 100, 59-76.

Giret A. and Lameyre J. (1983) A study of Kerguelen plutonism : Petrology, geochronology and geological implications. In Antarctic Earth Science (ed. R. L. Oliver, P. R. James, and J. B. Jago), pp. 646-651. Cambridge University Press.

Grègoire M., Cottin J. Y., Giret A., Mattielli N., and Weis D. (1998) The meta-igneous granulite xenoliths from Kerguelen Archipelago: evidence of a continent nucleation in an oceanic setting. Cont. Mineral. Petrol. 133, 259-283.

Grègoire M., Mattielli N., Nicollet C., Cottin J. Y., Leyrit H., Weis D., Shimizu N., and Giret A. (1994) Oceanic mafic granulite xenoliths from the Kerguelen archipelago. Nature 367, 360 - 363.

Hart S. and Zindler A. (1989) Constraints on the Nature and Development of Chemical Heterogeneities in the Mantle. In Mantle Convection (ed. R. Peltier), pp. 261 - 388. Gordon and Breach.

Hart S. R. (1984) A large-scale isotope anomaly in the Southern Hemisphere mantle. Nature 309, 753-757.

Hart S. R., Hauri E. H., Oschmann L. A., and Whitehead J. A. (1992) Mantle Plumes and Entrainment: Isotopic Evidence. Science 256, 517-520.

Harte B., Hawkesworth C. J., and Norry M. J. (1983) Mantle peridotites and processes; the kimberlite sample

Continental basalts and mantle xenoliths; papers prepared for a UK Volcanic Studies Group meeting at the University of Leicester

Shiva geology series. In UK Volcanic Studies Group meeting; Continental basalts and mantle xenoliths, pp. 46-91.

Hauri E. H. (1997) Melt migration and mantle chromatography; 1, Simplified theory and conditions for chemical and isotopic decoupling. Earth Planet. Sci. Lett. 153, 1-19.

Hofmann A. W. (1997) Mantle geochemistry: the message from oceanic volcanism. Nature 385, 219-229.

Houtz R. E., Hayes D. E., and Markl R. G. (1977) Kerguelen Plateau bathymetry, sediment distribution, and crustal structure. Mar. Geol, 25, 95-130.

Johnson K. T. M., Dick H. J. B., and Shimizu N. (1990) Melting in the oceanic upper mantle: an ion microprobe study of diopsides in abyssal peridotites. J. Geophys. Res. 95, 2661-2678.

Leclaire L., Bassias Y., Denis-Clocchiatti M., Davies H., Gautier I., Gensous B., Giannesini P.-J., Patriat P., Segoufin J., Tesson M., and Wannesson J. (1987) Lower Cretaceous basalt and sediments from the Kerguelen Plateau. Geo-Mar. Lett. 7, 169-176. 
Mahoney J. J., Jones W. B., Frey F. A., Salters V. J. M., Pyle D. G., and Davies H. L. (1994) Geochemical characteristics of lavas from Broken Ridge, the Naturaliste Plateau, and southernmost Kerguelen Plateau: Cretaceous Plateau volcanism in the southeast Indian Ocean. Chem. Geol. 120, 315-345.

Mahoney J. J., Natland J. H., White W. M., Poreda R., Bloomer S. H., Fisher R. L., and Baxter A. N. (1989) Isotopic and geochemical provinces of the western Indian Ocean spreading centers. J. Geophys. Res. 94, 4033-4052.

McKenzie D. and Sclater J. G. (1971) The evolution of the Indian Ocean since the Late Cretaceous. Geophys. J. R. Astr. Soc. 24, 437-528.

Menzies M. A. e. and Hawkesworth C. J. e. (1987) Mantle metasomatism, pp. 472.

Morgan W. J. (1972) Plate motions and deep mantle convection. Geological Society of America Memoir 132, 7-22.

Navon O. and Stolper E. (1987) Geochemical consequences of melt percolation: the upper mantle as a chromatographic column. J. Geol.95, 285-307.

Nicolaysen K., Frey F. A., Hodges K. V., Weis D., and Giret A. (1999) ${ }^{40} \mathrm{Ar} /{ }^{39} \mathrm{Ar}$ geochronology of flood basalts from the Kerguelen Archipelago, southern Indian Ocean: implications for Cenozoic eruption rates of the Kerguelen plume. Earth Planet. Sci. Lett., submitted.

Nougier J. (1972) Geochronology of the volcanic activity in Iles Kerguelen. In Antarctic Geology and Geophysics, Vol. International Union of Geological Sciences, Ser. BNo. 1 (ed. R. J. Adie), pp. 803-808. Scandinavian Univ. Books.

Nougier J., Pawlowski D., and Cantagrel J. M. (1983) Chrono-spatial evolution of the volcanic activity in southeastern Kerguelen (T.A.A.F.). In Antarctic Earth Science (ed. R. L. Oliver, P. R. James, and J. B. Jago), pp. 640-645. Cambridge University Press.

Operto S. and Charvis P. (1995) Kerguelen Plateau: a volcanic passive margin fragment? Geol. 23, 137-140.

Pearson D. G., Carlson R. W., Shirey S. B., Boyd F. R., and Nixon P. H. (1995) Stabilization of Archean lithospheric mantle: A Re-Os isotope study of peridotite xenoliths from the Kaapvaal craton. Earth Planet. Sci. Lett. 134, 341-357.

Pringle M. S., Coffin M. F., and Storey M. S. (1997) Estimated melt production of the Kerguelen hot spot. EOS, Trans. Am. Geophys. Un. 78, 728.

Recq M. and Charvis P. (1986) A seismic refraction survey in the Kerguelen Isles, southern Indian Ocean. Geophys. J. R. Astr. Soc. 84, 529-559.

Ribe N. M. (1996) The dynamics of plume-ridge interaction; 2, Off-ridge plumes. Journal of Geophysical Research, B, Solid Earth and Planets 101, 16,195-16,204.

Royer J.-Y. and Sandwell D. T. (1989) Evolution of the Eastern Indian Ocean since the late Cretaceous: constraints from Geosat altimetry. J. Geophys. Res. 94, 13,75513,782 .

Schilling J.-G. (1991) Fluxes and excess temperatures of mantle plumes inferred from their interaction with migrating mid-ocean ridges. Nature (London) 352, 397-403.

Schlich R. (1982) The Indian Ocean: Aseismic ridges, spreading centers, and ocean basins. In The Ocean Basins and Margins, Vol. 6, The Indian Ocean (ed. A. E. M. Nairn and F. G. Stehli), pp. 51-147. Plenum Press. 
Sen G., Frey F. A., Shimizu N., and Leeman W. P. (1993) Evolution of the lithosphere beneath Oahu, Hawaii: rare earth element abundances in mantle xenoliths. Earth Planet. Sci. Lett. 119, 53-69.

Small C. (1995) Observations of ridge-hotspot interactions in the Southern Ocean. $J$. Geophys. Res. 100, 17,931-17,946.

Stein M. and Hofmann A. W. (1994) Mantle plumes and episodic crustal growth. Nature (London) 372, 63-68.

Storey M., Pringle M. S., Coffin M. F., and Wijbrams J. (1996) Geochemistry and geochronology of Kerguelen Plateau basalts: Results from ODP legs 119 and 120. EOS, Trans. Am. Geophys. Un.77, W123.

Storey M., Saunders A. D., Tarney J., Gibson I. L., Norry M. J., Thirwall M. F., Leat P., Thompson R. N., and Menzies M. A. (1989) Contamination of Indian Ocean asthenosphere by the Kerguelen-Heard mantle plume. Nature 338, 574 - 576.

Takazawa E., Frey F. A., Shimizu N., Obata M., and Bodinier J. L. (1992) Geochemical evidence for melt migration and reaction in the upper mantle. Nature 359, 55-58.

ten Brink U. S. and Brocher T. M. (1987) Multichannel seismic evidence for a subcrustal intrusive complex under Oahu and a model for Hawaiian volcanism. J. Geophys. Res. 92, 13,687-13,707.

Walker R. J., Carlson R. W., Shirey S. B., and Boyd F. R. (1989) Os, Sr, Nd, Pb isotope systematics of southern African peridotite xenoliths: Implications for the chemical evolution of subcontinental mantle. Geochim. Cosmochim. Acta 53, 15831595.

Watkins N. D., Gunn B. M., Nougier J., and Baksi A. K. (1974) Kerguelen: Continental Fragment or Oceanic Island? Geol. Soc. Am. Bull. 85, 201 -212.

White W. M. and Hofmann A. W. (1982) Sr and Nd isotope geochemistry of oceanic basalts and mantle evolution. Nature 296, 821-825.

Whitechurch H., Montigny R., Sevigny J., Storey M., and Salters V. J. M. (1992) K-Ar and ${ }^{40} \mathrm{Ar} /{ }^{39} \mathrm{Ar}$ ages of central Kerguelen Plateau basalts. In Proc. of the Ocean Drilling Program, Sci. Res., Vol. 120 (ed. S. W. Wise Jr., R. Schlich, and et al.), pp. 71-77. Ocean Drilling Program.

Wilson J. T. (1963) Evidence from islands on the spreading of ocean floors. Nature (London) 197, 536-538.

Wise S. W. J., Schlich R., and et al. (1992) Proceedings of the Ocean Drilling Program, Scientific Results, Vol. 120. College Station, TX (Ocean Drilling Program).

Yale M. M. and Phipps Morgan J. (1998) Asthenosphere flow model of hotspot-ridge interactions; a comparison of Iceland and Kerguelen. Earth Planet. Sci.Lett. 161, 4556.

Yang H.-J., Frey F. A., Weis D., Giret A., Pyle D., and Michon G. (1998a) Petrogenesis of the flood basalts forming the northern Kerguelen Archipelago: implications for the Kerguelen plume. J. Petrol. 39, 711-748.

Yang H.-J., Sen G., and Shimizu N. (1998b) Mid-ocean ridge melting: constraints from lithospheric xenoliths at Oahu, Hawaii. J. Petrol. 39, 277-295.

Zindler A. and Hart S. (1986) Chemical Geodynamics. Ann. Rev. Earth Planet. Sci. 14, 493-571. 


\subsection{Figures}

Figure 1-1. Map of the Indian Ocean (after Coffin, 1992). Submarine ridges and plateaus related to the Kerguelen plume are highlighted in light gray shading. Major plate boundaries are labeled (SWIR, SEIR, CIR). Filled circles mark ODP and DSDP drill sites. The ages or range of ages (Duncan, 1978; Duncan, 1991; Duncan and Storey, 1992; Whitechurch et al., 1992; Storey et al., 1996; Pringle et al., 1997) of recovered basaltic basement or oldest fossils (marked with "greater than" symbol) are adjacent to the symbols. Ages of dredged samples are marked with the suffix (Dr). The Kerguelen Islands (inset) are located at the northern end of the Kerguelen Plateau and range from 39-0 Ma (Giret and Lameyre, 1983; Nougier, 1972; Nicolaysen et al., 1999). Xenolith localities are shown as filled stars. The samples from this study are from the Lac Superieur site on the Courbet Peninsula.

Southeast Province localities are labeled 1: Pointe de l'Espérance, 2:Val Phonolite, 3: Dome Rouge, and 4: Mont Tizard. 


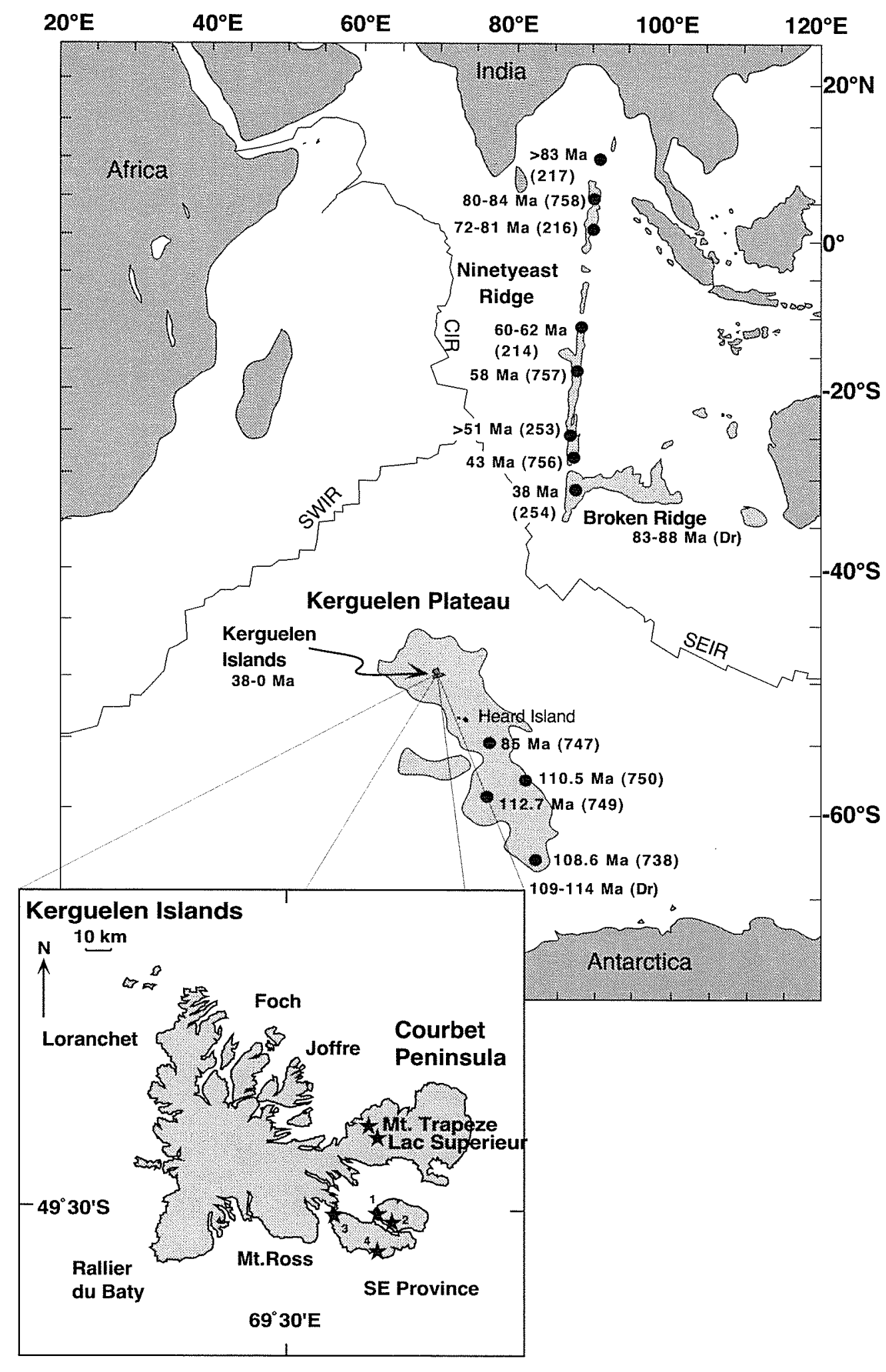




\section{Chapter 2 The Geochemistry of Peridotite Xenoliths from the Courbet Peninsula, Northern Kerguelen Islands}

\subsection{Introduction}

Peridotite xenoliths brought to the earth's surface by erupting magmas are a window through which the lithospheric mantle can be studied directly and in detail. Indeed, much of the present knowledge about the materials that make up the continental lithosphere has been derived from studies of kimberlite-borne peridotite xenoliths. For instance, Boyd (1973) determined the pressure and temperature conditions that were frozen in peridotite minerals and established that suites of peridotite xenoliths from the Kaapvaal craton defined geothermal gradients at the time of kimberlite eruption. This was the first quantitative information extracted from peridotite xenoliths and much progress has been made since in the understanding of evolutionary pathways of continental lithospheres. Applications of the Re-Os isotopic system to the sub-cratonic peridotites have confirmed their antiquity and their long term stabilization (e.g. Walker et al., 1989; Carlson and Irving, 1994; Pearson et al., 1995).

Peridotite xenoliths have also provided direct access to geochemical processes involved in the formation and evolution of the mantle lithosphere. Studies of mantle metasomatism (see for instance articles in Mantle Metasomatism (Menzies and Hawkesworth, 1987 and references therein) and the recognition that peridotites from the Kaapvaal and Siberian cratons are enriched in orthopyroxene to the extent that they cannot be simple residues of melt extraction at any pressure (e.g. Boyd, 1989; Kelemen et al., 1998) further stimulated the field in the direction of investigating interactions between 
lithospheric peridotites and infiltrating melts and fluids. As discussed in Chapter 1, peridotites can be a sensitive substrate upon which records of melt rock-reactions are imprinted. The combination of trace element abundances and $\mathrm{Sr}, \mathrm{Nd}$, and $\mathrm{Os}$ isotopic compositions is a useful tool to decipher processes responsible for cratonic mantle formation and evolution. In contrast to peridotite xenoliths from continental localities, where the major objective of study is the continental lithosphere itself, those from ocean islands basalts (OIB) have not attracted as much attention. As the source of OIB is getting better characterized however, geochemical studies of OIB peridotite xenoliths could help to understand the source mantle, melting process and perhaps more importantly, interaction between a plume and the lithosphere. For instance, Sen et al. (1993), Hauri et al . (1993), Hauri and Hart (1994) and Yang et al. (1998b) used trace element abundance patterns in clinopyroxenes from peridotite xenoliths from Hawaii, the Austral Islands, and Samoa to demonstrate that plume mantle melts more extensively than ridges, and noted complex plume-lithosphere interactions involving basaltic and carbonatite melts. Moreover, Schiano et al. (1994) discovered that carbonate-rich melts are present as melt inclusions in oceanic peridotites, including within xenoliths from the Kerguelen Islands.

Peridotites constitute a significant member of the Kerguelen Islands xenolith suites; all known xenolith localities thus far produce significant proportions of peridotites. As discussed in Chapter 1, the Kerguelen plume has evolved under different geodynamic environments and has possibly interacted with different types of lithosphere. If pieces of the different types of mantle lithosphere, such as oceanic mantle lithosphere, continental mantle lithosphere (related to Gondwanaland), or recrystallized plume mantle, were to be present as xenoliths, they would present a complex geochemical spectrum. This is especially true since geochemical and isotopic modification of original geochemical signatures by Kerguelen plume-derived melts would be expected during plume-lithosphere 
interaction. Conversely, if any of peridotite xenoliths could be identified as pieces of specific lithospheric types, the dynamics of plume-lithosphere interaction could be constrained.

The major purpose of this study is to present a detailed description of two suites of peridotite xenoliths from the Courbet Peninsula (Lac Superieur and Mont Trapeze), to constrain their provenance, and to examine the geochemical aspects of plume-lithosphere interaction as recorded by the geochemistry of these xenoliths. This study expands on the previous work of Grègoire (1994) on petrography and major and trace element compositions, and on the isotopic studies of Mattielli (1996), and Mattielli at al. (1996). These studies were made on peridotites from the Southeast Province of the Archipelago, whereas samples for the present study are from the Courbet Peninsula, to the northeast (Figure1-1).

\subsection{Sample description}

Thirty ultramafic xenoliths from the Lac Superieur locality (samples OB93-51 to OB93102) and twenty-five from Mt. Trapeze (samples OB93-280 to OB93-318) will be described in this chapter. The Lac Superieur suite comprises mostly spinel harzburgites, but also includes one spinel lherzolite, several wehrlitic dunites and pyroxenites. The Mt. Trapeze suite contains only spinel harzburgites. In situ trace element analyses were made on clinopyroxenes from all of these xenoliths. Representative samples of the various rock types were chosen for further study that included whole rock geochemistry, major element compositions of minerals, and isotopic compositions ( $\mathrm{Sr}, \mathrm{Nd}$, and $\mathrm{Os}$ ). As discussed below, the peridotites fall into distinct geochemical groups defined by their petrography and trace element geochemistry. 
The xenoliths from Lac Superieur are generally larger $(>6-7 \mathrm{~cm}$, often $>10 \mathrm{~cm}$ in the largest dimension) than those from Mt. Trapeze (4-5 cm diameter or less ). All of the harzburgites comprise olivine, orthopyroxene, less than 5\% clinopyroxene and chromite. Two types of harzburgites are present in both of the localities and are grouped on the basis of their clinopyroxene texture. In one type (the REE depleted group, defined below), clinopyroxenes occur predominantly in symplectite intergrowths with chromite and discrete (or individual) clinopyroxene grains are rarely present. In the other type (found in all of the other harzburgite REE groups), clinopyroxene and spinel occur as two textural populations, of which the majority are discrete grains, but which also occur together in symplectite intergrowths. The clinopyroxene and spinel grain sizes are variable; those in symplectites are $1 \mathrm{~mm}$ to $3 \mathrm{~mm}$, but discrete grains are as large as $5 \mathrm{~mm}$. Olivine and orthopyroxene can be as large as $1 \mathrm{~cm}$, and often are strained as exhibited by deformation bands and subgrain boundaries. Orthopyroxene occurs in poikilitic texture in one of the samples (OB93-306). Exsolution of clinopyroxene from orthopyroxene is common in all of the harzburgites. Exsolution of orthopyroxene and spinel from clinopyroxene is present in some of the harzburgites. Symplectite textures vary from vermicular spinel contained entirely within $\sim 1-2 \mathrm{~mm}$ clinopyroxene grains, to coarsened intergrowths $(>2-3 \mathrm{~mm}$ ). Some of the Mt. Trapeze harzburgites have discrete spinels with an octahedral habit, in addition to the chromites with symplectite texture (e.g. OB93-287, OB93-291, OB93-297, OB93-309). Some samples contain accessory phlogopite (OB93-83, OB93-299) and apatite (OB93-83), a relatively rare assemblage in rocks from oceanic environments. To date, only Hauri et al. (1993) have described apatite-bearing harzburgite xenoliths from an OIB in Samoa.

Of the remaining Lac Superieur xenolith types, sample OB93-52 is a very rare piece of fertile spinel therzolite that comprises olivine, orthopyroxene, chromite, and nearly $10 \%$ 
clinopyroxene. The clinopyroxene in this rock occurs only in the discrete form and the spinel is euhedral. Wehrlitic dunites (OB93-61c, OB93-64, OB93-82), are finer-grained than the rest of the suite $(<2-3 \mathrm{~mm})$, and comprise olivine, euhedral spinels and less than $10 \%$ discrete clinopyroxene. Pyroxenites are megacrystic $(\sim 8 \mathrm{~cm})$ to coarse-grained $(2-3$ $\mathrm{cm}$ ), and two of the samples (OB93-94, OB93-81b), contain phlogopite and octahedral spinel. Exsolution lamellae of orthopyroxene are up to $0.5 \mathrm{~mm}$ wide in the phlogopite bearing pyroxenites. The pyroxenites (OB93-75, OB93-87, OB93-100, OB93-102), also have macroscopic exsolved orthopyroxene, but are lacking phlogopite and spinel and contain a small amount $(<1 \%)$ of partly altered plagioclase.

Some typical petrographic features of these rocks are shown in Figure 2-1, and a list of the samples of this study in Table $2-1$.

\subsection{Analytical Methods}

Surfaces were cut from the xenoliths and saw marks were polished off with 120 and 240 grit silicon-carbide paper. The polished pieces were crushed to smaller fragments between plastic with a hammer. Pieces that did not have any basalt veins or visible alteration were selected under a binocular microscope for grinding. All samples were powdered in an agate shatterbox vial except OB93-52, OB93-56, OB93-80, OB93-83, OB93-85, OB93-99, OB93-299, OB93-305, OB93-306, OB93-310, and OB93-317, which were ground in a tungsten carbide vial at the GeoAnalytical Laboratory at Washington State University (WSU). The samples powdered at WSU may have $\mathrm{W}, \mathrm{Co}, \mathrm{Nb}$ and $\mathrm{Ta}$ contamination from the grinding vessel. Whole rock major and trace element compositions were determined on the unleached powders by XRF and ICP-MS at the WSU. Precision for XRF major element analysis is $<0.4 \%$ (1 S.D.). The precision of all trace element analyses by ICP- 
MS is 1-3\%, except for $\mathrm{U}$ and Th, which are $\sim 10 \%$ (1 S.D.). Detection limits for the trace elements by ICP-MS are 0.1 to 0.5 times chondritic levels.

Major element compositions of the rock-forming minerals in thin sections or mounts of representative mineral grains were determined with the JEOL 733 Superprobe electron microprobe at the Massachusetts Institute of Technology (MIT) with an acceleration potential of $15 \mathrm{kV}$, a beam current of $10 \mathrm{nA}$ and a $1 \mu \mathrm{m}$ spot. Raw data were reduced online using the method of Bence and Albee (1968) modified by Albee and Ray (1970). The precision based on counting statistics are 6-25\% (1 S.D.) for $<0.5 \mathrm{wt} . \%, 2.5-6 \%$ for $0.5-1$ wt. $\%, 1-3 \%$ for $1-15$ wt. $\%,<0.5 \%$ for $>15$ wt. $\%$.

The Cameca IMS $3 \mathrm{f}$ ion probe at WHOI was used to analyze trace element and rare earth element contents of clinopyroxenes following the methods of Shimizu and Hart (1982). A primary beam of $\mathrm{O}^{-}$ions was focused to $20 \mu \mathrm{m}$ for $\mathrm{REE}$ ( $\mathrm{La}, \mathrm{Ce}, \mathrm{Nd}, \mathrm{Sm}, \mathrm{Eu}$, Dy, Er, Yb) and $\sim 10 \mu \mathrm{m}$ for other trace elements (Cr, V, Y, Ti, Zr, Sr). Molecular interferences were eliminated by energy filtering and a secondary voltage offset of -30 to $-60 \mathrm{~V}$ for the REE and $-90 \mathrm{~V}$ for the other trace elements. Uncertainties on the basis of counting statistics for the REE (1 S.D.) were $20-40 \%$ for chondrite normalized REE abundances of less than 1,5-10\% for those between 1 and 10, and 1-5\% for those greater than 10. Uncertainties (1 S.D.) for the other trace elements were as high as $25 \%$ for some of the ultradepleted samples (e.g. Ti $<100 \mathrm{ppm}$ ), but otherwise $<10 \%$. All normalized REE data are reported relative to abundances in C1 chondrites (Anders and Grevesse, 1989).

Strontium and $\mathrm{Nd}$ isotopic compositions were determined on hand picked mineral separates of phlogopite and clinopyroxenes. Phlogopites were not leached. Clinopyroxenes were leached for 30 minutes in $100^{\circ} \mathrm{C}, 2.5 \mathrm{~N} \mathrm{HCl}$, followed by 5 minutes in cold $\mathrm{HF}$, 
followed by another 30 minutes of $\mathrm{HCl}$, to remove minor surface alteration (Taras and Hart, 1987). The chemistry and mass spectrometry of $\mathrm{Sr}$ and $\mathrm{Nd}$ isotopes were done at WHOI, MIT and Okayama University. At WHOI, isotopes were measured using a VG-354 5-collector mass spectrometer. Cation exchange separation methods were used for $\mathrm{Sr}$ and the LREE, and HDEHP extraction was used for Sm and Nd, as described by Zindler (1980) and Richard et al. (1976). Strontium data are normalized to ${ }^{87} \mathrm{Sr} /{ }^{88} \mathrm{Sr}=0.1194$, and isotopic compositions are reported relative to ${ }^{87} \mathrm{Sr} /{ }^{86} \mathrm{Sr}=0.710240$ for NBS987 (average ${ }^{87} \mathrm{Sr} /{ }^{86} \mathrm{Sr}=0.710266 \pm 18, \mathrm{n}=3$ ). Neodymium data are normalized to ${ }^{146} \mathrm{Nd} /{ }^{144} \mathrm{Nd}=0.7219$, and isotopic compositions are reported relative to ${ }^{143} \mathrm{Nd} /{ }^{144} \mathrm{Nd}=0.511847$ for the La Jolla standard (average ${ }^{143} \mathrm{Nd} /{ }^{144} \mathrm{Nd}=0.511855 \pm 8, \mathrm{n}=3$ ). The procedural blank for $\mathrm{Sr}$ was 300 $\mathrm{pg} / \mathrm{g}$ sample, and $150 \mathrm{pg} / \mathrm{g}$ sample for $\mathrm{Nd}$. These were insignificant in relation to the amount of analyte, thus no blank corrections were made on these $\mathrm{Sr}$ or $\mathrm{Nd}$ isotopic ratios. Counting statistics $(2 \sigma)$ associated with mass spectrometry were $<25 \mathrm{ppm}$ for $\mathrm{Sr}$ and $<10$ ppm for $\mathrm{Nd}$. All concentrations of $\mathrm{Sr}$ and $\mathrm{Nd}$, were determined by isotope dilution, during isotopic analysis. Analyses of some samples with relatively low Sr concentrations in clinopyroxenes (OB93-94cpx, OB93-94phlog, OB93-64) were made at MIT, using the VG-Sector 54 mass spectrometer and methods optimized for low concentrations. The clinopyroxenes were acid-leached according to the same procedure. Separation of $\mathrm{Sr}$ was accomplished using Sr-spec ${ }^{\mathrm{TM}}$ resin (Horwitz et al., 1991; Pin and Bassin, 1992). Strontium was analyzed using the dynamic multi-collector mode with $\mathrm{Sr}$ intensity at ${ }^{88} \mathrm{Sr}=$ 3V. Analytical blanks for $\mathrm{Sr}$ were insignificant (4 pg total blank) and no correction was necessary. Strontium data are normalized to ${ }^{86} \mathrm{Sr} /{ }^{88} \mathrm{Sr}=0.1194$, and replicate analyses of NBS987 at MIT during the times of these analyses yielded ${ }^{87} \mathrm{Sr} /{ }^{86} \mathrm{Sr}$ of $0.710240 \pm 10$ $(n=147)$. Acid-leached clinopyroxene separates from samples with extremely low $\mathrm{Sr}$ and 
Nd concentrations (samples OB93-78, OB93-80, OB93-64) were analyzed for $\mathrm{Sr}$ and $\mathrm{Nd}$ isotopes by E. Nakamura at Okayama University, Misasa, Japan. Neodymium isotope analysis of clinopyroxene from OB93-78 failed because only $0.13 \mathrm{ng}$ of analyte was available. Strontium isotopic compositions were normalized to NBS987 ${ }^{87} \mathrm{Sr} /{ }^{86} \mathrm{Sr}=$ 0.710240 and $\mathrm{Nd}$ isotopic compositions to La Jolla ${ }^{143} \mathrm{Nd} /{ }^{144} \mathrm{Nd}=0.511847$. Total blanks at the Okayama lab were $45 \mathrm{pg}$ for $\mathrm{Sr}$ and $10 \mathrm{pg}$ for $\mathrm{Nd}$. Concentrations of $\mathrm{Sr}$ and $\mathrm{Nd}$ were determined by isotope dilution on the same aliquots.

Osmium isotopes for the peridotite are discussed in detail in Chapter 3 and the analytical techniques are quoted here for reference (Hassler and Shimizu, 1998; note 10). "Olivine separates and peridotite whole-rock powders were ground in an agate shatterbox vial, prepared for Os analysis by NiS fire-assay and distillation, and measured using negative thermal ionization mass spectrometry techniques at Woods Hole Oceanographic Institution (Ravizza, 1993; Hauri and Hart, 1993). On the basis of counting statistics, the precision associated with ${ }^{187} \mathrm{Os} /{ }^{188} \mathrm{Os}$ range from $0.10-0.44 \%(2 \sigma)$, although replicate analyses (one was a separate aliquot from the same powder split and another from a separate powder split) agree within $\pm 0.5 \%$ and $\pm 0.7 \%$ respectively. Osmium standard runs were reproducible within $0.3 \%(2 \sigma)$. Osmium concentrations were determined by fireassay and isotope dilution, and were reproducible at $\pm 7 \%(2 \sigma)$. Blank corrections for Os isotopic composition and concentrations were less than the uncertainty of counting statistics in most cases, and only applied when the correction was greater than the counting error. Rhenium concentrations were measured on separate powder splits by inductively coupled plasma-mass spectrometry at the Lamont-Doherty Earth Observatory. Reported Re concentrations are not blank-corrected (procedural blank was approximately 10-20 ppt), 
and counting statistics were $0.6-3.2 \%(2 \sigma)$. Thus, most of the samples had negligible amounts of Re."

\subsection{Results and Discussion}

\subsubsection{Whole rock compositions}

Major and trace element abundances were determined on whole rock powders from a subset of samples (Table 2-2). Often, difficulties in obtaining representative whole rock powders for peridotite xenoliths arise from their small size relative to their grain size. Assuming a minimum dimension of ten times the average grain size for a representative sample, a rock with an average grain size of $5 \mathrm{~mm}$ would require $125 \mathrm{~cm}^{3}(\sim 375 \mathrm{~g}$, assuming average mineral density $=3 \mathrm{~g} / \mathrm{cm}^{3}$ ) to be representative. Because of the small size of xenoliths in this study, whole rock powders were prepared using a maximum of approximately $50 \mathrm{~g}$ of sample, and often much less (20-30 g). This is much less than the above requirement, and the representativeness of the bulk rock powder for major element compositions may therefore be suspect (cf. Boyd, 1989; Boyd et al., 1997).

In a general sense, the whole rock major element compositions of the harzburgites reflect their depleted character. For instance, $\mathrm{CaO}$ ranges from 0.51 to $1.2 \mathrm{wt} \%$ and $\mathrm{Al}_{2} \mathrm{O}_{3}$ from 0.47 to $1.3 \mathrm{wt} . \%$. These ranges are similar to harzburgite and lherzolite xenoliths from Samoa (Hauri and Hart, 1994) and Hawaii (Sen, 1988). The Samoan peridotites described by Hauri and Hart (1994) appear (on the basis of rock reconstruction from mineral modes and compositions) to be more depleted that the xenoliths of the present study with $\mathrm{CaO}$ and $\mathrm{Al}_{2} \mathrm{O}_{3}$ ranging from 0.21 to 0.88 wt.\% and 0.41 to 1.11 wt.\% respectively. The Hawaiian xenolith suites described by Sen (1988) contain lherzolites and harzburgites with similar olivine compositions to the present suites, and with $\mathrm{CaO}$ and 
$\mathrm{Al}_{2} \mathrm{O}_{3}$ contents within the range reported here (e.g. 77SL-31 with $\mathrm{Fo}_{91.7}$ olivine has bulk $\mathrm{CaO}=0.42$ wt. $\%$ and $\mathrm{Al}_{2} \mathrm{O}_{3}=1.84$ wt. $\%$, whereas $77 \mathrm{KASP}-4$ with $\mathrm{Fo}_{90.9}$ olivine contains bulk $\mathrm{CaO} 2.28$ wt.\% and $\mathrm{Al}_{2} \mathrm{O}_{3} 2.29$ wt.\%). In the xenoliths of the present study, the $\mathrm{Mg \#}$ [atomic $\mathrm{Mg} /(\mathrm{Mg}+\mathrm{Fe}) \times 100]$ for the harzburgites are greatest, ranging from 89.8 to 91.9 , except for OB93-306 (Mg\# = 84.3), followed by 88.8 for the lherzolite (OB93-52), and 87.9 and 88.4 for the dunites (OB93-64, OB93-82). No major oxide correlations are present other than slight negative correlations of $\mathrm{CaO}$ and $\mathrm{Al}_{2} \mathrm{O}_{3}$ with $\mathrm{MgO}$.

\section{Whole rock geochemistry and the "oceanic trend"}

Modal abundances of clinopyroxene, orthopyroxene, olivine and spinel were calculated by mass balance for the peridotites that have both whole rock and mineral major element data available (Table 2-3). The modes of these rocks lie in the harzburgite field, except for the one lherzolite (OB93-52; Figure 2-2). Apparent negative spinel modes (with large errors) in some of the rocks probably results from the presence of spinel in trace amounts, and the possibility that the whole rock powder may not be wholly representative (i.e. a nugget effect). Figure 2-3 illustrates the relationship between modal abundance of olivine and olivine composition. This diagram is often used to characterize suites of peridotites with respect to their origin. Boyd (1989) was among the first to note that low-temperature peridotite xenoliths from the Kaapvaal and Siberian lithosphere possess lower and variable modal olivine for their high Fo contents relative to abyssal peridotites. Abyssal peridotites are believed to be residues of melting process that occurred at relatively low pressures, and the oceanic trend is constructed on the basis of observations made on these rocks (Boyd, 1989). Kelemen et al. (1998) postulated that the cratonic peridotites initially formed as residues of extensive melting and then reacted with $\mathrm{SiO}_{2}$-rich slab derived melts to produce an excess of orthopyroxene as well as an olivine deficiency. 
Of the xenoliths in this study, four lie on or near the oceanic trend (OB93-52, OB93287, OB93-289, OB93-297; Figure 2-3). In comparison, the remaining samples have a higher Mg\# for a given olivine mode than that defined by the oceanic trend, similar to the low-temperature cratonic xenoliths. Moreover, it is also notable that the Samoan peridotites of Hauri and Hart (1994) as well as some Hawaiian samples of Sen (1988) also lie considerably off the oceanic trend and within the range observed here for the Kerguelen peridotites.

One of the reasons for the occurrence of an oceanic trend is that modal olivine increases with increasing degrees of melting. This happens as long as the melting reactions produce olivine. It has been well established that peridotite melting does produce olivine at pressures below $1.5 \mathrm{GPa}$ (Kinzler and Grove, 1992; Walter, 1998 among others). That the Kerguelen xenoliths (and those from other OIB) have too little olivine for their Fo contents and plot off the oceanic trend, suggests that they are not simple residues of melting at low pressures. Niu et al. (1997) argued that melt-rock reactions could consume orthopyroxene and produce olivine, and that abyssal peridotites show evidence for this process. For the present suite of xenoliths this type of process is clearly not applicable on the basis of the following reasoning. As suggested by Kelemen et al. (1998), reaction between olivine-rich residues and $\mathrm{SiO}_{2}$-rich melt could produce orthopyroxene and shift a peridotite off the oceanic trend. Because of the discovery of the ubiquitous occurrence of $\mathrm{SiO}_{2}$-rich melt inclusions in peridotite xenoliths, including those from the Kerguelen Islands (Schiano et al., 1992; Schiano et al., 1994; Schiano and Clocchiatti, 1994), the mechanism of Kelemen et al. (1998) must be considered as a potential origin of the major element characteristics of the Kerguelen peridotites. However, as Schiano et al. (1992) noted, these $\mathrm{SiO}_{2}$-rich melt inclusions are enriched in LREE, and the proposed reaction would produce LREE-enriched signatures in the minerals of the rocks with which it 
interacted. As will be discussed below, the REE abundance patterns in clinopyroxenes from some of the Kerguelen harzburgites that plot off the oceanic trend are not LREE enriched. For instance, OB93-80, with the least modal olivine at $41 \mathrm{wt} \%$, has clinopyroxene with $\mathrm{La}=0.28$ times chondrite and $\mathrm{Yb}=0.67$ times chondrite. Thus, $\mathrm{a}$ reaction between olivine and silica-rich melt does not appear to be the major mechanism to produce the observed $\mathrm{SiO}_{2}$ enrichment that is observed here.

As discussed above, experiments have shown that mantle melting reactions change from olivine-producing at pressures $<1.5 \mathrm{GPa}$ to olivine consuming and orthopyroxeneproducing at higher pressures (e.g. Walter et al., 1995; Kinzler, 1997; Walter, 1998 among others). Melting residues that formed at high pressures could therefore plot above and off the oceanic trend and resemble the Kerguelen (and Samoan) peridotites. Indeed, Walter's (1998) experimental results on the melting of garnet-free peridotite showed that after $18 \%$ melting at $3.0 \mathrm{GPa}$, the residual harzburgite has $63.2 \mathrm{wt} . \%$ olivine with a composition of $\mathrm{Fo}_{91.1}$, similar to one of the harzburgites from Mt. Trapeze (OB93-291; see Figure 2-3). This experimental residue has a bulk composition of $2.6 \mathrm{wt} . \% \mathrm{Al}_{2} \mathrm{O}_{3}$ and $1.4 \mathrm{wt} . \% \mathrm{CaO}$, similar to the bulk compositions of those elements in the harzburgites of this study. If this experimental residue were to recrystallize at a lower pressure (less than approximately 1.0 $\mathrm{GPa})$, mass balance indicates that the olivine mode would not change (63.2 wt.\%), and that the new modal mineralogy would be $25 \mathrm{wt} . \%$ orthopyroxene, $6.9 \%$ calcic-clinopyroxene and $4.9 \%$ spinel, near the modes that are observed here.

Low pressure recrystallization of a garnet-bearing harzburgite residue that originally formed at high pressures could also result in modal olivine with a Fo content that lies off of the oceanic trend. Garnet breakdown during recrystallization would further consume olivine and produce orthopyroxene, thereby shifting a point horizontally to the right and off of the oceanic trend shown in Figure 2-3. In fact, Hauri and Hart (1994) interpreted trace 
element abundance patterns of clinopyroxenes in some of the Samoan harzburgites as originating from the recrystallization of garnet-bearing precursors, and they, too, plot above the oceanic trend (see Figure 2-3). As will be discussed below, clinopyroxenes of the Kerguelen harzburgites do not possess any garnet-derived signatures; nevertheless their major element characteristics are consistent with an origin as recrystallized residues of extensive melting at high-pressure. Such extensive melting at high pressures can easily be envisioned in mantle plumes.

In contrast to the harzburgites, the lherzolite in this suite (OB93-52) plots on the oceanic trend. Its modal abundances are slightly depleted relative to KLB-1, a primitive peridotite from Kilborne Hole, NM, that is widely used as a starting material for experiments: 61.7 wt.\% olivine in OB93-52 v. 58 wt.\% in KLB-1, 9.5 wt.\% clinopyroxene in OB93-53 v. 15 wt.\% in KLB-1 (Takahashi, 1986). Sample OB93-52 has geochemical and isotopic characteristics that indicate it may be unmelted piece of the Kerguelen plume mantle, and these will be described in various sections to follow.

Present-day bulk major element compositions of the Kerguelen peridotites may not be a primary feature if new mineral phases were added during a late melt-rock interaction (or metasomatic) event. Petrographic details will be described in more detail below, but it should be noted here that petrographic evidence exists for the addition of new clinopyroxene to some of these harzburgites. The amounts of added clinopyroxene could be significant in comparison to the original clinopyroxene modes. In such specimens, the $\mathrm{CaO}$ contents (as well as most of the incompatible trace element contents) must be treated with caution. This reinforces the importance of microbeam-based trace element petrography like that practiced here, in deciphering the history of peridotites. 


\section{Trace element mass balance between whole-rocks and clinopyroxenes}

Whole rock and mineral data can be used to examine which mineral phase hosts the trace elements and whether clinopyroxene can account for the trace element budget of the whole rocks. This calculation relies on the clinopyroxene modes that were calculated by mass balance from the whole rock and mineral major element data, and is therefore subjected to the uncertainties previously discussed. In addition, some of the harzburgites contain clinopyroxenes with vastly different trace element abundances, and the whole rock mass balance is influenced by this type of chemical heterogeneity. Although whole rock powders were carefully prepared to avoid minute veins of the host alkaline basalt, contamination may still be present. Given the contrast in trace element abundances between these strongly depleted harzburgites and those of enriched alkaline basalts, the magnitude of undetected contamination could be large.

To illustrate this situation, calculations were made for $\mathrm{La}$ and $\mathrm{Yb}$ to assess how much of the whole rock concentrations can be accounted for by clinopyroxene. Sample OB93-52 (a lherzolite), is one of the few cases where clinopyroxene is shown to be a predominant host for those elements; $68 \%$ of the $\mathrm{La}$, and $82 \%$ of the $\mathrm{Yb}$ in the bulk rock can be accounted for by the $9.5 \mathrm{wt} . \%$ modal clinopyroxene in this sample (Table 2-2, Table 2-3, and see Table 2-8). Among harzburgites, OB93-297 presents another straightforward case; $100 \%$ of the $\mathrm{La}$ and $81 \%$ of the $\mathrm{Yb}$ are in clinopyroxene. For samples with heterogeneous clinopyroxenes (e.g. OB93-99, OB93-287), the La mass balance can be achieved with appropriate amounts of La-rich discrete grains. Concentrations of $\mathrm{Yb}$ are generally homogeneous among texturally different clinopyroxenes. Clinopyroxenes account for $66 \%$ of whole rock $\mathrm{Yb}$ in OB93-287, whereas about $40 \%$ of $\mathrm{Yb}$ is in clinopyroxene for OB9399. For other depleted harzburgites such as OB93-289, OB93-307 and OB93-310, abundances of clinopyroxene and concentrations of these elements in clinopyroxene are so 
low that whole rock abundances cannot be explained. The mass balance for $\mathrm{Sr}$ and $\mathrm{Nd}$ is particularly important when isotopic compositions of these elements are obtained only for whole rocks. This type of whole rock analysis is normally done because of the technical difficulties associated with the separation of pure clinopyroxene from a rock and the subsequent handling of minute quantities of these elements in clinopyroxene. The points presented above describe the difficulties associated with whole rock data and caution against reliance upon it.

Studies of mantle metasomatism began with the pioneering work of Frey and Green (1974) who recognized for the first time that unaccountable enrichment in incompatible elements occurs in rocks that are depleted in basaltic components. Petrographic manifestations of this phenomenon were not made clear until ion microprobe based trace element data of clinopyroxenes were produced (e.g. Sen, 1988; Takazawa et al., 1992; Hauri et al., 1993; Yang et al., 1998b among others). In these studies however, the connection between whole rock and mineral trace element data was not clearly made. In this sense, this study provides rare unequivocal petrographic evidence for trace element enrichment process in depleted rocks.

Figure 2-4 compares REE patterns for clinopyroxene and whole rocks for selected samples. Mass balance is violated for samples that show greater REE concentrations for whole rocks than clinopyroxenes (e.g. OB93-78, OB93-80, OB93-85). Until residential hosts other than clinopyroxene for incompatible elements in harzburgites can be identified, geochemical discussions based solely on whole rock data could be grossly misleading. In addition, the geochemical characterization of the lithosphere on the basis of whole rock data without that of trace element petrography can be equally misleading. In the sections that follow, most of the geochemical arguments are presented on the basis of clinopyroxene trace element data. 


\subsubsection{Mineral compositions}

\section{Major Elements}

Representative major element compositions of minerals in peridotite xenoliths are summarized in Table $2-4$, Table $2-5$, Table $2-6$, and Table $2-7$. The entire dataset is tabulated in Appendix 1. Mineral compositions vary consistently among rock types, and the salient features can be summarized as follows. 1.) The Mg\# of minerals are lowest in the wehrlitic dunites, followed by the lherzolite, and are highest in the harzburgites. For instance, the wehrlitic dunites have olivines with $\mathrm{Fo}_{88.3}$ to $\mathrm{Fo}_{90.2}$, the lherzolite has olivines with $\mathrm{Fo}_{89.9}$ to $\mathrm{Fo}_{90.2}$, and olivines in harzburgites have $\mathrm{Fo}_{90.0}$ to $\mathrm{Fo}_{92.2} .2$.) Clinopyroxenes are broadly chromian diopsides in all of the rock types. Their compositions vary from $\mathrm{Wo}_{47-50}, \mathrm{En}_{46-48}, \mathrm{Fs}_{3.6-4.9}$ for wehrlitic dunites, $\mathrm{Wo}_{48.8}, \mathrm{En}_{47}, \mathrm{Fs}_{4.2}$ for the lherzolite, and $\mathrm{Wo}_{44-48}, \mathrm{En}_{48-53}, \mathrm{Fs}_{2.9-5.5}$ for harzburgites. 3.) $\mathrm{The}^{\mathrm{TiO}} \mathrm{T}_{2}$ and $\mathrm{Al}_{2} \mathrm{O}_{3}$ contents of clinopyroxenes are generally high in wehrlitic dunites $\left(0.25-0.80 \mathrm{wt}\right.$ \% $\mathrm{TiO}_{2}, 2.30-4.20$ wt. $\left.\% \mathrm{Al}_{2} \mathrm{O}_{3}\right)$, followed by the lherzolite $\left(0.95\right.$ wt. $\% \mathrm{TiO}_{2}, 5.4$ wt. $\left.\% \mathrm{Al}_{2} \mathrm{O}_{3}\right)$ and those in harzburgites are quite low $\left(<0.26 \mathrm{wt} . \% \mathrm{TiO}_{2},<2.8 \mathrm{wt} . \% \mathrm{TiO}_{2}\right)$. 4.) Orthopyroxenes are low in Ca with Wo contents less than 2.3 for all samples. The orthopyroxene $\mathrm{Mg \#}$ is the lowest in wehrlitic dunites at 89.5 followed by the lherzolite at 90.5 , and $91.9-92.7$ for the harzburgites. 5.) The $\mathrm{Cr} \#$ [atomic $\mathrm{Cr} /(\mathrm{Cr}+\mathrm{Al})$ ] of spinels varies from 25 in the lherzolite (OB93-52), to 27 - 46 in OB93-83, 33 - 48 in wehrlitic dunites and 39-60 in harzburgites (Figure 2-5). 6.) Two pyroxene temperatures range from 878 to $1042^{\circ} \mathrm{C}$.

The whole rock and mineral major element geochemistry of many of the Kerguelen harzburgites indicate their refractory nature. For instance, the spinel compositions, in comparison to those from abyssal peridotites (Dick and Bullen, 1984), suggest that these rocks are residual from relatively high degrees of partial melting, consistent with the elemental depletions noted above. Dick and Bullen (1984), postulated that the apparent 
maximum $\mathrm{Cr} \#$ of 60 observed in abyssal peridotites is a result of mantle melting to the clinopyroxene-out phase boundary. Similarly, in the case of the harzburgites of this study, the high $\mathrm{Cr} \#$ of spinels (Figure 2-5) suggests that melting may have consumed all original clinopyroxene.

Major element compositions of minerals not only reflect the varying degrees of depletion of the peridotites, but also demonstrate subtle but significant changes during meltrock interaction process and are closely related to trace element abundances in clinopyroxenes. For instance, "cpx4" in sample OB93-51 is depleted in its trace element abundances, has a higher $\mathrm{Mg \#} \mathrm{(94.3)} \mathrm{than} \mathrm{the} \mathrm{trace} \mathrm{element} \mathrm{enriched} \mathrm{"cpx2"} \mathrm{(Mg \#} \mathrm{=} \mathrm{93.2;}$ Table 2-4, Table 2-8, and see Figure 2-6). In addition, "cpx4" is more diopsidic ( $\mathrm{Wo}_{46}$, $\mathrm{En}_{51}, \mathrm{Fs}_{3.3}$ v. $\mathrm{Wo}_{43}, \mathrm{En}_{52}, \mathrm{Fs}_{4}$ ), lower in $\mathrm{TiO}_{2}, \mathrm{Al}_{2} \mathrm{O}_{3}\left(1.61\right.$ wt.\% v. 2.05 wt.\%) and $\mathrm{Na}_{2} \mathrm{O}$ (0.26 wt.\% v. 1.15 wt.\%) than "cpx2". Similar trends can be detected at different levels of subtlety for OB93-99, OB93-287, and OB93-307, for which significant trace element diversity is also observed. These observations clearly indicate that the process which

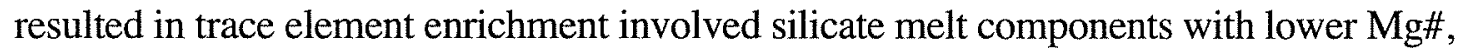
higher $\mathrm{Na}_{2} \mathrm{O}, \mathrm{TiO}_{2}$, and $\mathrm{Al}_{2} \mathrm{O}_{3}$ contents than the precursor peridotite. Sample OB93-83, a phlogopite and apatite-bearing harzburgite that is considered to be most metasomatized sample of this study, has mineral major element compositions that are distinctly lower in $\mathrm{Mg}$ \# (e.g. olivine with $\mathrm{Fo}_{89.7}$ ), spinel $\mathrm{Cr}$ as low as 27 , and clinopyroxene with $\mathrm{Wo}_{41}$, $\mathrm{En}_{53}, \mathrm{Fs}_{5.5}$, consistent with these other grain-by-grain trends (Figure 2-5).

As previously noted, OB93-52 has a whole rock composition that is slightly depleted relative to KLB-1, a popular primitive lherzolite (e.g. Takahashi, 1986). Mineral compositions of the two further reflect their similarities, with olivine Fo content $\left(\mathrm{Fo}_{90.2} \mathrm{v}\right.$. $\mathrm{Fo}_{89.1}$ in $\left.\mathrm{KLB}-1\right), \mathrm{TiO}_{2}$ in clinopyroxene (0.95 wt.\% in OB93-52 v. 0.58 wt. $\%$ in KLB- 
1), $\mathrm{Al}_{2} \mathrm{O}_{3}$ in clinopyroxene (5.41 wt.\% v. 7.4 wt.\%), $\mathrm{Al}_{2} \mathrm{O}_{3}$ in orthopyroxene (2.78 wt.\% v. 4.97 wt.\%), and Cr\# of spinel (25.2 v. 8.2).

\section{Trace elements}

Representative trace element compositions of clinopyroxenes from peridotite xenoliths are summarized in Table 2-8. The entire dataset is tabulated in Appendix 1. Clinopyroxenes in harzburgites from the two localities have variable REE contents both among and within individual xenoliths. The range of REE contents in clinopyroxenes from the harzburgites and the one lherzolite from Lac Superieur are shown in Figure 2-6, and those from the Mt. Trapeze harzburgites are shown in Figure 2-7.

\section{The relationship between texture and chemistry}

Trace element compositions of clinopyroxenes from the xenoliths were extensively examined in this work, and constitute one of the major results of this chapter. Particularly important is the observation that changes of clinopyroxene texture and geochemistry are correlated, indicating their mechanisms of formation. For example, trace element abundance patterns of clinopyroxenes that are highly metasomatized can be used to infer the identities of the metasomatic agents that created them. Figure 2-6 and Figure 2-7 illustrate the ranges of REE abundances observed in the clinopyroxenes from the peridotites of this study. The total range of REE concentrations for the Lac Superieur specimens (Figure 2-6) are greater than those of any other peridotites observed thus far. For instance, kimberliteborne peridotite xenoliths are known to be heterogeneous within individual pipes (e.g. Shimizu et al., 1997), but the variability seen in the Lac Superieur suite is much greater. In these samples, Ce varies by a factor of 5000 (from 0.04 times chondrite to more than 200 times chondrite). The Samoan peridotite xenoliths display trace element variations nearly comparable, but smaller than the Lac Superieur suite (Hauri and Hart, 1994). It is likely 
that a combination of geochemical variability among pre-metasomatic lithosphere pieces and further variations induced by metasomatism create these observed trace element ranges. It is therefore important to note in this context that large variations are also observed within a single sample (OB93-51; Figure 2-6). Samples from Mt. Trapeze show much less variation; nevertheless it is notable that Ce varies by a factor of 500 between OB93-307 and OB93-286, and is accompanied by identical $\mathrm{Yb}$ concentrations for the two samples (Figure 2-7). This is reminiscent of the type of single-sample variation shown by OB93-51 (Figure 2-6).

Figure 2-8 summarizes the REE variations in clinopyroxenes from individual harzburgites in which a correlation between texture and chemistry is observed. For instance, in OB93-51, clinopyroxenes occur in two separate textural domains: in symplectite intergrowth with spinel (Figure 2-1), and also as discrete grains. The data for "cpx4s" (a symplectite grain) resembles numerous other harzburgitic clinopyroxenes, which also occur as symplectites, in abundances of $\mathrm{Yb}$ through $\mathrm{Nd}$, whereas $\mathrm{La}$ and $\mathrm{Ce}$ concentrations are significantly elevated in comparison (Table 2-8). Another symplectite clinopyroxene from this same sample, "cpx3s", appears to be more extensively modified, while maintaining an identical $\mathrm{Yb}$ concentration as "cpx $4 \mathrm{~s}$ ". In contrast, co-existing discrete clinopyroxene grains in this sample ("cpx1" and "cpx2") have smooth, LREE-enriched patterns that are indicative of complete equilibration with a strongly LREE-enriched melt. Thus, it appears that the REE variations in OB93-51 record successive modifications of originally REE depleted clinopyroxenes and precipitation of new grains that are equilibrated with the metasomatic melt. Comparisons of the REE variations shown in Figure 2-8 clearly exhibit a progressive change of REE patterns from La, at the most modified, and diminishing towards $\mathrm{Yb}$. This type of progressive variation in clinopyroxene REE abundances has been observed in numerous peridotite clinopyroxenes, and has been 
successfully modeled by chromatographic melt-mantle reaction mechanisms (Navon and Stolper, 1987; Bodinier et al., 1990; Takazawa et al., 1992; Hauri and Hart, 1994; Yang et al., 1998b among others). That the clinopyroxene Wo content for OB93-51 decreases from 45.73 for "cpx $4 s$ " to 43.48 for "cpx2", indicates that "cpx2" equilibrated at higher temperatures than "cpx $4 \mathrm{~s}$ ". The ubiquity of harzburgitic clinopyroxenes similar to "cpx $4 \mathrm{~s}$ " and that various extents of modification are illustrated in these internally heterogeneous samples suggest: 1.) harzburgites were a common precursor rock to metasomatism, 2.) the melt-rock reaction that resulted in metasomatism was of short duration, and 3.) this process occurred shortly before the eruption that carried these xenoliths to the surface.

It should be noted that this relation does not seem to hold for some of the Mt. Trapeze xenoliths; in some cases the symplectite clinopyroxenes show a greater metasomatic signature than the discrete clinopyroxenes (OB93-299, OB93-318). However, because these analyses were made on clinopyroxenes in grain mounts rather than in thin section, it is possible that the grains we describe as discrete may actually be fragments of symplectite clinopyroxenes. Regardless of an imperfect textural correlation in some of the Mt. Trapeze harzburgites, that it does exist in many of the xenoliths it is the important observation. It demonstrates that the metasomatic event modified some existing grains as well as resulted in the precipitation of new discrete grains.

\section{Carbonatite melts and metasomatism}

The majority of the LREE enriched samples are from Mt. Trapeze, and over half of the Mt. Trapeze samples are LREE enriched (Table 2-8, Figure 2-9). The $[\mathrm{La} / \mathrm{Yb}]_{\mathrm{N}}$ ranges of this type of sample are from 1.3 to 31.8 , and the middle to heavy REE are relatively constant at $\sim 2$ to 3 times chondritic values. The LREE enrichment is indicative of advanced stages of metasomatic modification of these clinopyroxenes. That the middle to heavy REE are 
mostly unfractionated and at abundances much the same as those in the REE depleted harzburgites is evidence that the precursor clinopyroxenes probably had a similar origin as clinopyroxenes from the depleted harzburgites. Some of these clinopyroxenes posses smooth and strongly LREE-enriched REE patterns that are indicative of near-equilibrium with a LREE-enriched melt. In addition, $\mathrm{Ti}$ and $\mathrm{Zr}$ abundances in these clinopyroxenes are typically less than the neighboring REE in chondrite-normalized trace element diagrams (spidergrams), indicating that melts in equilibrium with these clinopyroxenes are also depleted in $\mathrm{Ti}$ and $\mathrm{Zr}$ (Figure 2-10)

With known clinopyroxene/melt partitioning it is possible to determine the REE contents of melts that were in REE equilibrium with the clinopyroxenes from these rocks. These hypothetical melts can then be compared to the REE contents of other melts that could be potential metasomatic agents. Many of the samples have clinopyroxenes that are in REE equilibrium with melts that are similar to Kerguelen Islands basalts (Figure 2-11). In contrast, Figure 2-12 illustrates that trace element patterns of equilibrium melts for OB9351, OB93-83, OB93-99, OB93-280, OB93-286 (cpx1), OB93-291, OB93-297 and OB93313 plot within the field defined by the trace element abundances of carbonatites (Nelson et al., 1988). This indicates that carbonatitic melts were involved in metasomatic processes associated with the Kerguelen plume system. These characteristics of carbonatite metasomatism are similar to those found in mantle xenoliths from Samoa and the Society Islands (Schiano et al., 1992; Hauri et al., 1993), indicating that carbonatite metasomatism could be a common mantle process even in oceanic environments. Furthermore, Schiano et al. (1994), found cogenetic carbonate and silicate melt inclusions in peridotites from the Southeastern Province of the Kerguelen Islands, proof that carbonate is at the least present in the mantle beneath Kerguelen. Sample OB93-83 is an extreme case and was metasomatized to the point of having precipitated new clinopyroxene, as well as phlogopite 
and apatite. These minerals are also observed in other examples of carbonatite metasomatism in mantle xenoliths from both continental and oceanic environments (Green and Wallace, 1988; Yaxley et al., 1991; Hauri et al., 1993; Ionov et al., 1993; Rudnick et al., 1993), and thus may a be characteristic of carbonatite metasomatism.

\section{The origin of the precursor harzburgites}

One of the characteristics of the Kerguelen peridotite suites is the ubiquitous occurrence of depleted harzburgites upon which metasomatic signatures were imprinted. As discussed earlier, their major element compositions are inconsistent with their origin as residues of low pressure melting processes. It is thus unlikely that these xenoliths are pieces of oceanic lithosphere upon which the Kerguelen plume impinged.

The argument was presented that residues of melting at high pressure, where melting reactions produce orthopyroxene and consume olivine, could potentially explain the major element compositions of the harzburgites of this study. It was further noted that low-

pressure recrystallization of the experimental residues of Walter (1998) could produce bulk major element compositions similar to the range of those of the Kerguelen harzburgites.

As shown in Figure 2-13, the REE abundance patterns of the clinopyroxenes encountered here are substantially different than those from abyssal peridotites (Johnson et al., 1990) and those from Samoan peridotites (Hauri and Hart, 1994). The strong mid to heavy REE fractionation and characteristic positive $\mathrm{Zr}$ anomalies observed by Hauri and Hart (1994) in clinopyroxenes from the Samoan peridotites led these authors to argue for their origin as recrystallized residues of extensive melting in the presence of garnet. In the case of Kerguelen, the clinopyroxenes from the peridotites are characterized by much less fractionation of the REE and low overall concentrations that are devoid of any recognizable precursor signatures. The following arguments are made to supplement the those made 
from the major elements, but now using trace element abundance patterns in clinopyroxenes in an attempt to understand the history of the Kerguelen peridotites.

Assuming a starting material that has chondritic REE abundances, the bulk rock trace element abundance patterns of the high pressure residues reported in Walter (1998) can be estimated with the mineral-melt partition coefficients recently reported by Salters and Longhi (1999). It is necessary to use these particular partition coefficients in this calculation because the clinopyroxene in Walter's (1998) high pressure residue is pigeonitic and partition coefficients obtained for high-Ca pyroxenes are not relevant. The parameters used to determine the bulk REE abundances of the residue in this calculation were: run 30.07 , at $3.0 \mathrm{GPa}$ and $1530^{\circ} \mathrm{C}$, with olivine + orthopyroxene + subcalcic clinopyroxene with $18.5 \%$ batch melting (from Walter, 1998). The REE abundances of the calcic clinopyroxenes that would be present after the originally high pressure residual harzburgite recrystallizes at low pressures were then calculated. This was done according to the clinopyroxene/orthopyroxene ratio that is predicted from the major element composition of the experimental charge and using clinopyroxene/orthopyroxene partitioning for the REE (Eggins et al., 1998). The results of this calculation predict this low pressure calcic clinopyroxene to have the following chondrite-normalized concentrations: Ce: 0.067 ; Nd: 0.18; Sm: 0.29; Er: 0.62; and Y: 0.65 . These abundances are remarkably close to the those of the LREE-depleted clinopyroxenes found in OB93-307 (Figure 2-14). Similarly LREEdepleted patterns are observed in OB93-95 (cpx2) and OB93-310 and can easily be interpreted in the same manner. Walter (1998) also reports results on residues from different pressures that are both garnet-free harzburgitic as well as olivine-pigeonite, and they could produce similar results as described above. The important point is that the magnitude of REE fractionation for an olivine + orthopyroxene + subcalcic clinopyroxene melt assemblage is much less than that of a garnet-bearing one. 
As shown in Figure 2-14, these LREE-depleted clinopyroxenes coexist with clinopyroxenes that have LREE enriched patterns (OB93-307, "cpx10") or flat patterns (OB93-95) within the same rock. In particular, OB93-307 has clinopyroxenes with extreme LREE abundances, but share identical $\mathrm{Yb}$ and Er concentrations. This demonstrates that originally LREE-depleted patterns were modified by metasomatism to various extents and that HREE concentrations in these clinopyroxenes were maintained during that process.

Most of the harzburgites have clinopyroxenes that possess upward-sloping HREE abundances from Dy to Er to $\mathrm{Yb}$ that are accompanied by relatively flat LREE (Figure 2-15). The observations just mentioned and those on the metasomatized clinopyroxenes (Figure 2-9) clearly suggest that LREE are most susceptible to reaction with LREEenriched melts, whereas the HREE such as Dy, Er and Yb are the last of the REE to be modified during metasomatism. Therefore, this suggests that most of the harzburgite clinopyroxenes originally had LREE-depleted patterns such as OB93-307 or OB93-95 ("cpx2") and were modified by metasomatism. Because the LREE concentrations of these clinopyroxenes are so low ( $« 0.01$ times chondrite), even incipient metasomatism could easily modify light through heavy REE.

On the basis of the discussion presented here, the conclusion is that the majority of the harzburgites in the Kerguelen peridotite suites were originally residues of extensive melting at high pressures. These residues were subsequently metasomatized to vastly different extents by plume-related melts including those that are carbonatitic. Although the model of low pressure recrystallization of high pressure melting accounts for many of the major and trace element characteristics of these harzburgites, it does not predict the low olivine modes (down to $40 \mathrm{wt} . \%$ ) that are present in some of the rocks (OB93-80, OB93-85), and an additional process be involved in the petrogenesis of these two particular olivine-poor and orthopyroxene-rich rocks. 


\section{Lherzolites}

Only one spinel lherzolite (from Lac Superieur, OB93-52) is present in this suite of xenoliths. It is relatively fertile and contains clinopyroxenes and olivines with low $\mathrm{Mg \#}$ relative to the harzburgites $(\mathrm{Mg \#}=92$ and 90 respectively; Table $2-4$, Table $2-6)$. The clinopyroxenes in this xenolith also have the highest $\mathrm{TiO}_{2}$ content of the sample suite $(\sim 0.95 \mathrm{wt} . \%)$. The spinel $\mathrm{Cr} \#$ are among the lowest observed in these xenoliths $(\sim 25$; Table 2-7, Figure 2-5). As previously noted, the major element mineral compositions are similar to but slightly depleted relative to those of the KLB-1 peridotite. Clinopyroxene REE patterns are somewhat LREE depleted $\left([\mathrm{La} / \mathrm{Yb}]_{\mathrm{N}}=0.65\right)$, at about 10 times chondritic abundances (Figure 2-16). These data indicate that sample OB93-52 is a fertile piece of mantle that could be typical of the source of Kerguelen lavas. As discussed below, the Sr, $\mathrm{Nd}$, and Os isotopic composition of this rock support this interpretation. The REE patterns show no signs of metasomatism. This, combined with the fertile nature of the whole rock and mineral geochemistry, argue against a metasomatic origin for this xenolith. Normalized REE contents of melts in equilibrium with these clinopyroxenes lie within the field of REE abundances of Kerguelen basalts (Figure 2-11). Thus, this xenolith is a good candidate for a Kerguelen basalt source, and may represent a piece of unmelted plume mantle.

\section{Wehrlitic dunites}

All minerals from the wehrlitic-dunites (OB93-61c, OB93-64, OB93-82; Lac Superieur only), have significantly lower $\mathrm{Mg \#}$ than the other peridotites in this suite (e.g. olivine Mg\# $=88.3$ to 90.2; Table 2-4, Table 2-6, Table 2-7). Clinopyroxenes contain higher $\mathrm{TiO}_{2}$, $\mathrm{Al}_{2} \mathrm{O}_{3}, \mathrm{Na}_{2} \mathrm{O}$, and $\mathrm{Cr}_{2} \mathrm{O}_{3}$ contents relative to the Lac Superieur harzburgites, and are closer to the abundances observed in clinopyroxene from the Mt. Trapeze harzburgites. The spinels have a variable $\mathrm{Cr} \#$ and are within the range defined by the other peridotites, but are offset to lower Mg\# for a given $\mathrm{Cr}$ (Table 2-7, Figure 2-5). The REE compositions of the 
clinopyroxenes are all similar at approximately 6-10 times chondritic values, though clinopyroxenes from OB93-82 have heterogeneous HREE (Table 2-8, Figure 2-17).

The geochemistry of these rocks indicate that they are not melting residues, nor are they fertile peridotites. However, these data are consistent with both a cumulate and a replacive origin similar to the clinopyroxene-bearing dunites discussed by Kelemen et al. (1995). The clinopyroxenes are in REE equilibrium with Kerguelen Islands basalts (Figure $2-11$ ), and these rocks could be the product of reaction with or cumulates of melts directly connected to Kerguelen Islands basalts. The clinopyroxene trace element variations especially LREE/HREE ratios appear to be correlated with $\mathrm{Mg \# ,} \mathrm{TiO}_{2}$, and $\mathrm{Al}_{2} \mathrm{O}_{3}$ contents, and these features could be attributed to a chromatographic-type reaction with basaltic melt that has equilibrated to different degrees among these samples (Navon and Stolper, 1987; Takazawa et al., 1992; Hauri and Hart, 1994). Although these data do not distinguish between a cumulate or replacive origin for the dunites, they are likely related to the Kerguelen Islands basalts. The isotopic data presented below also support this interpretation.

\section{REE enriched harzburgites}

Clinopyroxenes from the REE enriched harzburgites have unfractionated REE patterns at abundances of approximately 10 times chondritic values (Figure 2-18). This type of harzburgite is only present in the Mt. Trapeze location, but is similar in its REE patterns to the dunite xenoliths from Lac Superieur. Clinopyroxenes from these samples have REE equilibrium melts that are similar to the Kerguelen Islands basalts and may have formed by reaction with this type of melt. Sample OB93-297 belongs to the LREE-enriched group, but its normalized HREE abundances are at approximately 10 times chondrites like the 
enriched samples. This suggests that it may have been an enriched sample before it was yet again metasomatized by a carbonatite melt.

\section{Pyroxenites}

Pyroxenite samples are only present in the Lac Superieur suite and have approximately 10 times chondritic REE concentrations (Table 2-8). On the basis of the REE and mineralogy, there are two compositional types (Figure 2-19): phlogopite-bearing with LREE enriched clinopyroxenes $\left([\mathrm{La} / \mathrm{Yb}]_{\mathrm{N}}=3\right.$ to $6 ; \mathrm{OB} 93-81 \mathrm{~b}$ and OB93-94), and those with LREE depleted clinopyroxenes $\left([\mathrm{La} / \mathrm{Yb}]_{N}=0.3\right.$ to 1$)$. Overall, the six pyroxenites are close to trace element equilibrium with Kerguelen basalts. This, and that they are megacrystic suggests that they are probably high pressure cumulates of Kerguelen magmatism (e.g. Irving and Frey, 1984).

\subsubsection{Isotopic compositions of $\mathrm{Sr}, \mathrm{Nd}$ and $\mathrm{Os}$ $\mathrm{Sr}$ and $\mathrm{Nd}$ isotopes}

The $\mathrm{Sr}$ and $\mathrm{Nd}$ isotopic compositions of clinopyroxenes are summarized in Table $2-9$ and shown in Figure 2-20. The total ranges of the isotopic compositions observed in this study far exceed those of Kerguelen basalts and are greater than the published datasets on the Kerguelen system (Gautier et al., 1990; Weis and Frey, 1991; Weis et al., 1993; Barling et al., 1994; Mattielli et al., 1996; Weis et al., 1998; Yang et al., 1998a).

The lherzolite sample (OB93-52) falls within the center of the range of Sr and $\mathrm{Nd}$ isotopic compositions of Kerguelen basalts $\left({ }^{87} \mathrm{Sr} /{ }^{86} \mathrm{Sr}=0.705205, \varepsilon_{\mathrm{Nd}}=-0.3\right)$, consistent with its proposed origin as a piece of fertile plume mantle. The isotopic composition of dunite sample OB93-64 is also similar to Kerguelen basalts $\left({ }^{87} \mathrm{Sr} /{ }^{86} \mathrm{Sr}=0.705238, \varepsilon_{\mathrm{Nd}}=\right.$ 
$-2.5)$. That this sample is nearly in $\mathrm{Sr}$ and $\mathrm{Nd}$ isotopic equilibrium with Kerguelen basalts is consistent with either of the proposed origins for the dunites.

At the "isotopically depleted" end of the spectrum is harzburgite OB93-78, with ${ }^{87} \mathrm{Sr} /{ }^{86} \mathrm{Sr}=0.70330$. The Nd content and the abundance of clinopyroxene in this rock are so low that an attempt to measure the Nd isotopic composition was unsuccessful (Dr. E. Nakamura at Okayama University). This is one of the most depleted samples among the rocks in this study, and despite its slightly LREE-depleted pattern (see Figure 2-15) it is uncertain whether any metasomatic changes have occurred. Because of the ${ }^{87} \mathrm{Sr} /{ }^{86} \mathrm{Sr}$ of clinopyroxene from this rock, which is within the range of SEIR basalts and lower than any known Kerguelen samples, the provenance of this xenolith is important. Although the olivine composition is not available for this rock, the whole-rock major element composition $\left(\mathrm{Mg} \#=91.6, \mathrm{SiO}_{2}=48.79 \mathrm{wt} . \%\right.$, Table 2-2) strongly indicates that this sample could well plot off the oceanic trend together with the other harzburgites from Kerguelen (Figure 2-3). If this were the case, and if it were taken to suggest its origin as a high pressure residue that was recrystallized at low pressure, like many of the other harzburgites, the ${ }^{87} \mathrm{Sr}{ }^{86} \mathrm{Sr}$ data might have to be considered as defining the most depleted member of the Kerguelen plume observed thus far. The most depleted isotopic compositions known were reported by White and Hofmann (1982) on basalts from Foch Island $\left({ }^{87} \mathrm{Sr} /{ }^{86} \mathrm{Sr}=0.70388,{ }^{143} \mathrm{Nd} /{ }^{144} \mathrm{Nd}=0.51291\right.$ ), northern Kerguelen Islands (Figure 1-1). An alternative scenario for the origin of this rock is that a recrystallized high-pressure residue was originally LREE depleted was metasomatized by MORB melt from the SEIR. This process would have increased the LREE, but not affected the ${ }^{87} \mathrm{Sr} /{ }^{86} \mathrm{Sr}$. The Os isotopic composition (see below) is ${ }^{187} \mathrm{Os} /{ }^{188} \mathrm{Os}=0.1266$, indistinguishable from many of the other harzburgites and is not definitive for the provenance of this rock. 
At the most "isotopically enriched" end of the spectrum is a megacrystic clinopyroxenite, OB93-94, with ${ }^{87} \mathrm{Sr} /{ }^{86} \mathrm{Sr}=0.70869$ and ${ }^{143} \mathrm{Nd} /{ }^{144} \mathrm{Nd}=0.51199\left(\varepsilon_{\mathrm{ND}}=\right.$ $-12.7)$. This is the most enriched isotopic composition that has been observed in any rocks from the Kerguelen Islands. Basalts from ODP drill-site 738 in the southern Kerguelen Plateau $\left(62^{\circ} 42 \mathrm{~S}, 82^{\circ} 47^{\prime} \mathrm{E}\right.$, Figure1-1) have eruption age corrected ${ }^{87} \mathrm{Sr} /{ }^{86} \mathrm{Sr}=0.7090$ to 0.7130 and $\varepsilon_{\mathrm{ND}}=-7$ to -13 (Alibert, 1991; Mahoney et al., 1994). These isotopic signatures were interpreted as being derived from the incorporation of old subcontinental lithosphere beneath Gondwanaland. Mahoney et al. (1994) reported similar isotopic compositions for basalts from the Naturaliste Plateau, and argued that contamination by continental lithosphere produced these isotopic signatures as well. One of the basalts (in the late Pleistocene-Holocene Big Ben series) from Heard Island, also believed to be derived from the Kerguelen plume, has ${ }^{87} \mathrm{Sr} /{ }^{86} \mathrm{Sr}=0.70792$ and ${ }^{143} \mathrm{Nd} /{ }^{144} \mathrm{Nd}=0.51239$ (Barling et al., 1994). These authors postulated that recycling of upper crustal material that had previously been subducted beneath a continental precursor of Gondwanaland produced this isotopic signature.

Sample OB93-94, as noted above, is a cumulate from a melt with trace element characteristics similar to those of the Kerguelen Islands basalts, and was subsequently ( $\sim 20$ $\mathrm{Ma}$, on the basis of a two-point $\mathrm{Rb}$-Sr isochron for the phlogopite-clinopyroxene pair) metasomatized to produce phlogopite. Incorporating the Heard Island isotopic data with the present dataset significantly enlarges the ranges of $\mathrm{Sr}$ and $\mathrm{Nd}$ isotopic compositions of the Kerguelen plume as a whole, in comparison to the Kerguelen basalts alone. Overall, these data appear to encompass the isotopic ranges observed in the present study, except for the isotopically depleted OB93-78. 
The Sr and Nd isotopic compositions of clinopyroxene from peridotites of this study and clinopyroxene data from Mattielli et al. (1996) and Mattielli et al. (1999) plot near the isotopically enriched end of the Kerguelen basalts and extend into the ranges of the Heard Island basalts (Figure 2-20). The host dike that brought the xenoliths to the surface has ${ }^{87} \mathrm{Sr} /{ }^{86} \mathrm{Sr}=0.70638$ and ${ }^{143} \mathrm{Nd} /{ }^{144} \mathrm{Nd}=0.51242$, isotopically more enriched than any basalts that have been analyzed from the Kerguelen Islands. It is, however, well within the ranges for the Heard Island basalts (Barling et al., 1994) and a legitimate member of the Kerguelen plume diversity. Note also that OB93-52, the alleged unmelted Kerguelen plume peridotite, possesses $\mathrm{Sr}$ and $\mathrm{Nd}$ isotopic compositions typical for the Kerguelen basalts.

Samples OB93-51 and OB93-83 were identified as being metasomatized by carbonatitic melts. In this sense, it is notable that their $\mathrm{Sr}$ and $\mathrm{Nd}$ isotopic compositions are identical, suggesting a unique carbonatitic component in the plume. However, Mattielli et al. (1999) reported the $\mathrm{Sr}$ and $\mathrm{Nd}$ isotope data for a harzburgitic clinopyroxene that was evidently metasomatized by carbonatite, but is not as isotopically enriched as these two samples (see Figure 2-20). This data point appears to indicate that the "carbonate components" of the Kerguelen plume are also isotopically heterogeneous

As discussed earlier, when trace element-enriched plume melts interact with depleted peridotites, the $\mathrm{Sr}$ and $\mathrm{Nd}$ isotopic compositions of the melts would remain unchanged, whereas the $\mathrm{Sr}$ in the peridotites would be equilibrated with the infiltrating melts. A study by Lesher et al. (1990) of isotopic v. chemical equilibration rates during magma mixing demonstrated that isotopic equilibration is achieved much faster than chemical equilibration during the mixing of melts. On the basis of this result, it is possible that during melt-rock reaction processes such as those observed here, isotopic exchange could occur more quickly than trace element equilibrium. Therefore, this suggests that even for samples with signatures of incomplete reactions with infiltrating melt (e.g. clinopyroxenes with highly 
heterogeneous trace element abundance patterns in individual rocks), the incompatible element isotopic compositions would be completely dominated by the plume-derived melts. Taking this idea one step further, the diversity of the $\mathrm{Sr}$ and $\mathrm{Nd}$ isotopic compositions observed here could be evidence for isotopic heterogeneities of the Kerguelen plume that are much larger than that sampled by Kerguelen Islands basalts.

In the two xenoliths where clinopyroxene-phlogopite pairs were analyzed (OB93-83, OB93-94), a two-point Rb-Sr isochron gives an "age" of $18 \mathrm{Ma}$ for OB93-83 and $20 \mathrm{Ma}$ for OB93-94. As described before, OB93-83 is fully equilibrated with the metasomatic agent, and clinopyroxene and phlogopite may have formed under isotopic equilibrium. If this is true, the two-point isochron could have significant meaning, namely the time when metasomatism occurred. Sample OB93-94 however, is a clinopyroxene substrate into which a phlogopite-producing melt infiltrated and isotopic equilibrium between clinopyroxene and phlogopite may not have been achieved. Thus, it is equivocal whether if these ages have significance.

\section{Os isotopes}

It has been well documented that the Os isotopic composition of peridotites are insensitive to melt-rock interaction due to the compatible character of Os in the peridotite-basalt system (Morgan et al., 1981; Walker et al., 1989; Pearson et al., 1995; Hart and Ravizza, 1996). It follows that interaction between plume-derived melts and peridotites should not modify the Os isotopes of the peridotites, but those of the melts could be equilibrated with the peridotites. For instance, Hauri (1997) concluded that partial melts of pyroxenites should acquire the Os isotopic signature of the peridotite through which is traveling within a distance of 200 to $1000 \mathrm{~m}$. The data from this study indicates that the major elements and incompatible trace elements are decoupled. Figure 2-21 shows that there is no relation 
between Os isotopic composition and bulk $\mathrm{Al}_{2} \mathrm{O}_{3}$ contents nor with $[\mathrm{La} / \mathrm{Yb}]_{N}$, demonstrating that the metasomatism in this case did not include Os.

On the basis of this discussion, the Os isotope compositions of peridotite xenoliths can be used to decipher their provenance. For the Kerguelen plume, which has evolved through different geodynamic environments, the provenance of peridotite xenoliths could shed new light on the dynamics of mantle plumes. The results of the Os isotope analysis of peridotite xenoliths are one of the major contributions of this study and are presented in Chapter 3 .

The ${ }^{187} \mathrm{Os} /{ }^{188} \mathrm{Os}$ of whole-rock peridotites show that these that they have differing provenance. Many of the samples from Mt. Trapeze have an origin in the Gondwanaland subcontinental lithospheric mantle (Hassler and Shimizu, 1998). It is important to note here that significant isotopic heterogeneities exist among peridotites of non-Gondwanaland origin (all samples from Lac Superieur and OB93-306 and OB93-314). Table 2-10 shows that ${ }^{187} \mathrm{Os} /{ }^{188} \mathrm{Os}$ varies from 0.1252 to 0.1383 , covering a significant portion of the Os isotopic variations reported for individual plume systems. For instance, this range covers all but one sample of the Loa trend of Hawaii discussed by Hauri (1996), showing that the peridotite "matrix" of a plume system could contain a large indigenous Os isotopic variability. Possible correlations between Os and other isotopes are not discussed here, because as noted earlier, the $\mathrm{Sr}$ and $\mathrm{Nd}$ compositions in clinopyroxenes are dominated by plume-derived melts, but the Os compositions are primary. Therefore, identifying the less radiogenic end of the spectrum (excluding the extreme unradiogenic samples) with the modern-day oceanic lithosphere is tempting but not straightforward. This is because the major element and mineralogy-based discussion given earlier implies that the bulk of the harzburgites are recrystallized residues of high-pressure melting and thus members of the plume, rather than modern oceanic lithosphere. 


\subsection{Summary}

The results of this study of ultramafic xenoliths from the Courbet Peninsula, Kerguelen Islands provide the following conclusions:

1. Harzburgites, a lherzolite, wehrlitic dunites, and pyroxenites comprise the ultramafic xenolith suites. The harzburgites of the suite have the highest whole rock Mg\#, followed by the lherzolite, and the wehrlitic dunites and pyroxenites. The harzburgites are depleted in basaltic components. Many of the harzburgites plot off the oceanic trend that is defined by the relationship between modal abundances of olivine and olivine composition. This indicates that these rocks did not form by a simple melting process. However, residues of melting at high pressures that recrystallized at lower pressure, could create the olivine modes and compositions of some of the harzburgites observed here. The composition of the lherzolite is fertile and lies on the oceanic trend. Its composition is similar to those of fertile peridotites such as KLB-1 from Kilborne Hole, NM.

2. The major element compositions of minerals that make up these rocks also reflect their depleted character in the case of the harzburgites, or the degree of fertility for the lherzolite. In situ trace element compositions of clinopyroxenes as determined by ion microprobe, are correlated with the petrographic occurrence of clinopyroxene and indicate their mechanism of formation. The total range of REE content is large, and varies by a factor of 5000 in the Lac Superieur suite. Large REE variations are also present within single samples, and these REE differences correspond to clinopyroxene texture. Discrete clinopyroxenes have significant elevations in their REE contents relative to those that occur in symplectite intergrowths with spinel. Clinopyroxenes from some samples record successive metasomatic modifications of originally depleted 
clinopyroxenes as well as the precipitation of new grains that are equilibrated with the metasomatic melt. This type of successive REE variation in clinopyroxenes occurs by a chromatographic melt-mantle reaction mechanism.

3. Trace element abundances of melts in equilibrium with the clinopyroxenes from these rocks indicate carbonatite melts and alkaline basalts as the metasomatic agents. The low pressure recrystallization of high pressure residues model that was developed from major element considerations is also supported by the clinopyroxene trace element compositions. The LREE depleted nature of clinopyroxenes from some of these harzburgites can be recreated by this model. Other REE enriched harzburgites, the lherzolite, the wehrlitic dunites and the pyroxenites all have trace element characteristics indicative of a relation to the Kerguelen Islands basalts.

4. The $\mathrm{Sr}$ and $\mathrm{Nd}$ isotopic compositions of clinopyroxenes from the peridotites were dominated by the infiltrating melts. The lherzolite lies in the center of the field defined by the basalts, further supporting the idea that it is a piece of unmelted plume mantle. The ranges of isotopic composition of the xenoliths are much larger than those observed thus far for the Kerguelen Islands basalts, and it is possible that all of these compositions are associated with the Kerguelen plume. One sample, a pyroxenite is extreme in its isotopic enrichment, and probably formed as a cumulate from magmas that were contaminated by continental crust.

5. The Osmium isotopic compositions show that subcontinental lithosphere, probably stranded from the rifting of Gondwanaland, are present beneath the Kerguelen Islands. The remaining samples cover a significant portion of the ${ }^{187} \mathrm{Os} /{ }^{188} \mathrm{Os}$ ranges reported on basalts from other plumes, demonstrating that the Kerguelen plume may have a diverse Os isotopic composition. 


\subsection{References Cited}

Albee A. L. and Ray L. (1970) Correction factors for electron microprobe analysis of silicates, oxides, carbonates, phosphates and sulfates. Anal. Chem. 42, 14081414.

Alibert C. (1991) Mineralogy and geochemistry of a basalt from site 738: implications for the tectonic history of the southernmost part of the Kerguelen Plateau. In Proceedings of the Ocean Drilling Program, Scientific Results, Vol. 119 (ed. J. Barron, B. Larsen, and et al.), pp. 293-298. Ocean Drilling Program.

Anders E. and Grevesse N. (1989) Abundances of the elements: Meteoritic and solar. Geochim. Cosmochim. Acta 53, 197-214.

Barling J., Goldstein S. L., and Nicholls I. A. (1994) Geochemistry of Heard Island (southern Indian Ocean): characterization of an enriched mantle component and implications for enrichment of the sub-Indian Ocean mantle. J. Petrol. 35, 1017 . 1053.

Bence A. E. and Albee A. L. (1968) Empirical correction factors for the electron microanalysis of silicates and oxides. J. Geol. 76, 382-403.

Bodinier J. L., Vasseur G., Vernieres J., Dupuy C., and Fabries J. (1990) Mechanisms of mantle metasomatism: geochemical evidence from the Lherz orogenic peridotite. $J$. Petrol. 31, 597-628.

Boyd F. R. (1973) A pyroxene geotherm. Geochim. Cosmochim. Acta 37, 2533-2546.

Boyd F. R. (1989) Compositional distinction between oceanic and cratonic lithosphere. Earth Planet. Sci. Lett. 96, 15-26.

Boyd F. R., Pokhilenko N. P., Pearson D. G., Mertzman S. A., Sobolev N. V., and Finger L. W. (1997) Composition of the Siberian cratonic mantle: evidence from Udachnaya peridotite xenoliths. Cont. Mineral. Petrol.128, 228-246.

Carlson R. W. and Irving A. J. (1994) Depletion and enrichment history of subcontinental lithospheric mantle: An $\mathrm{Os}, \mathrm{Sr}, \mathrm{Nd}$ and $\mathrm{Pb}$ isotopic study of ultramafic xenoliths from the northwestern Wyoming Craton. Earth Planet. Sci. Lett. 126, 457-472.

Davies H. L., Sun S.-S., Frey F. A., Gautier I., McCulloch M. T., Price R. C., Bassias Y., Klotwijk C. T., and Leclaire L. (1989) Basalt basement from the Kerguelen Plateau and the trail of Dupal plume. Contrib. Mineral. Petrol. 103, 457-469.

Dick H. J. B. and Bullen T. (1984) Chromian spinel as a petrogenetic indicator in abyssal and alpine-type peridotites and spatially associated lavas. Cont. Mineral. Petrol. 86, 54-76.

Dosso L., Bougault H., Beuzart P., Calvez J.-Y., and Joron J.-L. (1988) The geochemical structure of the South-East Indian Ridge. Earth Planet. Sci. Lett. 88, 47-59.

Eggins S. M., Rudnick R. L., and McDonough W. F. (1998) The composition of peridotites and their minerals: a laser-ablation ICP-MS study. Earth Planet. Sci. Lett. 154, 53-71.

Frey F., A. and Green D. H. (1974) The mineralogy, geochemistry and origin of lherzolite inclusions in Victorian basanites. Geochim. Cosmochim. Acta 38, 1023-1059.

Gautier I., Weis D., Mennessier J.-P., Vidal P., Giret A., and Loubet M. (1990) Petrology and geochemistry of the Kerguelen Archipelago basalts (South Indian 
Ocean): evolution of the mantle sources from ridge to intraplate position. Earth Planet. Sci. Lett. 100, 59-76.

Green D. H. and Wallace M. E. (1988) Mantle metasomatism by ephemeral carbonatite melts. Nature 336, 459-462.

Grègoire M. (1994) Pètrologie des enclaves ultrabasiques and basiques des îles Kerguelen (T.A.A.F.). Les contraintes minèralogiques et thermobaromètriques et leurs implications gèodynamiques. PhD Thesis, Université Jean Monnet-St. Etienne.

Hart S. R. and Ravizza G. E. (1996) Os partitioning between phases in lherzolite and basalt. In Earth Processes: Reading the Isotopic Code, Vol. 95 (ed. A. Basu and S. R. Hart), pp. 123-134. American Geophysical Union.

Hassler D. R. and Shimizu N. (1998) Osmium isotopic evidence for ancient subcontinental lithospheric mantle beneath the Kerguelen Islands, Southern Indian Ocean. Science 280, 418-421.

Hauri E. H. (1996) Major-element variability in the Hawaiian mantle plume. Nature 382, 415-419.

Hauri E. H. (1997) Melt migration and mantle chromatography; 1, Simplified theory and conditions for chemical and isotopic decoupling. Earth Planet. Sci. Lett. 153, 119.

Hauri E. H. and Hart S. R. (1993) Re-Os isotope systematics of HIMU and EMII oceanic island basalts from the south Pacific Ocean. Earth Planet. Sci. Lett. 114, 353-371.

Hauri E. H. and Hart S. R. (1994) Constraints on melt migration from mantle plumes: A trace element study of peridotite xenoliths from Savai'i, Western Samoa. $J$. Geophys. Res. 99, 24,301-24,321.

Hauri E. H., Shimizu N., Dieu J. J., and Hart S. R. (1993) Evidence for hotspot-related carbonatite metasomatism in the oceanic upper mantle. Nature 365, 221-227.

Horwitz E. P., Dietz M. L., and Fisher D. E. (1991) Separation and preconcentration of strontium from biological, environmental, and nuclear waste samples by extraction chromatography using a crown ether. Anal. Chem. 63, 522-525.

Ionov D. A., Dupuy C., O'Reilly S. Y., Kopylova M. G., and Genshaft Y. S. (1993) Carbonated peridotite xenoliths from Spitsbergen: implication for trace element signature of mantle carbonate metasomatism. Earth Planet. Sci. Lett. 119, 283297.

Irving A. J. and Frey F. A. (1984) Trace element abundances in megacrysts and their host basalts: constraints on partition coefficients and megacryst genesis. Geochim. Cosmochim. Acta 48, 1201-1221.

Johnson K. T. M., Dick H. J. B., and Shimizu N. (1990) Melting in the oceanic upper mantle: an ion microprobe study of diopsides in abyssal peridotites. J. Geophys. Res. 95, 2661-2678.

Kelemen P. B., Hart S. R., and Bernstein S. (1998) Silica enrichment in the continental upper mantle via melt/rock reaction. Earth Planet. Sci. Lett. 164, 387-406.

Kelemen P. B., Shimizu N., and Salters V. J. M. (1995) Extraction of mid-ocean-ridge basalt from the upwelling mantle by focused flow of melt in dunite channels. Nature 375, 747-753.

Kinzler R. J. (1997) Melting of mantle peridotites at pressures approaching the spinel to garnet transition. J. Geophys. Res. 102.

Kinzler R. J. and Grove T. L. (1992) Primary magmas of mid-ocean ridge basalts 1 . Experiments and methods. J. Geophys. Res. 97, 6885-6906. 
Lesher C. E. (1990) Decoupling of chemical and isotopic exchange during magma mixing. Nature 344, 235-237.

Mahoney J. J., Jones W. B., Frey F. A., Salters V. J. M., Pyle D. G., and Davies H. L. (1994) Geochemical characteristics of lavas from Broken Ridge, the Naturaliste Plateau, and southernmost Kerguelen Plateau: Cretaceous Plateau volcanism in the southeast Indian Ocean. Chem. Geol. 120, 315-345.

Mattielli N. (1996) Magmatisme et métasomatisme associés au panache des Kerguelen: Contribution de la géochimie des enclaves basiques et ultrabasiques. $\mathrm{PhD}$ Thesis, Université Libre de Bruxelles.

Mattielli N., Weis D., Grégoire M., Mennessier J. P., Cottin J. Y., and Giret A. (1996) Kerguelen basic and ultrabasic xenoliths: evidence for long-lived Kerguelen hotspot activity. Lithos 37, 261-280.

Mattielli N., Weis D., Scoates J. S., Shimizu N., Mennessier J.-P., Grègoire M., Cottin J.-Y., and Giret A. (1999) Evolution of heterogeneous lithospheric mantle in a plume environment beneath the Kerguelen Archipelago. J. Petrol. in press.

Menzies M. A. e. and Hawkesworth C. J. e. (1987) Mantle metasomatism, pp. 472.

Michard A., Montigny R., and Schlich R. (1986) Geochemistry of the mantle beneath the Rodriguez Triple Junction and the South-East Indian Ridge. Earth Planet. Sci. Lett. 78, 104-114.

Morgan J. W., Wandless G. A., Petrie R. K., and Irving A. J. (1981) Composition of the earth's upper mantle-I. Siderophile trace elements in ultramafic nodules. Tectonophys. 75, 47-67.

Navon O. and Stolper E. (1987) Geochemical consequences of melt percolation: the upper mantle as a chromatographic column. J. Geol. 95, 285-307.

Nelson D. R., Chivas A. R., Chappell B. W., and McCulloch M. T. (1988) Geochemical and isotopic systematics in carbonatites and implications for the evolution of oceanisland sources. Geochim. Cosmochim. Acta 52, 1-17.

Niu Y., Langmuir C. H., and Kinzler R. J. (1997) The origin of abyssal peridotites: a new perspective. Earth Planet. Sci. Lett. 152, 251-265.

Pearson D. G., Carlson R. W., Shirey S. B., Boyd F. R., and Nixon P. H. (1995) Stabilization of Archean lithospheric mantle: A Re-Os isotope study of peridotite xenoliths from the Kaapvaal craton. Earth Planet. Sci. Lett. 134, 341-357.

Pin C. and Bassin C. (1992) Evaluation for a strontium-specific extraction chromatographic method for isotopic analysis in geological materials. Analytica Chimica Acta 269, 249-255.

Ravizza G. (1993) Variations of the ${ }^{187} \mathrm{Os} / 186$ Os ratio of seawater over the past 28 million years as inferred from metalliferous carbonates. Earth Planet. Sci. Lett. 118, 335348.

Richard P., Shimizu N., and Allègre C. J. (1976) ${ }^{143} \mathrm{Nd} / 146 \mathrm{Nd}$, A natural tracer: an application to oceanic basalts. Earth Planet. Sci. Lett. 31, 269-278.

Rudnick R. L., McDonough W. F., and Chappell B. W. (1993) Carbonatite metasomatism in the northern Tanzanian mantle: petrographic and geochemical characteristics. Earth Planet. Sci. Lett. 114, 463-475.

Salters V. J. M. and Longhi J. (1999) Trace element partitioning during the initial stages of melting beneath mid-ocean ridges. Earth Planet. Sci. Lett. 166, 15-30. 
Schiano P. and Clocchiatti R. (1994) Worldwide occurrence of silica-rich melts in subcontinental and sub-oceanic mantle minerals. Nature 368, 621-624.

Schiano P., Clocchiatti R., and Joron J. L. (1992) Melt and fluid inclusions in basalts and xenoliths from Tahaa Island, Society archipelago: evidence for a metasomatized upper mantle. Earth Planet. Sci. Lett. 111, 69-82.

Schiano P., Clocchiatti R., Shimizu N., Weis D., and Mattielli N. (1994) Cogenetic silicarich and carbonate-rich melts trapped in mantle minerals in Kerguelen ultramafic xenoliths: Implications for metasomatism in the oceanic upper mantle. Earth Planet. Sci. Lett. 123, 167 - 178.

Sen G. (1988) Petrogenesis of spinel lherzolite and pyroxenite suite xenoliths from the Koolau shield, Oahu, Hawaii: Implications for petrology of the post-eruptive lithosphere beneath Oahu. Contrib. Miner. Petrol. 100, 61-91.

Sen G., Frey F. A., Shimizu N., and Leeman W. P. (1993) Evolution of the lithosphere beneath Oahu, Hawaii: rare earth element abundances in mantle xenoliths. Earth Planet. Sci. Lett. 119, 53-69.

Shimizu N. and Hart S. R. (1982) Applications of the ion microprobe to geochemistry and cosmochemistry. Ann. Rev. Earth Planet. Sci. 10, 483-526.

Shimizu N., Pokhilenko N. P., Boyd F. R., and Pearson D. G. (1997) Geochemical characteristics of mantle xenoliths from the Udachnaya kimberlite pipe. Russian Geology and Geophysics 38, 205-217.

Streckheisen A. L. (1973) Plutonic rocks: classification and nomenclature recommended by the IUGS Subcommission on the Systematics of Igneous Rocks. Geotimes, 26-30.

Takahashi E. (1986) Melting of dry peridotite KLB-1 up to 15 GPa: implications on the origin of peridotitic upper mantle. J. Geophys. Res. 91, 9367-9382.

Takazawa E., Frey F. A., Shimizu N., Obata M., and Bodinier J. L. (1992) Geochemical evidence for melt migration and reaction in the upper mantle. Nature 359, 55-58.

Taras B. D. and Hart S. R. (1987) Geochemical evolution of the New England Seamount Chain: isotopic and trace element constraints. Chem. Geol. 64, 35-54.

Walker R. J., Carlson R. W., Shirey S. B., and Boyd F. R. (1989) Os, Sr, Nd, Pb isotope systematics of southern African peridotite xenoliths: Implications for the chemical evolution of subcontinental mantle. Geochim. Cosmochim. Acta 53, 1583-1595.

Walter M. J. (1998) Melting of garnet peridotite and the origin of komatiite and depleted lithosphere. J. Petrol. 39, 29-60.

Walter M. J., Sisson T. W., and Presnall D. C. (1995) A mass proportion method for calculating melting reactions and application to melting of model upper mantle lherzolite. Earth Planet. Sci. Lett. 135, 77-90.

Weis D. and Frey F. A. (1991) Isotope geochemistry of Ninetyeast Ridge basement basalts: $\mathrm{Sr}, \mathrm{Nd}$, and $\mathrm{Pb}$ evidence for involvement of the Kerguelen hot spot. In Proc. ODP, Sci. Results, Vol. 121 (ed. J. Weissel, J. Peirce, E. Taylor, J. Alt, and e. al.), pp. 591 - 610. Ocean Drilling Program.

Weis D., Frey F. A., Giret A., and Cantagrel J.-M. (1998) Geochemical characteristics of the youngest volcano (Mount Ross) in the Kerguelen Archipelago: inferences for magma flux, lithosphere assimilation and composition of the Kerguelen plume. $J$. Petrol. 39, 973-994. 
Weis D., Frey F. A., Leyrit H., and Gautier I. (1993) Kerguelen Archipelago revisited: geochemical and isotopic study of the Southeast Province lavas. Earth Planet. Sci. Lett. 118, $101-119$.

White W. M. and Hofmann A. W. (1982) Sr and Nd isotope geochemistry of oceanic basalts and mantle evolution. Nature 296, 821-825.

Yang H.-J., Frey F. A., Weis D., Giret A., Pyle D., and Michon G. (1998a) Petrogenesis of the flood basalts forming the northern Kerguelen Archipelago: implications for the Kerguelen plume. J. Petrol. 39, 711-748.

Yang H.-J., Sen G., and Shimizu N. (1998b) Mid-ocean ridge melting: constraints from lithospheric xenoliths at Oahu, Hawaii. J. Petrol. 39, 277-295.

Yaxley G. M., Crawford A. J., and Green D. H. (1991) Evidence for carbonatite metasomatism in spinel peridotite xenoliths from western Victoria, Australia. Earth Planet. Sci. Lett. 107, 305-317.

Zindler A. (1980) Geochemical Processes in the Earth's Mantle and the Nature of CrustMantle Interactions: Evidence from Studies of Nd and Sr Isotope Ratios in MantleDerived Igneous Rocks and Lherzolite Nodules. PhD Thesis, Massachusetts Institute of Technology. 


\subsection{Tables}

Table 2-1.List of samples.

\begin{tabular}{|c|c|c|c|c|c|}
\hline Sample List & Lac Superieur & Mt.Trapeze & & c Superieur & Mt.Trapeze \\
\hline \multirow[t]{15}{*}{ REE depleted samples } & OB93-53 & OB93-289 & REE enriched samples & & OB93-283 \\
\hline & OB93-56 & OB93-314 & & & OB93-284 \\
\hline & OB93-58 & OB93-314 & & & OB93-297 \\
\hline & OB93-66 & & & & OB93-305 \\
\hline & OB93-74 & & & & OB93-306 \\
\hline & OB93-77 & & & & \\
\hline & OB93-78 & & Heterogeneous REE samples & OB93-51 & OB93-282 \\
\hline & OB93-79 & & & OB93-99 & OB93-299 \\
\hline & OB93-80 & & & & OB93-318 \\
\hline & OB93-81c & & & & \\
\hline & OB93-85 & & Iherzolite & OB93-52 & \\
\hline & OB93-86 & & & & \\
\hline & OB93-89 & & wehrlitic dunites & OB93-61c & \\
\hline & OB93-98 & & & OB93-64 & \\
\hline & & & & OB93-82 & \\
\hline \multirow[t]{3}{*}{ LREE depleted samples } & OB93-95 & OB93-307 & & & \\
\hline & & OB93-310 & Pyoxenites & OB93-75 & \\
\hline & & & & OB $93-87$ & \\
\hline \multirow[t]{12}{*}{ LREE enriched samples } & OB $93-83$ & OB93-280 & & OB93-100 & \\
\hline & & OB93-281 & & OB93-102 & \\
\hline & & OB93-286 & & OB93-81b & \\
\hline & & OB93-287 & & OB93-94 & \\
\hline & & OB93-288 & & & \\
\hline & & OB93-291 & & & \\
\hline & & OB93-298 & & & \\
\hline & & OB93-301 & & & \\
\hline & & OB93-302 & & & \\
\hline & & OB93-308 & & & \\
\hline & & OB93-309 & & & \\
\hline & & OB93-313 & & & \\
\hline
\end{tabular}


Table 2-2. Bulk rock major and trace element compositions of selected xenoliths.

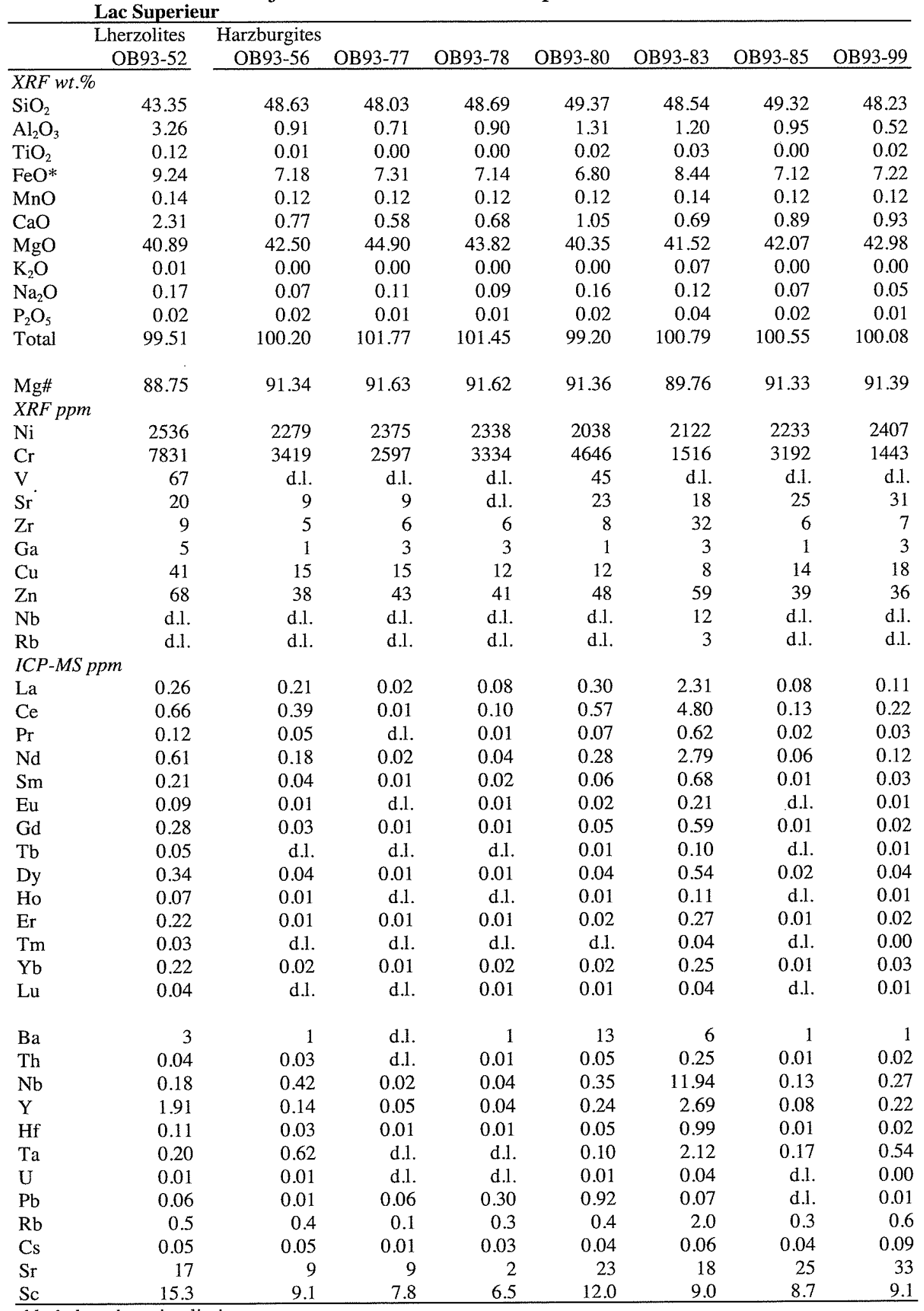

d.1.: below detection limit 
Table 2-2. Continued.

Lac Superieur

Mt. Trapeze

Dunites Harzburgites

\begin{tabular}{|c|c|c|c|c|c|c|c|c|}
\hline \multicolumn{3}{|c|}{ 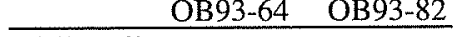 } & \multicolumn{2}{|l|}{$\mathrm{OB}$} & \multirow{2}{*}{\multicolumn{2}{|c|}{ ה }} & \multirow[t]{2}{*}{ UD $98-291$} & \multirow[t]{2}{*}{$407 x-2>1$} \\
\hline$\overline{X R F}$ n & & & & & & & & \\
\hline $\mathrm{SiO}_{2}$ & 43.25 & 44.08 & 48.58 & 47.41 & 44.70 & 48.52 & 47.45 & 45.36 \\
\hline $\mathrm{Al}_{2} \mathrm{O}_{3}$ & 1.33 & 1.12 & 0.98 & 0.85 & 0.55 & 1.14 & 0.66 & 0.60 \\
\hline $\mathrm{TiO}_{2}$ & 0.04 & 0.05 & 0.01 & 0.01 & 0.01 & 0.02 & 0.02 & 0.02 \\
\hline $\mathrm{FeO}^{*}$ & 10.45 & 10.65 & 6.94 & 7.51 & 8.19 & 7.99 & 7.69 & 8.31 \\
\hline $\mathrm{MnO}$ & 0.16 & 0.16 & 0.12 & 0.14 & 0.16 & 0.13 & 0.14 & 0.17 \\
\hline $\mathrm{CaO}$ & 0.43 & 1.00 & 0.51 & 1.21 & 1.06 & 0.67 & 1.05 & 0.78 \\
\hline $\mathrm{MgO}$ & 44.51 & 43.42 & 44.15 & 43.19 & 45.48 & 42.80 & 44.24 & 45.90 \\
\hline $\mathrm{K}_{2} \mathrm{O}$ & 0.00 & 0.00 & 0.00 & 0.00 & 0.00 & 0.00 & 0.00 & 0.00 \\
\hline $\mathrm{Na}_{2} \mathrm{O}$ & 0.10 & 0.09 & 0.11 & 0.15 & 0.09 & 0.14 & 0.16 & 0.10 \\
\hline $\mathrm{P}_{2} \mathrm{O}_{5}$ & 0.02 & 0.02 & 0.01 & 0.02 & 0.02 & 0.01 & 0.02 & 0.02 \\
\hline Total & 100.28 & 100.59 & 101.41 & 100.48 & 100.26 & 101.42 & 101.42 & 101.26 \\
\hline $\mathrm{Mg} \#$ & 88.36 & 87.90 & 91.90 & 91.11 & 90.82 & 90.52 & 91.12 & 90.78 \\
\hline$X R F P$ & & & & & & & & \\
\hline $\mathrm{Ni}$ & 2462 & 2724 & 2273 & 2259 & 2499 & 2209 & 2305 & 2656 \\
\hline $\mathrm{Cr}$ & 8716 & 3771 & 3772 & 1541 & 2631 & 2740 & 2162 & 2305 \\
\hline $\mathrm{V}$ & 37 & 37 & 33 & d.l. & d.l. & 35 & d.1. & d.l. \\
\hline $\mathrm{Sr}$ & d.l. & 23 & d.1. & 24 & 25 & 4 & 85 & 24 \\
\hline $\mathrm{Zr}$ & 8 & 8 & 6 & 7 & 10 & 7 & 10 & 10 \\
\hline $\mathrm{Ga}$ & 2 & 4 & 5 & 2 & 8 & 2 & 4 & 3 \\
\hline $\mathrm{Cu}$ & 10 & 11 & 13 & 12 & 15 & 16 & 12 & 21 \\
\hline $\mathrm{Zn}$ & 77 & 61 & 46 & 41 & 45 & 49 & 40 & 48 \\
\hline $\mathrm{Nb}$ & d.l. & d.l. & d.l. & d.l. & d.1. & d.1. & d.1. & d.l. \\
\hline $\mathrm{Rb}$ & d.l. & d.I. & 3 & d.l. & d.l. & d.1. & d.1. & 4 \\
\hline$I C P-\Lambda$ & & & & & & & & \\
\hline $\mathrm{La}$ & 0.31 & 0.17 & 0.20 & 0.19 & 0.28 & 0.11 & 0.41 & 0.32 \\
\hline $\mathrm{Ce}$ & 0.09 & 0.42 & 0.36 & 0.40 & 0.49 & 0.21 & 0.64 & 0.54 \\
\hline $\mathrm{Pr}$ & 0.02 & 0.06 & 0.04 & 0.05 & 0.05 & 0.03 & 0.06 & 0.07 \\
\hline $\mathrm{Nd}$ & 0.08 & 0.28 & 0.16 & 0.21 & 0.18 & 0.09 & 0.19 & 0.25 \\
\hline $\mathrm{Sm}$ & 0.02 & 0.12 & 0.05 & 0.06 & 0.05 & 0.03 & 0.05 & 0.07 \\
\hline $\mathrm{Eu}$ & 0.02 & 0.05 & 0.02 & 0.02 & 0.01 & 0.01 & 0.02 & 0.01 \\
\hline $\mathrm{Gd}$ & 0.03 & 0.15 & 0.04 & 0.04 & 0.04 & 0.03 & 0.04 & 0.05 \\
\hline $\mathrm{Tb}$ & 0.01 & 0.03 & 0.01 & 0.01 & 0.01 & 0.01 & 0.01 & 0.01 \\
\hline Dy & 0.04 & 0.15 & 0.04 & 0.06 & 0.05 & 0.04 & 0.04 & 0.06 \\
\hline Ho & 0.01 & 0.03 & 0.01 & 0.01 & 0.01 & 0.01 & 0.01 & 0.01 \\
\hline $\mathrm{Er}$ & 0.03 & 0.09 & 0.02 & 0.05 & 0.03 & 0.03 & 0.03 & 0.04 \\
\hline $\mathrm{Tm}$ & 0.01 & 0.01 & 0.00 & 0.01 & d.l. & 0.01 & d.l. & d.l. \\
\hline $\mathrm{Yb}$ & 0.04 & 0.10 & 0.02 & 0.05 & 0.03 & 0.04 & 0.03 & 0.03 \\
\hline $\mathrm{Lu}$ & 0.01 & 0.02 & d.1. & 0.01 & 0.01 & 0.01 & 0.01 & 0.01 \\
\hline $\mathrm{Ba}$ & 1 & 2 & d.l. & 1 & 1 & 2 & 1 & d.1. \\
\hline $\mathrm{Th}$ & 0.03 & 0.04 & 0.04 & 0.03 & 0.06 & 0.03 & 0.28 & 0.06 \\
\hline $\mathrm{Nb}$ & 0.02 & 0.07 & 0.19 & 0.20 & 0.41 & 0.14 & 0.22 & 0.36 \\
\hline$Y$ & 0.35 & 0.82 & 0.16 & 0.31 & 0.24 & 0.18 & 0.20 & 0.30 \\
\hline $\mathrm{Hf}$ & 0.01 & 0.06 & 0.03 & 0.02 & 0.06 & 0.03 & 0.03 & 0.06 \\
\hline $\mathrm{Ta}$ & d.l. & 0.01 & 0.01 & 0.01 & 0.02 & 0.01 & 0.01 & 0.02 \\
\hline $\mathrm{U}$ & 0.01 & 0.01 & 0.01 & 0.02 & 0.06 & 0.01 & 0.09 & 0.02 \\
\hline $\mathrm{Pb}$ & 0.19 & 0.36 & 0.16 & 0.21 & 0.15 & 0.12 & 0.26 & 2.04 \\
\hline $\mathrm{Rb}$ & 0.1 & 0.2 & 0.7 & 0.7 & 0.4 & 0.8 & 0.4 & 2.2 \\
\hline $\mathrm{Cs}$ & d.l. & 0.03 & d.l. & 0.01 & d.1. & d.1. & 0.01 & 0.01 \\
\hline $\mathrm{Sr}$ & 0 & 24 & 1 & 25 & 24 & 3 & 88 & 23 \\
\hline $\mathrm{Sc}$ & 4.8 & 10.0 & 7.6 & 9.9 & 5.2 & 8.1 & 7.2 & 3.6 \\
\hline
\end{tabular}


Table 2-2. Continued.

Mt. Trapeze

\begin{tabular}{|c|c|c|c|c|c|c|c|}
\hline \multicolumn{8}{|c|}{ Harzburgites } \\
\hline & OB93-299 & OB93-305 & OB93-306 & OB93-307 & OB93-310 & OB93-314 & OB93-317 \\
\hline \multicolumn{8}{|c|}{$X R F w t \%$} \\
\hline $\mathrm{SiO}_{2}$ & 47.90 & 46.96 & 41.55 & 48.29 & 46.00 & 47.60 & 47.12 \\
\hline $\mathrm{Al}_{2} \mathrm{O}_{3}$ & 1.21 & 0.98 & 0.47 & 1.26 & 1.32 & 0.80 & 0.67 \\
\hline $\mathrm{TiO}_{2}$ & 0.00 & 0.02 & 0.03 & 0.00 & 0.00 & 0.01 & 0.01 \\
\hline $\mathrm{FeO}^{*}$ & 6.96 & 7.22 & 13.93 & 7.11 & 6.99 & 7.38 & 7.65 \\
\hline $\mathrm{MnO}$ & 0.13 & 0.17 & 0.18 & 0.12 & 0.13 & 0.12 & 0.14 \\
\hline $\mathrm{CaO}$ & 1.17 & 1.17 & 1.06 & 0.74 & 1.16 & 0.82 & 0.64 \\
\hline $\mathrm{MgO}$ & 42.31 & 41.91 & 41.83 & 43.31 & 43.10 & 44.45 & 43.86 \\
\hline $\mathrm{K}_{2} \mathrm{O}$ & 0.00 & 0.00 & 0.00 & 0.00 & 0.00 & 0.00 & 0.00 \\
\hline $\mathrm{Na}_{2} \mathrm{O}$ & 0.07 & 0.06 & 0.05 & 0.10 & 0.05 & 0.12 & 0.06 \\
\hline $\mathrm{P}_{2} \mathrm{O}_{5}$ & 0.02 & 0.02 & 0.02 & 0.01 & 0.01 & 0.01 & 0.02 \\
\hline Total & 99.77 & 98.51 & 99.12 & 100.95 & 98.76 & 101.31 & 100.16 \\
\hline $\mathrm{Mg \#}$ & 91.55 & 91.19 & 84.26 & 91.57 & 91.66 & 91.48 & 91.09 \\
\hline \multicolumn{8}{|c|}{$X R F p p m$} \\
\hline $\mathrm{Ni}$ & 2167 & 2197 & 2436 & 2308 & 2010 & 2348 & 2252 \\
\hline $\mathrm{Cr}$ & 3948 & 3208 & 308 & 2488 & 3985 & 2001 & 1668 \\
\hline V & 44 & d.l. & d.l. & d.1. & 38 & d.1. & d.l. \\
\hline $\mathrm{Sr}$ & 39 & 40 & 38 & d.l. & d.l. & 11 & 4 \\
\hline $\mathrm{Zr}$ & 7 & 9 & 9 & 7 & 6 & 6 & 6 \\
\hline $\mathrm{Ga}$ & 1 & 4 & 2 & 3 & 3 & 1 & 1 \\
\hline $\mathrm{Cu}$ & 12 & 16 & 36 & 20 & 13 & 11 & 11 \\
\hline $\mathrm{Zn}$ & 45 & 47 & 98 & 40 & 42 & 39 & 38 \\
\hline $\mathrm{Nb}$ & d.l. & d.l. & d.l. & d.1. & d.1. & d.I. & d. 1 . \\
\hline $\mathrm{Rb}$ & d.1. & d.1. & d.l. & 3 & d.1. & d.l. & d.1. \\
\hline \multicolumn{8}{|c|}{$I C P-M S p p m$} \\
\hline $\mathrm{La}$ & 0.15 & 0.17 & 0.17 & 0.07 & 0.12 & 0.42 & 0.23 \\
\hline $\mathrm{Ce}$ & 0.26 & 0.32 & 0.37 & 0.11 & 0.20 & 0.79 & 0.36 \\
\hline $\operatorname{Pr}$ & 0.03 & 0.04 & 0.04 & 0.02 & 0.03 & 0.11 & 0.05 \\
\hline $\mathrm{Nd}$ & 0.09 & 0.19 & 0.15 & 0.06 & 0.09 & 0.43 & 0.17 \\
\hline $\mathrm{Sm}$ & 0.02 & 0.05 & 0.03 & 0.02 & 0.02 & 0.20 & 0.04 \\
\hline $\mathrm{Eu}$ & 0.01 & 0.02 & 0.01 & d.l. & d.l. & 0.14 & 0.01 \\
\hline $\mathrm{Gd}$ & 0.02 & 0.04 & 0.04 & 0.02 & 0.01 & 0.25 & 0.04 \\
\hline $\mathrm{Tb}$ & d.1. & 0.01 & 0.01 & d.l. & d.l. & 0.04 & 0.01 \\
\hline Dy & 0.02 & 0.06 & 0.06 & 0.02 & 0.02 & 0.20 & 0.05 \\
\hline Ho & d.l. & 0.01 & 0.01 & 0.01 & 0.01 & 0.04 & 0.01 \\
\hline $\mathrm{Er}$ & 0.01 & 0.03 & 0.04 & 0.02 & 0.01 & 0.10 & 0.02 \\
\hline $\mathrm{Tm}$ & d.I. & d.l. & 0.01 & d.l. & d.l. & 0.02 & d.1. \\
\hline $\mathrm{Yb}$ & 0.03 & 0.03 & 0.04 & 0.02 & 0.03 & 0.11 & 0.03 \\
\hline $\mathrm{Lu}$ & 0.01 & 0.01 & 0.01 & 0.01 & 0.01 & 0.03 & 0.01 \\
\hline $\mathrm{Ba}$ & & 1 & 1 & 1 & 2 & 36 & 2 \\
\hline $\mathrm{Th}$ & 0.03 & 0.02 & 0.02 & 0.01 & 0.04 & 0.27 & 0.04 \\
\hline $\mathrm{Nb}$ & 0.18 & 0.29 & 0.38 & 0.12 & 0.30 & 0.28 & 0.24 \\
\hline$Y$ & 0.11 & 0.34 & 0.34 & 0.10 & 0.10 & 0.33 & 0.26 \\
\hline Hf & 0.02 & 0.04 & 0.03 & 0.02 & 0.02 & 0.04 & 0.04 \\
\hline $\mathrm{Ta}$ & 0.10 & 0.14 & 0.62 & d.l. & 0.52 & 0.02 & 0.16 \\
\hline $\mathrm{U}$ & 0.14 & 0.03 & 0.03 & 0.01 & 0.01 & 0.02 & 0.01 \\
\hline $\mathrm{Pb}$ & 0.07 & 0.02 & 0.03 & 0.09 & 0.06 & 0.19 & 0.03 \\
\hline $\mathrm{Rb}$ & 0.4 & 0.7 & 0.7 & 0.7 & 0.4 & 0.5 & 0.8 \\
\hline $\mathrm{Cs}$ & d.1. & 0.01 & 0.01 & 0.01 & 0.01 & 0.01 & 0.01 \\
\hline $\mathrm{Sr}$ & 39 & 40 & 40 & 2 & 1 & 11 & 6 \\
\hline $\mathrm{Sc}$ & 11.1 & 7.9 & 5.3 & 7.9 & 13.9 & 6.7 & 7.5 \\
\hline
\end{tabular}


Table 2-3. Calculated modes.

\begin{tabular}{lcccccccc}
\hline Sample & Cpx & error & Opx & error & Olivine & error & Spinel & error \\
\hline wt.\% mode & & & & & & & & \\
OB93-52 & 9.54 & 1.38 & 23.46 & 2.36 & 61.69 & 1.65 & 4.87 & 0.58 \\
OB93-80 & 2.66 & 1.14 & 54.88 & 1.96 & 40.79 & 1.38 & 1.14 & 0.50 \\
OB93-83 & 1.11 & 2.45 & 48.39 & 3.96 & 50.15 & 2.52 & -0.29 & 0.89 \\
OB93-85 & 1.91 & 0.85 & 49.17 & 1.45 & 48.25 & 1.01 & 0.35 & 0.36 \\
OB93-99 & 2.93 & 0.86 & 40.21 & 1.50 & 56.88 & 1.04 & -0.21 & 0.35 \\
OB93-284 & 3.86 & 0.70 & 35.51 & 1.19 & 60.78 & 0.81 & -0.48 & 0.30 \\
OB93-287 & 3.59 & 0.78 & 20.71 & 1.30 & 75.11 & 0.89 & 0.34 & 0.31 \\
OB93-289 & 0.38 & 0.38 & 44.90 & 0.65 & 54.62 & 0.44 & 0.03 & 0.16 \\
OB93-291 & 3.14 & 0.78 & 33.96 & 1.33 & 62.75 & 0.86 & -0.03 & 0.30 \\
OB93-297 & 2.88 & 0.79 & 22.40 & 1.37 & 74.18 & 0.90 & 0.31 & 0.28 \\
OB93-305 & 3.63 & 1.05 & 39.31 & 1.76 & 56.79 & 1.18 & 0.07 & 0.43 \\
OB93-307 & 1.05 & 0.42 & 42.35 & 0.71 & 56.85 & 0.47 & -0.39 & 0.18 \\
OB93-310 & 3.30 & 0.57 & 32.59 & 0.95 & 63.62 & 0.64 & 0.62 & 0.24 \\
OB93-314 & 2.45 & 0.56 & 35.46 & 0.96 & 62.16 & 0.66 & -0.25 & 0.24 \\
OB93-317 & 1.73 & 1.34 & 36.43 & 2.30 & 61.52 & 1.57 & -0.07 & 0.55 \\
\hline
\end{tabular}

Modes (in wt.\%) are calculated by mass balance using average composition of minerals.

Error is 1 S.D. 
Table 2-4. Clinopyroxene major element compositions

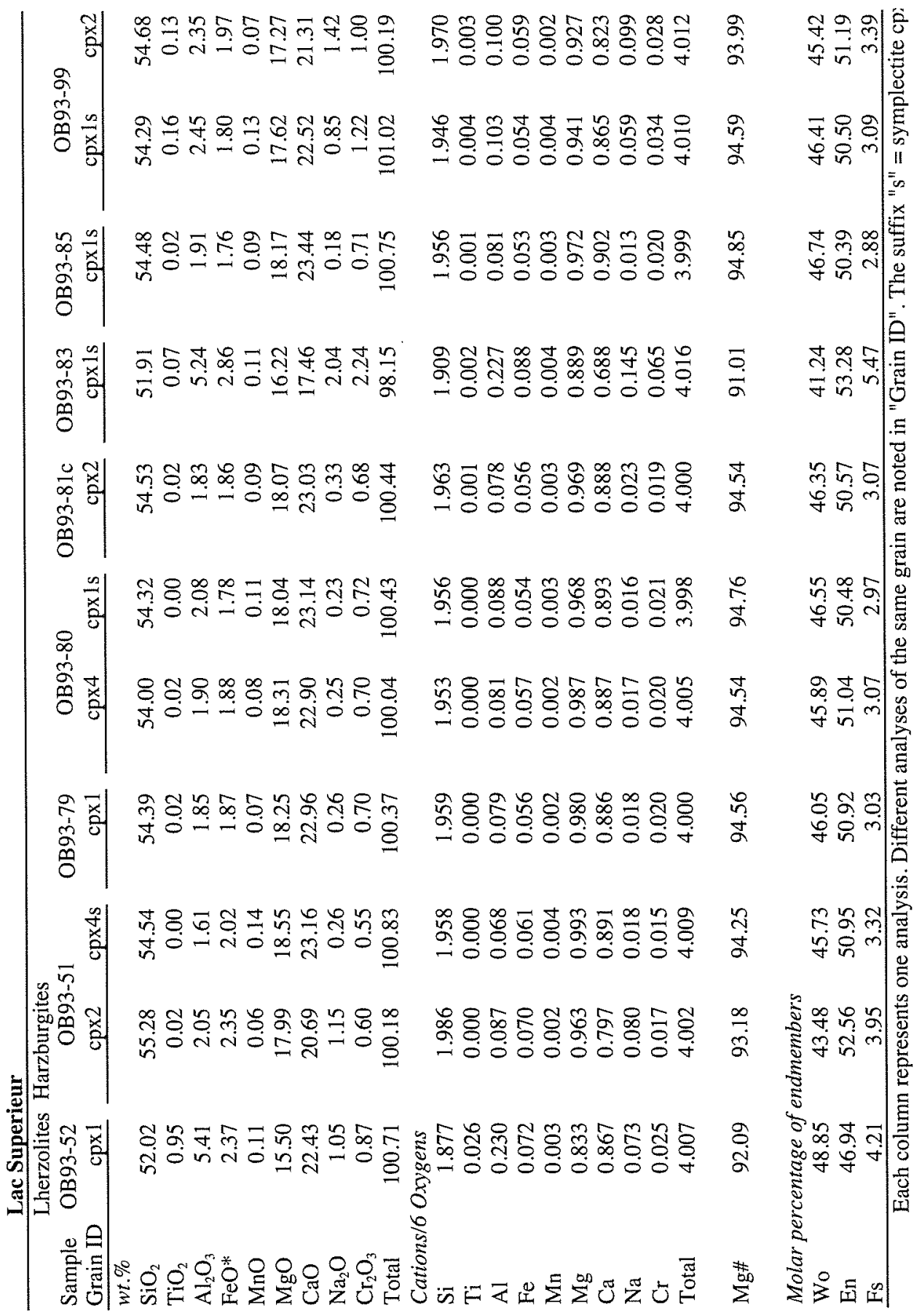


Table 2-4. Continued.

\begin{tabular}{|c|c|c|c|c|}
\hline 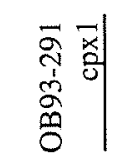 & 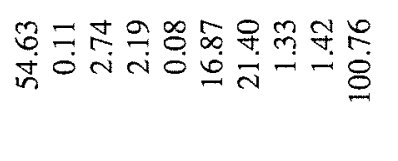 & 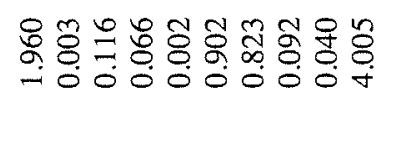 & $\underset{ભ 1}{~}$ & 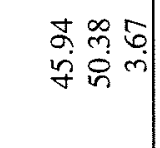 \\
\hline 袠 & 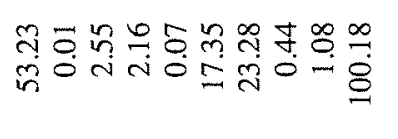 & $\vec{g}$ & 畩 & 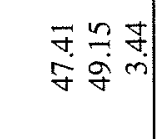 \\
\hline 商常 & 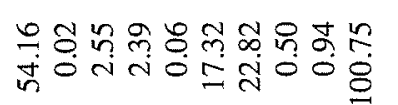 & 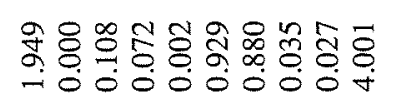 & 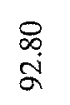 & og g m \\
\hline 总 & 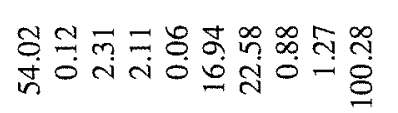 & 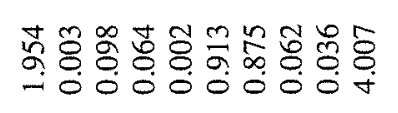 & 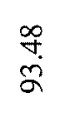 & 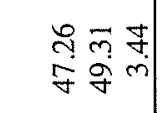 \\
\hline 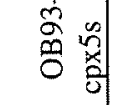 & 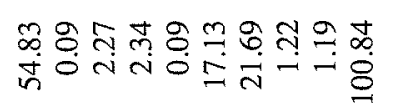 & 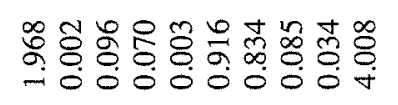 & $\underset{\infty}{\infty}$ & 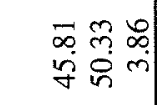 \\
\hline 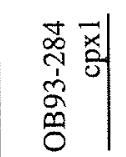 & 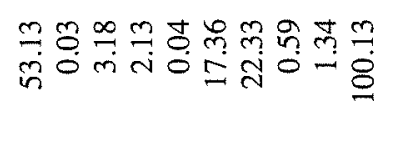 & 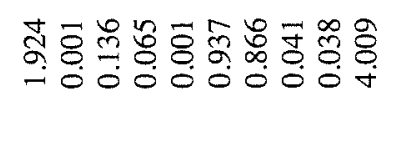 & $\begin{array}{l}\infty \\
n \\
n\end{array}$ & 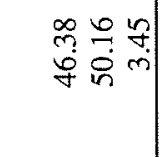 \\
\hline 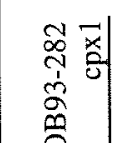 & 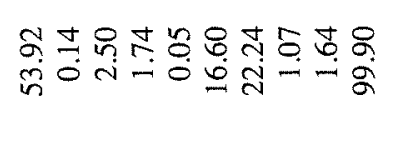 & 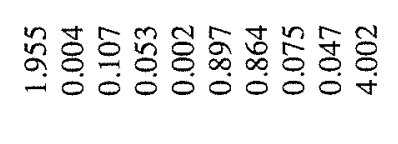 & $\stackrel{n}{\dot{f}}$ & 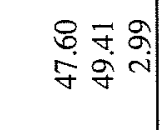 \\
\hline 年 & 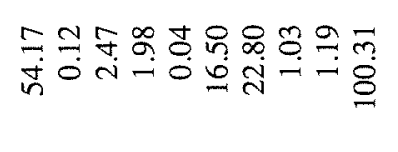 & 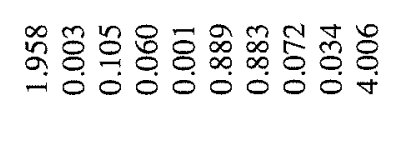 & $\underset{\infty}{\infty}$ & 专字 \\
\hline 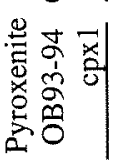 & 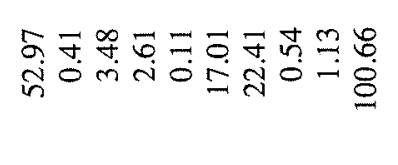 & 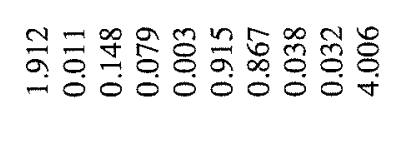 & $\stackrel{\infty}{\stackrel{\infty}{S}}$ & $\vec{n}$ \\
\hline 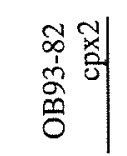 & 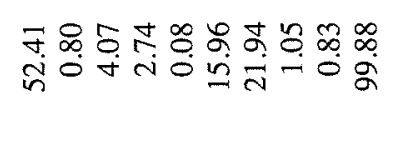 & 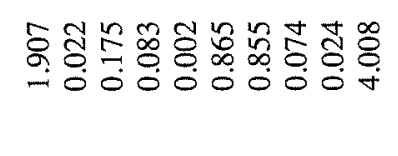 & $\vec{a}$ & $m \sigma$ \\
\hline 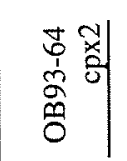 & ק్ & 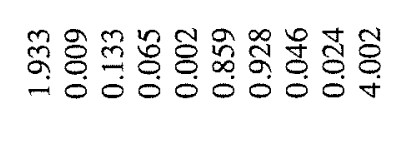 & ๙ू & 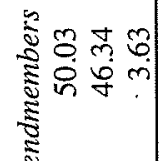 \\
\hline 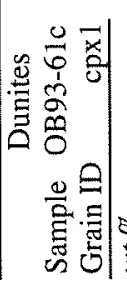 & 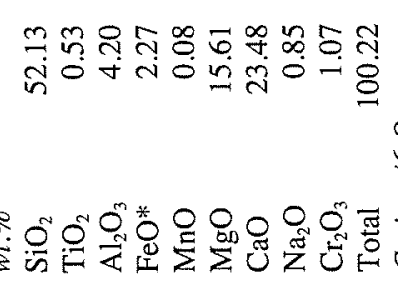 & $\frac{8}{0} \overline{0}$ & 龸 & 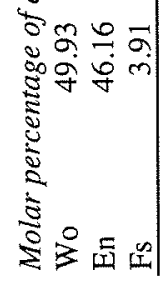 \\
\hline
\end{tabular}


Table 2-4. Continued.

\begin{tabular}{|c|c|c|c|c|}
\hline 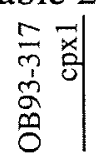 & 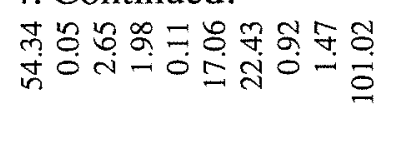 & 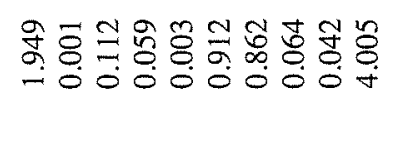 & $\begin{array}{l}\infty \\
\infty \\
\infty \\
\dot{\sigma}\end{array}$ & 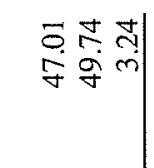 \\
\hline$\frac{t^{2}}{1}$ & 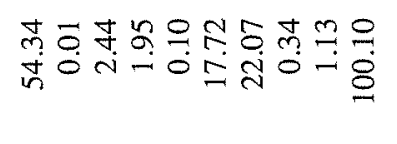 & 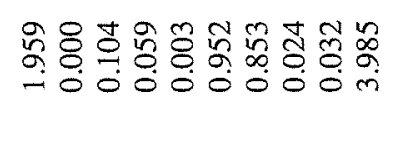 & 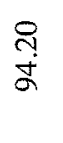 & 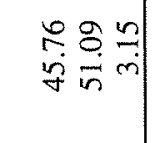 \\
\hline 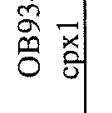 & 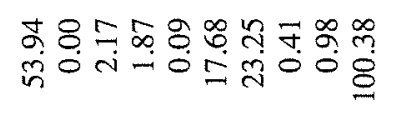 & 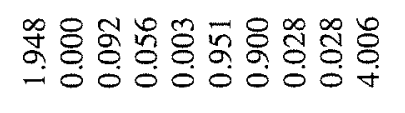 & $\begin{array}{l}\stackrel{P}{+} \\
\text { ț }\end{array}$ & 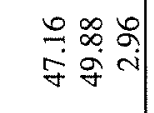 \\
\hline ㅇํํ & 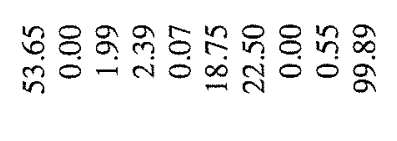 & 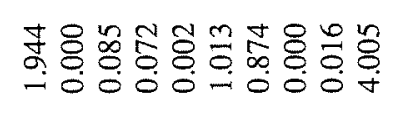 & $\stackrel{m}{m}$ & 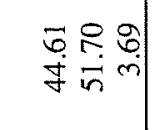 \\
\hline कै & 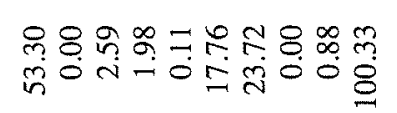 & 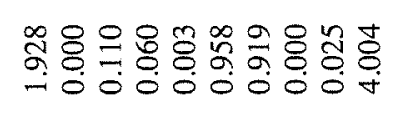 & $\stackrel{m}{\vec{g}}$ & 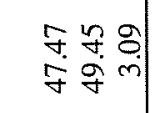 \\
\hline : & 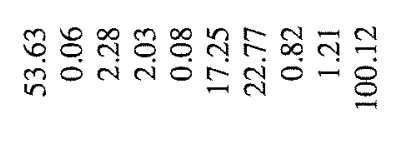 & 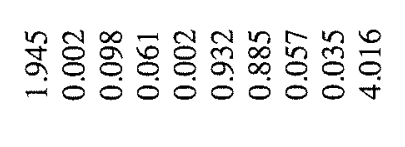 & $\begin{array}{l}\mathscr{\infty} \\
\stackrel{\infty}{\infty}\end{array}$ & 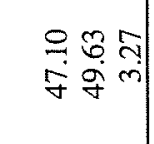 \\
\hline 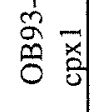 & 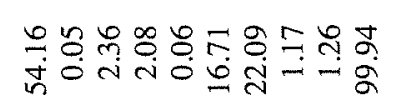 & 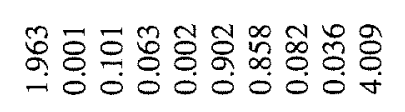 & $\begin{array}{l}\stackrel{i}{q} \\
\text { m. }\end{array}$ & 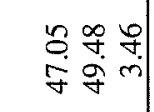 \\
\hline 点 & 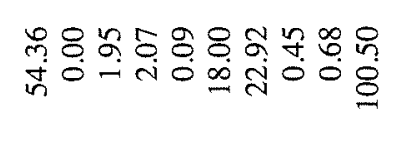 & 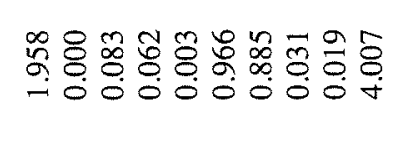 & 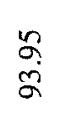 & 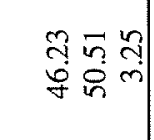 \\
\hline مै & 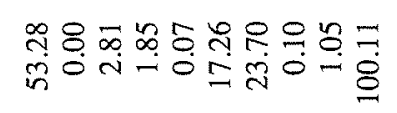 & 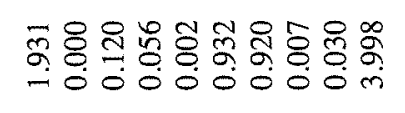 & $\underset{m}{\mathscr{m}}$ & 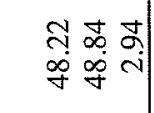 \\
\hline 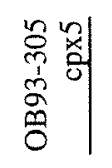 & 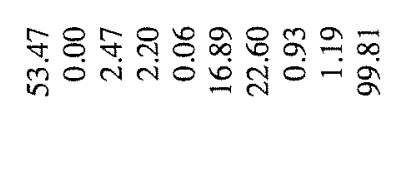 & 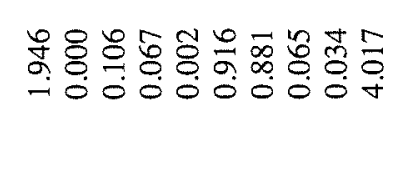 & 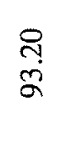 & 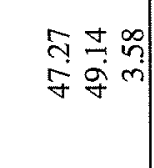 \\
\hline 气 & 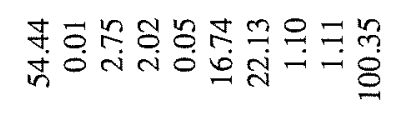 & 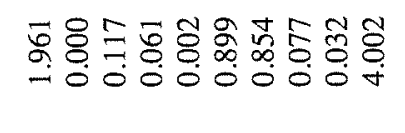 & $\begin{array}{l}\stackrel{8}{\circ} \\
\text { ă }\end{array}$ & 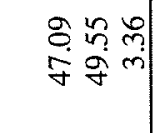 \\
\hline $\begin{array}{ll}2 & 0 \\
0 & 0 \\
0\end{array}$ & 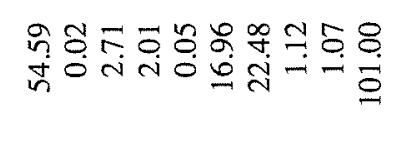 & 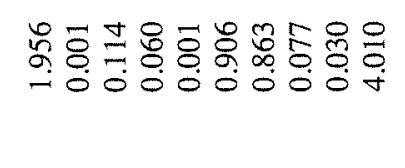 & $\stackrel{\infty}{\stackrel{\infty}{n}}$ & 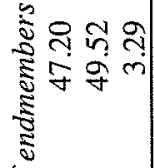 \\
\hline 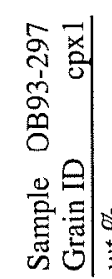 & 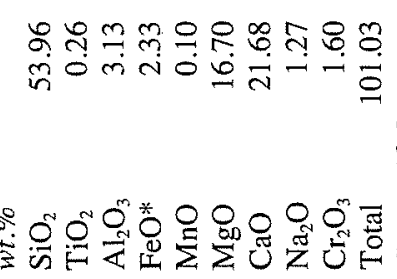 & 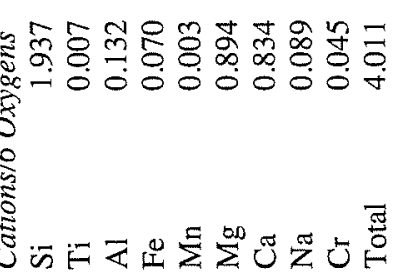 & $\stackrel{n}{i}$ & 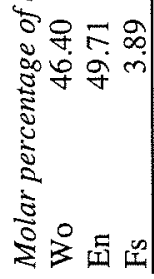 \\
\hline
\end{tabular}


Table 2-5. Orthopyroxene major element compositions.

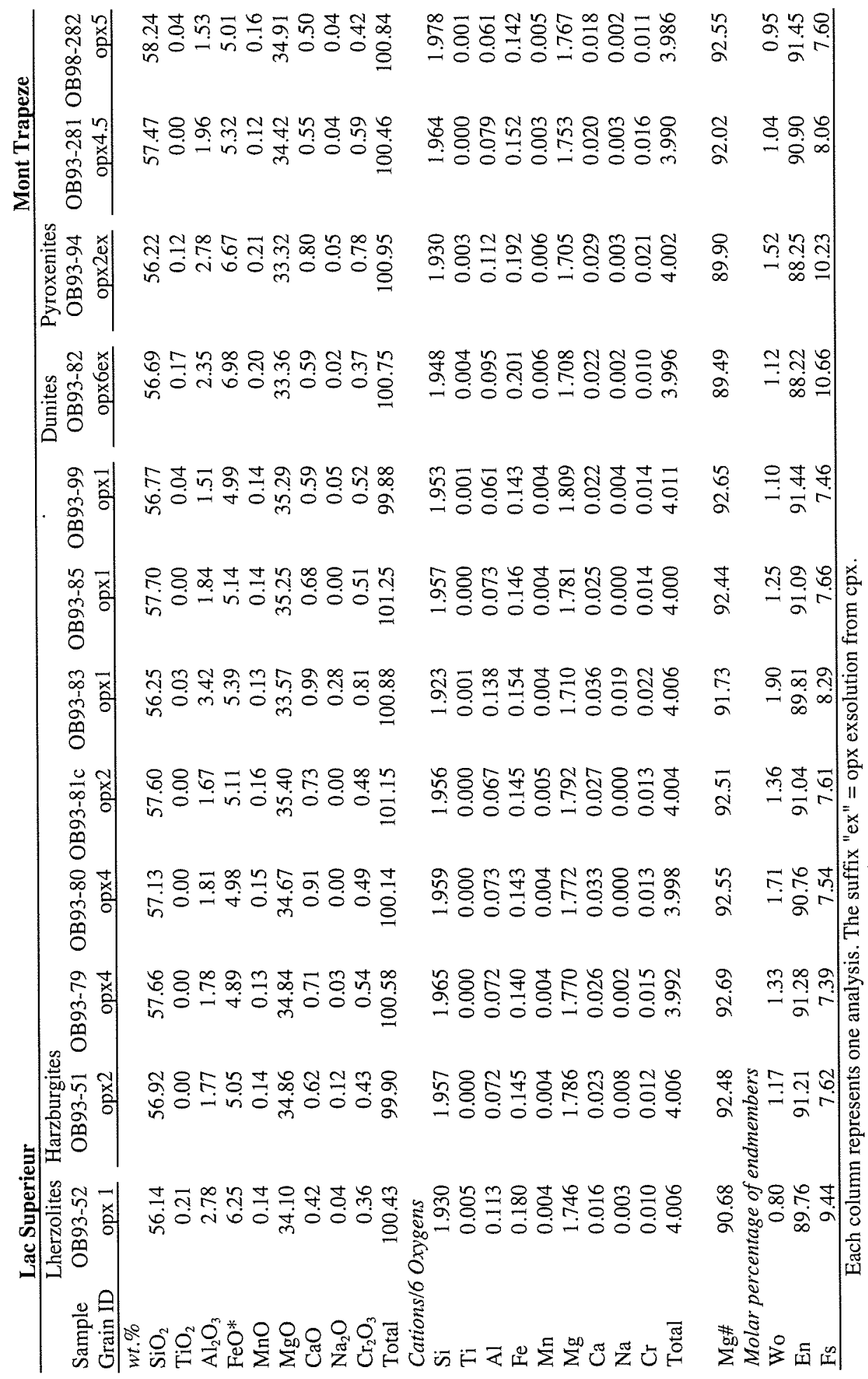


Table 2-5. Continued.

\begin{tabular}{|c|c|c|c|c|}
\hline $\begin{array}{ll}\frac{n}{2} & \text { 间 } \\
\frac{1}{2} & 0\end{array}$ & 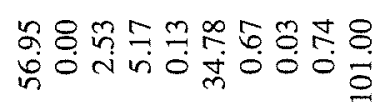 & 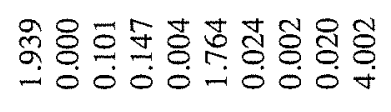 & $\vec{m}$ & 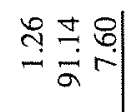 \\
\hline 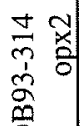 & 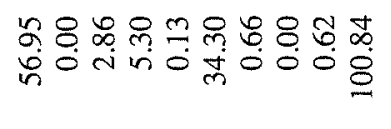 & 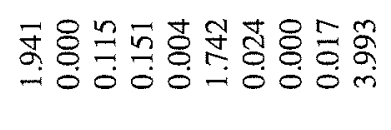 & $\underset{\text { Ș }}{\text { S̆ }}$ & 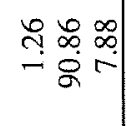 \\
\hline 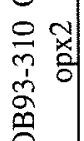 & 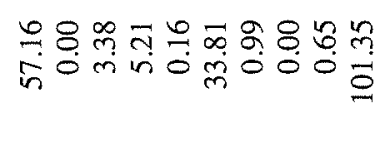 & 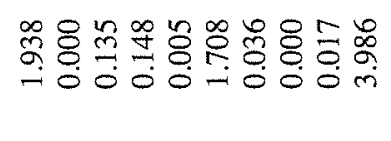 & $\underset{\text { S̆ }}{\text { S̆ }}$ & ஓ유 \\
\hline 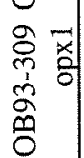 & 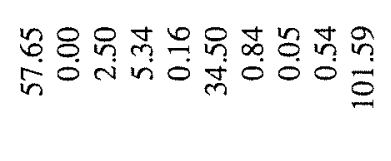 & 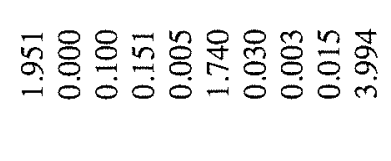 & $\begin{array}{l}8 \\
\stackrel{8}{i}\end{array}$ & 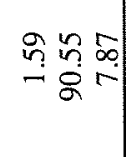 \\
\hline $\begin{array}{ll}5 & \bar{x} \\
\bar{c} & 0 \\
\tilde{\sigma} & 0\end{array}$ & 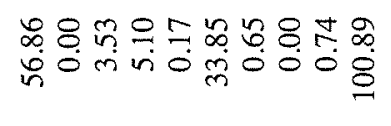 & 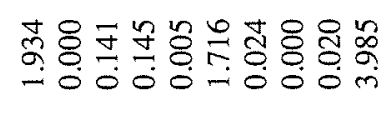 & $\underset{\pi}{\pi}$ & 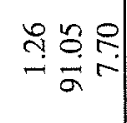 \\
\hline 点 & 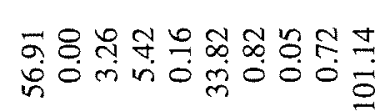 & 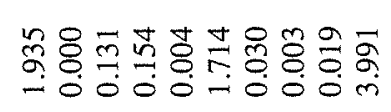 & $\stackrel{n}{a}$ & ำᅲ \\
\hline 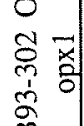 & 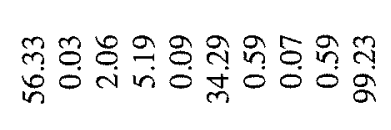 & 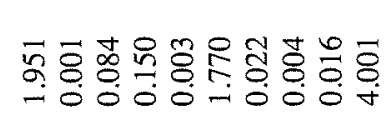 & $\stackrel{\bar{\pi}}{\pi}$ & $\underset{i}{\stackrel{i}{a}} \stackrel{t}{i}$ \\
\hline 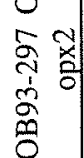 & 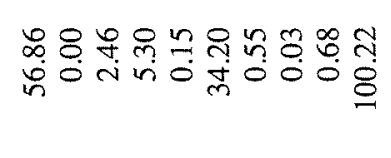 & 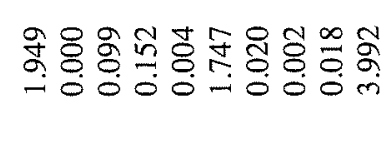 & 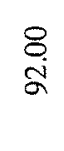 & 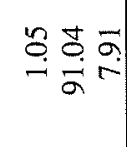 \\
\hline $\begin{array}{ll}\overrightarrow{\hat{\lambda}} & \vec{x} \\
\dot{2} & 0\end{array}$ & 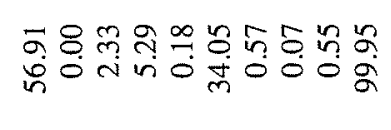 & 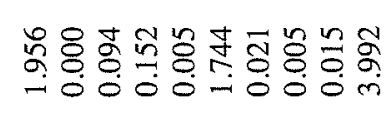 & $\stackrel{\circ}{\sigma}$ & 영 \\
\hline 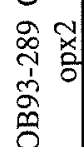 & 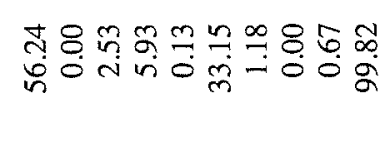 & 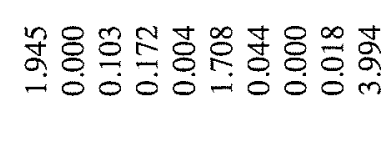 & $\begin{array}{l}\infty \\
\infty \\
\infty \\
\stackrel{8}{9}\end{array}$ & 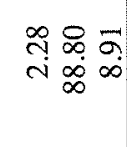 \\
\hline 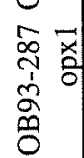 & 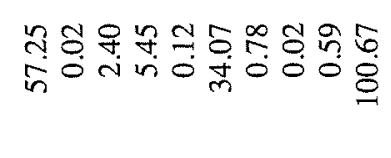 & బ气 & $F$ & $\frac{9}{8}=$ \\
\hline 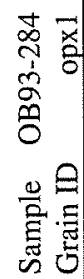 & 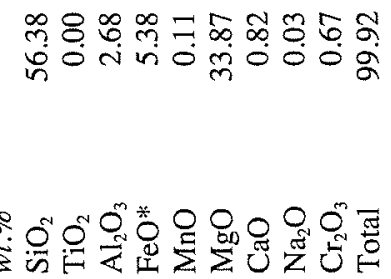 & 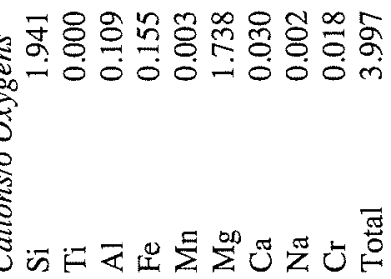 & $\widetilde{\infty}$ & 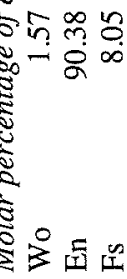 \\
\hline
\end{tabular}


Table 2-6. Olivine major element compositions

\begin{tabular}{|c|c|c|c|}
\hline $\begin{array}{l}\text { 잉 } \\
\text { } \\
\tilde{\alpha} \\
0 \\
0\end{array}$ & 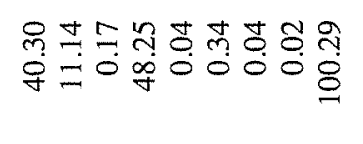 & 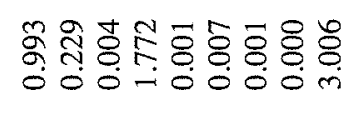 & ñ \\
\hline 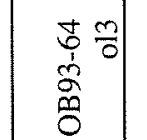 & 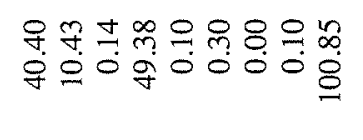 & 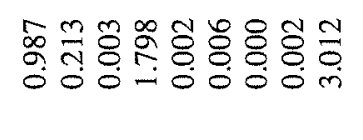 & $\begin{array}{c}\text { qे. } \\
\vdots \\
\infty\end{array}$ \\
\hline 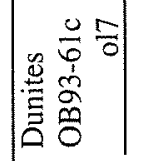 & 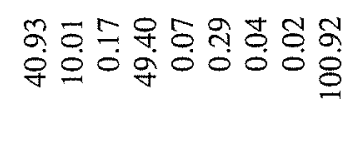 & 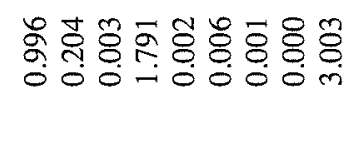 & ڤે. \\
\hline $\begin{array}{l}\frac{a}{5} \\
\vdots \\
\vdots \\
\frac{1}{0}\end{array}$ & 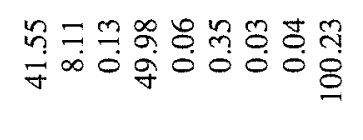 & 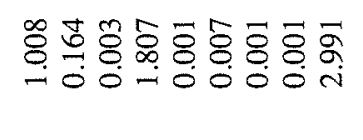 & 号 \\
\hline $\begin{array}{l}n \\
\infty \\
0 \\
\infty \\
0 \\
0\end{array}$ & 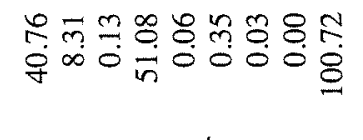 & 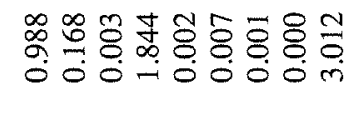 & a. \\
\hline$\approx$ & 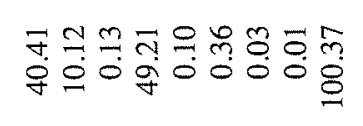 & 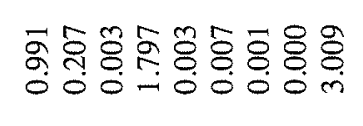 & $\begin{array}{l}6 \\
8 \\
\infty\end{array}$ \\
\hline ஸै & 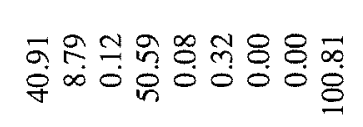 & 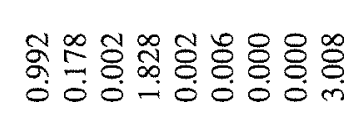 & ज: \\
\hline $\begin{array}{l}0 \\
\infty \\
0 \\
2 \\
2 \\
0 \\
0\end{array}$ & 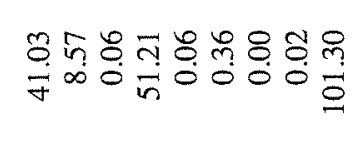 & 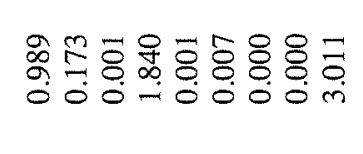 & จุ. \\
\hline $\begin{array}{ll}0 & 0 \\
0 & 0 \\
1 & 0 \\
2 & \\
0 & 0\end{array}$ & 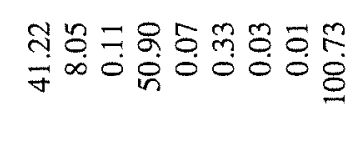 & 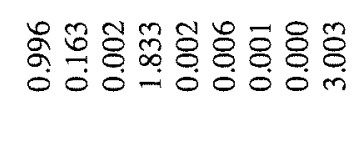 & $\begin{array}{l} \pm \\
\dot{a}\end{array}$ \\
\hline $\begin{array}{l}\frac{2}{1} \\
\tilde{\sigma} \\
\stackrel{0}{0}\end{array}$ & 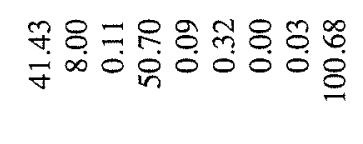 & 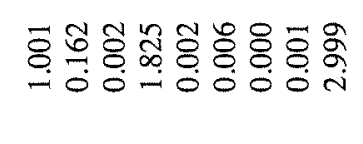 & 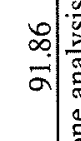 \\
\hline 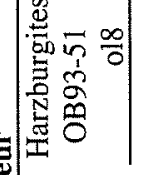 & 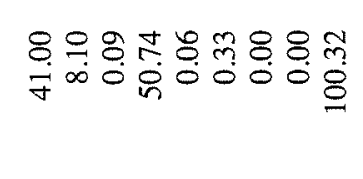 & 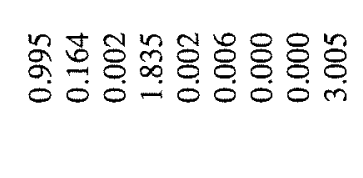 & $\stackrel{\infty}{\stackrel{\infty}{\sigma}}$ \\
\hline 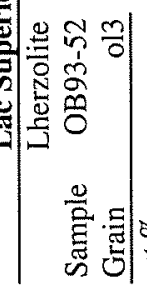 & 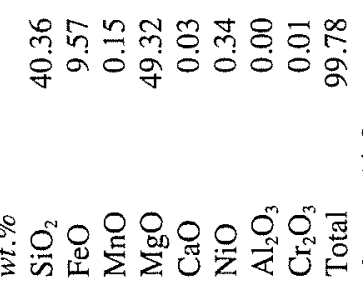 & 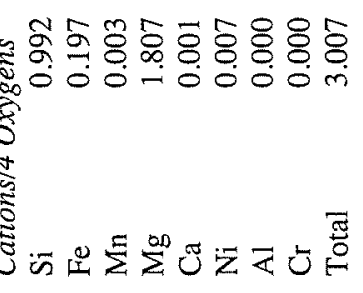 & $\stackrel{\infty}{\stackrel{2}{2}}$ \\
\hline
\end{tabular}


Table 2-6. Continued.

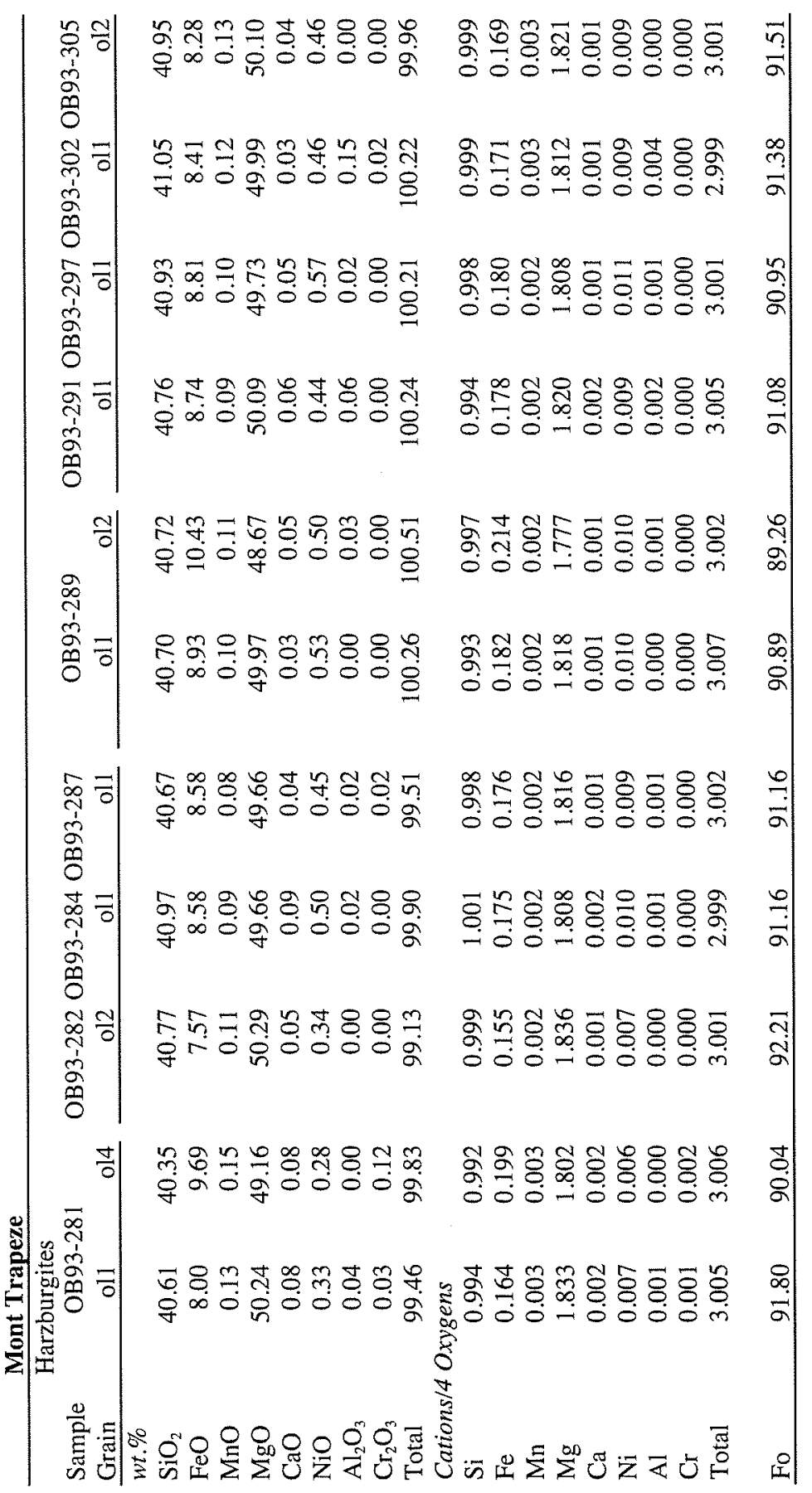


Table 2-6. Continued.

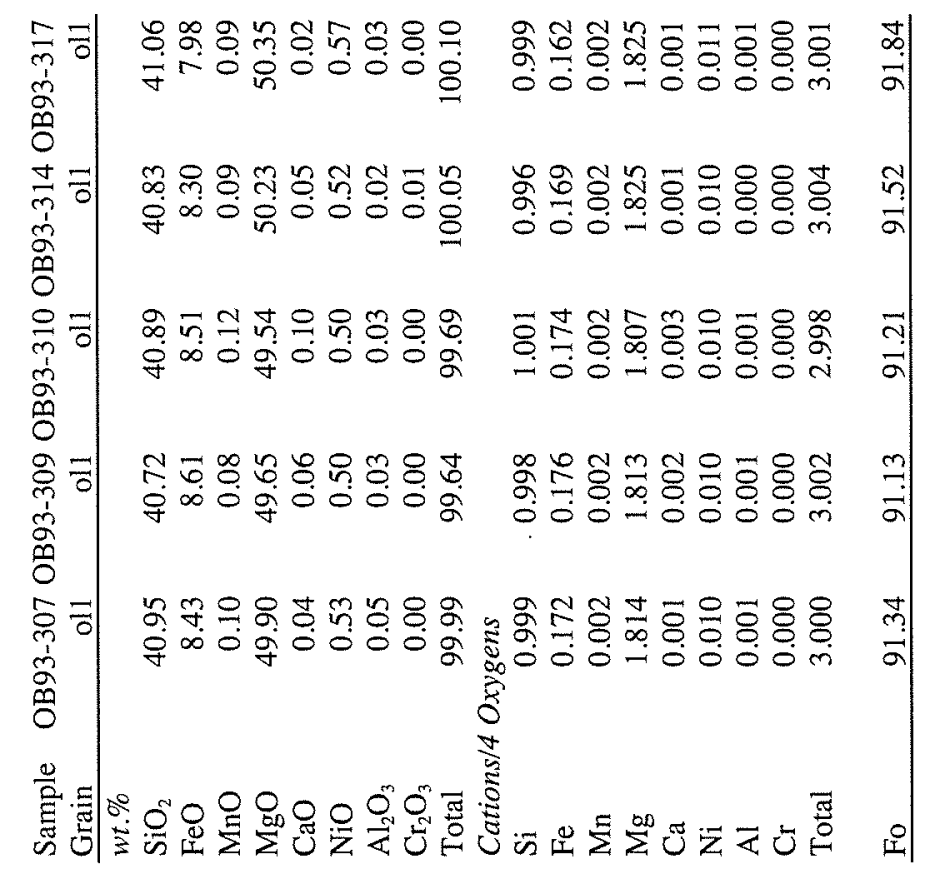


Table 2-7. Spinel major element compositions.

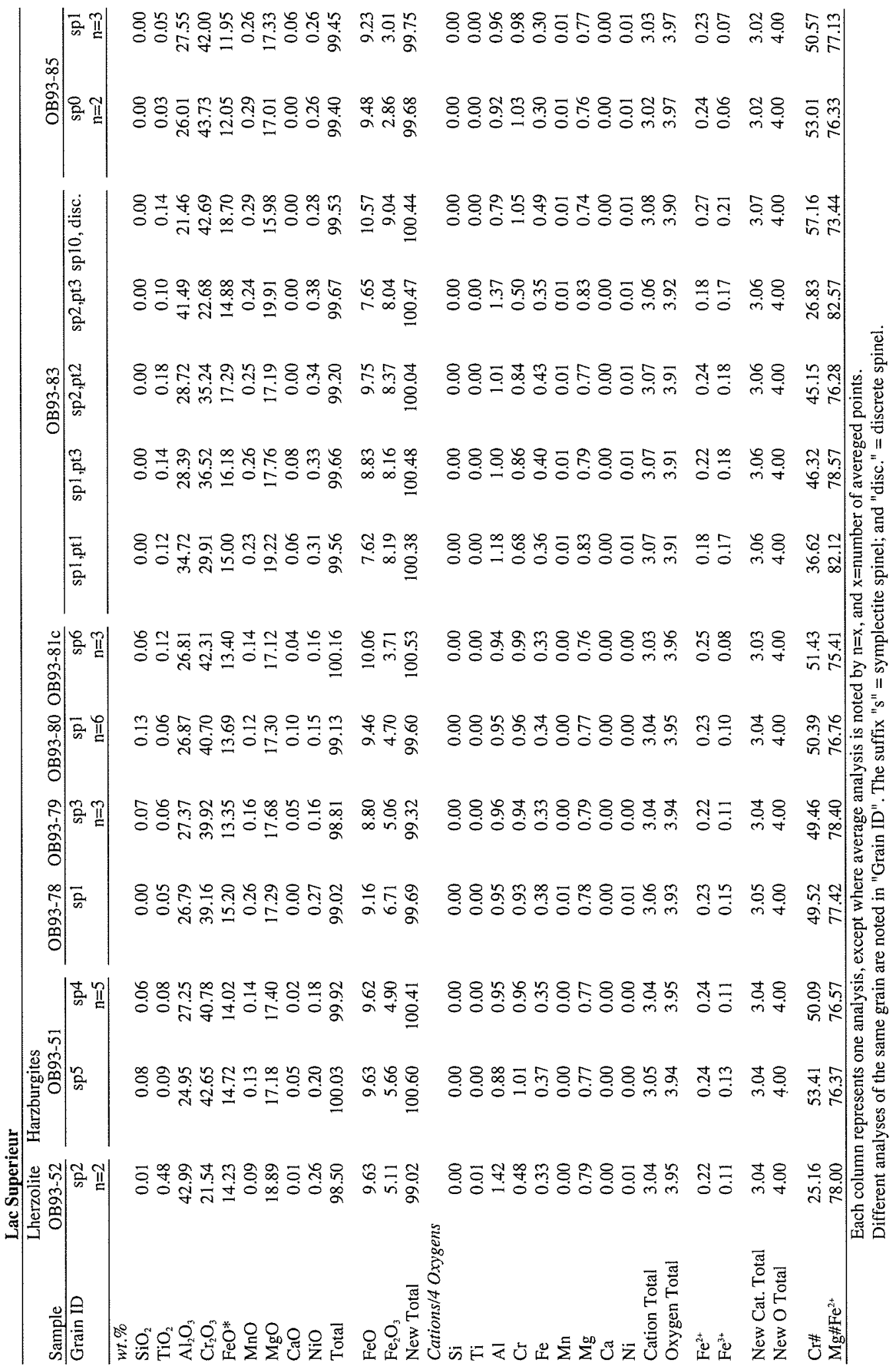


Table 2-7. Continued.

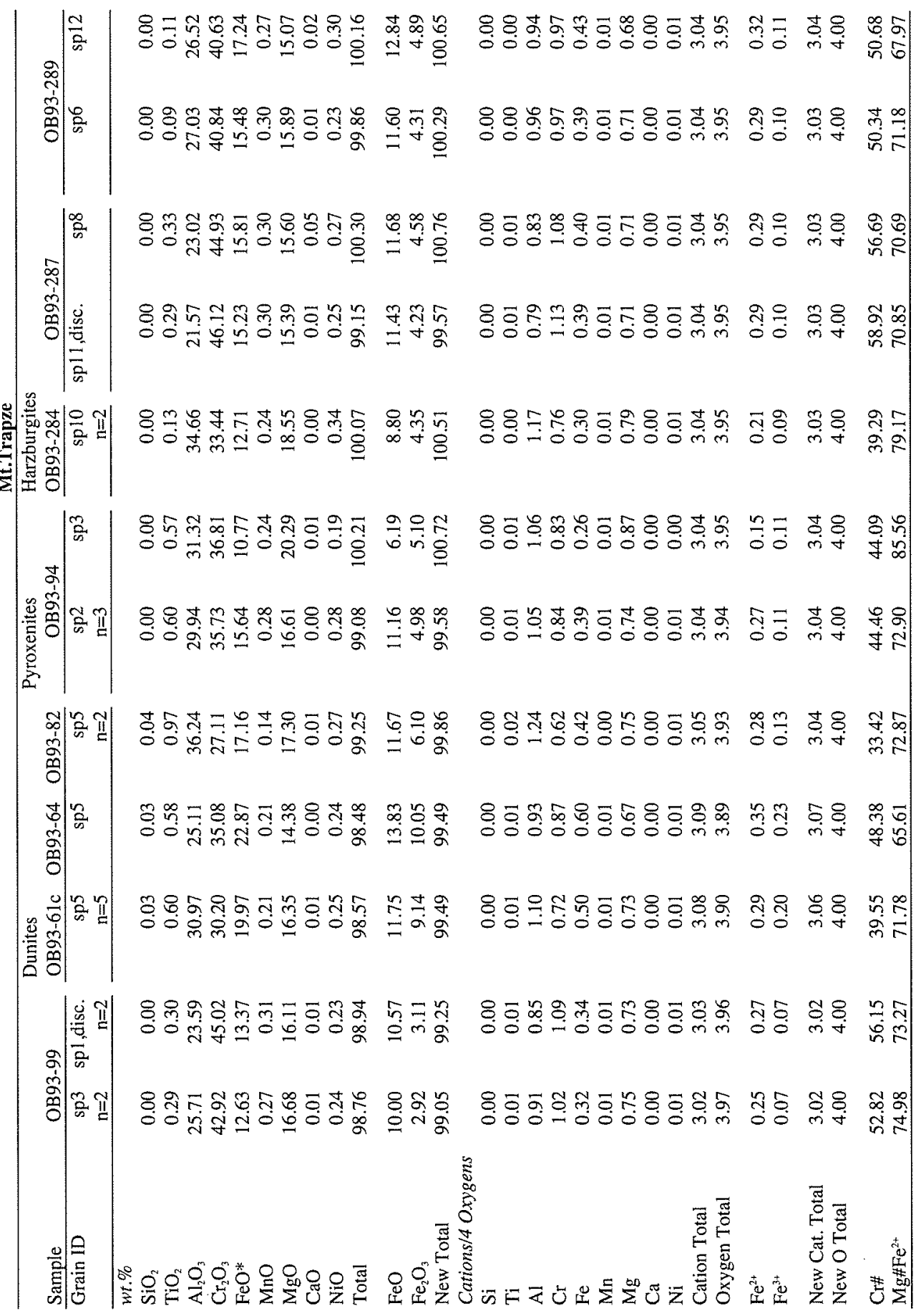


Table 2-7. Continued.

\begin{tabular}{|c|c|c|c|c|c|c|}
\hline 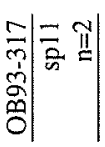 & 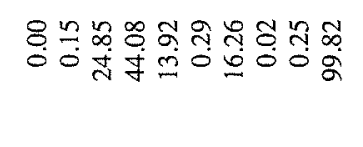 & 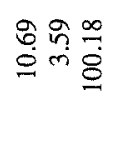 & \&: & 공융 & $\underset{m i}{m}$ & 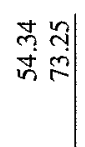 \\
\hline 点 & 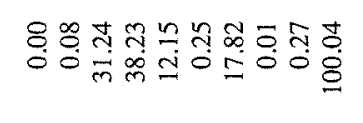 & $\stackrel{m}{m}=\frac{n}{m}$ & 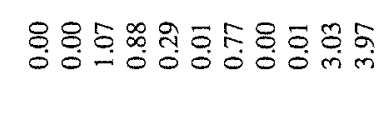 & สุธ & 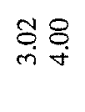 & 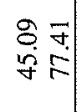 \\
\hline$=\pi$ & 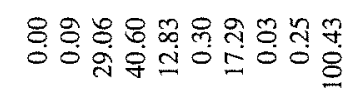 & 요ㅇㅠㅛ & 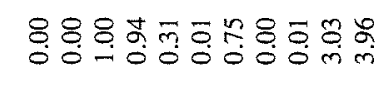 & đัđ & 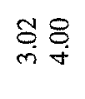 & 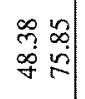 \\
\hline $\begin{array}{ll}\infty & 0 \\
0 & 0 \\
0 & 0\end{array}$ & 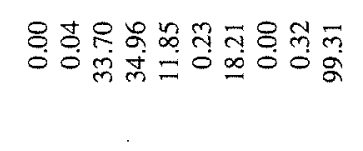 & 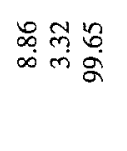 & 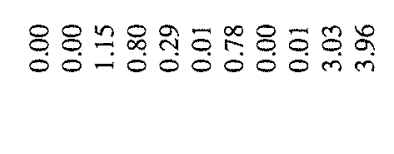 & तु: & S⿺辶 & \begin{tabular}{ll}
+ & 9 \\
\hdashline & 0 \\
$\forall$ & 0
\end{tabular} \\
\hline$\left|\frac{2}{2} \pi\right|$ & 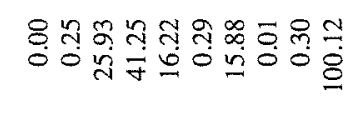 & 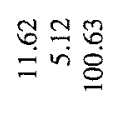 & 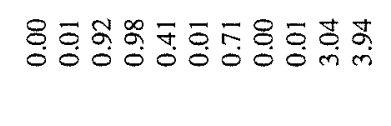 & 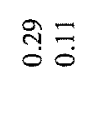 & 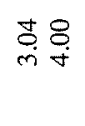 & ํㅜㅁำ \\
\hline$\frac{2}{2} \pi$ & ठ워 & 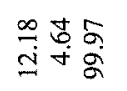 & 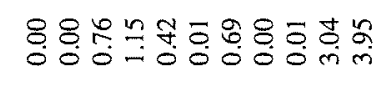 & $\bar{m}=\overline{0}$ & mo & $\begin{array}{c}8 \\
8 \\
8 \\
8\end{array}$ \\
\hline $\mid \frac{\infty}{6}, \frac{\pi}{\vdots}$ & 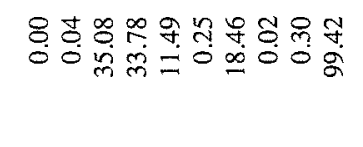 & 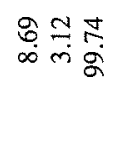 & 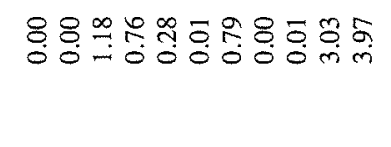 & สู่ & 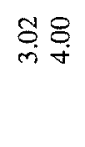 & तुં \\
\hline$\vec{s}$ & 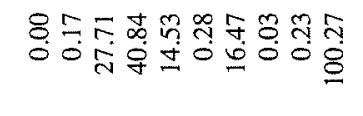 & 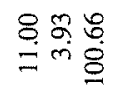 & 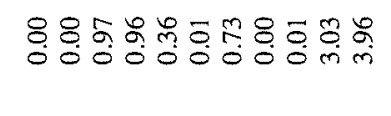 & 공 & 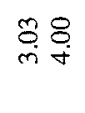 & 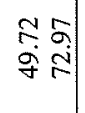 \\
\hline की & 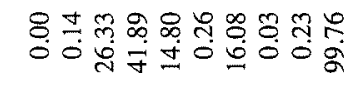 & 표용 & 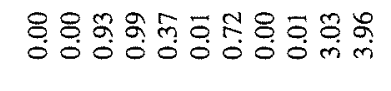 & 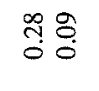 & 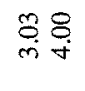 & 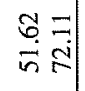 \\
\hline 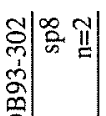 & 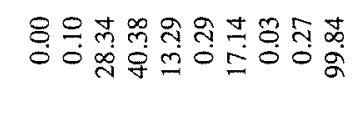 & 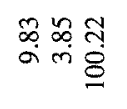 & 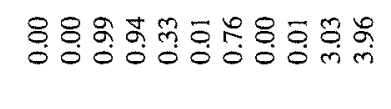 & ব্ণু & $\stackrel{m}{:} \underset{\dot{m}}{\stackrel{8}{+}}$ & 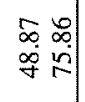 \\
\hline 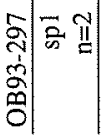 & 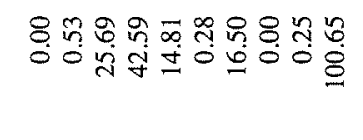 & 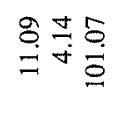 & 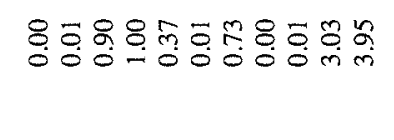 & ㅊํㅇ융 & $\underset{m}{8} \underset{+}{8}$ & 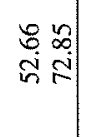 \\
\hline $\mid \overline{\bar{a}}$ & 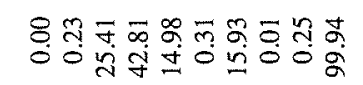 & $\stackrel{\infty}{=} \stackrel{+}{\rightarrow} \stackrel{+}{+}$ & 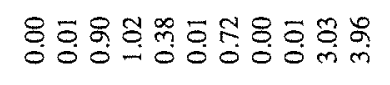 & ণ্ণ & $\stackrel{\substack{0 \\
\dot{m}}}{8}$ & 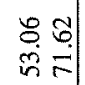 \\
\hline 竎|응 & 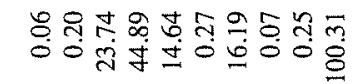 & 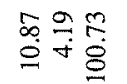 & 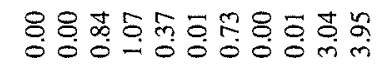 & 궁응 & 侢 & 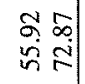 \\
\hline 商彦 & 象员 & 象 & 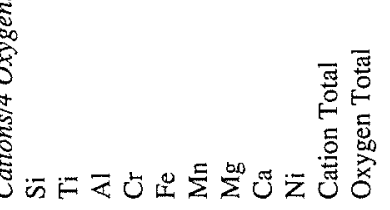 & & 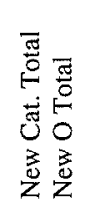 & 索 \\
\hline
\end{tabular}


Table 2-8. Clinopyroxene trace element compositions.

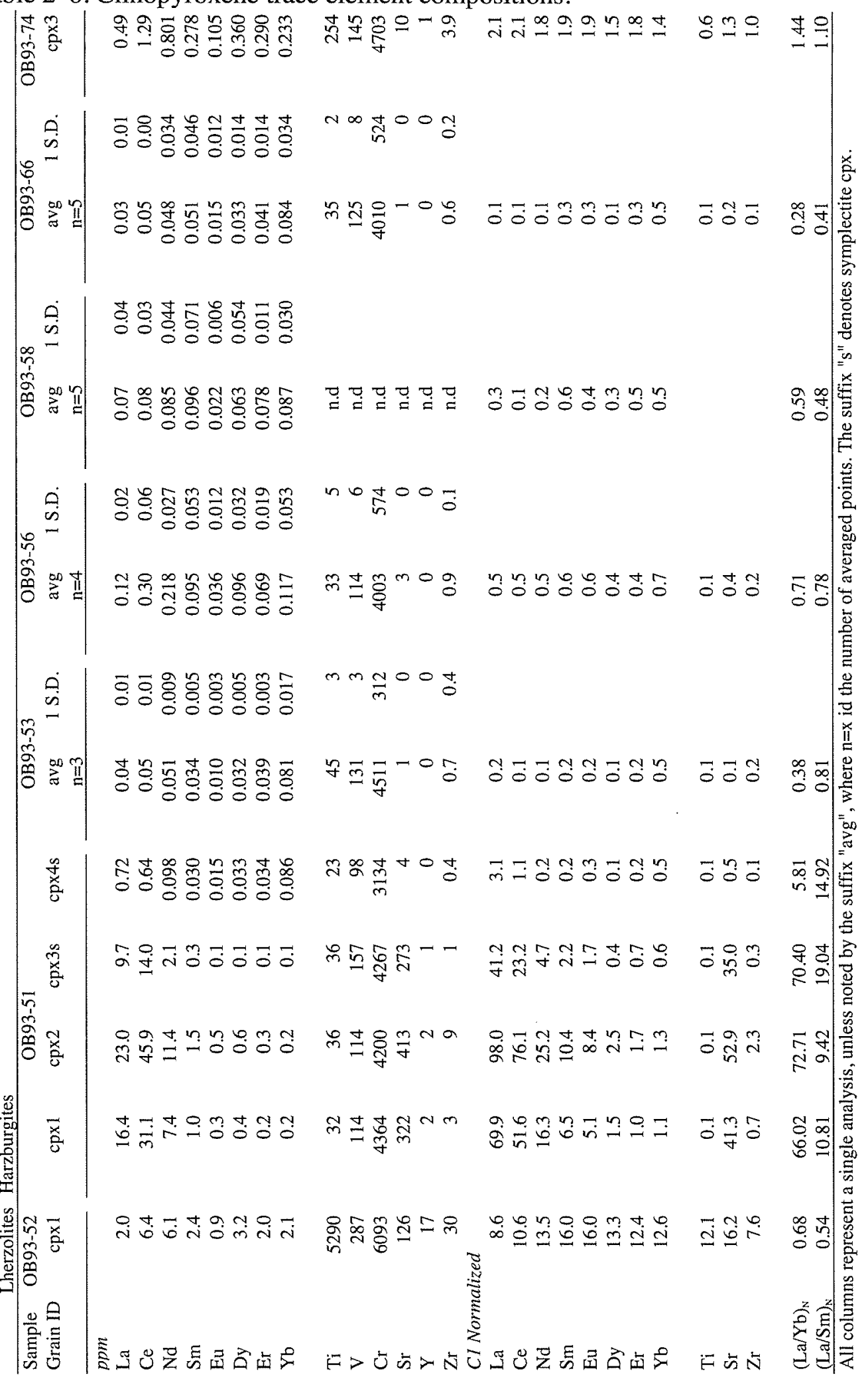


Table 2-8. continued.

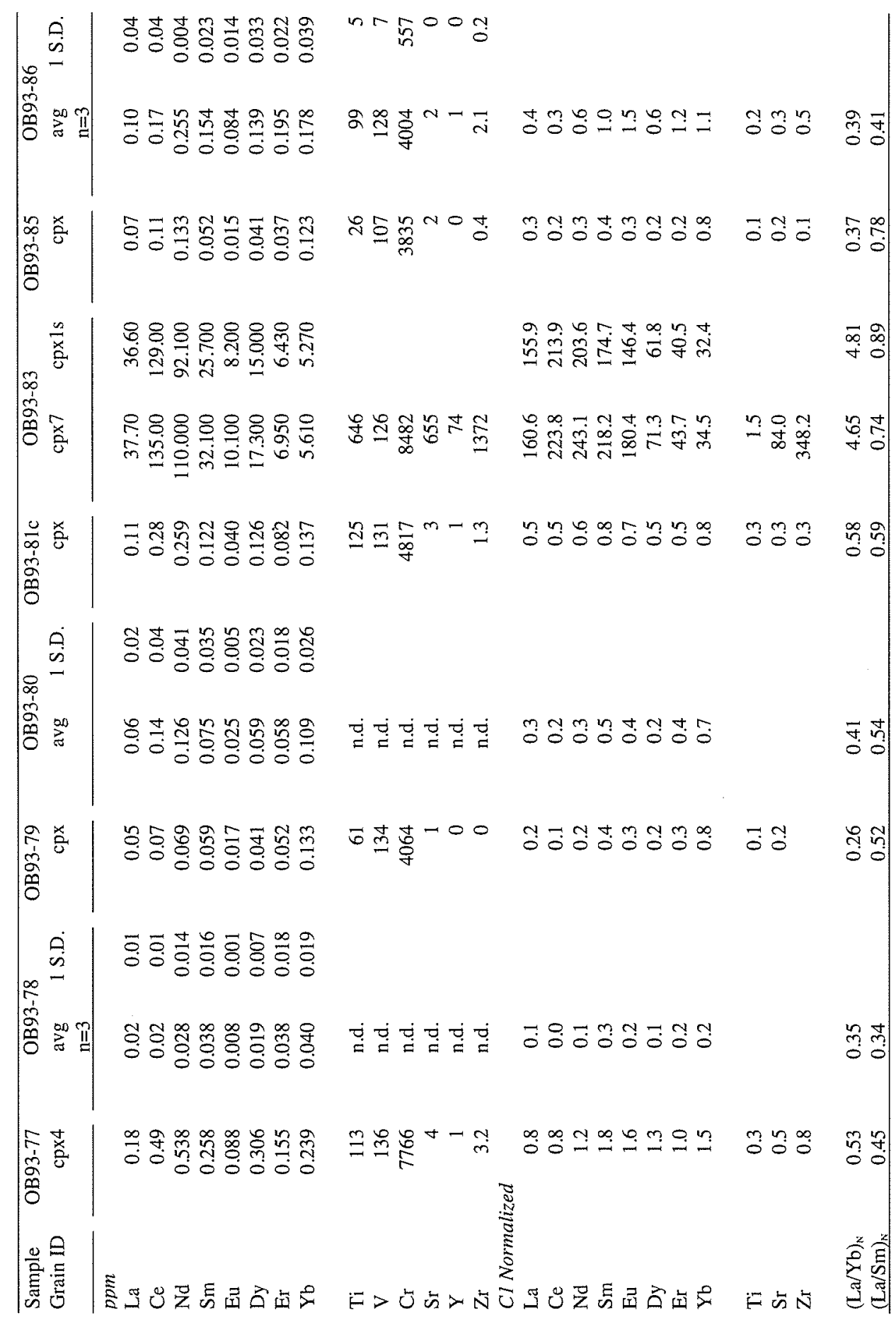


Table 2-8. continued.

\begin{tabular}{|c|c|c|c|c|c|}
\hline 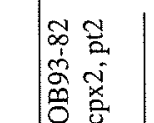 & 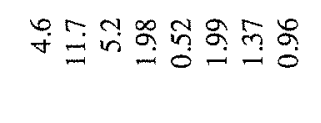 & 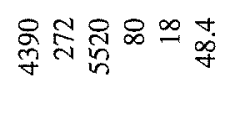 & 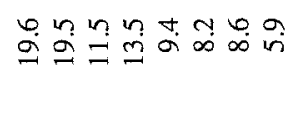 & 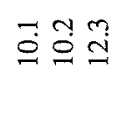 & 를 \\
\hline $\mid \begin{array}{ll}0 \\
0 \\
0 \\
0 \\
0 \\
0 \\
0\end{array}$ & 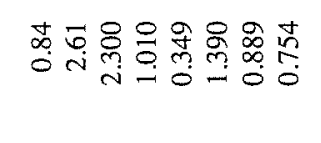 & 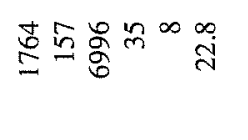 & 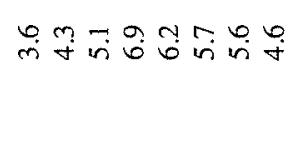 & $\stackrel{\circ}{\circ} \stackrel{\infty}{+}$ & 동 \\
\hline 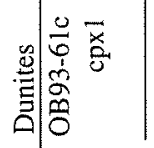 & 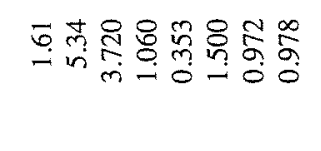 & 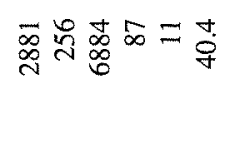 & Ğ & $\stackrel{0}{b}=\stackrel{?}{=}$ & \pm 0 \\
\hline a & 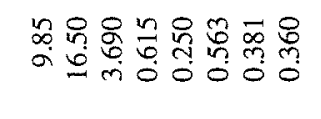 & 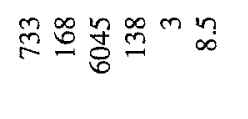 & 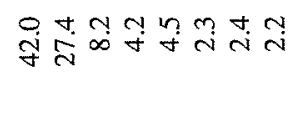 & 폴 & 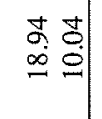 \\
\hline 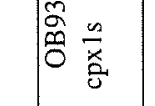 & 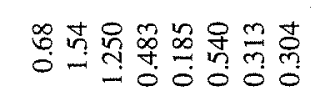 & 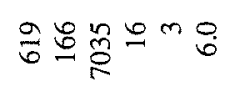 & 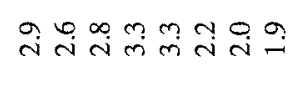 & 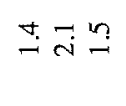 & 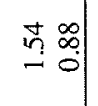 \\
\hline$\stackrel{\dot{\rho}}{\infty}$ & \begin{tabular}{l}
8 \\
\hdashline \\
$O$
\end{tabular} & $+r \underset{m}{0} 00 \tilde{g}$ & & & \\
\hline $\mid \begin{array}{lll}2 & \infty & 0 \\
\ddot{\tilde{O}} & \stackrel{\infty}{*} & \stackrel{1}{=}\end{array}$ & 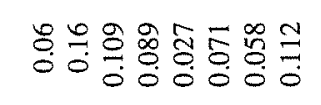 & 묘엥 & 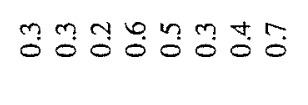 & & $\begin{array}{lll}0 & 0 \\
0 & 0 & 0 \\
0\end{array}$ \\
\hline$\stackrel{\dot{\theta}}{\dot{\theta}}$ & 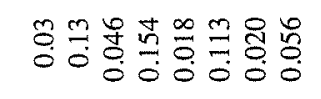 & 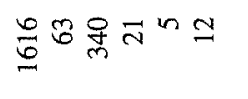 & & & \\
\hline 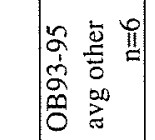 & 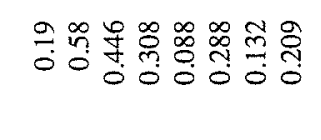 & $\cong g \stackrel{g}{=} n-N$ & 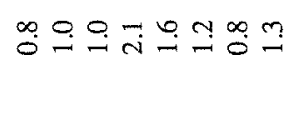 & & 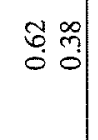 \\
\hline 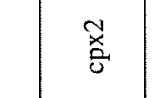 & 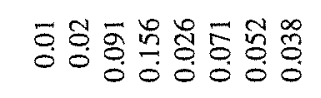 & & 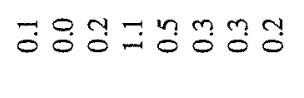 & & \begin{tabular}{ll}
\multirow{2}{*}{} & 8 \\
0 & 0 \\
0
\end{tabular} \\
\hline 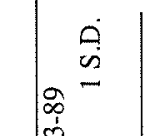 & 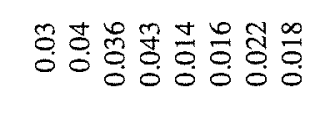 & tr $\underset{q}{\infty} 00 \mathrm{~m}$ & & & \\
\hline 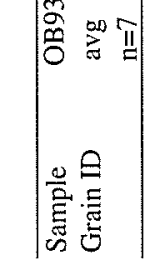 & 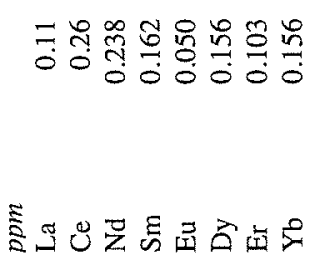 & 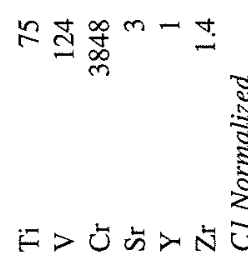 & 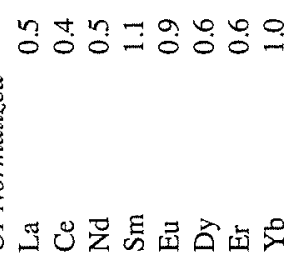 & 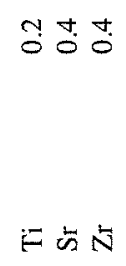 & 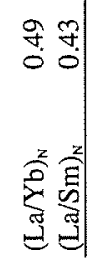 \\
\hline
\end{tabular}


Table 2-8. continued.

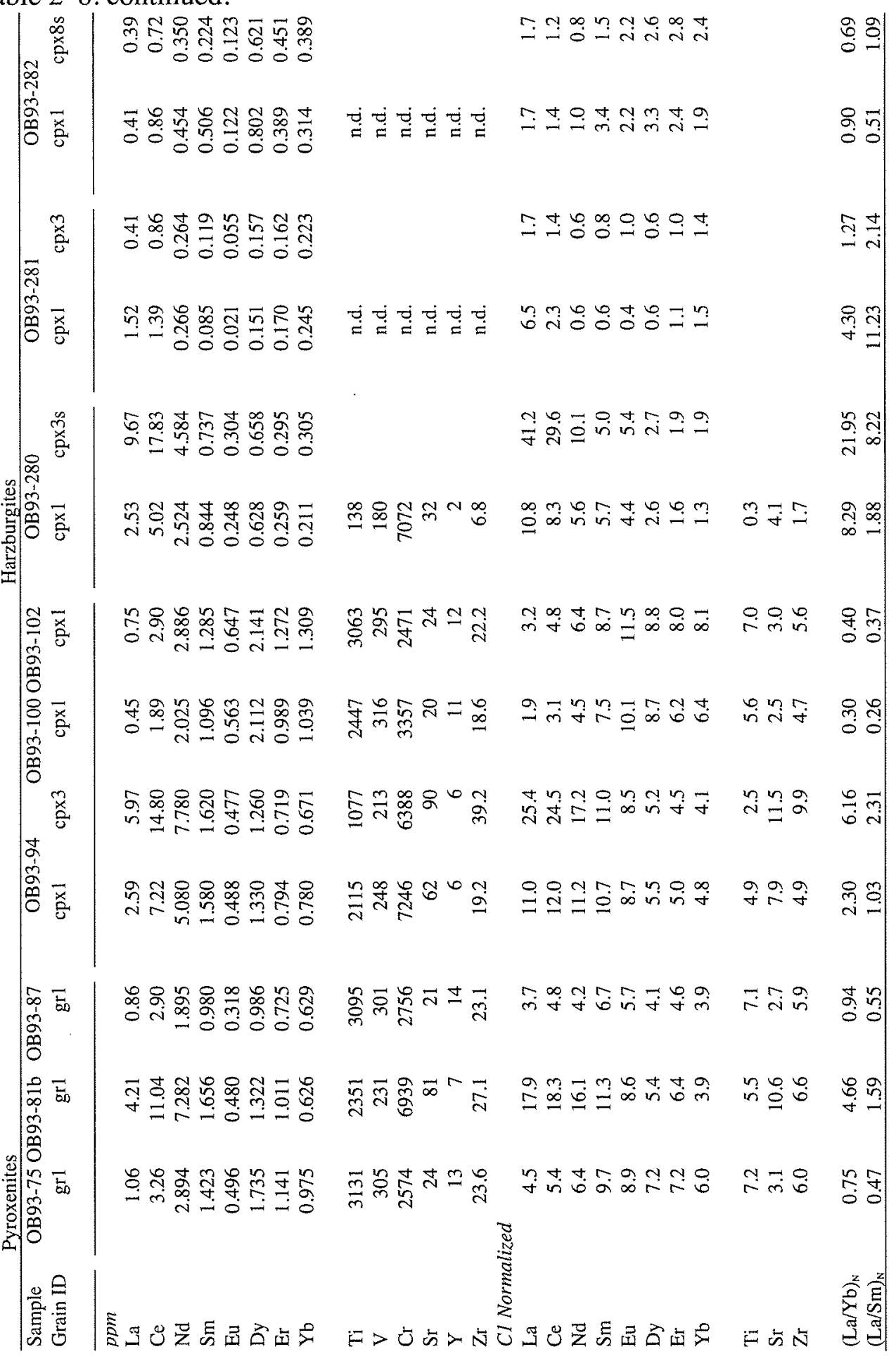


Table 2-8. continued.

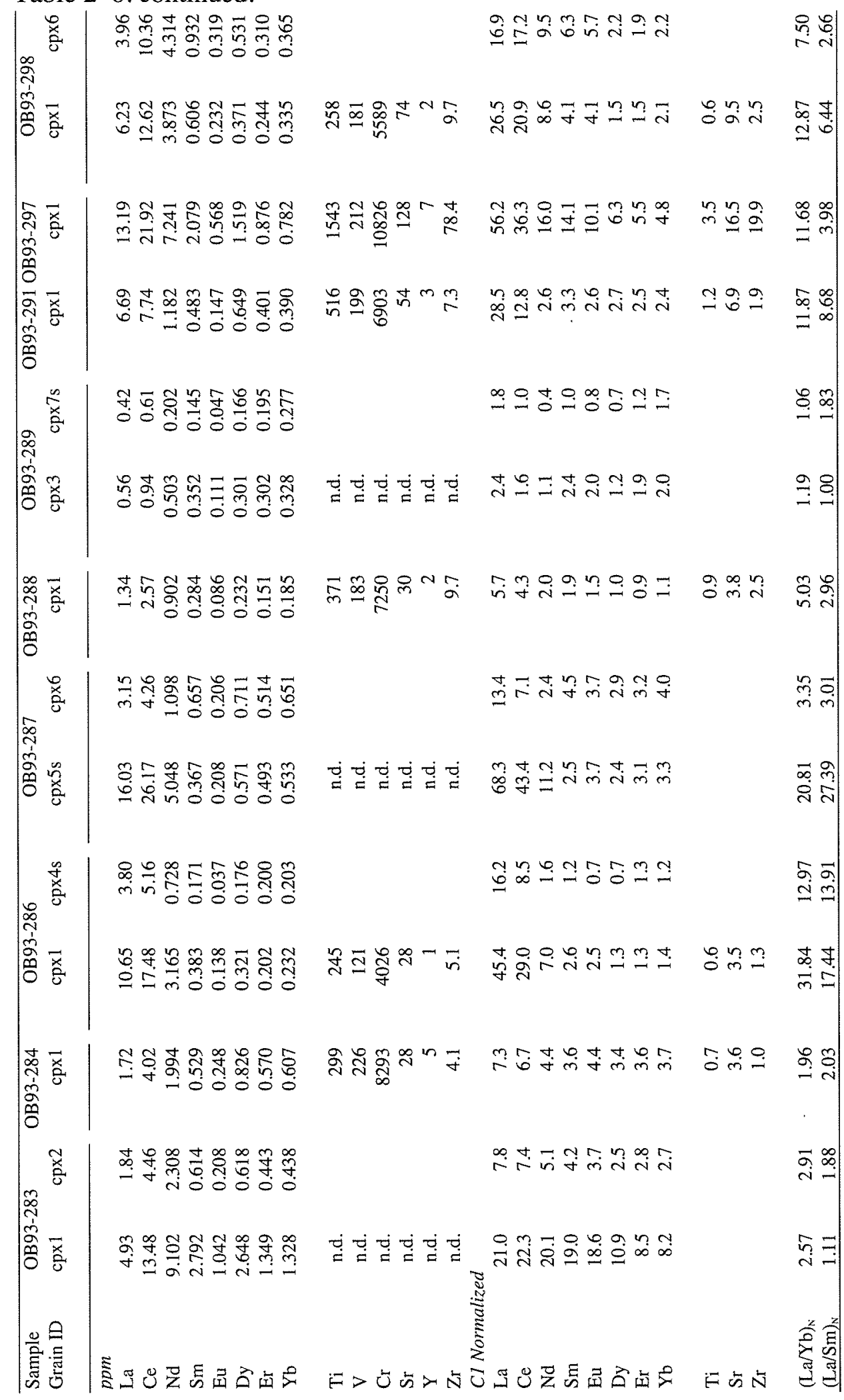


Table 2-8. continued.

\begin{tabular}{|c|c|c|c|c|c|}
\hline 苂 & 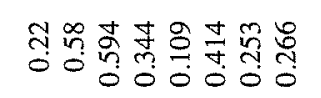 & 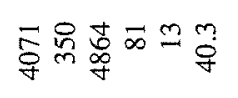 & 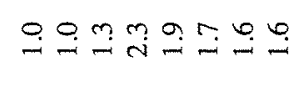 & 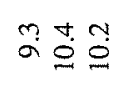 & i̊ \\
\hline कि & 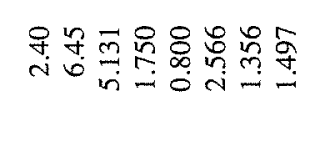 & 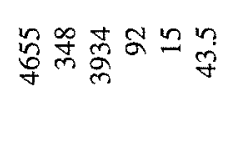 & 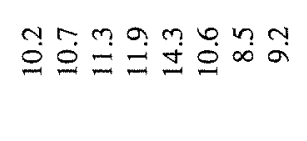 & $\stackrel{\infty}{\stackrel{\infty}{=}} \stackrel{0}{=}$ & \\
\hline 爻 & 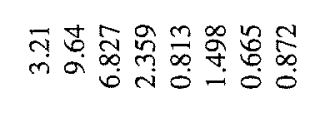 & 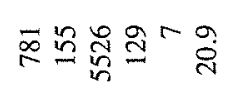 & r.ํ் & $\stackrel{\infty}{\rightarrow-n} \underset{-1}{n}$ & \\
\hline 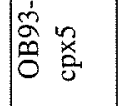 & 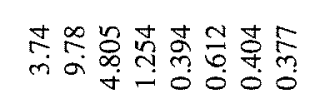 & 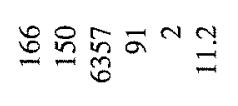 & 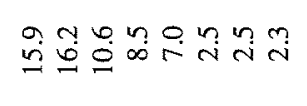 & $\stackrel{+}{\circ} \underset{=}{=}$ & \\
\hline$\overbrace{0}^{\bar{x}}$ & 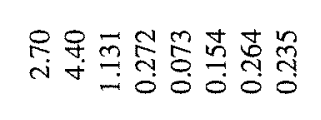 & 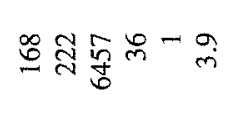 & $\stackrel{n}{=} \stackrel{n}{\sim} \stackrel{\infty}{-} \cong \stackrel{0}{0}=$ & பt. & \\
\hline 飧 & 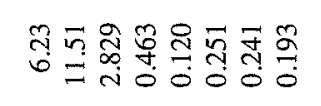 & 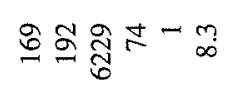 & 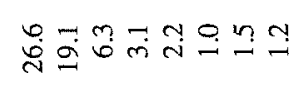 & $\tan \vec{i}$ & \\
\hline 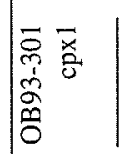 & m & $g \bar{n} \bar{g} g-m$ & $\stackrel{m}{ \pm}=\forall \dot{0} \stackrel{m}{m} \stackrel{\infty}{0} \stackrel{0}{=} \stackrel{\infty}{=}$ & 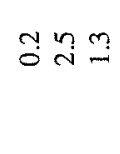 & \\
\hline$\dot{\theta}$ & 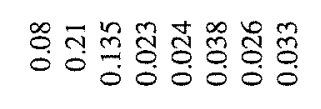 & & & & \\
\hline 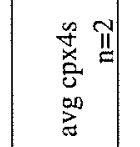 & 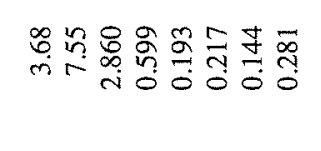 & 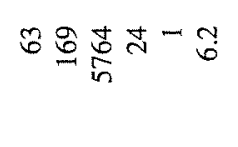 & 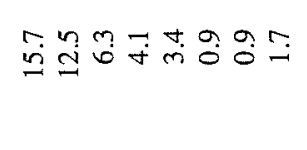 & $\overrightarrow{0} \vec{m}$ & \\
\hline$\underset{a}{0}$ & 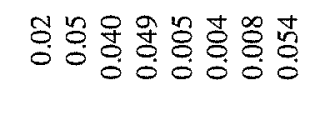 & & & & \\
\hline 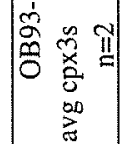 & 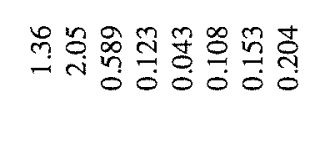 & 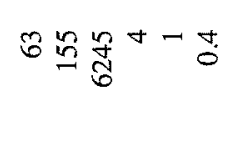 & 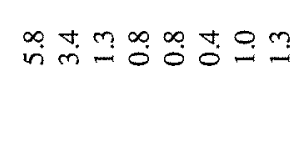 & 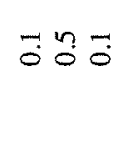 & \\
\hline$\dot{a}$ & 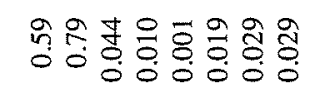 & & & & \\
\hline 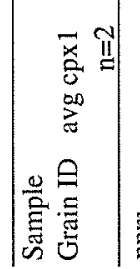 & 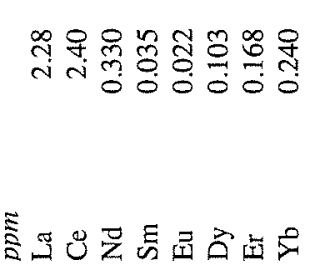 & 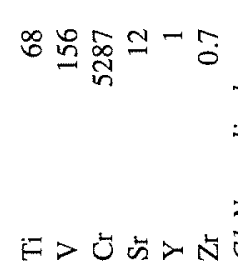 & 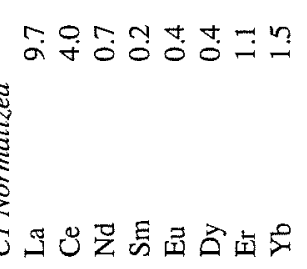 & ஸุํำ & $\sigma$ \\
\hline
\end{tabular}


Table 2-8. continued.

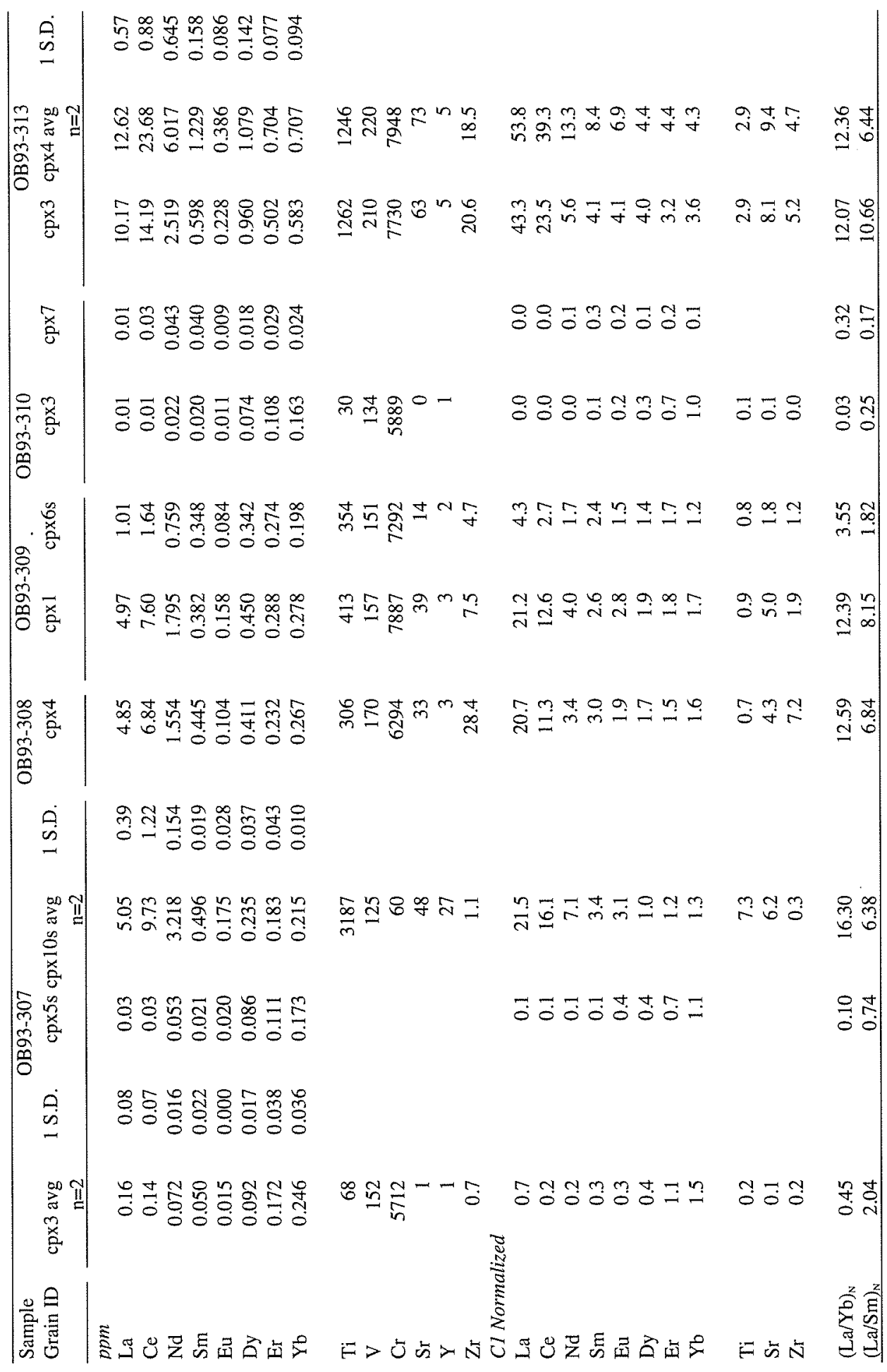


Table 2-8. continued.

\begin{tabular}{|c|c|c|c|c|c|}
\hline$\dot{\rho}$ & $\begin{array}{l}n=0 \\
0 \\
0\end{array}$ & & & & \\
\hline 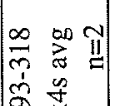 & 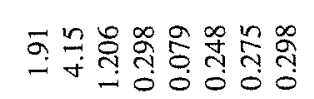 & & - & & $\begin{array}{ll}m & f \\
\dot{f} & f \\
\dot{f}\end{array}$ \\
\hline$\stackrel{\substack{x \\
\hdashline}}{a}$ & 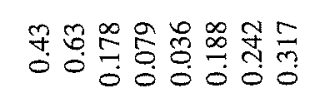 & 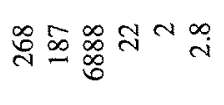 & 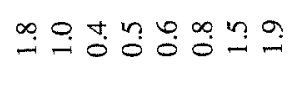 & 웅 & 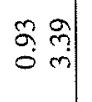 \\
\hline 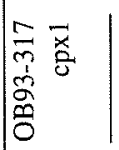 & 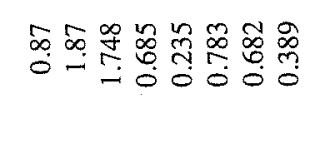 & 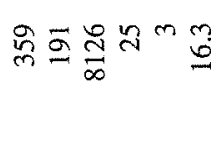 & 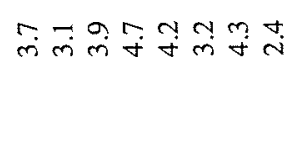 & 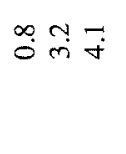 & \\
\hline$\stackrel{\dot{\theta}}{m}$ & $\begin{array}{l}\overrightarrow{0} \\
0\end{array}$ & & & & \\
\hline 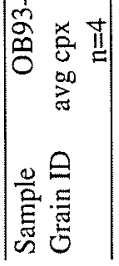 & 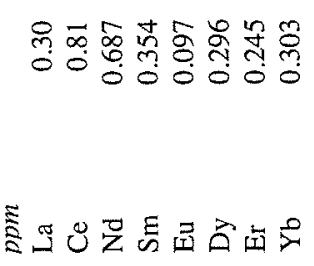 & 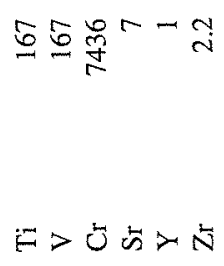 & 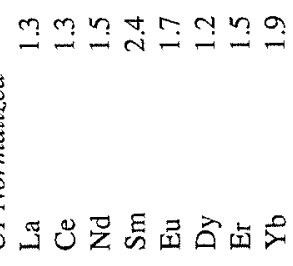 & 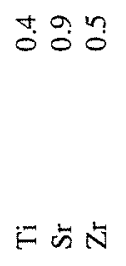 & $\lesssim$ \\
\hline
\end{tabular}


Table 2-9. Sr and Nd isotopic compositions.

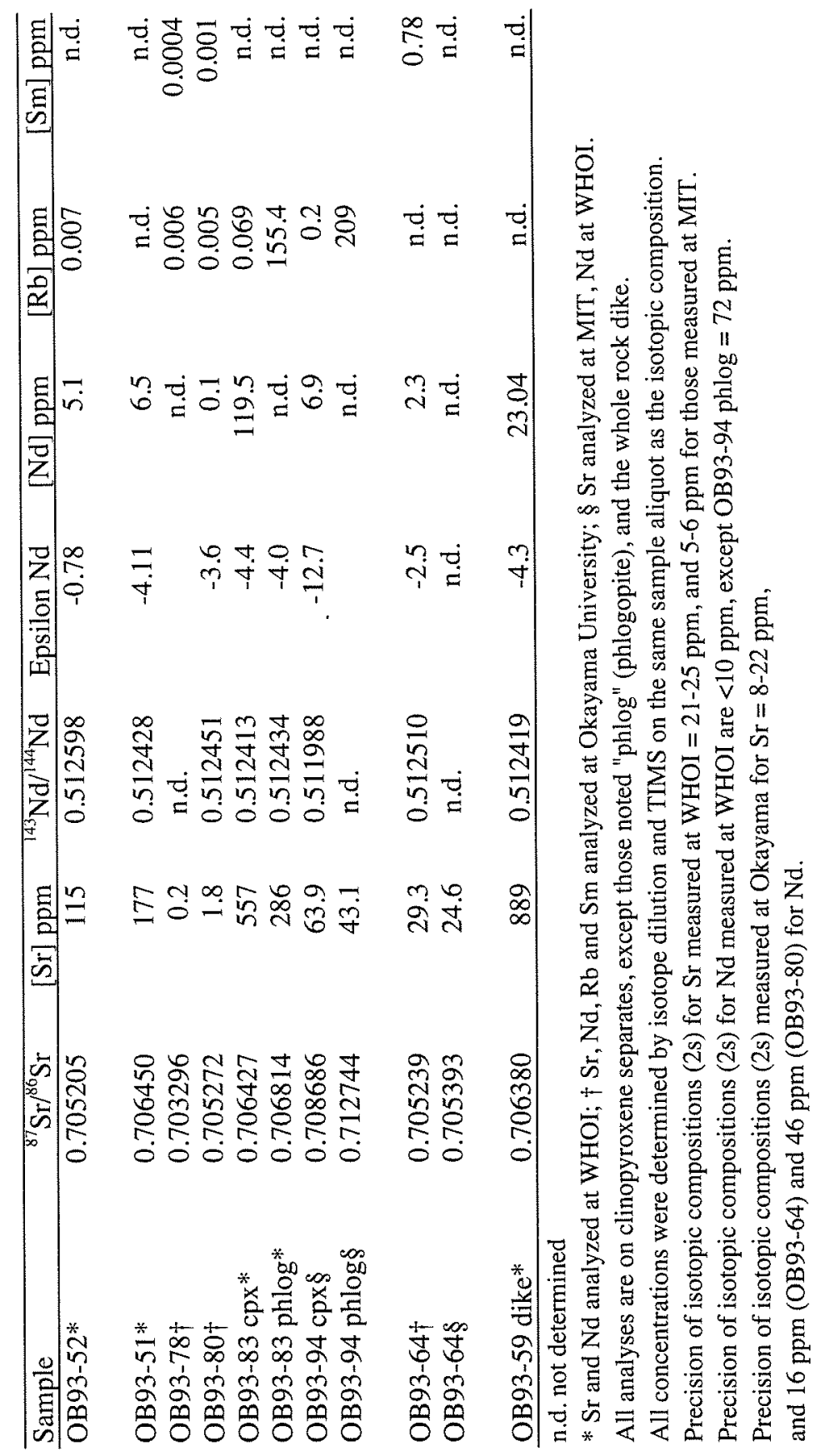


Table 2-10. Re-Os isotopic compositions (from Hassler and Shimizu, 1998).

\begin{tabular}{|c|c|c|c|c|c|}
\hline Sample & ${ }^{187} \mathrm{Os} /{ }^{188} \mathrm{Os}$ & Os (ppt) & $\operatorname{Re}(p p t)$ & $\begin{array}{l}\mathrm{Re} / \mathrm{Os} \\
\left(\times 10^{-3}\right)\end{array}$ & $\mathrm{T}_{\mathrm{RD}}(\mathrm{Ga})$ \\
\hline \multicolumn{6}{|c|}{ Lac Superieur } \\
\hline OB93-51* & $0.1262 \pm 2$ & 87 & n.d. & & \\
\hline OB93-52† & $0.1286 \pm 3$ & 4218 & n.d. & & \\
\hline OB93-64末 & $0.1300 \pm 2$ & 968 & n.d. & & \\
\hline OB93-77 & $0.1263 \pm 3$ & 3199 & 5 & 2 & \\
\hline OB93-78 & $0.1266 \pm 6$ & 2888 & n.d. & & \\
\hline OB93-80 & $0.1252 \pm 2$ & 1727 & n.d. & & \\
\hline OB93-82 & $0.1287 \pm 2$ & 6999 & n.d. & & \\
\hline OB93-83*§ & $0.1257 \pm 4$ & 44 & n.d. & & \\
\hline \multicolumn{6}{|c|}{ Mont Trapeze } \\
\hline OB93-280 & $0.1189 \pm 2$ & 3067 & 6 & 2 & 1.36 \\
\hline OB93-284 & $0.1236 \pm 1$ & 6652 & 29 & 4 & 0.63 \\
\hline OB93284bll & $0.1229 \pm 3$ & 6645 & n.d. & & 0.74 \\
\hline OB93-287 & $0.1239 \pm 3$ & 1267 & 49 & 39 & 0.58 \\
\hline OB93-289 & $0.1224 \pm 3$ & 3411 & 12 & 4 & 0.81 \\
\hline OB93-291 & $0.1205 \pm 4$ & 2157 & 11 & 5 & 1.11 \\
\hline OB93-297 & $0.1228 \pm 3$ & 2409 & 31 & 13 & 0.75 \\
\hline OB93-305 & $0.1211 \pm 3$ & 2012 & 72 & 36 & 1.02 \\
\hline OB93-305rll & $0.1202 \pm 4$ & 2179 & n.d. & & 1.16 \\
\hline OB93-306 & $0.1276 \pm 5$ & 516 & 41 & 80 & \\
\hline OB93-307 & $0.1229 \pm 3$ & 5605 & 49 & 9 & 0.74 \\
\hline OB93-314 & $0.1383 \pm 6$ & 3281 & 9 & 3 & \\
\hline OB93-317 & $0.1196 \pm 4$ & 2652 & 11 & 4 & 1.25 \\
\hline
\end{tabular}

*Olivine Separate. $†$ Spinel lherzolite. $\$$ Wehrlitic dunite. $\S$ Phlogopite-bearing spinel lherzolite. IIReplicate. 


\subsection{Figures}

Figure 2-1. Examples of peridotite textures and mineralogy. Reflected light

photomicrograph of spinel and cpx symplectite intergrowth from sample OB93-79. The light colored mineral with vermicular intergrowth is spinel and the darker gray is clinopyroxene. The scale is $1 \mathrm{~mm}$ across the grain.

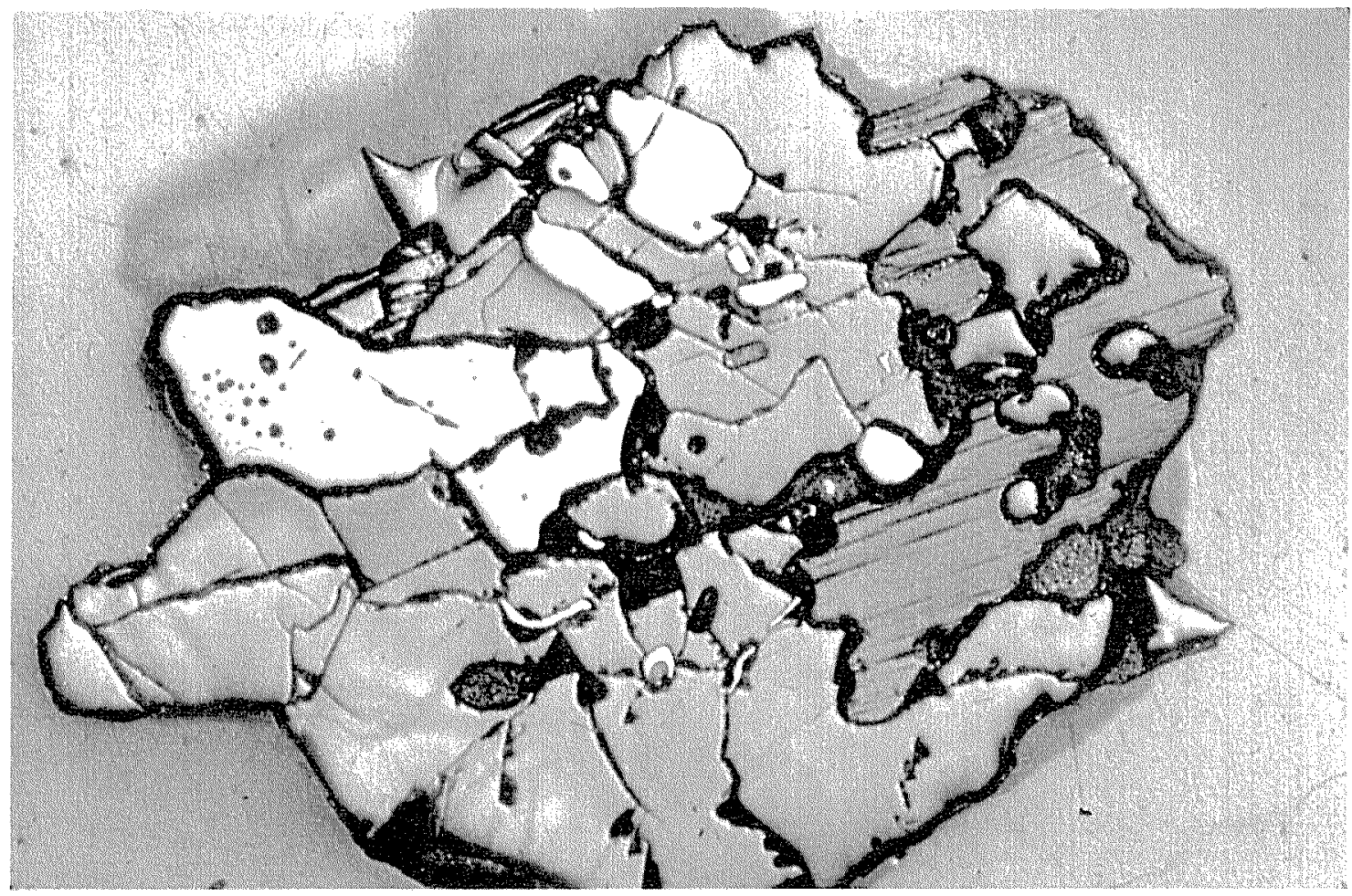


Figure 2-1. continued. Reflected light photomicrograph showing the metasomatic texture of sample OB93-83. Remnants of symplectite spinel (light colored, central lower part of the grain), can be seen in the clinopyroxene (darker gray color). Phlogopite (central small euhedral grain and the striated area on the right) coexists with apatite (stippled area to lower right of phlogopite). The scale is $1.5 \mathrm{~mm}$ across the grain.

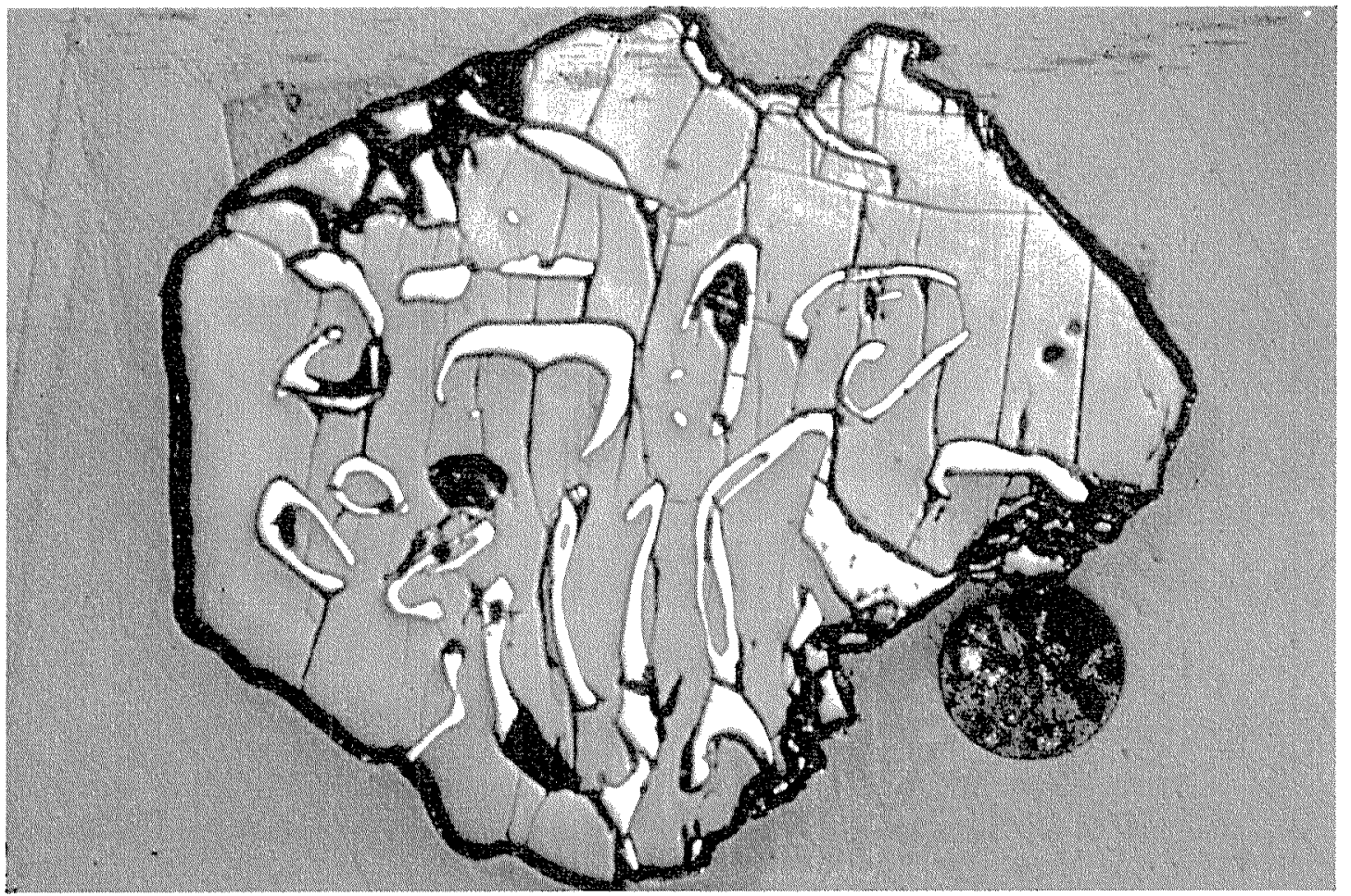


Figure 2-1. continued. Plane polarized light photomicrograph of sample OB93-301, exhibiting a typical coarse symplectite texture. Chromite spinel is the central dark vermicular mineral. One small clinopyroxene is present next to the leftmost clinopyroxene. Other minerals are orthopyroxene and olivine. The field of view is $10 \mathrm{~mm}$ across.

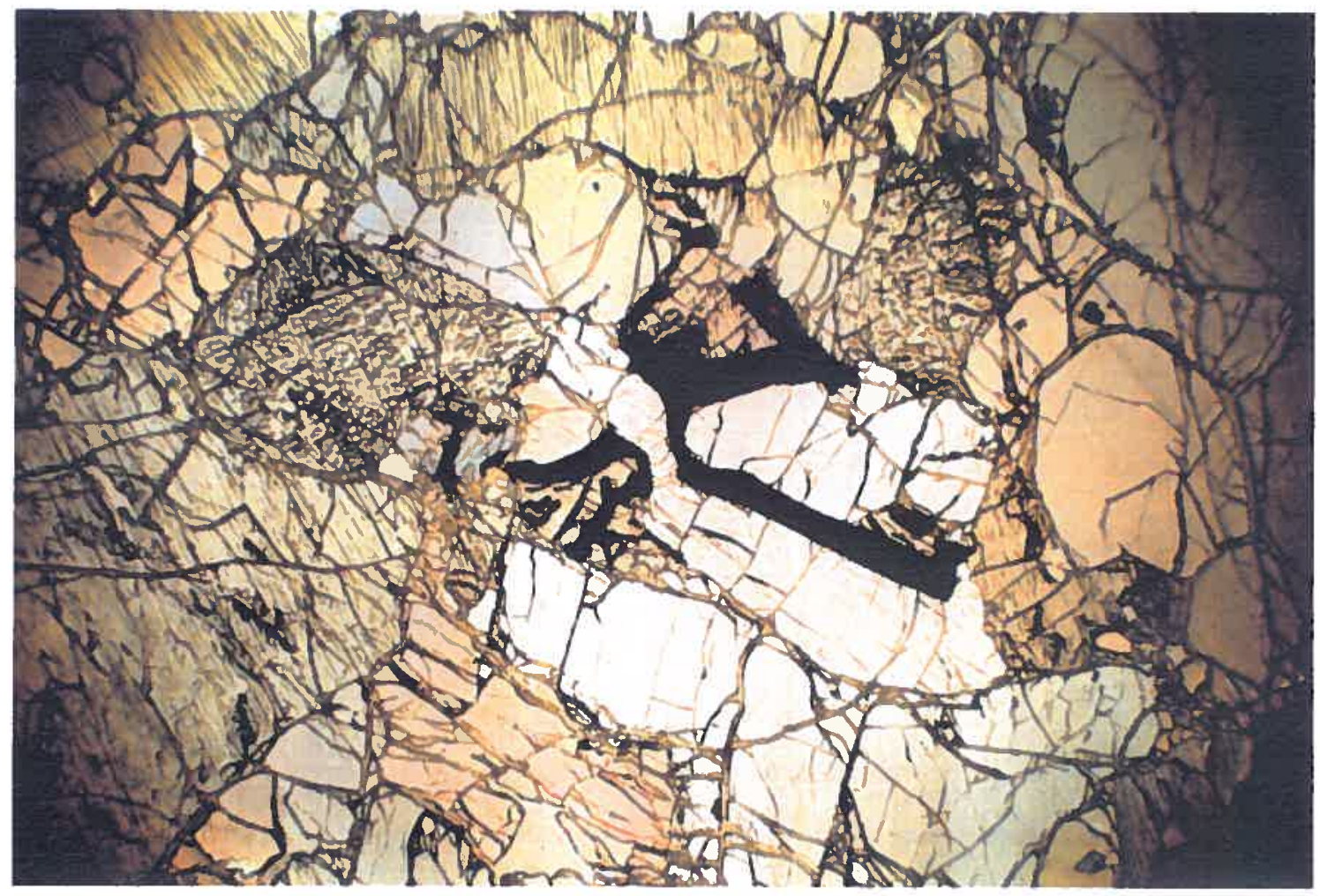


Figure 2-1. continued. Cross polarized light photomicrograph of sample OB93-22, showing the typical deformation texture that is present in these peridotite. Orthopyroxenes are the minerals with the lower birefringence, those with the higher order colors are olivine. Note the deformation banding and the subgrains (smaller rounded olivines) along larger olivine boundaries. The field of view is $10 \mathrm{~mm}$ across.

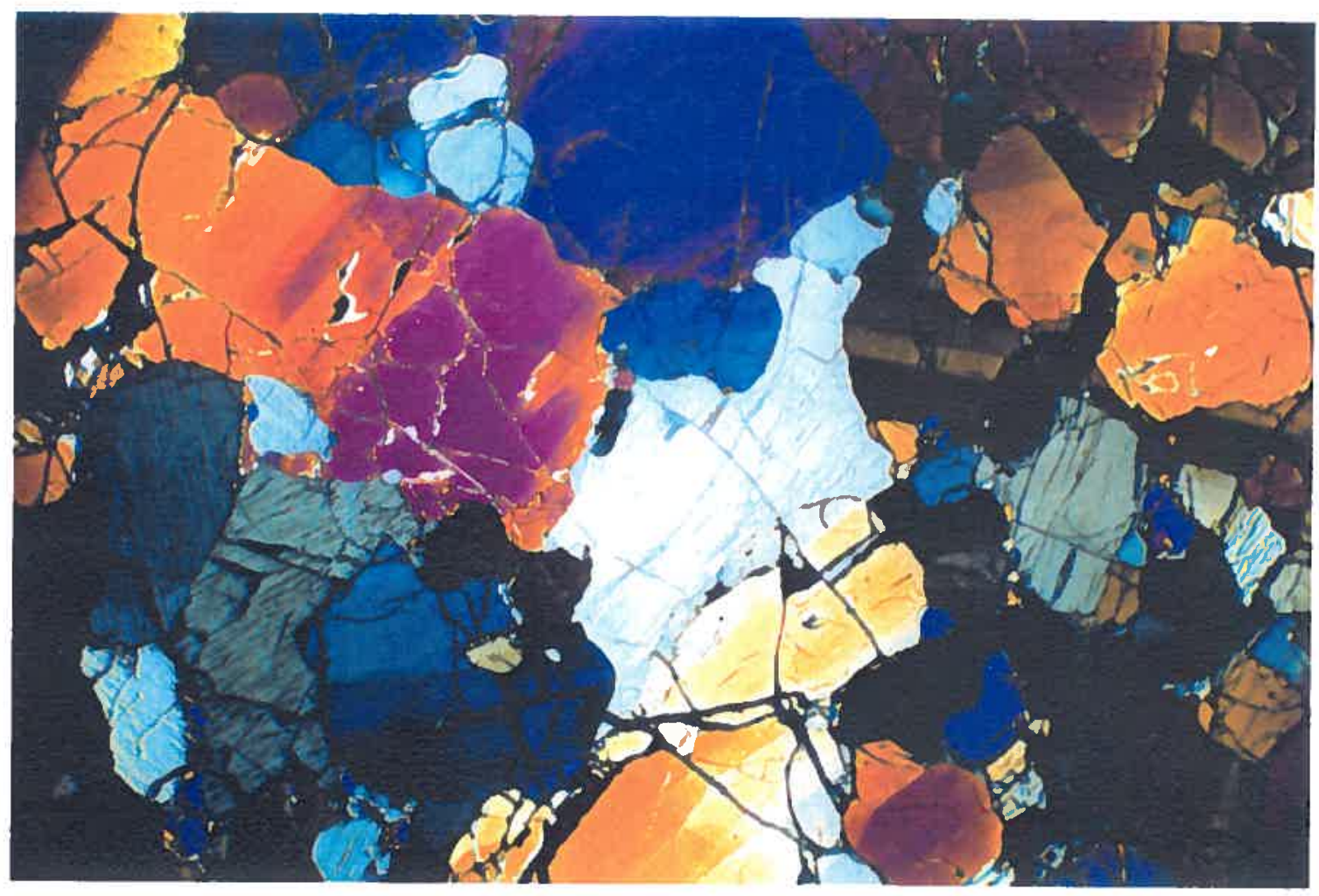




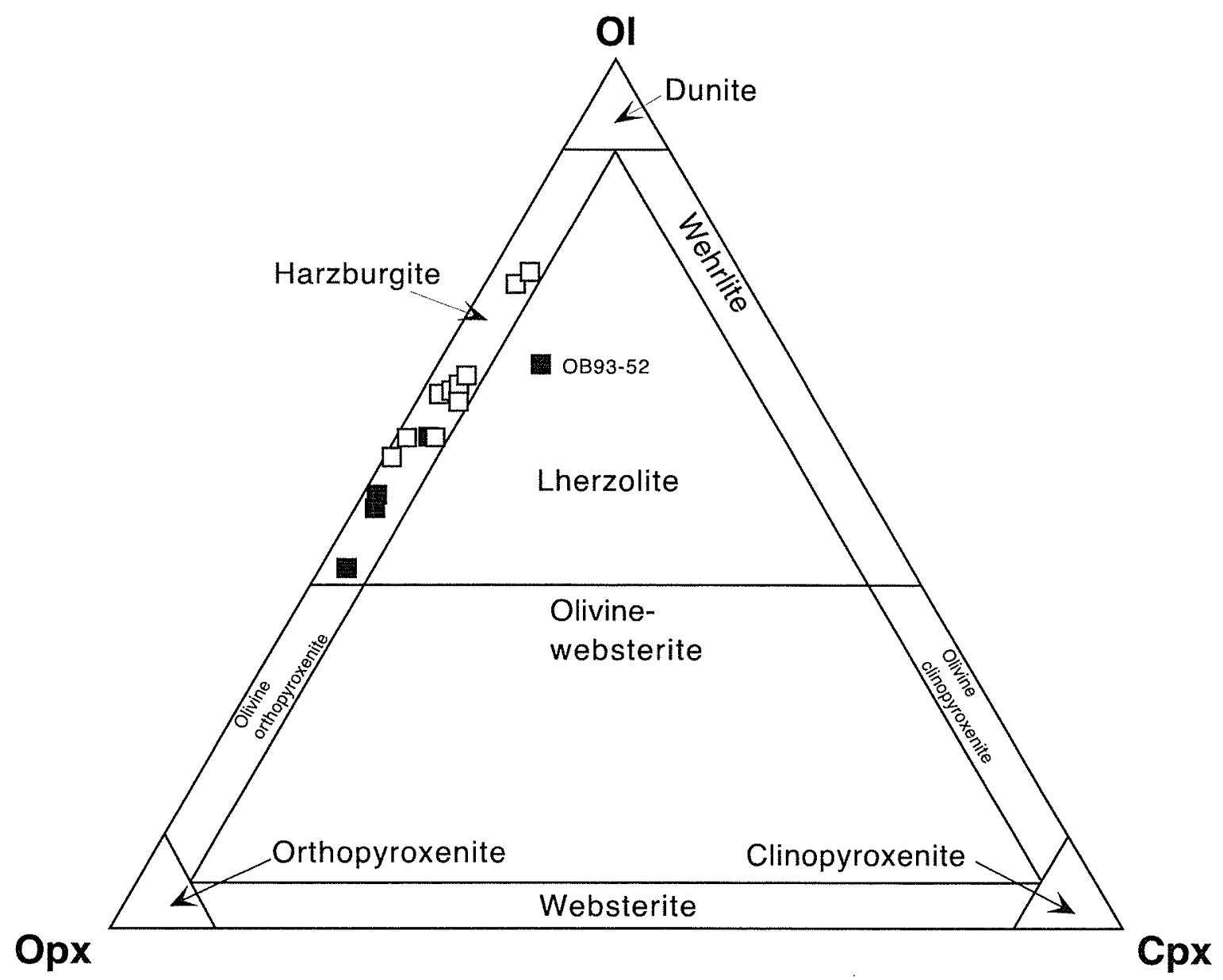

Figure 2-2. Whole rock geochemistry of Kerguelen peridotites classified according to the IUGS system (Streckheisen, 1973). The calculated mineral modal abundances are shown as filled squares. All samples are harzburgites, except sample OB93-52, which plots in the lherzolite field. Note that many of the samples are extremely rich in their orthopyroxene (Opx) contents. Mt. Trapeze: open squares; Lac Superieur: closed squares. 


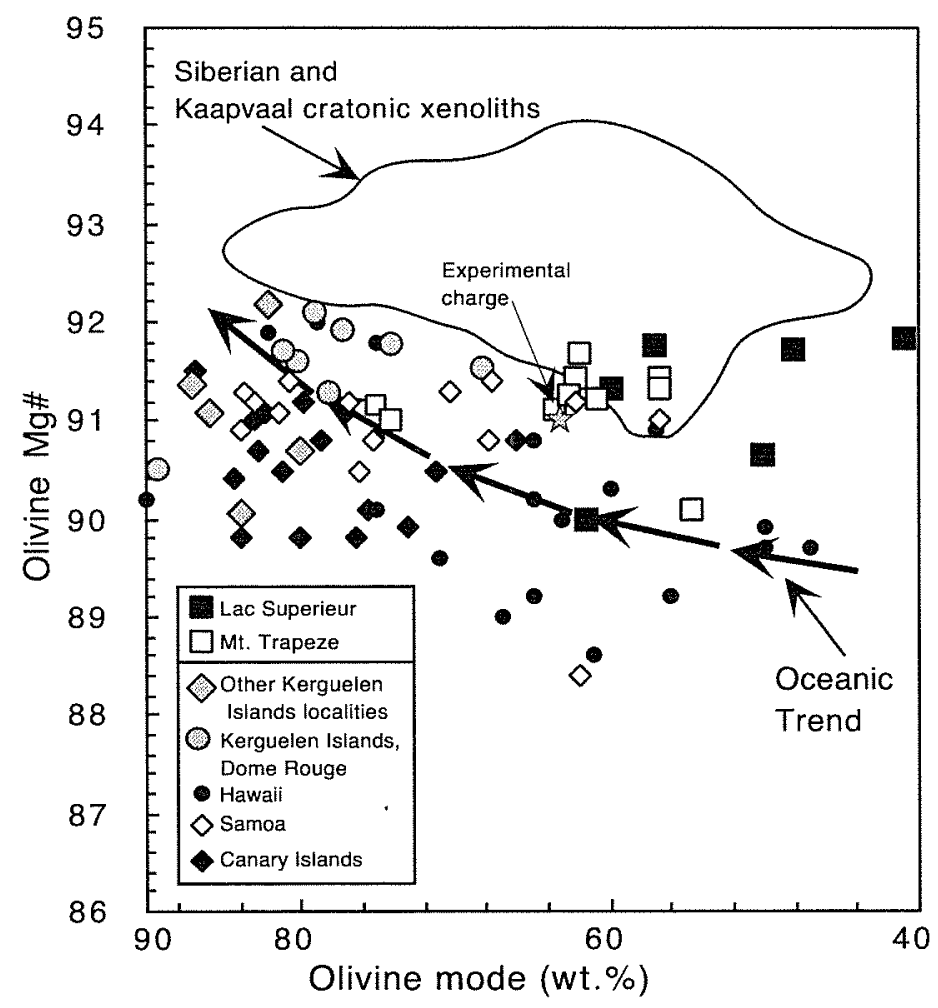

Figure 2-3. Oceanic trend diagram (after Boyd, 1989). Kerguelen samples of this study (Lac Superieur locality: filled squares, Mt. Trapeze open squares, and other Southeastern Province samples (Dome Rouge: gray circles and others: gray diamonds) are shown along with other oceanic samples (Hawaii: small filled circles, Samoa, small open diamonds, and the Canary Islands: small filled diamonds). The lherzolite (Lac Superieur sample OB93-52) plots on the oceanic trend, as do three of the Mt. Trapeze samples (OB93-287, OB93-289, OB93-297).The remaining samples of this study, and some samples from the Southeast Province, Hawaii, Samoa, and one from the Canary Islands lie above the oceanic trend, some even extending into the field defined by Siberian and Kaapvaal cratonic xenoliths. Fields and data from Boyd (1989), Boyd et al. (1997), Kelemen et al. (1998), Grègoire (1994), Hauri and Hart (1994), Sen (1988), and Wulff-Pedersen et al. (1996). 
Figure 2-4. Comparison of REE clinopyroxenes and whole rocks for selected samples, illustrating the trace element mass balance. See the text for more discussion. 

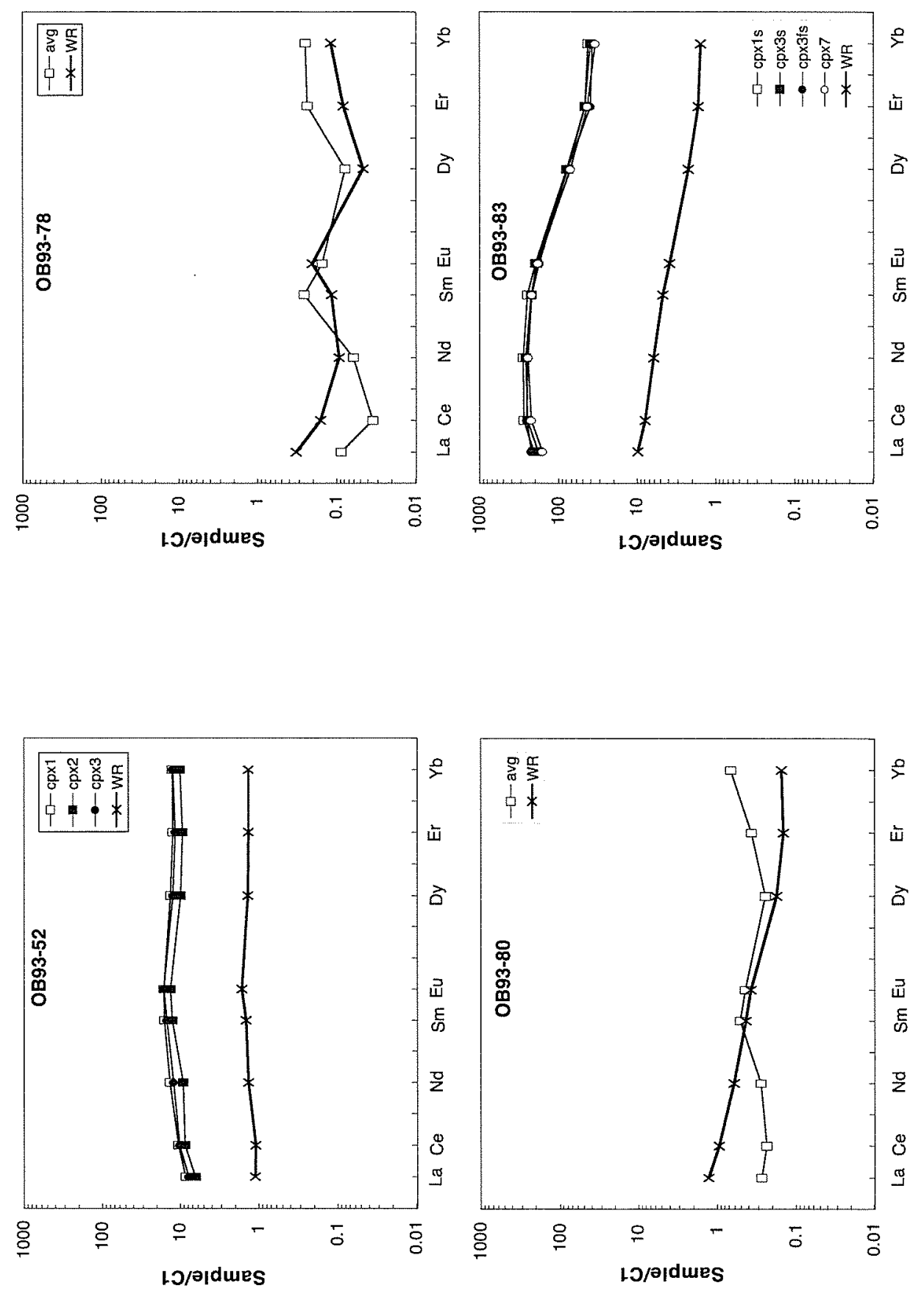

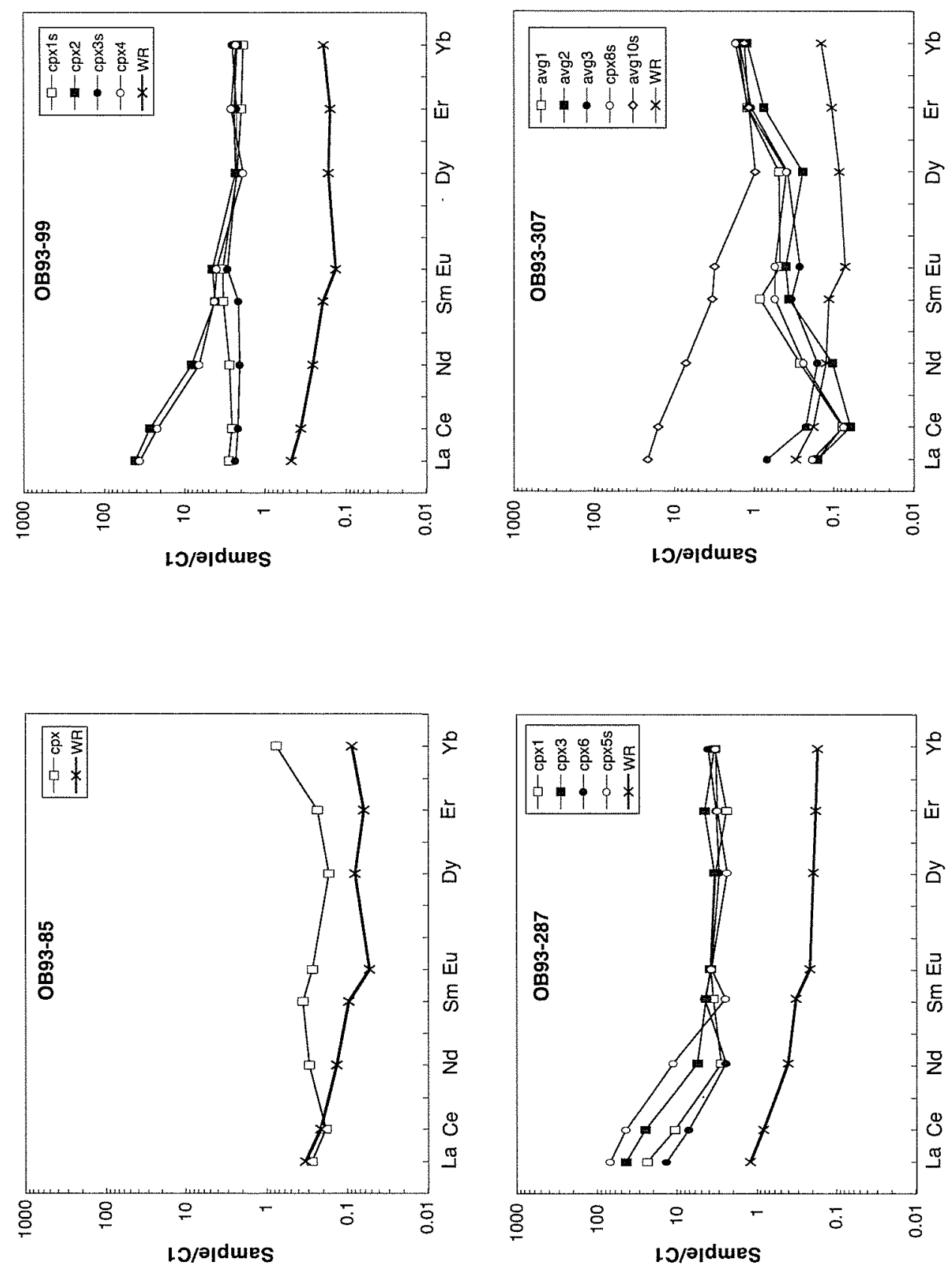


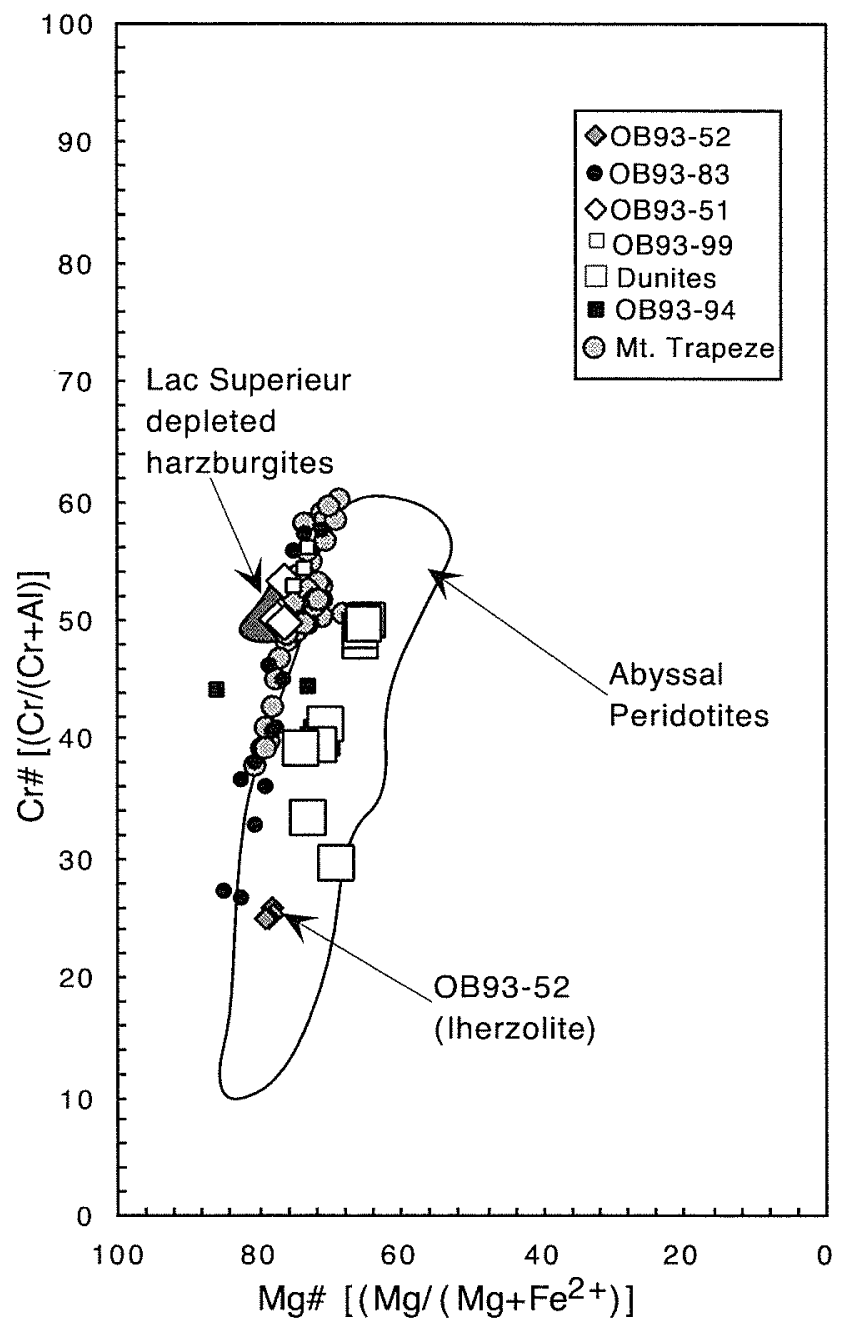

Figure 2-5. Spinel Cr\# v. Mg\#. Spinels from the Lac Superieur REE depleted samples (gray field) have a restricted range of $\mathrm{Cr}$-rich spinels indicating their extreme depletion. The lherzolite (OB93-52) plots towards the other end of the array, consistent with its fertile nature. The remaining samples fall between the two extremes, some extending to even more $\mathrm{Cr}$-rich compositions. This indicates the variation among residual and metasomatic

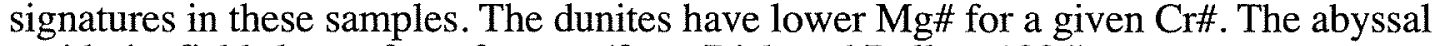
peridotite field shown for reference (from Dick and Bullen, 1984) 


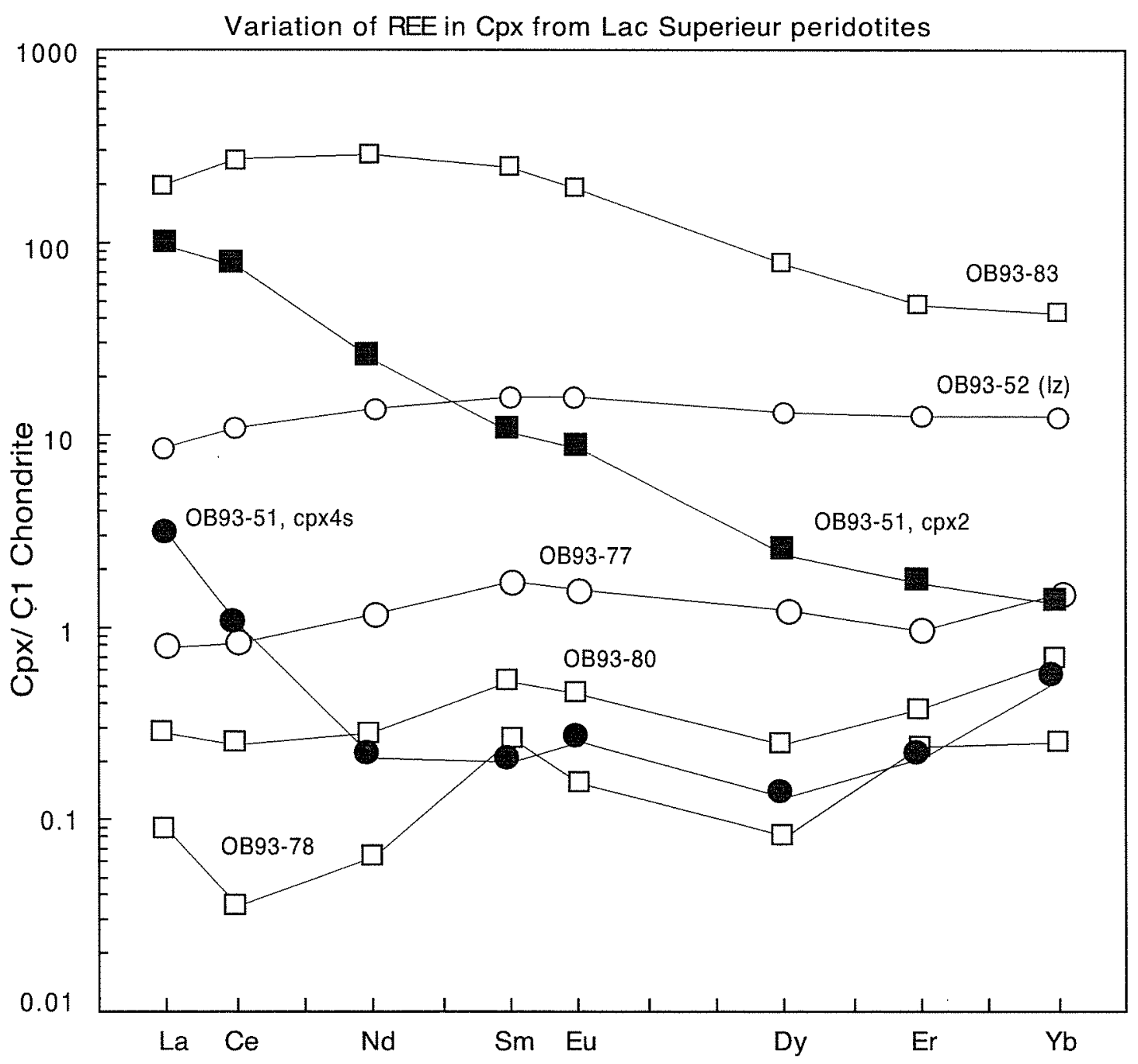

Figure 2-6. Range of clinopyroxene REE compositions from the Lac Superieur locality. Open symbols represent grains from individual rocks, closed symbols are from a single xenolith (OB93-51). 


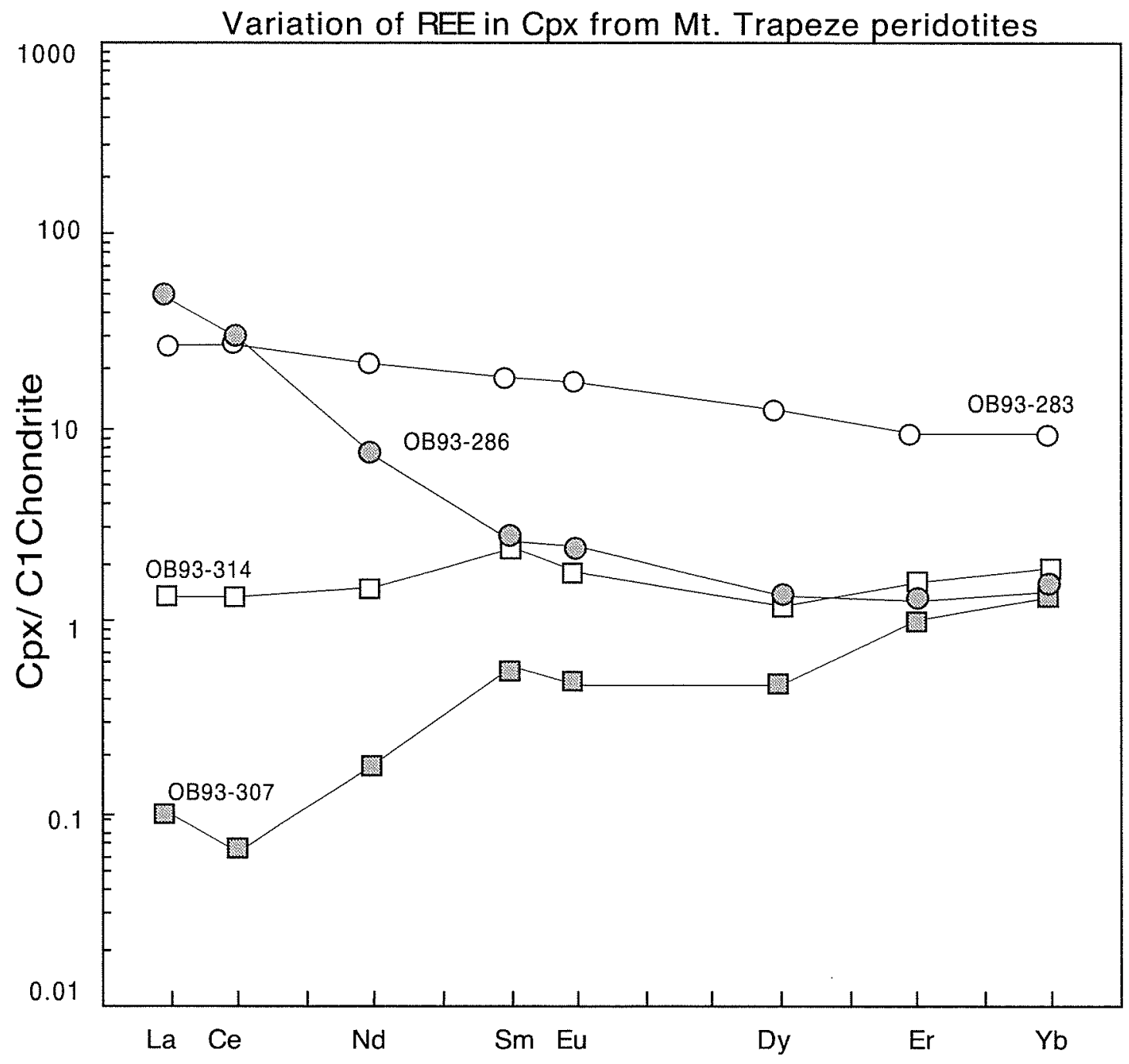

Figure 2-7. Range of clinopyroxene REE compositions from the Mt. Trapeze locality. 
Figure 2-8. Normalized REE patterns of harzburgites with heterogeneous REE abundances. 

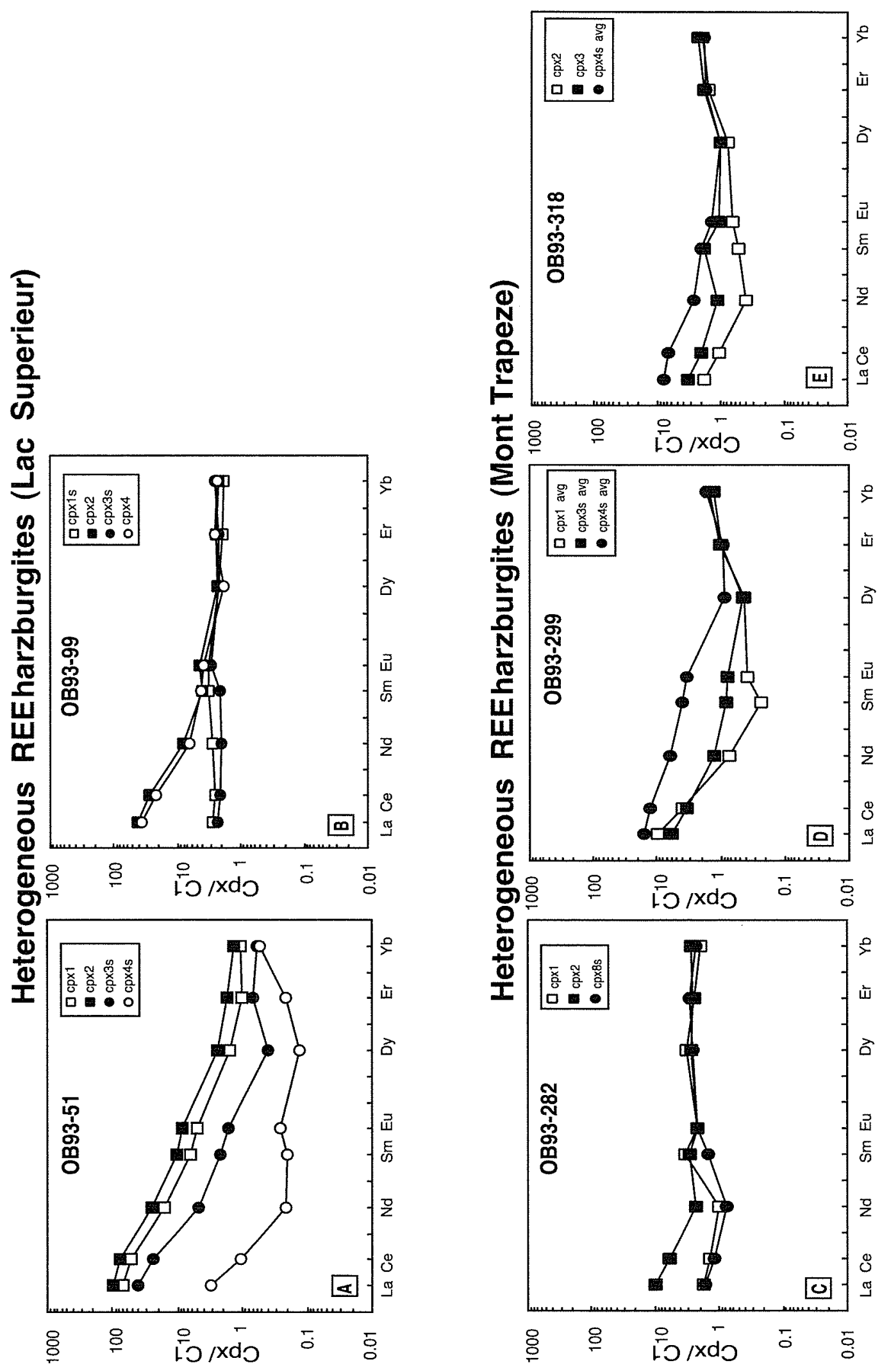
Figure 2-9. Normalized REE patterns of LREE enriched harzburgites. 

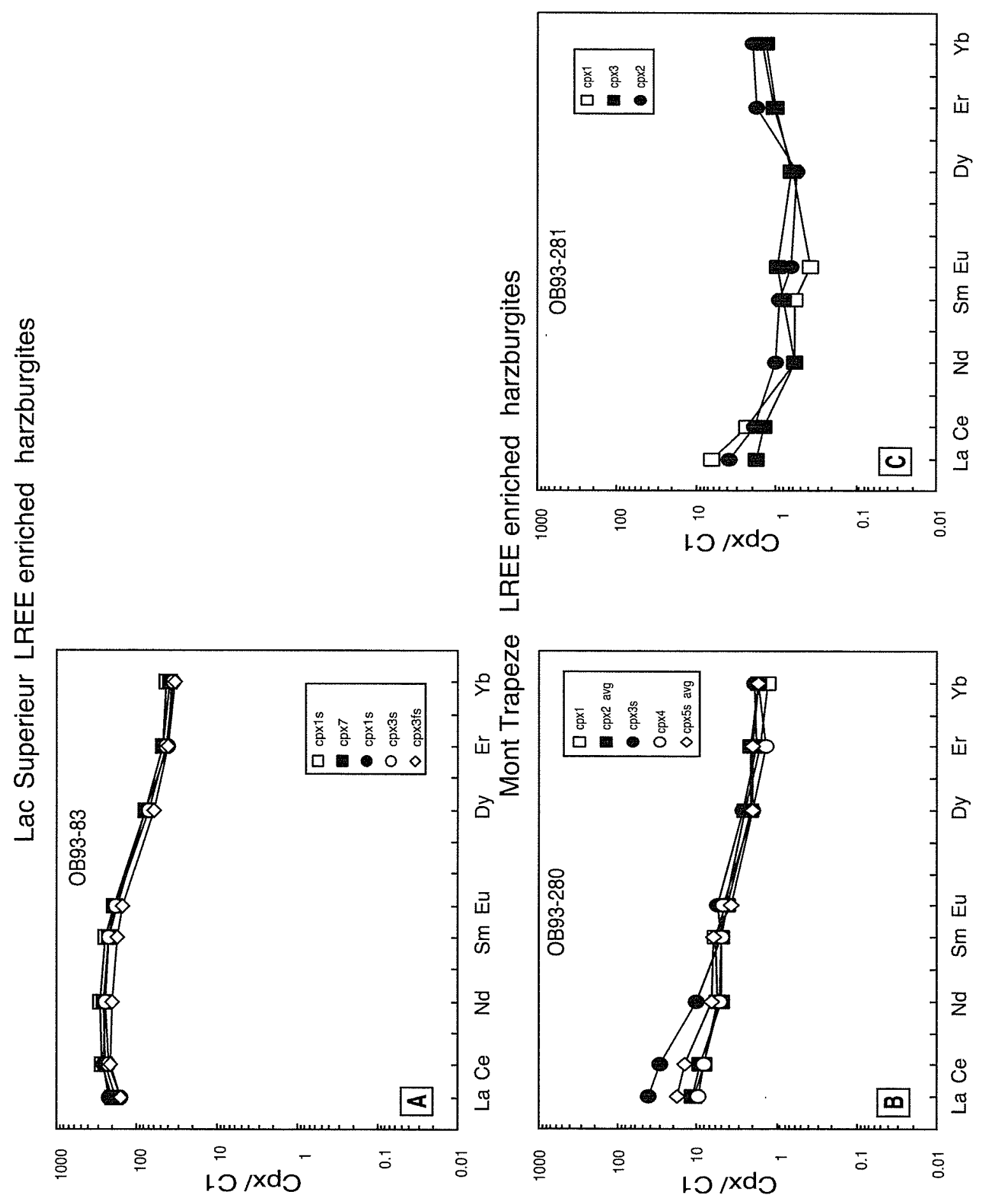


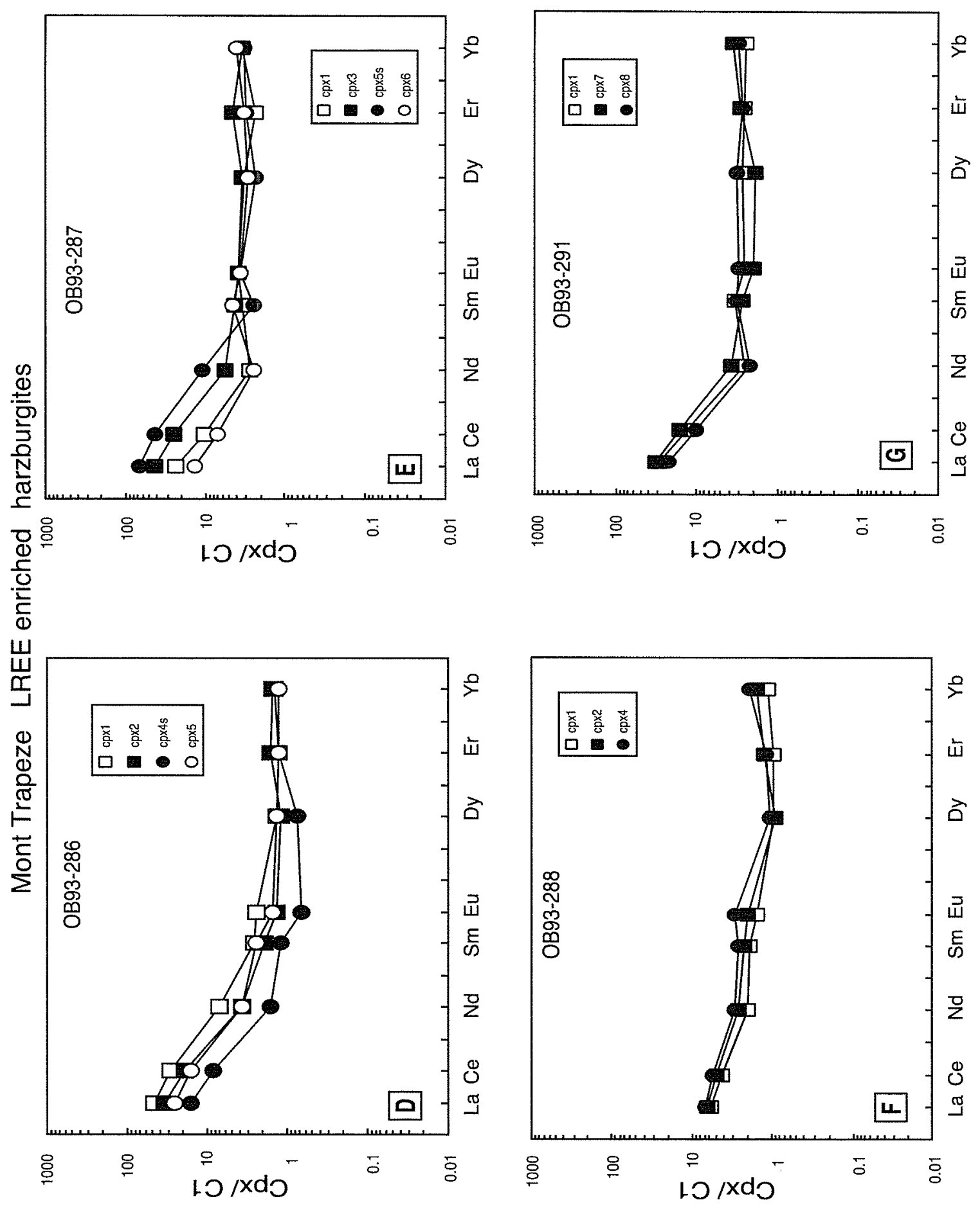




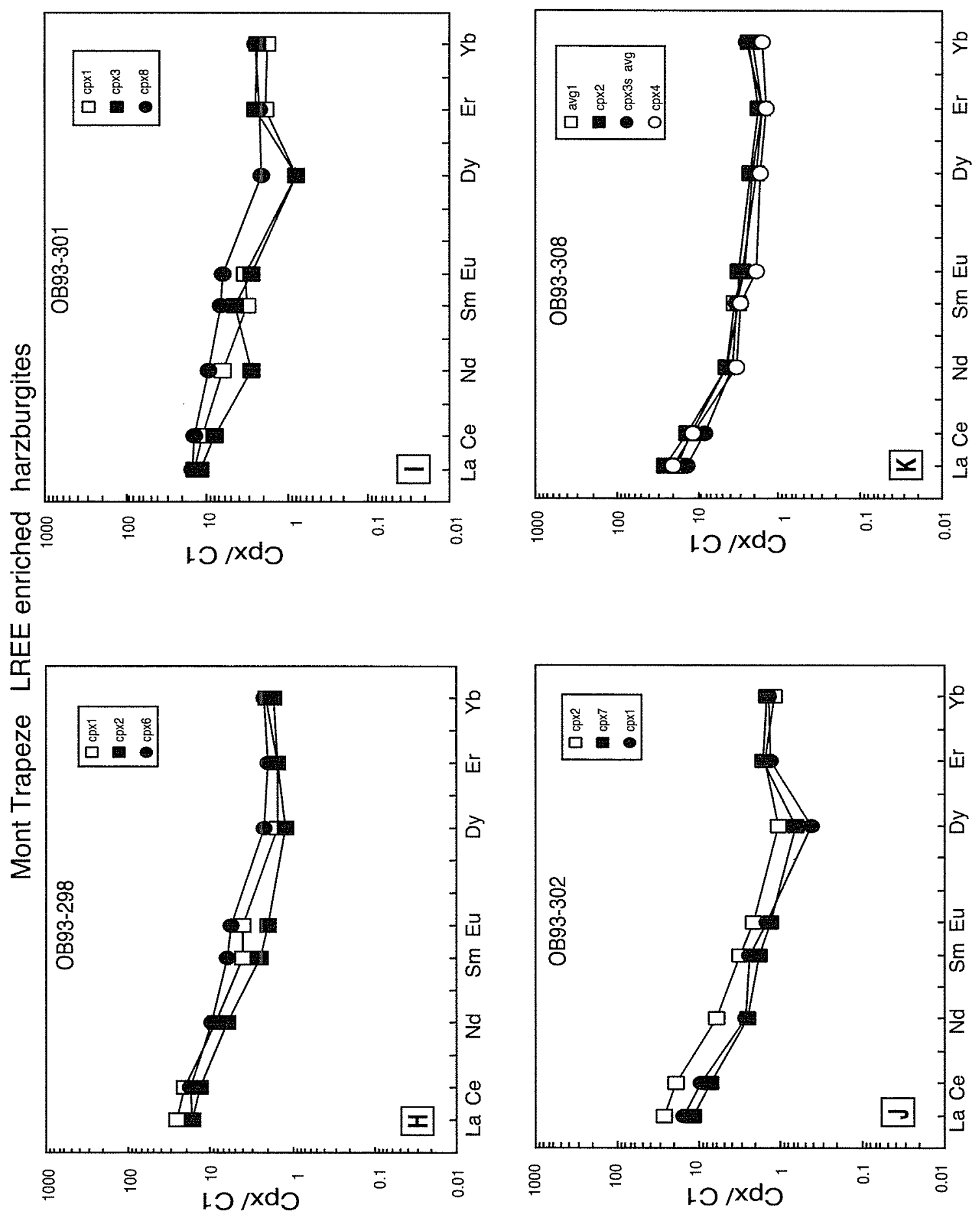




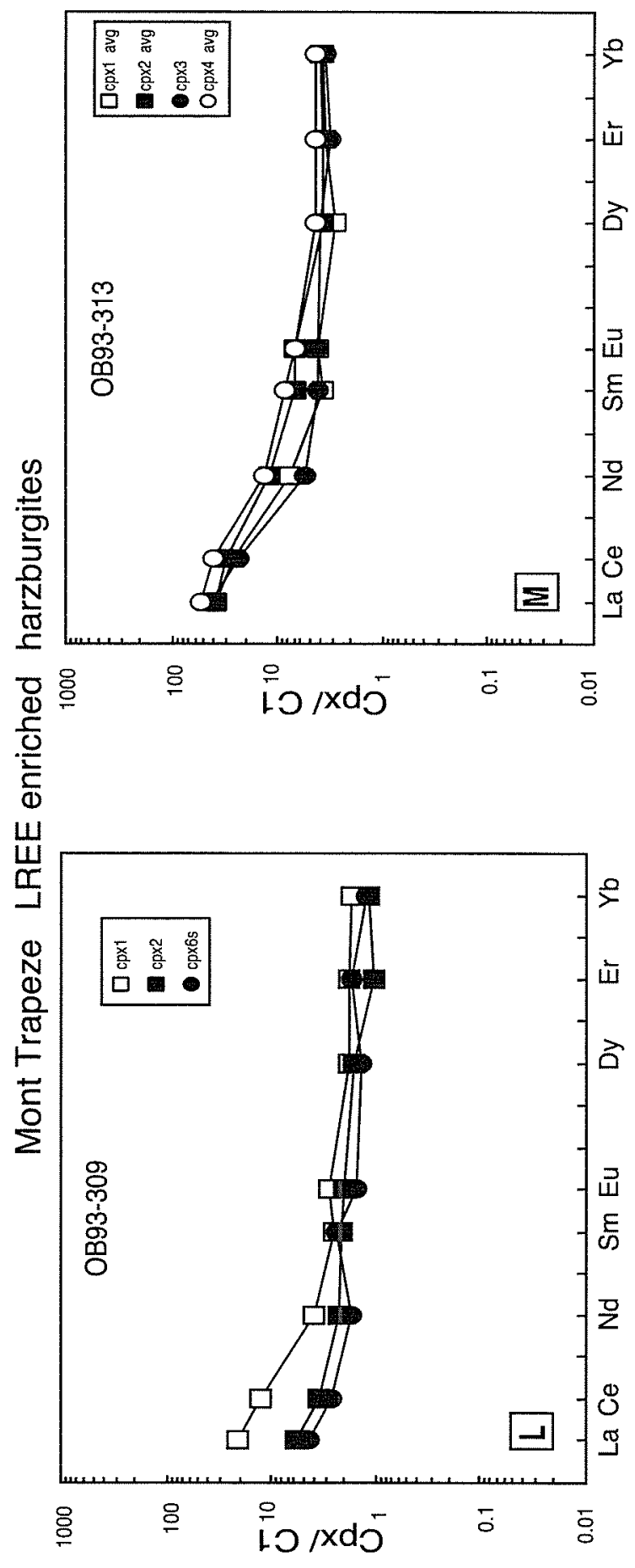


Figure 2-10. Spidergrams of samples with high REE abundances and negative relative Ti and $\mathrm{Zr}$ anomalies. 


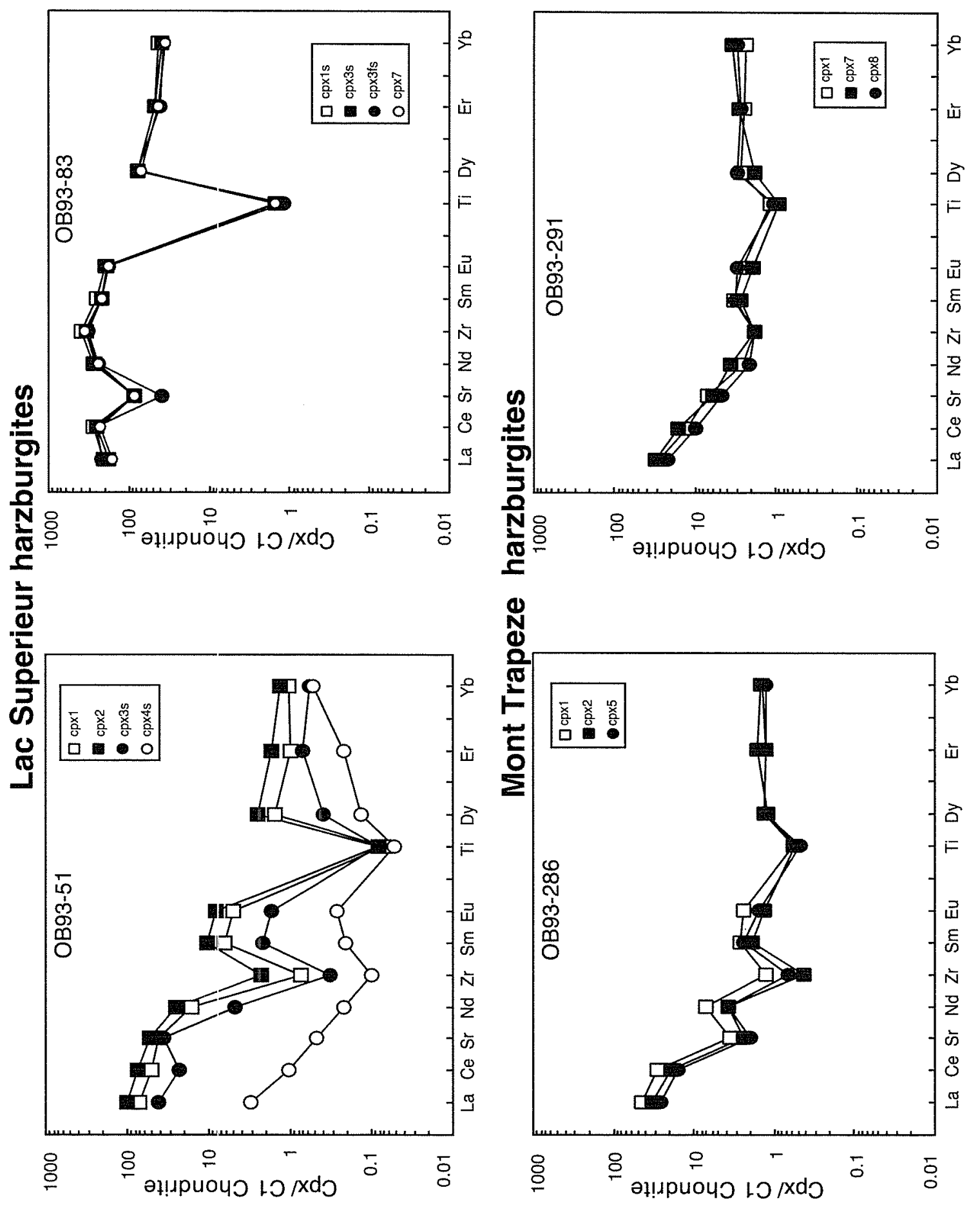




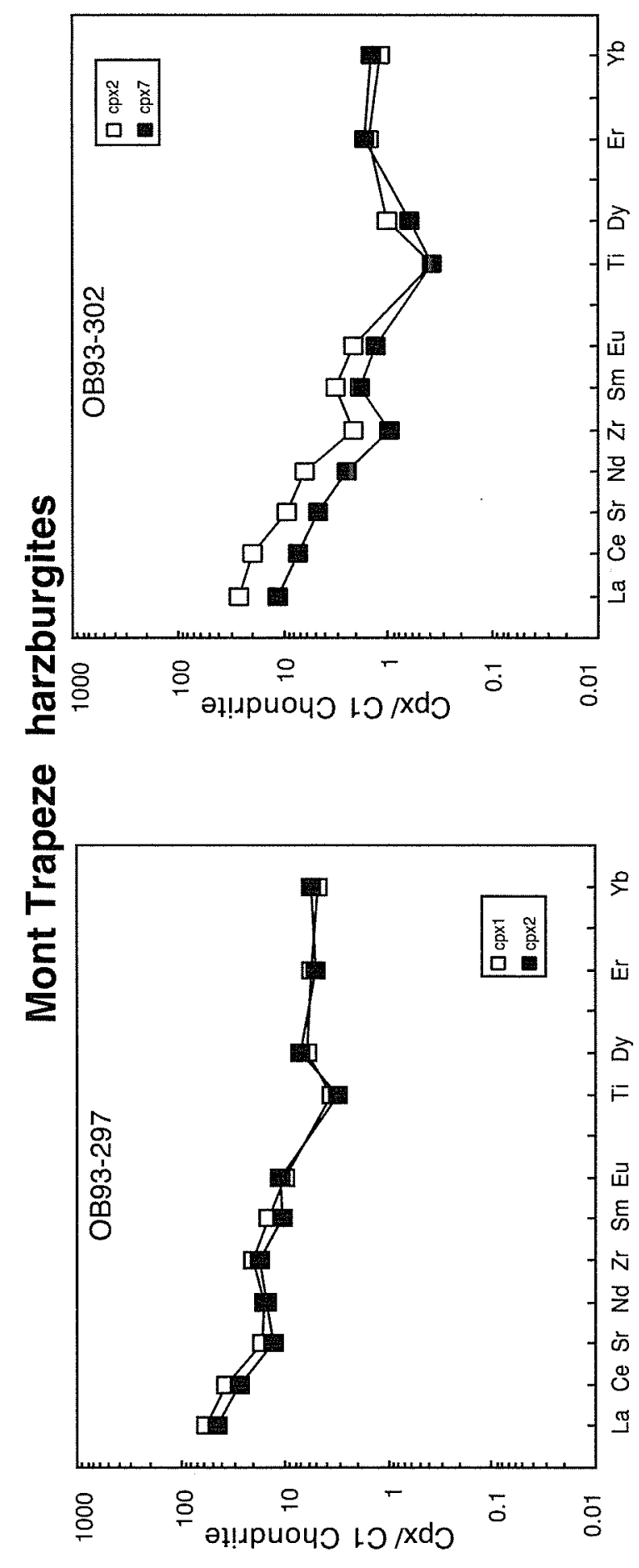



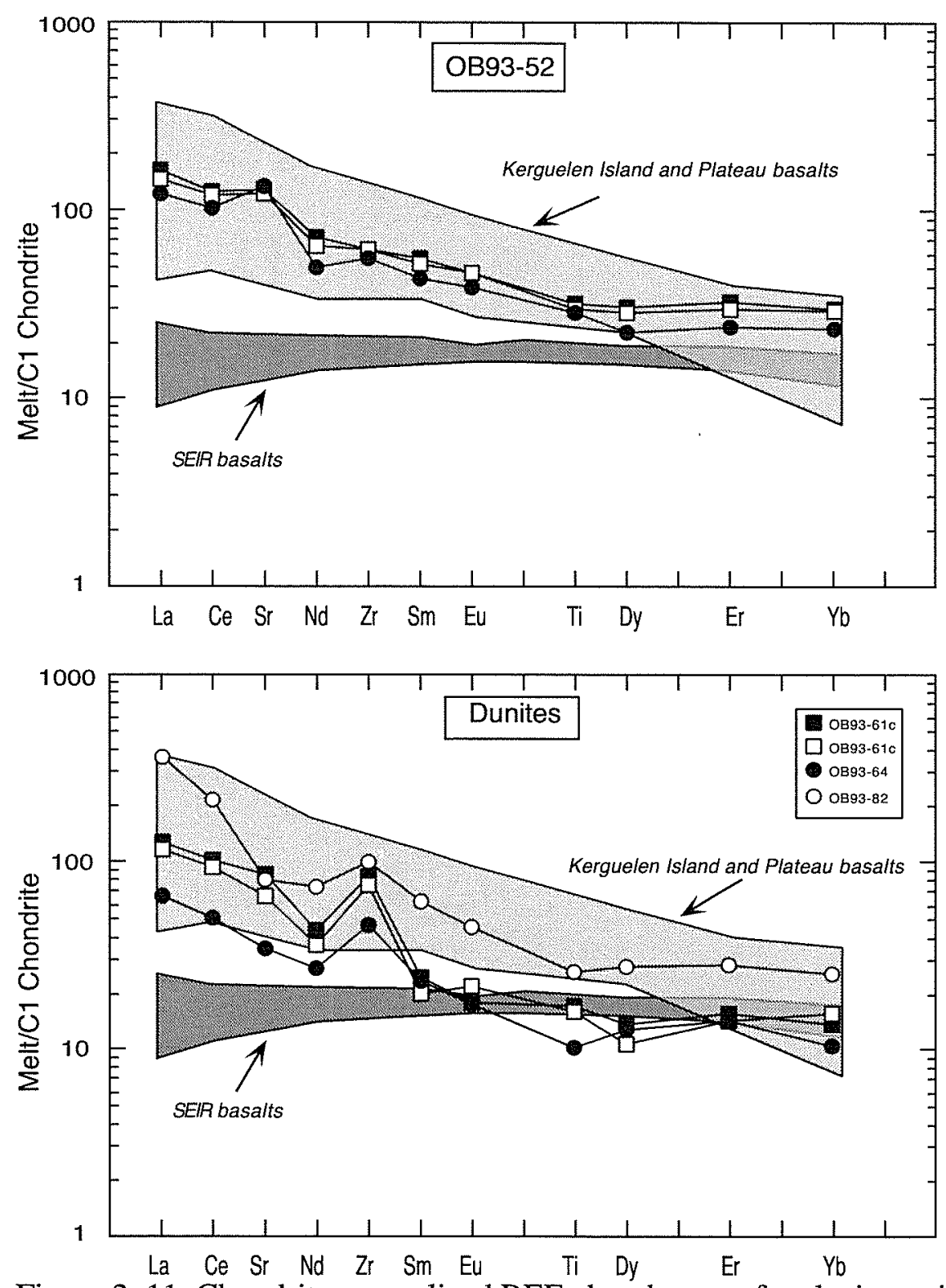

Figure 2-11. Chondrite-normalized REE abundances of melts in equilibrium with clinopyroxenes from lherzolite OB93-52 and from the wehrlitic-dunites. Abundances in Kerguelen basalts are shaded light gray, those from the SEIR are darker gray. Fields based on data from: (Davies et al., 1989; Alibert, 1991; Gautier et al., 1990; Weis et al., 1993; Yang et al., 1998a; Michard et al., 1986; Dosso et al., 1988). 


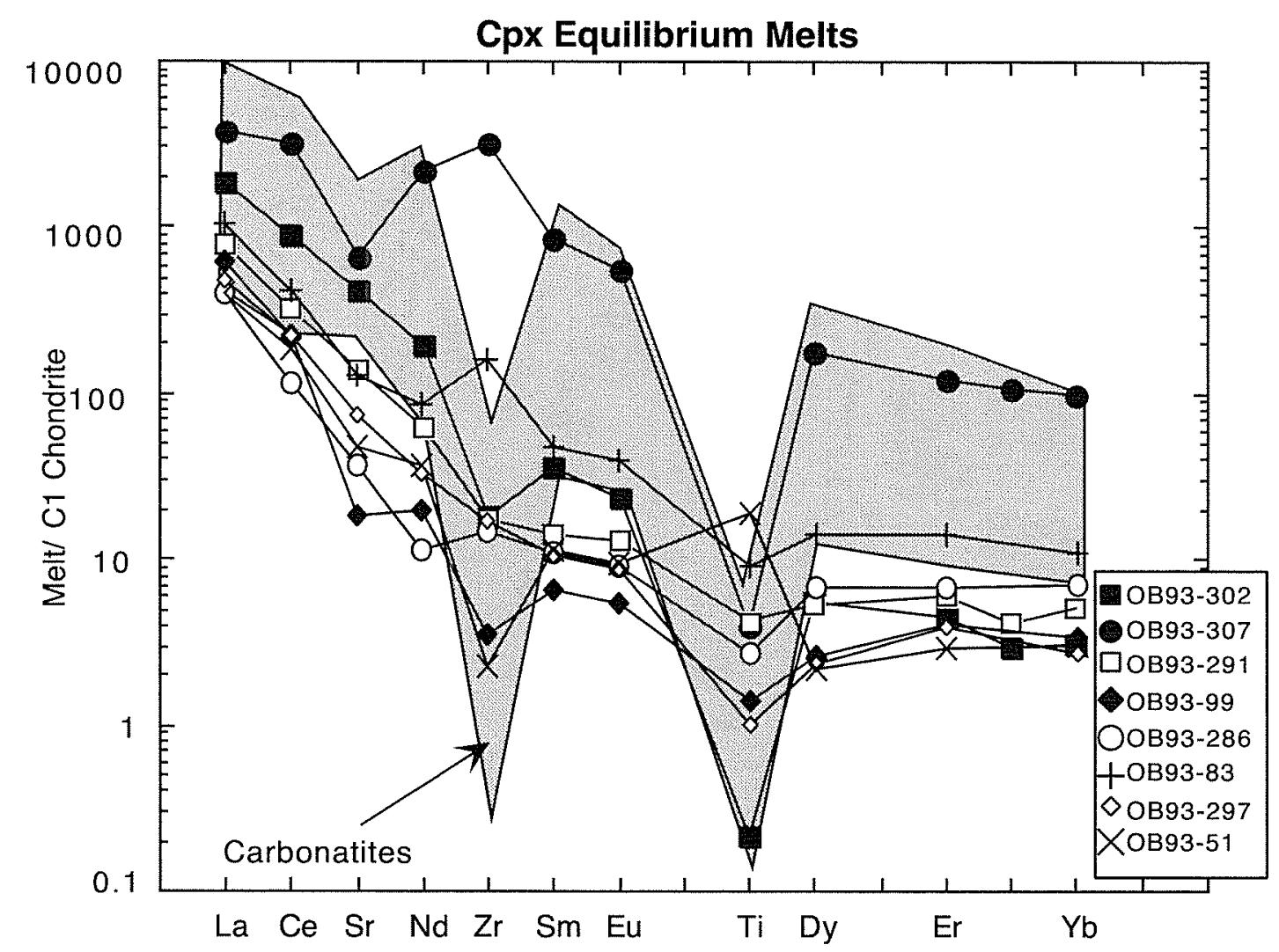

Figure 2-12. REE patterns of hypothetical melts that are similar to REE abundances observed in carbonatites (gray field; Nelson et al., 1988). 


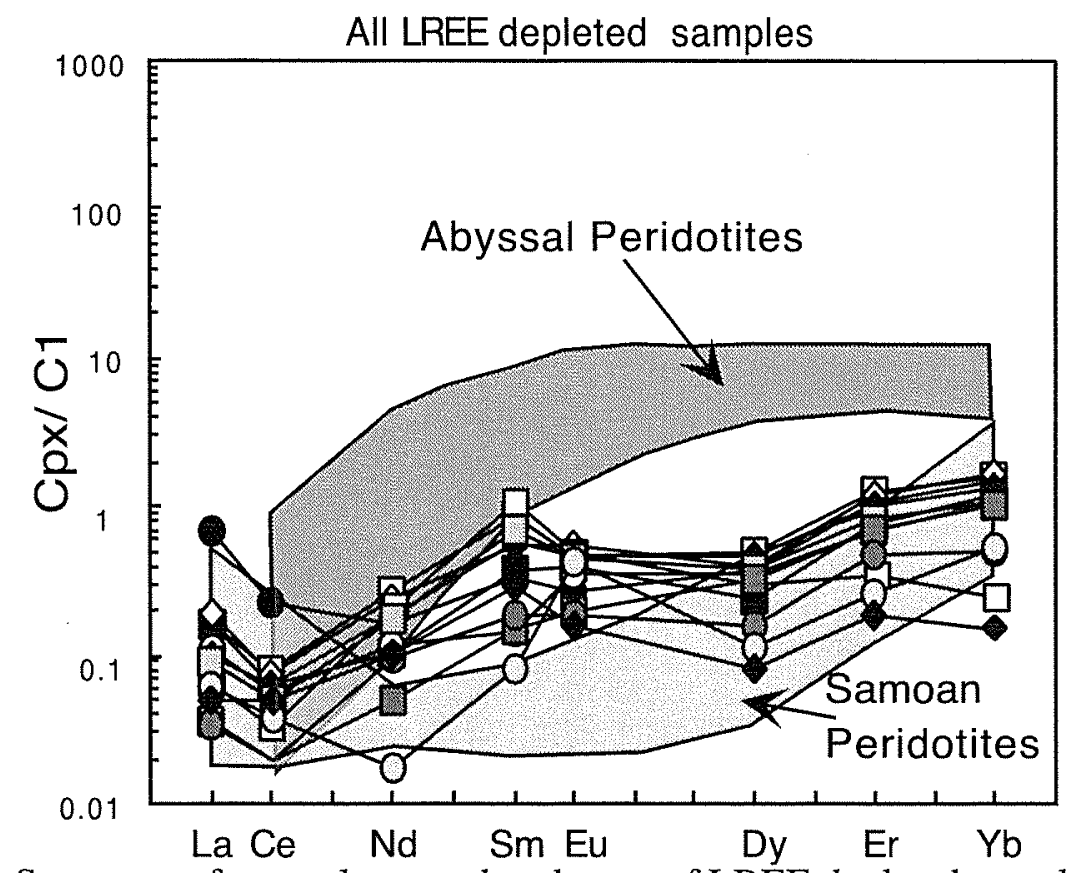

Figure 2-13. Summary of trace element abundances of LREE depleted samples. Fields for Samoan peridotites (Hauri and Hart, 1994) and abyssal peridotites (Johnson et al., 1990) are shown for comparison. 
Figure 2-14. Trace element abundances of clinopyroxenes from LREE depleted harzburgites. 

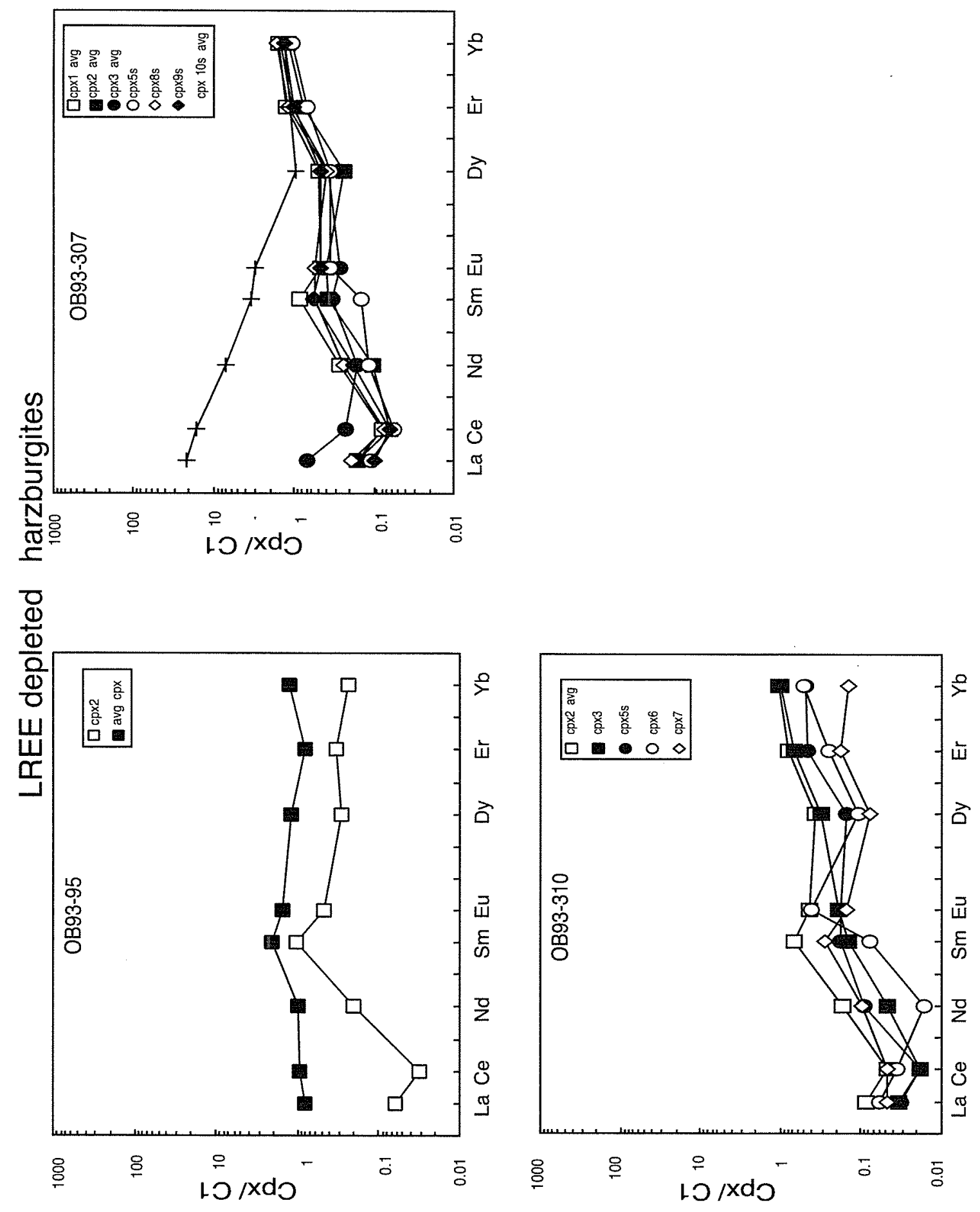
Figure 2-15. Normalized REE patterns of clinopyroxenes from depleted harzburgites. 


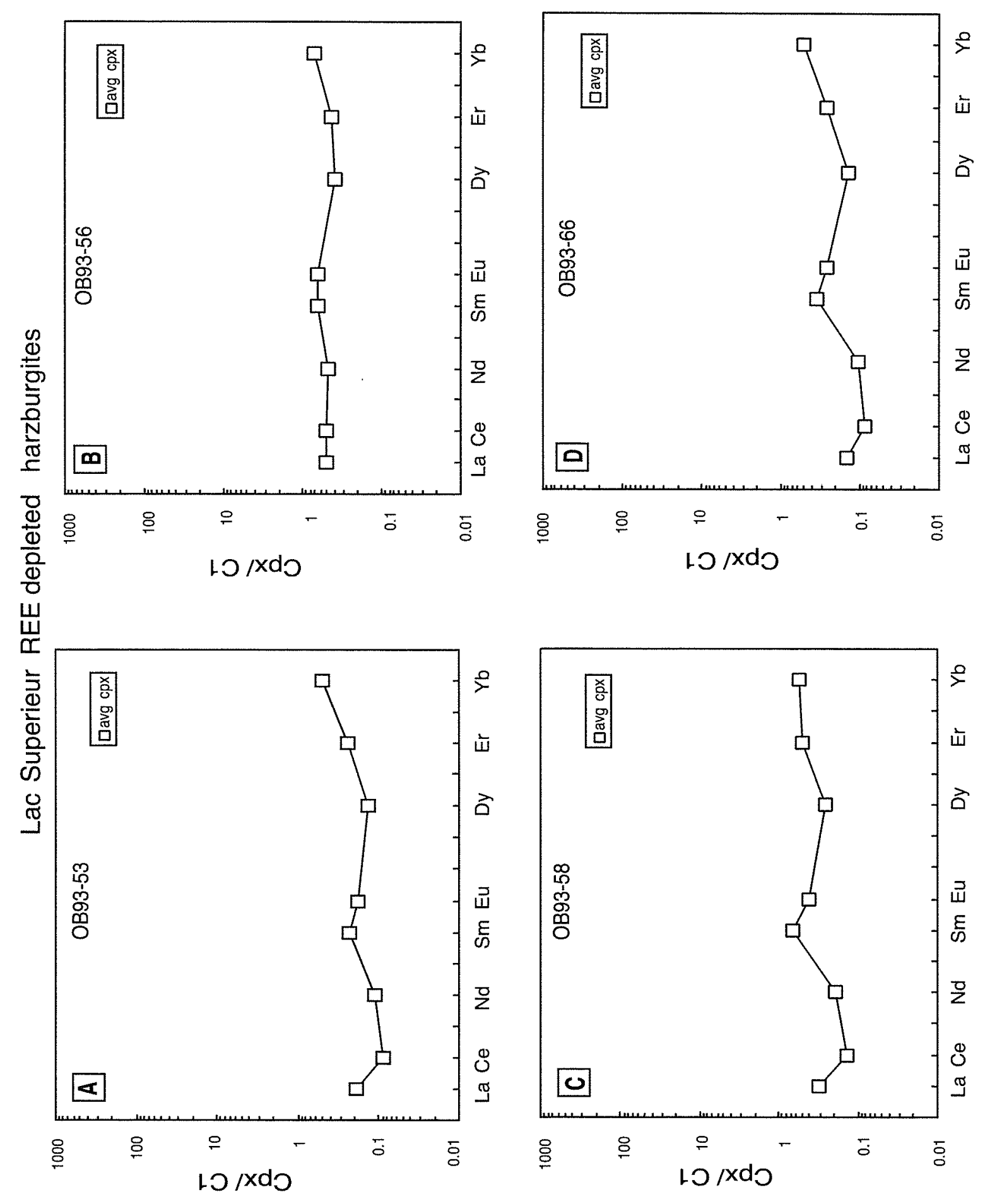




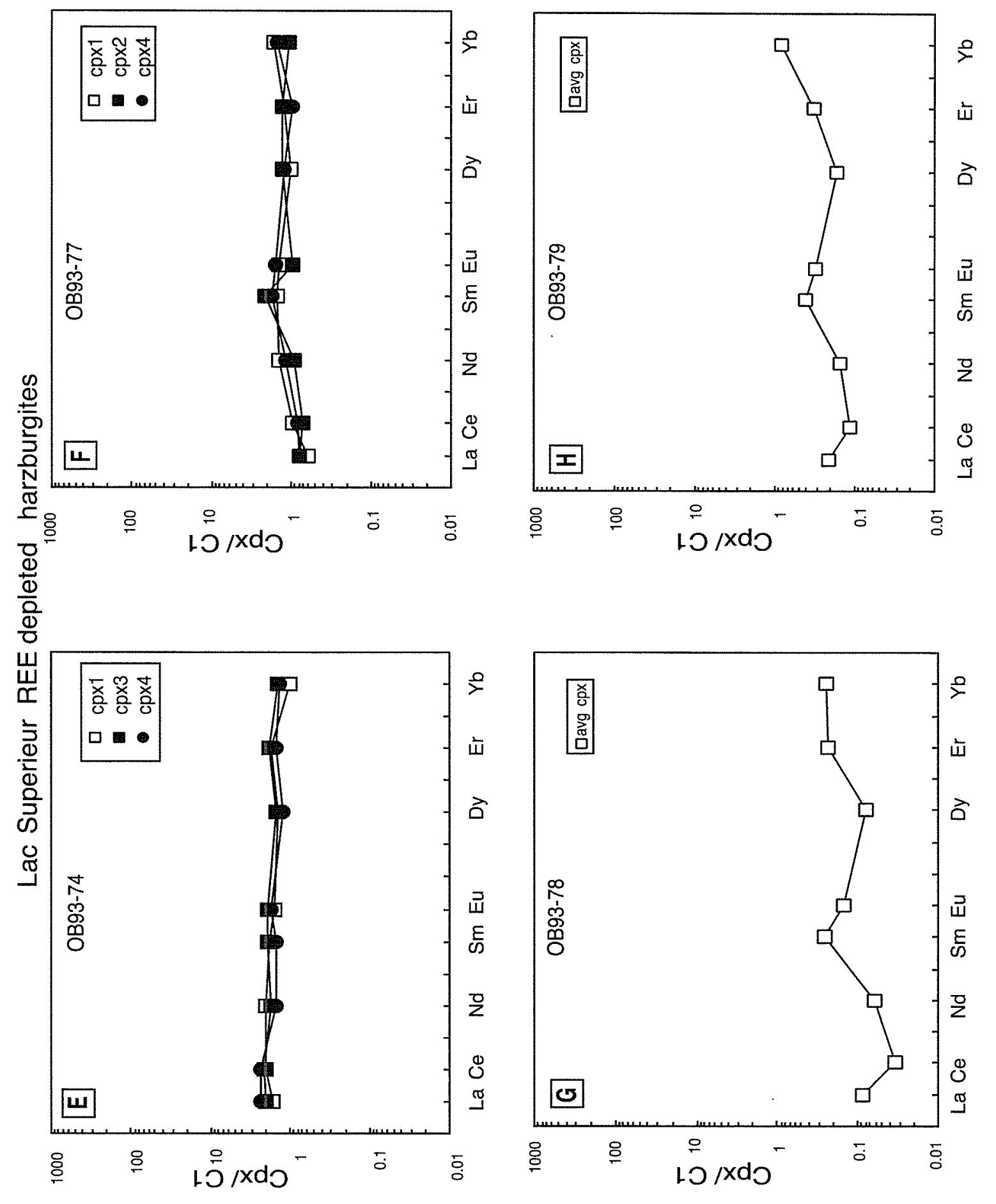




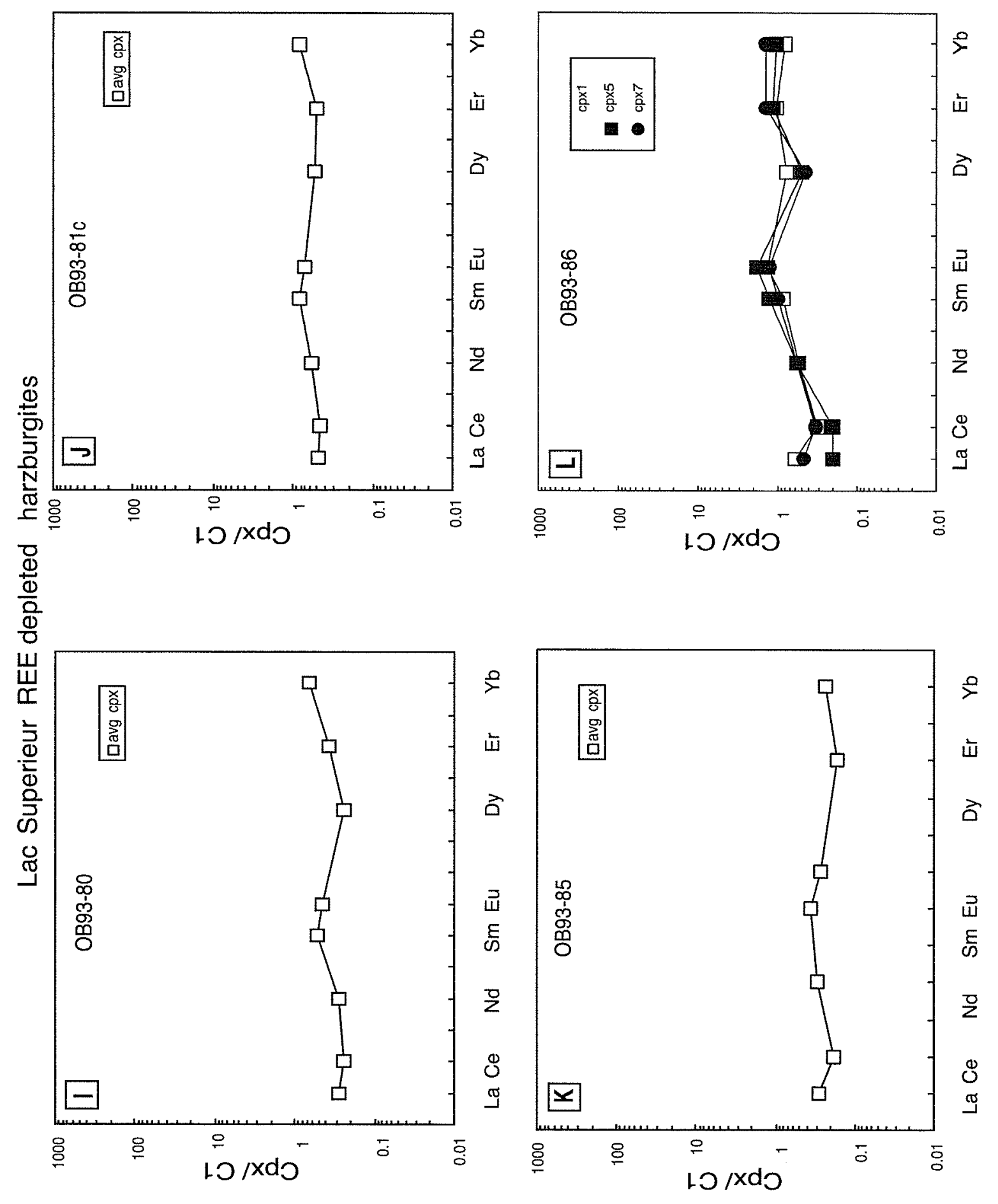




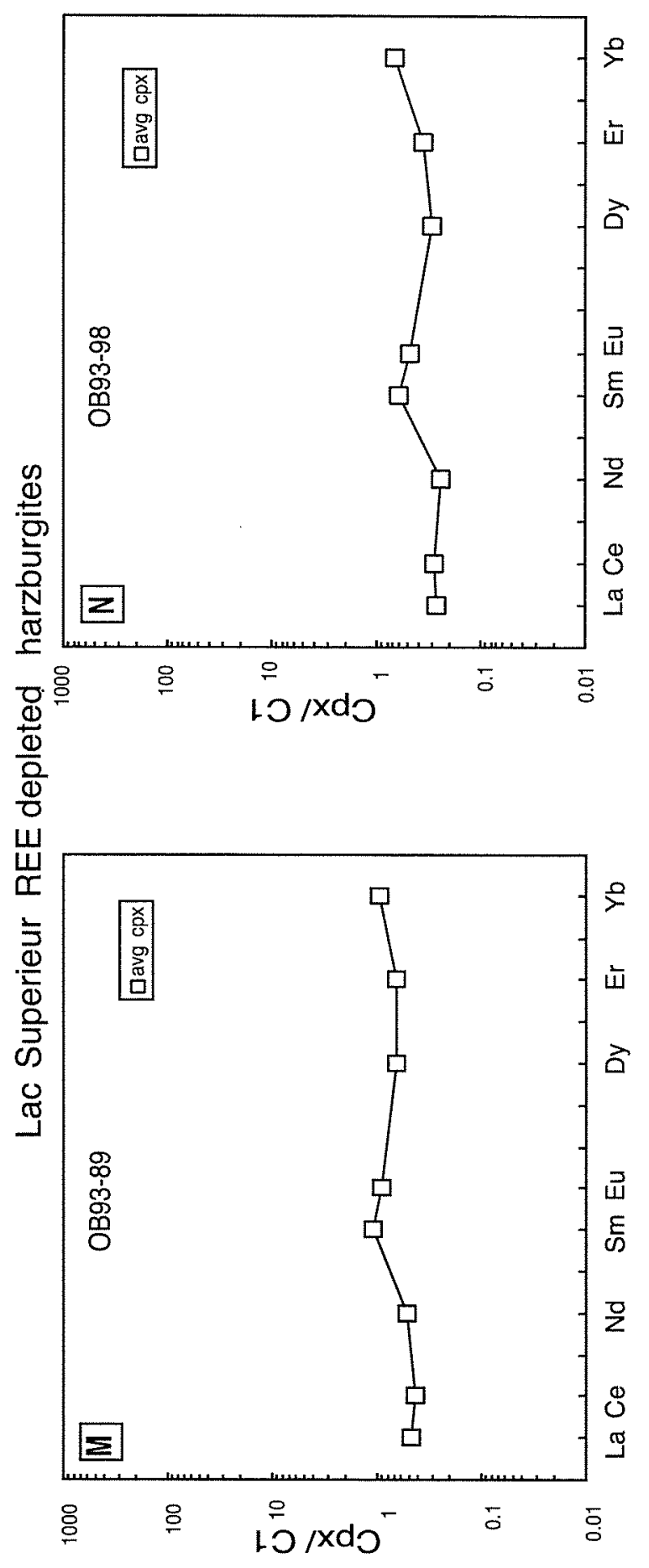




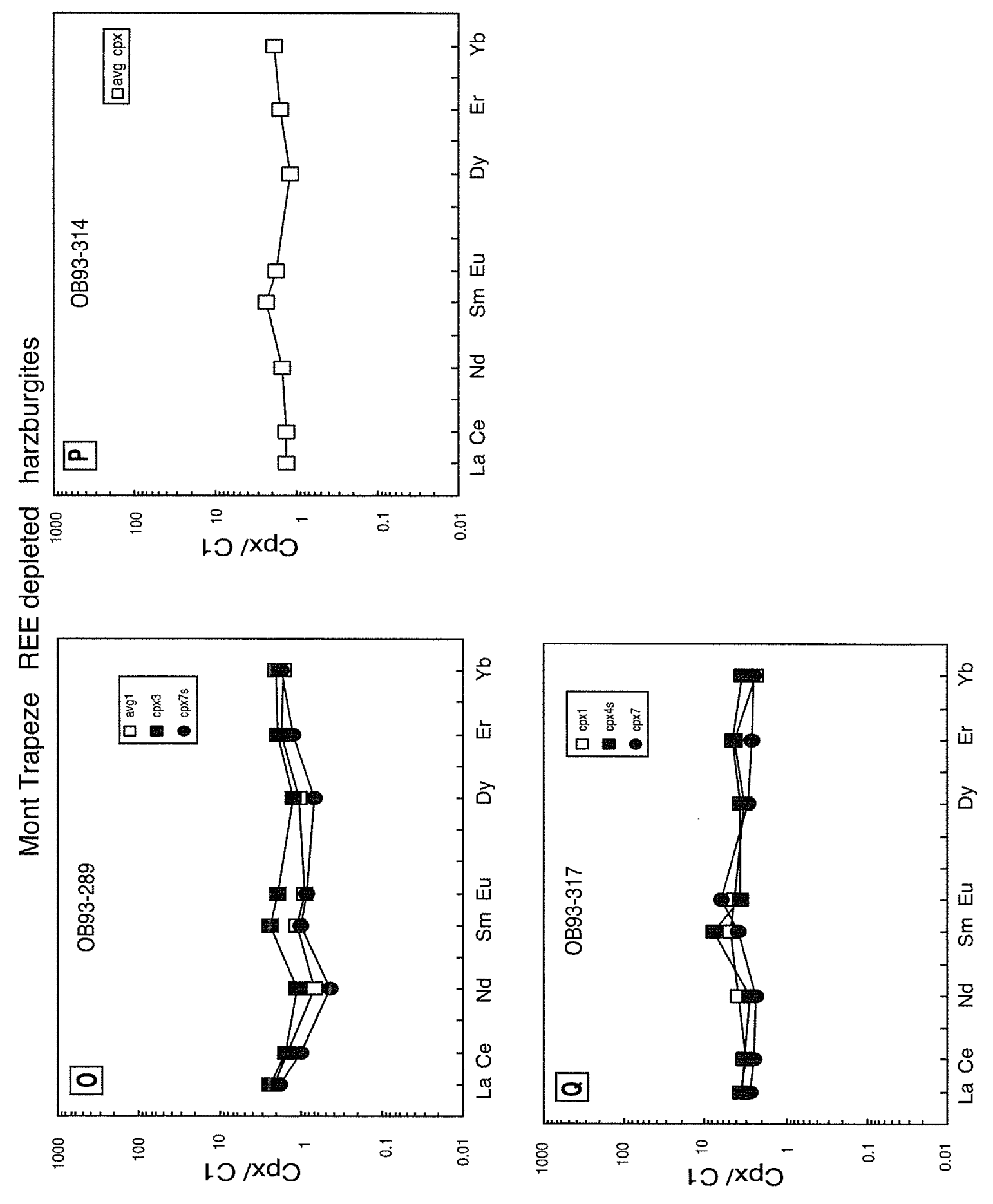




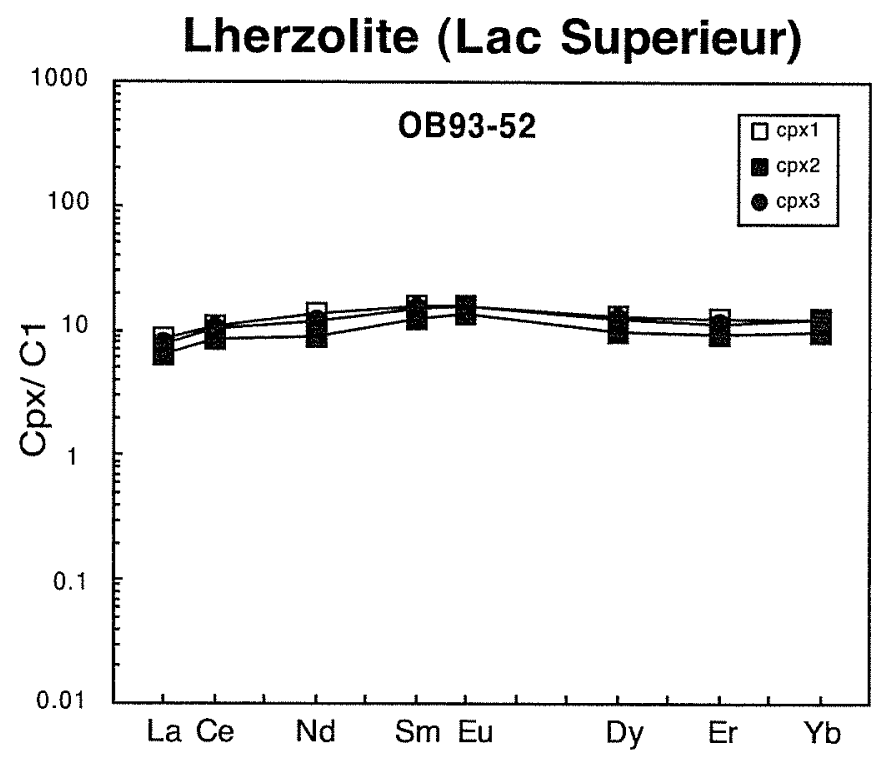

Figure 2-16. Normalized REE patterns of the lherzolite. 
Figure 2-17. Normalized REE abundances of the wehrlitic-dunites. 


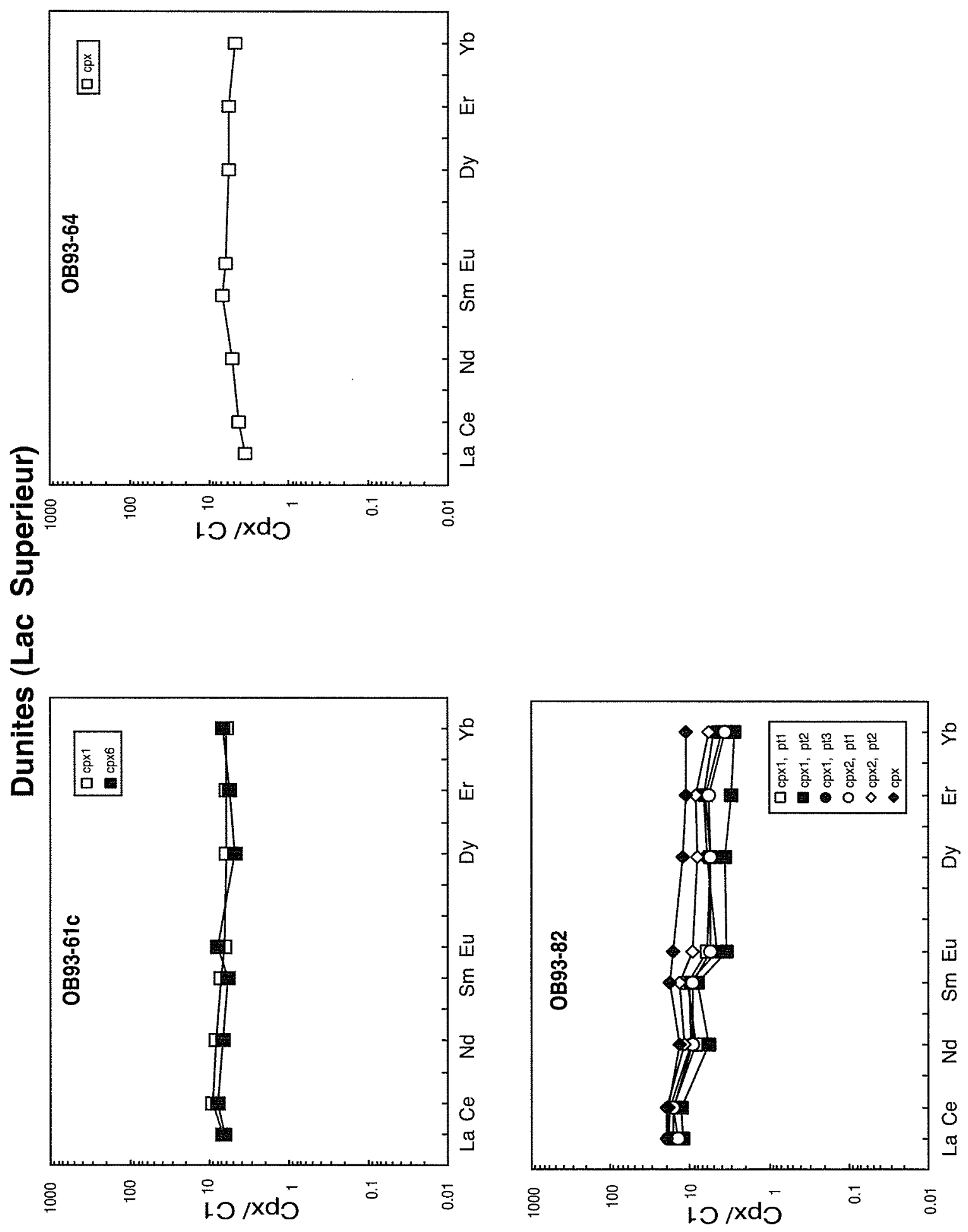


Figure 2-18. Normalized REE patterns of clinopyroxenes from the REE enriched harzburgites. 

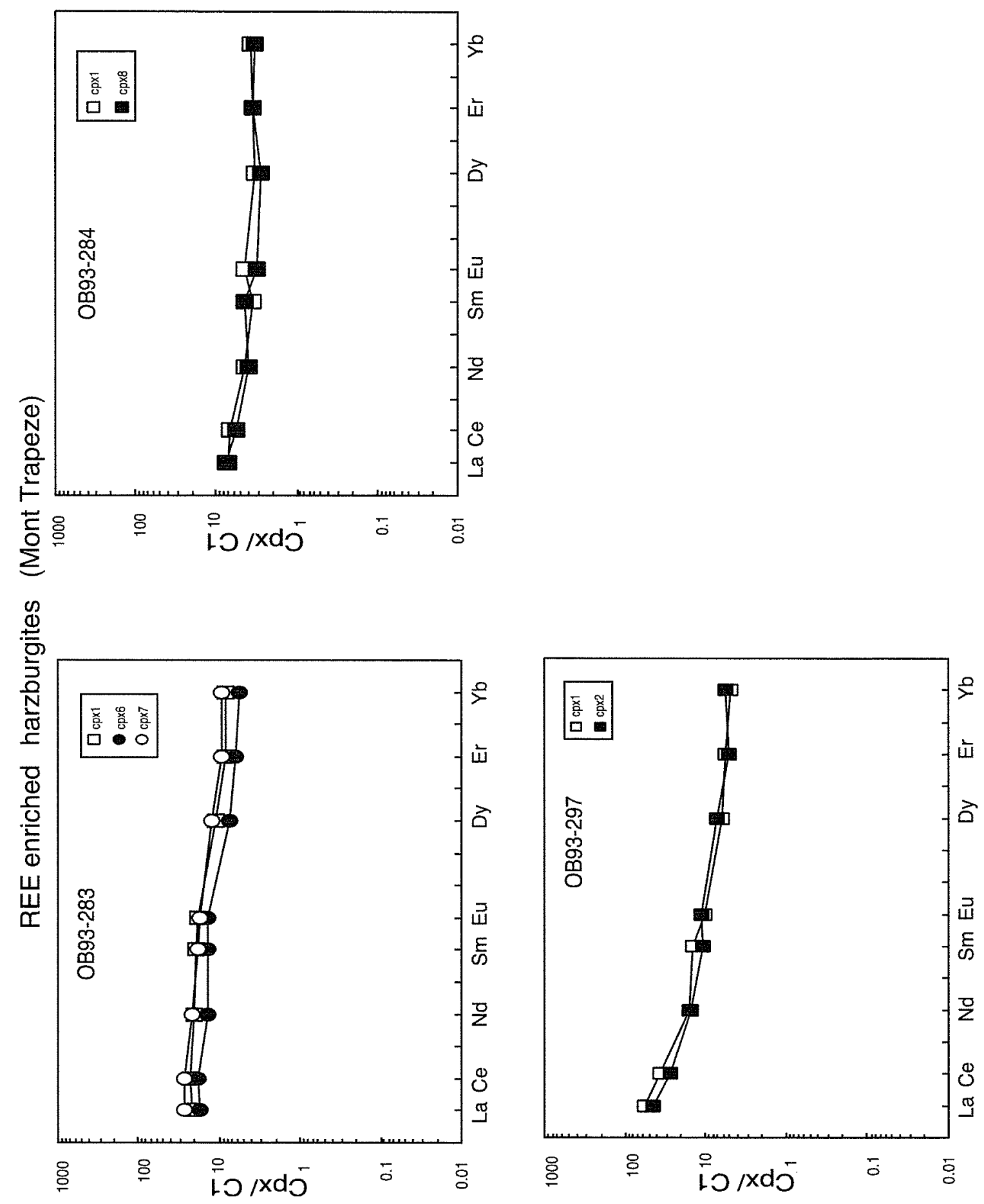

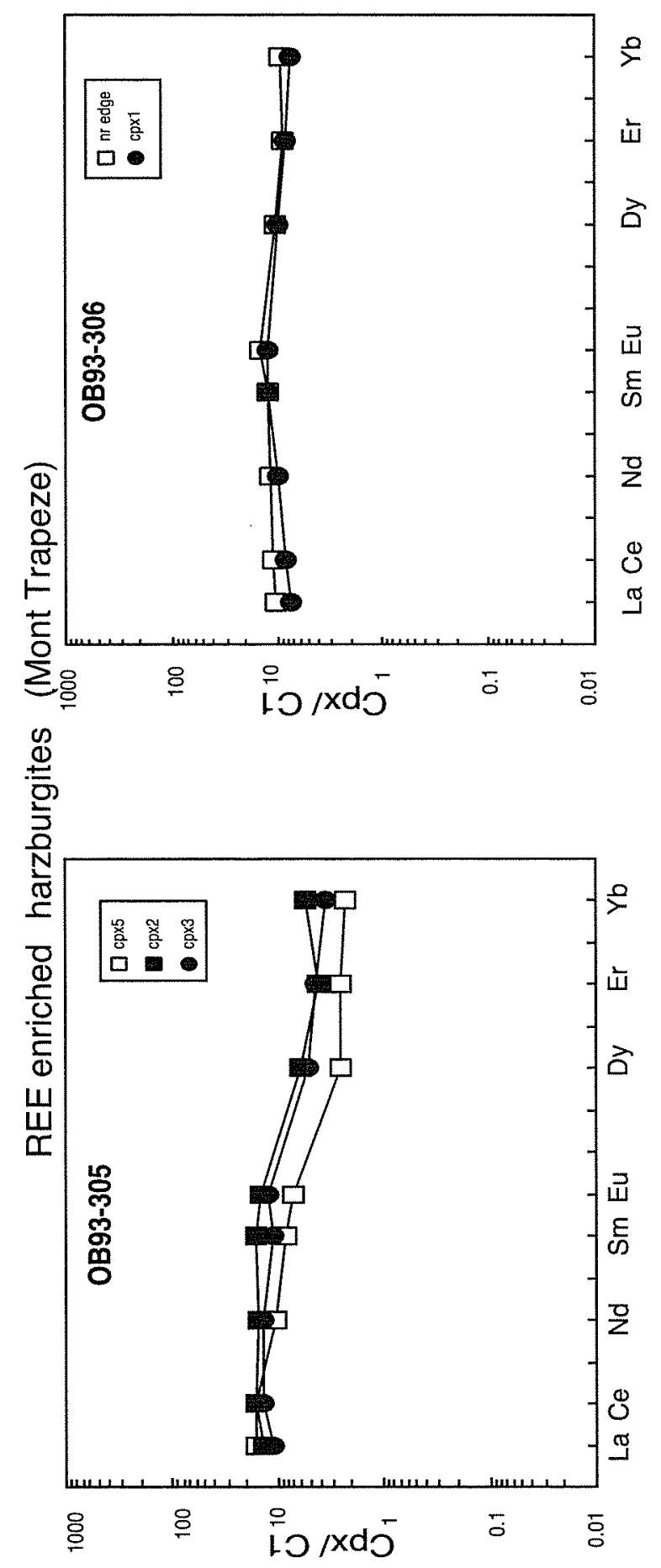
Figure 2-19. Normalized REE abundance patterns of clinopyroxenes from pyroxenites. 


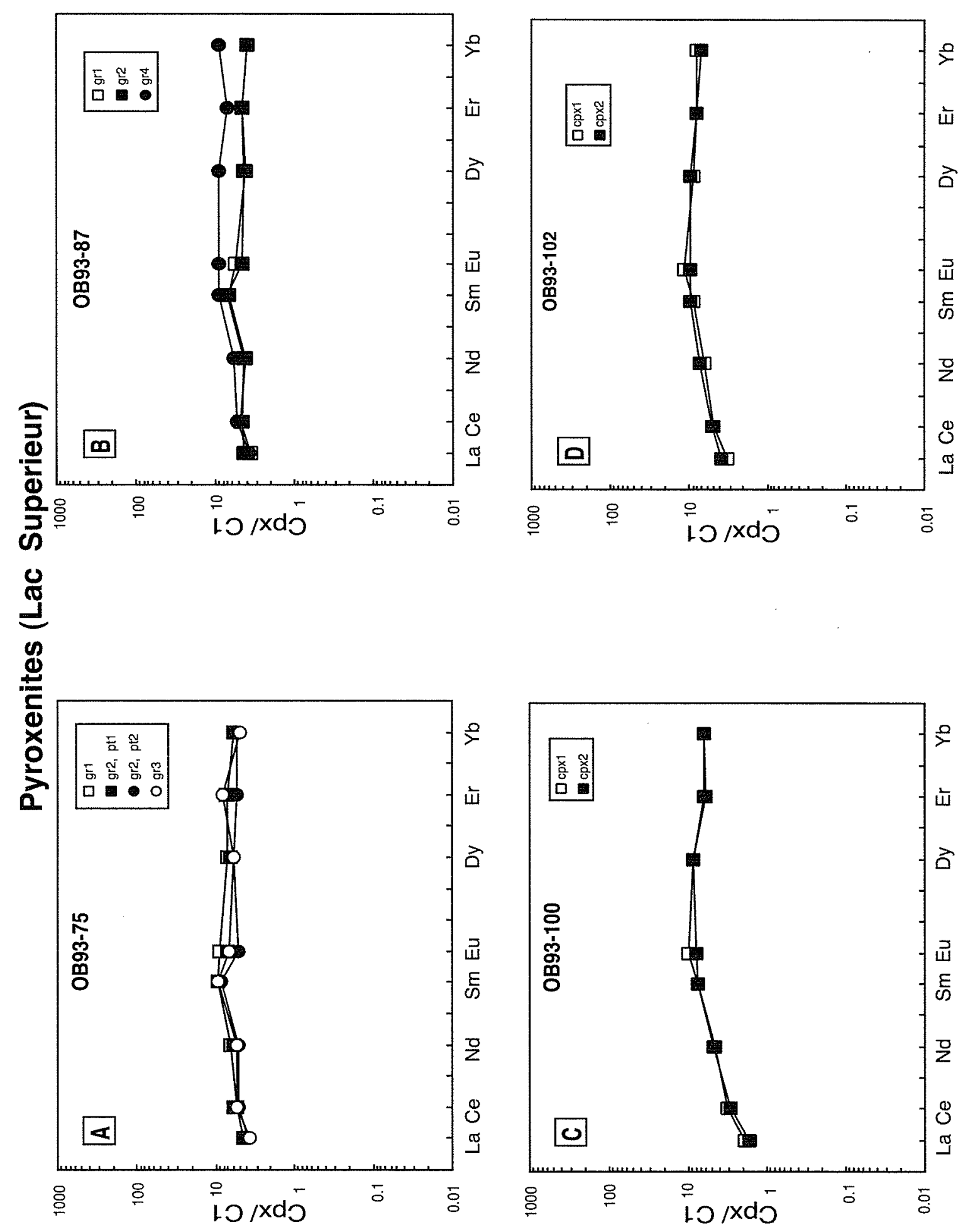




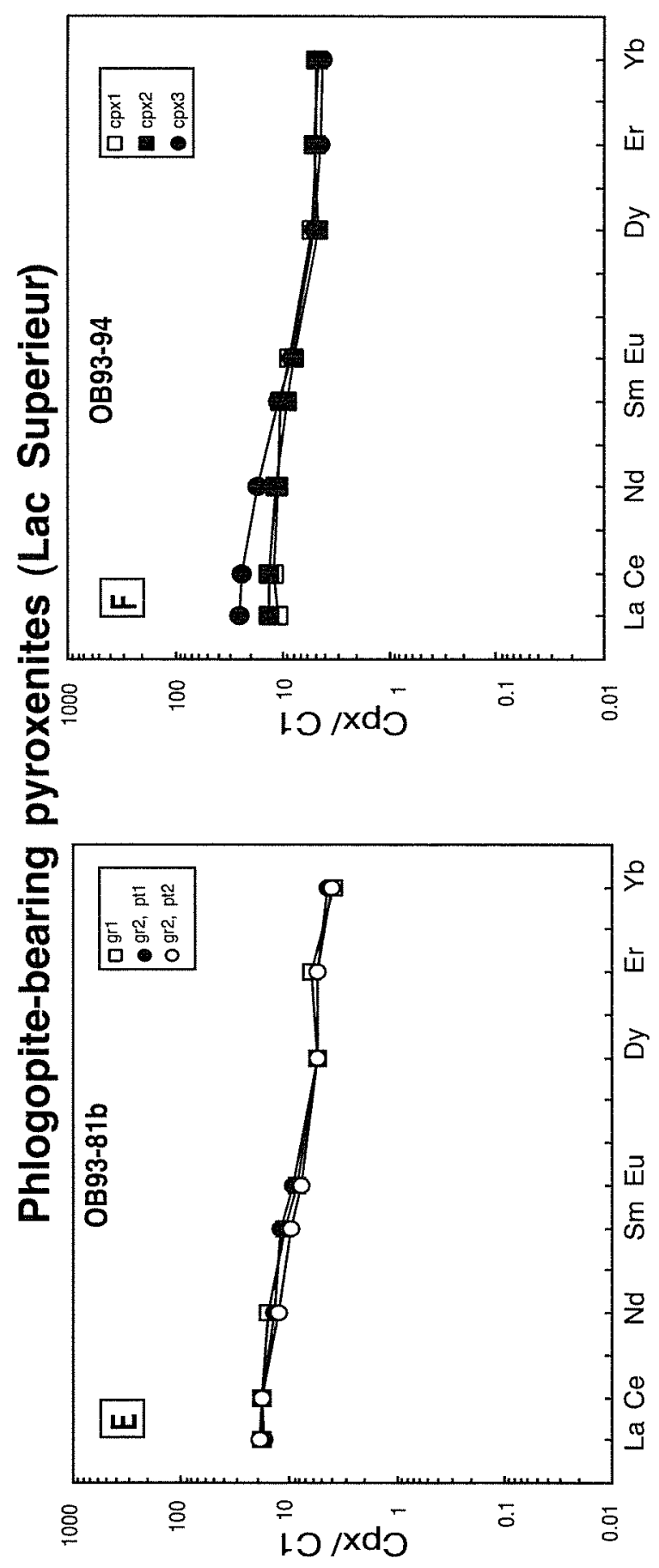


Figure 2-20. Nd v. Sr isotopic diagram of clinopyroxenes and host basalt from the Kerguelen xenolith suite. Clinopyroxenes from xenoliths from the Southeast Province are also shown for reference (small closed circles). Fields for the Indian Ocean MORB, Kerguelen Islands basalts, Heard Islands basalts and Site 735B and the Naturaliste Plateau are shown as shaded fields (from Alibert, 1991; Dosso et al., 1988; Gautier et al., 1990; Mahoney et al., 1994; Mattielli et al., 1996; Mattielli et al., 1999; Weis et al., 1993; Yang et al., 1998a). 


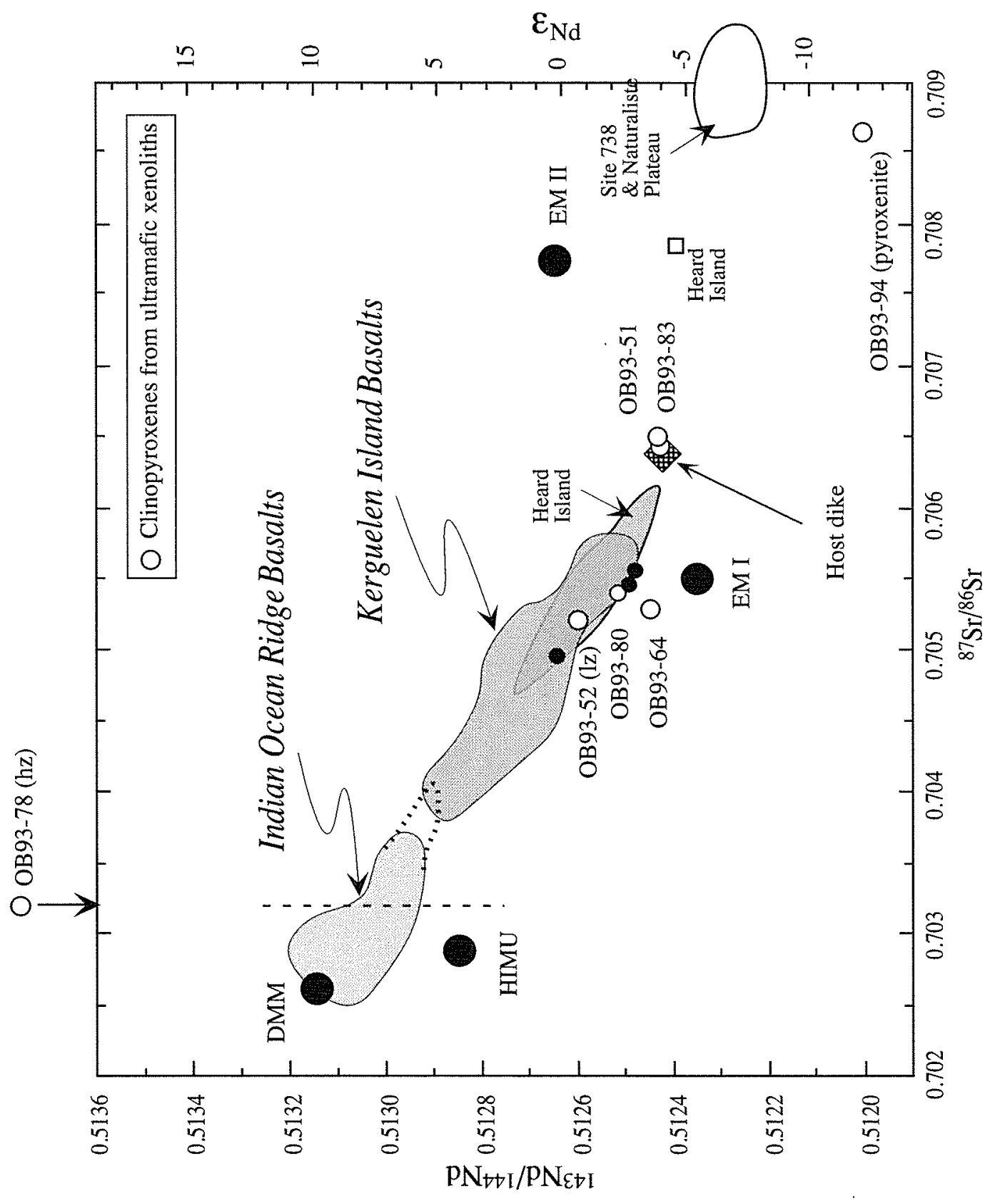



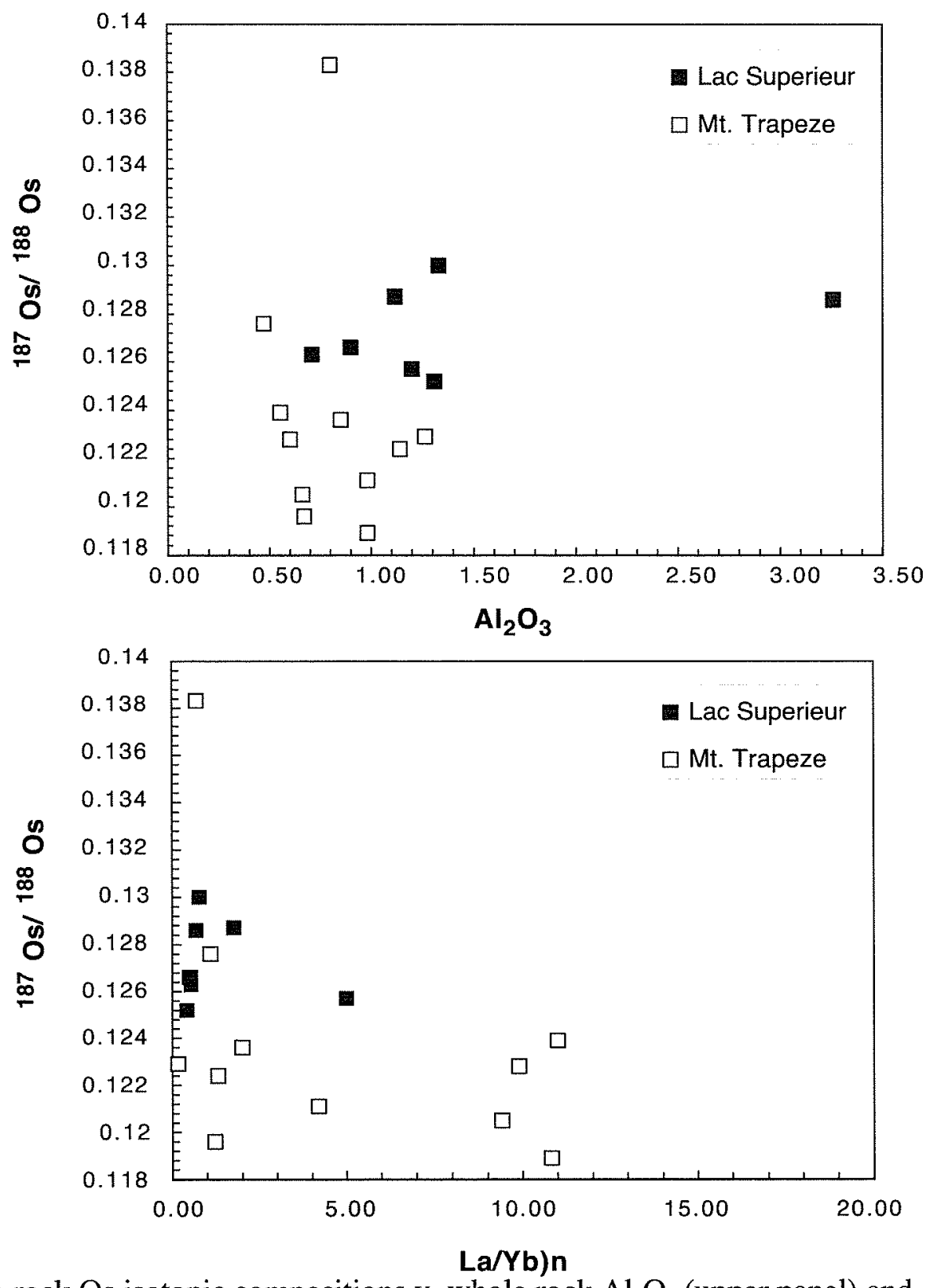

Figure 2-21. Whole rock Os isotopic compositions v. whole rock $\mathrm{Al}_{2} \mathrm{O}_{3}$ (upper panel) and clinopyroxene $[\mathrm{La} / \mathrm{Yb}]_{\mathrm{N}}$ (lower panel). No correlations are present among these parameters, indicating that metasomatism did not affect the Os isotopes. 
Reprinted with permission from Hassler D. R. and Shimizu N. (1998) Osmium isotopic evidence for ancient subcontinental lithospheric mantle beneath the Kerguelen Islands, Southern Indian Ocean. Science 280, 418-421.

(C) 1998 American Association for the Advancement of Science.

\section{Chapter 3 Osmium Isotopic Evidence for Ancient Subcontinental Lithospheric Mantle Beneath the Kerguelen Islands, Southern Indian Ocean}

\subsection{Abstract}

Upper mantle xenoliths found in ocean island basalts are an important window through which the oceanic mantle lithosphere may be viewed directly. Osmium (Os) isotopic data on peridotite xenoliths from the Kerguelen Islands, an archipelago that is located on the northern Kerguelen Plateau in the southern Indian Ocean, demonstrate that pieces of mantle of diverse provenance are present beneath the Islands. In particular, peridotites with unradiogenic Os and ancient rhenium ( $\mathrm{Re}$ )-depletion ages (to $1.36 \mathrm{Ga}$ old) may be pieces of the Gondwanaland subcontinental lithosphere that were incorporated into the Indian Ocean lithosphere as a result of the rifting process.

\subsection{Os evidence for subcontinental lithosphere}

The Kerguelen hotspot became active at least $115 \mathrm{Ma}(1)$, and possibly as long as $130 \mathrm{Ma}$, when India separated from Australia-Antarctica (2). The Kerguelen mantle plume is considered to be responsible for extensive hotspot volcanism in the Indian Ocean basin (3), including the Ninetyeast Ridge, Broken Ridge, as well as the Kerguelen Plateau, the second largest of the oceanic plateaus (Fig. 1). Moreover, the Kerguelen plume is a carrier of the DUPAL isotopic anomaly (4), a characteristic of basalts erupted in the Southern Hemisphere. The interaction of this plume with the Indian Ocean lithosphere has potentially affected the geochemical and tectonic evolution of the entire Indian Ocean basin $(2,5)$.

One notion for the origin of the Kerguelen Plateau and the Kerguelen Islands is that their lithospheric basement contains a continental fragment left behind from the breakup of 
Gondwanaland (6). Basalts from the southern Kerguelen Plateau (ODP drill-site 738) do have trace element and isotopic signatures indicative of a continental component in their source (7) and recent seismic experiments showed that the southern Kerguelen Plateau has a structure similar to a continental passive margin (8). However, a seismic refraction study, as well as early isotopic work on basalts from the archipelago, established an apparent oceanic origin $(6,9)$. Here we present Os isotopic data that establishes the presence of continental lithosphere in the northern Kerguelen Plateau and the involvement of continental materials in the formation of the Kerguelen Islands.

We examined the Re-Os isotopic systematics in peridotite xenoliths (IO) from two sample localities that are less than $10 \mathrm{~km}$ apart (Lac Superieur and Mont Trapeze) in the Courbet Peninsula, northeastern Kerguelen Islands (Fig. 1 inset). The xenoliths are abundant in alkaline basaltic dikes that cross-cut "plateau basalt" lavas that comprise the Courbet Peninsula and formed 23 to $25 \mathrm{Ma}$ (11).

The samples are predominantly refractory coarse granular harzburgites [olivine: $\sim 60$ $\%$ (forsterite content $=90-92 \%$ ), orthopyroxene: $\sim 35 \%$, clinopyroxene: $1-5 \%$, and trace amounts of spinel], but also include more clinopyroxene-rich lherzolites and wehrliticdunites. The rocks are fresh and do not contain any secondary alteration minerals. Many of the peridotites (from both localities) reacted with melts that percolated through them. For example, some harzburgites contain newly formed clinopyroxene crystals that are enriched in incompatible trace elements (for example, chondrite normalized $\mathrm{La}_{\mathrm{N}}=100$ ), whereas coexisting original clinopyroxene grains occur as symplectite intergrowths with both orthopyroxene and spinel, and have depleted incompatible trace element abundances (for example, $\mathrm{La}_{\mathrm{N}}=3$ ). Some peridotites at more advanced stages of reaction have trace element enriched clinopyroxenes (for example, $\mathrm{La}_{\mathrm{N}}=300$ ) that are intergrown with phlogopite (12). 
During interactions with percolating metasomatic melts, the $\mathrm{Sr}$ and $\mathrm{Nd}$ isotopic characteristics of the original peridotites are likely to be replaced by those of the melt, because the concentrations of these incompatible elements in the melt are much higher than in the peridotite. For instance, $\mathrm{Sr}$ isotopic compositions of clinopyroxenes from the few unmetasomatized peridotite xenoliths (for example OB93-78: ${ }^{87} \mathrm{Sr} /{ }^{86} \mathrm{Sr}=0.70329 \pm 2$ ) are similar to those of Indian mid-ocean ridge basalts [MORB, (13)], whereas metasomatic clinopyroxenes have $\mathrm{Sr}$ isotopic compositions (for example OB93-83: ${ }^{87} \mathrm{Sr} /{ }^{86} \mathrm{Sr}=$ $0.706427 \pm 10)$ similar to those of alkaline basalts from the Kerguelen Islands (6), reflecting their origin from Kerguelen plume melts $(12,14)$. Thus, the incompatible geochemical tracers record mantle processes associated with plume-lithosphere interaction, but information about xenolith provenance is lost in the xenoliths that have undergone metasomatic reaction.

In contrast, the isotopic compositions of elements that are compatible in peridotites are less likely to be modified during metasomatism because their concentrations are much higher in peridotites than in the percolating melts. Osmium is a compatible element during partial melting of peridotite (15); therefore, ${ }^{187} \mathrm{Os}$, the radiogenic daughter of ${ }^{187} \mathrm{Re}$, is an isotopic tracer that is relatively insensitive to subsequent mantle metasomatic processes. For these reasons, the Re-Os system is particularly suitable for determining the provenance of peridotites and for dating primary melting events of peridotite formation (16).

The Os isotopic compositions of peridotite xenoliths from the Kerguelen Islands (Table 1, Fig. 2) vary over a wide range $\left({ }^{187} \mathrm{Os} /{ }^{188} \mathrm{Os}=0.1189 \pm 2\right.$ to $\left.0.1383 \pm 6\right)$ and extend to compositions that are less radiogenic than have been observed in rocks from oceanic settings, including xenoliths from other ocean islands [for example, Samoan peridotites have ${ }^{187} \mathrm{Os} /{ }^{188} \mathrm{Os}=0.1225$ to $\left.0.1309,(17)\right]$. Re/Os ratios in the xenoliths are low $\left(2 \times 10^{-3}\right.$ to $80 \times 10^{-3}$; Table 1 ), and age correction for isotopic ingrowth since the time of the eruption 
of the host basalts is negligible. The more radiogenic Os isotopic compositions of this xenolith suite cannot be explained by contamination with Kerguelen Islands basalt because unrealistic additions of basalt would be required $\left[>20 \%\right.$; with ${ }^{187} \mathrm{Os} /{ }^{188} \mathrm{Os}=0.1565$, and $[\mathrm{Os}]=100 \mathrm{ppt}(18)]$. Thus, we interpret these variations as primary signatures that reflect the diversity of the xenolith provenance.

Within the sample suite, two spinel harzburgites from Mont Trapeze, and three comparatively clinopyroxene-rich lherzolites from Lac Superieur, have relatively radiogenic Os isotopic compositions $\left({ }^{187} \mathrm{Os} /{ }^{188} \mathrm{Os}\right.$ of $0.1276 \pm 5$ to $\left.0.1383 \pm 6\right)$. These values are typical of ocean island basalts (19-23), and may reflect a part of the spectrum of Os isotopic compositions of the Kerguelen plume.

The remaining xenoliths from Lac Superieur are grouped at ${ }^{187} \mathrm{Os} /{ }^{188} \mathrm{Os} \approx$ $0.1260 \pm 7$, within the range of compositions estimated for the modern oceanic lithosphere from abyssal peridotites $(19,24)$. Indeed, some clinopyroxenes in samples of this group have rare earth element abundance patterns comparable to those in abyssal peridotites, and Sr isotopic compositions of clinopyroxenes from these rocks are similar to Indian Ocean MORB values as noted above (12). These characteristics are evidence that these xenoliths originated from the Indian Ocean lithospheric mantle.

In contrast, the harzburgites from Mont Trapeze exhibit a greater range in Os isotopic composition, and most are significantly less radiogenic (to ${ }^{187} \mathrm{Os} /{ }^{188} \mathrm{Os}=$ $0.1189 \pm 2$ ) than the xenoliths from Lac Superieur. Such unradiogenic Os isotopic compositions require reservoirs that had extremely low Re/Os ratios for geologically long periods of time. The Re-depletion model ages $(16,25)$ for the Mont Trapeze xenoliths are from 0.58 to $1.36 \mathrm{Ga}\left(\mathrm{T}_{\mathrm{RD}}\right.$; Table 1). Such unradiogenic Os isotopic compositions have never been observed in oceanic environments, and are not expected to be part of the young 
( $\sim 40 \mathrm{Ma}$ beneath the Kerguelen Islands) Indian Ocean mantle lithosphere. Comparably unradiogenic Os isotopic compositions have only been found in ancient subcontinental lithospheric mantle peridotites such as orogenic massifs (26) and xenoliths from cratonic areas $(16,27)$.

We suggest that these anomalous unradiogenic xenoliths are pieces of the Gondwanaland subcontinental lithosphere. That the unradiogenic xenoliths are found in only one of the two localities suggests that the pieces of subcontinental lithosphere could be small and localized and thus undetectable in geophysical observations of the northern Kerguelen Plateau (9).

A possible mechanism for emplacing small discrete fragments of subcontinental lithosphere into the middle of a young ocean basin is that subcontinental lithospheric mantle was delaminated and incorporated into the newly-forming Indian Ocean lithosphere during the rifting of the eastern Gondwanaland continents. A similar process may explain the unusual geochemical characteristics of some basalts from the Southwest Indian Ridge (SWIR, $39^{\circ} \mathrm{E}$ to $41^{\circ} \mathrm{E}$ ), the Afanasy-Nikitin Rise in the northern Indian Ocean, the Oceanographer fracture zone on the Mid-Atlantic Ridge, the geochemical signatures of basalts from the Azores, as well as the origin of the DUPAL anomaly $(21,28)$. This process is consistent with the seismic structure of the southern Kerguelen Plateau (8). If delamination is common in continental rifting (29), it could contribute to mantle heterogeneities that are manifested in basalt geochemistry $(21,28)$.

Another possibility is that eastern Gondwanaland subcontinental lithospheric mantle was transported to the Kerguelen Plateau by the Kerguelen plume. In this scenario, the convecting incipient plume-head eroded the base of the Gondwanaland lithosphere, pieces of which were then integrated into the Indian Ocean lithosphere. The earliest volcanism 
that can be related to the Kerguelen plume with certainty is the southern Kerguelen Plateau, which formed at $115 \mathrm{Ma}(1,30)$. At $115 \mathrm{Ma}$, the Kerguelen Plateau was forming within the young Indian Ocean basin more than $500 \mathrm{~km}$ from the Gondwanaland continental margins (see 2, 31). In this case, an unusually large plume head (diameter $=1000 \mathrm{~km})$ would be required to erode and entrain the Gondwanaland lithosphere into the Kerguelen plume. If the $130 \mathrm{Ma}$ Bunbury Basalts (West Australia) and Rajmahal Traps (India) were identifiable as early Kerguelen plume activities, the requirement for such a large plume head may not be necessary. However, a genetic relationship of these rocks to the plume is still controversial (30). On the basis of these arguments, we consider that this model is unlikely.

Alternatively, these unradiogenic xenoliths could be pieces of Precambrian oceanic mantle lithosphere recycled through a subduction zone and returned to the lithosphere by way of the Kerguelen plume. That peridotites with unradiogenic Os isotopic compositions have not yet been observed from any other oceanic islands suggests that this hypothesis, too, is unlikely.

Our present data suggest that mantle of diverse provenance is present beneath the Kerguelen Islands. The results also indicate that the northern part of the Kerguelen Plateau is partially composed of lithospheric mantle derived from the Gondwanaland continents and is not completely oceanic in origin. 


\subsection{References and Notes}

1. H. Whitechurch, R. Montigny, J. Sevigny, M. Storey, V. J. M. Salters, Proc. Ocean Drill. Prog., Sci. Res. 120, 71 (1992); M. S. Pringle, M. F. Coffin, M. S. Storey, EOS, Trans. Am. Geophys. Un. 78, 728 (1997).

2. H. L. Davies, et al., Contrib. Mineral. Petrol. 103, 457 (1989); M. Storey, et al., Nature 338, 574 (1989).

3. The southern Kerguelen Plateau is one of the earliest known products of the extensive Kerguelen plume magmatism with dredge samples dated at 109-115 Ma old (1), and rocks from ODP drill-holes range from 112 to $85 \mathrm{Ma}$ [M. Storey, M. S. Pringle, M. F. Coffin, J. Wijbrams, EOS, Trans. Am. Geophys. Un. 77, W123 (1996)]. The Ninetyeast Ridge is the hotspot track from the northward migration of India from $>83$ to $43 \mathrm{Ma}[\mathrm{R}$. A. Duncan, J. Volcan. Geotherm. Res. 4, 283 (1978); R. A. Duncan, Proc. Ocean Drill. Prog., Sci. Res., 121507 (1991)]. Broken Ridge and its conjugate, the northern Kerguelen Plateau, were erupted from 88 Ma until 43 Ma [R. A. Duncan, J. Volcan. Geotherm. Res. 4, 283 (1978)], when rifting was initiated along the Southeast Indian Ridge (SEIR) between Broken Ridge and the northern Kerguelen Plateau [J.-Y. Royer and D. T. Sandwell, J. Geophys. Res. 94, 13 (1989)]. The Kerguelen Islands are the most recent of the Kerguelen Plume volcanism from 39 to $0.04 \mathrm{Ma}$ [(11); J. Nougier, in Antarctic Geology and Geophysics, R. J. Adie, Ed. (International Union of Geological Sciences,Ser. B-No. 1, Scandinavian Univ. Books, Oslo, 1972), pp. 803-808].

4. S. R. Hart, Nature 309, 753 (1984); D. Weis and F. A. Frey, J. Geophys. Res. 101, 13 (1996).

5. J. J. Mahoney, et al., J. Geophys. Res. 94, 4033 (1989).

6. N. D. Watkins, B. M. Gunn, J. Nougier, A. K. Baksi, Geol. Soc. Amer. Bull. 85, 201 (1974); L. Dosso, et al., Earth Planet. Sci. Lett. 43, 46 (1979); I. Gautier, et al., ibid. 100, 59 (1990); D. Weis, F. A. Frey, H. Leyrit, I. Gautier, ibid. 118, 101 (1993).

7. C. Alibert, Proc. Ocean Drill. Prog. Sci. Res., 119, 293 (1991); J. J. Mahoney, et al., Chem. Geol. 120, 315 (1994).

8. S. Operto and P. Charvis, Geology 23, 137 (1995).

9. M. Recq, D. Brefort, J. Malod, J.-L. Veinante, Tectonophysics 182, 227 (1990).

10. Olivine separates and peridotite whole-rock powders were ground in an agate shatterbox vial, prepared for Os analysis by NiS fire-assay and distillation, and measured using negative thermal ionization mass spectrometry techniques at Woods Hole Oceanographic Institution [(20); G. Ravizza, Earth Planet. Sci. Lett. 118, 335 (1993)]. On the basis of counting statistics, the precision associated with ${ }^{187} \mathrm{Os} /{ }^{\prime 88} \mathrm{Os}$ range from $0.10-0.44 \%(2 \sigma)$, although replicate analyses (one was a separate aliquot from the same powder split and another from a separate powder split) agree within $\pm 0.5 \%$ and $\pm 0.7 \%$ respectively. Osmium standard runs were reproducible within $0.3 \%(2 \sigma)$. Osmium concentrations were determined by fire-assay and isotope dilution, and were reproducible at $\pm 7 \%(2 \sigma)$. Blank corrections for Os isotopic composition and concentrations were less than the uncertainty of counting statistics in most cases, and only applied when the correction was greater than the counting error. Rhenium concentrations were measured on separate powder splits by inductively coupled plasmamass spectrometry at the Lamont-Doherty Earth Observatory. Reported Re concentrations are not blank-corrected (procedural blank was approximately 10-20 ppt), and counting statistics were $0.6-3.2 \%(2 \sigma)$. Thus, most of the samples had negligible amounts of Re. 
11. A. Giret and J. Lameyre, in Antarctic Earth Science, R. L. Oliver, P. R. James, et al., Eds. (Cambridge University Press, Cambridge, 1983), pp. 646-651; K. Nicolaysen, et al., EOS, Trans. Am. Geophys. Un. 77, 824 (1996).

12. D. R. Hassler and N. Shimizu, ibid. 75, 710 (1994); D. R. Hassler and N. Shimizu, in preparation.

13. A. Michard, R. Montigny, R. Schlich, Earth Planet. Sci. Lett. 78, 104 (1986); L. Dosso, et al., Earth Planet. Sci. Lett. 88, 47 (1988).

14. N. Mattielli, et al., Lithos 37, 261 (1996).

15. J. W. Morgan, J. Geophys. Res. 91, 12 (1986); S. R. Hart and G. E. Ravizza, in Earth Processes: Reading the Isotopic Code, A. Basu and S. R. Hart, Eds. (American Geophysical Union, Washington D. C., 1996), vol. 95, pp. 123-134.

16. R. J. Walker, R. W. Carlson, S. B. Shirey, F. R. Boyd, Geochim. Cosmochim. Acta 53, 1583 (1989).

17. E. H. Hauri, thesis, MITMHOI (1992).

18. H.-J. Yang, et al., J. Petrol. in press (1998).

19. C. E. Martin, Geochim. Cosmochim. Acta 55, 1421 (1991).

20. E. H. Hauri and S. R. Hart, Earth Planet. Sci. Lett. 114, 353 (1993).

21. E. Widom and S. B. Shirey, ibid. 142, 451 (1996).

22. L. Reisberg, et al., ibid. 120, 149 (1993).

23. E. H. Hauri, Nature 382, 415 (1996).

24. M. Roy-Barman and C. J. Allègre, Geochim. Cosmochim. Acta 58, 5043 (1994); J. E. Snow and L. Reisberg, Earth Planet. Sci. Lett. 133, 411 (1995).

25. The $T_{R D}$ model age is a special case of the Re-Os model age $\left(T_{M A}\right)$ and is defined as the time that the Os isotopic composition of the sample intersects a chondritic Re-Os mantle evolution curve, and the Re/Os ratio of the sample is 0 . That is

$$
T_{M A}=\frac{1}{\lambda} \cdot \ln \left[\frac{\left(\frac{{ }^{187} O S}{{ }^{188} O S}\right)_{\text {Mante }}-\left(\frac{{ }^{187} O S}{{ }^{188} O S}\right)_{\text {Sample }}}{\left(\frac{187 \mathrm{Re}}{{ }^{188} O S}\right)_{\text {Mante }}-\left(\frac{{ }^{187} \mathrm{Re}}{{ }^{188} O S}\right)_{\text {Sample }}}+1\right]
$$

where $\lambda=$ the decay constant for ${ }^{187} \operatorname{Re}\left[1.59 \times 10^{-11}\right.$; M. Lindner, et al., Nature 320,246 $(1986)]$ and $\left({ }^{187} \mathrm{Os} /{ }^{188} \mathrm{Os}\right)_{\text {Mantle }}=0.12757$ and $\left({ }^{187} \mathrm{Re} /{ }^{188} \mathrm{Os}\right)_{\text {Mantle }}=0.39716$ from the mean of carbonaceous chondrites as originally defined by Walker et al., (16). This age is a minimum because it assumes that $R e$ is completely removed during the melting event that formed these rocks. There is some uncertainty as to the exact Re/Os ratio of Earth's mantle. Present day $\left({ }^{187} \mathrm{Os} /{ }^{188} \mathrm{Os}\right)_{\text {Mantle }}$ may be as unradiogenic as some abyssal peridotites $[\sim 0.122$ (24)] in which case the model ages decrease, or more radiogenic as estimated from fertile xenoliths [ 0.1290; T. Meisel, R. J. Walker, J. W. Morgan, Nature 383, 517 (1996)], where model ages would be even older. Most estimates of $\left({ }^{187} \mathrm{Os} /{ }^{188} \mathrm{Os}\right)_{\text {Mantle }}$ are between 0.124 and $0.130(19,24)$, and the use of either extreme does not affect our conclusions. Ancient $\left({ }^{187} \mathrm{Os} /{ }^{188} \mathrm{OS}\right)_{\text {Mantle }}$ is better defined because of iron meteorite initial ratios [M. F. Horan, J.W. Morgan, R. J. Walker, J. N. Grossman, Science 255, 1118 (1992)], and because ingrowth of ${ }^{187}$ Os was still small. The $T_{M A}$ for most samples are within the estimates for $T_{R D}$ because of the samples' low Re contents. Ages were omitted for those samples giving future ages, or samples whose ${ }^{187} \mathrm{Os} /{ }^{188} \mathrm{Os}$ are similar to the estimated range of $\left({ }^{187} \mathrm{Os} /{ }^{188} \mathrm{Os}\right)_{\text {Mantle }}$.

26. L. Reisberg and J.-P. Lorand, Nature 376, 159 (1995); T. Meisel, G. G. Bino, T. F. Nägler, Geochim. Cosmochim. Acta 60, 2583 (1996).

27. R. W. Carlson and A. J. Irving, Earth Planet. Sci. Lett. 126, 457 (1994); D. G. Pearson, et al., ibid. 134, 341 (1995); D. G. Pearson, et al., Geochim. Cosmochim. Acta 59, 959 (1995). 
28. S. B. Shirey, J. F. Bender, C. H. Langmuir, Nature 325, 217 (1987); C. J. Hawkesworth, M. S. M. Mantovani, P. N. Taylor, Z. Palacz, ibid. 322, 356 (1986); J. Mahoney, A. P. LeRoex, Z. Peng, R. L. Fisher, J. H. Natland, J. Geophys. Res. 97, 19 (1992); J. J. Mahoney, W. M. White, B. G. J. Upton, C. R. Neal, R. A. Scrutton, Geology 24, 615 (1996).

29. R. S. White, Nature 327, 191 (1987); R. White and D. McKenzie, J. Geophys. Res. 94, 7685 (1989).

30. F. A. Frey, et al., Earth Planet. Sci. Lett. 144, 163 (1996).

31. R. D. Müller, J.-Y. Royer, L. A. Lawver, Geology 21, 275 (1993); B. C. Storey, Nature 377, 301 (1995).

32. The variation of ${ }^{187} \mathrm{Os} /{ }^{188} \mathrm{Os}$ and Os concentration do not appear to correlate with any petrographic features or incompatible trace element abundances.

33. Our samples were collected during the 1992 to 1993 austral field season. We thank A. Giret, F. Frey, D. Weis, and J.-Y. Cotin for assistance in sampling. We also thank G. Ravizza for discussions, S. Hart for sharing of laboratory facilities, J. Blusztajn for advice, K. Burrhus for technical support, E. Nakamura for Sr isotopic analysis of OB93-78 cpx, and F. Frey and M.F. Roden for comments. NS acknowledges support from the National Geographic Society (4629-91), and the National Science Foundation (EAR-9219158 and OPP -9417806). This research is also supported by a Cecil and Ida Green Fellowship to DRH. 


\subsection{Tables}

Table 3-1. Rhenium and osmium isotopic results from Kerguelen Islands peridotite xenoliths. All samples are spinel harzburgites except as noted.

\begin{tabular}{|c|c|c|c|c|c|}
\hline Sample & ${ }^{187} \mathrm{Os} /{ }^{188} \mathrm{Os}$ & $\begin{array}{c}\text { Os (32) } \\
\text { (ppt) }\end{array}$ & $\begin{array}{c}\mathrm{Re} \\
\text { (ppt) }\end{array}$ & $\begin{array}{l}\mathrm{Re} / \mathrm{Os} \\
\left(\times 10^{-3}\right)\end{array}$ & $\begin{array}{c}\mathrm{T}_{\mathrm{RD}}(25) \\
(\mathrm{Ga}) \\
\end{array}$ \\
\hline \multicolumn{6}{|c|}{ Lac Superieur } \\
\hline OB93-51* & $0.1262 \pm 2$ & 87 & n.d. & & \\
\hline OB93-52 & $0.1286 \pm 3$ & 4218 & n.d. & & \\
\hline OB93-64† & $0.1300 \pm 2$ & 968 & n.d. & & \\
\hline OB93-77 & $0.1263 \pm 3$ & 3199 & 5 & 2 & \\
\hline OB93-78 & $0.1266 \pm 6$ & 2888 & n.d. & & \\
\hline OB93-80 & $0.1252 \pm 2$ & 1727 & n.d. & & \\
\hline OB93-82† & $0.1287 \pm 2$ & 6999 & n.d. & & \\
\hline OB93-83* $\S$ & $0.1257 \pm 4$ & \multicolumn{2}{|c|}{ Mt. Trapeze } & & \\
\hline OB93-280 & $0.1189 \pm 2$ & 3067 & 6 & 2 & 1.36 \\
\hline OB93-284 & $0.1236 \pm 1$ & 6652 & 29 & 4 & 0.63 \\
\hline OB93284bll & $0.1229 \pm 3$ & 6645 & n.d. & & 0.74 \\
\hline OB93-287 & $0.1239 \pm 3$ & 1267 & 49 & 39 & 0.58 \\
\hline OB93-289 & $0.1224 \pm 3$ & 3411 & 12 & 4 & 0.81 \\
\hline OB93-291 & $0.1205 \pm 4$ & 2157 & 11 & 5 & 1.11 \\
\hline OB93-297 & $0.1228 \pm 3$ & 2409 & 31 & 13 & 0.75 \\
\hline OB93-305 & $0.1211 \pm 3$ & 2012 & 72 & 36 & 1.02 \\
\hline OB93-305rll & $0.1202 \pm 4$ & 2179 & n.d. & & 1.16 \\
\hline OB93-306 & $0.1276 \pm 5$ & 516 & 41 & 80 & \\
\hline OB93-307 & $0.1229 \pm 3$ & 5605 & 49 & 9 & 0.74 \\
\hline OB93-314 & $0.1383 \pm 6$ & 3281 & 9 & 3 & \\
\hline OB93-317 & $0.1196 \pm 4$ & 2652 & 11 & 4 & 1.25 \\
\hline
\end{tabular}




\subsection{Figures}

Figure 3-1. Map of the Indian Ocean and Kerguelen Islands. Submarine plateaus and ridges related to the Kerguelen Plume are highlighted in light gray shading, and the locations of the SWIR and SEIR are shown. Filled circles correspond to Deep Sea Drilling Project (DSDP) and Ocean Drilling Project (ODP) drill sites. The ages of recovered basaltic basement for each drill-hole are adjacent to the symbols. The Kerguelen Islands (inset), are located at the northern end of the Kerguelen Plateau. On the Courbet Peninsula, filled stars mark the two xenolith localities of this study, Lac Superieur and Mont Trapeze. 


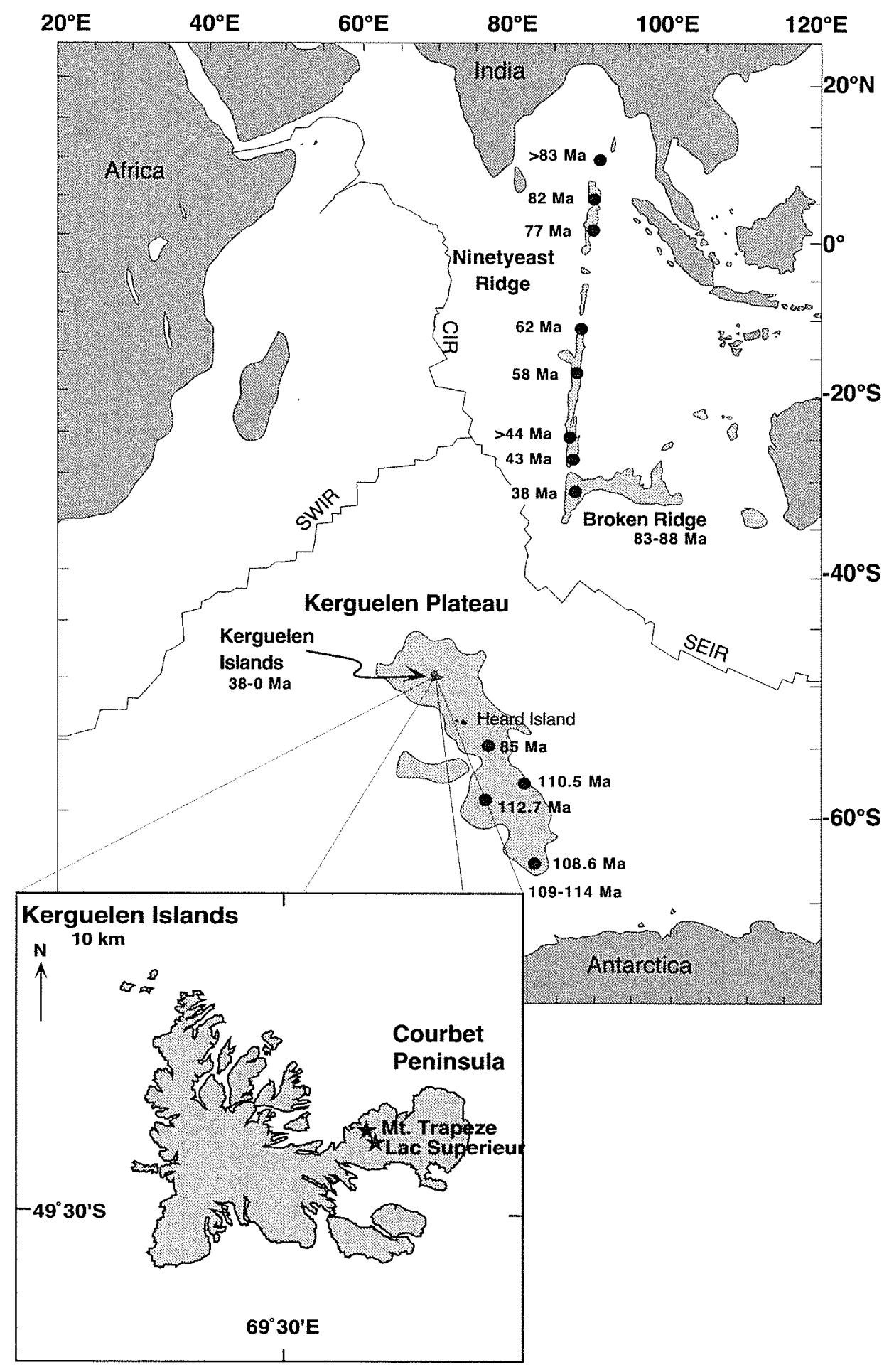




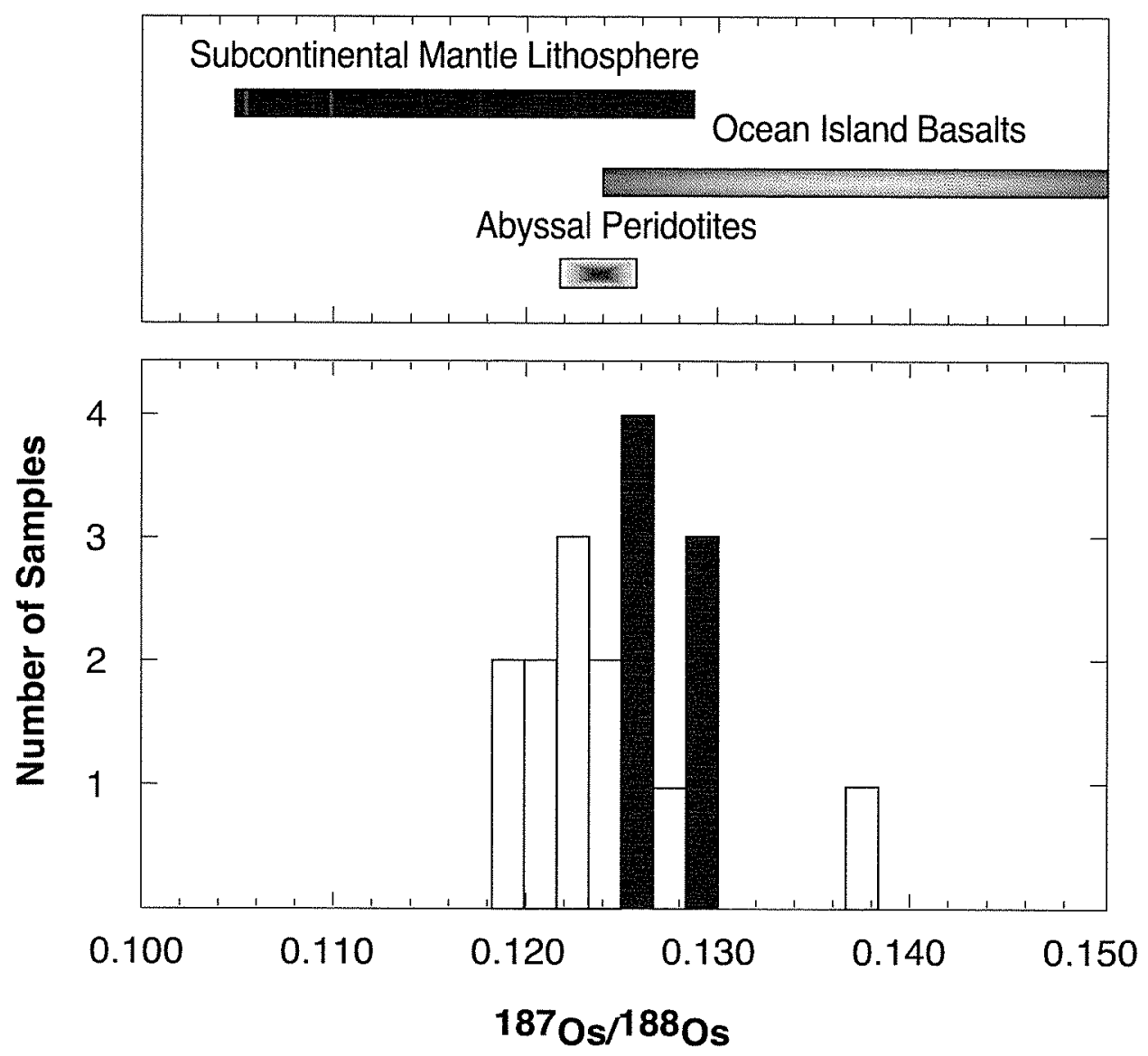

Figure 3-2. Histogram of the Os isotopic composition of the Kerguelen Islands peridotite xenoliths by location. Most samples from the Lac Superieur locality (black) are more radiogenic than most of those from the Mont Trapeze locality (white). The typical error is less than the width of a bar. Shown for comparison, is the range of initial Os isotopic compositions of other rock types from around the world $(16,19-24,26,27)$. Only data for abyssal peridotites that are not contaminated with seawater Os are shown. 


\section{Chapter 4 Trace Element and Sr, Nd and Os Isotopic Composition of Mafic Granulite Xenoliths from the Courbet Peninsula, Kerguelen Islands}

\subsection{Introduction}

The Kerguelen Islands are situated in the southern Indian Ocean atop the Kerguelen Plateau, the second largest of the giant oceanic plateaus. The Kerguelen Plateau and Islands, along with other large bathymetric features of the Indian Ocean (the Ninetyeast Ridge and Broken Ridge, Figure 1-1) are results of basaltic hotspot volcanism that is attributed to the long-lived Kerguelen mantle plume (Mahoney et al., 1983; Storey et al., 1989). Plume-related basalts (and included xenoliths) have been the subject of many comprehensive studies (Watkins et al., 1974; Dosso et al., 1979; Gautier et al., 1990; Weis et al., 1993; Yang et al., 1998; Grègoire, 1994; Mattielli, 1996; Hassler and Shimizu, 1998), two Deep Sea Drilling Project (DSDP) legs (Davies et al., 1974; von der Borch et al., 1974), and three Ocean Drilling Program (ODP) drilling legs [Leg 119 (Barron et al., 1991), Leg 120 (Wise et al., 1992), and Leg 183 (Dec., 1998 - Feb., 1999)] have sampled the basaltic basement of the plateau. But, mostly because of its huge size and remote location, large areas of the $2 \times 10^{6} \mathrm{~km}^{2}$ Kerguelen Plateau remain unsampled and unsurveyed.

It is not completely known how these large igneous provinces (LIP) form, but it is clear that they are not a result of normal seafloor spreading and require a mantle plume to 
produce such voluminous magmatism (Coffin and Eldholm, 1994). However, what role plume-ridge or plume-lithosphere interaction plays in oceanic plateau formation is also not understood. For example, the Ontong Java Plateau was near an oceanic spreading center early in its history, but a large part of it was emplaced off-axis (Neal et al., 1997). Similarly, the history of the Kerguelen LIP is believed to have included a spreading ridgecentered location for the Kerguelen plume, but its timing and details of tectonic history are not clearly delineated.

Mafic granulites are part of the Kerguelen Islands xenolith suite (Grègoire, 1994). This occurrence is quite unusual; pressure-temperature conditions for the oceanic crust are generally outside those for granulite facies metamorphism. In fact, the Kerguelen xenolith suites represent the first and only occurrence of granulite facies rocks in the oceanic environment (Grègoire et al., 1994). These granulite xenoliths are pieces of the plateau lower crust (Grègoire, 1994), and provide an excellent opportunity to study an inaccessible part of the plateau. The geochemistry of these rocks could contain information about the geodynamic evolution of the Kerguelen plume inaccessible through erupted lavas and its relationship to the formation of the Kerguelen Plateau. The crustal thickness of the Kerguelen Plateau generally increases from approximately $17 \mathrm{~km}$ in the immediate vicinity of the Archipelago to as much as $26 \mathrm{~km}$ in the south (Recq and Charvis, 1986). Charvis et al. (1995) however, report that the crustal thickness could be variable between 17 and 20 $\mathrm{km}$ beneath the Kergeuelen Islands and could be as much as $25 \mathrm{~km}$ in the Plateau between Kerguelen and Heard Islands. The southern Kerguelen Plateau has a seismic structure similar to that of a volcanic passive margin (Recq and Charvis, 1986; Operto and Charvis, 1995), and though geochemical evidence exists for discrete pieces of subcontinental lithosphere in the northern plateau (Chapter 2; Chapter 3; Hassler and Shimizu, 1998), the thickened crust here was interpreted to have an oceanic origin (e.g. Houtz et al., 1977; 
Recq and Charvis, 1986). The Ontong Java Plateau, and other oceanic islands such as Hawaii and the Marquesas also lie above a thickened oceanic layer 3 (e.g. Furumoto et al., 1976; Gladczenko et al., 1997; ten Brink and Brocher, 1987; Caress et al., 1995). In the case of the Marquesas, Caress et al. (1995) estimated that up to twice the volume erupted at the surface was present in the lower crust. Hence, this thickening of the lower oceanic crust is an important process in ocean island volcanism as well as in LIP formation. A study of such lower crustal rocks can help to answer questions about the origin of the Kerguelen Plateau in particular, and oceanic plateaus in general.

This study expands on the previous major and trace element and petrographic work of Grègoire et al. (1994; 1998) and the isotopic study of Mattielli et al. (1996) and Mattielli (1996), all of which concentrated on the xenoliths from localities in the southeastern province of the Islands. The xenoliths of this study are from the Lac Superieur location to the north on the Courbet Peninsula (Figure 1-1). Some of the granulites studied by Grègoire et al. (1994; 1998), Mattielli et al. (1996) and Mattielli (1996) contain garnet in a typical mafic garnet granulite mineral assemblage (clinopyroxene + orthopyroxene + plagioclase + garnet \pm ilmenite). A smaller number of samples contain sapphirine $\left[(\mathrm{Mg}, \mathrm{Fe})_{2} \mathrm{Al}_{4} \mathrm{O}_{6} \mathrm{SiO}_{4}\right]$; Grègoire et al. (1994) reported the first occurrence of this mineral in an oceanic setting. The presence of these minerals helps constrain pressure-temperature conditions of metamorphism. The samples of the present study are of a typical mafic pyroxene granulite assemblage (clinopyroxene + orthopyroxene + plagioclase \pm ilmenite) without garnet or sapphirine. One of the goals of this project is to compare the lower crust of the Islands and the Plateau as represented by the xenoliths from these two areas.

A major objective of this work is to determine the provenance of the granulites. Because of the tectonic history of the Indian Ocean and the presence of subcontinental mantle lithosphere beneath the Kerguelen Islands (Chapter 2; Chapter 3; Hassler and 
Shimizu, 1998), the possibility that these xenoliths have an origin in the continental lower crust cannot be precluded. In this chapter, the major element, trace element and $\mathrm{Sr}, \mathrm{Nd}$ and Os isotopic compositions of the Kerguelen granulites will be compared to those of mafic continental granulites in order to discuss their possible origin as pieces of continental lower crust. As it turns out, a simple comparison of elemental abundances is inadequate to constrain the origin of the Kerguelen granulites. It will be shown below that Os isotopes are the best indicators that these xenoliths have an oceanic rather than continental origin. Given that these granulites have an oceanic origin, the question remains: are the granulites recrystallized cumulates of melts that are related to the Southeast Indian Ridge (SEIR) midocean ridge basalts (MORB), the Kerguelen plume, or some mixture of these two? Further, is there a geochemical signature of contamination of their parent melts by continental crust?

These rocks could also serve as a geochemical record of plume-ridge and plumelithosphere interaction that one may use in an attempt to unravel part of the history of the Kerguelen plume. The argument presented here is that the origin of these xenoliths is most likely from an isotopically heterogeneous Kerguelen plume, and that a continental origin is unlikely. Though an origin as a plume-MORB mixture cannot be completely discounted, it is clear that none of the rocks formed solely by mid-ocean ridge processes.

\subsection{Tectonic Setting}

Earlier studies divided the Kerguelen Plateau into two distinct structures, the Mesozoic southern plateau and Cenozoic northern plateau, with the break just south of the Kerguelen Islands (Figure1-1) (Munschy and Schlich, 1987; Coffin and Eldholm, 1994). Broken Ridge and the conjugate southern and central Kerguelen Plateau erupted beginning in the Cretaceous and were later rifted from each other by seafloor spreading at the SEIR (Royer and Sandwell, 1989). Magnetic anomaly 18 ( 42.7 Ma, Harland et al., 1989) is the oldest 
identified lineation along the SEIR side of the south to central parts of the Kerguelen Plateau and the southern side of Broken Ridge (Munschy et al., 1992). Steeply dipping slopes, remnants of SEIR rifting, face the SEIR on both of these features, but there is a gentle slope towards the abyssal seafloor that looks like volcanic flows at the northernmost Kerguelen Plateau. Anomaly 9 is the oldest that is clearly present along this part of the Plateau. Anomaly 13 is tentatively identified in this area, but anomalies $18-13$ (42.7-35 Ma; Harland et al., 1989) may actually underlie the northern part of the plateau (Munschy et al., 1992). Moreover, plate tectonic reconstructions give an overlap between the northern part of the Kerguelen Plateau and the southern extension of Broken Ridge (Royer and Sandwell, 1989). Thus, the northern Kerguelen Plateau formed at least after anomaly 18 time, and portions of it must be no older than $35 \mathrm{Ma}$. The ages of submarine rocks from the northern Kerguelen Plateau are not known.

The oldest rocks on the Kerguelen Islands are from a $39 \pm 3$ Ma gabbroic pluton, the Val Gabbro, on the southeastern province (Giret and Lameyre, 1983). These rocks are somewhat zeolitized and age determinations were made using the K-Ar technique. However, $\mathrm{K}-\mathrm{Ar}$ is not a preferred method for dating pyroxene-bearing plutonic rocks, especially those that contain these secondary minerals (Faure, 1986), and these ages may not be accurate. The next oldest known rocks from the archipelago are $\sim 29$ Ma plateau flood basalts (Nicolaysen et al., 1999). It is possible then, that the Kerguelen Islands did not start to form until well after $35 \mathrm{Ma}$, after the SEIR had moved away from the plume. At a spreading rate of $25-45 \mathrm{~km} / \mathrm{Ma}$ (Munschy et al., 1992), the Kerguelen Islands (and the northern Kerguelen Plateau) could have been anywhere from $200-400 \mathrm{~km}$ away from the SEIR. This is complicated though, in that Kerguelen plume related basalts from DSDP site 254 on Broken Ridge give ages of 38 Ma (Duncan, 1978). 


\subsection{Sample Description}

The granulite xenoliths of this study are from the Lac Superieur locality on the Courbet Peninsula (Figure1-1), and are part of a suite of xenoliths that also contains lherzolites, harzburgites, and pyroxenites. The xenoliths are included a dike of unknown age that cross-cuts the 24.5 Ma plateau basalts (Nicolaysen et al., 1999) that make up the Courbet Peninsula.

The granulite xenoliths range in size from $\sim 5$ to $20 \mathrm{~cm}$ in the largest dimension. Most of the 11 rocks of this study are free of alteration, and are medium-grained and equigranular, with no relict igneous textures. They contain clinopyroxene (to $3.5 \mathrm{~mm}$ ), orthopyroxene (to $1.4 \mathrm{~mm}$ ), anorthitic plagioclase (to $1.2 \mathrm{~mm}$ ), \pm green spinel, \pm ilmenite, and \pm sulfides. Only one relict olivine grain was found, in sample OB93-71. Figure 4-1 shows photomicrographs of typical granulites. Some of the rocks contain strained pyroxene and plagioclase. Many have pyroxene exsolution, both orthopyroxene from clinopyroxene, and vice versa. Two samples, OB93-72 and OB93-90, have poikilitic orthopyroxene. Spinels and coarse symplectite textures $(\sim 400 \mu \mathrm{m}$ spinels $)$ are present in the samples with higher whole rock Mg\# (OB93-50, OB93-60, OB93-71, OB93-72, OB93-90, OB93-96), and very fine symplectites (2-10 $\mu \mathrm{m}$ spinels), ilmenite and Ti-rich magnetite occur only in the lowest Mg\# rocks (OB93-54, OB93-57, OB93-68, and O93-69 -no thin section is available for OB93-61A). Symplectite textures are present as clinopyroxene + spinel and orthopyroxene + spinel intergrowths. Sulfides occur as rounded blebs included clinopyroxene and along grain boundaries. They are generally Ferich, but $\mathrm{Fe}-\mathrm{Ni}, \mathrm{Fe}-\mathrm{Cu}, \mathrm{Ni}-\mathrm{Cu}$, and $\mathrm{Cu}-\mathrm{Zn}$-rich sulfides are also present. A summary of the petrographic characteristics of the xenolith suite are shown in Table 4-1. 


\subsection{Analytical Methods}

Surfaces were cut from the xenoliths and saw marks were polished off with 120 and 240 grit silicon-carbide paper. The polished pieces were crushed to smaller fragments between plastic with a hammer. Pieces that did not have any basalt veins or visible alteration were selected under a binocular microscope for grinding in an agate shatterbox vial. Whole rock major and trace element compositions were determined on unleached powders by XRF and ICP-MS at the GeoAnalytical Laboratory at Washington State University. Precision for $\mathrm{XRF}$ major element analysis is $<0.4 \%$ (1 S.D.). The precision of all trace element analyses by ICP-MS is $1-3 \%$, except for $\mathrm{U}$ and $\mathrm{Th}$, which are $10 \%$ (1 S.D.).

Major element compositions of the rock-forming minerals in thin sections or grain mounts were determined with the JEOL 733 Superprobe electron microprobe at the Massachusetts Institute of Technology with an acceleration potential of $15 \mathrm{kV}$, a beam current of $10 \mathrm{nA}$ and a $1 \mu \mathrm{m}$ spot. Raw data were reduced online using the method of Bence and Albee (1968) modified by Albee and Ray (1970). The precision based on counting statistics are 6-25\% (1 S.D.) for $<0.5 \mathrm{wt} . \%, 2.5-6 \%$ for $0.5-1 \mathrm{wt} . \%, 1-3 \%$ for $1-15$ wt. $\%,<0.5 \%$ for $>15$ wt. $\%$.

The Cameca IMS $3 \mathrm{f}$ ion probe at WHOI was used to analyze trace element and rare earth element contents of clinopyroxenes following the methods of Shimizu and Hart (1982). A primary beam of $\mathrm{O}^{-}$ions was focused to $\sim 20 \mu \mathrm{m}$ for REE ( $\mathrm{La}, \mathrm{Ce}, \mathrm{Nd}, \mathrm{Sm}, \mathrm{Eu}$, $\mathrm{Dy}, \mathrm{Er}, \mathrm{Yb})$ and $\sim 10 \mu \mathrm{m}$ for other trace elements $(\mathrm{Cr}, \mathrm{V}, \mathrm{Y}, \mathrm{Ti}, \mathrm{Zr}, \mathrm{Sr})$. Molecular interferences were eliminated by energy filtering and a secondary voltage offset of -30 to $-60 \mathrm{~V}$ for the REE and $-90 \mathrm{~V}$ for the other trace elements. Uncertainties on the basis of 
counting statistics were 5-10\% (1 S.D.) for the REE and 1-5\% (1 S.D.) for the other trace elements. All normalized REE data are reported relative to abundances in $\mathrm{C} 1$ chondrites (Anders and Grevesse, 1989).

The chemistry and mass spectrometry of $\mathrm{Sr}$ and $\mathrm{Nd}$ isotopes were done at WHOI. Isotopes were measured using a VG-354 5-collector mass spectrometer. Cation exchange separation methods were used for $\mathrm{Sr}$ and the LREE, and HDEHP extraction was used for Sm and Nd, as described by Zindler (1980) and Richard et al. (1976). For some samples (OB93-54, OB93-60, OB93-61A, OB93-68, OB93-69, OB93-71, OB93-72, OB93-90, OB93-96), Sr was separated with $\mathrm{Sr}-$ spec $^{\mathrm{TM}}$ resin (Horwitz et al., 1991; Pin and Bassin, 1992). Isotopic compositions of $\mathrm{Sr}$ and $\mathrm{Nd}$ were measured on whole rock powders that were leached in cold $2.5 \mathrm{~N} \mathrm{HCl}$ for 15 minutes. Some samples were leached in $6.2 \mathrm{~N} \mathrm{HCl}$ at $100^{\circ} \mathrm{C}$ for 1.5 hours, but this dissolved a large fraction, if not all, of the plagioclase from plagioclase-rich samples, and most of the $\mathrm{Sr}$ was lost. Strontium data are normalized to ${ }^{87} \mathrm{Sr} /{ }^{88} \mathrm{Sr}=0.1194$, and isotopic compositions are reported relative to ${ }^{87} \mathrm{Sr} /{ }^{86} \mathrm{Sr}=0.710240$ for NBS987 (average ${ }^{87} \mathrm{Sr} /{ }^{86} \mathrm{Sr}=0.710255 \pm 14, \mathrm{n}=7$ ). $\mathrm{Nd}$ data are normalized to ${ }^{146} \mathrm{Nd} /{ }^{144} \mathrm{Nd}=0.7219$, and isotopic compositions are reported relative to ${ }^{143} \mathrm{Nd} /{ }^{144} \mathrm{Nd}=$ 0.511847 for the La Jolla standard (average ${ }^{143} \mathrm{Nd} /{ }^{144} \mathrm{Nd}=0.511849 \pm 5, \mathrm{n}=11$ ). No blank corrections were made on $\mathrm{Sr}$ or $\mathrm{Nd}$ isotopic ratios. The procedural blank for Sr separation by cation column was $304 \mathrm{pg} / \mathrm{g}$ sample, and as much as $12 \mathrm{ng} / \mathrm{g}$ sample for Sr separated by $\mathrm{Sr}$-spec resin. The relatively high blank for the $\mathrm{Sr}$-spec method was most likely a result of inadequate cleaning of the resin prior to use. Assuming all of the Sr blank came from the Sr-spec resin, corrections on ${ }^{87} \mathrm{Sr} /{ }^{86} \mathrm{Sr}$ would be only between 2 and $10 \mathrm{ppm}$ for these samples, because 3 to $6.5 \mu \mathrm{g}$ of analyte was used. Procedural blanks for Nd were $665 \mathrm{pg} / \mathrm{g}$ sample and $255 \mathrm{pg} / \mathrm{g}$ sample for the two blanks analyzed during this study. Counting 
statistics $(2 \sigma)$ associated with mass spectrometry were less than $30 \mathrm{ppm}$ for $\mathrm{Sr}$, except OB93-54* (an unleached sample, Table 4-10), which was $186 \mathrm{ppm}$. The $2 \sigma$ counting statistics for Nd were less than $12 \mathrm{ppm}$, except OB93-60 and OB93-96, which were 56 and $36 \mathrm{ppm}$ respectively. In the figures where these data are shown, the errors are less than the width of the symbols. All concentrations of $\mathrm{Sr}$ and $\mathrm{Nd}$, were determined by isotope dilution, during isotopic analysis. Samarium concentrations were determined on the same sample dissolutions and were measured by isotope dilution ICP-MS at WHOI. Errors based on counting statistics varied from 0.23 to $0.47 \%(2 \sigma)$, but were $0.70 \%$ and $0.77 \%$ (2б) for OB93-54rep and OB93-57 respectively.

Unleached whole rock powders were prepared for Os analysis by NiS fire-assay and distillation, and measured using negative thermal ionization mass spectrometry techniques at WHOI (Hauri and Hart, 1993; Ravizza, 1993). Between 2.5 to $10 \mathrm{~g}$ of sample were fused. All Os analyses are corrected for the analytical blank (1.4 pg/g flux with ${ }^{187} \mathrm{Os} / 188 \mathrm{Os}=0.2648$ ). . Correction for the Os fusion procedure blank can be significant for low concentration samples, so it is important that the blank ${ }^{187} \mathrm{Os} /{ }^{188} \mathrm{Os}$ and the Os concentration are well known. This is difficult because the blank has such a low concentration. Measurements of blank concentration vary by 5.5\% (1 S.D) and the blank isotopic composition, by $8 \%$ (1 S.D.). For the samples of this study, that translates as up to $0.6 \%$ uncertainty in the accuracy of the isotopic composition due to blank correction, depending on the sample concentration. The other major source of uncertainty is sample reproducibility due to nugget effects. In this study, replicate analyses agree within $<0.5 \%$. The precisions associated with the ${ }^{187} \mathrm{Os} /{ }^{188} \mathrm{Os}$ counting statistics range from 0.10 to $0.44 \%$ $(2 \sigma)$ for the rocks of this study. Osmium standard runs had $2 \sigma=0.59 \%(n=7)$. Osmium 
concentrations were determined on the same sample splits by fire-assay and isotope dilution, and were within $4.6 \%$ and $8.5 \%$ of each other for the two replicated samples. Rhenium concentrations were measured on separate powder splits by acid digestion and isotope dilution ICP-MS at WHOI. All Re concentrations are blank-corrected, except OB93-60, OB93-61A, OB93-90, where the blank chemistry for this group of samples failed. Procedural blanks were 0.8 and $10 \mathrm{pg} / \mathrm{g}$ sample for the other samples of this study. Uncertainties based on counting statistics were \pm 0.13 to $0.38 \%(2 \sigma)$. Replicate analyses were within 5 and 20\% for the two repeated samples (OB93-71 and OB93-54 respectively).

\subsection{Results and Discussion}

\subsubsection{Major Element Compositions}

The bulk compositions of the granulites are broadly basaltic; $\mathrm{SiO}_{2}=45.60$ to 48.99 wt. \%, and $\mathrm{Mg \#}[$ molar $\mathrm{Mg} /(\mathrm{Mg}+\mathrm{Fe}) \times 100]=55.3$ to 82.8 (with Fe as total Fe, Table 4-2). These xenoliths can be divided into two geochemical groups, those that have bulk rock $\mathrm{Mg} \#<80$ (samples OB93-54, OB93-57, OB93-61A, OB93-68, OB93-69), and those where the Mg\# > 80 (samples OB93-50, OB93-60, OB93-71, OB93-72, OB93-90, OB93-96). Other

geochemical characteristics tend to follow this division.

The major element compositions of the granulites are shown on $\mathrm{MgO}$ variation diagrams in Figure 4-2. There are negative correlations of $\mathrm{Al}_{2} \mathrm{O}_{3}$ and $\mathrm{Na}_{2} \mathrm{O}$ with $\mathrm{MgO}$, and $\mathrm{FeO}^{*}$ (total $\mathrm{Fe}$ ) is positively correlated with $\mathrm{MgO}$. No other obvious major element relationships exist. The two outlier samples (OB93-71: highest $\mathrm{MgO}$, and OB93-54: least $\mathrm{MgO}$ ) are labeled in many figures, as they are extreme in some of their other geochemical characteristics (e.g. [Os] and ${ }^{187} \mathrm{Os} /{ }^{188} \mathrm{Os}$ ). The granulite xenoliths of this study show a 
similar compositional range as those from the Southeastern province of the archipelago (Figure 4-3) (Grègoire, 1994; Grègoire et al., 1998). Thus, the eleven xenoliths that comprise this study are geochemically representative of the lower crustal xenoliths from the Kerguelen Islands.

Table 4-3 through Table 4-7, and Table 4-9 summarize representative compositions of the constituent minerals. Where significant variations are present, more than one analysis is shown. In some cases, all of the data are plotted in the figures. The complete data can be found in Appendix 2.

Clinopyroxenes from the granulites are aluminous diopside, except for one augitic pyroxene in sample OB93-57 (Table 4-3). The Mg\# of these minerals range from 68.1 to 85.0. For the lower Mg\# samples, cation totals tend to be greater than 4.01 (up to 4.03 in OB93-61A). Stoichiometric corrections using $\mathrm{Fe}^{3+}$ bring the cation totals closer to 4.00 , indicating the presence of up to 2 wt. $\%$ of $\mathrm{Fe}_{2} \mathrm{O}_{3}$ in clinopyroxenes in the low $\mathrm{Mg \#}$ samples. The major element compositions of clinopyroxenes are relatively homogenous within a particular sample, though some samples that contain co-existing symplectite clinopyroxenes have compositional differences between the two types (Appendix 2). In many of these granulites (OB93-60, OB93-72, OB93-90, OB93-96), symplectite clinopyroxenes have less $\mathrm{Al}_{2} \mathrm{O}_{3}$ relative to discrete clinopyroxenes, but clinopyroxene from some (OB93-57 and $\mathrm{OB} 93-69)$ have higher relative $\mathrm{Al}_{2} \mathrm{O}_{3}$ contents. Symplectite clinopyroxenes may also be different from discrete clinopyroxenes in $\mathrm{SiO}_{2}, \mathrm{MgO}, \mathrm{TiO}_{2}$, $\mathrm{Cr}_{2} \mathrm{O}_{3}$, and $\mathrm{Na}_{2} \mathrm{O}$ abundances, but not consistently more or less.

Orthopyroxenes are enstatite, with $\mathrm{Mg \#}$ that range from 62.3 to 81.8 (Table 4 4). As with the clinopyroxene, orthopyroxene from the lower Mg\# samples may have significant $\mathrm{Fe}^{3+}\left(\mathrm{Fe}_{2} \mathrm{O}_{3}=1-2 \mathrm{wt} \%\right)$. Discrete orthopyroxenes are generally homogenous within 
samples, but symplectite orthopyroxenes tend to have higher $\mathrm{Al}_{2} \mathrm{O}_{3}$ and lower $\mathrm{SiO}_{2}$ and $\mathrm{MgO}$ contents than co-existing discrete orthopyroxenes.

Anorthite contents of plagioclase are $\mathrm{An}_{77-82.4}$ for rocks from the high $\mathrm{Mg \#}$ group, and $\mathrm{An}_{66-72}$ for the low Mg\# samples (Table 4-5). Orthoclase contents are generally less than $\mathrm{Or}_{1}$, except for some grains in samples $61 \mathrm{~A}$ and 68 that are up to $\mathrm{Or}_{1.9}$.

Only Sample OB93-71 contains rare relict olivine; the composition of the one analyzed point is $\mathrm{Fo}_{79.8}$ (Table 4-6).

The oxide minerals in these rocks are $\mathrm{Mg}$-rich spinels, $\mathrm{Ti}$-magnetite, and ilmenite (Table 4-7). In the high Mg\# samples, the Mg\# of spinels is approximately 70 . Of the low Mg\# xenoliths, samples OB93-54, OB93-68, and OB93-69 contain ilmenite as well as spinel. The Mg\# of spinels from samples OB93-57 and OB93-68 is 58.5 and 52 respectively. One spinel from $\mathrm{OB} 93-68$ has a Ti-rich rim with $\mathrm{Mg} \#=22$. Some spinels from OB93-69 are Cr-bearing; the Mg\# of spinels from this rock range from 38 to 60 . Spinels in OB93-54 are the most Fe-rich, with $\mathrm{Mg \#}=27$. Both magnetite and ilmenite coexist with the spinels in this sample, and both are rimmed with Ti-magnetite with a $\mathrm{Mg \#} \mathrm{of}$ 8 to 10 . For all of the granulites, the $\mathrm{Cr} \#$ of the spinels is generally low $(<10)$ and variable for a given $\mathrm{Mg \# .}$

In summary, the most magnesian pyroxenes and spinels, and the most calcic plagioclase are from the high Mg\# xenoliths (samples OB93-50, OB93-60, OB93-71, OB93-72, OB93-90 and OB93-96), and the least from the lower Mg\# samples (OB93-54, OB93-57, OB93-61A, OB93-68, and OB93-69). 


\subsubsection{These xenoliths are metamorphic rocks Evidence for metamorphism}

Gabbroic cumulates have been recovered from all ocean basins, but none of these rocks were considered to be metamorphic (e.g. Tiezzi and Scott, 1980; Elthon, 1987; Meyer et al., 1989; Hèbert et al., 1991; Dick et al., 1992; Ross and Elthon, 1997). As will be shown below, the xenoliths of the present study possess major and trace element characteristics of gabbroic cumulates, and are determined to be mafic granulites for the following reasons: 1) the equigranular metamorphic texture, 2) the lack of olivine, 3) the relatively high modal abundance of orthopyroxene, and 4) garnet-bearing granulite xenoliths occur on the southeastern province of the archipelago.

Determining the original characteristics of these rocks, including the protolith mineralogy, and ultimately their provenance and the nature of their parent melts, is complicated by the metamorphic recrystallization. An approach taken here to estimate the original igneous mineralogy of these rocks is by their CIPW normative compositions. Unlike volcanic rocks, CIPW norm compositions of gabbroic cumulates are good approximations for true mineralogy. This same approach was used by Rogers and Hawkesworth (1982) and Rudnick et al. (1986) for mafic granulites from continental localities. On the basis of this calculation, the granulites were originally igneous assemblages of olivine, clinopyroxene and plagioclase (Table 4-2). In ternary classification diagrams (Streckheisen, 1973), the normative mineral assemblages of the majority of the granulites fall in the field for olivine gabbros, whereas OB93-68 and OB93-69 lie just inside the orthopyroxene gabbro field (Figure 4-4). Nine of the samples are hypersthene normative, two (OB93-72 and OB93-90) are Si-undersaturated with nepheline as a normative phase. 
Modal abundances of minerals in the xenoliths were calculated by mass balance of the whole rock and mineral compositions (Table 4-2). A comparison of the CIPW norms (the postulated protolith mineralogy) and the calculated modes (the current mineralogy) reveals some notable differences. Namely, abundances of orthopyroxene, clinopyroxene and oxides are higher in the current than the postulated protolith mineralogy, whereas those of olivine and plagioclase are lower (Figure 4-4). Particularly conspicuous is a large difference in abundances of orthopyroxene. For instance, OB93-50 contains 4.4 wt.\% normative orthopyroxene, whereas its modal abundance is $18.4 \mathrm{wt} \%$ (Table 4-2). Another significant difference is the nearly complete disappearance of modal olivine. Sample OB9350 contains no modal olivine, in contrast to $15 \mathrm{wt} . \%$ of CIPW normative olivine. It should also be noted that clinopyroxene modes are 1.5 to 1.9 times their normative abundances.

The CIPW norms of the granulites are consistent with the mineral modes of oceanic olivine gabbros, but the calculated modes of the granulites are not. In particular, the modal orthopyroxene contents of the granulites are too high for their olivine gabbro bulk composition. Orthopyroxene only occurs in low modal abundances (usually $<1.5 \%$ ) in oceanic olivine gabbros with Mg\# comparable to these xenoliths (Tiezzi and Scott, 1980; Elthon, 1987; Meyer et al., 1989; Hèbert et al., 1991; Dick et al., 1992; Ross and Elthon, 1997; Schminke et al., 1998). For orthopyroxene to be an igneous phase, the protoliths should be more evolved than these granulites. Thus, during metamorphism primary olivine was almost completely consumed, clinopyroxene and orthopyroxene were produced, and excess plagioclase remains a modal constituent. This is indicative of the reaction olivine + plagioclase $\rightarrow$ orthopyroxene + clinopyroxene + spinel, supporting the idea that was previously proposed by McBirney and Aoki (1973) to explain the formation of similar Kerguelen xenoliths that they termed spinel gabbros. This reaction can be driven in two 
ways, either by an increase in pressure or a temperature decrease, both of which will be discussed as mechanisms of metamorphism in more detail below.

Further evidence for a metamorphic origin lies in the compositions of the rock forming minerals. For a given $\mathrm{Mg} \#$, pyroxenes from these xenoliths are more aluminous than pyroxenes from other oceanic cumulates, and clinopyroxenes are more sodic (Figure 4-5, Figure 4-6). These features are typical of pyroxenes that are metamorphic products of the olivine + plagioclase reaction (Kushiro and Yoder, 1966). Additionally, oceanic olivine gabbros usually have chromite as their oxide phase, but these rocks contain $\mathrm{Cr}$-poor spinels (Figure 4-7).

In summary, the Kerguelen gabbroic xenoliths contain essentially no olivine, too much modal orthopyroxene to be of primary igneous origin, orthopyroxenes and clinopyroxenes that are too rich in $\mathrm{Al}_{2} \mathrm{O}_{3}$, clinopyroxenes that are too sodic, and $\mathrm{Cr}$-poor spinels rather than chromite. Therefore, the conclusion is that these rocks must have been produced by metamorphism. The metamorphism was probably isochemical. Only one small amphibole was observed in sample OB93-54, otherwise no hydrous minerals or other evidence for geochemical changes are present in these rocks. The likelihood that metamorphism was isochemical will be discussed in more detail below in the context of trace elements.

Finally, that mafic granulites occur in the southeastern province of the Kerguelen Islands (Grègoire, 1994; Grègoire et al., 1998) is good indication that mafic granulites might also exist in some of the other xenolith localities. Some of the granulites from the Southeastern Province have both garnet and sapphirine, sometimes co-existing, indicating equilibration pressures and temperatures of at least $900^{\circ} \mathrm{C}$ and $1.0 \mathrm{GPa}$ (Figure 4-8) (Christy, 1989; Grègoire et al., 1994). 


\section{Conditions of Metamorphism}

It is not possible to determine the exact pressure of metamorphism for this suite of xenoliths because they do not contain garnet, although some constraints are possible. Given that garnet or sapphirine are not present in these granulites, the metamorphic pressures must have been between 0.6 and $1.0 \mathrm{GPa}$ at lower temperatures $\left(\sim 800^{\circ} \mathrm{C}\right)$ and 0.8-1.2 GPa at near solidus temperatures (Figure 4-8) (Kushiro and Yoder, 1966; Ringwood, 1975; Christy, 1989). These temperature and pressure ranges are defined by the reaction boundaries of the appearance of orthopyroxene and garnet \pm sapphirine as determined on the CMAS experimental system (e.g. Christy, 1989). The range of metamorphic conditions can be further refined with the temperatures of equilibration for these granulites as estimated with a two-pyroxene thermometer (Wells, 1977). These temperatures vary from 844 to $961^{\circ} \mathrm{C}$ (Table 4-8) and are consistent with the equilibration of these rocks in the granulite facies. The field of possible metamorphic pressure and temperature conditions for the rocks of this study are shown in Figure 4-8. This field is at significantly lower pressures and higher temperatures than the normal thermal structure of 40 Ma oceanic crust. This characteristic will be discussed in more detail below in relation to possible mechanisms of metamorphism.

There are no significant differences between temperatures calculated with co-existing discrete pyroxene pairs and symplectite pairs. Major element compositional differences do exist between discrete and symplectite pyroxenes, and are most pronounced for orthopyroxene pairs. If all orthopyroxenes in these rocks are products of a single metamorphic reaction, they should all have the same composition, regardless of their texture. The observed compositional differences in pyroxenes as a function of texture, suggest there may have been more than one stage of orthopyroxene formation. 
Symplectite textures can be a result of several different processes: cooling from igneous temperatures (Griffin and O'Reilly, 1987), reheating of the xenolith by the host magma on the way to the surface (McBirney and Aoki, 1973), garnet breakdown (Kushiro and Yoder, 1966), or a kinetic effect. No differences were seen in trace elements between symplectite and discrete clinopyroxenes, arguing against a kinetic origin. Moreover, the symplectite clinopyroxene trace element signatures rule out a garnet precursor. The origin of these symplectites is puzzling and will require further investigation beyond this study.

\subsubsection{Comparison to other oceanic cumulates}

Because the granulite xenoliths were originally oceanic olivine gabbros that underwent metamorphism, it is important to compare them to other oceanic gabbroic cumulates, especially for the purpose of determining provenance. Samples of oceanic gabbros come from several lower crustal drill sites: DSDP site 334, just west of the FAMOUS locality on the Mid-Atlantic Ridge (Aumento et al., 1977), ODP Leg 118, SWIR (Von Herzen et al., 1991; Hèbert et al., 1991; Dick et al., 1992), ODP Leg 147, Hess Deep (Mével et al., 1996; Natland and Dick, 1996), ODP Leg 153, MARK (Karson et al., 1997; Ross and Elthon, 1997), dredged from fracture zones: MAR, $26^{\circ} \mathrm{N}$ (Tiezzi and Scott, 1980), the Mid-Cayman Rise (Elthon, 1987), SWIR and CIR (Meyer et al., 1989), and xenoliths that are included in MORB (Dixon and Clague, 1986; Davis and Clague, 1990) and ocean island basalts (Clague and Chen, 1986; Clague and Bohrson, 1991; Grègoire et al., 1994; Grègoire et al., 1998; Mattielli et al., 1996; Hassler and Shimizu, 1998; Hoernle, 1998; Lassiter and Hauri, 1998; Schminke et al., 1998). Cumulate xenoliths are only rarely found in MORB, are small in size and often have a significant amount of interstitial melt (e.g. Dixon and Clague, 1986; Davis and Clague, 1990). They, and rocks dredged from fracture zones, are often quite altered, both by seafloor weathering and hydrothermal alteration. Thus, very little whole rock data exist for these rocks, and analyses of mineral 
compositions comprise the majority of the data. More whole rock data exist for the drill cores, though these rocks too can be altered. Xenoliths included in ocean island basalts (the Hawaiian Islands, the Canary Islands, and the Kerguelen Islands) are by far the least altered samples, but very few geochemical data are available.

Comparisons with other oceanic cumulate rocks are further complicated because the various rocks can represent different parts of complex magmatic systems. A spectrum of cumulate types exist, from pure adcumulates to frozen liquids, and determining which particular type a rock may be, is not always straightforward. The amounts of trapped melt are variable among cumulates, and diametrically opposed interpretations that were made even on the same rock samples (e.g. Hess Deep, Natland and Dick, 1996; Pederson et al., 1996) illustrate the difficulties inherent in these interpretations. Often, as in hole $735 \mathrm{~B}$, the transitions through the different cumulate types can occur over length scales of less than one meter (Dick et al., 1992).

Overall, the major element compositions of the granulites of this study are similar to other oceanic gabbros, as well as mafic granulite xenoliths from continents (Figure 4-9). A comparison of these rocks to olivine gabbros, gabbros, and troctolites with similar Mg\# from the MARK area, the SWIR, and the Canary Islands show no significant differences. The compositional fields for continental mafic granulites completely encompass all of the data from oceanic cumulates and the granulites of this study. The oceanic cumulates shown in Figure 4-9 were chosen for comparison not only because of geochemical similarities of the rocks to the granulites, but also because they are considered to have little to no trapped melt ( $<7 \%$, by definition of classic adcumulate).

The major element variations of cumulates are determined by the nature of the parent melt, fractional crystallization and the relative amounts of cumulate minerals and trapped 
melt. As noted above, the granulites in this study exhibit no obvious trends in major element space. They do not follow a MORB fractionation trend (liquid line of descent) and are therefore not related to each other by simple crystal fractionation (Figure 4-9). On the basis of the major element systematics of these rocks, and that they are most similar to other oceanic gabbros that are interpreted as nearly pure adcumulates, leads to the initial assertion that the granulites are recrystallized adcumulates that had negligible amounts of trapped melt. However, the major element compositions cannot discriminate among a ridge, a plume-ridge interaction, or a plume-only origin for these rocks. For this, the trace element and isotopic compositions of these rocks are used, and are described in the following sections.

\subsubsection{Trace Element compositions}

The granulite xenoliths have whole rock REE contents that are between 1 and 12 times $\mathrm{C} 1$ chondrite normalized values, except OB93-54, which has $\mathrm{C} 1$ normalized REE abundances that range from 15 to 25 (Figure 4-10). All of the granulites, but OB93-61A and OB93-54, have positive whole rock $\mathrm{Sr}$ and Eu anomalies. The REE abundances of these rocks also tend to correlate with $\mathrm{Mg \#}$; the lower Mg\# samples have the highest REE contents, and vice versa. Of the lower Mg\# samples, OB93-54, OB93-61 A, and OB93-68 are the most REE enriched, whereas samples OB93-57 and OB93-69 are transitional between these and the high Mg\# samples. Sample OB93-68 is LREE enriched with a normalized La/Sm ratio $\left(\mathrm{La} / \mathrm{Sm}_{\mathrm{N}}\right)=1.1$, OB93-61A has a flat REE pattern $\left(\mathrm{La} / \mathrm{Sm}_{\mathrm{N}} \sim 1\right)$, and the remaining samples of this group are LREE depleted $\left(\mathrm{La} / \mathrm{Sm}_{\mathrm{N}}<0.75\right)$. The high $\mathrm{Mg} \#$ group of rocks also tend to be LREE depleted $\left(\mathrm{La} / \mathrm{Sm}_{\mathrm{N}}<0.8\right)$. Sample OB93-60 is an exception with $\mathrm{La} / \mathrm{Sm}_{\mathrm{N}}=1.1$. The normalized whole rock HREE patterns of all the granulites are parallel to each other at values between 2 and 6 . 
Trace element data for clinopyroxenes, determined by ion microprobe, are shown in Table 4-9 and Figure 4-11. Again, representative analyses are shown in the table, whereas all of the data are plotted in Figure 4-11. The entire data set is tabulated in Appendix 2.

The highest REE abundances occur in clinopyroxenes from the lower Mg\# granulite sample group and vice versa. Trace element contents of clinopyroxenes generally display minor grain-to-grain variations within a particular sample and the symplectite clinopyroxenes possess very similar abundance patterns relative to co-existing discrete grains. A symplectite clinopyroxene in OB93-72 is an exception in that it has a significant positive Eu anomaly, suggesting that plagioclase was involved in a reaction that produced this symplectite intergrowth of clinopyroxene and spinel. A comparison of REE patterns between clinopyroxene and whole rocks, together with the clinopyroxene modes tabulated in Table 4-2, demonstrates that the bulk of the REE reside in clinopyroxene and calculations show that $>80 \%$ of most of the REE are in fact hosted by clinopyroxene. The LREE are not always consistent with this generalization; ion probe analyses made on plagioclase using clinopyroxene working curves indicate that the LREE are strongly partitioned into plagioclase.

Due to the overall mass balance, clinopyroxene REE patterns mimic those of whole rocks. In some samples (such as OB93-60), the LREE depletion in clinopyroxene relative to the whole rocks is accentuated because of the plagioclase effects mentioned above. The REE abundance patterns in OB93-54, the most Fe-rich sample, require special consideration because of their unique shape. While the whole rock pattern of this sample is slightly LREE depleted $\left([\mathrm{La} / \mathrm{Yb}]_{n}=0.99 ;[\mathrm{La} / \mathrm{Sm}]_{n}=0.59 ;\right.$ Table 4-9), the clinopyroxene patterns are characterized by significant depletion in the HREE. For instance, the whole rock $\mathrm{Yb}$ concentration $(2.60 \mathrm{ppm}$, Table $4-2)$ is 3.7 times that in clinopyroxene $(0.71 \mathrm{ppm}$, Table 4-9), completely opposite of the general observation made above. That is, less than 
$30 \%$ of the HREE are present in the clinopyroxene. It follows that mass balance requires the existence of a phase that could account for the HREE. One obvious candidate is garnet. Although garnet is not observed in this particular rock, many areas of fine-grained, partly opaque alteration or oxidation products are present. However, Grègoire (1994) describes granulites in which garnet is surrounded by dark-colored, opaque alteration coronas. They closely resemble the texture in which the granular fine-grained alteration areas occur in OB93-54.

Even though the original igneous textures of the granulites were obliterated by metamorphism, there are several lines of evidence that these rocks are cumulates. Whole rock $\mathrm{Cr}$ and $\mathrm{Ni}$ abundances have positive correlations with $\mathrm{MgO}$ that are usually associated with accumulations of olivine and clinopyroxene (Figure 4-12). Correlations of other compatible elements, such as $\mathrm{Sc}$ and V, with $\mathrm{MgO}$ are less clear (Figure 4-12). The abundances of $\mathrm{Ni}, \mathrm{Cr}$ and $\mathrm{Sc}$ are higher, and $\mathrm{V}$ lower for a given $\mathrm{MgO}$ content, than those in Kerguelen Islands basalts (e.g. Yang et al., 1998).

It is notable that the bulk rock trace element patterns lie within the field defined by gabbros from the Oman ophiolite, and have positive $\mathrm{Sr}$ and $\mathrm{Eu}$ anomalies of similar magnitudes as the Oman gabbros (Figure 4-10). The exception to this is sample OB93-54. In a plot of $\mathrm{Sr} / \mathrm{Sr}^{*}$ v. Eu/Eu* all of the xenoliths but $\mathrm{OB} 93-54$ are greater than one in both dimensions (Figure 4-13). These characteristics are indicative of plagioclase accumulation. The samples that are outliers in some of the panels of Figure 4-2 (OB93-54 and OB93-71) are also noted in Figure 4-10, Figure 4-12, and Figure 4-13. For example, sample OB9371, the most MgO-rich sample, is extreme in all of the panels of Figure 4-12, clearly indicating its cumulate origin. In contrast, sample OB93-54 does not lie in the trace element field of Oman gabbros, is an outlier in its V content, and has no Eu anomaly. Thus, the possibility that it is a cumulate is not as certain. However, it does have a small positive $\mathrm{Sr}$ 
anomaly (Figure 4-13), and is not significantly different than the other xenoliths in its $\mathrm{Cr}$, $\mathrm{Ni}$, and $\mathrm{Sc}$ contents. Moreover, the $\mathrm{Ba} / \mathrm{Th}$ of this rock is high, like that of the other xenoliths and the Oman gabbros (Figure 4-10), and has low abundances of other incompatible elements (e.g. $\mathrm{Rb}$ and $\mathrm{K}_{2} \mathrm{O}$, Table 4-2).

In a gabbro-basalt system, the overall concentration levels of the REE in both the liquid and the cumulate would continue to increase as crystallization proceeds, on the basis of partitioning arguments. At the same time, as plagioclase continues to crystallizes, the liquid would develop greater negative $\mathrm{Sr}$ and $\mathrm{Eu}$ anomalies and the positive anomalies of these elements in the cumulates would decrease. Hence, it would not be surprising if a late stage cumulate displayed no or even small negative $\mathrm{Sr}$ and Eu anomalies, and OB93-54 could be an example of such a process. An important point to note in this context is the low Th content of this sample $(0.03 \mathrm{ppm}$, Table $4-2)$, which argues strongly against a contribution from melt in the origin of this rock, either as an interstitial melt or as a frozen liquid. Therefore, the major and trace element data indicate that the protoliths of these xenoliths were formed as olivine-clinopyroxene-plagioclase cumulates from basaltic melts.

The whole of the data, including trace elements, seem to indicate that metamorphism has not significantly affected the geochemistry of these rocks. As noted above, the whole rock major element compositions are no different in any obvious ways from other oceanic cumulates. The similarity in trace element patterns between the granulites and the Oman gabbros are striking, and the REE part of these patterns are smooth (Figure 4-10). These characteristics argue against any significant elemental gain or loss during metamorphism. Therefore, it seems that metamorphism was isochemical, though there are no protoliths for which to compare these rocks for an unequivocal interpretation. 


\subsubsection{Did the granulite protoliths contain an intercumulus melt?}

If one accepts the assertion made above that the present day chemical compositions of the granulites represent those of their igneous precursors, the next step toward determining their provenance is to estimate the compositions of the melts from which they had accumulated. Because of the metamorphism however, this task is not straightforward.

For example, the trace elements in any melts that may have been trapped when the protoliths accumulated as olivine gabbros would be incorporated into the clinopyroxenes during recrystallization, and the compositions of equilibrium melts estimated from these clinopyroxenes would be in error. A similar situation would be true for equilibrium melts estimated from the whole rock trace element abundances. Therefore, it is necessary to attempt a quantitative assessment of the original assertion that the protoliths of these granulites contain a low trapped melt fraction before attempting to determine their provenance on the basis of trace element abundances.

There are at least two possible sources of inter-cumulus melt in a cumulate rock. In one, the melt is related to the parent melt; that is, the melt would have been trapped as the cumulus minerals precipitated. The second possibility is that a pre-existing rock is impregnated by a melt that is percolating through it. The percolating melt may be genetically related to the rock through which it is traveling, or not, as in the case of a plume related melt percolating through oceanic lithosphere.

Classically, abundances of trapped melt in cumulates were estimated by the amount of minerals in intercumulus texture and zoned overgrowths of cumulus minerals (Wager and Brown, 1967). However, because of the metamorphic recrystallization, this method is not possible in the present case. Others have estimated trapped melt abundances on the basis of 
the amount of $\mathrm{P}_{2} \mathrm{O}_{5}$ and $\mathrm{Zr}$ in the bulk rock (Wager and Brown, 1967; Natland et al., 1991). This method assumes that these two elements are perfectly incompatible, and that any trapped melt would contribute the entire bulk rock budget of these elements. In reality however, some minerals, particularly clinopyroxene could contain some small amount of $\mathrm{P}_{2} \mathrm{O}_{5}$ and more significant quantities of $\mathrm{Zr}$. Even so, the concentrations of both $\mathrm{P}_{2} \mathrm{O}_{5}$ and $\mathrm{Zr}$ are quite low in these rocks (Table 4-2), and by this reasoning the abundances of trapped melt should be relatively low.

A quantitative assessment of possible interstitial melt would require a prior knowledge of abundances of the trace elements in the melt. For unmetamorphosed cumulates the mass balance method described by Bédard (1994) can be applicable. This approach apportions the whole rock REE abundances among the cumulus minerals, but also includes a melt phase with a mineral/melt partition coefficient of 1 . He successfully used this model to calculate the trace element abundances of clinopyroxenes and feldspars of gabbro-norites from the Bay of Islands ophiolite. Given this, using the bulk rock and the CIPW norms, it should be possible to calculate the REE abundances of granulite clinopyroxenes, and compare these to what is actually measured in situ to get an indication of trapped melt effects. However, because the cumulates of the present study are metamorphosed, this approach is not applicable. In this case, the modal abundances of clinopyroxene increased by a factor of at least 1.5 during the metamorphic reaction, thereby diluting the original clinopyroxene REE abundances to their present concentrations.

Applying the incompatible element method mentioned above, the whole rock abundances of very incompatible elements, such as Th, can provide the most sensitive method to assess the amount of trapped melt in these rocks. If one assumes that all of the Th in the granulites came from a trapped Kerguelen basalt, the percentage of melt trapped in the granulites can be calculated. Thorium contents in Kerguelen basalts from the 
Raboulliere and Bureau sections vary from 0.19 to $7.4 \mathrm{ppm}$ with averages of 3.76 ( $\mathrm{n}=20$, 1 S.D. $=1.58)$ and $2.74(n=29,1$ S.D. $=1.33)$ respectively (Yang et al., 1998). The Kerguelen basalt with the least Th content $(0.19 \mathrm{ppm})$ gives unrealistic trapped melt abundances (up to 108\%), but the average Th content of the Raboulliere basalt gives melt contents that are less than $1 \%$ for six of the samples (OB93-54, OB93-57, OB93-69, OB93-71, OB93-72, OB93-96), less than 4\% for four (OB93-50, OB93-60, OB93-68, OB93-90), and one with 6.3\% (OB93-61A). These results argue against significant amounts of trapped melt.

If, as noted above, a plume melt impregnated a MORB cumulate, a mass balance calculation would not be valid. To determine if this type of process might have been involved in the petrogenesis of these rocks, calculations were made for the ${ }^{87} \mathrm{Sr} /{ }^{86} \mathrm{Sr}$ and $\mathrm{Sr}$ contents in two-component mixing of a gabbro in equilibrium with an SEIR MORB and Kerguelen Islands basalts. Figure 4-14 illustrates how bulk ${ }^{87} \mathrm{Sr} /{ }^{86} \mathrm{Sr}$ and $\mathrm{Sr}$ contents change in a gabbro as impregnation proceeds. The gabbro starting material was assumed to have formed from a SEIR melt with ${ }^{87} \mathrm{Sr} /{ }^{86} \mathrm{Sr}=0.70288$ and $[\mathrm{Sr}]=145 \mathrm{ppm}$ (Dosso et al., 1988). The abundance of Sr in the gabbro was calculated from the SEIR melt using bulk partitioning based on $13.5 \%$ olivine, $31.5 \%$ clinopyroxene, and 55\% plagioclase, and mineral partition coefficients from Dunn and Sen (1994) and Hart and Dunn (1993). Simple mixing of two different Kerguelen basaltic melts (Yang et al., 1998) with this gabbro increases both ${ }^{87} \mathrm{Sr} /{ }^{86} \mathrm{Sr}$ and $\mathrm{Sr}$ content. It is evident that the mixing curves do not match the observations: the granulites are more radiogenic and have less Sr than any of the mixtures. Even if the original starting gabbro was displaced to match the lowest $\mathrm{Sr}$ content observed in the granulites, the mixing curves are still away from the granulite data points. Thus, these calculations also argue against impregnation of Kerguelen basalt into SEIR 
gabbros in the formation of the granulite protoliths. The overall conclusion is that the amount of intercumulus melt present in the protoliths of these rocks $6 \%$ or less.

\subsubsection{Granulite Protolith Parent Melts}

Given that the granulite protoliths were gabbroic cumulates with only small quantities of trapped melt, the geochemical characteristics of their parental melts can be estimated on the basis of their trace element abundances.

To estimate parent melt geochemistry from bulk rock data, the bulk partition coefficient for each of the REE was calculated from the abundances of the CIPW normative minerals (representing the protolith minerals and their proportions) and partition coefficients from the literature (Schnetzler and Philpotts, 1970; Hart and Dunn, 1993; Dunn and Sen, 1994; Kelemen et al., 1993). Figure 4-15 demonstrates that the normalized REE patterns of the equilibrium melts that result from this calculation lie in the field defined by basalts from the Kerguelen Islands rather than that defined by "non-plume" SEIR MORB. The slopes of the melt REE patterns are within the range of those for the Kerguelen Islands basalts (e.g. $\mathrm{La} / \mathrm{Yb}_{\mathrm{N}}=2-13$ for basalts and 3-10 for granulite equilibrium melts). In detail however, the melts calculated from the whole rock data have slight negative Eu anomalies that are not present in most of the basalts. This is most likely an artifact of the $D$ value chosen for $\mathrm{Eu}$, which is dependent on the composition and the oxidation state of the magmatic system (e.g. Schnetzler and Philpotts, 1970; Dunn and Sen, 1994). The values used for this calculation may not be quite appropriate. Observed plagioclase/clinopyroxene REE partitioning from Oman ophiolite gabbros (Kelemen et al., 1997) are within 1 standard deviation of the plagioclase/clinopyroxene partition coefficients used here (Schnetzler and Philpotts, 1970), except for Dy and Yb. For these two elements the experimental data are both higher than the that observed at Oman, illustrating the variation of partition coefficients. Other uncertainties in the equilibrium melt calculation may be 
introduced from how accurately the CIPW normative minerals recreate the original mineralogy.

Trace element abundances in clinopyroxene can also be used for estimating the geochemistry of the parent melt. However, caution must exercised because recrystallization has changed the abundances of clinopyroxene in these rocks. As discussed above, nearly all of the REE reside in the clinopyroxene after metamorphism and the modal abundance of clinopyroxene has increased during recrystallization, thereby diluting the pre-metamorphic REE abundances in this mineral. It follows that equilibrium melts calculated from recrystallized clinopyroxene are minimum estimates of the REE abundances of the equilibrium melt. In addition, $\mathrm{La}$ abundances are further underestimated due to its partitioning into plagioclase.

Figure 4-16 illustrates the results of the REE abundances calculated from clinopyroxene. The overall shape and slope of the REE patterns of the equilibrium melts calculated from clinopyroxene are also similar to the Kerguelen basalts but have a larger variation than the equilibrium melts calculated from the whole rock. The clinopyroxene equilibrium melts have $\mathrm{La} / \mathrm{Yb}_{\mathrm{N}}=2-10$, and the patterns extend to the more enriched of the Kerguelen Islands basalts. Though some of these equilibrium patterns overlap the SEIR basalts field, they have greater slopes than the SEIR basalts: $[\mathrm{La} / \mathrm{Yb}]_{\mathrm{N}}=2-10$ for equilibrium melts v. $[\mathrm{La} / \mathrm{Yb}]_{\mathrm{N}}=0.4-1.3$ for the SEIR basalts (Michard et al., 1986). In summary, equilibrium melts calculated from both whole rocks and clinopyroxenes indicate that the granulite parent melts have stronger affinities to the Kerguelen basalts than the SEIR MORB. This conclusion is consistent with the isotopic compositions of the granulites, as will be discussed below. 


\subsection{7. $\mathrm{Sr}, \mathrm{Nd}$, and Os isotopic compositions}

Rubidium-Sr, Sm-Nd, and Re-Os isotopic compositions of the granulite xenoliths are listed in Table 4-10 and Table 4-11. The ${ }^{87} \mathrm{Sr}{ }^{86} \mathrm{Sr}$ for bulk rocks ranges from 0.704453 to 0.706048 , and ${ }^{143} \mathrm{Nd} /{ }^{144} \mathrm{Nd}$ varies from 0.512731 to $0.512838\left(\varepsilon_{\mathrm{Nd}}=1.81\right.$ to 3.90$)$. Samples OB93-57 and OB93-61A were not analyzed for Nd. The isotopic composition of the host dike is ${ }^{87} \mathrm{Sr} /{ }^{86} \mathrm{Sr}=0.706380$ and ${ }^{143} \mathrm{Nd} /{ }^{144} \mathrm{Nd}=0.512419\left(\varepsilon_{\mathrm{Nd}}=-4.27\right)$. The blank corrected ${ }^{187} \mathrm{Os} /{ }^{188} \mathrm{Os}$ of the granulites ranges from 0.1286 to 0.1792 .

The Sr and Nd isotopic compositions of all the granulites (both Courbet Peninsula and Southeast Province) are within the range observed for Kerguelen basalts (Figure 4-17). The $\mathrm{Sr}$ and Nd isotopic compositions for six granulite xenoliths from the Mt. Tizard location (Southeast Province) reported by Mattielli et al. (1996) plot on the isotopically "depleted" end of the spectrum, ranging in ${ }^{87} \mathrm{Sr} /{ }^{86} \mathrm{Sr}=0.70398$ to 0.70467 and in ${ }^{143} \mathrm{Nd} /{ }^{144} \mathrm{Nd}$ from 0.51277 to 0.51288 . Two granulites from the Dome Rouge and one from the Val Phonolite locations (Mattielli, 1996) plot at the most enriched part of the spectrum $\left({ }^{87} \mathrm{Sr} /{ }^{86} \mathrm{Sr}=0.70507\right.$ to 0.70523 , and ${ }^{143} \mathrm{Nd} /{ }^{144} \mathrm{Nd}=0.51254$ to 0.51258$)$. The results of this study fill the gap of $\mathrm{Sr}$ and $\mathrm{Nd}$ isotopic compositions and extend the isotopic range of the granulites toward a more isotopically enriched direction, with ${ }^{87} \mathrm{Sr} /{ }^{86} \mathrm{Sr}$ up to $0.70601\left({ }^{143} \mathrm{Nd} /{ }^{144} \mathrm{Nd}\right.$ for this sample, OB93-61A, was not determined). The $\mathrm{Sr}$ and $\mathrm{Nd}$ isotopic compositions of the granulite xenoliths of this study, combined with those of Mattielli et al. (1996) and Mattielli (1996), cover practically the entire range of Sr and Nd isotopes observed for Kerguelen Islands basalts. Furthermore, the isotopic distinction between peridotite and granulite xenoliths discussed by Mattielli et al. (1996) has virtually disappeared. Before further discussion on the origin of these isotopic signatures, it is important to assess the magnitude of alteration effects, age correction, and secondary processes, to establish that the observed isotopic characteristics are primary features. 
For $\mathrm{Sr}$ and $\mathrm{Nd}$ analyses, the majority of the samples were leached in a weak $\mathrm{HCl}$ solution. Some were leached in stronger hot $\mathrm{HCl}$, and three were not leached. Some of the rocks (OB93-54, OB93-68, OB93-71, OB93-72) were analyzed more than once and different aliquots of these were treated with the different leaching procedures. The $\mathrm{Sr}$ isotopic compositions of the samples that were most strongly leached are less radiogenic than those that were only weakly leached or weren't leached at all. The results indicate the presence of a leachable radiogenic component, but its quantity appears to be small. For instance, the ${ }^{87} \mathrm{Sr} /{ }^{86} \mathrm{Sr}$ for OB93-71 was reduced from 0.704617 in the unleached powder to 0.704453 in the strongly leached one, a total reduction of $1.6 \times 10^{-4}$. The $\mathrm{Nd}$ isotopic compositions of leached and unleached samples are identical. Rhenium and Os analyses were made on unleached whole rock powders, but given that the abundances of these elements in the granulites are relatively high, it seems unlikely that alteration much affected the Re-Os systematics. However, there is some evidence from ODP site 735B that a complex history of fluid and melt interaction had different effects on the different isotopic and trace element signatures of these rocks, including Os (Hart et al., 1999). A similar situation does not seem likely in this case, mainly because the co-variation of ${ }^{87} \mathrm{Sr}{ }^{86} \mathrm{Sr}$ with ${ }^{143} \mathrm{Nd} /{ }^{144} \mathrm{Nd}$ is not an alteration signal (Figure 4-17). Furthermore, neither Sr nor Nd correlates with any of the trace element indices of alteration (e.g. Cs, $\mathrm{Rb}, \mathrm{Ce}$ ).

The host basalt dike has high concentrations of isotopically enriched $\mathrm{Sr}$ and $\mathrm{Nd}$ and could potentially alter the isotopic signature of the granulites through interaction. Although the $\mathrm{Sr}$ and $\mathrm{Nd}$ isotopic signatures of the host dike could be affected by small disseminated metasomatic peridotites, this is highly unlikely. Mixing calculations between the most isotopically enriched basalt from the Islands $(87 \mathrm{Sr} / 86 \mathrm{Sr}=0.7055$ and $339 \mathrm{ppm} \mathrm{Sr}$; Yang et al., 1998), and peridotite clinopyroxene like that of sample OB93-83 (Chapter $2 ;{ }^{87} \mathrm{Sr} /{ }^{86} \mathrm{Sr}$ $=0.706427$ and $558 \mathrm{ppm} \mathrm{Sr}$ ) indicate that for this to happen, the basalt must consist of 
$80 \%$ clinopyroxene to explain the $\mathrm{Sr}$ isotopic composition of the dike. No thin section is available for this sample, but there is no evidence for this much clinopyroxene in the hand sample. Thus, the measured isotopic composition of the host dike is real.

To change the granulite sample with the least radiogenic Sr to that with the most radiogenic Sr by addition of the host basalt, the most radiogenic granulite must have had approximately $10 \%$ basalt physically added. There is no evidence that this much basalt is incorporated into any of these xenoliths. Along with the lack of petrographic signs of alteration or interaction with the host basalt, these data indicate that the geochemistry of the granulite xenoliths was not affected by alteration or the host basalt at the level of the interpretations, and that the isotopic compositions of these xenoliths are therefore considered primary.

Although the age of the xenolith host dike is unknown, it must be younger than approximately $24.5 \mathrm{Ma}$, the age of basalts in the area (Nicolaysen et al., 1999). The absolute ages of the granulites are also not known, but as will be discussed below, they could be relatively young ( $<70 \mathrm{Ma}$ ). Though the absolute initial isotopic ratios of the granulites cannot be determined, corrections for isotopic ingrowth since the time of eruption of their host basalt can be estimated to compare their isotopic compositions to those of the Kerguelen Islands basalts. Corrections for $24.5 \mathrm{Ma}$ on the granulites, the maximum age of the host dike, are only 7-19 ppm for ${ }^{87} \mathrm{Sr} /{ }^{86} \mathrm{Sr}$, and $0.5-0.9$ epsilon units for ${ }^{143} \mathrm{Nd} /{ }^{144} \mathrm{Nd}$. Thus, no correction is applied for $\mathrm{Sr}$ and $\mathrm{Nd}$. Corrections for $24.5 \mathrm{Ma}$ of Os isotopic ingrowth are less than $1.4 \%$ for all samples (most are less than $1 \%$ ) except OB93-54, for which the correction was 9.8\% (Table 4-11).

Figure 4-18 shows that the ${ }^{187} \mathrm{Os} /{ }^{188} \mathrm{Os}$ of the granulites are independent of their Os concentrations, and no obvious mixing relationships are present. The most radiogenic 
granulite (OB93-54) is among the lowest Os content samples, but its Os concentration (100 ppt; Table 4-11) is well above the 20 ppt cut-off for potentially significant contamination effects that have been observed in many basalts (e.g. Shirey and Walker, 1998). Indeed, several of the Kerguelen plume related basalts that have been analyzed exhibit elevated ${ }^{187} \mathrm{Os} /{ }^{188}$ Os at low concentrations (Figure 4-18) (Reisberg et al., 1993; Yang et al., 1998). After eruption age correction, the ${ }^{187} \mathrm{Os} /{ }^{188} \mathrm{Os}$ of these basalts are quite similar to the 24.5 Ma corrected ${ }^{187} \mathrm{Os} /{ }^{188} \mathrm{Os}$ of OB93-54 (see Figure 4-21). The two analyzed basalts from Heard Island also have relatively low Os contents and have ${ }^{187} \mathrm{Os} /{ }^{188} \mathrm{Os}$ similar to the remaining granulites (Barling et al., 1997). On the basis that Os concentrations in the granulites are beyond the "susceptibility" limit of $20 \mathrm{ppt}$ and that the ${ }^{187} \mathrm{Os} /{ }^{188} \mathrm{Os}$ can be considered primary, the Os isotope similarity between granulites and basalts provides credibility to the basalt data. It is noteworthy that the Os isotope heterogeneity observed in the granulites appears to be reproduced in the difference between the Kerguelen and Heard Islands basalts, although the numbers of analyzed basalt samples are currently limited.

No isochron relationship exists among these xenoliths, though the most radiogenic sample OB93-54 does have the highest ${ }^{187} \mathrm{Re} /{ }^{188}$ Os (Figure 4-18). As shown in the figure, this sample would have roughly the same ${ }^{187} \mathrm{Os} /{ }^{188} \mathrm{Os}$ as the other granulites at $69 \mathrm{Ma}$. A best fit line gives an initial ${ }^{187} \mathrm{Os} /{ }^{188} \mathrm{Os}=0.1290$.

\section{Comparison to isotopic compositions of other lower crustal rocks}

In comparison to other oceanic cumulates, the isotopic composition of these rocks are unique. The Sr and Nd isotopic compositions of unaltered gabbros from the SWIR, MARK, Hawaii and the Canary Islands are all isotopically less enriched than any of the Kerguelen granulites and basalts. Gabbros from the SWIR are isotopically similar to Indian Ocean MORB (Kempton et al., 1991; Hart et al., 1999), and the MARK gabbros are 
isotopically like the North Atlantic MORB (Kempton and Hunter, 1997). The gabbro xenoliths from the Canary Islands have primary $\mathrm{Sr}$ and $\mathrm{Nd}$ isotopic signatures of ca. 170 Ma Atlantic N-MORB (Hoernle, 1998), and Hawaiian gabbro xenoliths have Sr and Nd isotopic compositions of modern East Pacific Rise MORB (Lassiter and Hauri, 1998). In short, no other oceanic cumulates, not even the mafic xenoliths included in plume-related basalts, come near to exhibiting the isotopic enrichment seen in the Kerguelen granulites.

Mafic granulites from continental settings have quite variable geochemistry. In general, those from granulite terrains are richer in $\mathrm{SiO}_{2}(>55 \mathrm{wt} . \%)$ than granulite xenoliths erupted through continental crust ( $\mathrm{SiO} 2<55$ wt.\%; Rudnick and Presper, 1990), thus the comparison presented here is restricted to mafic granulite xenoliths from continental localities. As noted above, the major element compositions of the continental granulites vary widely and encompass the entire ranges shown by the granulites of this study, and other oceanic cumulates (Figure 4-9). Trace element and $\mathrm{Sr}$ and $\mathrm{Nd}$ isotopic compositions of continental granulite xenoliths are similarly diverse (see reviews by Rudnick and Presper, 1990; Rudnick, 1992; Rudnick and Fountain, 1995 and references therein) and a simple conclusion cannot be drawn for a continental $v$. oceanic origin for the xenoliths of this study. Figure 4-19 shows that the $\mathrm{Sr}$ and $\mathrm{Nd}$ isotopic compositions of the mafic continental granulites are highly variable and completely enclose the isotopic compositions displayed by the Kerguelen granulites.

In contrast, Re-Os systematics within the continental and oceanic lower crust are quite different and inferences can be made from these data on the provenance of the Kerguelen granulite xenoliths. Figure 4-20 compares the Os isotopic compositions of the granulites of this study with those of both oceanic and continental lower crust. It is evident that the Kerguelen granulites are less radiogenic than gabbros from site $735 \mathrm{~B}$ and the Hawaiian Islands (Hart et al., 1999; Lassiter and Hauri, 1998), and lower crustal samples from 
Udachnaya (Pearson et al., 1995), Australia (Saal et al., 1998), and the western USA (Esperança et al., 1997). All of the Australian samples and one of the western USA samples are granulites; all the remaining samples from the western USA and Udachnaya are eclogites. The Os concentrations in the Kerguelen granulites are an order of magnitude greater than the gabbros from site $735 \mathrm{~B}$ and the Hawaiian Islands $(<25 \mathrm{ppt}$, Lassiter and Hauri, 1998; Hart et al., 1999), and have Os concentrations that are more similar to those of the high Os concentration end of the spectrum for the continental lower crust (3-1043 ppt; Pearson et al., 1995; Esperança et al., 1997; Saal et al., 1998). Figure 4-20 also shows that the ${ }^{187} \mathrm{Re} /{ }^{188} \mathrm{Os}$ of the granulites of this study have a much more limited range and overall lower value than all of the other samples. Rhenium concentrations for most of the Kerguelen granulites are substantially less than the $2 \mathrm{ppb}$ average for $735 \mathrm{~B}$ samples (Hart et al., 1999), though a few (OB93-54, OB93-68, and OB93-71) overlap the ranges of the other samples.

Osmium model ages of the continental samples are obtained by tracing back isotopic growth on the basis of the present-day Re/Os to the time where an intersection with mantle growth curve occurs. These model ages are $>250$ Ma for Australia (Saal et al., 1998), >1 Ga for Siberia (Pearson et al., 1995), and >160 Ma for the western USA (Esperança et al., 1997). The Os model ages of the Kerguelen granulites range from $-8 \mathrm{Ga}$ to $14 \mathrm{Ga}$ (Table 4-11) (calculated with parameters from Lindner et al., 1986; and Walker and Morgan, 1989), and it is clear that these numbers must be carefully examined. The ${ }^{187} \mathrm{Os} /{ }^{188}$ Os of many of the Kerguelen granulites are near, or slightly more radiogenic than the present-day value for primitive mantle $(0.12757$, based on carbonaceous chondrites; Walker and Morgan, 1989), and are much less radiogenic than the majority of the continental samples. In this case, small variations in the Re/Os of a sample will magnify the error in model age and negative ages result from sub-chondritic Re/Os. The cumulate character of the 
Kergeuelen granulite protoliths contributes to this effect. Note in Table 4-11 that sub- or near chondritic Re/Os occur in many samples with high Mg\# and low incompatible element abundances (e.g. OB93-71). Given that Re and Os concentrations were reproducible at 4.6 to $20 \%$ on the basis of replicate analyses (mainly due to nugget effects; see Analytical Methods section), the Os model ages for samples with ${ }^{187} \mathrm{Re} /{ }^{188} \mathrm{Os}$ close to (or below) chondritic values would not have significance. For those with ${ }^{187} \operatorname{Re} /{ }^{188}$ Os greater than 1.0 however (OB93-50, OB93-54, OB93-60, OB93-61A, OB93-68 and OB93-90), the closeness of the measured ${ }^{187} \mathrm{Os} /{ }^{188} \mathrm{Os}$ to the present-day primitive mantle indicates their relatively young ages. The ${ }^{187} \mathrm{Os} /{ }^{188} \mathrm{Os}$ of the granulites are also consistent with the idea that these rocks are related to the Kerguelen plume rather than having an origin in the continental crust. This is because the Os isotopic composition of mantle plumes were postulated to have a primitive mantle composition (e.g. Martin, 1991) or even a radiogenic core contribution. Although not completely unequivocal, the Re-Os characteristics of the granulites argue for their provenance connected to the Kerguelen plume rather than the lower continental crust of Gondwanaland.

\section{Origin of the isotopic signatures}

As discussed above, the $\mathrm{Sr}$ and $\mathrm{Nd}$ isotope variations in the granulites cover practically the entire range observed for the Kerguelen Islands basalts. This, together with the trace element arguments presented above for a genetic relation of the granulites to the Kerguelen Islands basalts, indicates that the isotopic signatures of the two should have similar origins. Previous models for basalt petrogenesis invoked variations on the theme of two-component mixing (Storey et al., 1988; Gautier et al., 1990; Weis et al., 1993; Yang et al., 1998). For example, Gautier et al. (1990) found a correlation of isotopic composition and sample age: the youngest basalts were the most alkaline and isotopically enriched. They postulated that the input of the DMM component declined and that of the plume component increased 
during the $\sim 40 \mathrm{Ma}$ that the SEIR has been moving northeastward, away from the Kerguelen plume. However, no basalt from Kerguelen that is as isotopically depleted as the normal Indian MORB has yet been found (although some Indian Ocean MORB with hotspot influence do extend into field of Kerguelen basalts, Figure 4-17). Though the proposed plume endmember is commonly seen in the Kerguelen Islands basalts, the DMM endmember has not yet been observed in any of the mafic rocks. More recent results from Yang et al. (1998) found the entire range of isotopic composition of the Kerguelen Islands basalts in one stratigraphic sequence. These basalts had erupted over a $\sim 1$ Ma time span between 29-30 Ma (Nicolaysen et al., 1999) in an oscillatory fashion between two isotopic extremes (e.g. ${ }^{87} \mathrm{Sr} /{ }^{86} \mathrm{Sr}=0.7040$ and 0.7053$)$. Consequently, the origin of those basalts could not be explained by simple DMM-plume mixing where the proportions changed with time. These authors proposed an origin for these rocks as the tapping of distinct melts from an isotopically enriched plume and a relatively isotopically depleted plateau lower crust, as represented by the granulites reported by Mattielli (1996). That even the most isotopically depleted granulites still possess the $\mathrm{Sr}$ and $\mathrm{Nd}$ characteristics of Kergeuelen basalts, suggests that a DMM-plume mixing origin for the granulites encounters the same difficulty as that for the basalts.

Another dilemma exists for the DMM-plume mixing hypothesis. It is well known that mantle plumes can affect the chemistry of MORB (e.g. Schilling, 1985), and geophysical studies of plume-ridge interaction indicate that plume mantle flows towards mid-ocean ridges even when they are separated by up to $1000 \mathrm{~km}$ (Schilling, 1991; Small, 1995; Ribe, 1996; Yale and Phipps Morgan, 1998). Given that plume mantle flows toward ridges because of thermal and rheological gradients, it appears that the invoked DMM-plume geochemical mixing could occur only when a plume is located directly beneath a ridge. For the case of the Kerguelen Islands basalts, if one assumes endmember compositions for the 
SEIR melt (pure DMM with ${ }^{87} \mathrm{Sr} /{ }^{86} \mathrm{Sr}=0.70275,{ }^{143} \mathrm{Nd} /{ }^{144} \mathrm{Nd}=0.51315$; and depleted MORB concentrations with $100 \mathrm{ppm} \mathrm{Sr}, 4.5 \mathrm{ppm} \mathrm{Nd})$ and the plume melt $\left({ }^{87} \mathrm{Sr} /{ }^{86} \mathrm{Sr}=\right.$ $0.70550,{ }^{143} \mathrm{Nd} /{ }^{144} \mathrm{Nd}=0.51255,339 \mathrm{ppm} \mathrm{Sr}$, and $20 \mathrm{ppm} \mathrm{Nd:} \mathrm{GM-59} \mathrm{of} \mathrm{Yang} \mathrm{et} \mathrm{al,}$ 1998), the most depleted Kerguelen Islands basalt $\left({ }^{87} \mathrm{Sr} /{ }^{86} \mathrm{Sr}=.7040\right.$ and ${ }^{143} \mathrm{Nd} /{ }^{144} \mathrm{Nd}=$ 0.5219 ) requires a mix of $80 \%$ SEIR melt and $20 \%$ plume melt. Changing the SEIR endmember to an isotopically less depleted composition causes the mixing proportions to become even greater for the SEIR endmember. Eruption of such a ridge dominated melt as a part of plume volcanism appears unlikely even for a ridge-centered plume, considering the greater melt production rate for a plume at a depth where ridge melting is occurring. For basalts erupted after SEIR moved away from the Kerguelen plume, the physical difficulties for mixing distal ridge melts into plume magmas appear insurmountable and require that the geophysical reasoning behind the popular model be re-invented.

The Os data also do not support a simple plume-DMM mixing model. On an Os v. Sr isotopic diagram (Figure 4-21) the bulk of the granulite data lie halfway between DMM and EM II, but in Os v. Nd space (Figure 4-21), the granulites nearly overlap the proposed EM II component. If the isotopic compositions of these rocks were a result of DMM-plume mixing it would be DMM-EM II mixing which contradicts a general view that the Kerguelen plume is strongly EM I, and the relative proportions would need to be different for $\mathrm{Sr}$ and $\mathrm{Nd}$. Even if the Os isotopic characteristics of EM I were similar to the Kerguelen granulites, the mismatch in mixing proportions for $\mathrm{Sr}$ and $\mathrm{Nd}$ remain. Overall, these isotopic data argue against a MORB-plume mixing for the observed isotopic characteristics for the granulites.

Whole rock powders from six granulite xenoliths from the Southeastern Province of the Kerguelen Islands were analyzed for Pb by Mattielli et al. (1996). These data plot near the unradiogenic end of the range defined by Kerguelen Islands basalts and within that of 
Indian Ocean ridge basalts. Thus, these granulites were interpreted to represent "deep cumulates of tholeiitic magmas" that were DMM-plume (both EM I and EM II) mixtures with high proportions of the DMM component. Given the body of the available isotopic data for both basalts and granulites, no coherent mixing model can explain the observed isotopic variations.

Contamination of the granulites' parental basalt magmas with differing amounts of continental material could also result in the observed $\mathrm{Sr}$ and $\mathrm{Nd}$ variation. This idea is not unreasonable because evidence for continental material does exist in various parts of the Kerguelen Plateau. Basalts drilled from the southern Kergeuelen Plateau have trace element and isotopic compositions indicative of continental contamination (Alibert, 1991; Salters et al., 1992; Mahoney et a1., 1994), some peridotite xenoliths from the archipelago have an Os signature of subcontinental lithosphere, and a clinopyroxene megacryst has ${ }^{87} \mathrm{Sr} /{ }^{86} \mathrm{Sr}$ and ${ }^{143} \mathrm{Nd} /{ }^{144} \mathrm{Nd}$ characteristic of continental crust contamination (Chapter 2; Chapter 3; Hassler and Shimizu, 1998). However, no definitive continental signatures have been discovered in the basalts from the islands, and all of the studies on basalts ruled out a continental source of isotopic variation (Gautier et al., 1990; Weis et al., 1993; Yang et al., 1998).

The data shown in Figure 4-19 imply that crustal contamination could significantly change the $\mathrm{Sr}$ and $\mathrm{Nd}$ isotopic characteristics of mafic magmas, and the parental magmas that precipitated the granulite precursor gabbros might have been contaminated by Gondwanaland lower crust. The granulites of this study and those of Mattielli et al. (1996) plot on the "mantle array", and if their $\mathrm{Sr}$ and $\mathrm{Nd}$ variations were produced by crustal contamination, the amounts of contaminant must have been very small. Such crustal contamination could alter the Os isotopic composition toward much more radiogenic 
values. The closeness of the Os isotopic data of the granulites of the present study to the present-day primitive mantle value, strongly argues further against crustal contamination.

The favored alternative to explain the isotopic diversity of the granulites, and by their genetic association, the basalts as well, is plume heterogeneity. It is still unclear whether the Kerguelen plume consists of mantle material with two different isotopic compositions that melt and mix in various proportions to eventually form the granulites and basalts, or if more endmembers within the plume are required. In the proposed scenario, a depleted component of the plume would be similar isotopically to the most depleted Kerguelen basalt or granulite observed, and the enriched end member could be isotopically like the host dike or the metasomatic melts described in Chapter 2.

It is notable that although the granulites have virtually the same $\mathrm{Sr}$ and $\mathrm{Nd}$ isotopic composition as the Kerguelen basalts, the eruption age corrected ${ }^{187} \mathrm{Os} /{ }^{188}$ Os are much less radiogenic (Reisberg et al., 1993; Yang et al., 1998). The exception is sample OB93-54; the ${ }^{187} \mathrm{Os} /{ }^{188} \mathrm{Os}$ is as radiogenic as the basalts, but its concentration is much higher (Figure 4-18). Conversely, the $\mathrm{Sr}, \mathrm{Nd}$, and Os isotopes of two basalts from Heard Island (Barling et al., 1994; Barling et al., 1997), which also have a Kerguelen plume origin, are like the majority of the Kerguelen granulites. Thus, the granulites cover the known ${ }^{187} \mathrm{Os} /{ }^{188} \mathrm{Os}$ range of Kerguelen plume basalts. This implies that the plume is heterogeneous in its Os isotopic composition as well as the other isotopes. But because $\mathrm{Sr}, \mathrm{Nd}$, and Os data exist only for a few Kerguelen Islands basalts and the granulites of this study, the full Os isotopic spectrum of the Kerguelen plume may not yet be known.

Yang et al. (1998) discounted the heterogeneous plume hypothesis for the Kerguelen Islands basalts. One reason was because the samples with the most isotopic variation have a mafic, plagioclase-rich component in their source (group D basalts). They named the 
Kerguelen Plateau lower crust as the source of this mafic component on the basis of the geochemistry of the granulites measured by Mattielli et al. (1996). These authors postulated that plume heat induced the melting of the lower crust which was inferred to be made of SEIR-derived cumulates by Mattielli et al. (1996). Yang et al. (Yang et al., 1998) further noted that the most isotopically enriched basalts had the least isotopic variation and no mafic source component, and postulated that this isotopic signature was intrinsic to the plume. The major difficulty with this model stems from the REE patterns of the group D melts, and from the fact that they are undersaturated with plagioclase. Figure 8 of Yang et al. (1998) shows that the group D basalts have $[\mathrm{Sm} / \mathrm{Yb}]_{\mathrm{N}}>3$ for all but one (GM92-46), indicating their origin of melting in the presence of garnet. This is not consistent with the melting of plagioclase-bearing, SEIR-derived cumulates at low pressures by plume heat. The absence of plagioclase phenocrysts in these basalts indicates that the group D melts are undersaturated with plagioclase. Again this inconsistent with the hypothesis of melting of plagioclase bearing lower crustal rocks, and points to a plume origin instead.

Sobolev and Hofmann (1998) recently discussed a similar situation found in Mauna Loa melt inclusions. These authors found basaltic melt inclusions with large positive $\mathrm{Sr}$ and smaller positive Eu anomalies included in high- $\mathrm{Mg}$ olivines. Despite these obvious plagioclase signatures, these melts were found to be undersaturated with plagioclase. Their explanation was that a recycled plagioclase-bearing cumulate component was present within the Hawaiian plume and melted at depths where plagioclase is absent. The same explanation could apply to the group D basalts of the Kerguelen Islands, and suggests that these basalts are products of the Kerguelen plume, rather than melts of the plateau lower crust.

This further implies that the Kerguelen plume is heterogeneous with respect to its $\mathrm{Sr}$ and $\mathrm{Nd}$ isotopic compositions and that distinct parts of the plume were tapped in succession 
to produce the basalts of the Mt. Bureau and Rabouillere without mixing. The co-existence of different melts in close proximity in space and time occur in nature and has been well documented by melt inclusion studies (Sobolev and Shimizu, 1994; Shimizu, 1998; Shimizu and Grove, 1998) and the lack of mixing in the Kerguelen basalts need not be surprising.

\subsubsection{Cumulate emplacement in time and space}

It has been discussed above that the trace element and isotopic compositions of the granulites indicate a strong genetic link to the Kerguelen plume. Their mineralogical constitution and major element compositions indicate their origin as gabbroic cumulates that were recrystallized under granulite facies conditions as shown by Figure 4-8. The metamorphic reaction responsible for granulite formation is olivine + plagioclase $\rightarrow$ clinopyroxene + orthopyroxene + spinel. For this reaction to occur, the gabbro protoliths must have either experienced an increase in pressure or decrease in temperature (Figure 4-8). An increase in depth, and thereby an increase in pressure, could have occurred as the originally subaerial Kerguelen Plateau subsided and the repeated volcanic eruptions that built the Plateau and Islands were piled onto the surface. This scenario seems unlikely however, in that subsidence rates are too small. The estimated maximum subsidence of the Kerguelen Plateau during a 50 Ma time span is only 1-2 km (Munschy and Schlich, 1987; Coffin, 1992). Thus, it appears more likely that the granulites formed by crossing the reaction boundary as a result of isobaric cooling. It follows that a thick northern Kerguelen Plateau already existed when cumulate emplacement occurred. Clearly, cumulate formation at the SEIR, where crustal thickness is approximately $7 \mathrm{~km}$, does not satisfy the pressure conditions. In addition to the problems for pressure increase due to subsidence, the idea that the Kerguelen granulites are "deep cumulates from tholeiitic magma" (Mattielli et al., 1996; Grègoire et al., 1998) must be reconsidered. 
Seismic experiments showed that the crustal thickness beneath the Kerguelen Islands and the Kerguelen Plateau ranges from 15 to $23 \mathrm{~km}$ (Recq, 1990, 1994, Charvis, 1993, 1995, Operto and Charvis, 1995, 1996). Because of the presence of both pyroxene and garnet granulite assemblages, and of sapphirine-bearing assemblages (Christy, 1989), the pressure of metamorphism must have been at least $0.6-0.7 \mathrm{GPa}$, or about $21 \mathrm{~km}$ deep (Figure 4-8). This observation suggests that the granulite protoliths formed by magmatic underplating at the base of the crust. Mechanisms by which the lower oceanic crust forms have been a subject of debate and recent development based on studies of ODP site 735B (Dick et al., 1992; Hart et al., 1999) and the Oman ophiolite (Kelemen et al., 1997) can be used to infer processes of underplating for the present case. Particularly interesting are the observations of Kelemen et al. (1997) for the emplacement of gabbro sills in the Moho transition zone of the Oman ophiolite. Numerous small ( $<1$ to $50 \mathrm{~m}$ thick by $>10$ to $200 \mathrm{~m}$ long) gabbro bodies are formed by the crystallization of melts at the Moho. In this model, ascending melts are trapped at the Moho and crystallize because of permeability and density barriers (Stolper and Walker, 1980; Parsons et al., 1992; Kelemen et al., 1997). The more evolved residual melts are effectively extracted by a mechanism of periodic hydrofracture of the overlying brittle crust, leaving behind a nearly pure cumulate. In addition to being observed in Oman (Kelemen et al., 1997), these types of gabbros are inferred by geophysical methods to be currently in the process of forming at the East Pacific Rise (Crawford et al., 1999), and their formation was successfully modeled in hotspot settings using the MELTS code (Farnetani et al., 1996). Moreover, the presence of underplated lower crustal material was observed seismically beneath Hawaii and the Marquesas (ten Brink and Brocher, 1987; Caress et al., 1995). Thus, underplating seems to be a common process of lower crustal growth in oceanic settings, both ridge and hotspot. 
If the metamorphism occurred by isobaric cooling, then why and when did the cooling begin? This is somewhat problematic in that cooling of the lithosphere is not easily explained in a plume setting. The absolute motion of Antarctic plate is in a slow northeasterly direction, and it is possible that the Islands have moved away from the plume, although the current location of the Kerguelen plume is not known (e.g. Duncan, 1991; Duncan and Storey, 1992; Royer et al., 1991). It is clear however, that plume activity is now a fraction of what it was at times during the last $30 \mathrm{Ma}$, i.e. the plume may be waning. Together, the plate movement and the waning plume may have allowed the temperature of the lithosphere to decrease enough to drive the metamorphism. If the high temperature anomaly is completely removed, conductive cooling can happen relatively quickly. Ten $\mathrm{km}$ of lithosphere can cool to the ambient geothermal gradient within $300 \mathrm{ka}$ after the heat source is removed.

Why are granulites present beneath the Kerguelen Islands and not other oceanic Islands? The answer is that they may well be present beneath other islands, but they have just not been sampled by plume volcanism. As noted earlier, other oceanic island platforms, including Hawaii, the Marquesas and the Ontong Java Plateau, have indications that large igneous bodies are underplated below (ten Brink and Brocher, 1987; Caress et al., 1995). Thus, granulites may potentially exist beneath these islands as well.

It has also been discussed in this chapter that the $\mathrm{Sr}$ and $\mathrm{Nd}$ isotope variations in the granulites are due to inherent heterogeneities of the Kerguelen plume. The fact that the small isotopically and geochemically heterogeneous pieces of recrystallized gabbro cumulates are sampled by the Kerguelen Islands dikes suggests that the original emplacement of gabbros might have occurred in numerous small units, similar to those observed in Oman (Kelemen et al., 1997). In this regard, it is notable that granulites from individual localities appear to form distinct groups of $\mathrm{Sr}$ and $\mathrm{Nd}$ isotopic compositions. 
Figure 4-19 shows that granulites from Mt Tizard have the lowest ${ }^{87} \mathrm{Sr} /{ }^{86} \mathrm{Sr}$ and highest ${ }^{143} \mathrm{Nd} /{ }^{144} \mathrm{Nd}$ (Mattielli et al., 1996), followed by the Lac Superieur granulites of this study, and those from Dome Rouge have the most isotopically enriched signatures (Mattielli, 1996). The combination of these isotopic characteristic with the locality-dependent differences in the relative abundances of the different xenolith types and granulite mineralogy implies that plume-derived magmas with distinct isotopic characteristics were emplaced at different depths in the crust-mantle transition zone and under varied thermal conditions. That is, because garnet and sapphirine-bearing granulites are present only in the Southeastern Province, and two-pyroxene granulites in the Courbet Peninsula, the crustal thickness is probably different between these two localities.

\subsubsection{What is the ${ }^{187} \mathrm{Os} /{ }^{188}$ Os of the EM I component?}

The Os composition of the EM I component is not yet well defined, though there is some indication that the EM I end member has radiogenic ${ }^{187} \mathrm{Os} /{ }^{188} \mathrm{Os}$ relative to EM II (Hauri and Hart, 1993; Reisberg et al., 1993; Yang et al., 1998; Shirey and Walker, 1998). Basalts from the Kerguelen plume have a strong EM I component (e.g. Gautier et al., 1990; Weis et al., 1993; Yang et al., 1998), so the Os data from the Kerguelen plume related rocks may give some indication of the Os isotopic composition of EM I. The eruption age corrected basalts and granulites fall into two Os isotopic groups, a relatively radiogenic group $\left({ }^{187} \mathrm{Os} /{ }^{188} \mathrm{Os}=0.1600\right)$ and unradiogenic group $\left({ }^{187} \mathrm{Os} /{ }^{188} \mathrm{Os}=0.1300 ;\right.$ Figure 4-21). As noted above, that basalts and granulites are present in both isotopic groups is evidence for a heterogeneous plume. It follows that the Os isotopic signature of the EM I component of the Kerguelen plume is heterogeneous as well. This is consistent with the origin of the EM I component in the subcontinental lithosphere (Hart, 1988).

One caveat to this idea, is that the absolute ages of the granulites are not known. Corrections for a $70 \mathrm{Ma}$ crystallization age for the granulite protoliths gives a range in 
${ }^{187} \mathrm{Os} /{ }^{188} \mathrm{Os}$ of 0.1266 to 0.1337 , and OB93-54, the most radiogenic sample, has ${ }^{187} \mathrm{Os} /{ }^{188} \mathrm{Os}=0.1285$ (see Figure $4-18$ ). Hence, at $70 \mathrm{Ma}$ the Os isotopic heterogeneity of these rocks significantly decreases. At this time, rocks from the DSDP site 216 indicate that the Ninetyeast Ridge was being constructed by the Kerguelen plume at $\sim 50^{\circ} \mathrm{S}$ (as determined by paleomagnetic studies; e.g. Royer et al., 1991). Therefore, it is possible that these granulites' precursor could have been underplated during the Ninetyeast Ridge formation. Preliminary seismic data indicate the crust is about $25 \mathrm{~km}$ thick beneath the ridge near ODP site 757, and also exhibits evidence for crustal underplating (Flueh et al., 1999). Although these conditions satisfy those necessary for granulite metamorphism, the geography is more difficult to reconcile. For the protolith of these granulites to be related to Ninetyeast Ridge formation, a sizeable piece of the Ninetyeast Ridge should be present beneath the northern Kerguelen Plateau. That is, a piece of the ridge would have been rifted from the rest of the structure and subsequently covered by the volcanism that created the northern plateau and the Kerguelen Islands. A determination of the absolute ages of the granulites and a better understanding of the structure and tectonic history of the northern Kerguelen Plateau will be necessary to solve this problem.

\subsubsection{What is the mineral host for Re and Os?}

Because Re and Os are chalcophile elements, it is generally assumed that they are controlled by sulfides during processes such as melting and fractional crystallization (Jagoutz et al., 1979; Stockman, 1982; Morgan and Baedecker, 1983; Hart and Ravizza, 1996). Sulfides can account for as much as $80 \%$ of the Re and Os budget of peridotites, and therefore do have a significant role in their geochemistry (Jagoutz et al., 1979; Morgan and Baedecker, 1983; Hart and Ravizza, 1996). It seems clear that if sulfides are present in the magmatic system, they should dominate Re and Os geochemistry 
The granulites of this may hold some clues to the geochemistry of Re and Os during crystallization of basaltic magmas, because as noted above, many of the granulites contain sulfides. Figure 4-22 shows a series of variation diagrams of whole rock abundances of chalcophile elements and Re and Os. No correlation exists between Re and Os, possibly indicating different mineral hosts for these elements. Correlations are present however, with $\mathrm{Re}$ and Os and other chalcophile elements, though not the same ones. Osmium has a good positive correlation with $\mathrm{Zn}$ and $\mathrm{Pb}$, but not as good with $\mathrm{Cu}$. In contrast, $\mathrm{Re}$ correlates positively with $\mathrm{Cu}$ and less well with $\mathrm{Zn}$, but shows no correlation with $\mathrm{Pb}$. These data indicate that both $\operatorname{Re}$ and Os are controlled by sulfide segregation, but not necessarily the same sulfide phase. If this is true, then Re tends to occur in the same sulfides as $\mathrm{Cu}$ but not $\mathrm{Pb}$-rich sulfides, whereas $\mathrm{Os}$ will be present in the same sulfides as $\mathrm{Pb}$ rather than $\mathrm{Cu}$-rich sulfides. Zinc can be present in sulfides that contain both $\mathrm{Re}$ and Os. Moreover, Os does not correlate with $\mathrm{Ni}$, but rather remains relatively constant for a given Ni content and does not follow an olivine control line. This demonstrates that Os contents of these rocks are buffered by sulfide segregation (Hart and Ravizza, 1996). That many of the granulites contain sulfides supports this idea.

\subsection{Summary}

The results of this geochemical study of granulite xenoliths from the Courbet Peninsula, Kerguelen Islands provide the following conclusions:

The xenoliths of this study are two-pyroxene granulites, with olivine gabbro protoliths. Their equigranular texture, absence of olivine and high modal abundance of orthopyroxene provide evidence for a metamorphic origin. Differences in CIPW normative mineralogy (olivine + clinopyroxene + plagioclase) and modal mineralogy (clinopyroxene + 
orthopyroxene + plagioclase) indicate that the protoliths were olivine gabbro and the reaction that formed the granulites was olivine + plagioclase $\rightarrow$ orthopyroxene + clinopyroxene + spinel. Although it is not possible to determine the absolute pressure of metamorphism for these rocks, on the basis of two-pyroxene thermometry and the CMAS experimental system reaction boundaries, pressure-temperature conditions must have been between 0.6 and $1.0 \mathrm{GPa}$, and from 845 to $960^{\circ} \mathrm{C}$ respectively.

The bulk rock major element compositions of these rocks are similar to both oceanic gabbros and mafic granulite xenoliths from continents. Thus, these type of data are not sufficient to determine the provenance of the parent melts of the granulites. Furthermore, these granulites are not related to each other by simple crystal fractionation of a single parent magma. Whole rock trace element abundances indicate that these rocks are cumulates. Positive correlations of compatible elements with $\mathrm{MgO}$, and positive $\mathrm{Sr}$ and $\mathrm{Eu}$ anomalies of a similar magnitude as gabbro cumulates from the Oman ophiolite support this interpretation. The body of whole rock data also suggest that metamorphism was isochemical. Two line of evidence rule out a significant interstitial melt in the granulites: a.) The low level of incompatible elements present in the granulites argues for a minimal melt fraction that may have been trapped during mineral accumulation, and b.) Sr isotopes rule out impregnation of a lower oceanic crustal gabbro by a plume melt.

Rare earth element abundances of bulk granulites and of clinopyroxenes are used to infer the trace element compositions of the parent melts of the granulite protoliths. Equilibrium melts of both whole rocks and clinopyroxenes give similar REE patterns that are comparable to those of Kerguelen Islands basalts rather than SEIR MORB. This characteristics are show that the granulite protoliths are genetically related to the magmatism that produced the Kerguelen Islands basalts rather than the SEIR MORB. 
The $\mathrm{Sr}$ and $\mathrm{Nd}$ isotopes of the granulites are in equilibrium with the Kerguelen Islands basalts, further supporting an origin of the precursor's parent melt from the Kerguelen plume. Combining the data of the present study with the isotope data of granulites from the Southeastern Province shows that the granulites as a whole span the isotopic range exhibited by the Kerguelen basalts. This implies a similar origin for the isotopic variations of the two.

The Re-Os systematics of the granulites are very similar to that of the present-day primitive mantle and show that the rocks cannot be very old, probably less than $\sim 100 \mathrm{Ma}$. The Os isotopic compositions of the granulites are less radiogenic than samples of both the oceanic and continental lower crust. Together, these characteristics also point to a plume rather than mid-ocean ridge or lower continental crustal origin for the granulites.

The proposed origin of the diversity of isotopic signatures is a heterogeneous plume rather than a result of DMM-plume mixing, as was previously proposed. At $30 \mathrm{Ma}$, the age of the oldest basalts on the Kerguelen Islands, the Kerguelen plume would have been up to 400 $\mathrm{km}$ from the SEIR. Given that plume mantle flows towards ridges, it is unlikely that the mixing of $80 \%$ SEIR melt and $20 \%$ plume melt that is required by the $\mathrm{Sr}$ and $\mathrm{Nd}$ isotopes could have occurred. The $\mathrm{Sr}, \mathrm{Nd}$, and $\mathrm{Os}$ isotopic systematics also argue against any significant contamination of the granulite precursor parent melt by continental crust. That none of the isotopic systems ( $\mathrm{Rb}-\mathrm{Sr}, \mathrm{Sm}-\mathrm{Nd}, \mathrm{Re}-\mathrm{Os}$ and $\mathrm{U}-\mathrm{Pb}$ ) allow a coherent mixing model among the mantle endmembers is further evidence that the isotopic variations originated within the Kerguelen plume.

The parent melts of the granulite protoliths were most likely emplaced at the Moho (i.e. underplated) by Kerguelen plume related magmatism as a series of small bodies, similar to the gabbro sills observed at the Oman ophiolite. Metamorphism occurred by isobaric 
cooling of the olivine gabbro protoliths, perhaps caused by migration of the Kerguelen Islands away from the plume, or a waning of the plume itself. The differences in the mineralogy of the granulites from the Southeast Province (garnet and sapphirine-bearing) and those of this study (two-pyroxenes, plagioclase and spinel), though the bulk chemistry is generally similar, indicates a variable depth of emplacement for the protoliths, and hence a variable crustal thickness beneath the Kerguelen Islands. 


\subsection{References Cited}

Albee A. L. and Ray L. (1970) Correction factors for electron microprobe analysis of silicates, oxides, carbonates, phosphates and sulfates. Anal. Chem. 42, 1408-1414.

Alibert C. (1991) Mineralogy and geochemistry of a basalt from site 738: implications for the tectonic history of the southernmost part of the Kerguelen Plateau. In Proceedings of the Ocean Drilling Program, Scientific Results, Vol. 119 (ed. J. Barron, B. Larsen, and et al.), pp. 293-298. Ocean Drilling Program.

Anders E. and Grevesse N. (1989) Abundances of the elements: Meteoritic and solar. Geochim. Cosmochim. Acta 53, 197-214.

Aumento F., Melson W. G., and et al. (1977) Initial reports of the Deep Sea Drilling Project, Vol. 37, pp. 1008. U.S. Government Printing Office.

Barling J., Goldstein S. L., and Nicholls I. A. (1994) Geochemistry of Heard Island (southern Indian Ocean): characterization of an enriched mantle component and implications for enrichment of the sub-Indian Ocean mantle. J. Petrol. 35, 1017 1053.

Barling J., McBride J. S., Lambert D. D., and Nicholls I. A. (1997) The Heard Island Continental Component: Osmium-isotopic evidence for mantle vs. magma contamination. Seventh Annual V.M. Goldschmidt Conference LPI Cont. 921, 17-18.

Barron J., Larsen B., and et al. (1991) Proceedings of the Ocean Drilling Program, Scientific Results, Vol. 119. College Station, TX (Ocean Drilling Program).

Bédard J. H. (1994) A procedure for calculating the equilibrium distribution of trace elements among the minerals of cumulate rocks, and the concentration of trace elements in the coexisting liquids. Chem. Geol. 118, 143-153.

Bence A. E. and Albee A. L. (1968) Empirical correction factors for the electron microanalysis of silicates and oxides. J. Geol. 76, 382-403.

Caress D. W., McNutt M. K., Detrick R. S., and Mutter J. C. (1995) Seismic imaging of hotspot-related crustal underplating beneath the Marquesas Islands. Nature 373, 600603.

Casey J. F. (1997) Comparison of major- and trace-element geochemistry of abyssal peridotites and mafic plutonic rocks with basalts from the MARK region of the MidAtlantic Ridge. In Proceedings of the Ocean Drilling Program, Scientific Results, Vol. 153 (ed. J. A. Karson, M. Cannat, D. J. Miller, and D. Elthon), pp. 181-241. Ocean Drilling Program.

Charvis P., Recq M., Operto S., and Brefort D. (1995) Deep structure of the northern Kerguelen Plateau and hotspot-related activity. Geophys. J. Int. 122, 899-924.

Christy A. G. (1989) The stability of sapphirine+clinopyroxene: implications for phase relations in the $\mathrm{CaO}-\mathrm{MgO}-\mathrm{Al}_{2} \mathrm{O}_{3}-\mathrm{SiO}_{2}$ system under deep crustal and upper mantle conditions. Cont. Mineral. Petrol. 102, 422-428. 
Clague D. A. and Bohrson W. A. (1991) Origin of xenoliths in the trachyte at Puu Waawaa, Hualalai volcano, Hawaii. Cont. Mineral. Petrol. 108, 439-452.

Clague D. A. and Chen C.-H. (1986) Ocean crust xenoliths from Hualalai volcano, Hawaii. Geol. Soc. Am. Abs. Progs. 18, 565.

Coffin M. F. (1992) Emplacement and subsidence of Indian Ocean plateaus and submarine ridges. In Synthesis of Results from Scientific Drilling in the Indian Ocean, Vol. Geophysical Monograph 70 (ed. R. A. Duncan, D. K. Rea, and et al.), pp. 115-125. American Geophysical Union.

Coffin M. F. and Eldholm O. (1994) Large igneous provinces: Crustal structure, dimensions, and external consequences. Rev. Geophys. 32, 1-36.

Crawford W. C., Webb S. C., and Hildebrand J. A. (1999) Constraints on melt in the lower crust and Moho at the East Pacific Rise $948 \mathrm{~N}$, using seafloor compliance measurements. J. Geophys. Res. 104, 2923-2939.

Davies H. L., Sun S.-s., Frey F. A., Gautier I., McCulloch M. T., Price R. C., Bassias Y., Klotwijk C. T., and Leclaire L. (1989) Basalt basement from the Kerguelen Plateau and the trail of Dupal plume. Contrib. Mineral. Petrol. 103, 457-469.

Davies T. A., Luyendyk B. P., and et al. (1974) Initial Reports of the Deep Sea Drilling Project, Vol. 26, pp. 1129. U.S. Government Printing Office.

Davis A. S. and Clague D. A. (1990) Gabbroic xenoliths from the Northern Gorda Ridge: implications for magma chamber processes under slow spreading centers. $J$. Geophys. Res. 95, 10,885-10,905.

Dick H. J. B. and Bullen T. (1984) Chromian spinel as a petrogenetic indicator in abyssal and alpine-type peridotites and spatially associated lavas. Cont. Mineral. Petrol. 86, 54-76.

Dick H. J. B., Robinson P. T., and Meyer P. S. (1992) The plutonic foundation of a slow-spreading ridge. In Synthesis of Results from Scientific Drilling in the Indian Ocean, Vol. Geophysical Monograph 70 (ed. R. A. Duncan, D. K. Rea, R. B. Kidd, U. von Rad, and J. K. Weissel). American Geophysical Union.

Dixon J. E. and Clague D. A. (1986) Gabbroic xenoliths and host ferrobasalt from the Southern Juan de Fuca Ridge. J. Geophys. Res. 91, 3795-3820.

Dosso L., Bougault H., Beuzart P., Calvez J.-Y., and Joron J.-L. (1988) The geochemical structure of the South-East Indian Ridge. Earth Planet. Sci. Lett. 88, 47-59.

Dosso L., Vidal P., Cantagrel J. M., Lameyre J., Marot A., and Zimine S. (1979) "Kerguelen: continental fragment or oceanic island?": Petrology and isotopic geochemistry. Earth Planet. Sci. Lett. 43, 46-60.

Duncan R. A. (1978) Geochronology of basalts from the Ninetyeast Ridge and continental dispersion in the eastern Indian Ocean. J. Volcan. Geotherm. Res. 4, 283-305.

Duncan R. A. (1991) Age distribution of volcanism along aseismic ridges in the eastern Indian Ocean. In Proc. of the Ocean Drilling Program, Sci. Res., Vol. 121 (ed. J. Weissel, J. Pierce, E. Taylor, J. Alt, and et al.), pp. 507-517. Ocean Drilling Project.

Duncan R. A. and Storey M. (1992) The life cycle of Indian Ocean hotspots. In Synthesis of Results from Scientific Drilling in the Indian Ocean, Vol. AGU Monograph 70 
(ed. R. A. Duncan, D. K. Rea, R. B. Kidd, U. von Rad, and J. K. Weissel). American Geophysical Union.

Dunn T. and Sen C. (1994) Mineral/matrix partition coefficients for orthopyroxene, plagioclase, and olivine in basaltic to andesitic systems: a combined analytical and experimental study. Geochim. Cosmochim. Acta 58, 717-733.

Elthon D. (1987) Petrology of gabbroic rocks from the Mid-Cayman Rise spreading center. J. Geophys. Res. 92, 658-682.

Elthon D., Stewart M., and Ross D. K. (1992) Compositional trends of minerals in oceanic cumulates. J. Geophys. Res. 97, 15,189-15,199.

Esperança S., Carlson R. W., Shirey S. B., and Smith D. (1997) Dating crust-mantle separation; Re-Os isotopic study of mafic xenoliths from central Arizona. Geol.25, 651-654.

Farnetani C. G., Richards M. A., and Ghiorso M. S. (1996) Petrological models of magma evolution and deep crustal structure beneath hotspots and flood basalt provinces. Earth Planet. Sci. Lett. 143, 81-94.

Faure G. (1986) Principles of Isotope Geology. John Wiley \& Sons.

Flueh E. R., Grevemeyer I., and Reichert C. (1999) Ocean site survey reveals anatomy of a hotspot track. Eos, Transactions, American Geophysical Union 80, 77.

Fowler C. M. R. (1990) The Solid Earth: An Introduction to Global Geophysics. Cambridge University Press.

Furumoto A. S., Webb J. P., Odegard M. E., and Hussong D. M. (1976) Seismic studies on the Ontong Java Plateau. Tectonophys. 34, 71-90.

Garrido C. and Kelemen P. (1999) Composition of gabbros and parental melts in the Wadi Tayin massif, southern Oman ophiolite,. Geol. in prep.

Gautier I., Weis D., Mennessier J.-P., Vidal P., Giret A., and Loubet M. (1990) Petrology and geochemistry of the Kerguelen Archipelago basalts (South Indian Ocean): evolution of the mantle sources from ridge to intraplate position. Earth Planet. Sci. Lett. 100, 59-76.

Giret A. and Lameyre J. (1983) A study of Kerguelen plutonism : Petrology, geochronology and geological implications. In Antarctic Earth Science (ed. R. L. Oliver, P. R. James, and J. B. Jago), pp. 646-651. Cambridge University Press.

Gladczenko T. P., Coffin M. F., and Eldholm O. (1997) Crustal structure of the Ontong Java Plateau; modeling of new gravity and existing seismic data. J. Geophys. Res. 102, 22,711-22,729.

Grègoire M. (1994) Pètrologie des enclaves ultrabasiques and basiques des îles Kerguelen (T.A.A.F.). Les contraintes minèralogiques et thermobaromètriques et leurs implications gèodynamiques. PhD Thesis, Université Jean Monnet-St. Etienne.

Grègoire M., Cottin J. Y., Giret A., Mattielli N., and Weis D. (1998) The meta-igneous granulite xenoliths from Kerguelen Archipelago: evidence of a continent nucleation in an oceanic setting. Cont. Mineral. Petrol. 133, 259-283.

Grègoire M., Mattielli N., Nicollet C., Cottin J. Y., Leyrit H., Weis D., Shimizu N., and Giret A. (1994) Oceanic mafic granulite xenoliths from the Kerguelen archipelago. Nature 367, 360 - 363. 
Griffin W. L. and O'Reilly S. Y. (1987) The composition of the lower crust and the nature of the continental Moho -xenolith evidence. In Mantle Xenoliths (ed. P. H. Nixon), pp. 413-432. John Wiley and Sons, Ltd.

Grove T. L., Kinzler R. J., and Bryan W. B. (1992) Fractionation of mid-ocean ridge basalt (MORB). In Mantle Flow and Melt Generation at Mid-Ocean Ridges, Vol. Geophysical Monograph 71 (ed. J. Phipps Morgan, D. K. Blackman, and J. M. Sinton), pp. 281-310. American Geophysical Union.

Hamelin B., Dupre B., and Allègre C. J. (1986) Pb-Sr-Nd isotopic data of Indian Ocean ridges; new evidence of large-scale mapping of mantle heterogeneities. Earth Planet. Sci. Lett. 76, 288-298.

Harland W. B., Armstrong R. L., Cox A. V., Craig L. E., Smith A. G., and G. S. D. (1989) A Geologic Time Scale 1989. Cambridge University Press.

Hart S. R. (1988) Heterogeneous mantle domains: signatures, genesis and mixing chronologies. Earth Planet. Sci. Lett. 90, 273-296.

Hart S. R., Blusztajn J., Dick H. J. B., Meyer P. S., and Muehlenbachs K. (1999) The fingerprint of seawater circulation in a 500-meter section of ocean crust gabbro. Geochim. Cosmochim. Acta in press.

Hart S. R. and Dunn T. (1993) Experimental cpx/melt partitioning of 24 trace elements. Cont. Mineral. Petrol. 113,1-8.

Hart S. R. and Ravizza G. E. (1996) Os partitioning between phases in lherzolite and basalt. In Earth Processes: Reading the Isotopic Code, Vol. 95 (ed. A. Basu and S. R. Hart), pp. 123-134. American Geophysical Union.

Hassler D. R. and Shimizu N. (1998) Osmium isotopic evidence for ancient subcontinental lithospheric mantle beneath the Kerguelen Islands, Southern Indian Ocean. Science 280, 418-421.

Hauri E. H. and Hart S. R. (1993) Re-Os isotope systematics of HIMU and EMII oceanic island basalts from the south Pacific Ocean. Earth Planet. Sci. Lett. 114, 353-371.

Hèbert R., Constantin M., and Robinson P. T. (1991) Primary mineralogy of Leg 118 gabbroic rocks and their place in the spectrum of oceanic mafic igneous rocks. In Proceedings of the Ocean Drilling Program, Scientific Results, Vol. 118 (ed. R. P. Von Herzen, P. T. Robinson, and et al.), pp. 3-20. Ocean Drilling Program.

Hoernle K. (1998) Geochemistry of Jurassic Oceanic crust beneath Gran Canaria (Canary Islands): implications for crustal recycling and assimilation. J. Petrol. 39, 859-880.

Horwitz E. P., Dietz M. L., and Fisher D. E. (1991) Separation and preconcentration of strontium from biological, environmental, and nuclear waste samples by extraction chromatography using a crown ether. Anal. Chem. 63, 522-525.

Houtz R. E., Hayes D. E., and Mark1 R. G. (1977) Kerguelen Plateau bathymetry, sediment distribution, and crustal structure. Mar. Geol, 25, 95-130.

Jagoutz E., Palme H., Baddenhausen H., Blum K., Cendales M., Dreibus G., Spettel B., Lorenz V., and Wänke H. (1979) The abundances of major, minor, and trace elements in the earth's mantle as derived from primitive ultramafic nodules. Proc. Lunar Planet. Sci. Conf. 10th, 2031-2050. 
Karson J. A., Cannat M., Miller D. J., and Elthon D. (1997) Proceedings of the Ocean Drilling Program, Scientific Results, Vol. 153. Ocean Drilling Program.

Kelemen P. B., Koga K., and Shimizu N. (1997) Geochemistry of gabbro sills in the crust-mantle transition zone of the Oman ophiolite: implications for the origin of the oceanic lower crust. Earth Planet. Sci. Lett. 146, 475-488.

Kelemen P. B., Shimizu N., and Dunn T. (1993) Relative depletion of niobium in some arc magmas and the continental crust: partitioning of $\mathrm{K}, \mathrm{Nb}, \mathrm{La}$ and $\mathrm{Ce}$ during melt/rock reaction in the upper mantle. Earth Planet. Sci. Lett. 120, 111-134.

Kempton P. D., Hawkesworth C. J., and Fowler M. (1991) Geochemistry and isotopic composition of gabbros from layer 3 of the Indian Ocean crust, Hole 735B. In Proceedings of the Ocean Drilling Program, Scientific Results, Vol. 118 (ed. R. P. Von Herzen, P. T. Robinson, and et al.), pp. 127-143. Ocean Drilling Program.

Kempton P. D. and Hunter A. G. (1997) A Sr-, Nd-, Pb-, O-isotope study of plutonic rocks from MARK, Leg 153: implications for mantle heterogeneity and magma chamber processes. In Proceedings of the Ocean Drilling Program, Scientific Results, Vol. 153 (ed. J. A. Karson, M. Cannat, D. J. Miller, and D. Elthon), pp. 305-319. Ocean Drilling Program.

Kushiro I. and Yoder H. S. (1966) Anorthite-forsterite and anorthite-enstatite reactions and their bearing on the basalt eclogite transformation. J. Petrol. 7, 337-362.

Lassiter J. C. and Hauri E. H. (1998) Osmium-isotope variations in Hawaiian lavas: evidence for recycled oceanic lithosphere in the Hawaiian plume. Earth Planet. Sci. Lett. 164, 483-496.

Lindner M., Leich D. A., Borg R. J., Russ G. P., Bazan J. M., Simons D. S., and Date A. R. (1986) Direct laboratory determination of the ${ }^{187}$ Re half-life. Nature $\mathbf{3 2 0}$, 246-248.

Mahoney J. J., Jones W. B., Frey F. A., Salters V. J. M., Pyle D. G., and Davies H. L. (1994) Geochemical characteristics of lavas from Broken Ridge, the Naturaliste Plateau, and southernmost Kerguelen Plateau: Cretaceous Plateau volcanism in the southeast Indian Ocean. Chem. Geol. 120, 315-345.

Mahoney J. J., MacDougall J. D., Lugmair G. W., and Gopalan K. (1983) Kerguelen hotspot source for Rajmahal Traps and Ninetyeast Ridge. Nature 303, 385 - 389.

Marcantonio F., Zindler A., Elliott T., and Staudigel H. (1995) Os isotope systematics of La Palma, Canary Islands: evidence for recycled crust in the mantle source of HIMU ocean islands. Earth Planet. Sci. Lett. 133, 397-410.

Martin C. E. (1991) Osmium characteristics of mantle-derived rocks. Geochim. Cosmochim. Acta 55, 1421-1434.

Mattielli N. (1996) Magmatisme et métasomatisme associés au panache des Kerguelen: Contribution de la géochimie des enclaves basiques et ultrabasiques. PhD Thesis, Université Libre de Bruxelles.

Mattielli N., Weis D., Grégoire M., Mennessier J. P., Cottin J. Y., and Giret A. (1996) Kerguelen basic and ultrabasic xenoliths: evidence for long-lived Kerguelen hotspot activity. Lithos 37, 261-280. 
McBirney A. R. and Aoki K.-I. (1973) Factors governing the stability of plagioclase at high pressures as shown by spinel-gabbro xenoliths from the Kerguelen Archipelago. Am. Mineral. 58, 271-276.

Mével C., Gillis K. M., Allan J. F., and Meyer P. (1996) Proceedings of the Ocean Drilling Program, Scientific Results, Vol. 147. Ocean Drilling Program.

Meyer P. S., Dick H. J. B., and Thompson G. (1989) Cumulate gabbros from the Southwest Indian Ridge, $54^{\circ} \mathrm{S}-7^{\circ} 16^{\prime} \mathrm{E}$ : implications for magmatic processes at a slow spreading ridge. Cont. Mineral. Petrol. 103, 44-63.

Michard A., Montigny R., and Schlich R. (1986) Geochemistry of the mantle beneath the Rodriguez Triple Junction and the South-East Indian Ridge. Earth Planet. Sci. Lett. 78, 104-114.

Morgan J. W. and Baedecker P. A. (1983) Elemental composition of sulfide particles from an ultramafic xenolith and the siderophile element content of the upper mantle. Lunar and Planetary Science Conference 14, 513-514.

Munschy M., Dyment J., Boulanger M. O., Boulanger D., Tissot J. D., Schlich R., Rotstein Y., and Coffin M. F. (1992) Breakup and seafloor spreading between the Kerguelen Plateau-Labuan Basin and the Broken Ridge-Diamantina Zone. In Proceedings of the Ocean Drilling Program, Scientific Results, Vol. 120 (ed. S. W. Wise, Jr., R. Schlich, and et al.), pp. 931-944. College Station, TX (Ocean Drilling Program).

Munschy M. and Schlich R. (1987) Structure and evolution of the Kerguelen-Heard Plateau (Indian Ocean) deduced from seismic stratigraphy studies. Mar. Geol, 76, 131-152.

Natland J. H. and Dick H. J. B. (1996) Melt migration through high-level gabbroic cumulates of the East Pacific Rise at Hess Deep: the origin of magma lenses and the deep crustal structure of fast-spreading ridges. In Proceedings of the Ocean Drilling Program, Scientific Results, Vol. 147 (ed. C. Mével, K. M. Gillis, J. F. Allan, and P. Meyer), pp. 21-54. Ocean Drilling Program.

Natland J. H., Meyer P. S., Dick H. J. B., and Bloomer S. H. (1991) Magmatic oxides and sulfides in gabbroic rocks from Hole 735B and the later development of the liquid line of descent. In Proceedings of the Ocean Drilling Program, Scientific Results, Vol. 118 (ed. R. P. Von Herzen, P. T. Robinson, and et al.), pp. 75-111. Ocean Drilling Program.

Neal C., Mahoney J. J., Kroenke L. W., Duncan R. A., and Petterson M. G. (1997) The Ontong Java Plateau. In Large Igneous Provinces Continental, Oceanic and Planetary Flood Volcanism, Vol. AGU Monograph 100 (ed. J. J. Mahoney and M. F. Coffin). American Geophysical Union.

Nicolaysen K., Frey F. A., Hodges K. V., Weis D., and Giret A. (1999) $40^{\mathrm{Ar}} /{ }^{39} \mathrm{Ar}$ geochronology of flood basalts from the Kerguelen Archipelago, southern Indian Ocean: implications for Cenozoic eruption rates of the Kerguelen plume. Earth Planet. Sci. Lett., submitted.

Nougier J. (1972) Geochronology of the volcanic activity in Iles Kerguelen. In Antarctic Geology and Geophysics, Vol. International Union of Geological Sciences, Ser. BNo. 1 (ed. R. J. Adie), pp. 803-808. Scandinavian Univ. Books. 
Operto S. and Charvis P. (1995) Kerguelen Plateau: a volcanic passive margin fragment? Geol. 23, 137-140.

Parsons T., Sleep N. H., and Thompson G. A. (1992) Host rock rheology controls on the emplacement of tabular intrusions: implications for underplating of extending crust. Tectonics 11, 1348-1356.

Pearson D. G., Snyder G. A., Shirey S. B., Taylor L. A., Carlson R. W., and Sobolev N. V. (1995) Archean Re-Os age for Siberian eclogites and constraints on Archean tectonics. Nature 374, 711-713.

Pederson R. B., Malpas J., and Falloon T. (1996) Petrology and geochemistry of gabbroic and related rocks from Site 894, Hess Deep. In Proceedings of the Ocean Drilling Program, Scientific Results, Vol. 147 (ed. C. Mével, K. M. Gillis, J. F. Allan, and P. Meyer), pp. 3-19. Ocean Drilling Program.

Pin C. and Bassin C. (1992) Evaluation for a strontium-specific extraction chromatographic method for isotopic analysis in geological materials. Analytica Chimica Acta 269, 249-255.

Pringle M. S., Coffin M. F., and Storey M. S. (1997) Estimated melt production of the Kerguelen hot spot. EOS, Trans. Am. Geophys. Un. 78, 728.

Ravizza G. (1993) Variations of the ${ }^{187} \mathrm{Os} / 186$ Os ratio of seawater over the past 28 million years as inferred from metalliferous carbonates. Earth Planet. Sci. Lett. 118, 335348 .

Recq M. and Charvis P. (1986) A seismic refraction survey in the Kerguelen Isles, southern Indian Ocean. Geophys. J. R. Astr. Soc. 84, 529-559.

Reisberg L., Zindler A., Marcantonio F., White W., Wyman D., and Weaver B. (1993) Os isotope systematics in ocean island basalts. Earth Planet. Sci. Lett. 120, 149-167.

Ribe N. M. (1996) The dynamics of plume-ridge interaction; 2, Off-ridge plumes. Journal of Geophysical Research, B, Solid Earth and Planets 101, 16,195-16,204.

Richard P., Shimizu N., and Allègre C. J. (1976) ${ }^{143} \mathrm{Nd} / 146 \mathrm{Nd}$, A natural tracer: an application to oceanic basalts. Earth Planet. Sci. Lett. 31, 269-278.

Ringwood A. E. (1975) Composition and Petrology of the Earth's Mantle. McGraw Hill.

Rogers N. W. and Hawkesworth C. J. (1982) Proterozoic age and cumulate origin for granulite xenoliths, Lesotho. Nature 299, 409-413.

Ross K. and Elthon D. (1997) Cumulus and postcumulus crystallization in the oceanic crust: major- and trace-element geochemistry of Leg 153 gabbroic rocks. In Proceedings of the Ocean Drilling Program, Scientific Results, Vol. 153 (ed. J. A. Karson, M. Cannat, D. J. Miller, and D. Elthon), pp. 333-350. Ocean Drilling Program.

Royer J.-Y., Peirce J. W., and Weissel J. K. (1991) Tectonic constraints on the hot-spot formation of Ninetyeast ridge. In Proceedings of the Ocean Drilling Program, Scientific Results, Vol. 121 (ed. J. Weissel, J. Peirce, E. Taylor, J. Alt, and et al.). Ocean Drilling Program.

Royer J.-Y. and Sandwell D. T. (1989) Evolution of the Eastern Indian Ocean since the late Cretaceous: constraints from Geosat altimetry. J. Geophys. Res. 94, 13,75513,782 . 
Rudnick R. L. (1992) Xenoliths - samples of the lower continental crust. In Continental Lower Crust (ed. D. M. Fountain and R. Arculus), pp. 269-316. Elsevier.

Rudnick R. L. and Fountain D. M. (1995) Nature and composition of the continental crust: a lower crustal perspective. Rev. Geophys. 33, 267-309.

Rudnick R. L., McDonough W. F., McCulloch M. T., and Taylor S. R. (1986) Lower crustal xenoliths from Queensland, Australia: evidence for deep crustal assimilation and fractionation of continental basalts. Geochim. Cosmochim. Acta 50, 1099-1115.

Rudnick R. L. and Presper T. (1990) Geochemistry of intermediate/- to high-pressure granulites. In Granulites and Crustal Evolution (ed. D. Vielzeuf and P. Vidal), pp. 523-550. Kluwer Academic Publishers.

Saal A. E., Rudnick R. L., Ravizza G. E., and Hart S. R. (1998) Re-Os isotope evidence for the composition, formation and age of the lower continental crust. Nature 393, $58-61$.

Salters V. J. M., Storey M., Sevigny J. H., and Whitechurch H. (1992) Trace element and isotopic characteristics of Kerguelen-Heard Plateau basalts. In Proceedings of the Ocean Drilling Program, Scientific Results, Vol. 120 (ed. S. W. J. Wise, R. Schlich, and et al.), pp. 55-62. Ocean Drilling Program.

Schilling J.-G. (1985) Upper mantle heterogeneities and dynamics. Nature (London) 314, 62-67.

Schilling J.-G. (1991) Fluxes and excess temperatures of mantle plumes inferred from their interaction with migrating mid-ocean ridges. Nature (London) 352, 397-403.

Schminke H.-U., Klügel A., Hansteen T. H., Hoernle K., and Bogaard P. v. d. (1998) Samples from the Jurassic ocean crust beneath Gran Canaria, La Palma and Lanzarote (Canary Islands). Earth Planet. Sci. Lett. 163, 343-360.

Schnetzler C. C. and Philpotts J. A. (1970) Partition coefficients of rare-earth elements between igneous matrix material and rock-forming mineral phenocrysts-II. Geochim. Cosmochim. Acta 34, 331-340.

Sen G. (1987) Xenoliths associated with the Hawaiian hotspot. In Mantle Xenoliths (ed. P. H. Nixon), pp. 357-375. John Wiley \& Sons.

Shimizu N. (1998) The geochemistry of olivine-hosted melt inclusions in a FAMOUS basalt ALV519-4-1. Phys. Earth Planet Interiors 107, 183-201.

Shimizu N. and Grove T. L. (1998) Geochemical studies of olivine-hosted melt inclusions from ridges and arcs. EOS, Trans. Am. Geophys. Un. 79, 1002-1003.

Shimizu N. and Hart S. R. (1982) Applications of the ion microprobe to geochemistry and cosmochemistry. Ann. Rev. Earth Planet. Sci. 10, 483-526.

Shirey S. B. and Walker R. J. (1998) The Re-Os isotope system in cosmochemistry and high-temperature geochemistry. Ann. Rev. Earth Planet. Sci. 26, 423-500.

Small C. (1995) Observations of ridge-hotspot interactions in the Southern Ocean. $J$. Geophys. Res. 100, 17,931-17,946.

Sobolev A. and Hofmann A. W. (1998) Anomalous Sr in melt inclusions from Mauna Loa, Hawaii: fingerprint of recycled gabbro. EOS, Trans. Am. Geophys. Un. 79, 345. 
Sobolev A. V. and Shimizu N. (1994) The origin of typical NMORB; the evidence from a melt inclusions study. Mineralogical Magazine; V. M. Goldschmidt conference 58A, 862-863.

Stockman H. W. (1982) Noble Metals in the Ronda and Josephine Peridotites. Doctoral Thesis, Massachusetts Institute of Technology.

Stolper E. and Walker D. (1980) Melt density and average composition of basalt. Cont. Mineral. Petrol. 74, 7-12.

Storey M., Pringle M. S., Coffin M. F., and Wijbrams J. (1996) Geochemistry and geochronology of Kerguelen Plateau basalts: Results from ODP legs 119 and 120. EOS, Trans. Am. Geophys. Un. 77, W123.

Storey M., Saunders A. D., Tarney J., Gibson I. L., Norry M. J., Thirwall M. F., Leat P., Thompson R. N., and Menzies M. A. (1989) Contamination of Indian Ocean asthenosphere by the Kerguelen-Heard mantle plume. Nature 338, 574 - 576.

Storey M., Saunders A. D., Tarney J., Leat P., Thirwall M. F., Thompson R. N., Menzies M. A., and Marriner G. F. (1988) Geochemical evidence for plume-mantle interactions beneath Kerguelen and Heard Islands, Indian Ocean. Nature 336, 371 374.

Streckheisen A. L. (1973) Plutonic rocks: classification and nomenclature recommended by the IUGS Subcommission on the Systematics of Igneous Rocks. Geotimes, 26-30.

ten Brink U. S. and Brocher T. M. (1987) Multichannel seismic evidence for a subcrustal intrusive complex under Oahu and a model for Hawaiian volcanism. J. Geophys. Res. 92, 13,687-13,707.

Tiezzi L. J. and Scott R. B. (1980) Crystal fractionation in a cumulate gabbro, Mid-Atlantic Ridge, $26^{\circ}$ N. J. Geophys. Res. 85, 5438-5454.

von der Borch C. C., Slater J. G., and et al. (1974) Initial Reports of the Deep Sea Drilling Project, pp. 890. U.S. Government Printing Office.

Von Herzen R. P., Robinson P. T., and al e. (1991) Proceedings of the Ocean Drilling Program, Scientific Results, Vol. 118. Ocean Drilling Program.

Wager L. R. and Brown G. M. (1967) Layered Igneous Rocks. W.H. Freeman and Company.

Walker R. J. and Morgan J. W. (1989) Rhenium-Osmium isotope systematics of cabonaceous chondrites. Science 243, 519-522.

Watkins N. D., Gunn B. M., Nougier J., and Baksi A. K. (1974) Kerguelen: Continental Fragment or Oceanic Island? Geol. Soc. Am. Bull. 85, 201 -212.

Weis D., Frey F. A., Giret A., and Cantagrel J.-M. (1998) Geochemical characteristics of the youngest volcano (Mount Ross) in the Kerguelen Archipelago: inferences for magma flux, lithosphere assimilation and composition of the Kerguelen plume. $J$. Petrol. 39, 973-994.

Weis D., Frey F. A., Leyrit H., and Gautier I. (1993) Kerguelen Archipelago revisited: geochemical and isotopic study of the Southeast Province lavas. Earth Planet. Sci. Lett. 118, 101 - 119.

Wells P. R. A. (1977) Pyroxene thermometry in simple and complex systems. Cont. Mineral. Petrol. 62, 129-139. 
White W. M. and Hofmann A. W. (1982) Sr and Nd isotope geochemistry of oceanic basalts and mantle evolution. Nature 296, 821-825.

Whitechurch H., Montigny R., Sevigny J., Storey M., and Salters V. J. M. (1992) K-Ar and ${ }^{40} \mathrm{Ar} /{ }^{39} \mathrm{Ar}$ ages of central Kerguelen Plateau basalts. In Proc. of the Ocean Drilling Program, Sci. Res., Vol. 120 (ed. S. W. Wise Jr., R. Schlich, and et al.), pp. 71-77. Ocean Drilling Program.

Widom E. and Shirey S. B. (1996) Os isotope systematics in the Azores: implications for the mantle plume sources. Earth Planet. Sci. Lett. 142, 451-465.

Wise S. W. J., Schlich R., and et al. (1992) Proceedings of the Ocean Drilling Program, Scientific Results, Vol. 120. College Station, TX (Ocean Drilling Program).

Yale M. M. and Phipps Morgan J. (1998) Asthenosphere flow model of hotspot-ridge interactions; a comparison of Iceland and Kerguelen. Earth Planet. Sci. Lett. 161, 45-56.

Yang H.-J., Frey F. A., Weis D., Giret A., Pyle D., and Michon G. (1998) Petrogenesis of the flood basalts forming the northern Kerguelen Archipelago: implications for the Kerguelen plume. J. Petrol. 39, 711-748.

Zindler A. (1980) Geochemical Processes in the Earth's Mantle and the Nature of CrustMantle Interactions: Evidence from Studies of Nd and Sr Isotope Ratios in MantleDerived Igneous Rocks and Lherzolite Nodules. PhD Thesis, Massachusetts Institute of Technology. 


\subsection{Tables:}

Table 4-1. Petrographic characteristics of the granulite xenolith suite.

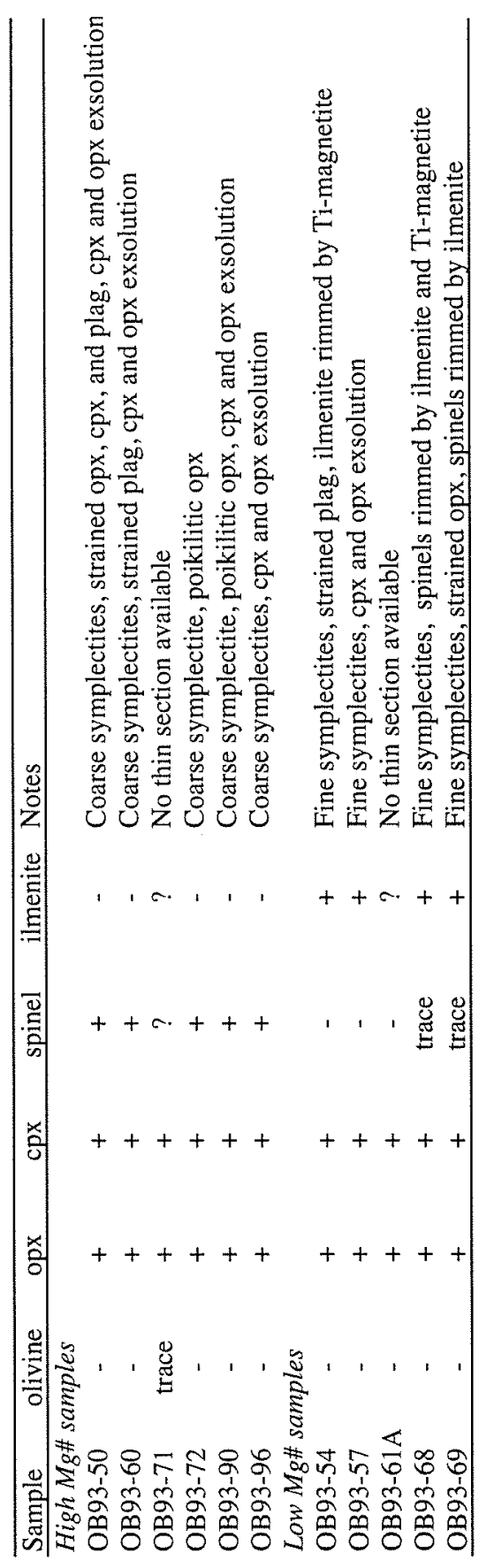


Table 4-2. Major element and trace element compositions, CIPW normative compositions and modes of granulite whole rocks.

\begin{tabular}{|c|c|c|c|c|c|c|}
\hline Sample & OB93-50 & OB93-54 & OB93-57 & OB93-60 & $3-61 A$ & OB93-68 \\
\hline Rock Type & $\mathrm{H}$ & $\mathrm{L}$ & $\mathrm{L}$ & $\mathrm{H}$ & L & $\mathrm{L}$ \\
\hline \multicolumn{7}{|l|}{$X R F w t \%$} \\
\hline $\mathrm{SiO}_{2}$ & 48.51 & 46.27 & 48.93 & 48.31 & 48.99 & 47.36 \\
\hline $\mathrm{Al}_{2} \mathrm{O}_{3}$ & 14.47 & 14.22 & 17.03 & 16.95 & 13.96 & 17.04 \\
\hline $\mathrm{TiO}_{2}$ & 0.25 & 2.22 & 0.37 & 0.36 & 0.74 & 0.62 \\
\hline $\mathrm{FeO} *$ & 5.34 & 12.91 & 6.19 & 5.02 & 5.78 & 6.73 \\
\hline $\mathrm{MnO}$ & 0.11 & 0.19 & 0.12 & 0.10 & 0.13 & 0.12 \\
\hline $\mathrm{CaO}$ & 16.09 & 12.16 & 14.56 & 15.85 & 15.75 & 13.62 \\
\hline $\mathrm{MgO}$ & 14.04 & 8.97 & 11.00 & 12.17 & 12.52 & 12.42 \\
\hline $\mathrm{K} 2 \mathrm{O}$ & 0.02 & 0.05 & 0.04 & 0.05 & 0.16 & 0.08 \\
\hline $\mathrm{Na}_{2} \mathrm{O}$ & 0.93 & 2.18 & 1.78 & 1.15 & 1.40 & 1.32 \\
\hline $\mathrm{P}_{2} \mathrm{O}_{5}$ & 0.02 & 0.14 & 0.02 & 0.03 & 0.02 & 0.03 \\
\hline Total & 99.77 & 99.31 & 100.03 & 99.99 & 99.45 & 99.33 \\
\hline $\mathrm{Mg \#}$ & 82.42 & 55.33 & 76.01 & 81.21 & 79.43 & 76.69 \\
\hline
\end{tabular}

Rock type: $\mathrm{L}=\mathrm{Low} \mathrm{Mg} \#$ sample; $\mathrm{H}=$ High $\mathrm{Mg} \#$ sample; *Total $\mathrm{Fe}$ as $\mathrm{FeO}$

\begin{tabular}{crrrrrr} 
CIPW norms & \multicolumn{7}{c}{} \\
\hline fo & 12.28 & 9.19 & 10.78 & 11.13 & 10.63 & 12.33 \\
fa & 2.84 & 6.90 & 3.66 & 2.71 & 2.72 & 3.86 \\
en & 3.62 & 1.97 & 2.15 & 2.84 & 1.71 & 5.31 \\
fs & 0.76 & 1.34 & 0.66 & 0.63 & 0.40 & 1.51 \\
di & 29.85 & 15.65 & 21.28 & 25.00 & 30.86 & 17.32 \\
hd & 5.46 & 9.29 & 5.72 & 4.82 & 6.25 & 4.29 \\
wo & 0.00 & 0.00 & 0.00 & 0.00 & 0.00 & 0.00 \\
an & 35.25 & 28.87 & 38.36 & 40.94 & 31.33 & 40.33 \\
ab & 7.87 & 18.45 & 15.06 & 9.73 & 11.85 & 11.17 \\
or & 0.12 & 0.30 & 0.24 & 0.30 & 0.95 & 0.47 \\
ilm & 0.47 & 4.21 & 0.69 & 0.68 & 1.41 & 1.17 \\
ap & 0.04 & 0.36 & 0.05 & 0.07 & 0.06 & 0.07 \\
q & 0.00 & 0.00 & 0.00 & 0.00 & 0.00 & 0.00 \\
co & 0.00 & 0.00 & 0.00 & 0.00 & 0.00 & 0.00 \\
mt & 1.16 & 2.81 & 1.35 & 1.09 & 1.26 & 1.46 \\
ne & 0.00 & 0.00 & 0.00 & 0.00 & 0.00 & 0.00 \\
$\mathrm{Cr}_{2} \mathrm{O}_{3}$ & 0.14 & 0.04 & 0.07 & 0.13 & 0.08 & 0.11 \\
\hline $\mathrm{CIPW}$ & & & 0.00
\end{tabular}

CIPW norms calculated assuming $\mathrm{Fe}_{2} \mathrm{O}_{3} / \mathrm{FeO}^{*}=0.15$.

\begin{tabular}{lrlrrrr} 
Modes & \multicolumn{7}{l}{} \\
\hline Cpx & 57.85 & n.d & 46.45 & 49.54 & 57.11 & 35.72 \\
error & 1.04 & n.d & 1.44 & 0.75 & 3.24 & 5.87 \\
Opx & 18.42 & n.d & 16.07 & 16.58 & 15.18 & 23.30 \\
error & 0.60 & n.d & 0.87 & 0.44 & 2.28 & 4.18 \\
Plag & 20.53 & n.d & 34.29 & 30.51 & 26.68 & 37.80 \\
error & 0.73 & n.d & 0.96 & 0.53 & 2.02 & 3.57 \\
Sp & 3.45 & n.d & 3.15 & 3.20 & n.d. & 1.29 \\
error & 0.33 & n.d & 0.43 & 0.24 & - & 1.96 \\
\hline
\end{tabular}

Modes (in wt.\%) are calculated by mass balance using average composition of non-symplectite minerals.

Error is 1 S.D.; n.d.: not determined 
Table 4-2. Whole rock chemistry continued.

\begin{tabular}{|c|c|c|c|c|c|}
\hline Sample & OB93-69 & OB93-71 & OB93-72 & OB93-90 & OB93-96 \\
\hline Rock Type & $\mathrm{L}$ & $\mathrm{H}$ & $\mathrm{H}$ & $\mathrm{H}$ & $\mathrm{H}$ \\
\hline \multicolumn{6}{|l|}{$X R F w t . \%$} \\
\hline $\mathrm{SiO}_{2}$ & 48.57 & 45.60 & 48.18 & 46.49 & 48.41 \\
\hline $\mathrm{Al}_{2} \mathrm{O}_{3}$ & 19.54 & 11.68 & 20.29 & 18.48 & 15.72 \\
\hline $\mathrm{TiO}_{2}$ & 0.47 & 0.33 & 0.23 & 0.23 & 0.24 \\
\hline $\mathrm{FeO}^{*}$ & 6.02 & 8.65 & 3.58 & 4.23 & 4.96 \\
\hline $\mathrm{MnO}$ & 0.11 & 0.15 & 0.07 & 0.08 & 0.10 \\
\hline $\mathrm{CaO}$ & 14.10 & 11.53 & 16.44 & 15.48 & 16.09 \\
\hline $\mathrm{MgO}$ & 9.48 & 21.17 & 9.57 & 10.86 & 13.42 \\
\hline $\mathrm{K} 2 \mathrm{O}$ & 0.06 & 0.02 & 0.04 & 0.06 & 0.01 \\
\hline $\mathrm{Na}_{2} \mathrm{O}$ & 1.76 & 0.83 & 1.51 & 1.32 & 0.98 \\
\hline $\mathrm{P}_{2} \mathrm{O}_{5}$ & 0.02 & 0.02 & 0.02 & 0.02 & 0.01 \\
\hline Total & 100.12 & 99.98 & 99.93 & 97.25 & 99.94 \\
\hline $\mathrm{Mg \#}$ & 73.73 & 81.35 & 82.66 & 82.07 & 82.83 \\
\hline
\end{tabular}

Rock type: $\mathrm{L}=$ Low $\mathrm{Mg}$ \# sample; $\mathrm{H}=$ High $\mathrm{Mg} \#$ sample;

$$
\text { *Total } \mathrm{Fe} \text { as } \mathrm{FeO}
$$

\begin{tabular}{crrrrr} 
CIPW norms & \multicolumn{7}{c}{} \\
\hline fo & 8.42 & 29.36 & 9.47 & 11.91 & 12.09 \\
fa & 3.13 & 7.33 & 2.10 & 2.78 & 2.71 \\
en & 4.54 & 1.91 & 0.00 & 0.00 & 3.28 \\
fs & 1.54 & 0.43 & 0.00 & 0.00 & 0.67 \\
di & 15.23 & 19.25 & 22.26 & 21.70 & 27.81 \\
hd & 4.49 & 3.80 & 3.91 & 4.01 & 4.94 \\
wo & 0.00 & 0.00 & 0.00 & 0.00 & 0.00 \\
an & 45.24 & 28.08 & 48.47 & 44.32 & 38.46 \\
ab & 14.89 & 7.02 & 11.47 & 10.20 & 8.29 \\
or & 0.35 & 0.12 & 0.24 & 0.35 & 0.06 \\
$\mathrm{ilm}$ & 0.89 & 0.62 & 0.44 & 0.44 & 0.45 \\
ap & 0.04 & 0.05 & 0.05 & 0.04 & 0.04 \\
$\mathrm{q}$ & 0.00 & 0.00 & 0.00 & 0.00 & 0.00 \\
$\mathrm{co}$ & 0.00 & 0.00 & 0.00 & 0.00 & 0.00 \\
$\mathrm{mt}$ & 1.31 & 1.88 & 0.78 & 0.92 & 1.08 \\
$\mathrm{ne}$ & 0.00 & 0.00 & 0.71 & 0.53 & 0.00 \\
$\mathrm{Cr}_{2} \mathrm{O}_{3}$ & 0.11 & 0.26 & 0.11 & 0.14 & 0.13 \\
\hline $\mathrm{CW}$ & &
\end{tabular}

CIPW norms calculated assuming $\mathrm{Fe}_{2} \mathrm{O}_{3} / \mathrm{FeO}^{*}=0.15$.

\begin{tabular}{lrlrrr} 
Modes & \multicolumn{7}{l}{} \\
\hline Cpx & 33.26 & n.d & 46.29 & 47.69 & 55.37 \\
error & 2.78 & n.d & 1.63 & 0.94 & 1.18 \\
Opx & 17.17 & n.d & 8.95 & 12.84 & 16.76 \\
error & 1.78 & n.d & 0.95 & 0.56 & 0.68 \\
Plag & 46.64 & n.d & 41.59 & 35.28 & 24.23 \\
error & 1.77 & n.d & 1.13 & 0.66 & 0.82 \\
Sp & 2.92 & n.d & 3.38 & 4.30 & 3.89 \\
error & 0.97 & n.d & 0.50 & 0.30 & 0.37 \\
\hline
\end{tabular}

Modes (in wt.\%) are calculated by mass balance using average composition of non-symplectite minerals.

Error is 1 S.D.; n.d.: not determined 
Table 4-2. Whole rock chemistry continued.

\begin{tabular}{rrrrrrr}
\hline Sample & OB93-50 & OB93-54 & OB93-57 & OB93-60 OB93-61A & OB93-68 \\
\hline Rock Type & $\mathrm{H}$ & \multicolumn{1}{c}{$\mathrm{L}$} & $\mathrm{L}$ & $\mathrm{H}$ & $\mathrm{L}$ & $\mathrm{L}$ \\
\hline$X R F p p m$ & & & & & & \\
$\mathrm{Ni}$ & 247 & 83 & 186 & 217 & 209 & 231 \\
$\mathrm{Cr}$ & 960 & 263 & 465 & 871 & 525 & 747 \\
$\mathrm{Sc}$ & 45 & 45 & 43 & 44 & 53 & 38 \\
$\mathrm{~V}$ & 212 & 402 & 170 & 196 & 268 & 207 \\
$\mathrm{Ba}$ & $\mathrm{d} .1$. & 61 & $\mathrm{~d} .1$. & $\mathrm{d} .1$. & 143 & 30 \\
$\mathrm{Sr}$ & 104 & 184 & 156 & 135 & 248 & 179 \\
$\mathrm{Zr}$ & 13 & 66 & 18 & 19 & 36 & 28 \\
$\mathrm{Y}$ & 5 & 27 & 7 & 6 & 10 & 7 \\
$\mathrm{Ga}$ & 14 & 18 & 15 & 14 & 12 & 15 \\
$\mathrm{Cu}$ & 4 & 245 & 5 & 11 & 13 & 41 \\
$\mathrm{Zn}$ & 22 & 94 & 33 & 24 & 16 & 43 \\
& & & & & & \\
\hline ICP-MS ppm & & & & & & \\
$\mathrm{La}$ & 0.52 & 3.71 & 0.63 & 1.25 & 2.67 & 2.07 \\
$\mathrm{Ce}$ & 0.98 & 11.51 & 1.52 & 2.50 & 6.85 & 4.84 \\
$\mathrm{Pr}$ & 0.19 & 1.92 & 0.27 & 0.38 & 1.06 & 0.72 \\
$\mathrm{Nd}$ & 1.04 & 10.97 & 1.56 & 1.87 & 5.42 & 3.45 \\
$\mathrm{Sm}$ & 0.49 & 3.96 & 0.72 & 0.69 & 1.74 & 1.14 \\
$\mathrm{Eu}$ & 0.30 & 1.52 & 0.44 & 0.38 & 0.68 & 0.56 \\
$\mathrm{Gd}$ & 0.74 & 5.01 & 1.01 & 0.98 & 2.04 & 1.34 \\
$\mathrm{~Tb}$ & 0.15 & 0.90 & 0.19 & 0.18 & 0.36 & 0.24 \\
$\mathrm{Dy}$ & 0.95 & 5.78 & 1.23 & 1.10 & 2.23 & 1.52 \\
$\mathrm{Ho}$ & 0.19 & 1.17 & 0.25 & 0.23 & 0.45 & 0.30 \\
$\mathrm{Er}$ & 0.52 & 3.09 & 0.67 & 0.57 & 1.14 & 0.80 \\
$\mathrm{Tm}$ & 0.08 & 0.43 & 0.09 & 0.08 & 0.16 & 0.11 \\
$\mathrm{Yb}$ & 0.44 & 2.60 & 0.59 & 0.49 & 0.97 & 0.66 \\
$\mathrm{Lu}$ & 0.07 & 0.40 & 0.09 & 0.08 & 0.14 & 0.10 \\
$\mathrm{Ba}$ & 10.7 & 99.2 & 11.2 & 23.3 & 135.6 & 30.0 \\
$\mathrm{Th}$ & 0.07 & 0.03 & 0.02 & 0.12 & 0.21 & 0.09 \\
$\mathrm{Nb}$ & 0.36 & 6.86 & 0.22 & 1.18 & 1.65 & 0.58 \\
$\mathrm{Y}$ & 5.08 & 29.41 & 6.47 & 5.77 & 11.16 & 7.72 \\
$\mathrm{Hf}$ & 0.19 & 1.96 & 0.29 & 0.32 & 0.91 & 0.60 \\
$\mathrm{Ta}$ & 0.02 & 0.48 & 0.02 & 0.08 & 0.11 & 0.06 \\
$\mathrm{U}$ & 0.02 & 0.03 & 0.00 & 0.03 & 0.04 & 0.03 \\
$\mathrm{~Pb}$ & 1.23 & 0.26 & 2.67 & 1.03 & 3.79 & 2.65 \\
$\mathrm{Rb}$ & 0.81 & 1.04 & 0.54 & 1.17 & 2.98 & 1.21 \\
$\mathrm{Cs}$ & 0.13 & 0.10 & 0.04 & 0.08 & 0.69 & 0.07 \\
$\mathrm{Sr}$ & 105 & 186 & 157 & 138 & 258 & 181 \\
$\mathrm{Sc}$ & 54.0 & 53.3 & 45.1 & 46.2 & 61.3 & 39.9 \\
\hline $\mathrm{dr}$ & & & & &
\end{tabular}

d.1: below detection limit 
Table 4-2. Whole rock chemistry continued.

\begin{tabular}{rrrrrr}
\hline Sample & OB93-69 & OB93-71 & OB93-72 & OB93-90 & OB93-96 \\
\hline Rock Type & $\mathrm{L}$ & $\mathrm{H}$ & $\mathrm{H}$ & $\mathrm{H}$ & $\mathrm{H}$ \\
\hline XRF ppm & & & & & \\
$\mathrm{Ni}$ & 167 & 701 & 189 & 241 & 238 \\
$\mathrm{Cr}$ & 762 & 1772 & 782 & 926 & 903 \\
$\mathrm{Sc}$ & 40 & 30 & 40 & 40 & 43 \\
$\mathrm{~V}$ & 159 & 130 & 103 & 103 & 214 \\
$\mathrm{Ba}$ & 34 & $\mathrm{~d} .1$ & 41 & 125 & $\mathrm{~d} .1$. \\
$\mathrm{Sr}$ & 179 & 77 & 199 & 169 & 126 \\
$\mathrm{Zr}$ & 18 & 18 & 18 & 17 & 14 \\
$\mathrm{Y}$ & 6 & 5 & 4 & 3 & 5 \\
$\mathrm{Ga}$ & 17 & 9 & 13 & 11 & 14 \\
$\mathrm{Cu}$ & 39 & 55 & 16 & 15 & 6 \\
$\mathrm{Zn}$ & 35 & 72 & 16 & 22 & 16 \\
& & & & & \\
\hline ICP-MS ppm & & & & & \\
$\mathrm{La}$ & 0.87 & 0.55 & 0.57 & 0.53 & 0.39 \\
$\mathrm{Ce}$ & 1.91 & 1.56 & 1.13 & 1.09 & 0.76 \\
$\mathrm{Pr}$ & 0.31 & 0.27 & 0.20 & 0.20 & 0.15 \\
$\mathrm{Nd}$ & 1.74 & 1.50 & 1.03 & 0.99 & 0.88 \\
$\mathrm{Sm}$ & 0.74 & 0.63 & 0.46 & 0.43 & 0.44 \\
$\mathrm{Eu}$ & 0.54 & 0.31 & 0.29 & 0.29 & 0.28 \\
$\mathrm{Gd}$ & 1.04 & 0.87 & 0.68 & 0.68 & 0.66 \\
$\mathrm{~Tb}$ & 0.20 & 0.17 & 0.13 & 0.12 & 0.13 \\
$\mathrm{Dy}$ & 1.28 & 1.09 & 0.83 & 0.81 & 0.88 \\
$\mathrm{Ho}$ & 0.27 & 0.23 & 0.17 & 0.18 & 0.19 \\
$\mathrm{Er}$ & 0.71 & 0.59 & 0.45 & 0.45 & 0.47 \\
$\mathrm{Tm}$ & 0.10 & 0.08 & 0.06 & 0.06 & 0.07 \\
$\mathrm{Yb}$ & 0.61 & 0.52 & 0.38 & 0.37 & 0.41 \\
$\mathrm{Lu}$ & 0.09 & 0.08 & 0.06 & 0.05 & 0.06 \\
$\mathrm{Ba}$ & 22.1 & 3.2 & 37.7 & 116.7 & 27.6 \\
$\mathrm{Th}$ & 0.03 & 0.01 & 0.02 & 0.04 & 0.01 \\
$\mathrm{Nb}$ & 0.21 & 0.06 & 0.18 & 0.24 & 0.15 \\
$\mathrm{Y}$ & 6.65 & 5.51 & 4.25 & 4.11 & 4.65 \\
$\mathrm{Hf}$ & 0.29 & 0.36 & 0.21 & 0.21 & 0.16 \\
$\mathrm{Ta}$ & 0.01 & 0.02 & 0.02 & 0.02 & 0.01 \\
$\mathrm{U}$ & 0.01 & 0.00 & 0.00 & 0.01 & 0.00 \\
$\mathrm{~Pb}$ & 1.31 & 18.74 & 0.21 & 0.62 & 3.23 \\
$\mathrm{Rb}$ & 0.93 & 0.51 & 0.71 & 1.93 & 0.33 \\
$\mathrm{Cs}$ & 0.05 & 0.08 & 0.29 & 0.35 & 0.07 \\
$\mathrm{Sr}$ & 183 & 78 & 195 & 166 & 125 \\
$\mathrm{Sc}$ & 36.9 & 35.9 & 35.7 & 36.1 & 51.1 \\
\hline $\mathrm{d}$ l $\mathrm{bel}$ & & & & & \\
& & & & &
\end{tabular}

d.l: below detection limit 
Table 4-3. Representative clinopyroxene major element compositions.

\begin{tabular}{|c|c|c|c|c|c|c|}
\hline \multirow{2}{*}{$\frac{\text { Sample }}{w t . \%}$} & \multirow[t]{2}{*}{ OB93-50 } & \multirow{2}{*}{ OB93-54 } & \multicolumn{2}{|c|}{ OB93-57 } & \multirow{2}{*}{ OB93-60 } & \multirow{2}{*}{ OB93-61A } \\
\hline & & & & & & \\
\hline $\mathrm{SiO}_{2}$ & 50.11 & 50.30 & 50.76 & 49.55 & 50.05 & 48.29 \\
\hline $\mathrm{TiO}_{2}$ & 0.47 & 0.61 & 0.72 & 0.79 & 0.43 & 1.20 \\
\hline $\mathrm{Al}_{2} \mathrm{O}_{3}$ & 7.34 & 5.17 & 6.31 & 6.67 & 7.00 & 7.23 \\
\hline $\mathrm{Cr}_{2} \mathrm{O}_{3}$ & 0.28 & 0.03 & 0.16 & 0.18 & 0.23 & 0.09 \\
\hline $\mathrm{FeO}^{*}$ & 4.76 & 9.85 & 8.74 & 6.53 & 4.75 & 6.34 \\
\hline $\mathrm{MnO}$ & 0.10 & 0.10 & 0.16 & 0.11 & 0.12 & 0.13 \\
\hline $\mathrm{MgO}$ & 13.82 & 11.78 & 15.53 & 13.16 & 14.05 & 12.89 \\
\hline $\mathrm{CaO}$ & 21.74 & 20.19 & 16.98 & 20.61 & 21.64 & 21.58 \\
\hline $\mathrm{Na}_{2} \mathrm{O}$ & 0.74 & 1.35 & 0.87 & 1.02 & 0.77 & 0.99 \\
\hline Total & 99.37 & 99.39 & 100.24 & 98.62 & 99.04 & 98.75 \\
\hline \multicolumn{7}{|c|}{ Cations/6 Oxygens } \\
\hline $\mathrm{Si}$ & 1.845 & 1.892 & 1.862 & 1.852 & 1.850 & 1.811 \\
\hline $\mathrm{Ti}$ & 0.013 & 0.017 & 0.020 & 0.022 & 0.012 & 0.034 \\
\hline $\mathrm{Al}$ & 0.319 & 0.229 & 0.273 & 0.294 & 0.305 & 0.319 \\
\hline $\mathrm{Cr}$ & 0.008 & 0.001 & 0.005 & 0.005 & 0.007 & 0.003 \\
\hline $\mathrm{Fe}$ & 0.147 & 0.310 & 0.268 & 0.204 & 0.147 & 0.199 \\
\hline $\mathrm{Mn}$ & 0.003 & 0.003 & 0.005 & 0.003 & 0.004 & 0.004 \\
\hline $\mathrm{Mg}$ & 0.759 & 0.660 & 0.849 & 0.733 & 0.774 & 0.721 \\
\hline $\mathrm{Ca}$ & 0.858 & 0.814 & 0.667 & 0.825 & 0.857 & 0.867 \\
\hline $\mathrm{Na}$ & 0.053 & 0.099 & 0.062 & 0.074 & 0.056 & 0.072 \\
\hline Total & 4.005 & 4.025 & 4.011 & 4.013 & 4.010 & 4.030 \\
\hline $\mathrm{Mg \#}$ & 83.80 & 68.06 & 76.00 & 78.21 & 84.05 & 78.36 \\
\hline $\mathrm{Eq} \operatorname{Liq} \mathrm{Mg \#}$ & 56.93 & 35.26 & 44.74 & 47.85 & 57.39 & 48.06 \\
\hline \multicolumn{7}{|c|}{ Molar percentage of endmembers } \\
\hline Wo & 48.64 & 45.60 & 37.39 & 46.82 & 48.19 & 48.53 \\
\hline En & 43.04 & 37.02 & 47.58 & 41.60 & 43.54 & 40.33 \\
\hline Fs & 8.32 & 17.37 & 15.02 & 11.59 & 8.26 & 11.14 \\
\hline
\end{tabular}

Eq Liq Mg\#: Mg\# of cpx equilibrium melt, calculated from $\left[\left(\mathrm{Fe}^{2+} / \mathrm{Mg}\right) \mathrm{cpx} /\left(\mathrm{Fe}^{2+} / \mathrm{Mg}\right)\right.$ liq $]=0.23$ (Grove, and Bryan, 1983); and $\mathrm{Fe}^{2+} / \mathrm{Fe}^{3+}=0.9$. 
Table 4-3. Clinopyroxene major element compositions continued.

\begin{tabular}{|c|c|c|c|c|c|c|}
\hline Sample & OB93-68 & OB93-69 & OB93-71 & OB93-72 & OB93-90 & OB93-96 \\
\hline \multicolumn{7}{|l|}{$w t \%$} \\
\hline $\mathrm{SiO}_{2}$ & 48.73 & 49.87 & 50.52 & 50.36 & 51.01 & 50.50 \\
\hline $\mathrm{TiO}_{2}$ & 1.50 & 1.20 & 0.61 & 0.60 & 0.52 & 0.44 \\
\hline $\mathrm{Al}_{2} \mathrm{O}_{3}$ & 7.49 & 6.17 & 7.14 & 7.59 & 7.19 & 7.29 \\
\hline $\mathrm{Cr}_{2} \mathrm{O}_{3}$ & 0.13 & 0.28 & 0.20 & 0.20 & 0.21 & 0.26 \\
\hline $\mathrm{FeO}^{*}$ & 6.84 & 7.07 & 4.39 & 4.87 & 4.73 & 4.77 \\
\hline $\mathrm{MnO}$ & 0.11 & 0.14 & 0.13 & 0.11 & 0.07 & 0.12 \\
\hline $\mathrm{MgO}$ & 12.66 & 12.71 & 13.89 & 13.52 & 14.19 & 14.22 \\
\hline $\mathrm{CaO}$ & 21.41 & 21.37 & 20.92 & 20.99 & 21.53 & 21.78 \\
\hline $\mathrm{Na}_{2} \mathrm{O}$ & 0.93 & 0.95 & 1.29 & 0.85 & 0.84 & 0.74 \\
\hline Total & 99.81 & 99.76 & 99.09 & 99.10 & 100.28 & 100.12 \\
\hline \multicolumn{7}{|c|}{ Cations/6 Oxygens } \\
\hline $\mathrm{Si}$ & 1.809 & 1.852 & 1.860 & 1.855 & 1.857 & 1.845 \\
\hline $\mathrm{Ti}$ & 0.042 & 0.034 & 0.017 & 0.017 & 0.014 & 0.012 \\
\hline $\mathrm{Al}$ & 0.328 & 0.270 & 0.310 & 0.329 & 0.308 & 0.314 \\
\hline $\mathrm{Cr}$ & 0.004 & 0.008 & 0.006 & 0.006 & 0.006 & 0.008 \\
\hline $\mathrm{Fe}$ & 0.212 & 0.220 & 0.135 & 0.150 & 0.144 & 0.146 \\
\hline $\mathrm{Mn}$ & 0.004 & 0.004 & 0.004 & 0.003 & 0.002 & 0.004 \\
\hline $\mathrm{Mg}$ & 0.700 & 0.703 & 0.762 & 0.742 & 0.770 & 0.775 \\
\hline $\mathrm{Ca}$ & 0.852 & 0.850 & 0.825 & 0.828 & 0.840 & 0.853 \\
\hline $\mathrm{Na}$ & 0.067 & 0.068 & 0.092 & 0.061 & 0.059 & 0.052 \\
\hline Total & 4.017 & 4.010 & 4.012 & 3.991 & 4.001 & 4.008 \\
\hline Mg\# & 76.73 & 76.20 & 84.95 & 83.18 & 84.24 & 84.15 \\
\hline Eq Liq Mg\# & 45.73 & 45.00 & 59.05 & 55.82 & 57.74 & 57.57 \\
\hline \multicolumn{7}{|c|}{ Molar percentage of endmembers } \\
\hline Wo & 48.27 & 47.96 & 47.90 & 48.14 & 47.89 & 48.09 \\
\hline En & 39.69 & 39.66 & 44.25 & 43.13 & 43.90 & 43.68 \\
\hline Fs & 12.04 & 12.39 & 7.84 & 8.72 & 8.21 & 8.23 \\
\hline
\end{tabular}

Eq Liq Mg\#: $\mathrm{Mg} \#$ of cpx equilibrium melt, calculated from $\left[\left(\mathrm{Fe}^{2+} / \mathrm{Mg}\right) \mathrm{cpx} /\left(\mathrm{Fe}^{2+} / \mathrm{Mg}\right)\right.$ liq $]=0.23$ (Grove, and Bryan, 1983); and $\mathrm{Fe}^{2+} / \mathrm{Fe}^{3+}=0.9$. 
Table 4-4. Representative orthopyroxene major element compositions.

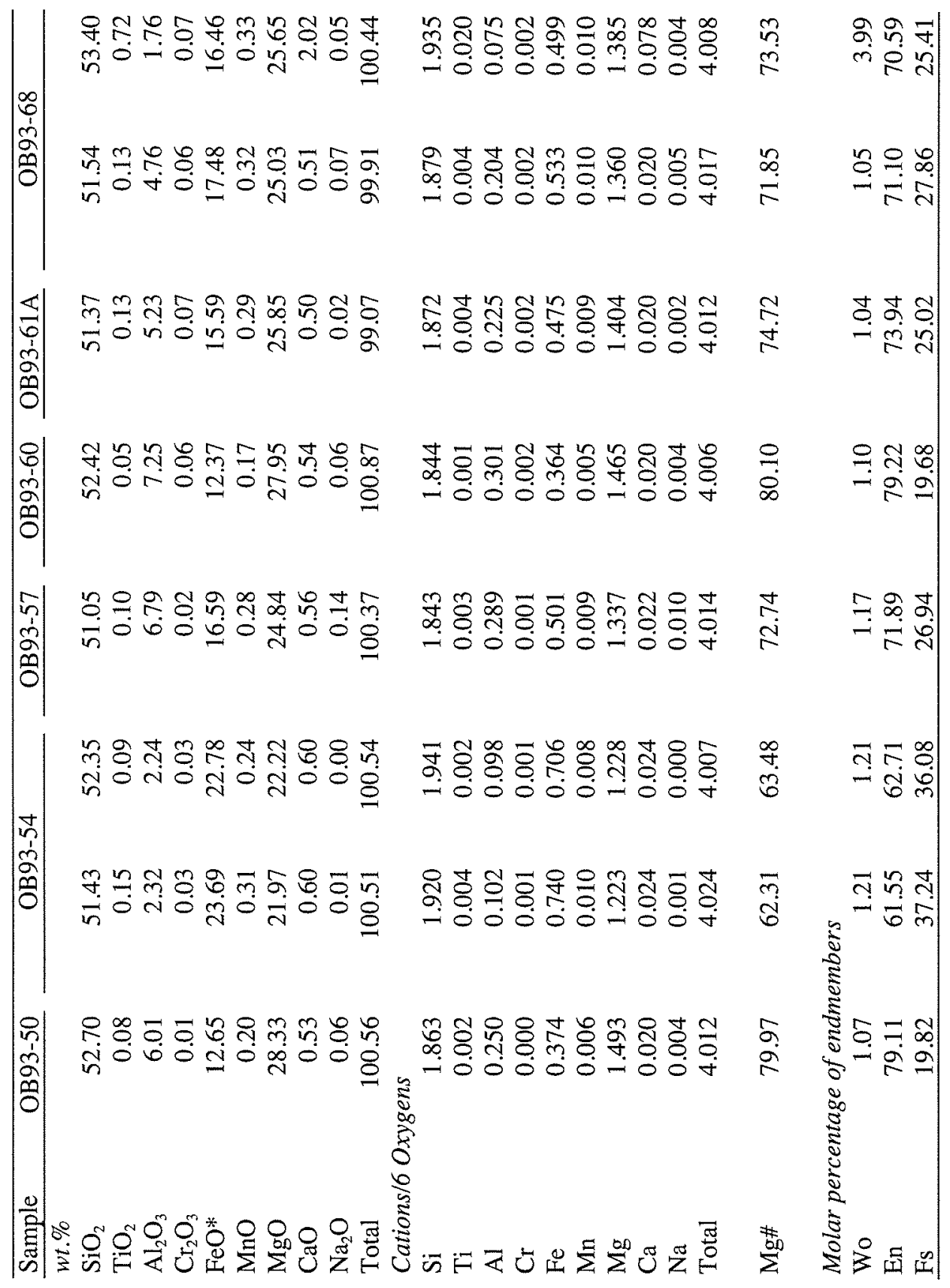


Table 4 4. Orthopyroxene major element compositions continued.

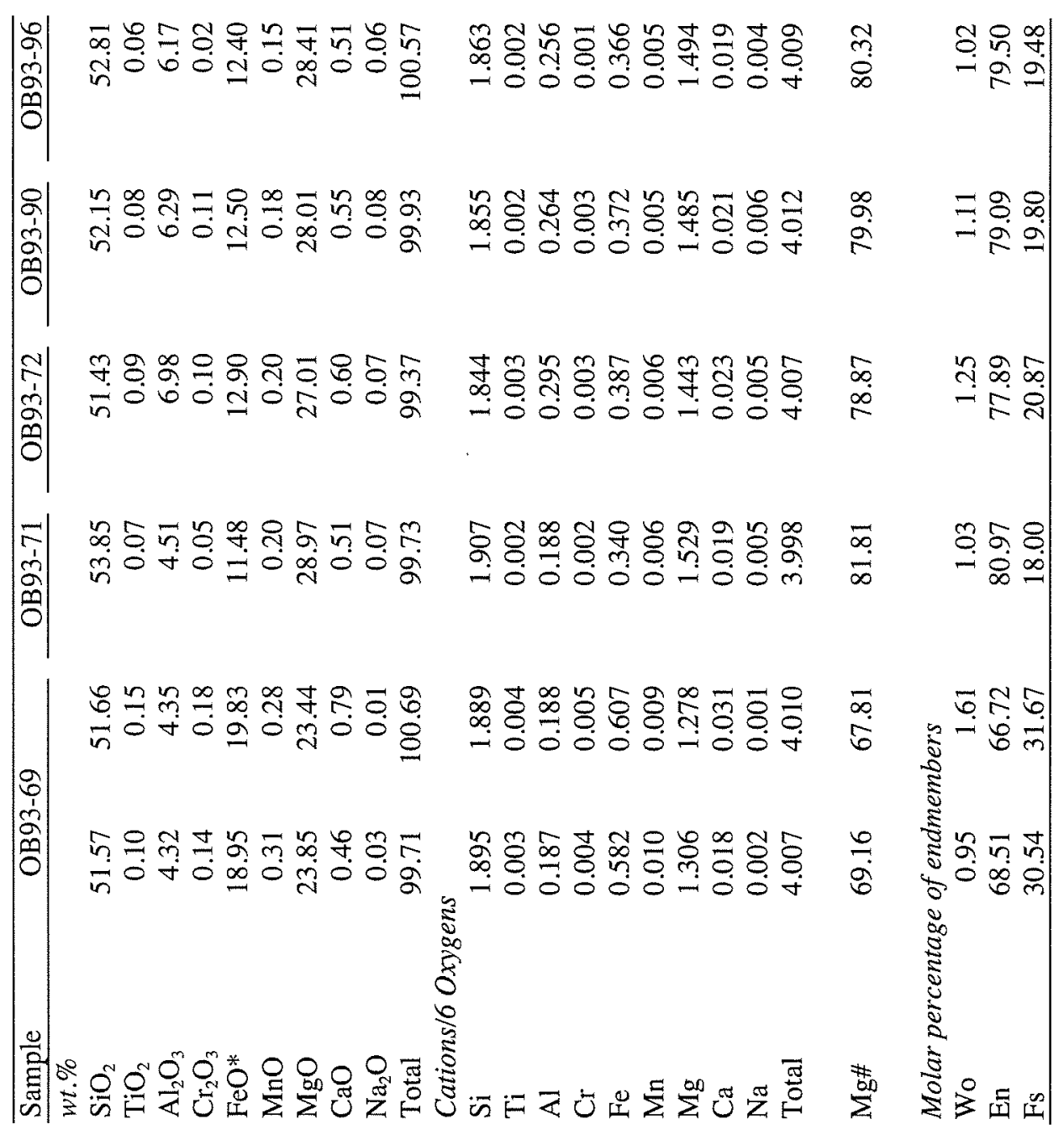


Table 4-5. Representative plagioclase major element compositions.

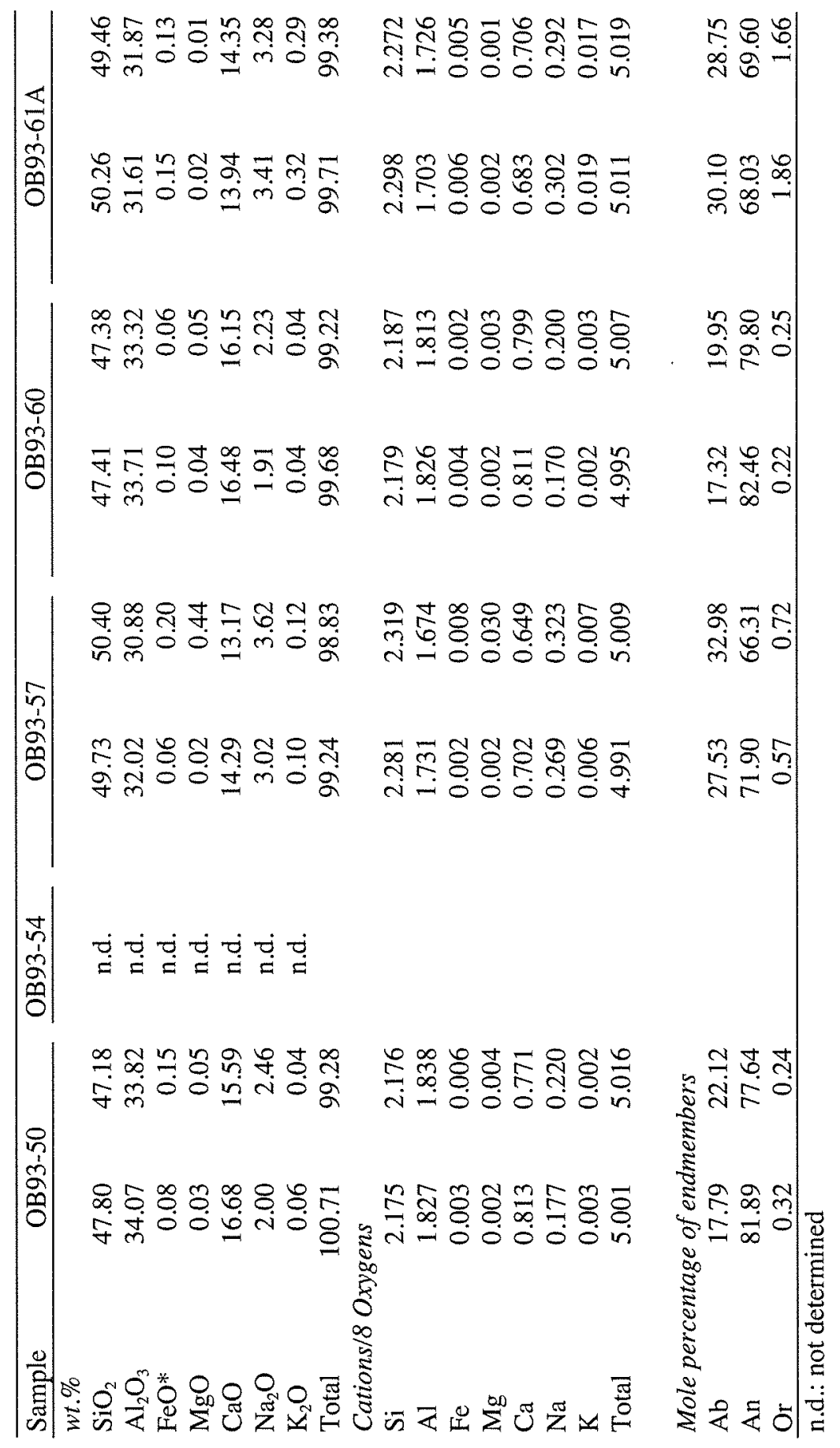


Table 4-5. Plagioclase major element compositions continued.

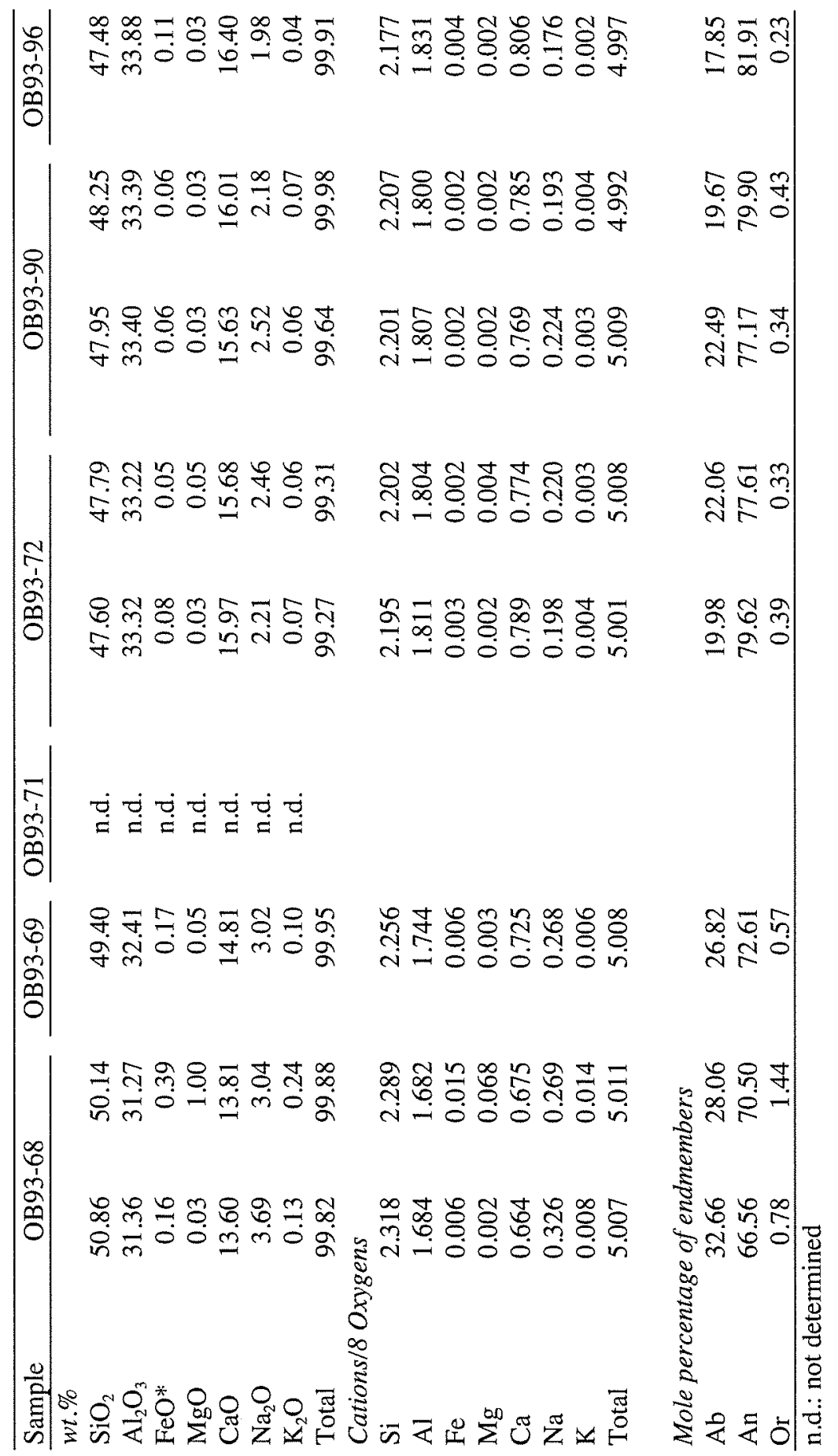


Table 4-6. Olivine major element compositions.

\begin{tabular}{lr}
\hline Sample & OB93-71 \\
\hline$w t . \%$ & 39.44 \\
$\mathrm{SiO}_{2}$ & 0.02 \\
$\mathrm{TiO}_{2}$ & 0.00 \\
$\mathrm{Al}_{2} \mathrm{O}_{3}$ & 0.01 \\
$\mathrm{Cr}_{2} \mathrm{O}_{3}$ & 18.86 \\
$\mathrm{FeO}^{*}$ & 0.22 \\
$\mathrm{MnO}$ & 41.84 \\
$\mathrm{MgO}$ & 0.04 \\
$\mathrm{CaO}$ & 0.00 \\
$\mathrm{Na} 2$ & 100.42 \\
$\mathrm{Total}$ & \\
$\mathrm{Cations} / 4$ Oxygens & 1.003 \\
$\mathrm{Si}$ & 0.000 \\
$\mathrm{Ti}$ & 0.000 \\
$\mathrm{Al}$ & 0.000 \\
$\mathrm{Cr}$ & 0.401 \\
$\mathrm{Fe}$ & 0.005 \\
$\mathrm{Mn}$ & 1.586 \\
$\mathrm{Mg}$ & 0.001 \\
$\mathrm{Ca}$ & 0.000 \\
$\mathrm{Na}$ & 2.997 \\
$\mathrm{Cation}$ & \\
& 79.81 \\
$\mathrm{Fo}$ content &
\end{tabular}


Table 4-7. Representative spinel major element compositions.

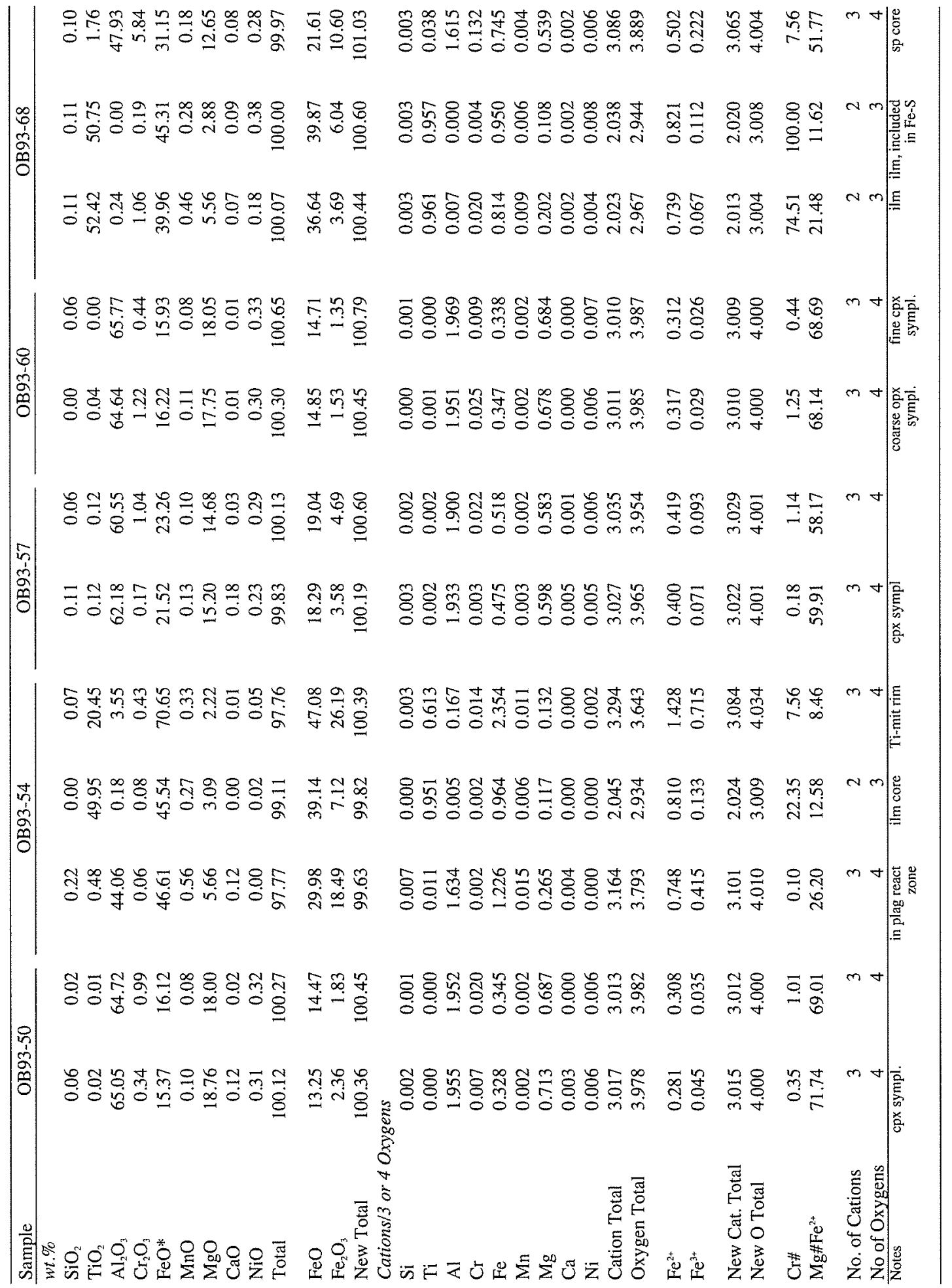


Table 4-7. Spinel major elemenet compositions continued.

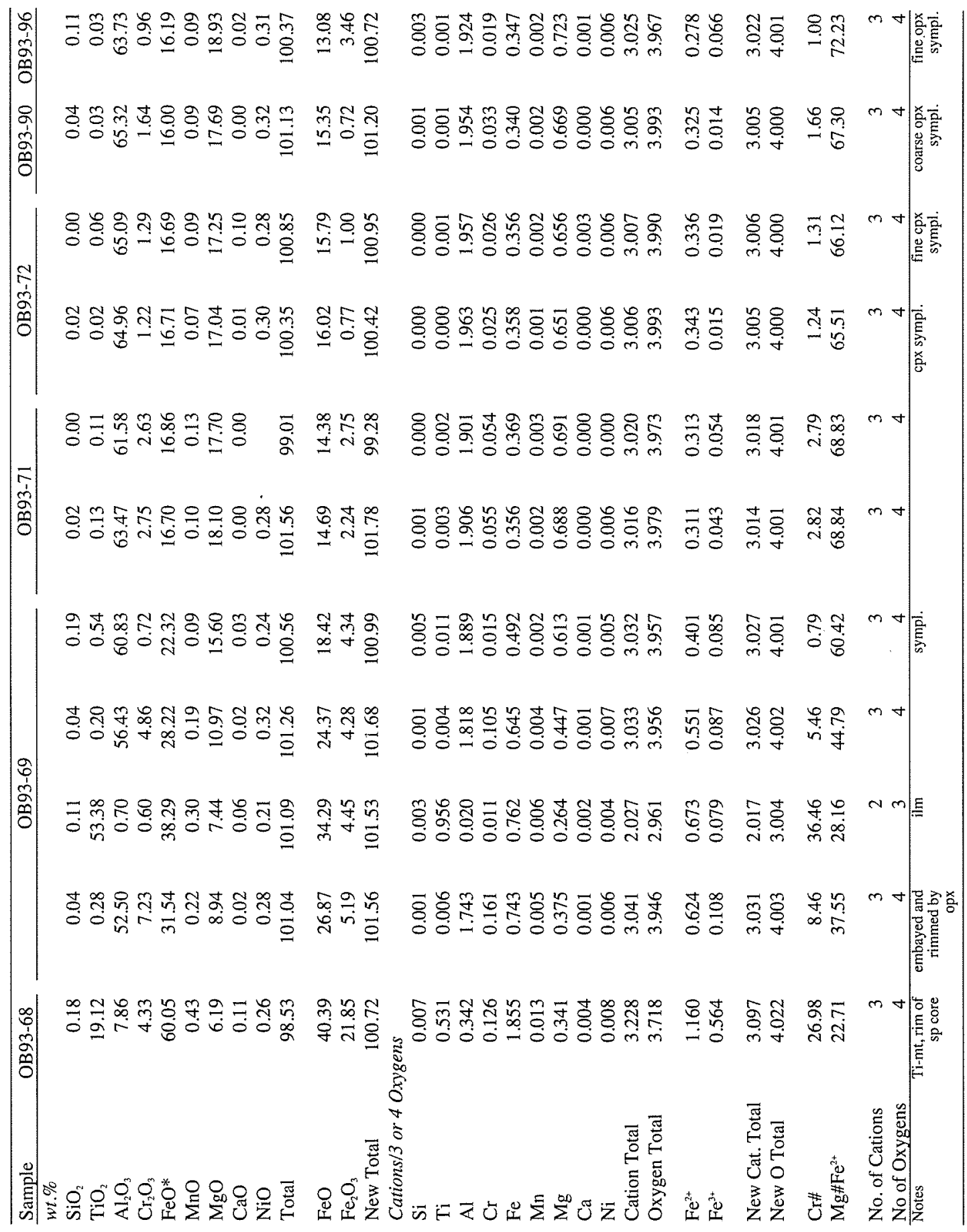


Table 4-8. Metamorphic equilibration temperatures estimated with the two pyroxene thermometer of Wells (1977).

\begin{tabular}{|c|c|c|c|}
\hline Sample & Mineral Combinations & $\begin{array}{c}\text { Average } \\
\text { Temperature }\left({ }^{\circ} \mathrm{C}\right)\end{array}$ & $\begin{array}{l}\text { Temperature } \\
\text { Range }\left({ }^{\circ} \mathrm{C}\right)\end{array}$ \\
\hline \multicolumn{4}{|c|}{$M g \#<90$} \\
\hline OB93-54 & 3 Cpx \& 2 Opx, both discrete & 841 & $830-850$ \\
\hline \multirow[t]{2}{*}{ OB93-57 } & 3 Cpx \& 4 Opx, both discrete & 902 & 898-907 \\
\hline & 1 Cpx \& 2 Opx, both symplectites & 901 & $898-903$ \\
\hline OB93-61A & 2 Cpx \& 2 Opx, both discrete & 864 & $808-907$ \\
\hline \multirow[t]{2}{*}{ OB93-68 } & 3 Cpx \& 3 Opx, both discrete & 848 & $844-849$ \\
\hline & 3 discrete Cpx \& 1 symplectite Opx & 844 & \\
\hline \multirow[t]{2}{*}{ OB93-69 } & 2 Cpx \& 3 Opx, both discrete & 867 & $851-882$ \\
\hline & 1 Cpx \& 1 Opx, both symplectites & 870 & \\
\hline \multirow{3}{*}{ OB93-50 } & $M g \#>90$ & & \\
\hline & 2 Cpx \& 1 Opx, both discrete & 899 & $896-902$ \\
\hline & 2 discrete Cpx \& 3 symplectite Opx & 896 & $894-898$ \\
\hline \multirow[t]{2}{*}{ OB93-60 } & $4 \mathrm{Cpx} \& 2$ Opx, both discrete & 912 & 903-917 \\
\hline & 2 Cpx \& 2 Opx, both symplectite & 922 & $902-933$ \\
\hline OB93-71 & 3 Cpx \& 2 Opx, both discrete & 888 & $876-905$ \\
\hline \multirow[t]{2}{*}{ OB93-72 } & 1 Cpx \& 2 Opx, both discrete & 945 & $942-947$ \\
\hline & $1 \mathrm{Cpx} \& 1 \mathrm{Opx}$, both symplectites & 961 & 961 \\
\hline \multirow[t]{2}{*}{ OB93-90 } & $3 \mathrm{Cpx} \& 2$ Opx, both discrete & 939 & $937-941$ \\
\hline & $1 \mathrm{Cpx} \& 1 \mathrm{Opx}$, both symplectites & 933 & \\
\hline \multirow[t]{2}{*}{ OB93-96 } & 2 Cpx \& 2 Opx, both discrete & 919 & $915-922$ \\
\hline & $1 \mathrm{Cpx} \& 1 \mathrm{Opx}$, both symplectites & 943 & $942-943$ \\
\hline
\end{tabular}

Equilibrium temperatures determined with

the two-pyroxene thermometer of Wells (1977). 
Table 4-9. Representative trace element compositions of clinopyroxenes.

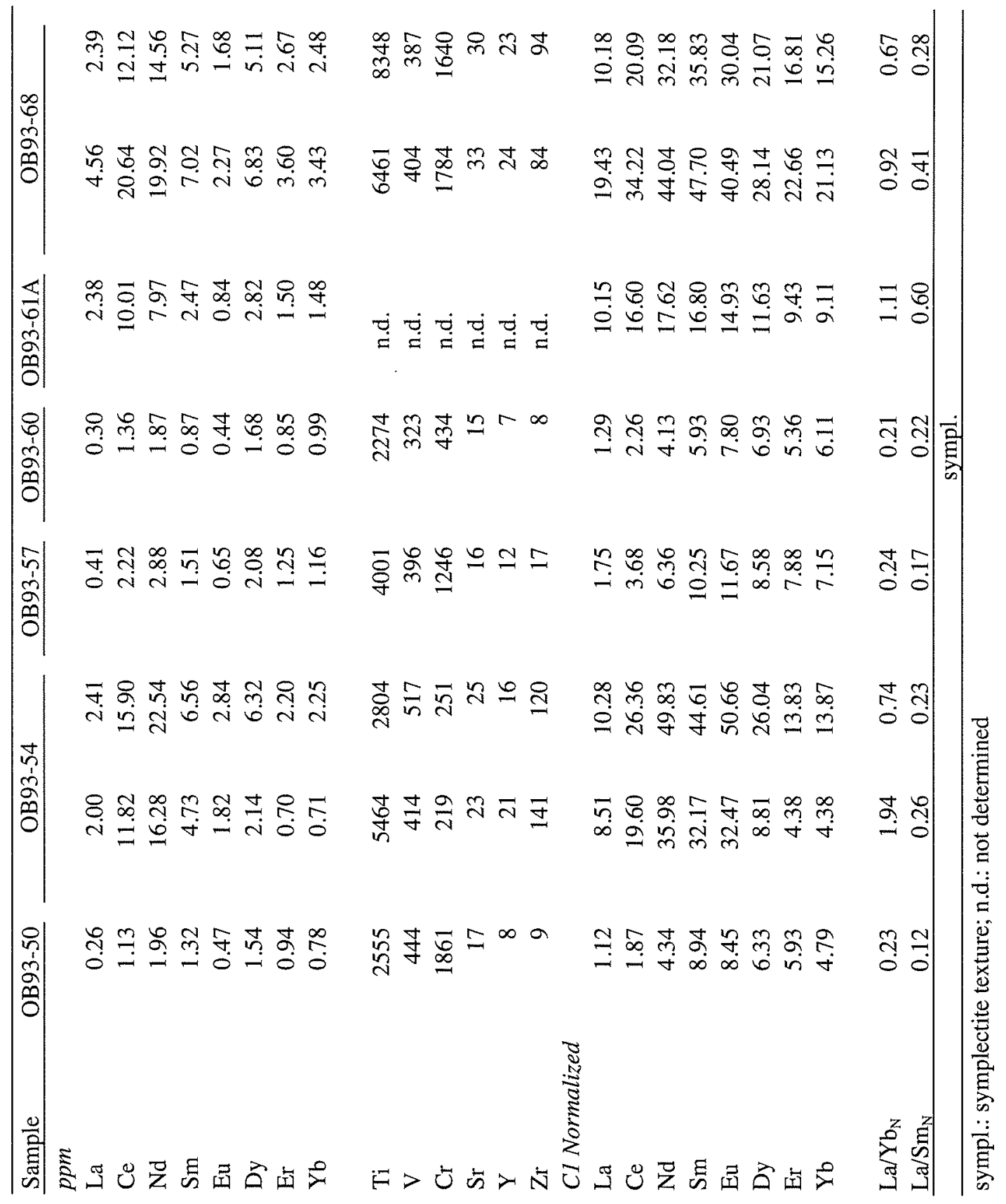


Table 4-9. Trace element compositions of clinopyroxenes continued.

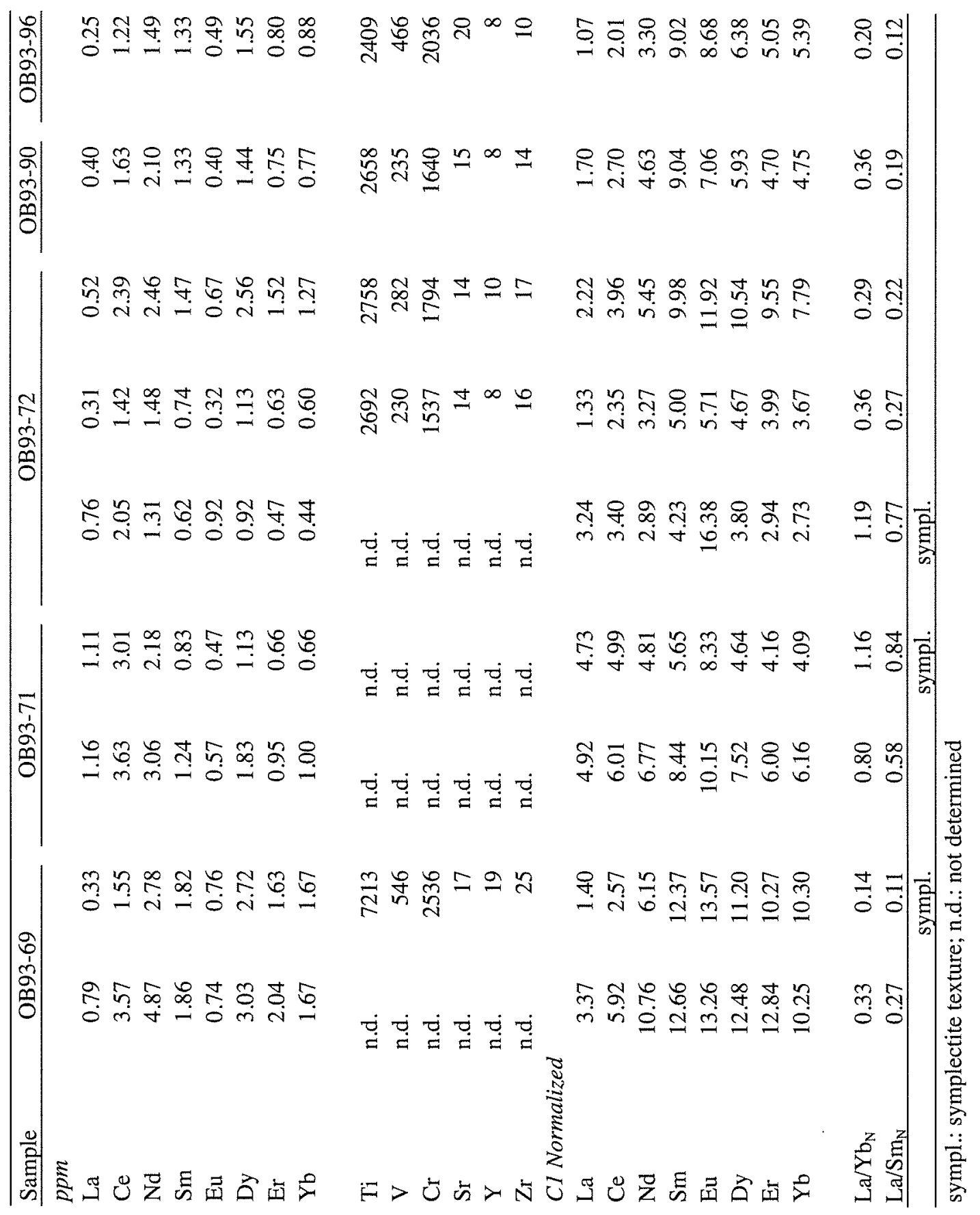


Table 4-10. Sr and $\mathrm{Nd}$ isotopic compositions.

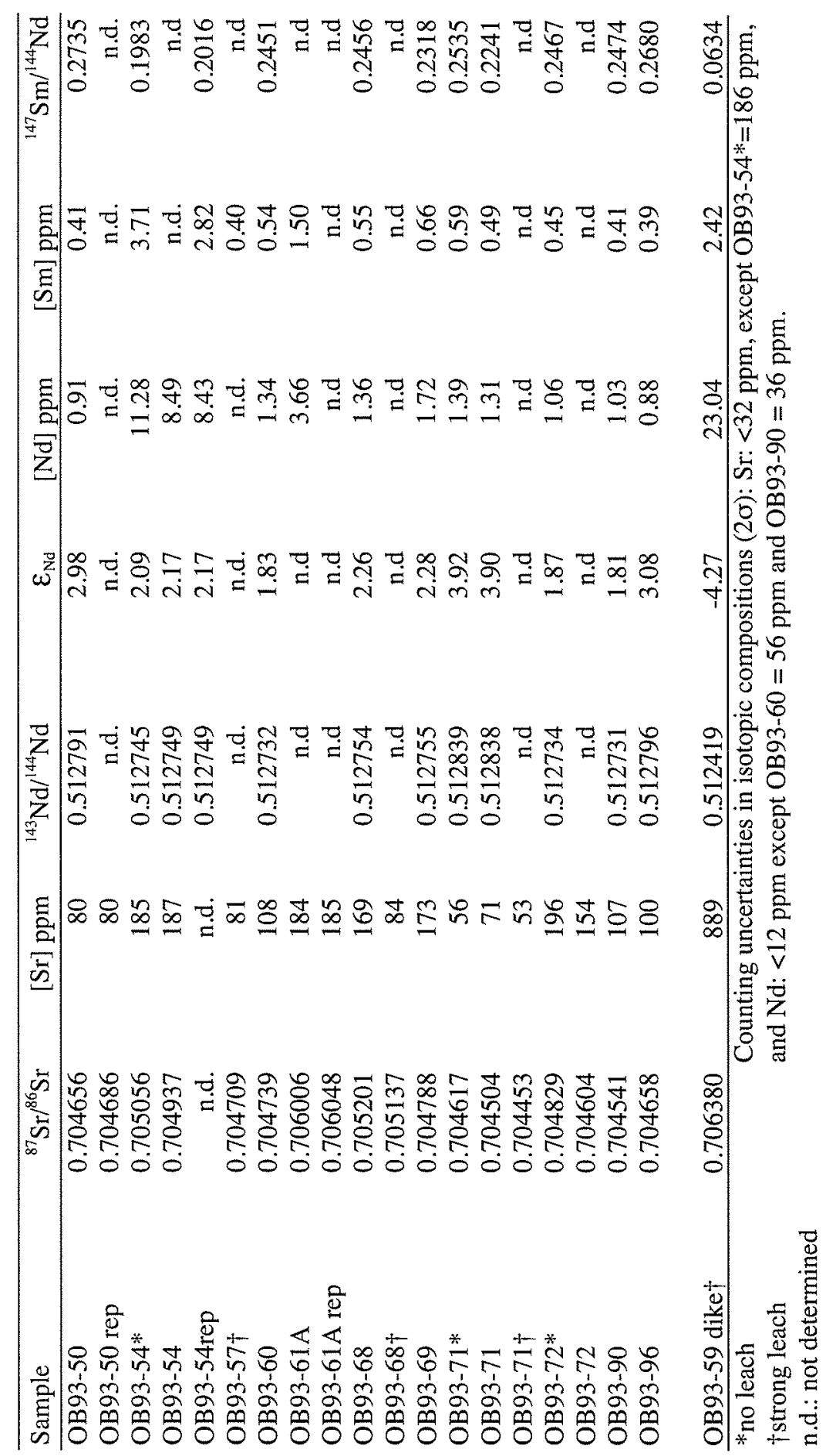


Table 4-11. Re-Os isotopic compositions.

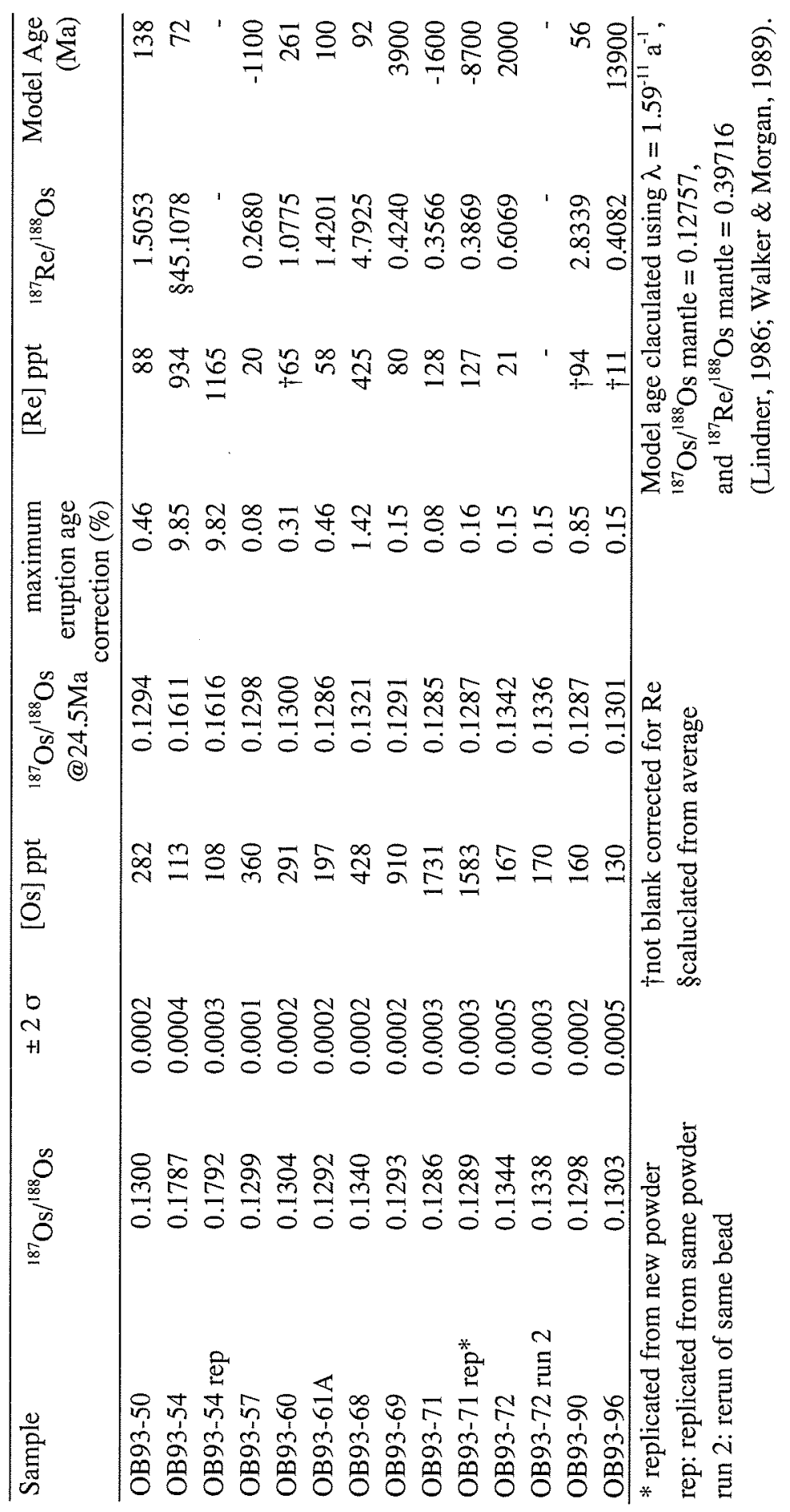




\subsection{Figures}

Figure 4-1. Examples of granulite textures and mineralogy. Crossed polarized light photomicrograph of the typical granulite texture (Sample OB93-50). Note the relatively equigranular texture. Plagioclase (low birefringent and twinned grains), orthopyroxene (low birefringence with no twinning), and clinopyroxene (high order colors) are present. Pyroxene exsolution is present in both orthopyroxene and clinopyroxene. The field of view is $10 \mathrm{~mm}$ across.

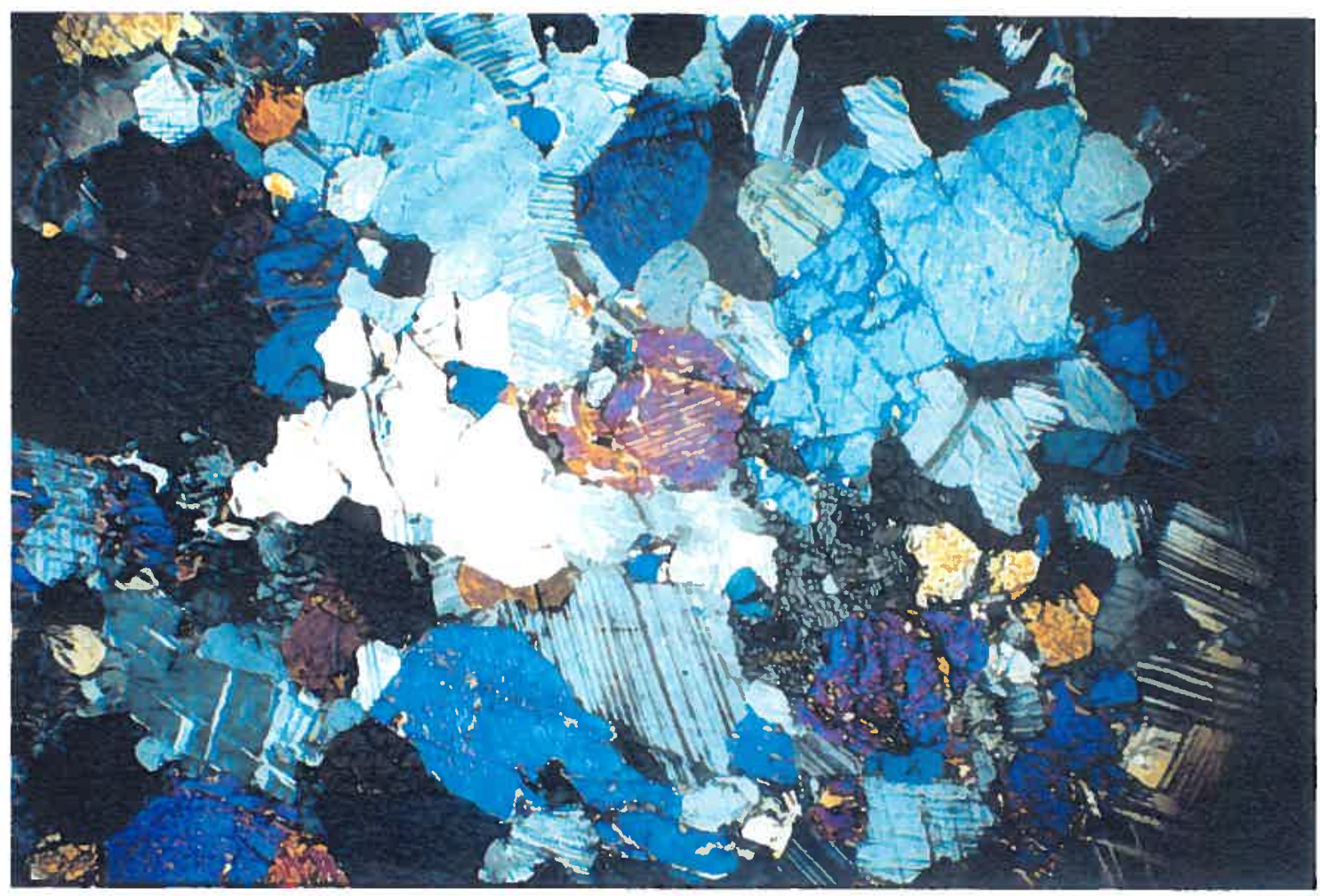


Figure 4-1 continued. Close up crossed polarized light photomicrograph of the typical granulite texture (Sample OB93-90). Note the equigranular texture and $120^{\circ}$ grain boundaries among plagioclase and orthopyroxene grains (central). A spinel (black) is visible in the top central part of the frame. The field of view is $2.5 \mathrm{~mm}$ across.

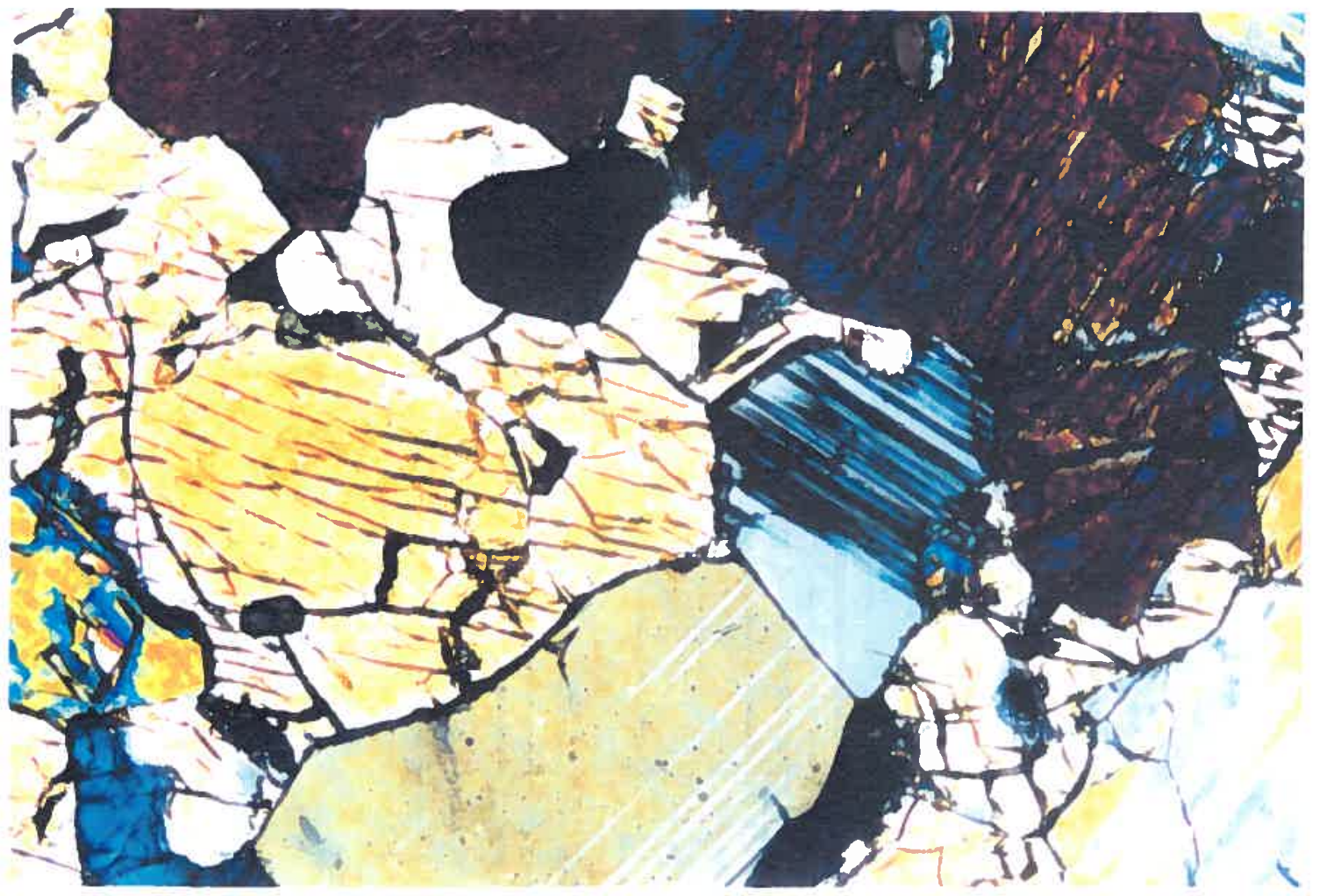


Figure 4-1 continued. Crossed polarized light photomicrograph of an example of the coarse symplectite texture (Sample OB93-57). Again, note the equigranular texture with $120^{\circ}$ grain boundaries. Symplectite spinel (black, lower left) is within an orthopyroxene grain. The field of view is $2.5 \mathrm{~mm}$ across.

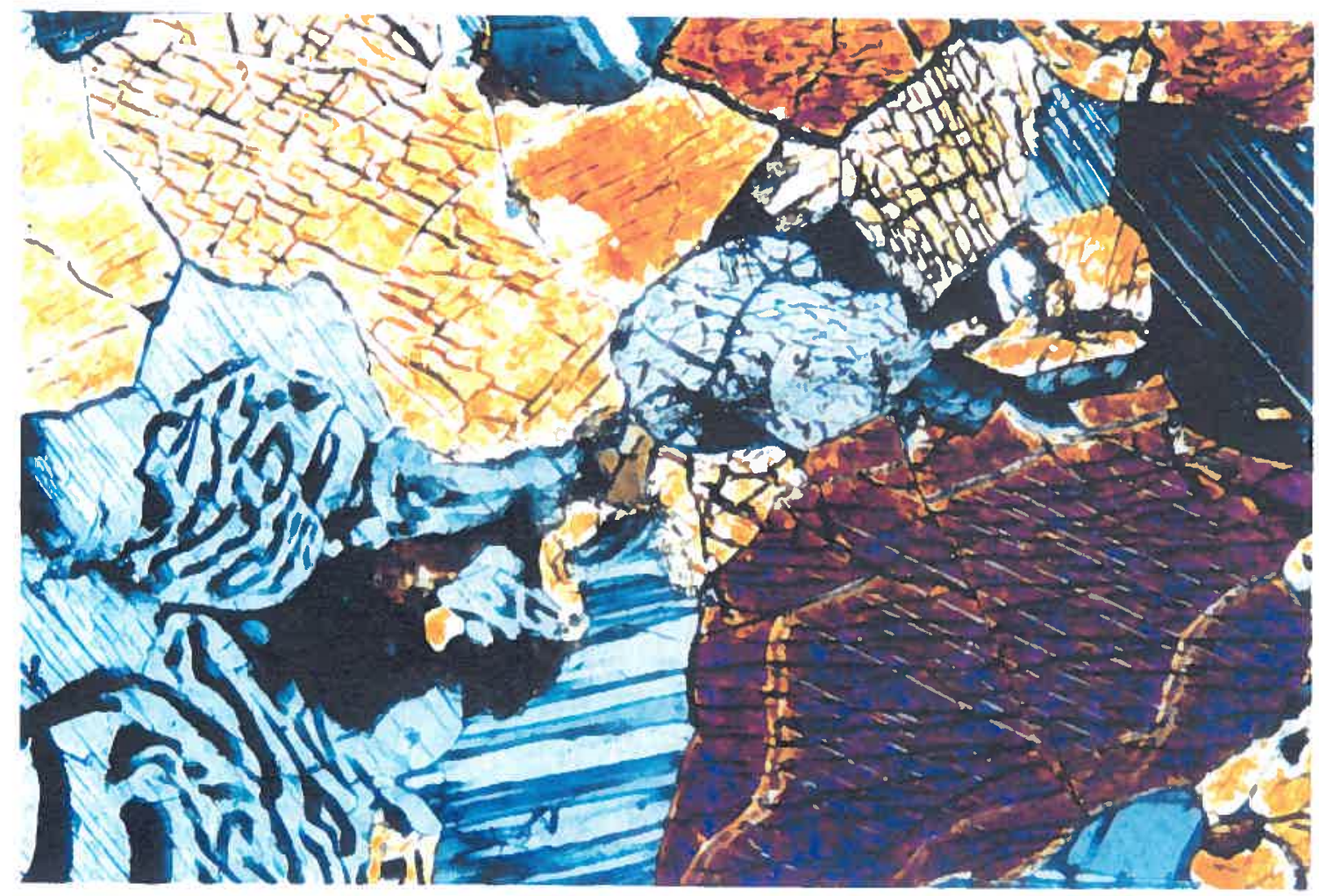


Figure 4-1 continued. Crossed polarized light photomicrograph of an example of the fine symplectite texture (Sample OB93-68). Symplectite spinel (black, upper central) is within an orthopyroxene grain. Plagioclase (lower central) and clinopyroxene are present. The field of view is $1.25 \mathrm{~mm}$ across.

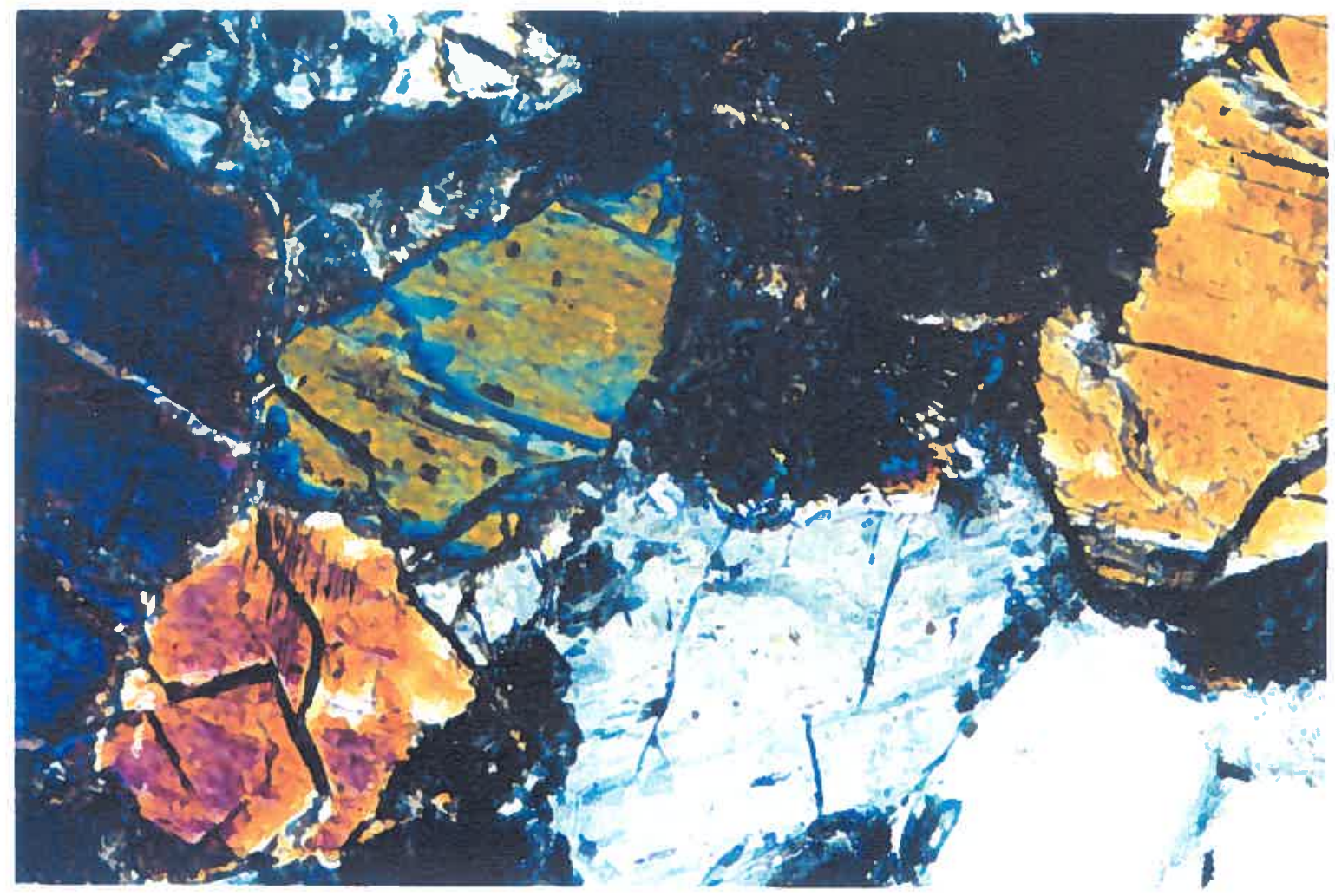



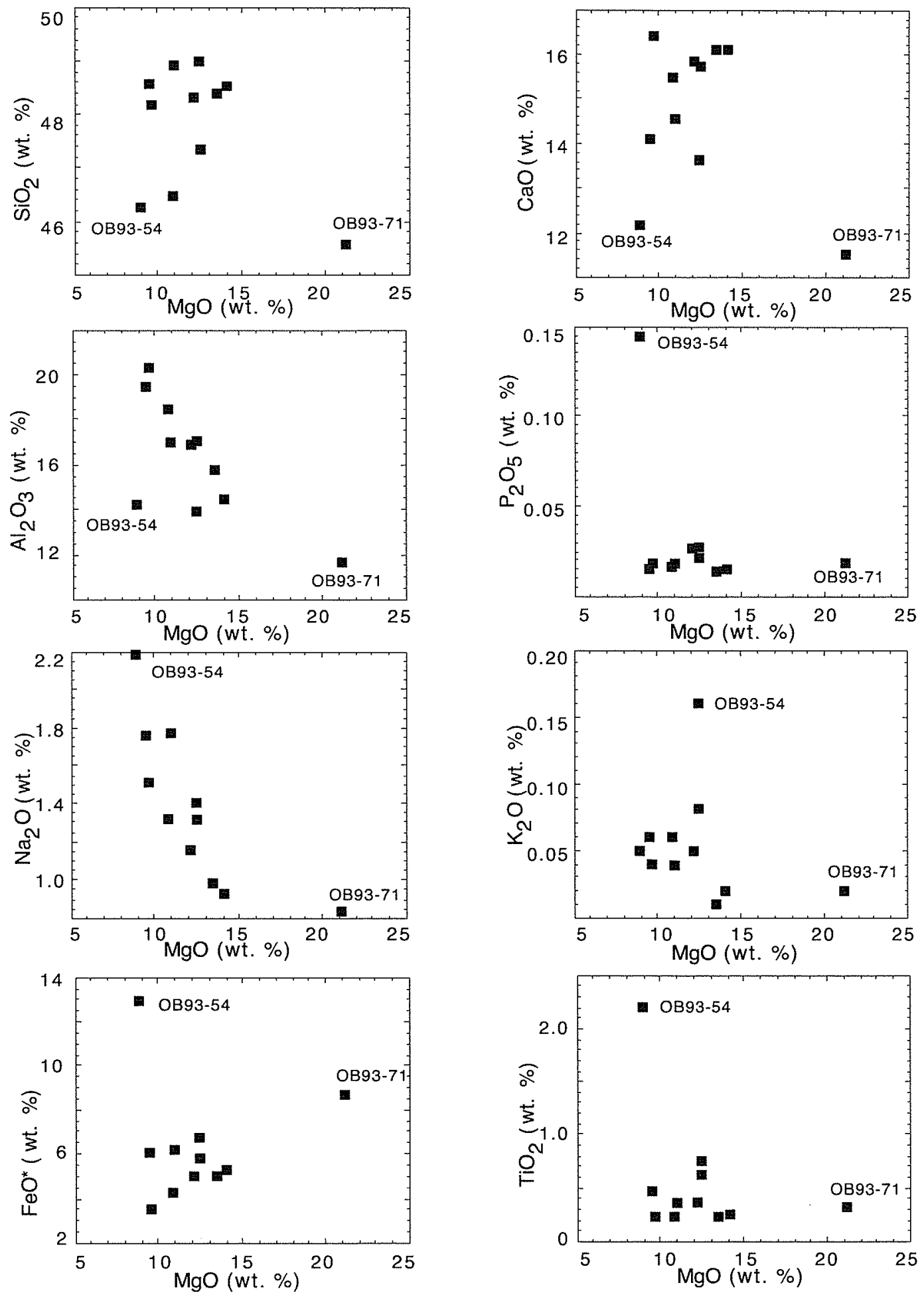

Figure 4-2. Major element bulk-rock variation diagrams. Granulite compositions are shown as filled squares. Each symbol represents a single sample. 
Figure 4-3. Bulk rock major element compositions (Mg\# v. $\mathrm{SiO}_{2}$ wt.\%) of Courbet Peninsula granulites compared to those from the Southeastern Province. The granulites of this study (filled squares) show a similar variation as those from the Southeastern Province (Grègoire et al., 1994; Grègoire, 1994; Grègoire et al., 1998). Granulite types from the Southeastern Province are two pyroxene (open squares), ilmenite-bearing (gray squares), ilmenite and spinel-bearing (x), sapphirine-bearing (open circles), sapphirine and garnetbearing (closed circles) and garnet-bearing $(+)$. 


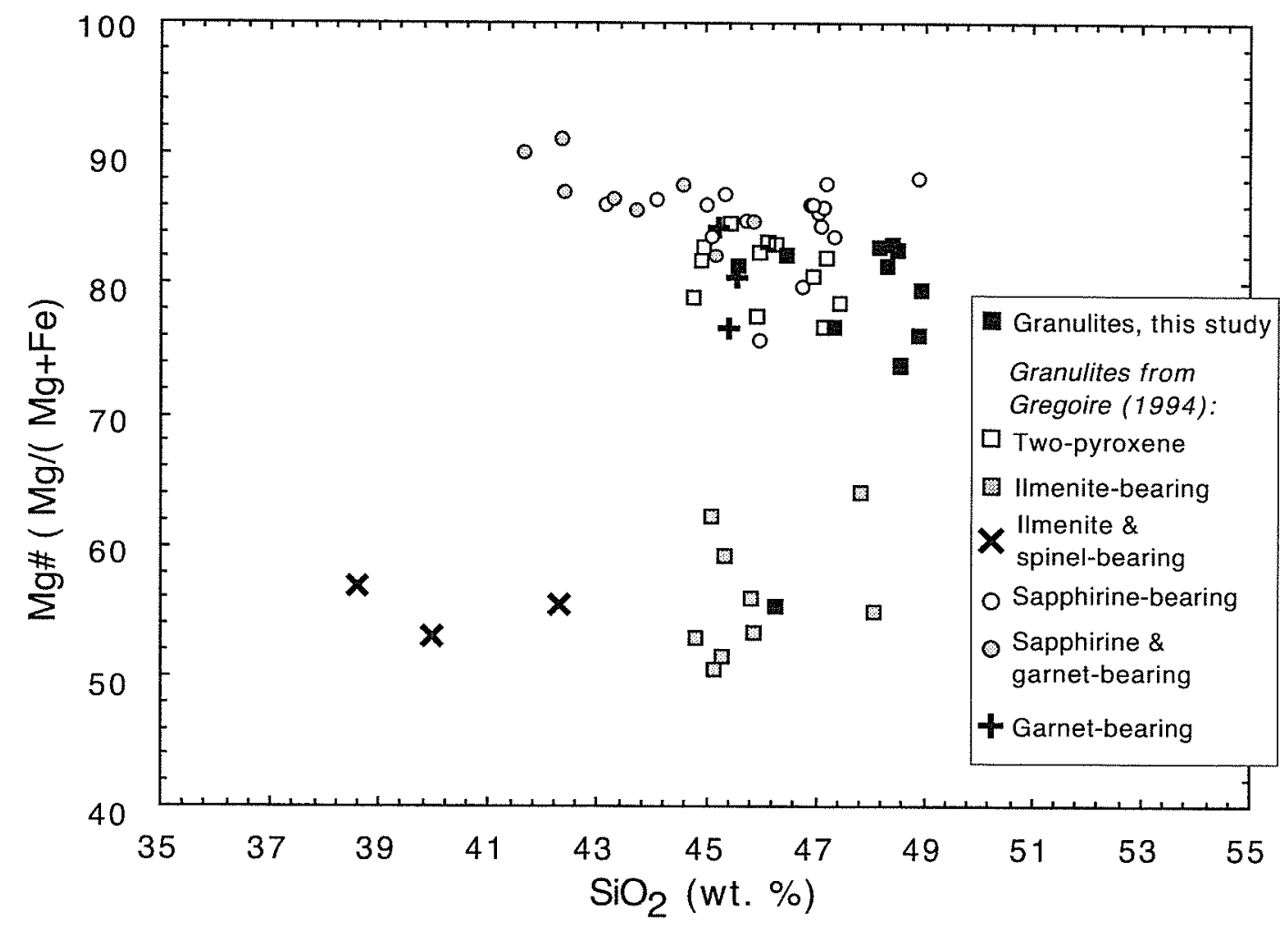


Figure 4 4. Whole rock geochemistry of Kerguelen granulites classified according to the IUGS system (Streckheisen, 1973). Calculated mineral modal abundances (gray circles) and CIPW normative minerals (filled squares) are shown. 


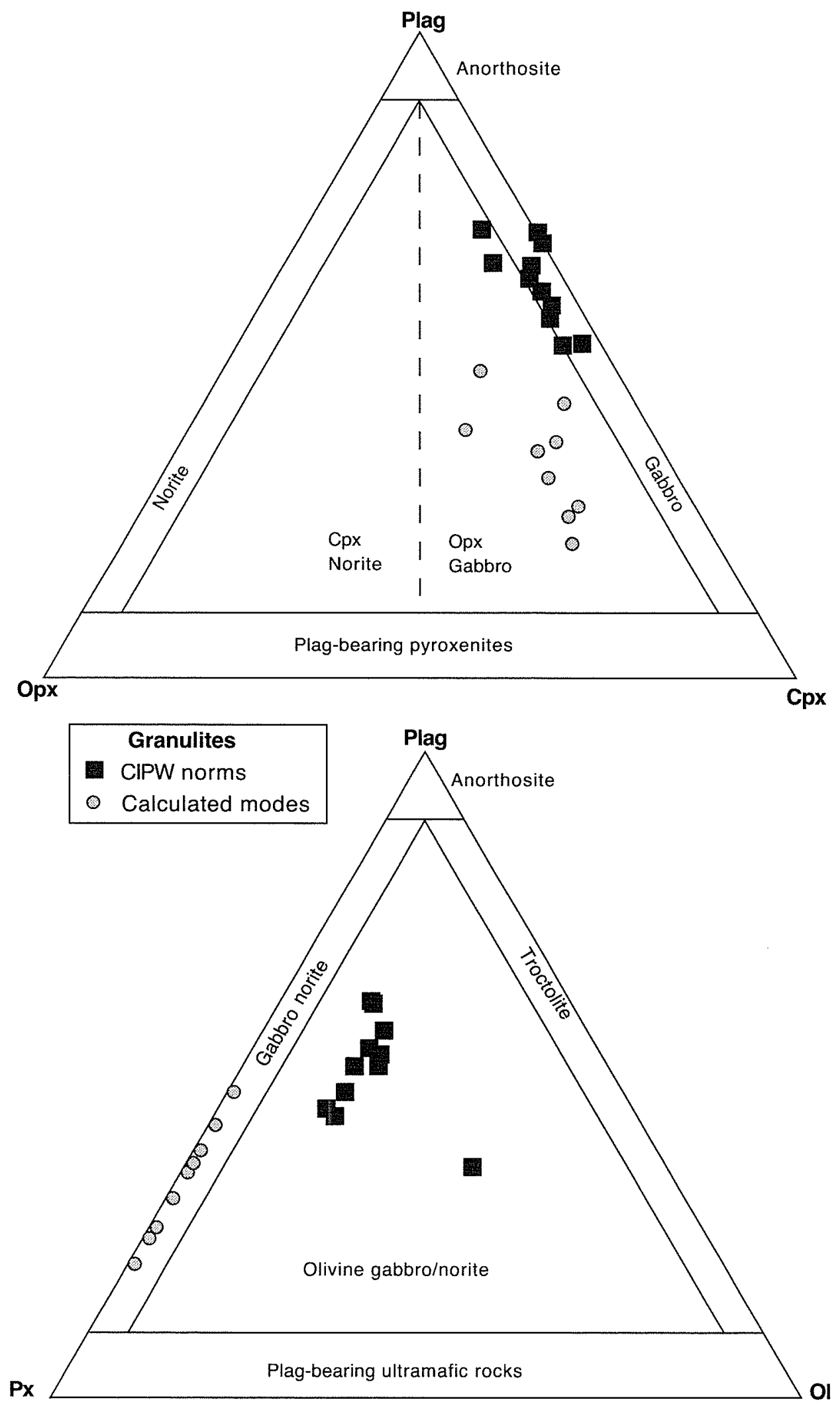


Figure 4-5. Granulite clinopyroxene major element compositions compared to those from other oceanic cumulate rocks. Granulite clinopyroxenes (filled diamonds) are more aluminous and sodic than other oceanic gabbros (panels $\mathrm{A}$ and $\mathrm{D}$ ), but have similar $\mathrm{TiO}_{2}$ and $\mathrm{Cr}_{2} \mathrm{O}_{3}$ for a given $\mathrm{Mg} \#$ (panels $\mathrm{B}$ and $\mathrm{C}$ ). Fields for oceanic cumulates and abyssal peridotite clinopyroxene compositions from a review paper by Elthon et al. (1992). 


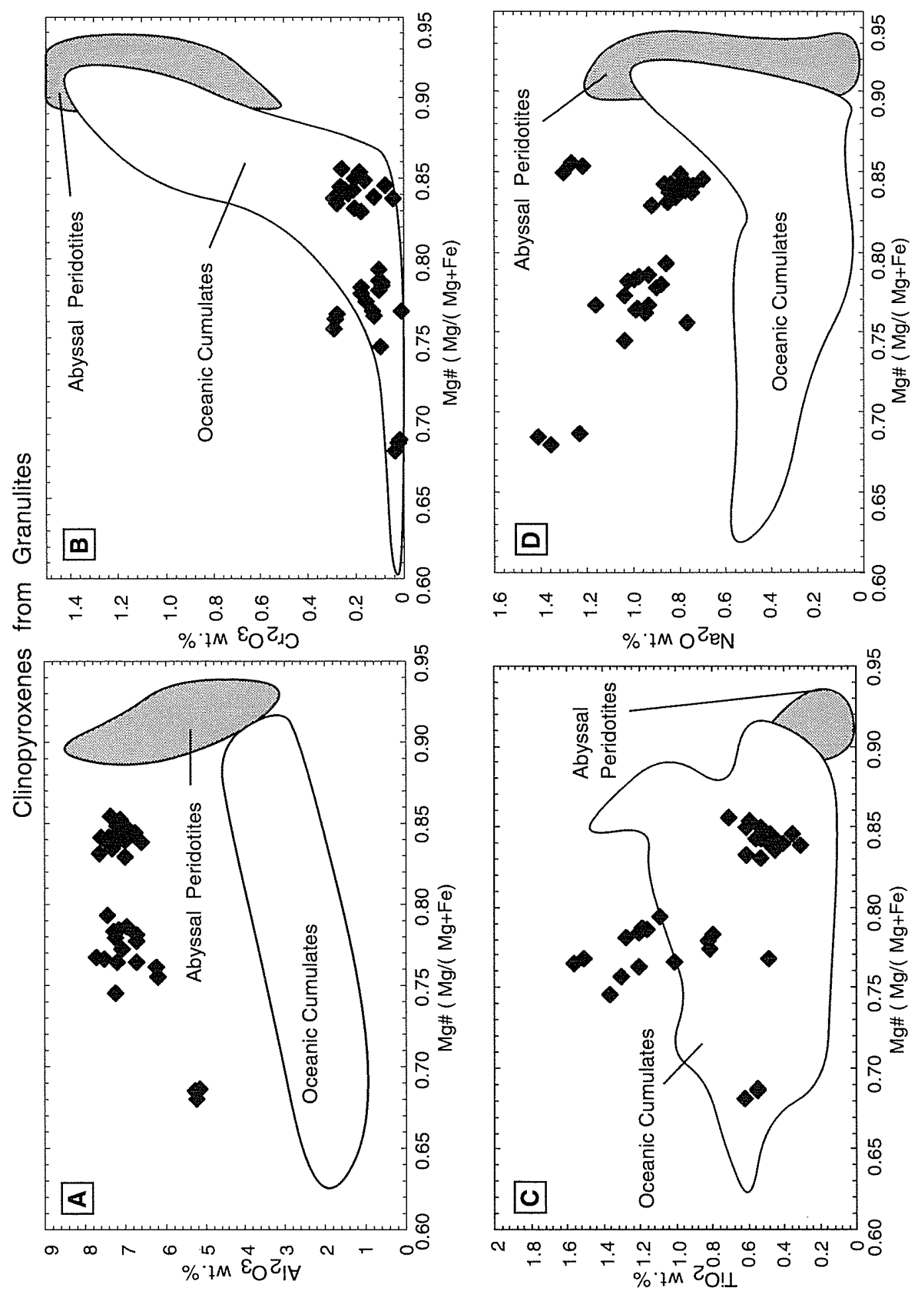


Figure 4-6. Granulite orthopyroxene major element compositions compared to orthopyroxene compositions from other oceanic cumulate rocks. Granulite orthopyroxenes (filled diamonds) are more aluminous than other oceanic cumulate rocks (panel A), but have similar $\mathrm{TiO}_{2}$ and $\mathrm{Cr}_{2} \mathrm{O}_{3}$ contents for a given $\mathrm{Mg \#} \mathrm{(panels} \mathrm{Band} \mathrm{C}$ ). Oceanic cumulates and abyssal peridotite fields from a review by Elthon et al. (1992). 

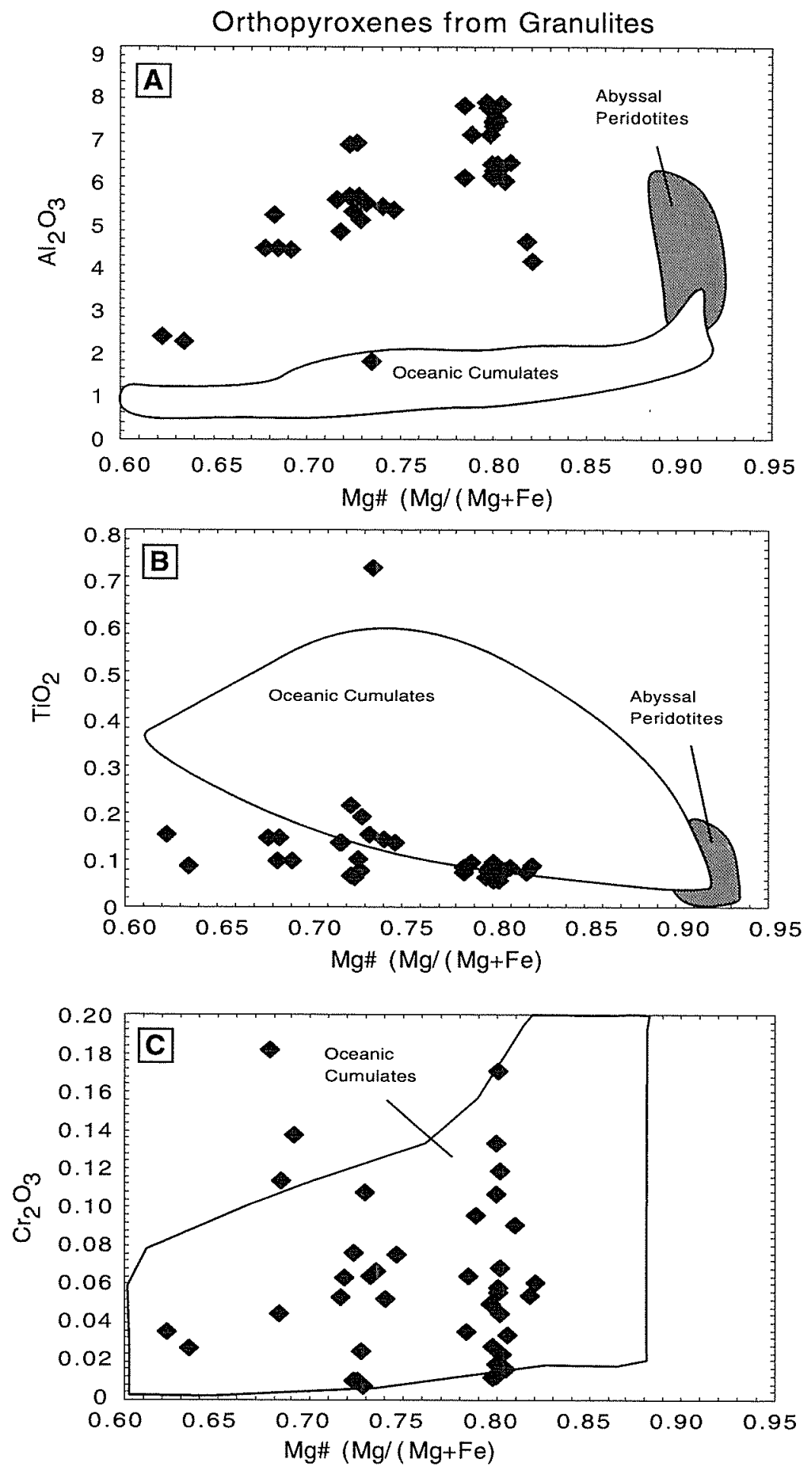


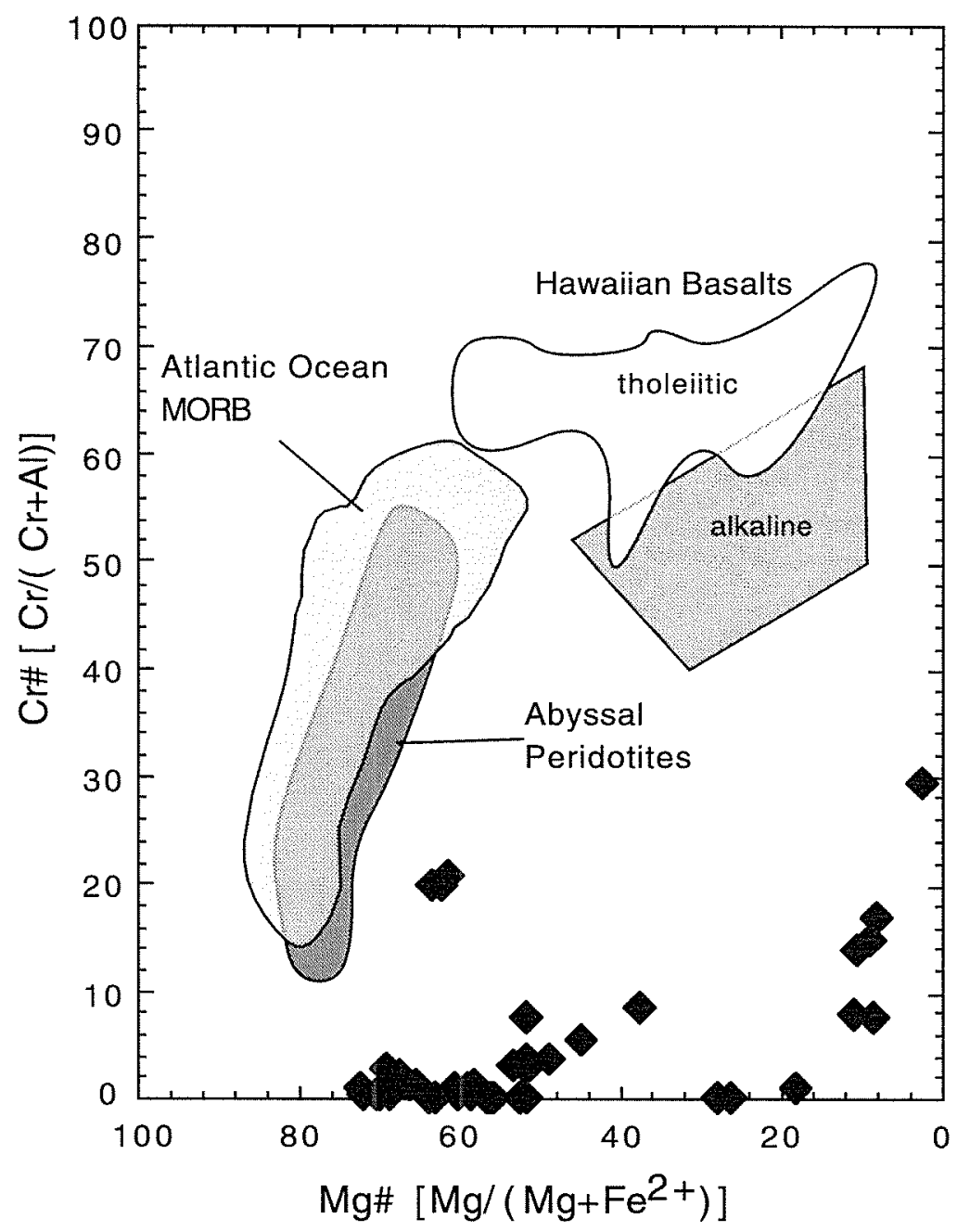

Figure 4-7. Cr\# v. Mg\# diagram of spinels from granulites. Granulites (filled diamonds) are significantly less chromian in comparison to other oceanic rocks, signifying their metamorphic origin. Compositional fields of spinels from abyssal peridotites (Dick and Bullen, 1984), Hawaiian basalts (Sen, 1987), and Atlantic MORB (Dick and Bullen, 1984) are shown for comparison. 


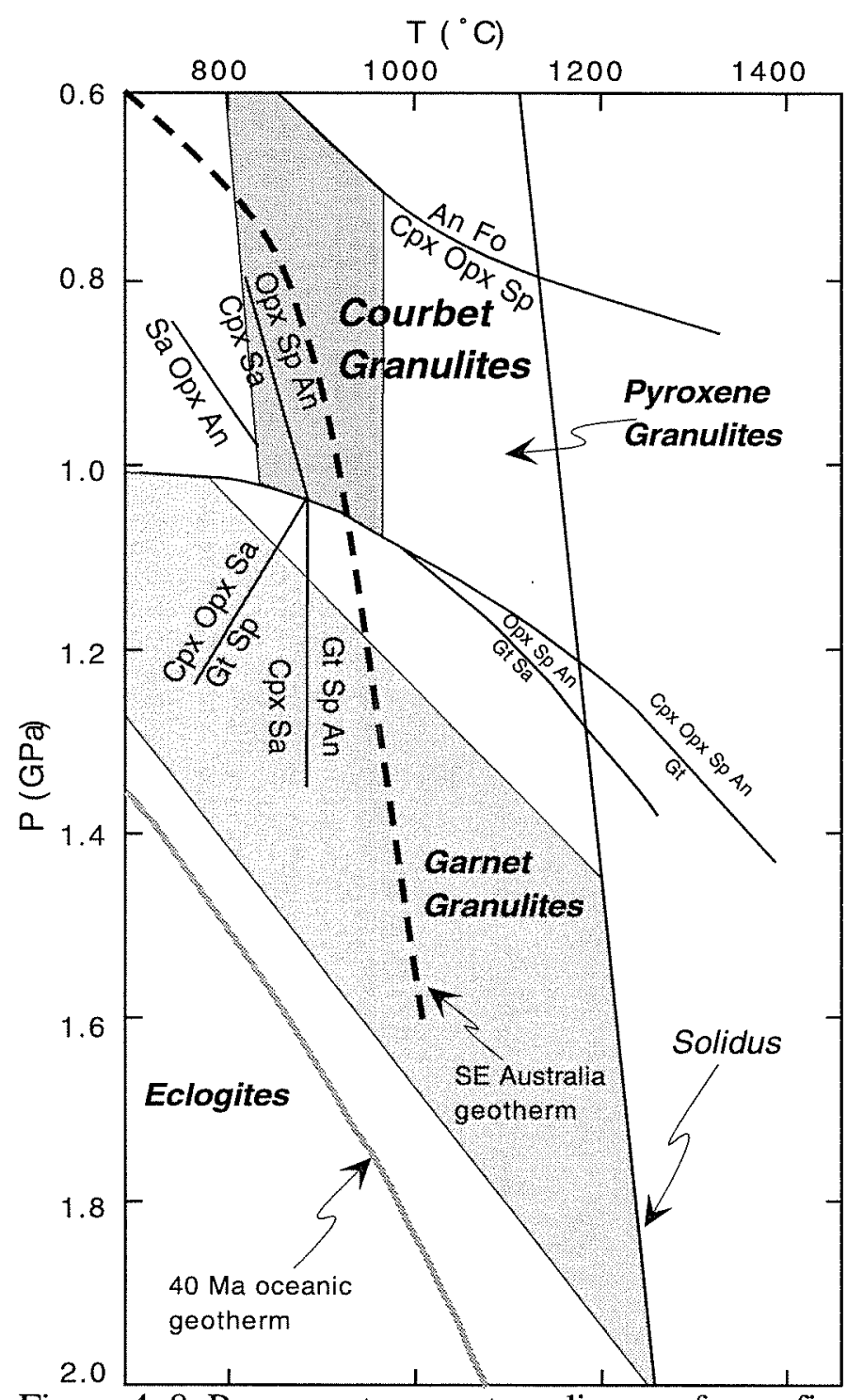

Figure 4-8. Pressure -temperature diagram for mafic composition granulite-facies metamorphism (after Ringwood, 1975; Christy, 1989). Reaction boundaries are labeled with the reactant and product mineral phases. These, and the basalt solidus define the fields for garnet granulites (light shaded field) and pyroxene granulites (labeled). The conditions of metamorphism for the xenoliths of this study are shown as the darker gray field that is labeled "Courbet Granulites". Shown for reference are an oceanic geotherm calculated for $40 \mathrm{Ma}$ (solid gray line; after Fowler, 1990), and a geotherm for southeastern Australia (after Rudnick et al., 1986). 
Figure 4-9. Whole rock major element compositions in comparison to oceanic gabbros and continental granulite xenoliths. Granulites from this study are shown as filled squares. Fields represent the ranges of compositions of oceanic gabbros from ODP site 735B, SWIR (dark gray; Dick et al., 1992), ODP Leg 153, MARK (medium gray; Casey, 1997), dredged gabbros from the SWIR (light gray; Meyer et al., 1989), and gabbro xenoliths from the Canary Islands (white; Schminke et al., 1998). The black arrow represents a liquid line of descent (after Grove et al., 1992). The fields for granulite xenoliths from continents are also outlined in gray. Continental data from Rudnick and Presper (1990). 

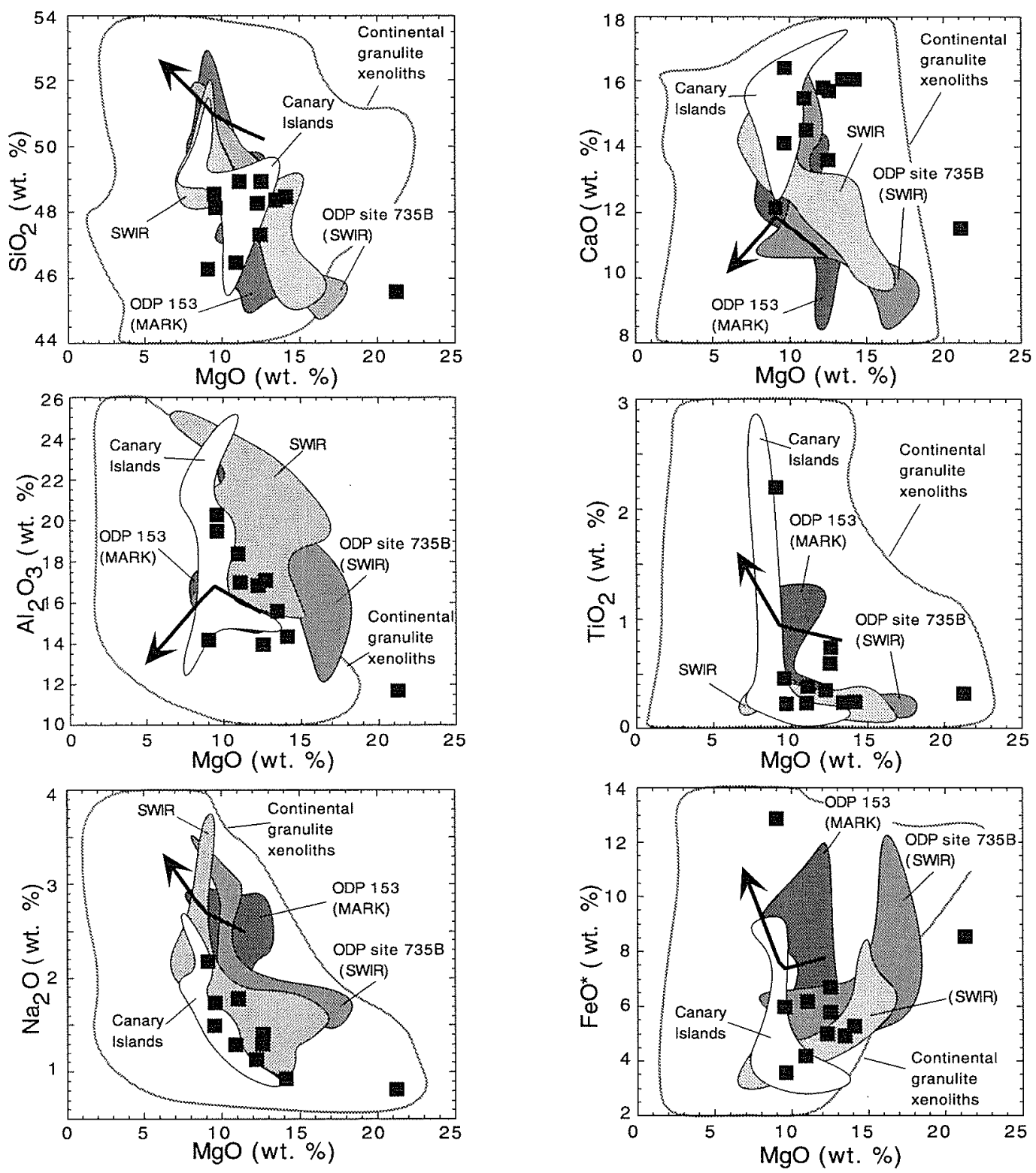
Figure 4-10. Semi-log plot of granulite whole rock trace element contents normalized to C1 chondrites. Each pattern represents the elemental abundances of a single xenolith. The upper panel shows the trace element patterns of the lower $\mathrm{Mg \#}$ samples; the lower panel, the higher Mg\# samples. Also shown for comparison is the field (gray shade) defined by whole rock trace element abundances of gabbros from the Oman ophiolite (Garrido and Kelemen, 1999). The Kerguelen granulites have similar abundances, as well as positive $\mathrm{Sr}$ and $\mathrm{Eu}$ anomalies, as the Oman ophiolites. 


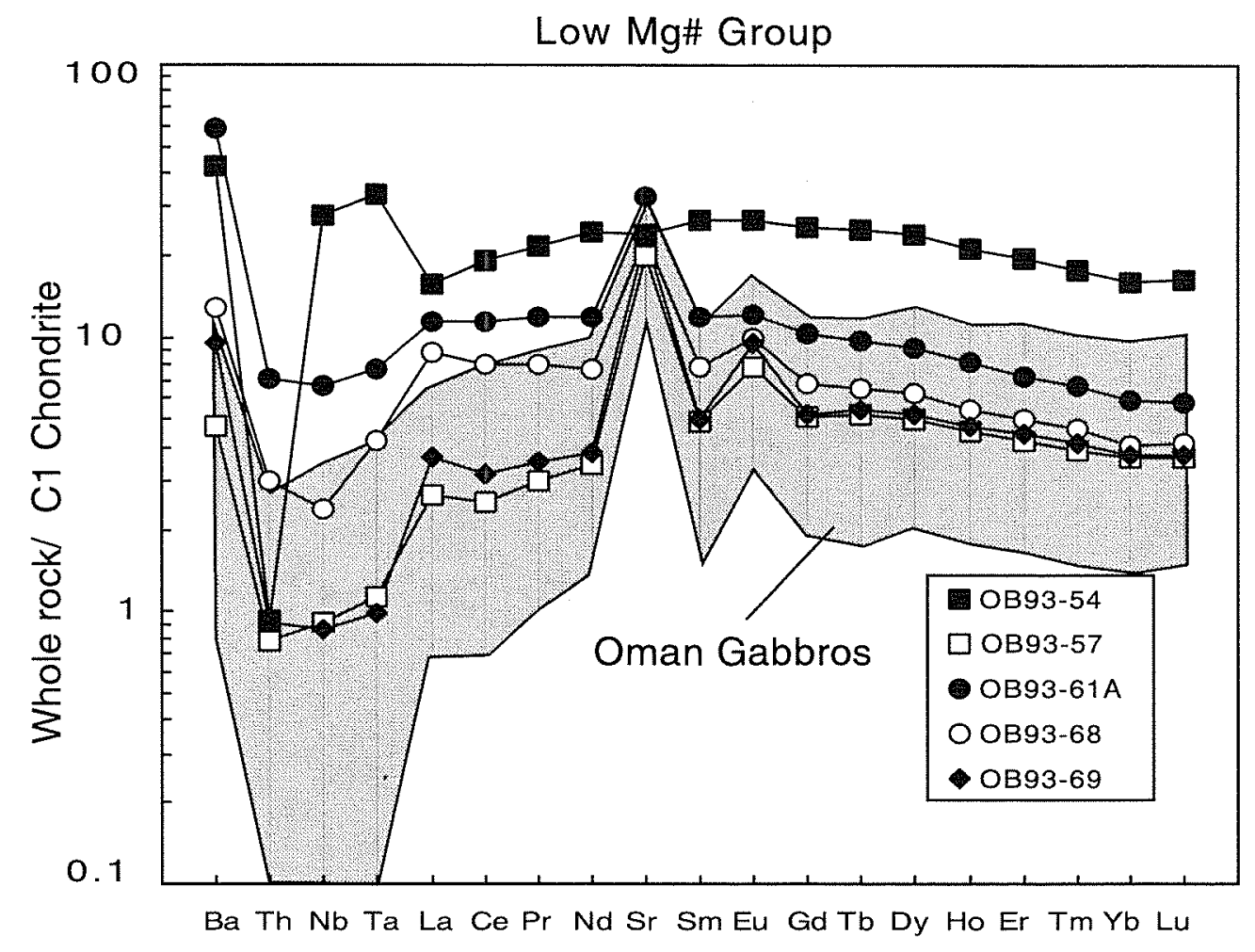

High Mg\# Group

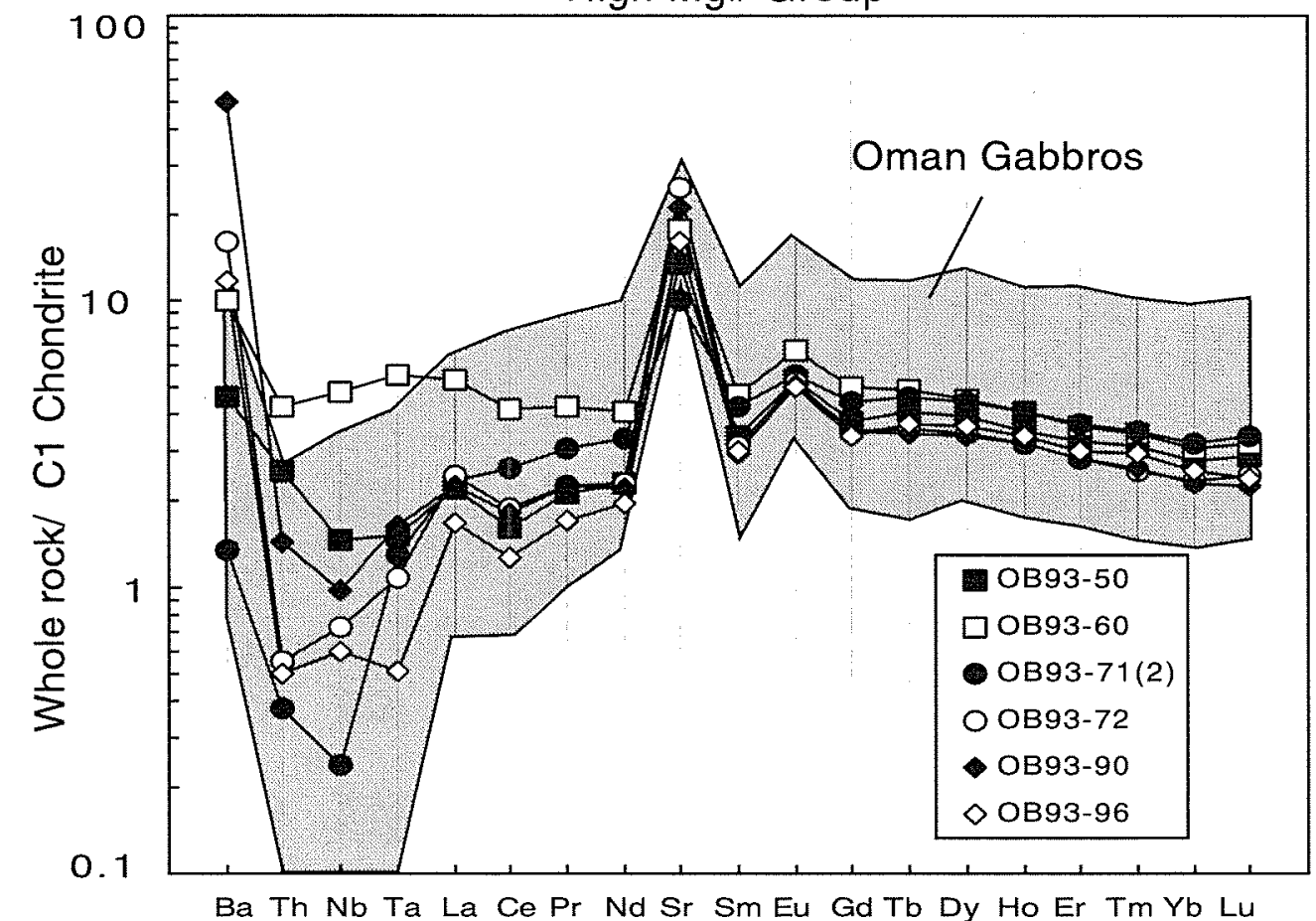

Figure 4-11. C1 chondrite normalized REE abundances of clinopyroxenes and bulk rocks. Whole rock patterns (filled squares) are shown along with clinopyroxene patterns. Each 
panel represents one sample, and each clinopyroxene pattern corresponds to a single analysis. Repeat analyses are noted as "pt 1, pt 2" etc, all other analyses are from different clinopyroxene grains. Grains with symplectite textures are marked as "symp". Higher Mg\# samples are shown in panels $\mathrm{A}$ to $\mathrm{F}$, lower $\mathrm{Mg} \#$ samples in panels $\mathrm{G}$ to $\mathrm{K}$.


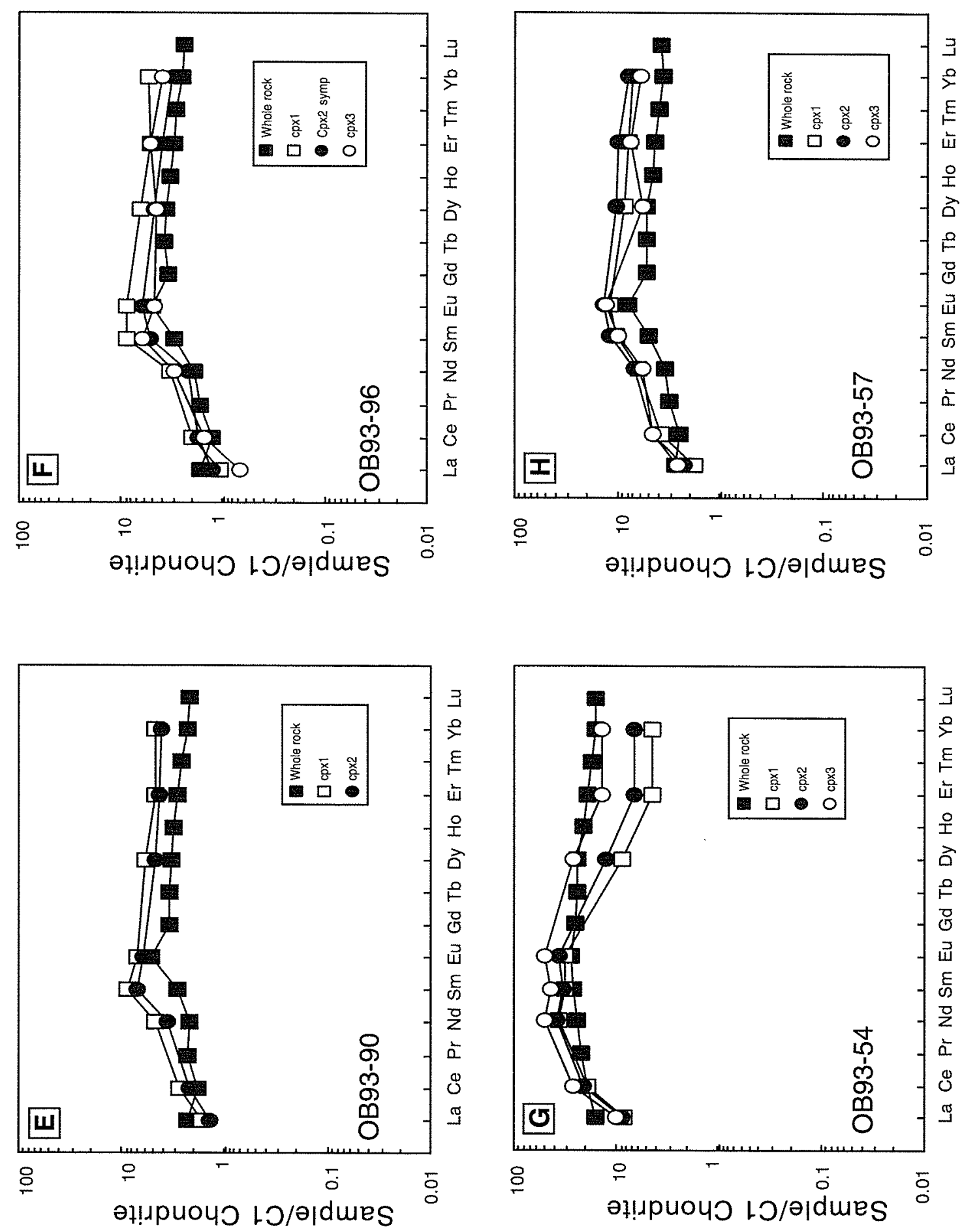

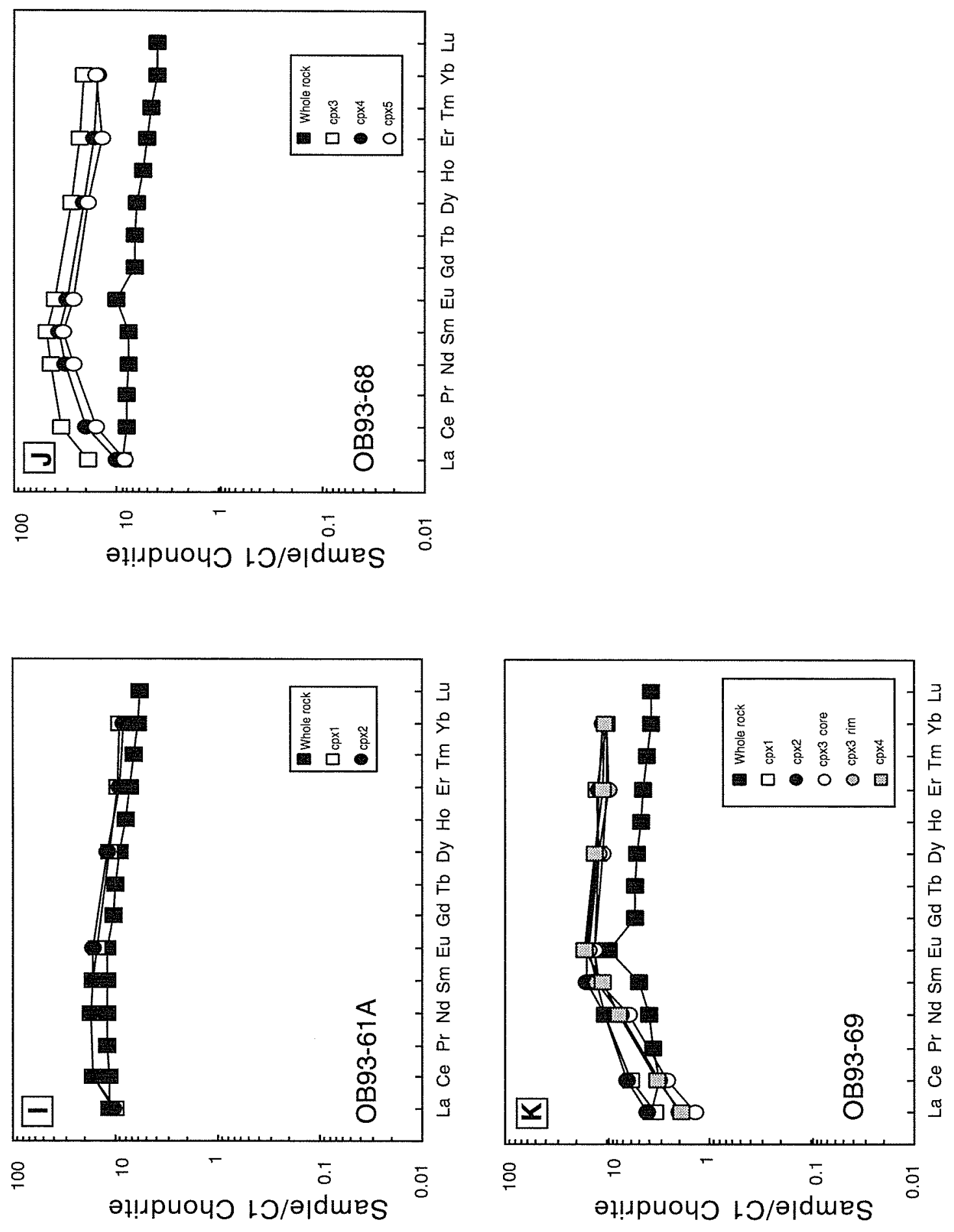
Figure 4-12. Whole rock abundances of transition metals (Cr, Ni, V, Sc) v. MgO wt.\%. Granulites are shown as filled squares. Each point represents a single sample. 

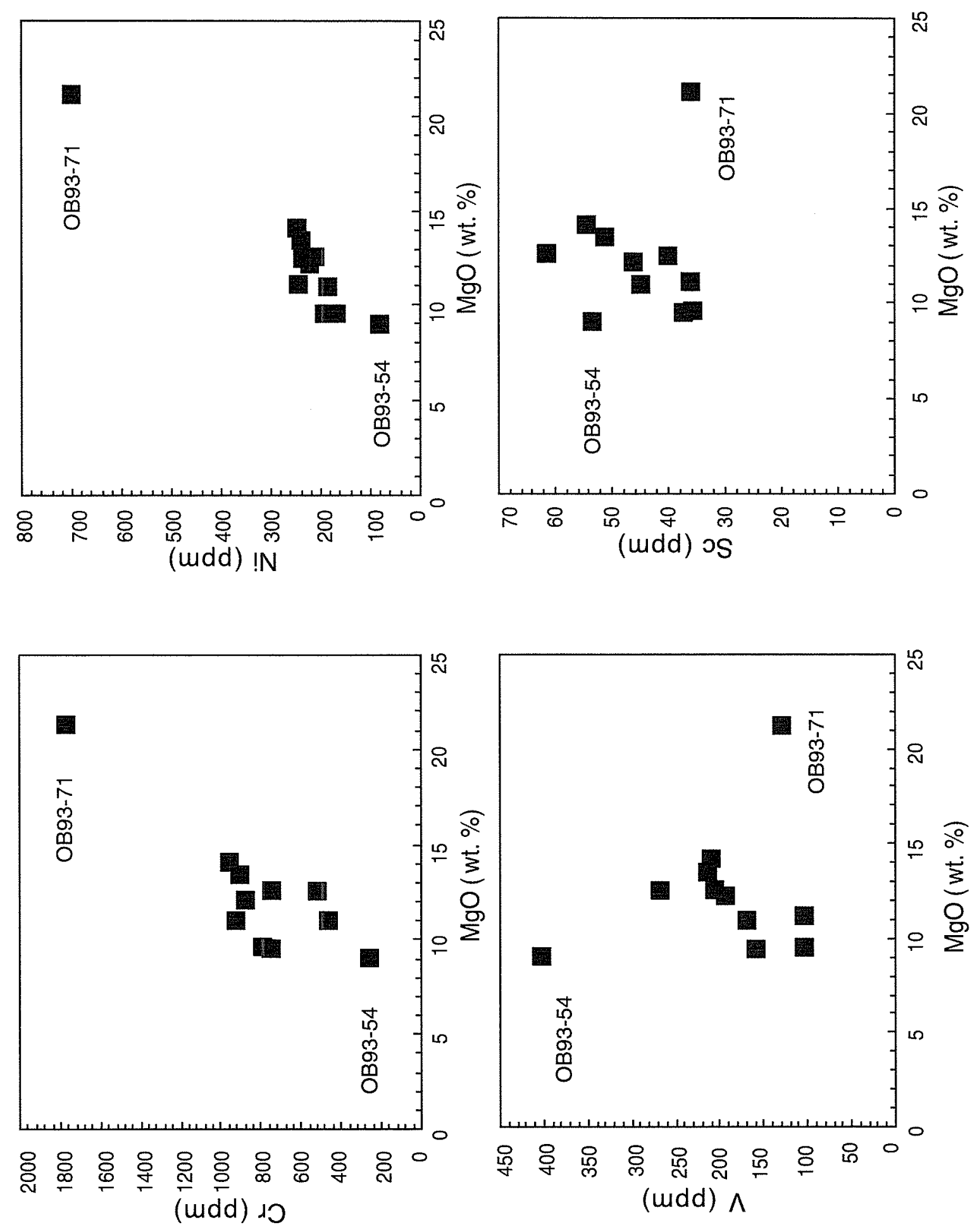


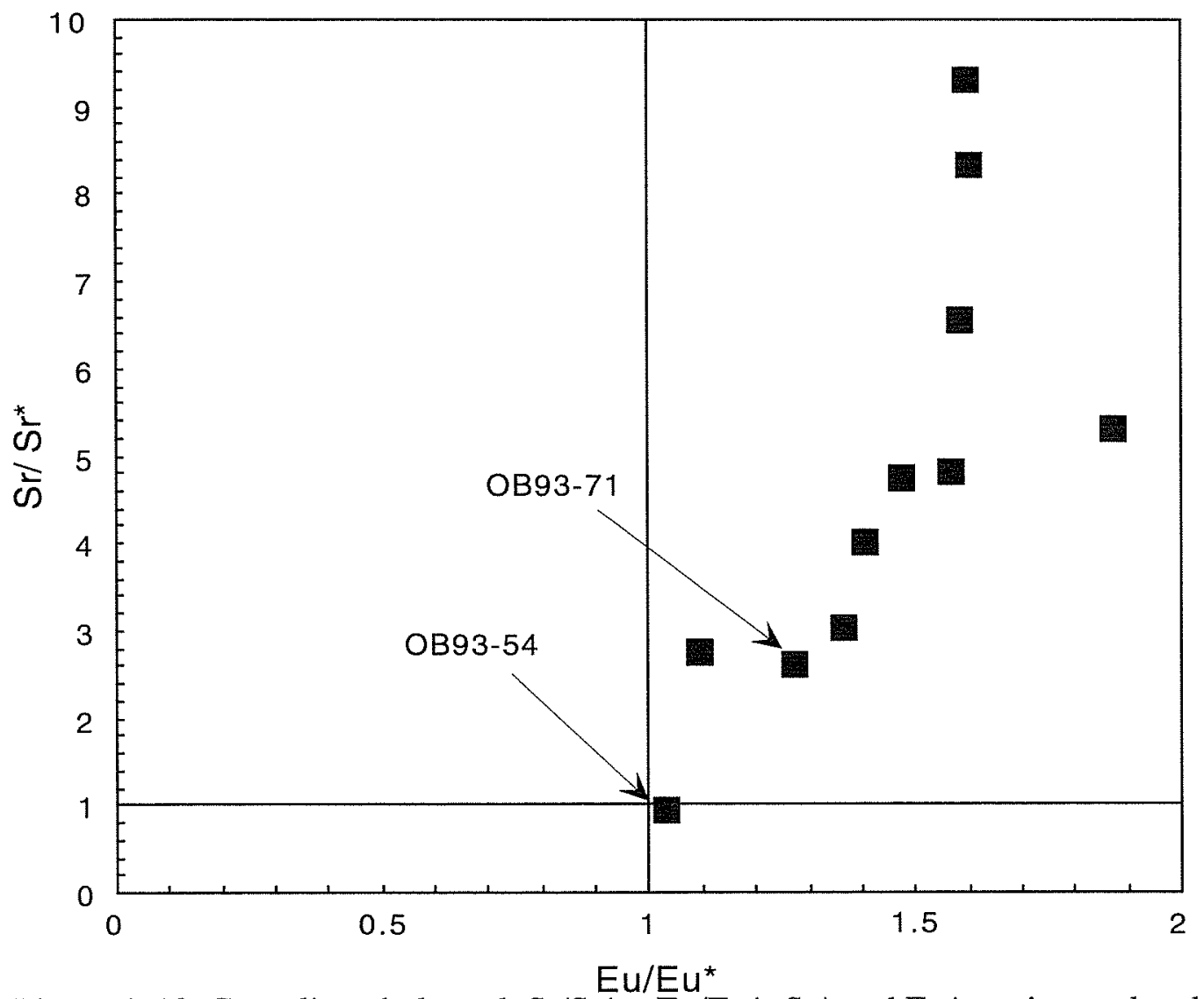

Figure 4-13. Granulite whole rock $\mathrm{Sr} / \mathrm{Sr}^{*}$ v $\mathrm{Eu} / \mathrm{Eu}^{*}$. $\mathrm{Sr}^{*}$ and $\mathrm{Eu}^{*}$ are interpolated from the concentrations (in ppm) of the neighboring trace elements $\left(\mathrm{Sr}^{*}=(\mathrm{Nd}+\mathrm{Sm}) / 2\right.$ and $\mathrm{Eu}^{*}=$ $(\mathrm{Sm}+\mathrm{Gd}) / 2)$. All samples, except $\mathrm{OB} 93-54$ have both $\mathrm{Sr}^{*}$ and $\mathrm{Eu}^{*}>1$, indicating a cumulate protolith. Sample OB93-54 is also interpreted as a cumulate, as discussed in the text. 


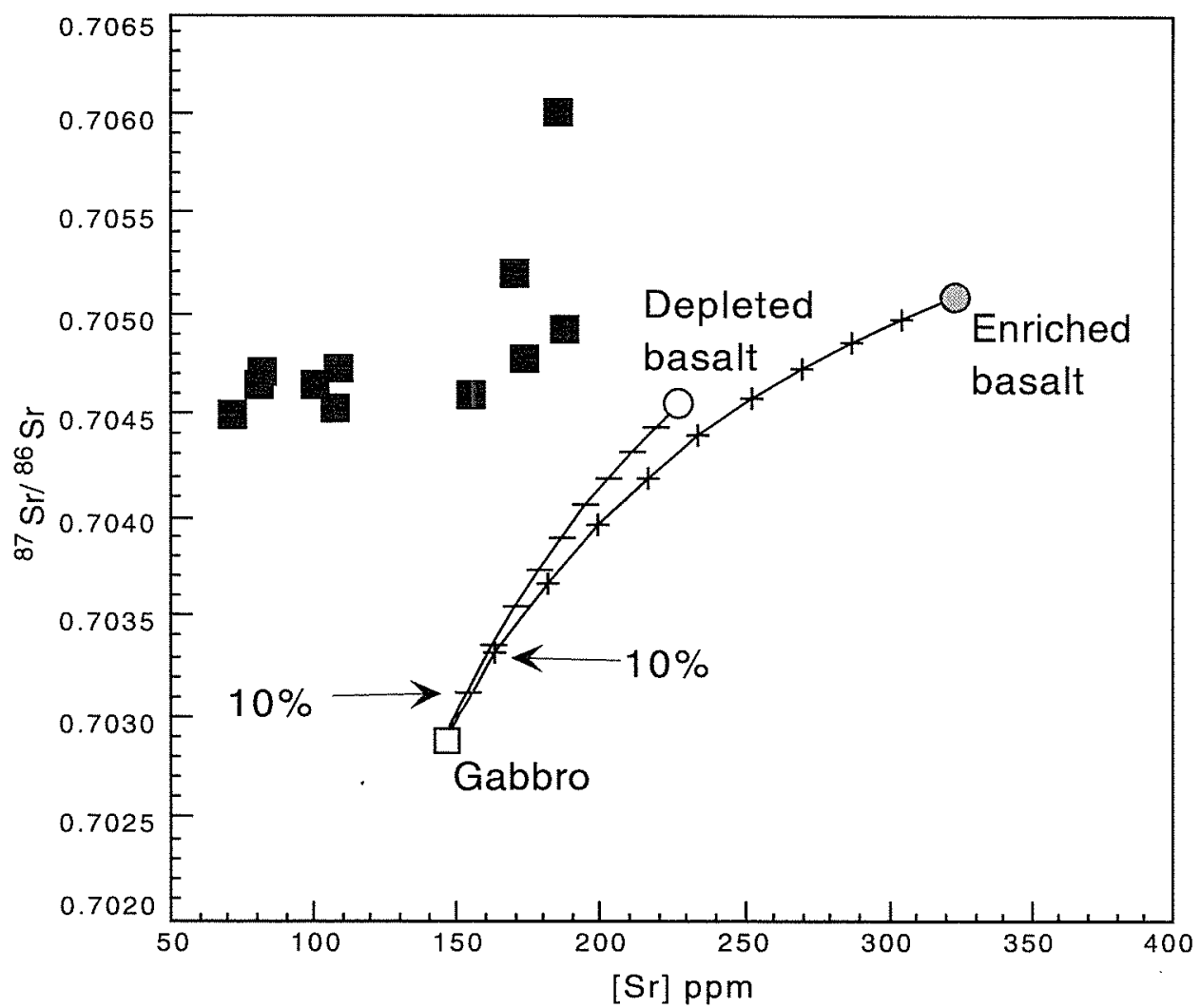

Figure 4-14. Strontium isotopic composition v. [Sr] (ppm). Bulk rock compositions of granulites are compared to those of two component mixtures of a calculated SEIR basalt equilibrium gabbro and two Kerguelen Islands basalts. The possibility of an oceanic olivine gabbro adcumulate (open square) impregnated with Kerguelen OIB (open and gray circles) as a protolith for the granulites (filled squares) is illustrated in this figure. Mixtures of the gabbro with a REE depleted basalt $(-)$ and REE enriched basalt $(+)$ are shown. Symbols mark the melt fraction in $10 \%$ increments. On the basis of this calculation, the granulites could not have originally been a mixture of lower oceanic crust and Kerguelen OIB. The basalt data is from Yang et al. (1998). The gabbro data is calculated from a SEIR basalt from Dosso et al. (1988) using gabbro modes of $13.5 \%$ olivine, $31.5 \%$ clinopyroxene and $55 \%$ plagioclase, and Sr partition coefficients from Dunn and Sen (1994) and Hart and Dunn (Hart and Dunn, 1993). 
Figure 4-15. Normalized REE compositions of equilibrium melts calculated from whole rock trace element contents. Granulite equilibrium melt patterns (white field, open squares) are more similar in shape and abundance to the field defined by the Kerguelen Islands and Plateau basalts (dark gray; Storey et al., 1988; Davies et al., 1989; Gautier et al., 1990; Alibert, 1991; Salters et al., 1992; Weis et al., 1993; Yang et al., 1998) than that defined by the SEIR MORB (medium gray; Michard et al., 1986; Dosso et al., 1988). 


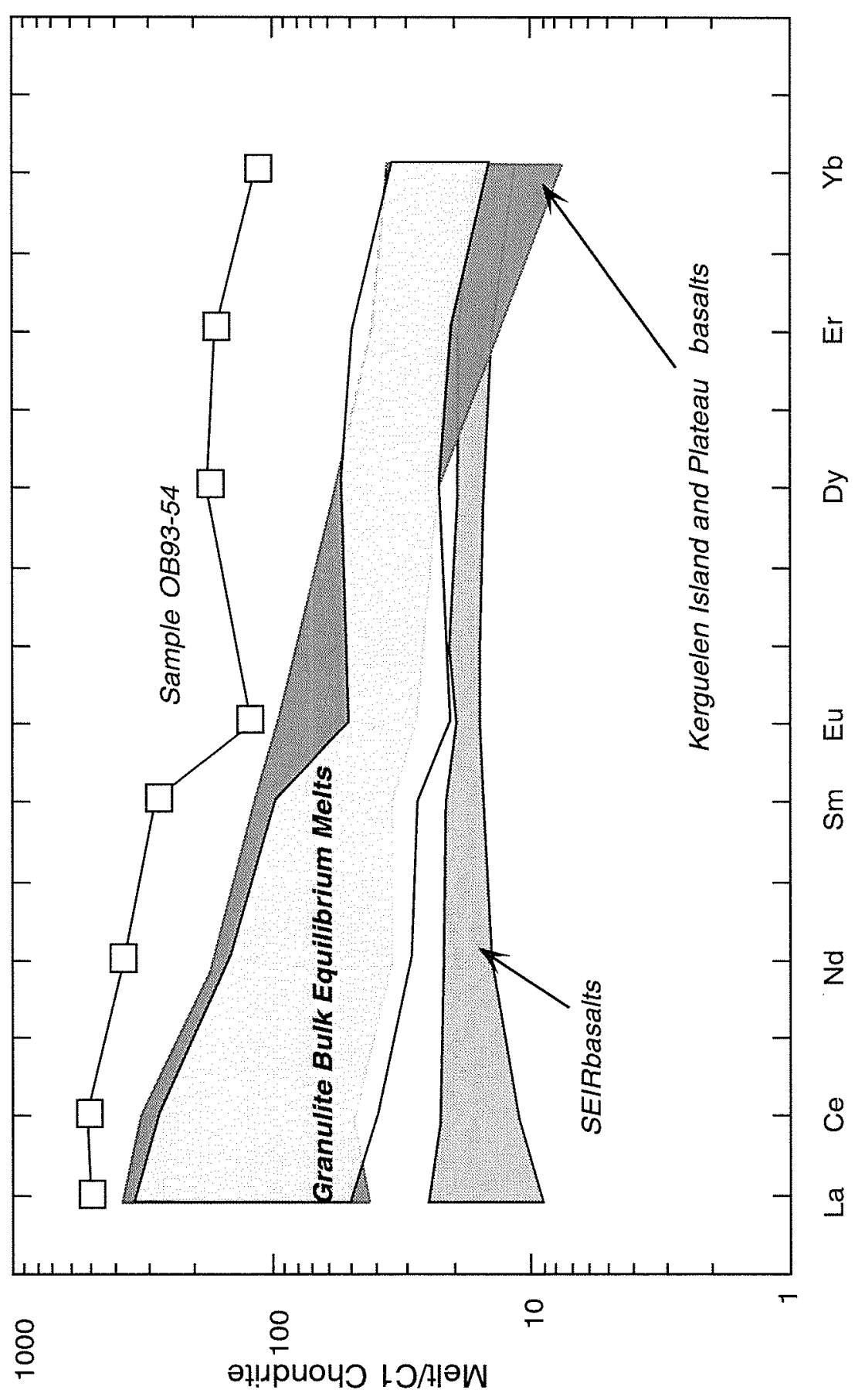


Figure 4-16. Normalized REE content of melts in equilibrium with granulite clinopyroxenes. Granulite clinopyroxene equilibrium melt patterns (white field) are similar in shape and abundance to the field defined by the Kerguelen Islands and Plateau basalts (dark gray; Storey et al., 1988; Davies et al., 1989; Gautier et al., 1990; Alibert, 1991; Salters et al., 1992; Weis et al., 1993; Yang et al., 1998). The field defined by the SEIR MORB (medium gray; Michard et al., 1986; Dosso et al., 1988) has lower REE abundances and is less REE enriched than the Kerguelen basalts and the clinopyroxene equilibrium melts. The clinopyroxene equilibrium melts lack the negative Eu anomalies that are present in the whole rock equilibrium melts and have higher overall REE abundances (Figure 4-15). 


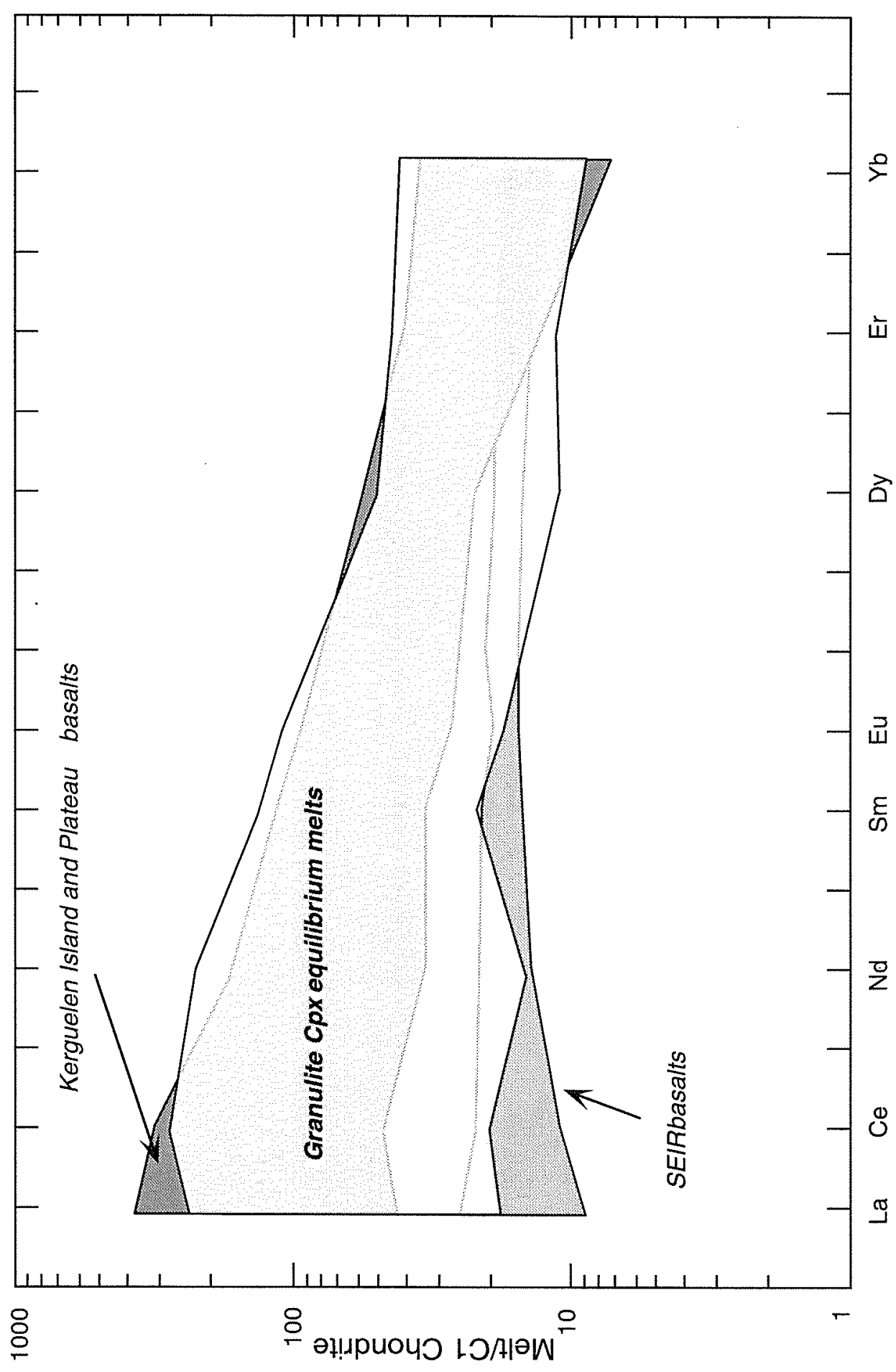


Figure 4-17. Sr v. Nd isotopic diagram of bulk rock granulite compositions. Measured isotopic compositions of granulites from this study (open squares), granulites from the Southeastern Province (Mt.Tizard: gray diamonds, Dome Rouge and Val Phonolite: white diamonds; Mattielli et al., 1996; Mattielli, 1996), clinopyroxenes from peridotites (open circles; Chapter 2), and the host dike are shown in comparison to initial isotopic compositions of basalts from the Indian Ocean ridges (MORB with no plume influence: light gray, all Indian Ocean MORB: light gray + dashed line extension) and the Kerguelen Islands (dark gray). The $\mathrm{Sr}$ isotopic composition of OB93-61A is shown as a broken line. Granulites lie nearly completely within the field defined by Kerguelen Islands basalts (White and Hofmann, 1982; Gautier et al., 1990; Weis et al., 1993; Weis et al., 1998; Yang et al., 1998), and none overlap the compositions of Indian Ocean MORB (Hamelin et al., 1986; Michard et al., 1986; Dosso et al., 1988). Mantle isotopic endmembers are shown for reference (filled circles; Hart, 1988). 


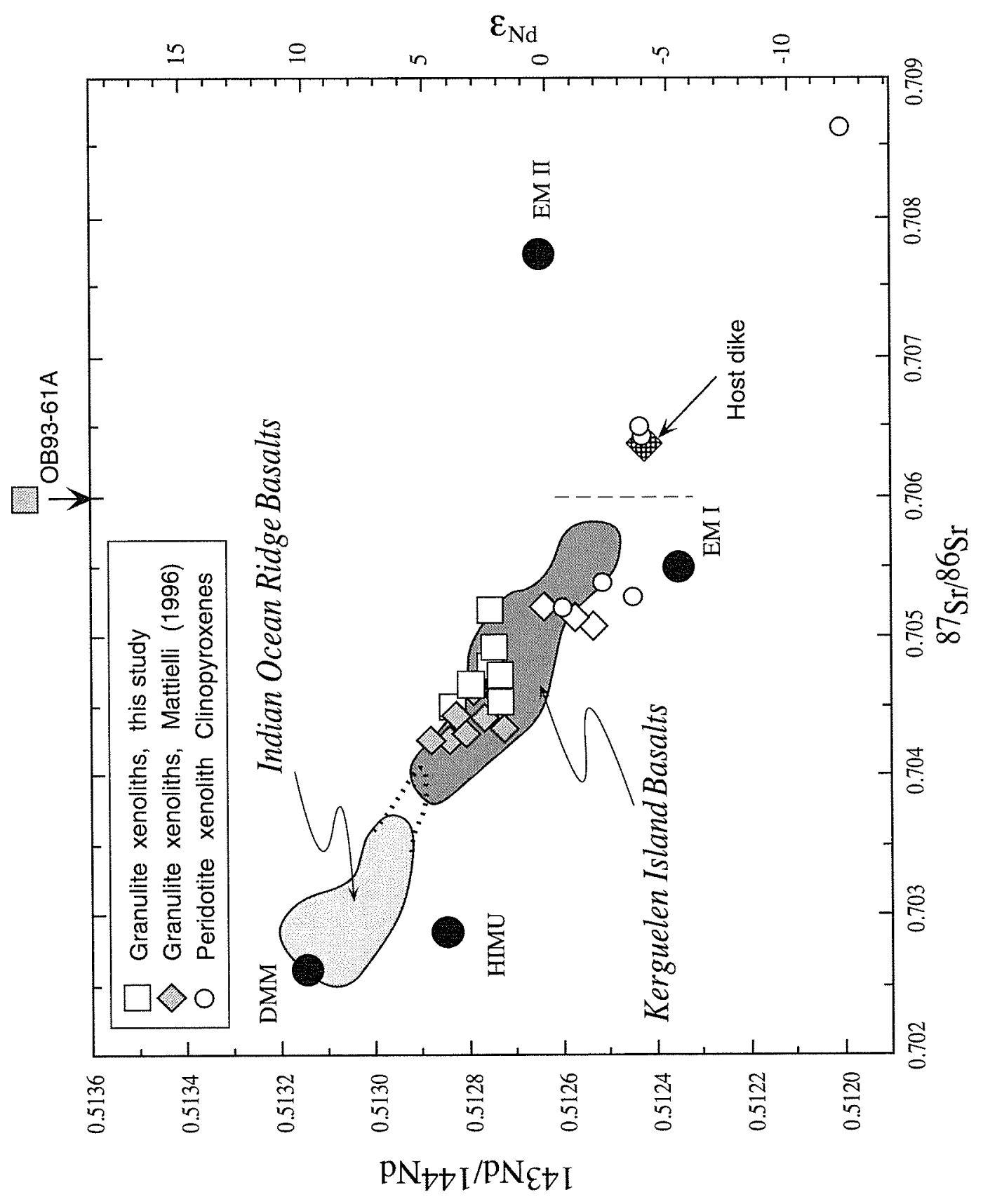


Figure 4-18. ${ }^{187} \mathrm{Os} /{ }^{188} \mathrm{Os} \mathrm{v.} \mathrm{[Os]} \mathrm{(ppt)} \mathrm{upper} \mathrm{panel,} \mathrm{and}{ }^{187} \mathrm{Os} /{ }^{188} \mathrm{Os} \mathrm{v} \cdot{ }^{187} \mathrm{Re} /{ }^{188} \mathrm{Os}$, lower panel, of granulite whole rocks (filled squares) and Kerguelen plume related basalts (open and gray circles; Reisberg et al., 1993; Barling et al., 1997; Yang et al., 1998). Data are blank corrected, but not age corrected. Samples show the general trend of more radiogenic ${ }^{187} \mathrm{Os} /{ }^{188} \mathrm{Os}$ at lower concentrations, though the most radiogenic granulite (OB93-54) has a higher concentration than that thought to be easily susceptible to contamination. In the isochron diagram of the lower panel, a $69 \mathrm{Ma}$ isochron is plotted for reference. Although there is no isochron relationship among these samples, this indicates that OB93-54 would have had a similar ${ }^{187} \mathrm{Os} /{ }^{188} \mathrm{Os}$ as the other samples at $\sim 69 \mathrm{Ma}$. 

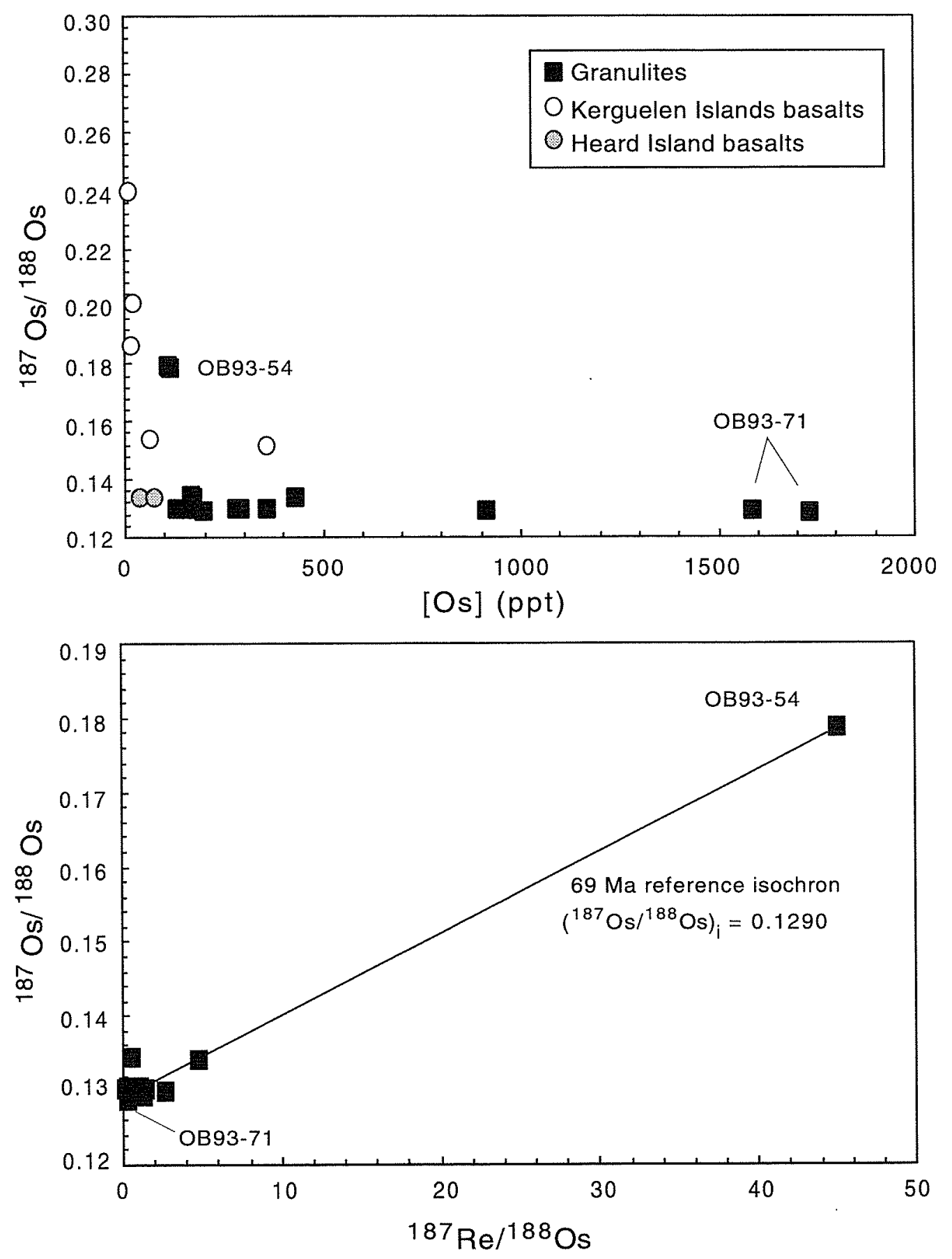
Figure 4-19. Nd v. Sr isotopic compositions of continental granulites (after Rudnick, 1992). Labeled fields are for mafic granulites, other mafic granulite xenoliths are designated as ' + '. Other granulites are also shown for comparison. The white field delineates the Kerguelen granulite xenoliths. Continental samples have a large isotopic variation that encompasses the relatively limited isotopic compositions of the Kerguelen granulites. 


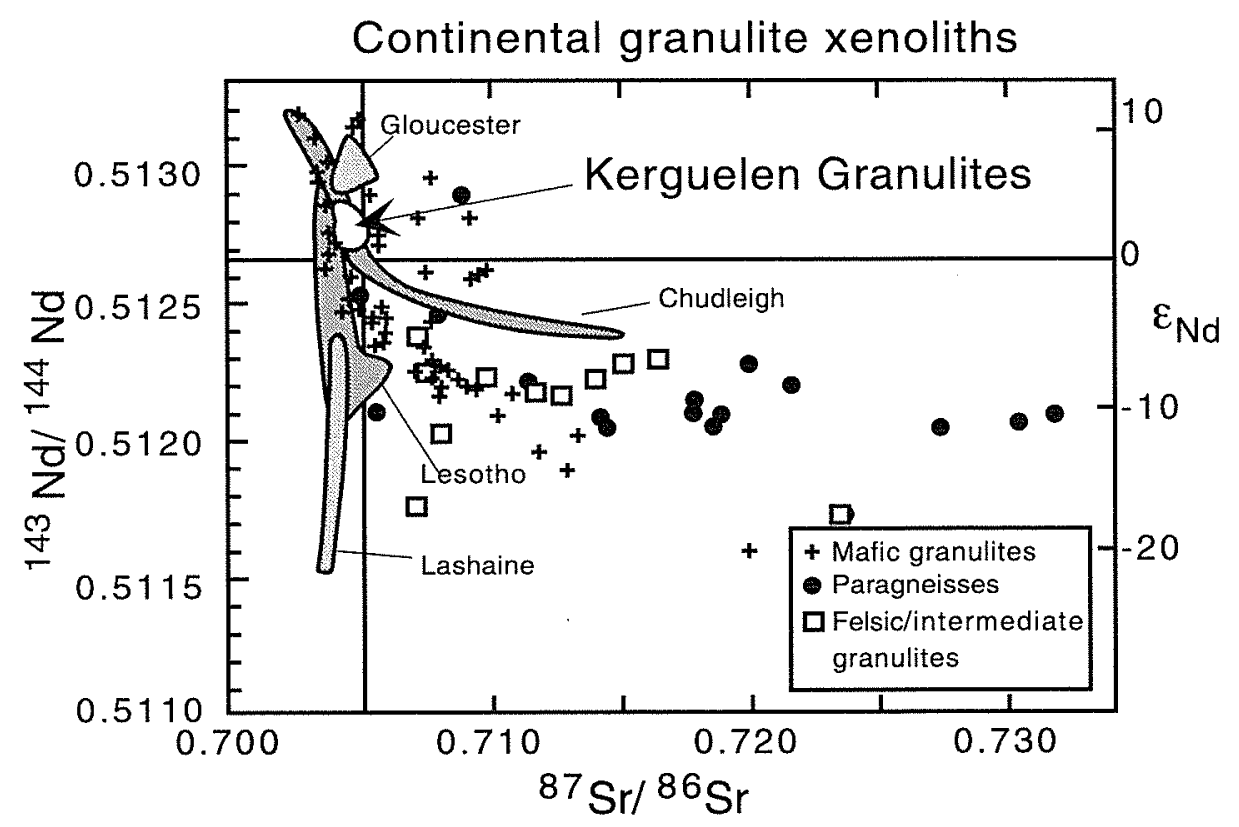


Figure 4-20. Comparison of the present day values of the ${ }^{187} \mathrm{Os} /{ }^{188} \mathrm{Os}$ and ${ }^{187} \mathrm{Re} /{ }^{188} \mathrm{Os}$ of all lower crustal xenoliths analyzed to date. The location and number of samples in each dataset are noted next to each bar. Present-day primitive mantle values are shown as a broken line in each panel. The Kerguelen granulites have a limited range of these values, especially ${ }^{187} \mathrm{Re} /{ }^{188} \mathrm{Os}$, relative to the other analyzed samples. Comparison data are from Hart et al. (1999), Lassiter et al. (1998), Pearson et al. (1995), Saal et al. (1998), and Esperança et al. (1997).

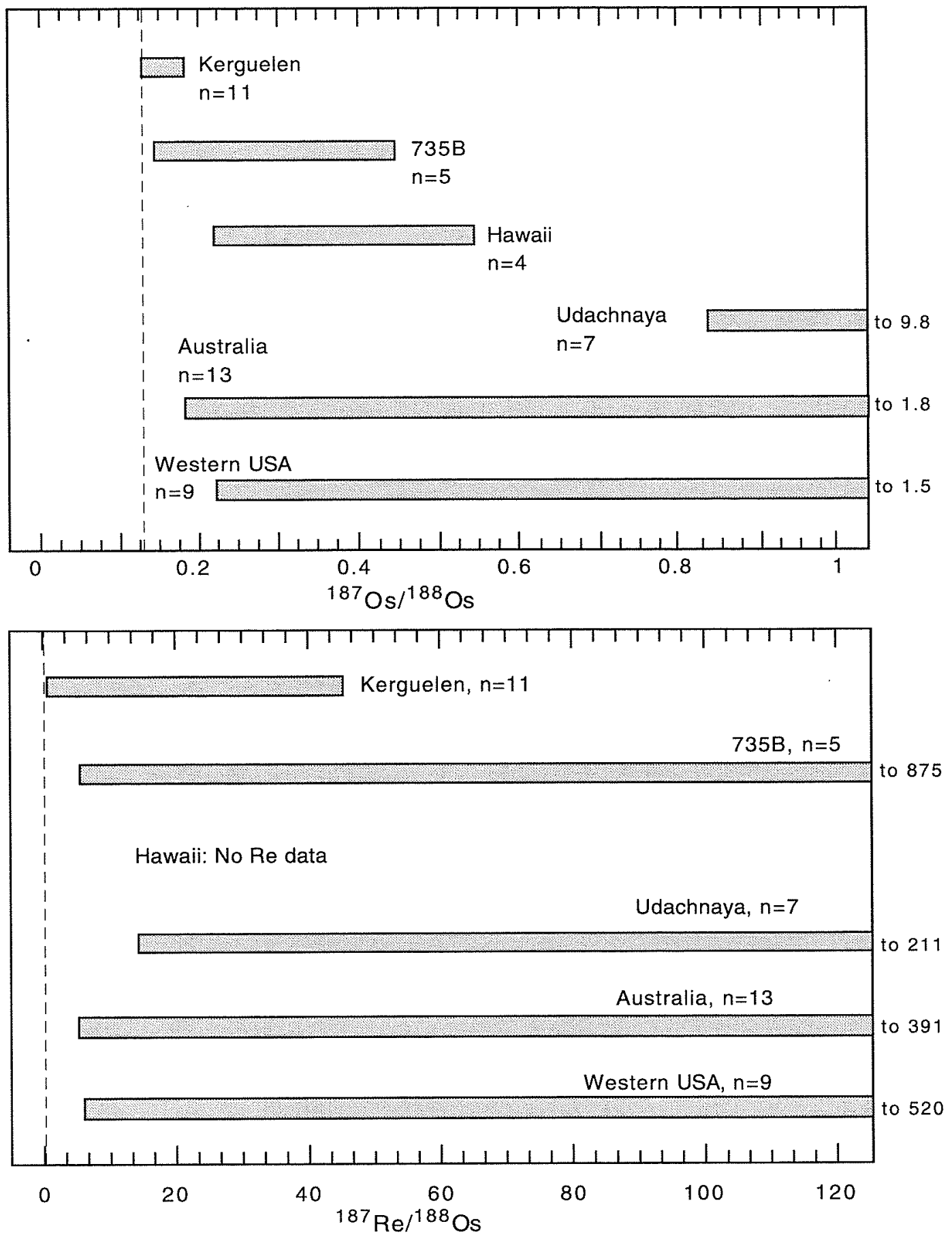


Figure 4-21. Os v. Sr (upper panel) and v. Nd (lower panel) isotopic compositions of Kerguelen plume rocks. Isotopic compositions of Courbet Peninsula granulites (filled squares), Kerguelen Islands basalts (open circles; Reisberg et al., 1993; Yang et al., 1998), and Heard Island basalts (gray circles: Barling et al., 1994; Barling et al., 1997) have a relatively large variation. Isotopic compositions shown for Kerguelen basalts are initial values and those for Heard basalts are measured values ( zero age). Osmium compositions for the granulites are corrected for a maximum eruption age of 24.5 Ma (Nicolaysen et al., 1999); $\mathrm{Sr}$ and $\mathrm{Nd}$ isotopic compositions are as measured (correction for $24.5 \mathrm{Ma}$ eruption age is negligible). Compositions of mantle endmembers (Hart, 1988; Martin, 1991; Hauri and Hart, 1993; Reisberg et al., 1993; Marcantonio et al., 1995; Widom and Shirey, 1996) are labeled and displayed as open diamonds. Compositional fields for endmember ocean islands are also shown; EM I: Kerguelen Islands and Pitcairn Islands; EM II: Samoa and Tahaa; HIMU: St. Helena, Rurutu, Tubuai, and Mangaia. Data sources for these fields are as noted in the figure explanation. A vertical line through the symbol marks the reported range of the $187 \mathrm{Os} / 188 \mathrm{Os}$ EM $I I$ component. No one mixing relation among the isotopic endmember components can account for all of the Kerguelen plume related rocks. 
Kerguelen Granulites and basalts, eruption-age corrected
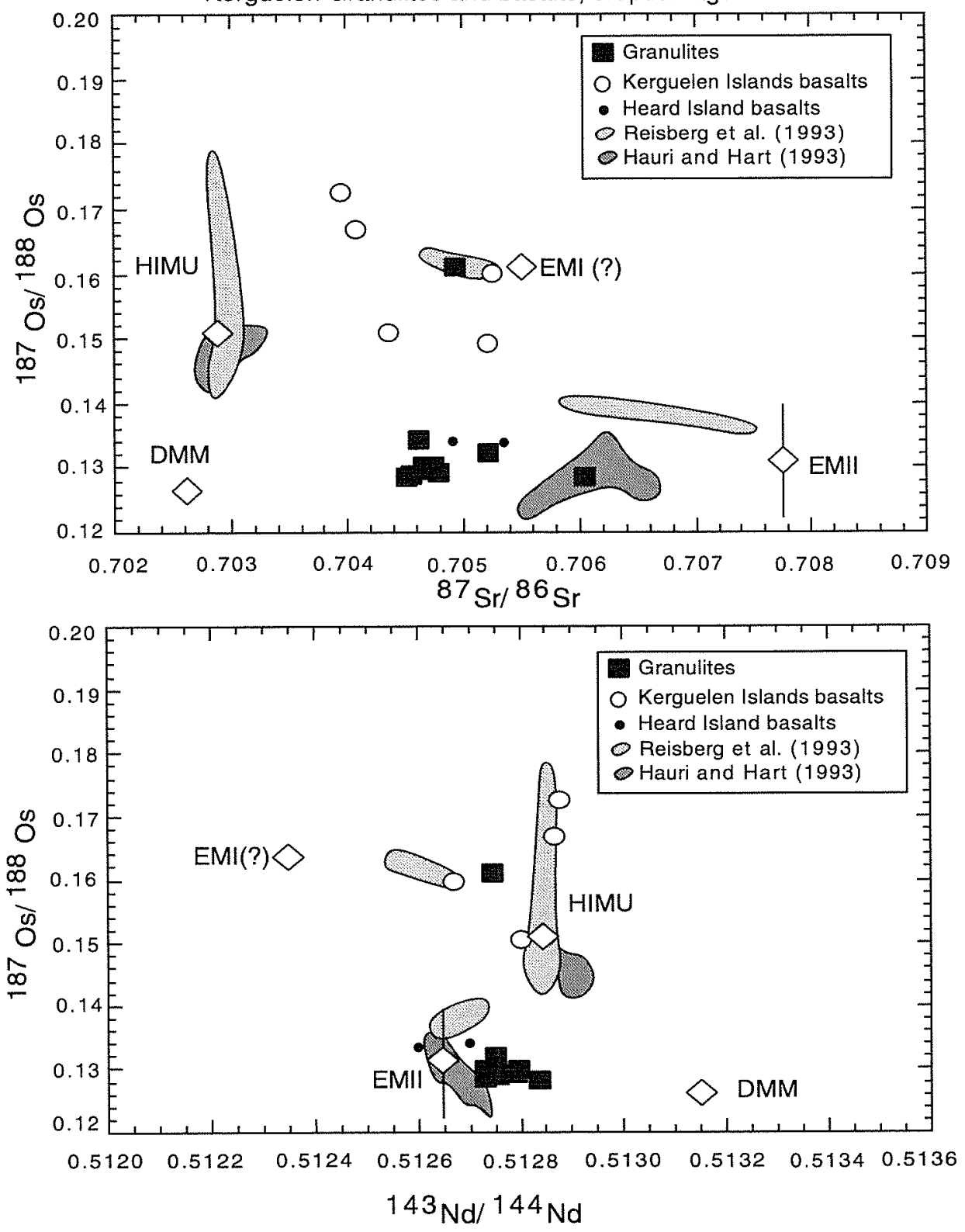
Figure 4-22. Granulite whole rock abundances (filled squares) of the chalcophile element $(\mathrm{Ni}, \mathrm{Zn}, \mathrm{Pb}, \mathrm{Cu})$ v. Re and Os concentrations. Rhenium and Osmium co-vary with different chalcophile elements, indicating their tendency to occur in different mineral phases. The most likely mineral hosts for Re and Os are sulfides. Further evidence for this is that the granulite $\mathrm{Ni}$ and Os compositions do not follow an olivine control line, but plot as a vertical trend, suggesting buffering of the Os content by sulfides (Hart and Ravizza, 1996). 

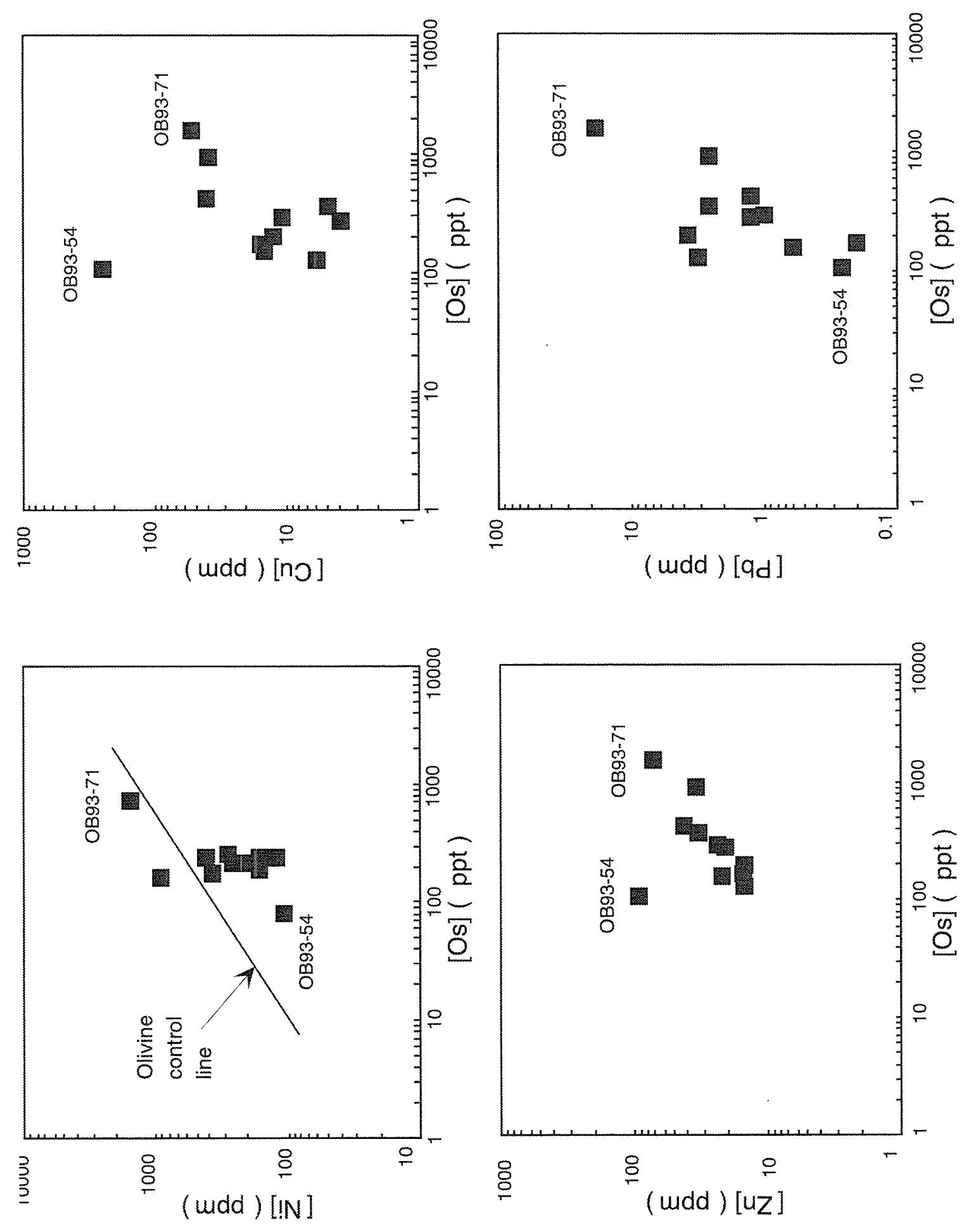

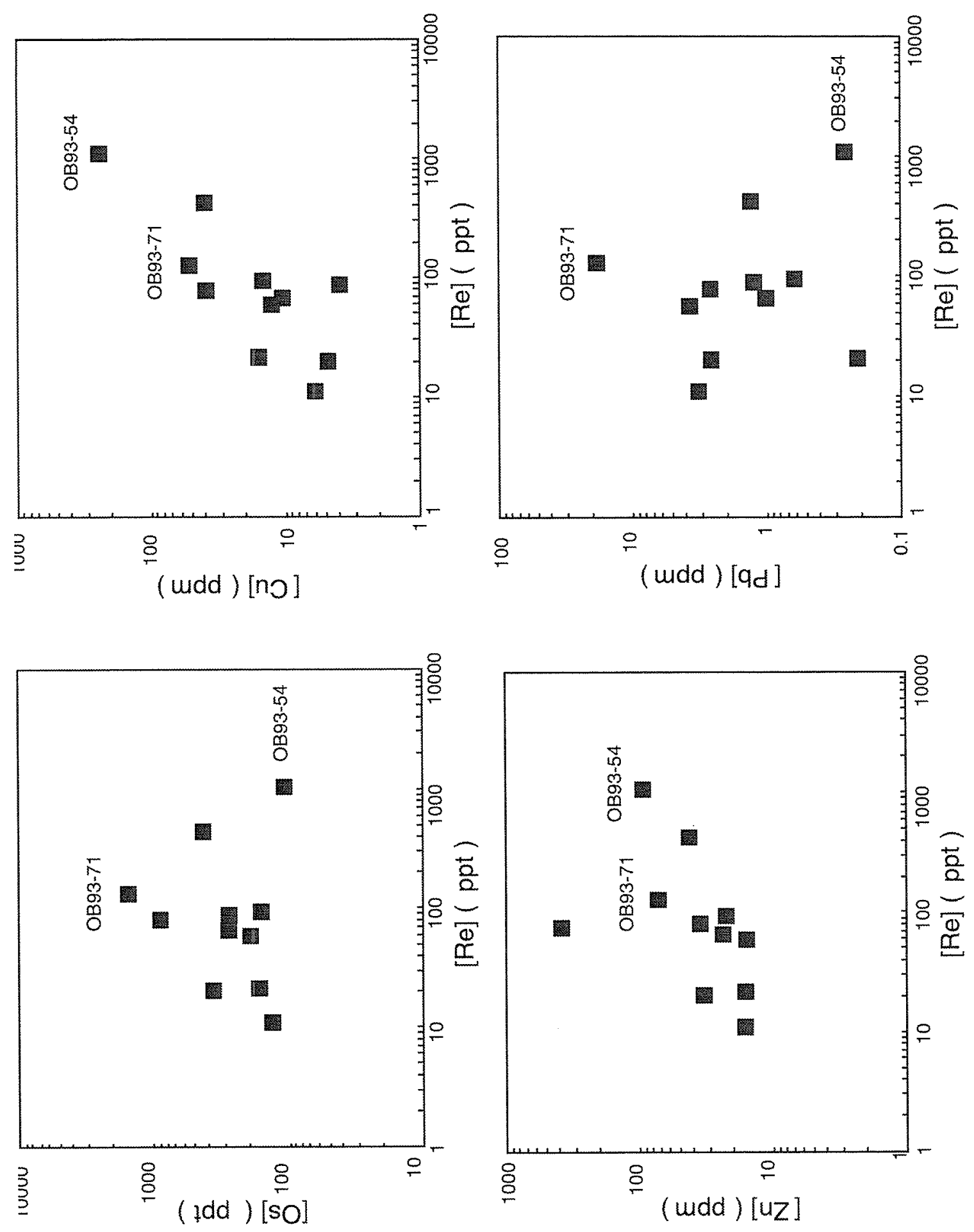


\section{Chapter 5 Summary of Results and Conclusions}

The major focus of this thesis is a study of the geochemistry of lower crustal and upper mantle xenoliths included in Kerguelen magmas. The objective was to gain insights into the materials and processes that were involved in the evolution of the Kerguelen plume. Of particular interest was the examination of whether the xenoliths carry information pertinent to evaluating the effects of diverse geodynamic environments on the evolution of the Kerguelen plume. For this reason, the determination of the provenance of the different xenoliths was essential. Specifically, the thesis addresses whether pieces of Gondwanaland lithosphere are present beneath the Kerguelen Islands and whether lower crustal xenoliths originated from the Kerguelen plume-derived magmas or the SEIR-derived ones. The process of determining the answers to these questions, whole-rock and mineral major element compositions, trace-element abundances and isotopic compositions of $\mathrm{Sr}, \mathrm{Nd}$ and Os were used in close connection so that an internally consistent interpretation could be made.

\subsection{Upper mantle xenoliths}

The major element compositions and modal abundances of minerals were found to place important constraints on the origins of the majority of the harzburgites. Their olivine compositions and modal abundances were found to be off the "oceanic trend" of Boyd (1989). The oceanic trend is interpreted to define a trend of melt extraction at low pressures

(e.g. at mid-ocean ridges). The Kerguelen harzburgites generally have too little olivine for a given olivine composition to be residues of low-pressure melting. Many of the Samoan 
xenoliths studied by Hauri \& Hart (1994), and some of the Hawaiian xenoliths (Sen, 1988) share these same characteristics but have never been discussed in this context.

On the basis that melting reactions change from olivine-producing at low pressures to orthopyroxene-producing and olivine-consuming at higher pressures (Walter et al., 1995; Walter, 1998; Kinzler, 1997), it was determined that the major element characteristics of the Kerguelen harzburgites are consistent with their origin as residues of extensive melt extraction at high pressures. This therefore suggests that the harzburgites are not pieces of oceanic lithosphere upon which the Kerguelen plume impinged, but rather pieces of plume mantle residues.

Abundance patterns of incompatible trace elements in clinopyroxenes from peridotite xenoliths were then used to evaluate whether the interpretation of a high pressure origin on the basis of the major elements is consistent with the trace element abundances. Moreover, the clinopyroxene trace element abundances were used to determine the magnitude of chemical modifications that occurred to the peridotite xenoliths during reactions with plume-derived melt. Rare earth element patterns were calculated for the high-Ca clinopyroxenes that are predicted to be present after the low pressure recrystallization of high pressure melting residues. These calculated patterns produced a close match with the LREE-depleted clinopyroxenes that are present in some of the harzburgites. This trace element evidence further supports the model for the formation of many of the Kerguelen harzburgites by low pressure recrystallization of high pressure melting residues.

Furthermore, it was found that these depleted patterns were modified, sometimes significantly during metasomatism, resulting in ranges of trace element abundances in clinopyroxenes that are staggeringly large (a factor of 5000!). Cerium concentration varies from 0.04 times chondrite in depleted "unmetasomatized" harzburgites to 200 times 
chondrite in a fully metasomatized harzburgite that contain phlogopite and apatite. In many samples, a correlation was found between texture and chemistry. Clinopyroxenes in symplectite are depleted in trace elements, whereas discrete grains were are enriched. Additionally, symplectite clinopyroxenes were found to show various stages of modification within a single sample. These observations show that metasomatism began with a reaction between harzburgite and infiltrating melts, with a chromatographic mechanism that has previously been well described (e.g. Navon and Stolper, 1987; Bodinier et al., 1990; Takazawa et al., 1992; Hauri and Hart, 1994) and ended with the precipitation of new clinopyroxene crystals, particularly when the infiltrating melt was carbonatitic.

It is evident that the $\mathrm{Sr}$ and $\mathrm{Nd}$ isotopic compositions of clinopyroxenes were completely dominated by those of infiltrating melts, i.e. the plume melts. The ranges of the $\mathrm{Sr}$ and Nd isotopic compositions were found to be much larger than those found thus far for the Kerguelen basalts. If a harzburgite with the most depleted ${ }^{87} \mathrm{Sr} /{ }^{86} \mathrm{Sr}$ were to be considered as a plume residue on the basis of its major element composition, the ${ }^{87} \mathrm{Sr} /{ }^{86} \mathrm{Sr}$ of the plume ranges from 0.7033 to 0.70681 . The enriched end of the spectrum is much more enriched than any of the Kerguelen Islands basalts, but are within those of the Heard Island basalts.

Because of the compatible nature of Os, its isotopes provide a different perspective. Osmium isotopic compositions in peridotites are "indigenous" characteristics, reflecting their provenance. One of the most significant contributions of this study is the discovery of a group of harzburgites with unradiogenic Os. Their Re depletion model ages go up to $1.36 \mathrm{Ga}$, strongly indicating their origin in the sub-continental lithosphere of Gondwanaland. Their major element characteristics that indicate their origin as high pressure residues are consistent with this interpretation. It is suggested that they represent 
pieces of delaminated Gondwanaland lithosphere during continental rifting which coincided with an early part of the Kerguelen plume activation.

The Os isotopic compositions of the non-Gondwanaland peridotites reveal a large heterogeneity within the Kerguelen plume. The range of ${ }^{187} \mathrm{Os} /{ }^{188} \mathrm{Os}$ from 0.1224 to 0.1383 covers practically the entire range observed for the Hawaiian basalts (Hauri, 1996) but is only for peridotites. This, together with the Os data for the granulite xenoliths represents one of the most comprehensive datasets for a plume system, and is particularly important for defining the Os isotopic character of the EM-I endmember.

\subsection{Lower crustal xenoliths}

Lower crustal xenoliths in ocean island basalts are very rare and the Kerguelen suites are the first granulite facies rocks reported from the oceanic environment (Grègoire et al., 1994). It has been unclear, however, whether their magmatic lineage is connected to the SEIR or the Kerguelen plume. It appears that Grègoire et al. (1998) and Mattielli et al. (1996) linked them to the SEIR because their Sr and Nd isotopic compositions are intermediate between the SEIR basalts and an enriched plume component, represented by basalts from the Southeast Province.

A comparison of the whole rock major element compositions and modal abundances of minerals clearly shows that these rocks were originally olivine-rich gabbros and recrystallized under the reaction: olivine + plagioclase $\rightarrow$ orthopyroxene + clinopyroxene + spinel. Practically all olivine was lost and orthopyroxene was gained as a result of this reaction. The whole rock trace element compositions are indicative that these rocks were gabbroic cumulates, exhibiting large positive $\mathrm{Sr}$ anomalies and moderate positive Eu 
anomalies. These characteristics, and that Th contents are extremely low argue that the amounts of interstitial melt were very small $(<6 \%)$.

Abundance patterns of trace elements in granulite whole-rocks and clinopyroxenes were then used to determine their magmatic provenance. This is clearly akin to the Kerguelen basalts rather than to the SEIR mid-ocean ridge basalts. Their $\mathrm{Sr}$ and $\mathrm{Nd}$ isotopic compositions $\left({ }^{87} \mathrm{Sr} /{ }^{86} \mathrm{Sr}=0.70450\right.$ to $0.70520 ; \varepsilon_{\mathrm{Nd}}=1.81$ to 3.9$)$ are within the ranges observed for the Kerguelen Islands basalts and are remarkably similar to basalts from the Ninetyeast Ridge (particularly the 58-88 Ma samples from ODP sites 757 and 758 $\left({ }^{87} \mathrm{Sr} /{ }^{86} \mathrm{Sr}=0.70433\right.$ to $0.70501 ; \varepsilon_{\mathrm{Nd}}=2.5$ to 4.9$)$ (Weis and Frey, 1991). Thus the genetic link of granulites to the Kerguelen plume is well established.

The Os isotopic compositions were close to the present-day bulk earth and are similar to those reported for Heard Island basalts (Barling et al., 1997), but much less radiogenic than values reported for some Kerguelen basalts by Reisburg (1993) and Yang et al. (1998a). Only one sample (OB93-54) has radiogenic ${ }^{187} \mathrm{Os} /{ }^{188} \mathrm{Os}$ similar to the Kerguelen basalts, but because the age of this granulite is unknown precludes any significant inferences to be made. If however, it is assumed that the granulites had uniform initial Os isotopic composition, $\sim 70 \mathrm{Ma}$ of radiogenic ingrowth for the measured ${ }^{187} \mathrm{Re} /{ }^{188} \mathrm{Os}$ could account for the observed ${ }^{187} \mathrm{Os} /{ }^{188} \mathrm{Os}$ in OB93-54. If this is correct, a genetic link between the granulites and the Ninetyeast Ridge could be supported.

Accepting the geochemical conclusion of this study, the granulites were cumulates from Kerguelen plume-derived magmas and subsequently recrystallized under granulite facies conditions by isobaric cooling. On the basis of the mineral assemblages containing sapphirine and garnet, Grègoire et al. (1994) estimated a pressure of recrystallization of $\sim 1$ GPa. The granulites studied here are almost garnet-free and may have recrystallized at $\sim 0.6$ 
$\mathrm{GPa}$. This requires cumulate formation at depths of approximately $20 \mathrm{~km}$. By analogy to the formation of the lower crust at ocean ridges, as viewed at the Moho transition zone of the Oman ophiolite (e.g. Kelemen et al., 1997), it could be visualized that magmatic underplating for plume systems occurs as emplacement of series' of gabbroic bodies in much the same way as the Oman Gabbro sills are emplaced.

\subsection{Evolution of the Kerguelen plume: a brief synthesis}

The results of this study can be placed with previous geochemical and geophysical studies in a context of the evolution of the Kerguelen plume. Although a genetic link with the Bunbury basalts (105-136 Ma, W. Australia) and the Rajmahal traps (108-128 Ma, northeastern India) is uncertain (Storey et al., 1989; Frey et al., 1996), the first certain inception of the Kerguelen Plateau is placed around $115 \mathrm{Ma}$ (Weis et al., 1989). The delamination of Gondwanaland lithosphere and subsequent entrainment into the plume must have occurred by this time. The isotopic data of basalts from ODP site $738((\sim 115$ Ma; Alibert, 1991; Mahoney et al., 1994) appear to require contamination by continental crust in a situation where plume magmatism is not distal to sources of the required contaminants. A pyroxenite from the Kerguelen Islands may have been produced in this period (OB93-94).

The record of magmatic activity between 90 and 40 Ma appears to be on the Ninetyeast Ridge, which is interpreted as a hotspot track. A recent seismological study reveals that the crustal thickness beneath the Ninetyeast Ridge exceeds $25 \mathrm{~km}$ (Flueh et al., 1999). This provides an ideal ground for postulating that underplating of plume-derived melts as gabbroic cumulates and subsequent recrystallization as granulites may have occurred during this time. 
After the SEIR drifted away from the plume, the Kerguelen Islands were constructed. Temporal variations of the $\mathrm{Sr}$ and $\mathrm{Nd}$ isotopic compositions from the northwest to the southeast areas of the Kerguelen Islands were previously interpreted as due to a temporal decrease in the mixing proportions of the DMM components (e.g. Gautier et al., 1990; Weis et al., 1993) but in light of Yang et al. (1998a), the mixing hypothesis should be discounted. The position of this study however, is that the observed isotopic variations are due to the heterogeneity of the plume source, rather than the Yang et al. (1998a) hypothesis, which calls for plume heat-induced melting of granulites as a source component. This position is made on petrological and geochemical grounds, in that the basalts are undersaturated in plagioclase and the basalts lack positive $\mathrm{Sr}$ anomalies.

It appears that young volcanic rocks (Southeast Province, Mt. Ross and the host dike for the xenoliths of this study), as well as melts that caused young metasomatic events have the $\mathrm{Sr}$ and $\mathrm{Nd}$ isotopic characteristics of enriched mantle components. When the isotopic compositions of Heard Island (one of the youngest magmatic expressions of the plume; Barling et al., 1994) are added to the picture, temporal variations of the $\mathrm{Sr}$ and $\mathrm{Nd}$ compositions from the Ninetyeast Ridge stage to the present appear to emerge (Figure 5-1) summarizes this progression. This cannot be due to the aging of a uniform plume as advocated for the Ninetyeast Ridge U-Pb system by Class et al. (1993), because the ${ }^{143} \mathrm{Nd} /{ }^{144} \mathrm{Nd}$ decreases with the temporal progression.

As for plume-lithosphere interaction, the geochemical signatures for peridotite-melt reactions are abundant. It is important that the reactions leave behind rocks that are very heterogeneous on small spatial scales and that melts and peridotites were not equilibrated. That heterogeneities on such small scales under mantle conditions can survive only for limited lengths of time suggests that the metasomatism was a young process that occurred shortly before eruption. 
Rocks upon which metasomatic records are printed, are thought to be residues of melting at high pressures that are later recrystallized prior to metasomatism. Although this interpretation was formulated for the Kerguelen harzburgites, it is clearly applicable to the Samoan and some of the Hawaiian xenoliths. For the Samoan xenoliths, Hauri \& Hart (1994) reached the same conclusion from the garnet signatures in the trace elements; the interpretation of this study now suggests that their conclusion is consistent with the major element compositions.

Sen et al. (1988) and Yang et al. (1998b) analyzed selected peridotite xenoliths from Oahu which contained clinopyroxenes with original REE patterns resembling those of abyssal peridotites and discussed chemical interactions between the Hawaiian plume and oceanic lithosphere. As discussed above, not a single piece of peridotite which can unequivocally be considered as oceanic lithosphere was found among the Kerguelen peridotites. In terms of ${ }^{87} \mathrm{Sr} /{ }^{86} \mathrm{Sr}, \mathrm{OB} 93-78(=0.7033)$ could potentially be, but its major element composition classified this rock as a piece of the plume residue together with the other harzburgites.

The Os isotope data assembled in this study make up one of the most comprehensive datasets for a plume system. The range of ${ }^{187} \mathrm{Os} /{ }^{188} \mathrm{Os}$ obtained for the non-Gondwanaland peridotites is from 0.1252 to 0.1383 with a mean of 0.1283 . The range of present-day ${ }^{187} \mathrm{Os} /{ }^{188} \mathrm{Os}$ for the granulites (except for OB93-54) is from 0.1286 to 0.1344 , and one for 70 Ma corrected values (including OB93-54) is from 0.1270 to 0.1337 with a mean of 0.1293. Although the magnitude of the age correction is uncertain, the range for the granulites completely overlaps with that for the peridotites. It is also notable that the Os isotope data for the Heard Island basalts (Barling et al., 1997) also overlaps this range. 
Figure 5-2 illustrates the relationships between $\mathrm{Os}, \mathrm{Sr}$ and $\mathrm{Nd}$ isotopic compositions of some ocean island basalts and mantle endmember components. Based on the discussions presented earlier for identifying non-Gondwanaland peridotites and granulites with the Kerguelen plume system, the present results place strong constraints for the Os isotope compositions for EM-I, and perhaps more importantly, suggest that the xenolith-based approach taken here provides much better constraints than the conventional basalt-based approach in which low Os concentrations in basalts are extremely susceptible to alteration in surficial processes and present an insurmountable barrier for obtaining reliable answers. 


\subsection{References Cited}

Alibert C. (1991) Mineralogy and geochemistry of a basalt from site 738: implications for the tectonic history of the southernmost part of the Kerguelen Plateau. In Proceedings of the Ocean Drilling Program, Scientific Results, Vol. 119 (ed. J. Barron, B. Larsen, and et al.), pp. 293-298. Ocean Drilling Program.

Barling J., Goldstein S. L., and Nicholls I. A. (1994) Geochemistry of Heard Island (southern Indian Ocean): characterization of an enriched mantle component and implications for enrichment of the sub-Indian Ocean mantle. J. Petrol. 35, 10171053.

Barling J., McBride J. S., Lambert D. D., and Nicholls I. A. (1997) The Heard Island Continental Component: Osmium-isotopic evidence for mantle vs. magma contamination. Seventh Annual V.M. Goldschmidt Conference LPI Cont. 921, 1718.

Bodinier J. L., Vasseur G., Vernieres J., Dupuy C., and Fabries J. (1990) Mechanisms of mantle metasomatism: geochemical evidence from the Lherz orogenic peridotite. $J$. Petrol. 31, 597-628.

Class C., Goldstein S. L., Galer S. J. G., and Weis D. (1993) Young formation age of a mantle plume source. Nature 362, 715-721.

Dosso L., Bougault H., Beuzart P., Calvez J.-Y., and Joron J.-L. (1988) The geochemical structure of the South-East Indian Ridge. Earth Planet. Sci. Lett. 88, 47-59.

Flueh E. R., Grevemeyer I., and Reichert C. (1999) Ocean site survey reveals anatomy of a hotspot track. Eos, Transactions, American Geophysical Union 80, 77.

Frey F. A., McNaughton N. J., Nelson D. R., deLaeter J. R., and Duncan R. A. (1996) Petrogenesis of the Bunbury Basalt, Western Australia: interaction between the Kerguelen Plume and Gondwana lithosphere? Earth Planet. Sci. Lett. 144, 163-183.

Gautier I., Weis D., Mennessier J.-P., Vidal P., Giret A., and Loubet M. (1990) Petrology and geochemistry of the Kerguelen Archipelago basalts (South Indian Ocean): evolution of the mantle sources from ridge to intraplate position. Earth Planet. Sci. Lett. 100, 59-76.

Grègoire M., Cottin J. Y., Giret A., Mattielli N., and Weis D. (1998) The meta-igneous granulite xenoliths from Kerguelen Archipelago: evidence of a continent nucleation in an oceanic setting. Cont. Mineral. Petrol. 133, 259-283.

Grègoire M., Mattielli N., Nicollet C., Cottin J. Y., Leyrit H., Weis D., Shimizu N., and Giret A. (1994) Oceanic mafic granulite xenoliths from the Kerguelen archipelago. Nature 367, 360 - 363.

Hamelin B., Dupre B., and Allègre C. J. (1986) Pb-Sr-Nd isotopic data of Indian Ocean ridges; new evidence of large-scale mapping of mantle heterogeneities. Earth Planet. Sci. Lett. 76, 288-298.

Hart S. R. (1988) Heterogeneous mantle domains: signatures, genesis and mixing chronologies. Earth Planet. Sci. Lett. 90, 273-296.

Hauri E. H. (1996) Major-element variability in the Hawaiian mantle plume. Nature 382, 415-419.

Hauri E. H. and Hart S. R. (1993) Re-Os isotope systematics of HIMU and EMII oceanic island basalts from the south Pacific Ocean. Earth Planet. Sci. Lett. 114, 353-371. 
Hauri E. H. and Hart S. R. (1994) Constraints on melt migration from mantle plumes: A trace element study of peridotite xenoliths from Savai'i, Western Samoa. J. Geophys. Res. 99, 24,301-24,321.

Kelemen P. B., Koga K., and Shimizu N. (1997) Geochemistry of gabbro sills in the crust-mantle transition zone of the Oman ophiolite: implications for the origin of the oceanic lower crust. Earth Planet. Sci. Lett. 146, 475-488.

Kinzler R. J. (1997) Melting of mantle peridotites at pressures approaching the spinel to garnet transition. J. Geophys. Res. 102.

Mahoney J. J., Jones W. B., Frey F. A., Salters V. J. M., Pyle D. G., and Davies H. L. (1994) Geochemical characteristics of lavas from Broken Ridge, the Naturaliste Plateau, and southernmost Kerguelen Plateau: Cretaceous Plateau volcanism in the southeast Indian Ocean. Chem. Geol. 120, 315-345.

Marcantonio F., Zindler A., Elliott T., and Staudigel H. (1995) Os isotope systematics of La Palma, Canary Islands: evidence for recycled crust in the mantle source of HIMU ocean islands. Earth Planet. Sci. Lett. 133, 397-410.

Martin C. E. (1991) Osmium characteristics of mantle-derived rocks. Geochim. Cosmochim. Acta 55, 1421-1434.

Mattielli N. (1996) Magmatisme et métasomatisme associés au panache des Kerguelen: Contribution de la géochimie des enclaves basiques et ultrabasiques. PhD Thesis, Université Libre de Bruxelles.

Mattielli N., Weis D., Grégoire M., Mennessier J. P., Cottin J. Y., and Giret A. (1996) Kerguelen basic and ultrabasic xenoliths: evidence for long-lived Kerguelen hotspot activity. Lithos 37, 261-280.

Mattielli N., Weis D., Scoates J. S., Shimizu N., Mennessier J.-P., Grègoire M., Cottin J.-Y., and Giret A. (1999) Evolution of heterogeneous lithospheric mantle in a plume environment beneath the Kerguelen Archipelago. J. Petrol. in press.

Michard A., Montigny R., and Schlich R. (1986) Geochemistry of the mantle beneath the Rodriguez Triple Junction and the South-East Indian Ridge. Earth Planet. Sci. Lett. 78, 104-114.

Navon O. and Stolper E. (1987) Geochemical consequences of melt percolation: the upper mantle as a chromatographic column. J. Geol. 95, 285-307.

Nicolaysen K., Frey F. A., Hodges K. V., Weis D., and Giret A. (1999) ${ }^{40} \mathrm{Ar} /{ }^{39} \mathrm{Ar}$ geochronology of flood basalts from the Kerguelen Archipelago, southern Indian Ocean: implications for Cenozoic eruption rates of the Kerguelen plume. Earth Planet. Sci. Lett., submitted.

Reisberg L., Zindler A., Marcantonio F., White W., Wyman D., and Weaver B. (1993) Os isotope systematics in ocean island basalts. Earth Planet. Sci. Lett. 120, 149-167.

Sen G. (1988) Petrogenesis of spinel lherzolite and pyroxenite suite xenoliths from the Koolau shield, Oahu, Hawaii: Implications for petrology of the post-eruptive lithosphere beneath Oahu. Contrib. Miner. Petrol. 100, 61-91.

Storey M., Saunders A. D., Tarney J., Gibson I. L., Norry M. J., Thirwall M. F., Leat P., Thompson R. N., and Menzies M. A. (1989) Contamination of Indian Ocean asthenosphere by the Kerguelen-Heard mantle plume. Nature 338, 574 - 576.

Takazawa E., Frey F. A., Shimizu N., Obata M., and Bodinier J. L. (1992) Geochemical evidence for melt migration and reaction in the upper mantle. Nature 359, 55-58.

Walter M. J. (1998) Melting of garnet peridotite and the origin of komatiite and depleted lithosphere. J. Petrol. 39, 29-60. 
Walter M. J., Sisson T. W., and Presnall D. C. (1995) A mass proportion method for calculating melting reactions and application to melting of model upper mantle lherzolite. Earth Planet. Sci. Lett. 135, 77-90.

Weis D., Bassias Y., Gautier I., and Mennessier J.-P. (1989) Dupal anomaly in existence $115 \mathrm{Ma}$ ago: Evidence from isotopic study of the Kerguelen Plateau (South Indian Ocean). GCA 53, 2125 - 2131.

Weis D. and Frey F. A. (1991) Isotope geochemistry of Ninetyeast Ridge basement basalts: $\mathrm{Sr}, \mathrm{Nd}$, and $\mathrm{Pb}$ evidence for involvement of the Kerguelen hot spot. In Proc. ODP, Sci. Results, Vol. 121 (ed. J. Weissel, J. Peirce, E. Taylor, J. Alt, and e. al.), pp. 591 - 610. Ocean Drilling Program.

Weis D., Frey F. A., Giret A., and Cantagrel J.-M. (1998) Geochemical characteristics of the youngest volcano (Mount Ross) in the Kerguelen Archipelago: inferences for magma flux, lithosphere assimilation and composition of the Kerguelen plume. $J$. Petrol. 39, 973-994.

Weis D., Frey F. A., Leyrit H., and Gautier I. (1993) Kerguelen Archipelago revisited: geochemical and isotopic study of the Southeast Province lavas. Earth Planet. Sci. Lett. 118, 101 - 119.

White W. M. and Hofmann A. W. (1982) Sr and Nd isotope geochemistry of oceanic basalts and mantle evolution. Nature 296, 821-825.

Widom E. and Shirey S. B. (1996) Os isotope systematics in the Azores: implications for the mantle plume sources. Earth Planet. Sci. Lett. 142, 451-465.

Yang H.-J., Frey F. A., Weis D., Giret A., Pyle D., and Michon G. (1998a) Petrogenesis of the flood basalts forming the northern Kerguelen Archipelago: implications for the Kerguelen plume. J. Petrol. 39, 711-748.

Yang H.-J., Sen G., and Shimizu N. (1998b) Mid-ocean ridge melting: constraints from lithospheric xenoliths at Oahu, Hawaii. J. Petrol. 39, 277-295. 


\subsection{Figures}

Figure 5-1. Nd v. Sr isotopic diagram of peridotite clinopyroxenes, bulk rock granulite compositions, and the host basalt from the Kerguelen xenolith suite. Clinopyroxenes from xenoliths of this study are small open circles, and those from the Southeast Province are also shown for reference (small closed circles). Measured isotopic compositions of granulites from this study (open squares), granulites from the Southeastern Province (Mt.Tizard: gray diamonds, Dome Rouge and Val Phonolite: white diamonds; Mattielli et al., 1996; Mattielli, 1996), are shown in comparison to initial isotopic compositions of basalts from the Indian Ocean ridges (MORB with no plume influence: light gray, all Indian Ocean MORB: light gray + dashed line extension), the Kerguelen Islands (dark gray), Heard Island (medium gray, Barling, 1994) and the Ninetyeast Ridge (field "hidden" behind the Kerguelen Islands field; Weis and Frey, 1991). The Sr isotopic composition of OB93-61A is shown as a broken line. Granulites lie nearly completely within the field defined by Kerguelen Islands basalts (White and Hofmann, 1982; Gautier et al., 1990; Weis et al., 1993; Weis et al., 1998; Yang et al., 1998a), and none overlap the compositions of Indian Ocean MORB (Hamelin et al., 1986; Michard et al., 1986; Dosso et al., 1988). Mantle isotopic endmembers are shown for reference (filled circles; Hart, 1988). 


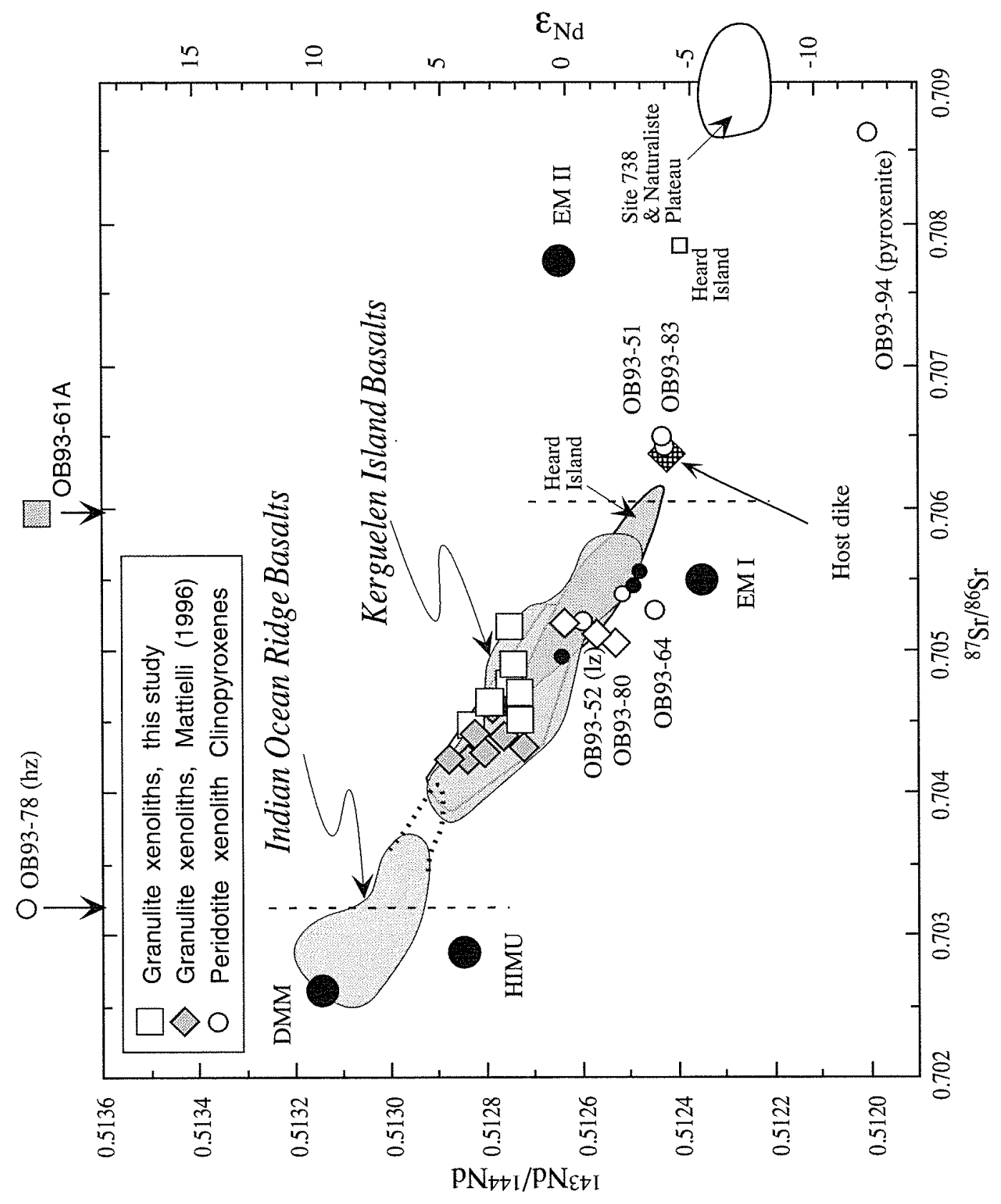


Figure 5-2. Os v. Sr (upper panel) and v. Nd (lower panel) isotopic compositions of Kerguelen plume rocks. Isotopic compositions of Courbet Peninsula granulites (filled squares), peridotite clinopyroxenes (open squares) Kerguelen Islands basalts (open circles; Reisberg et al., 1993; Yang et al., 1998a), and Heard Island basalts (gray circles: Barling et al., 1994; Barling et al., 1997) have a relatively large variation. Isotopic compositions shown for Kerguelen basalts are initial values and those for Heard basalts are measured values ( zero age). Osmium compositions for the granulites are corrected for a maximum eruption age of $24.5 \mathrm{Ma}$ (Nicolaysen et al., 1999); $\mathrm{Sr}$ and $\mathrm{Nd}$ isotopic compositions are as measured (correction for $24.5 \mathrm{Ma}$ eruption age is negligible). Compositions of mantle endmembers (Hart, 1988; Martin, 1991; Hauri and Hart, 1993; Reisberg et al., 1993; Marcantonio et al., 1995; Widom and Shirey, 1996) are labeled and displayed as open diamonds. Compositional fields for endmember ocean islands are also shown; EM I: Kerguelen Islands and Pitcairn Islands; EM II: Samoa and Tahaa; HIMU: St. Helena, Rurutu, Tubuai, and Mangaia. Data sources for these fields are as noted in the figure explanation. A vertical line through the symbol marks the reported range of the $187 \mathrm{Os} / 188 \mathrm{Os} \mathrm{EM}$ II component. No one mixing relation among the isotopic endmember components can account for all of the Kerguelen plume related rocks. 

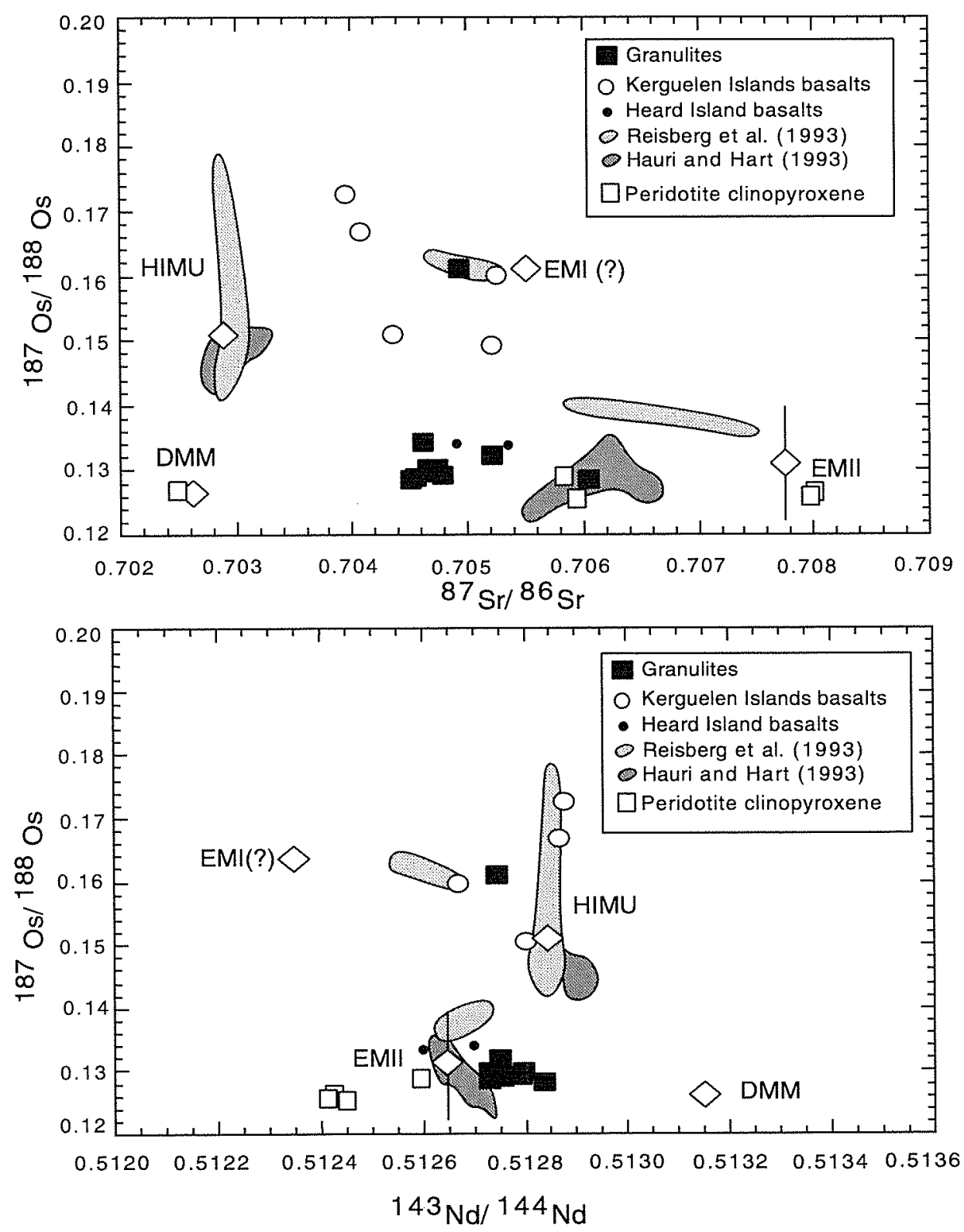
Appendix 1. Complete major and trace element compositions of minerals in the peridotites. 


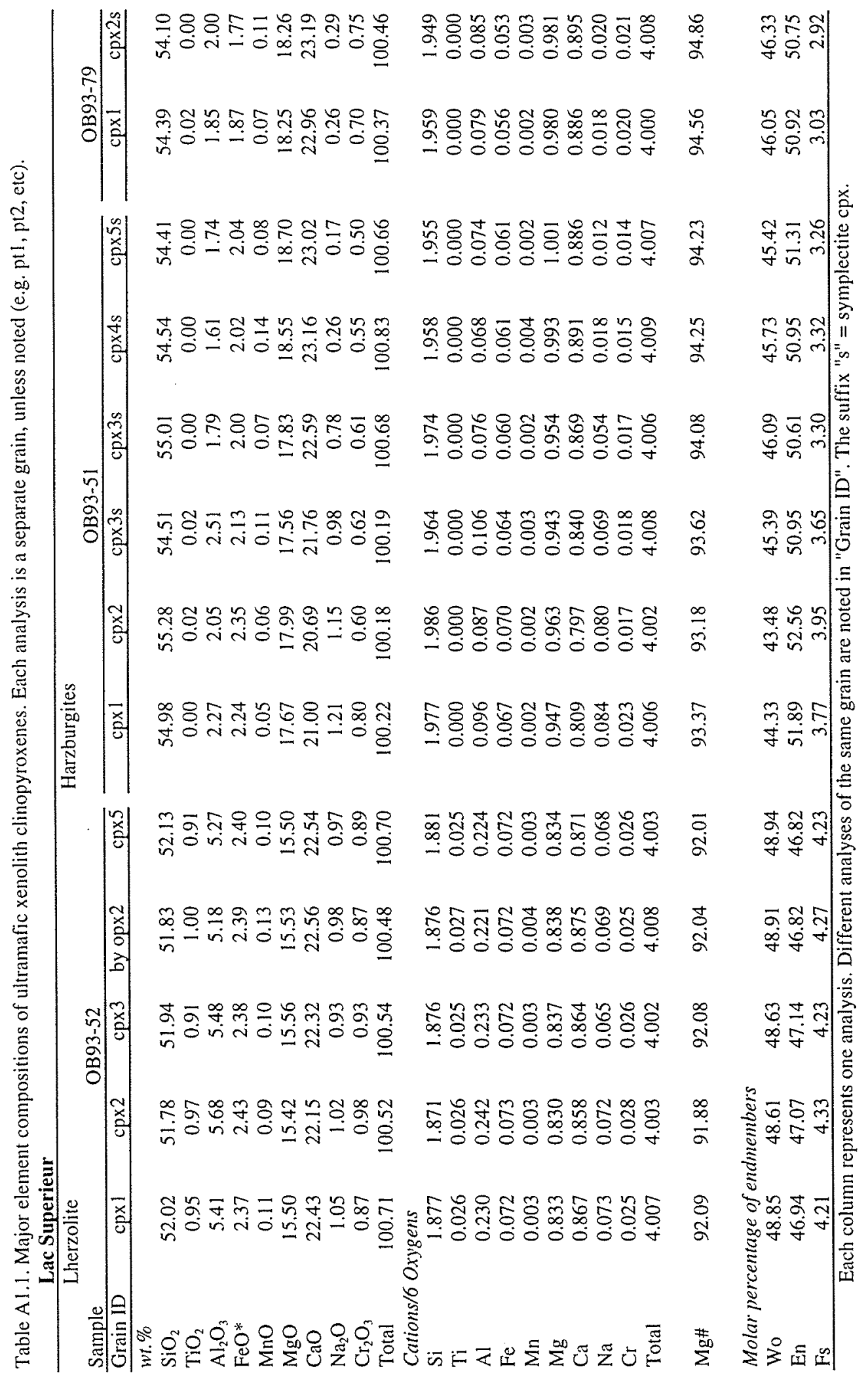




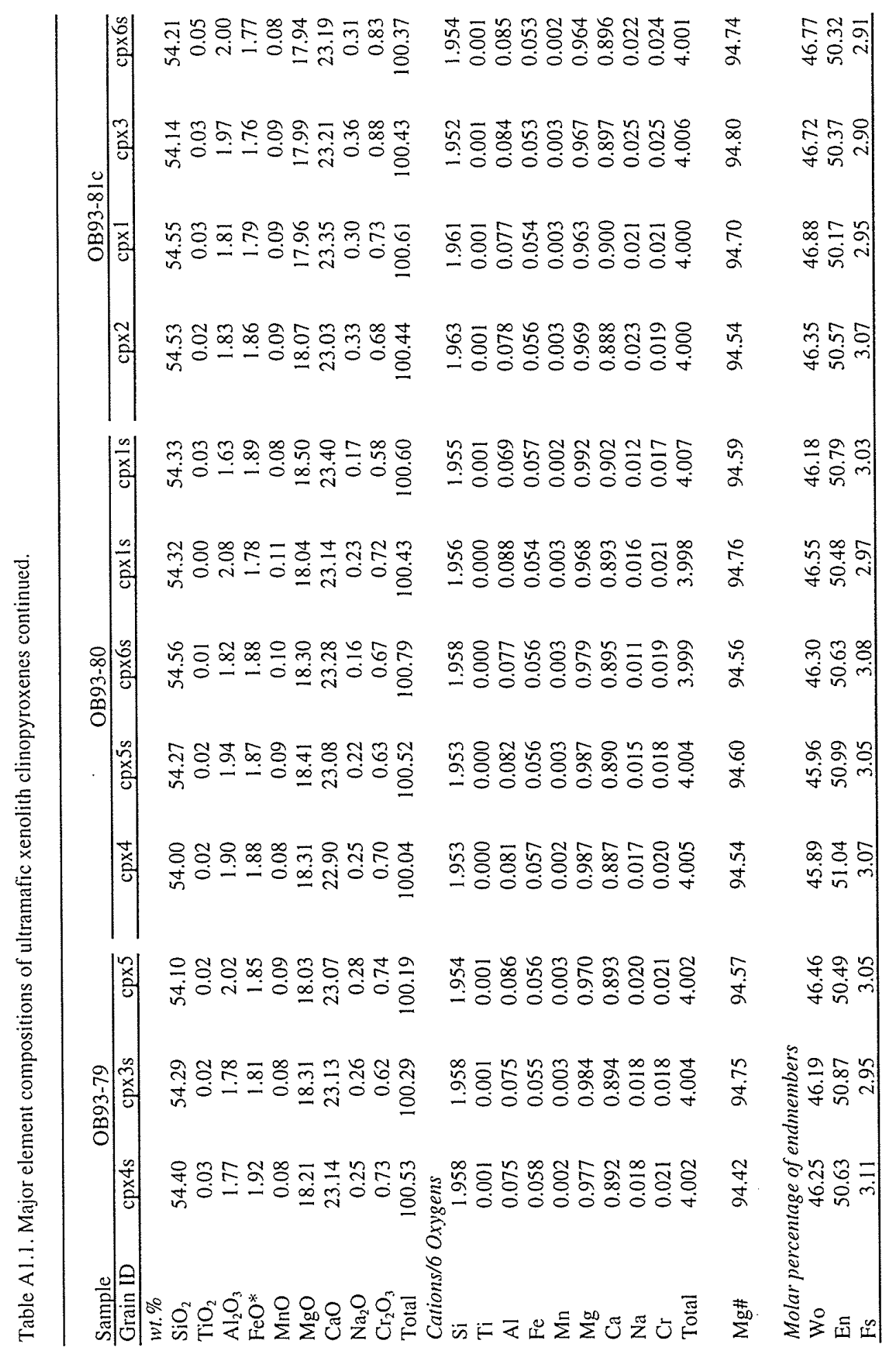




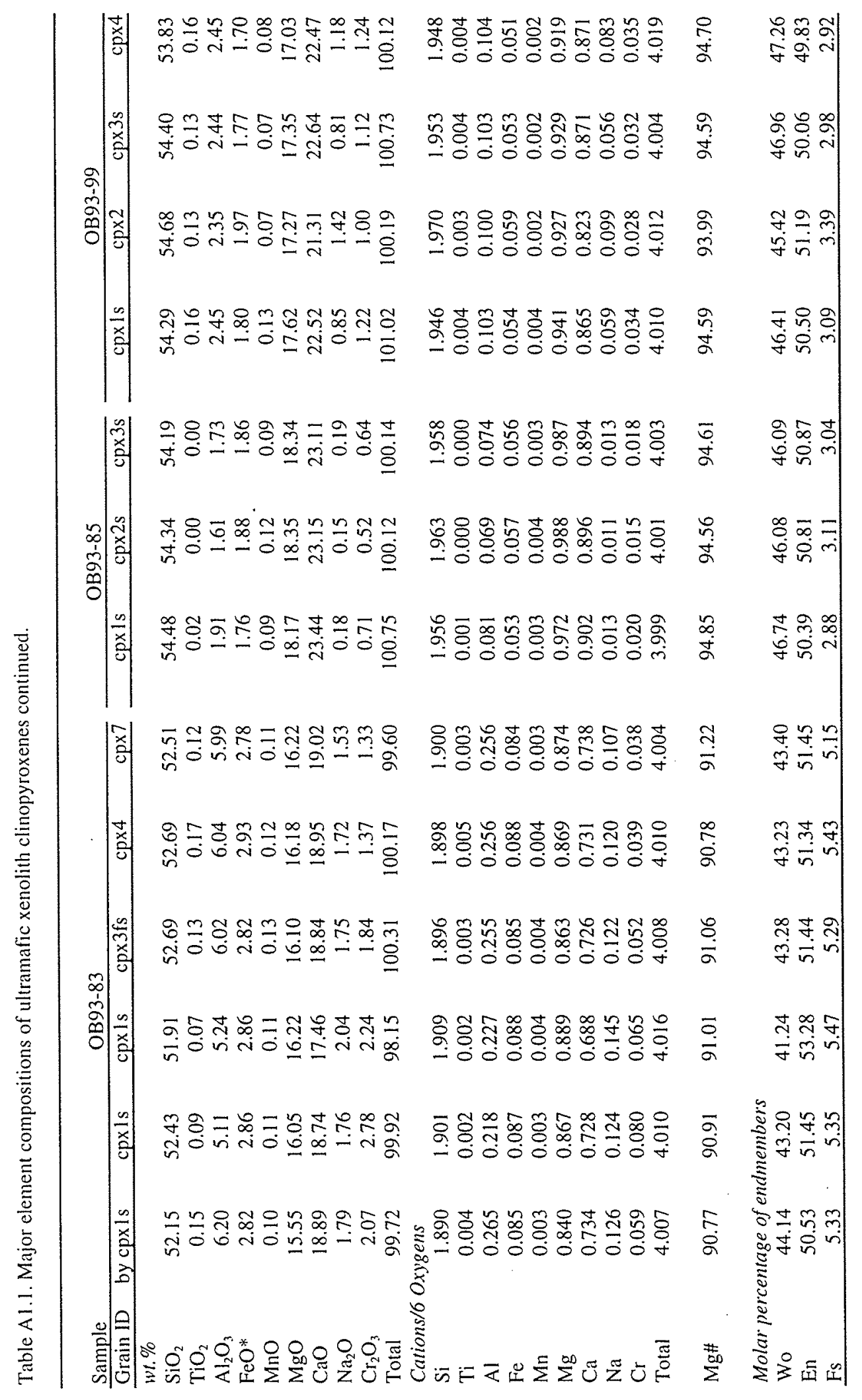




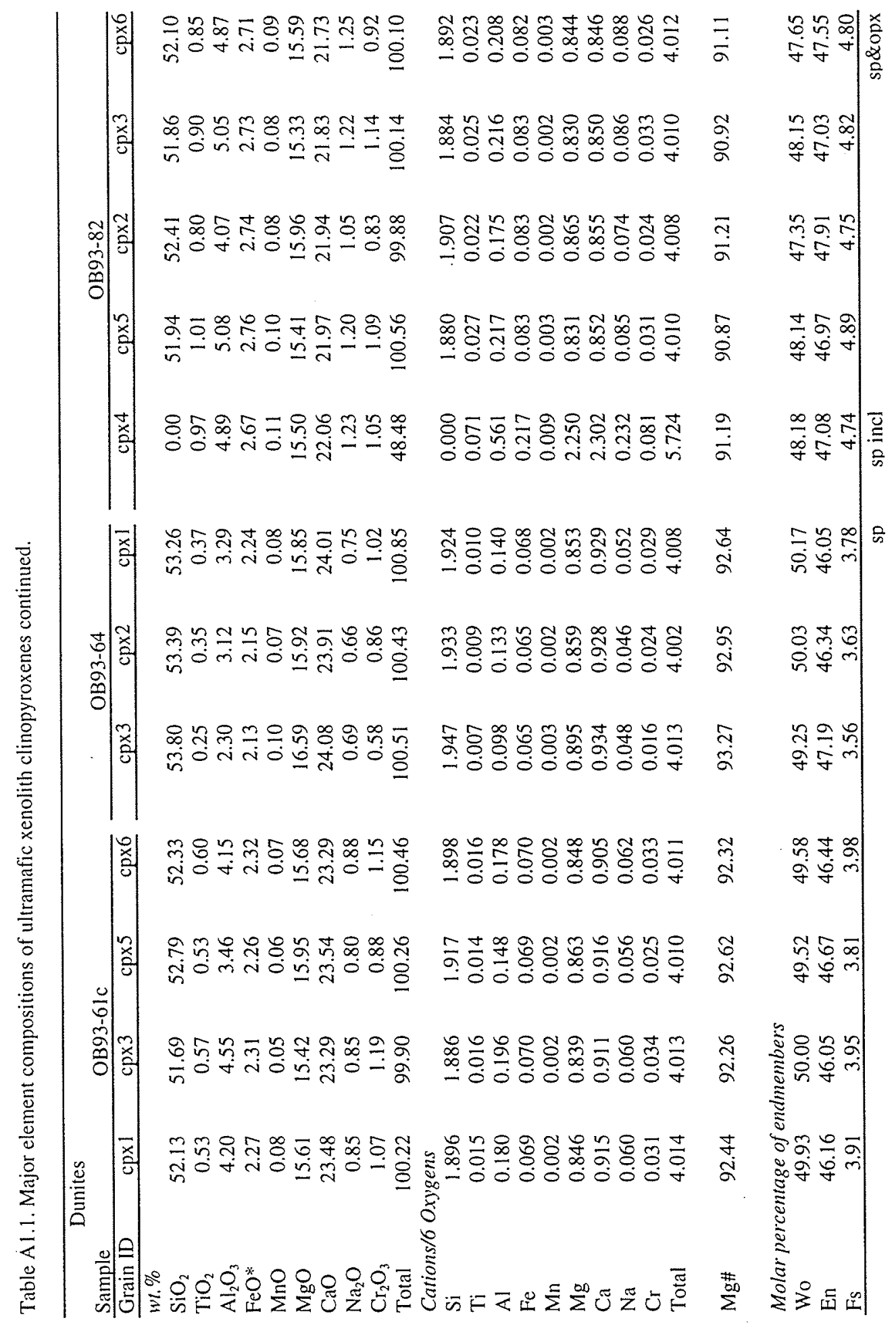




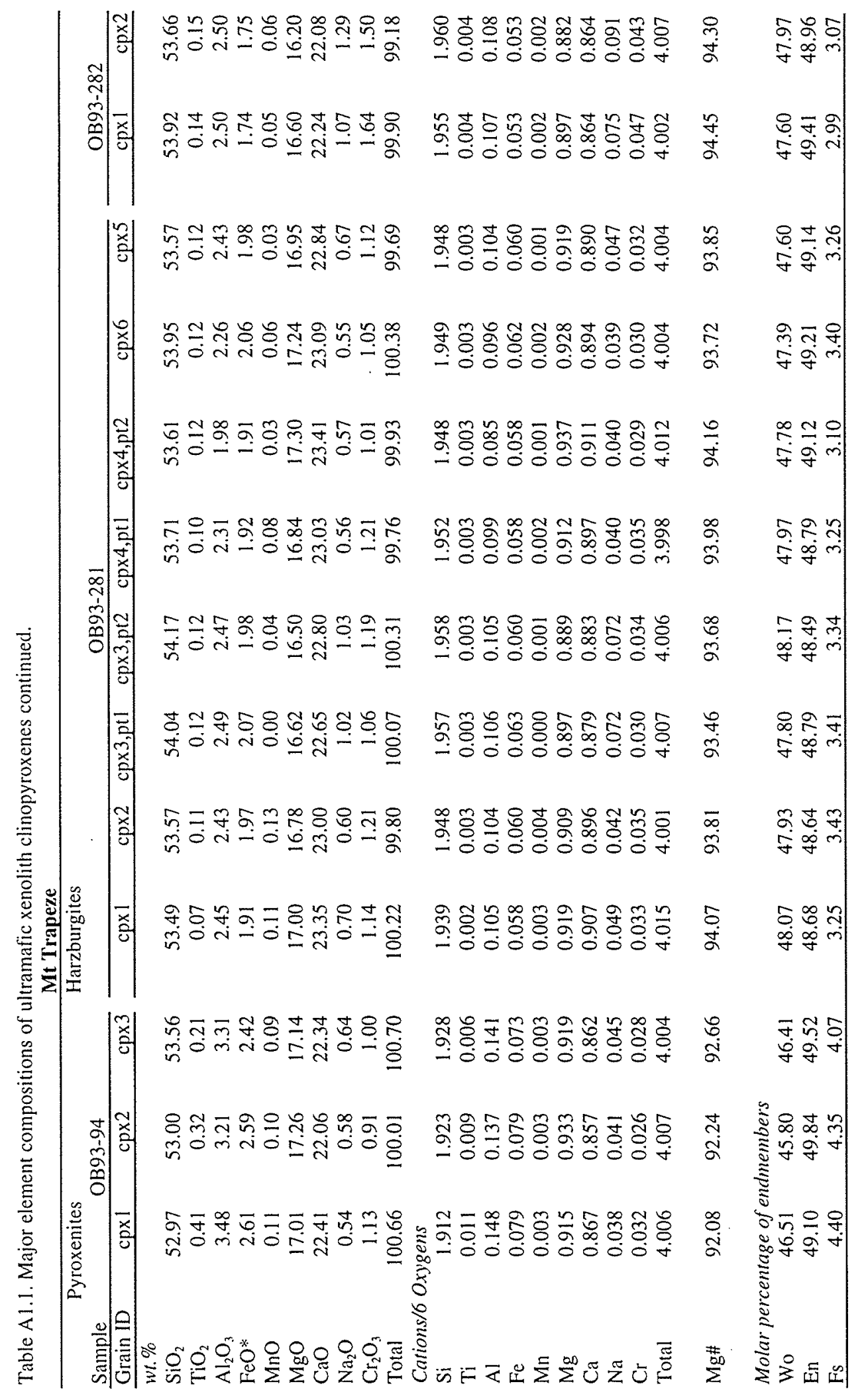




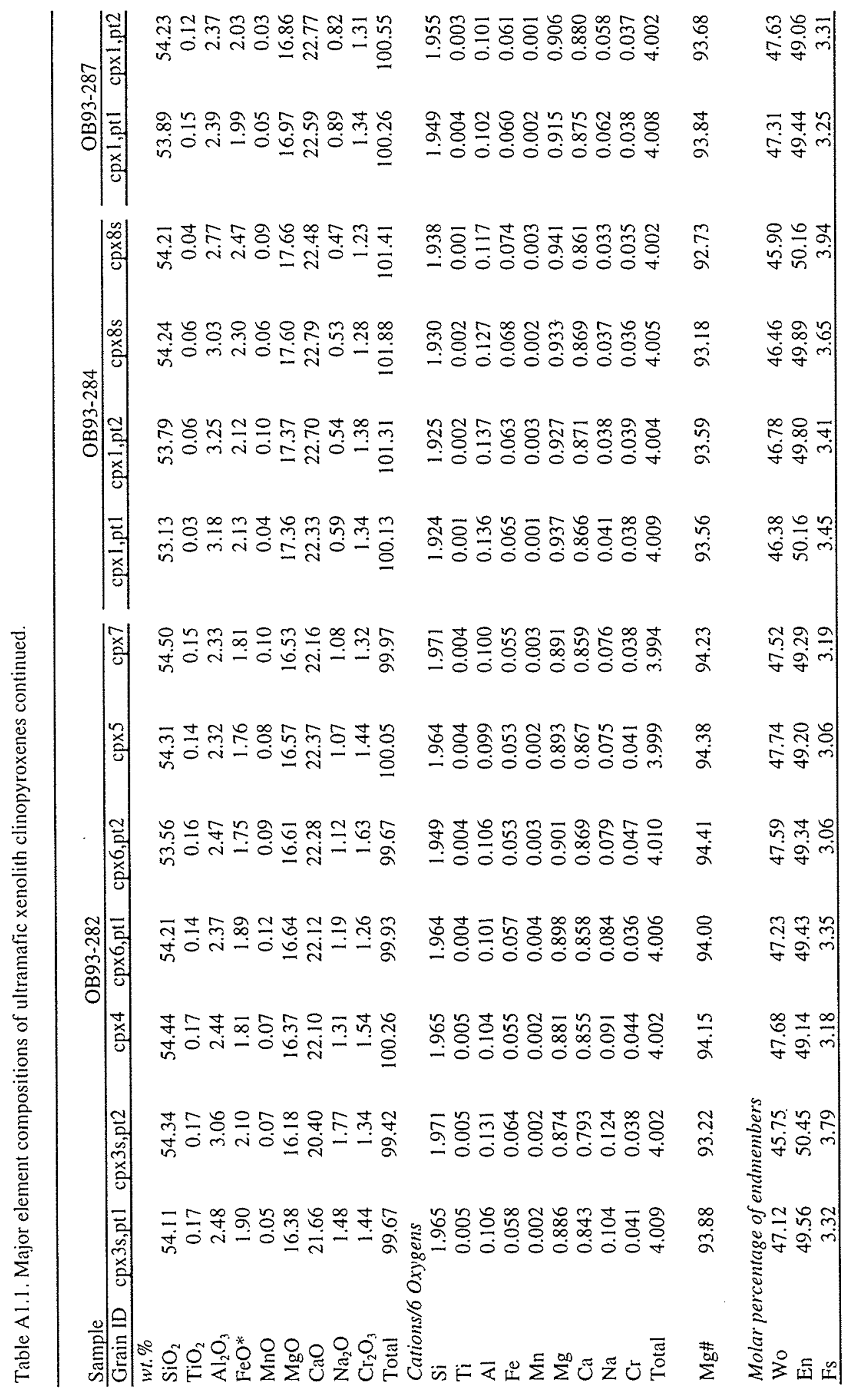




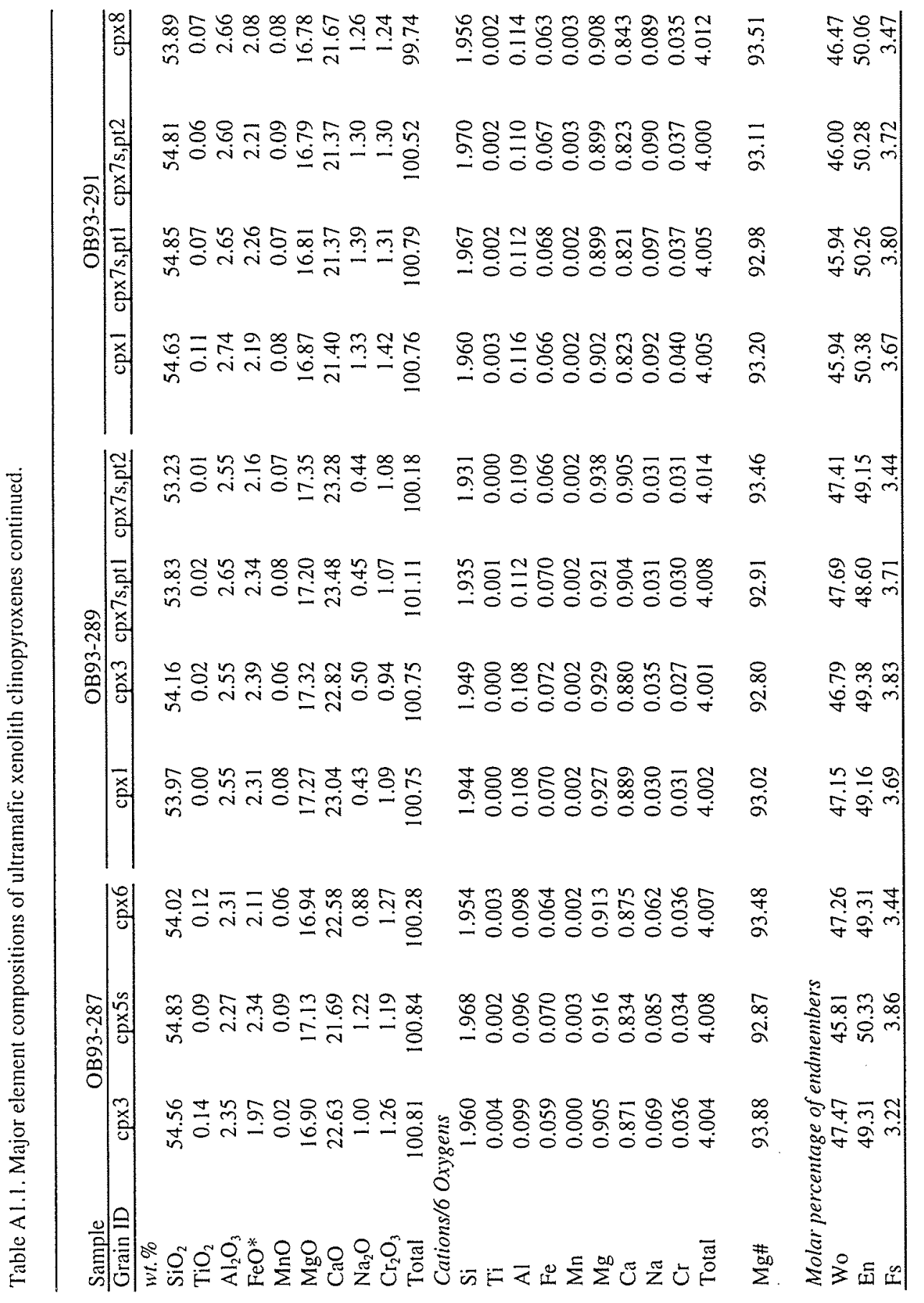




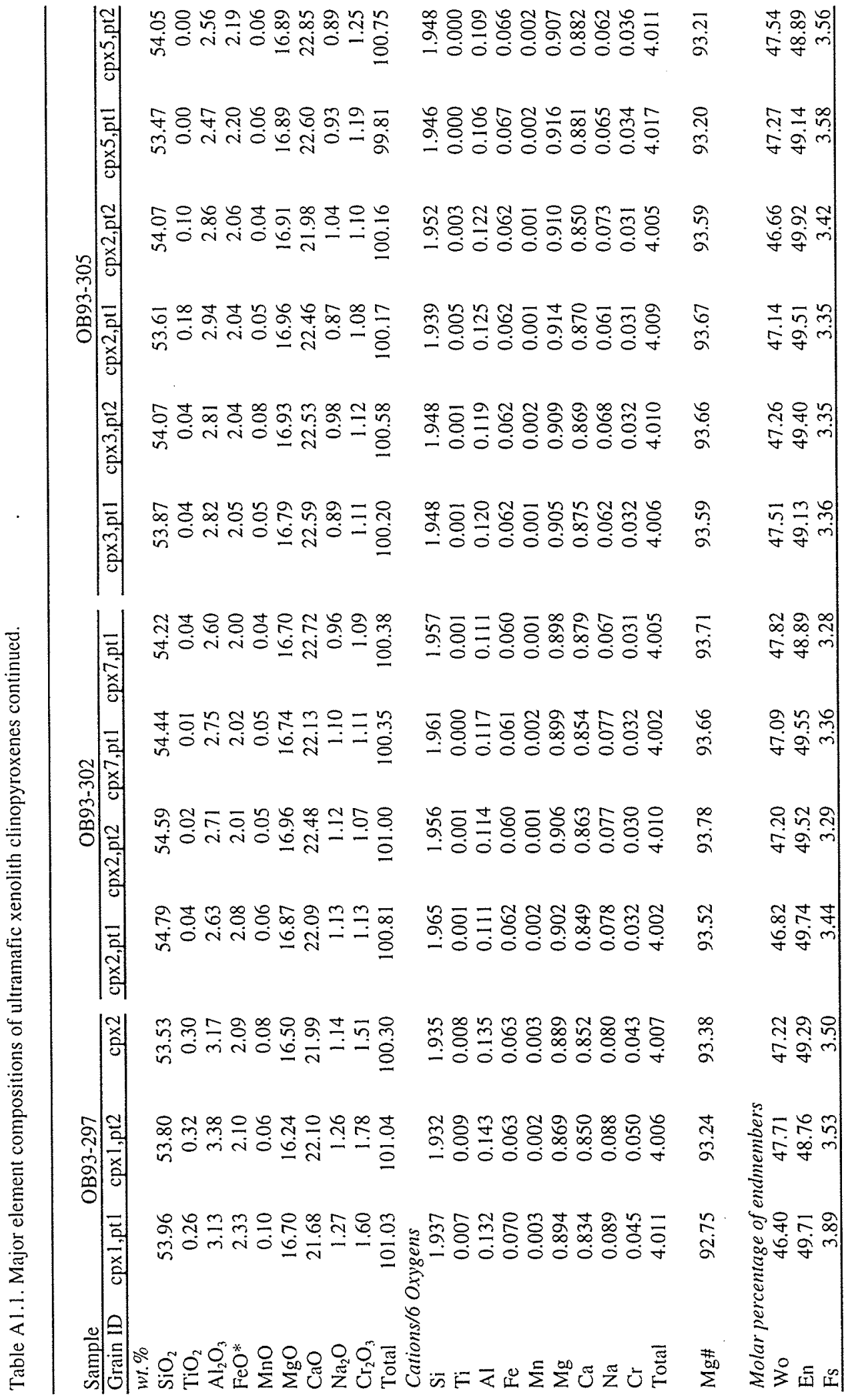




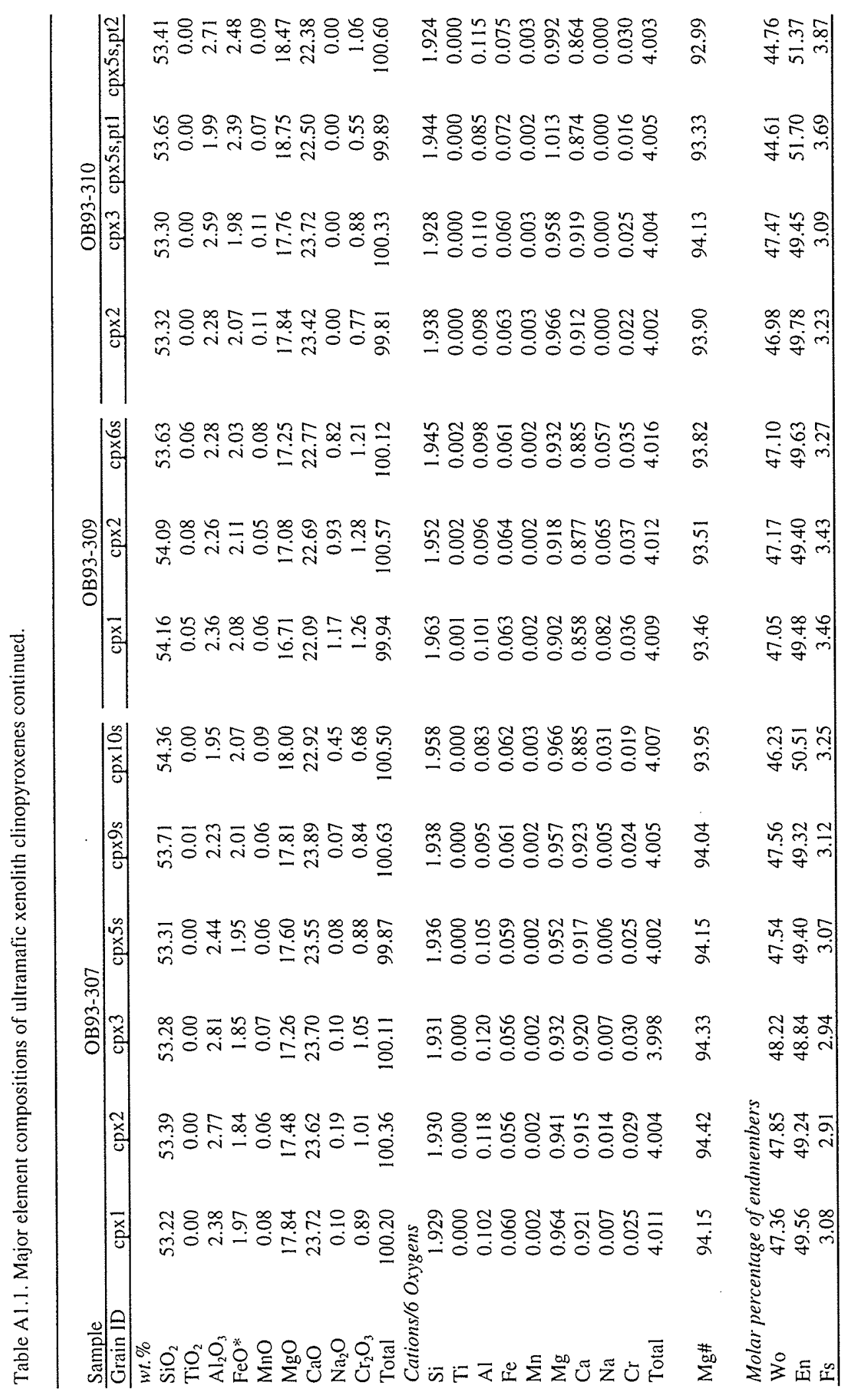




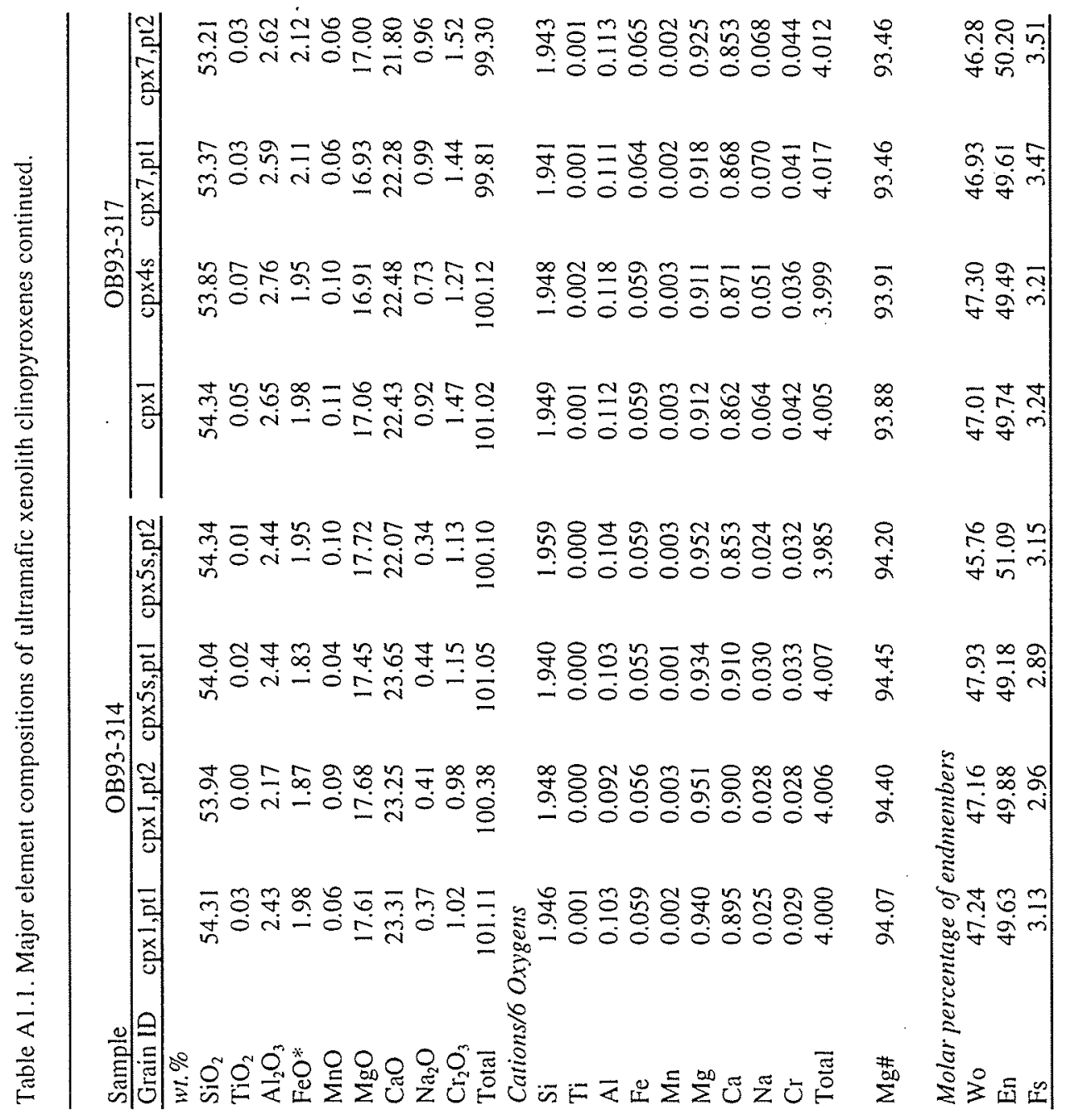




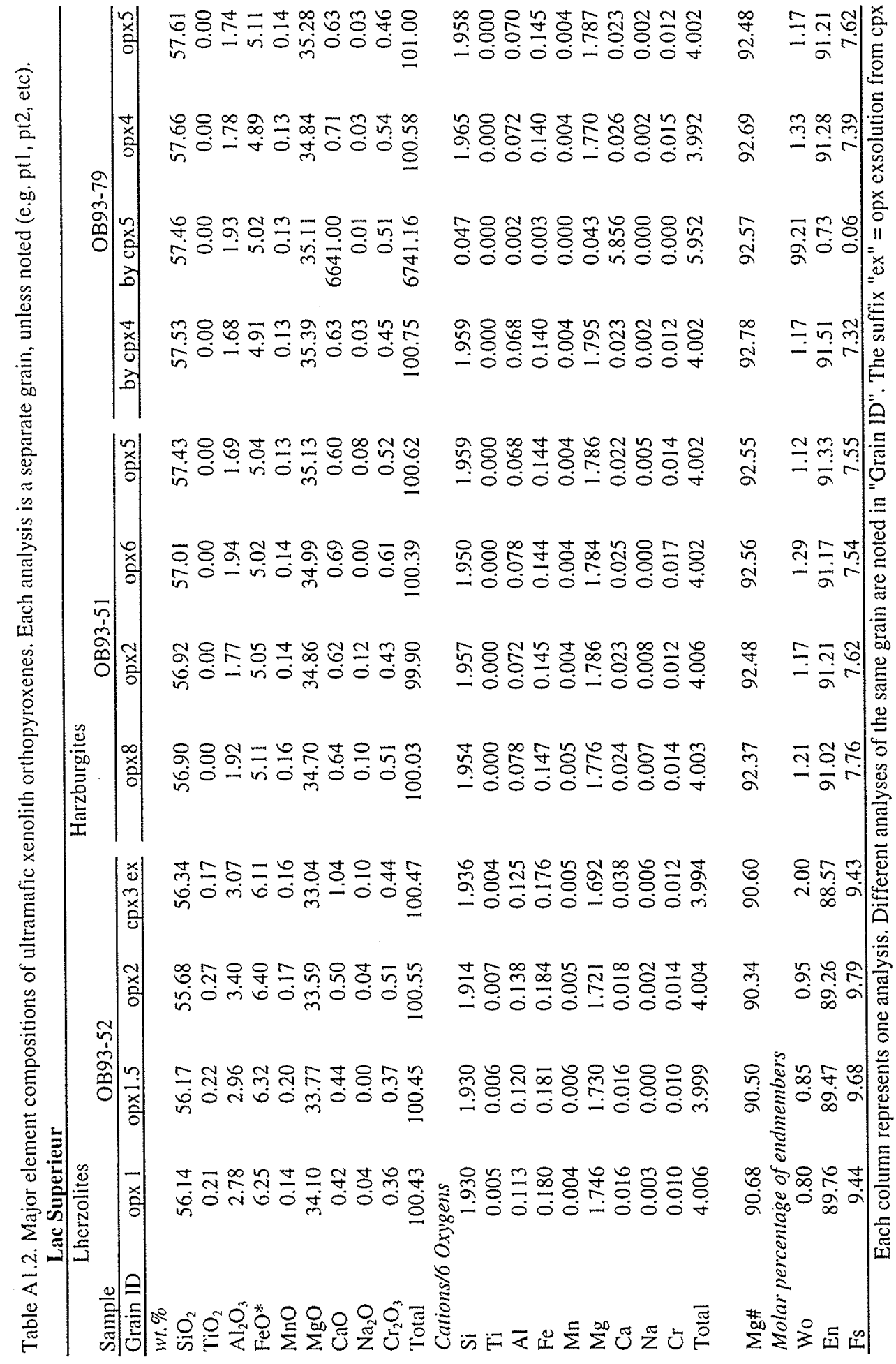




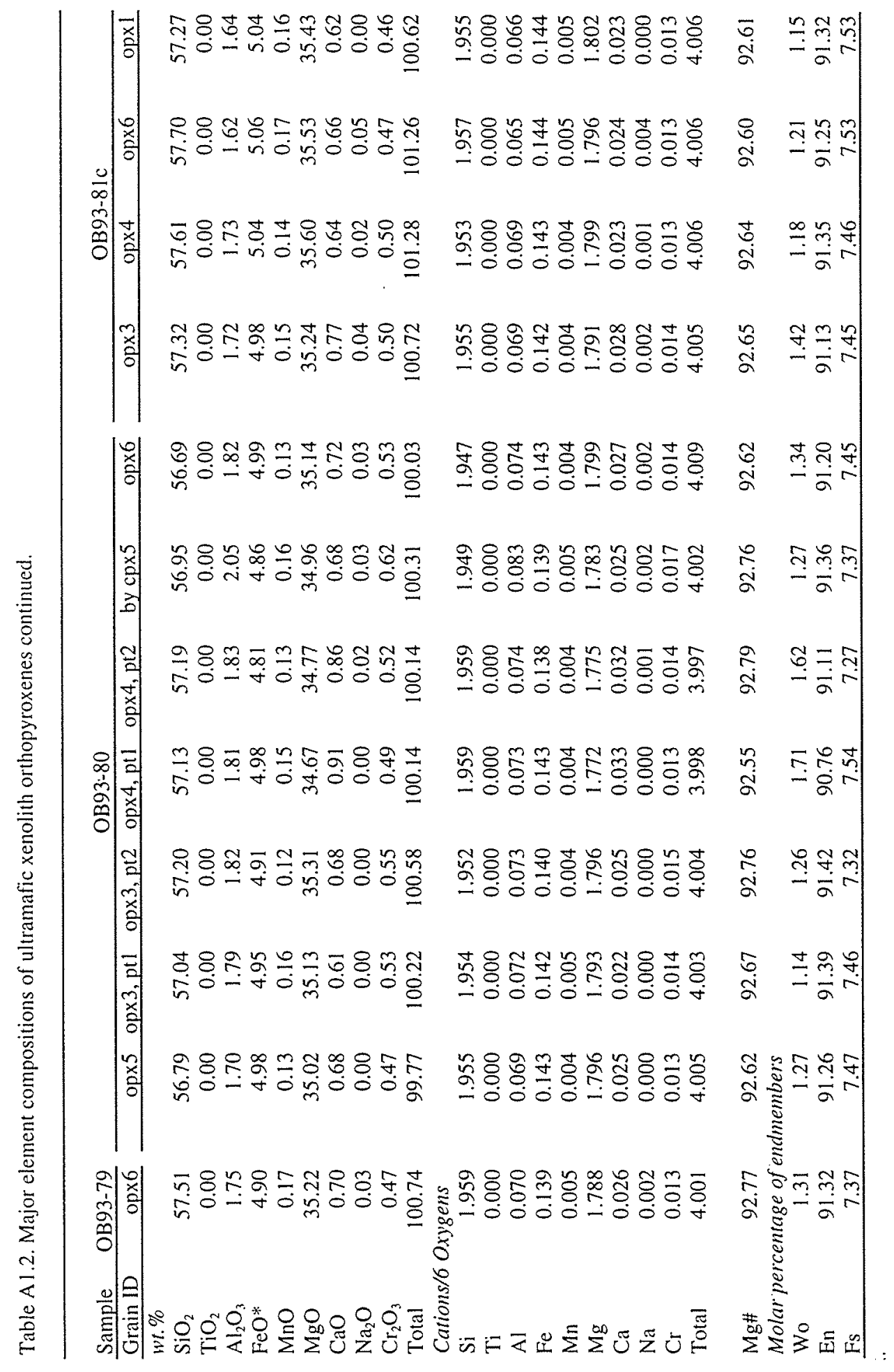




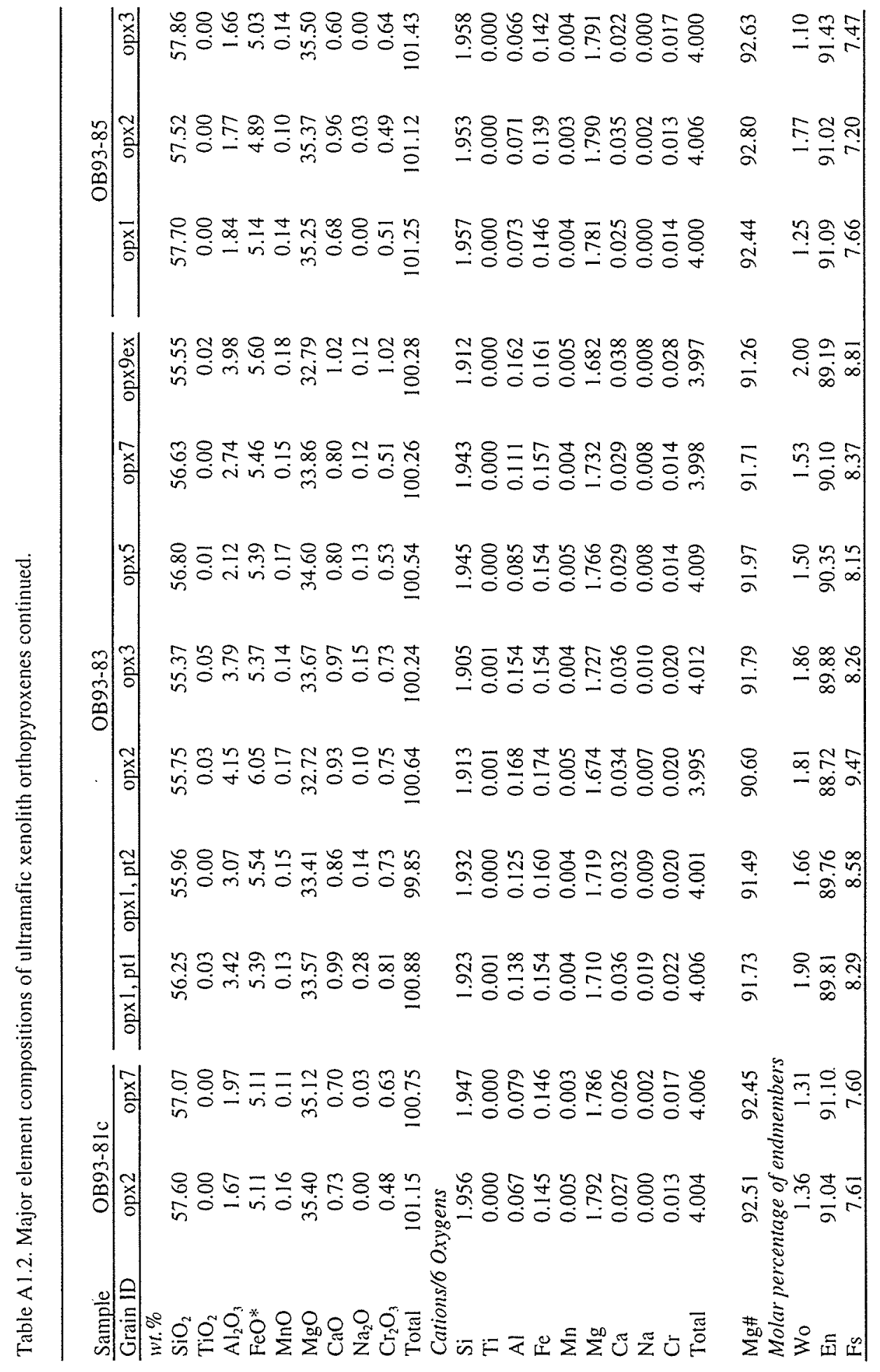




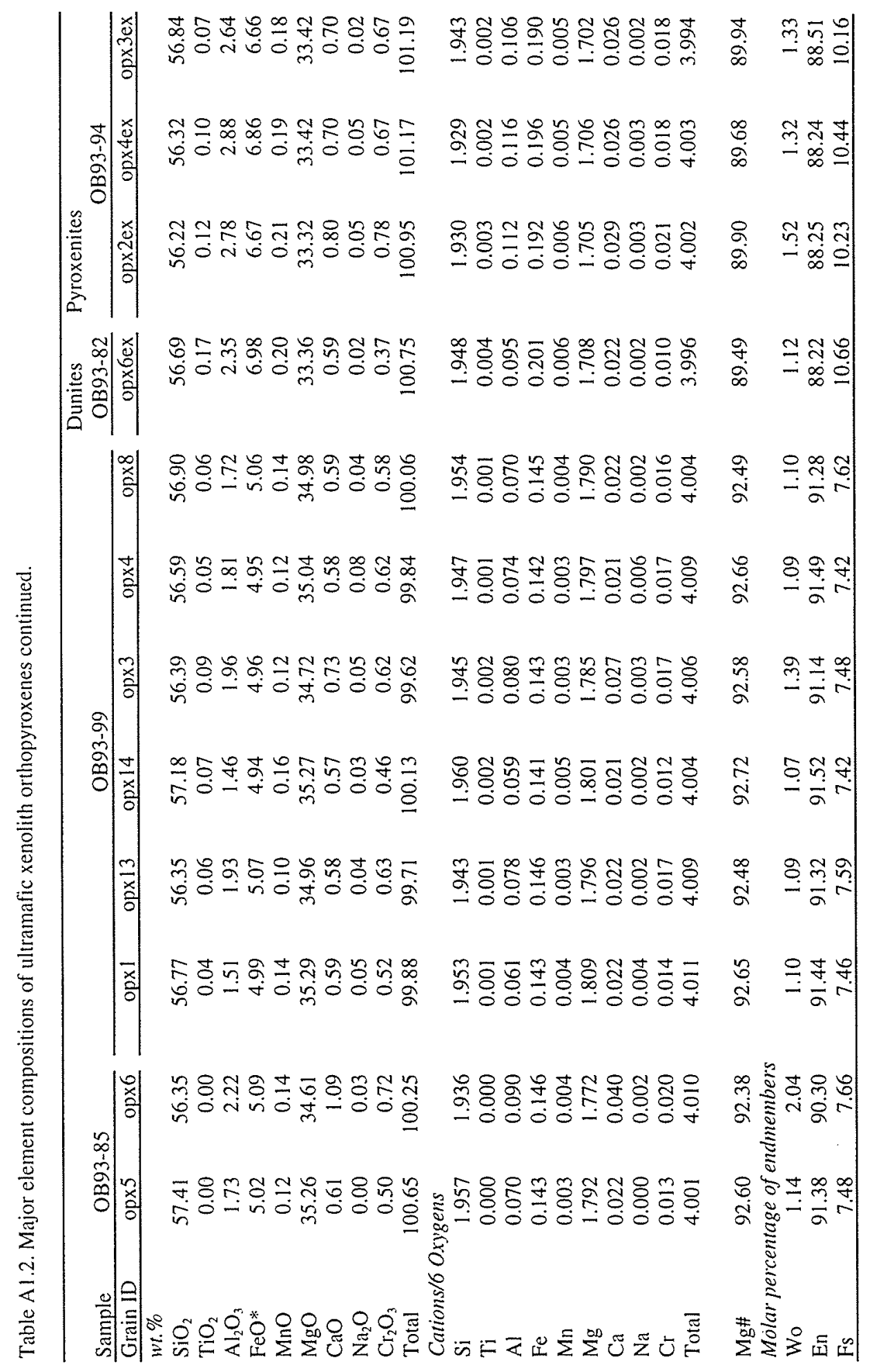




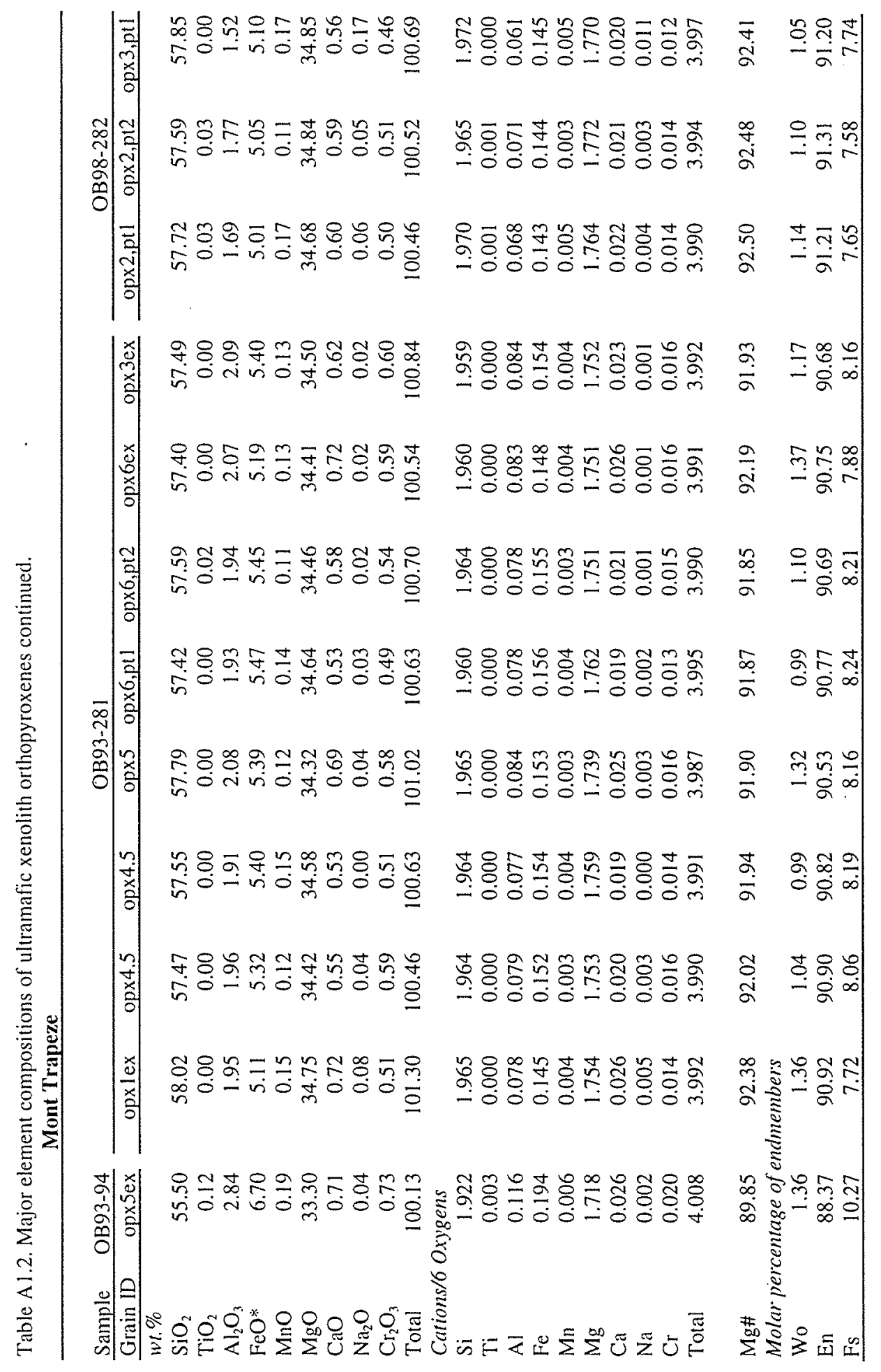




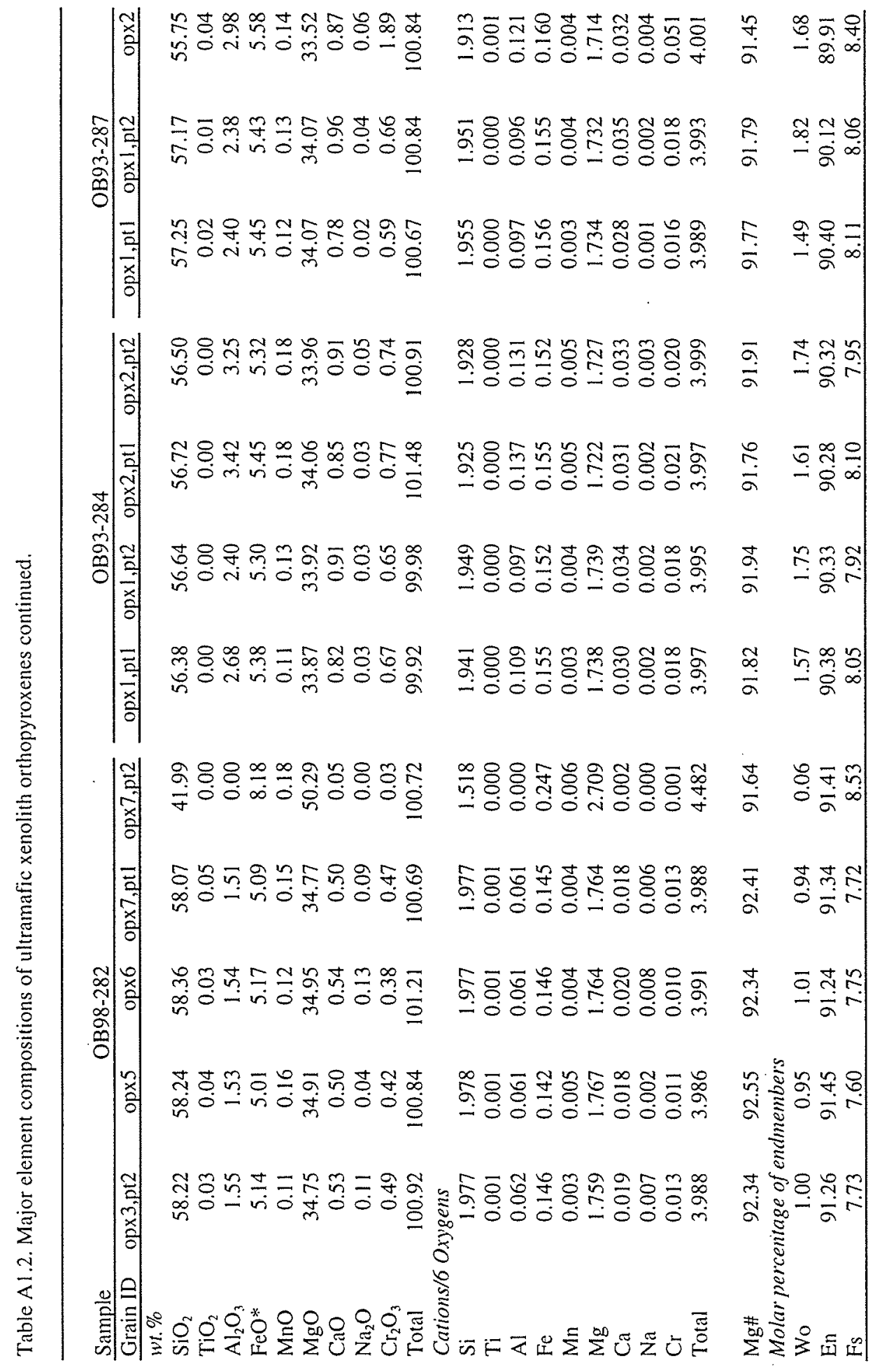




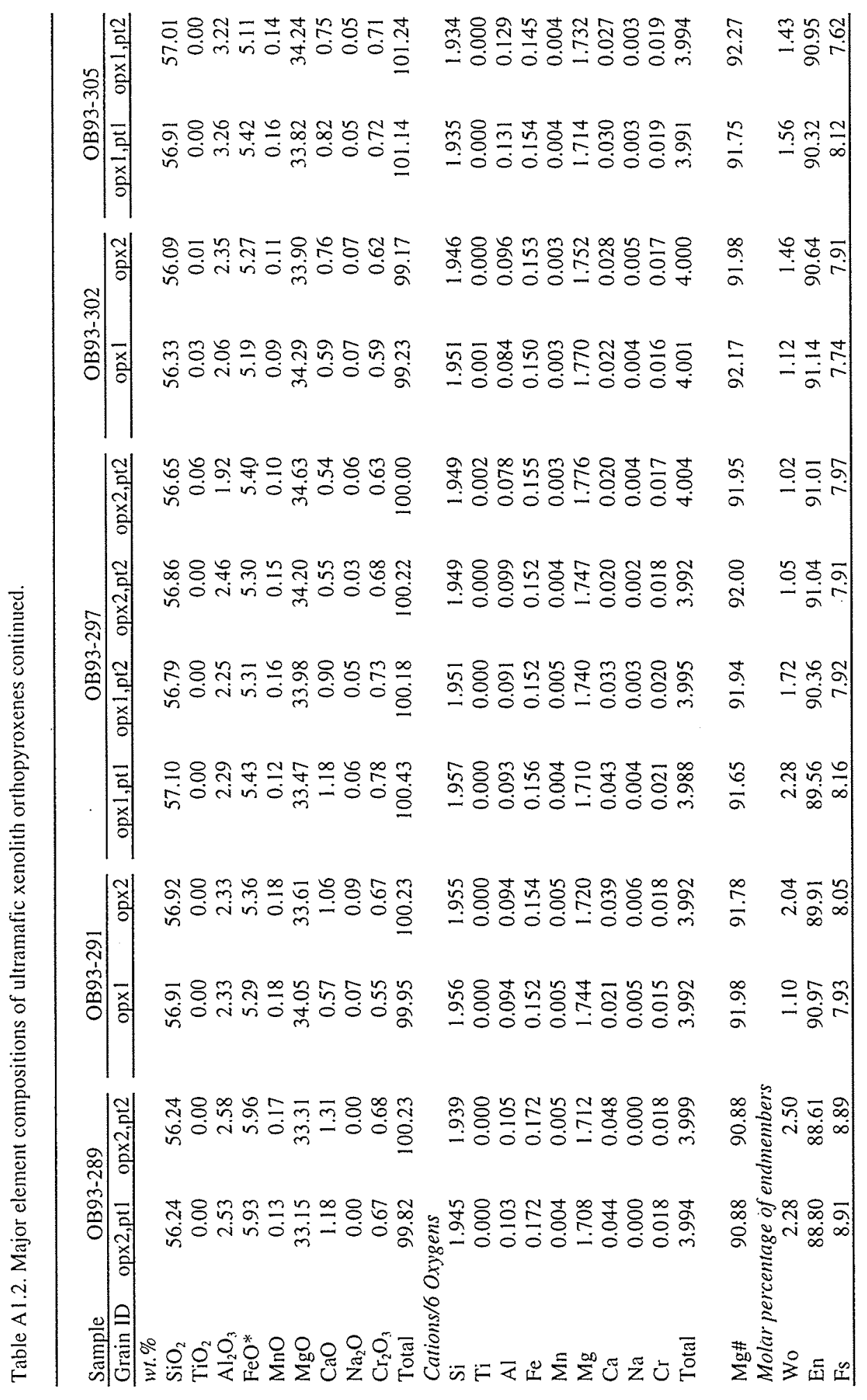




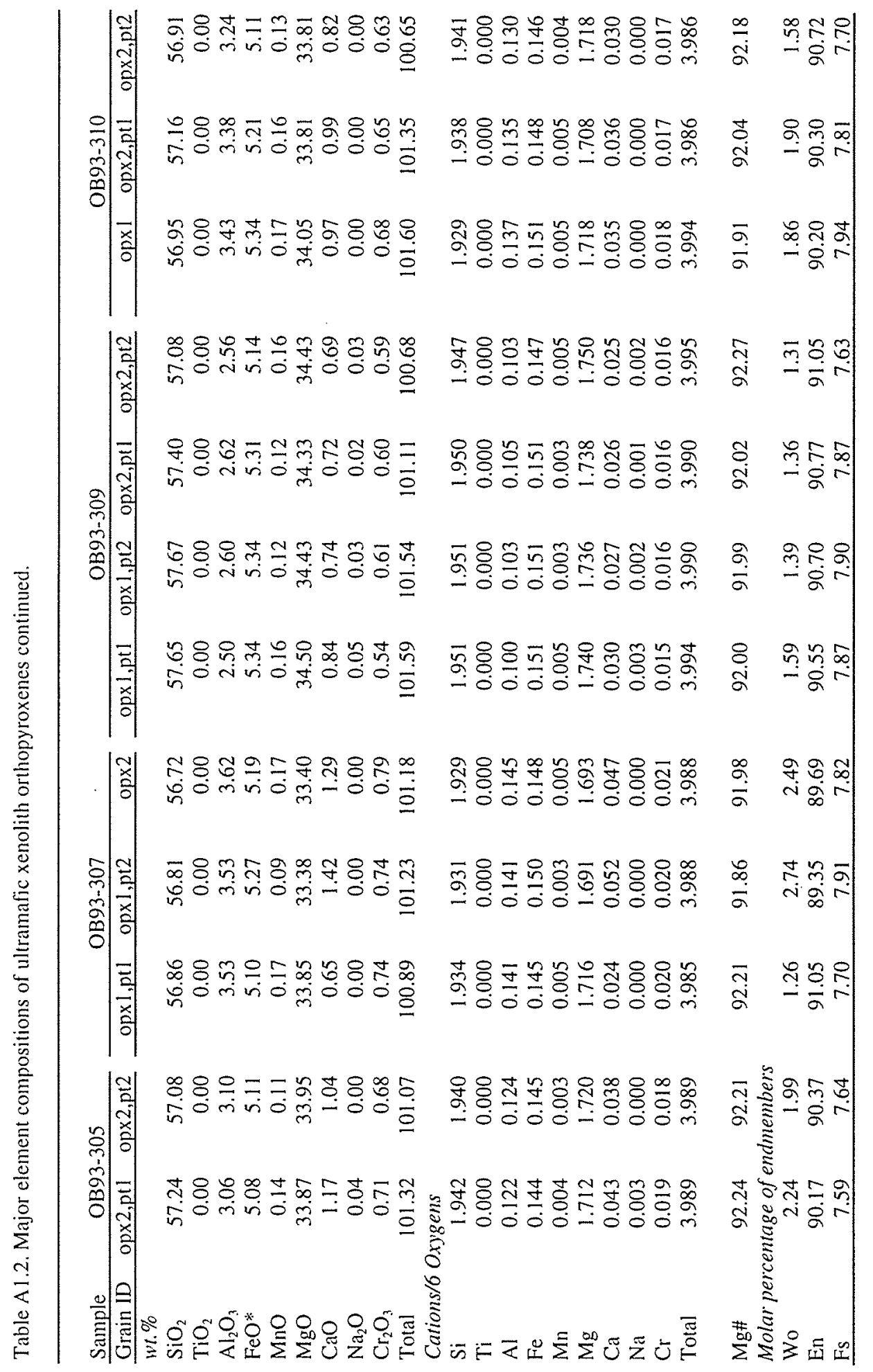




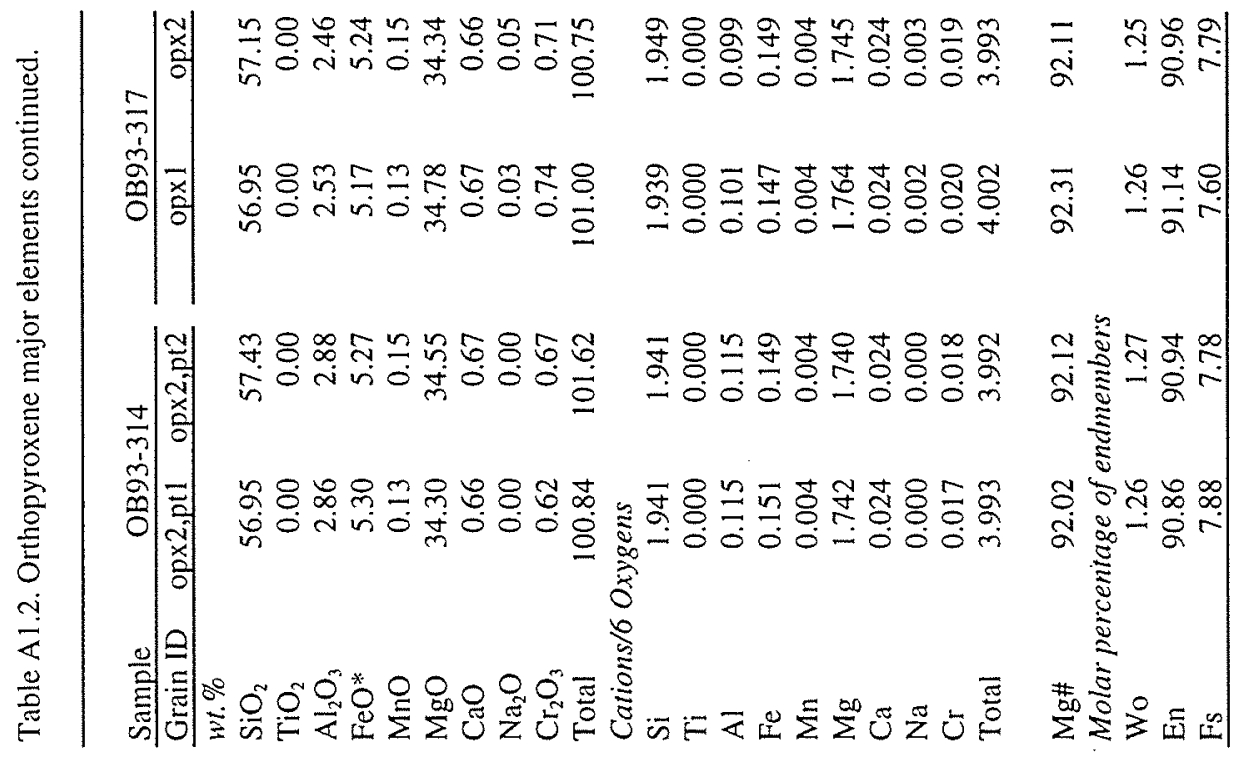




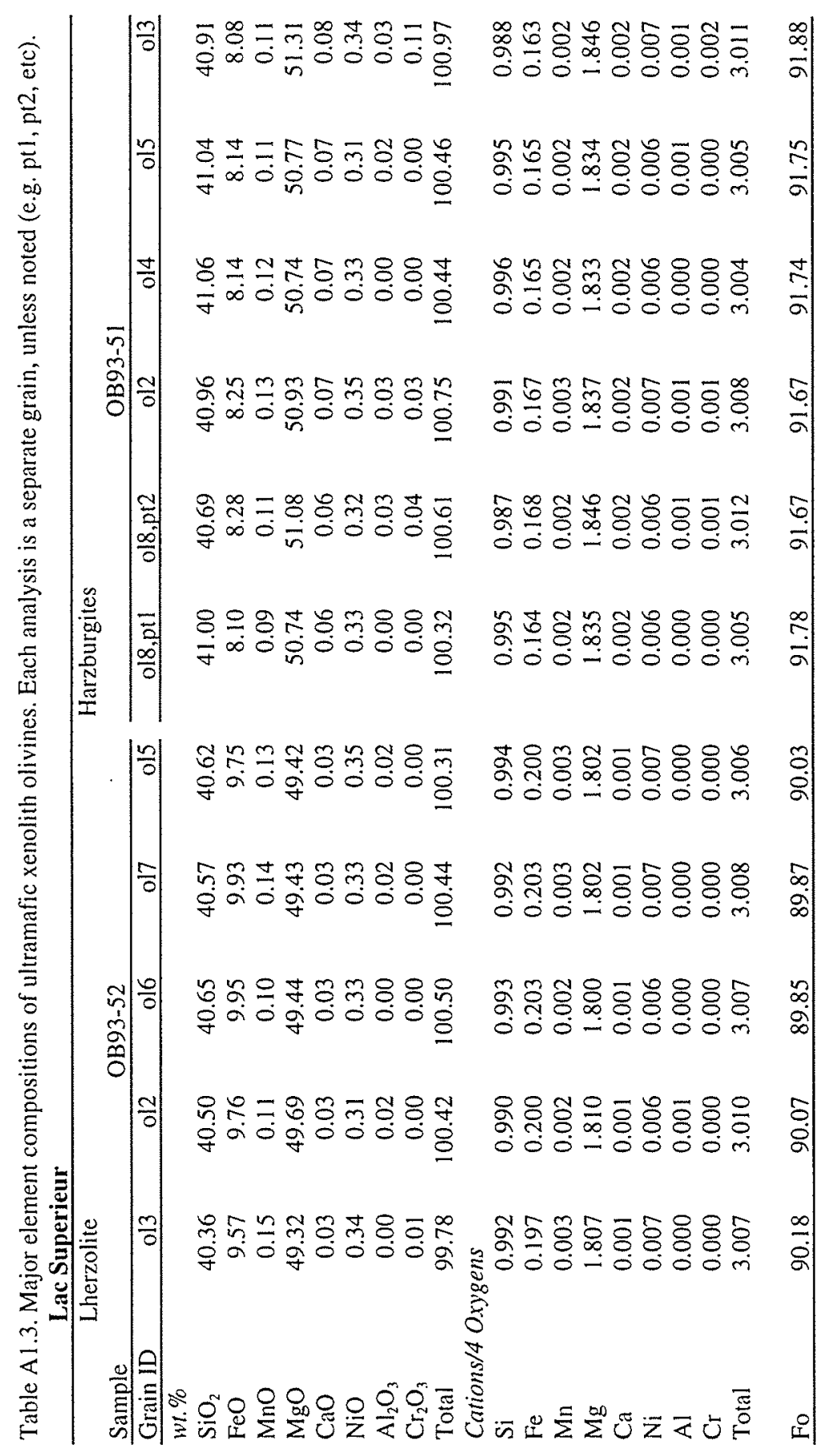




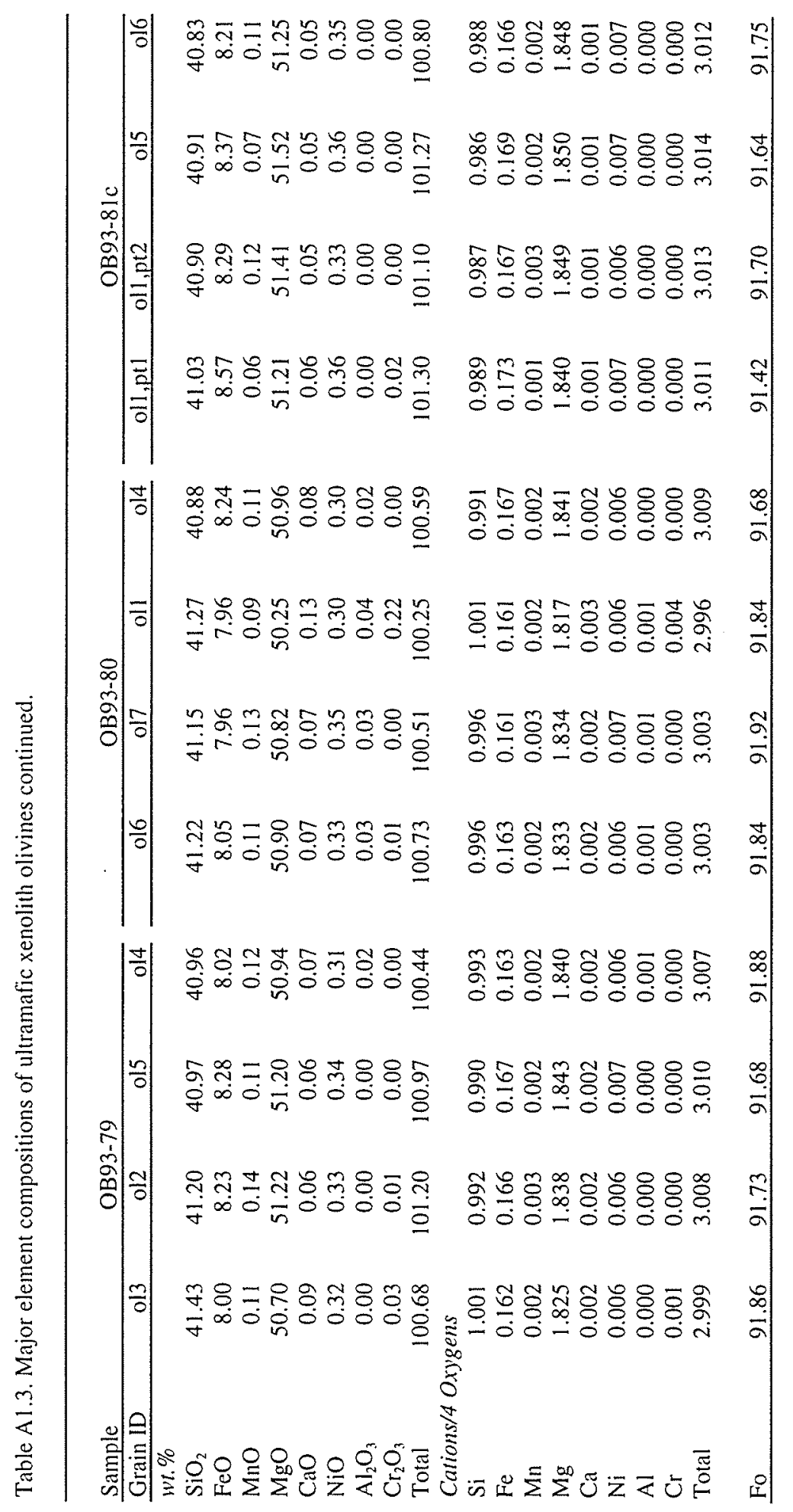




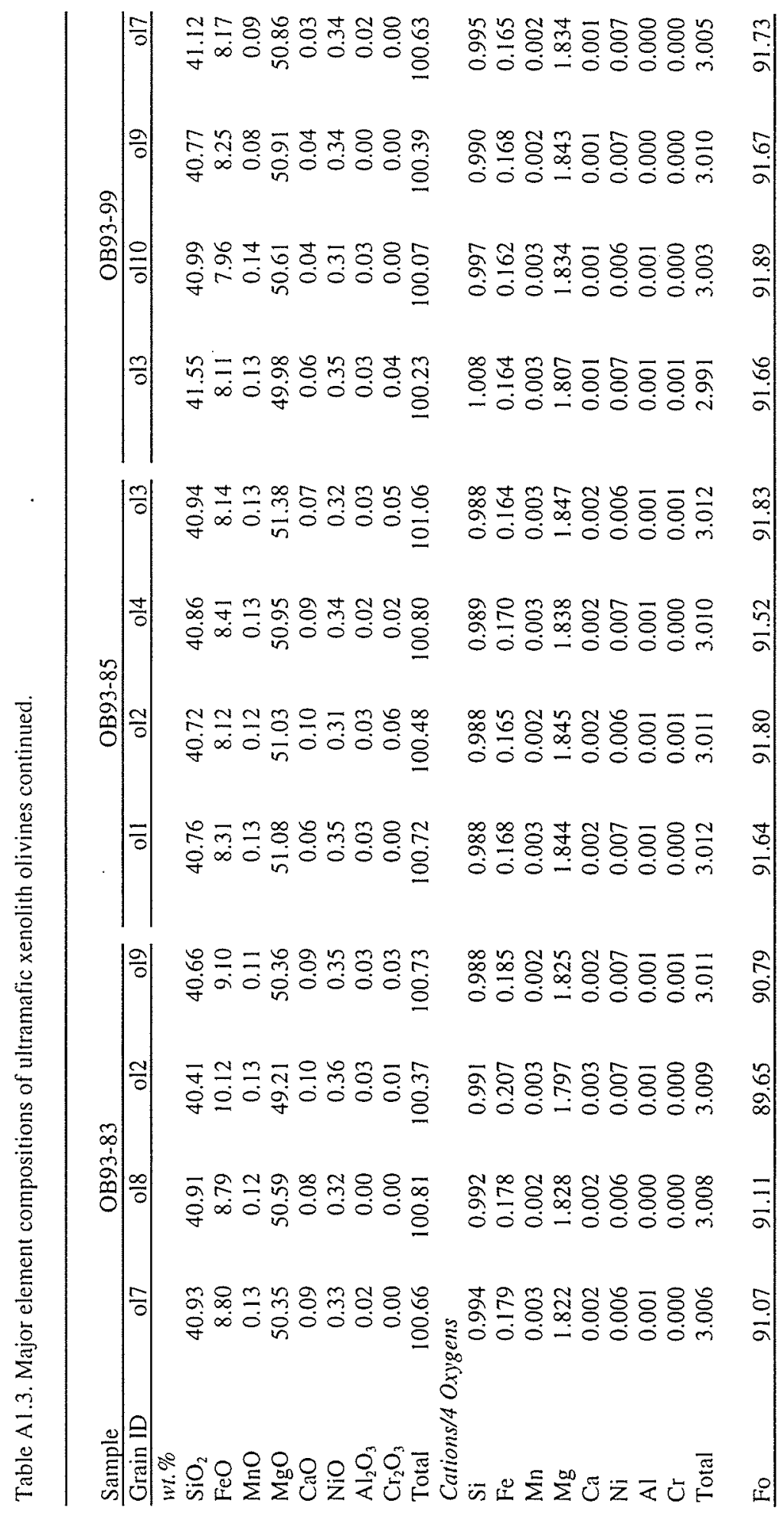




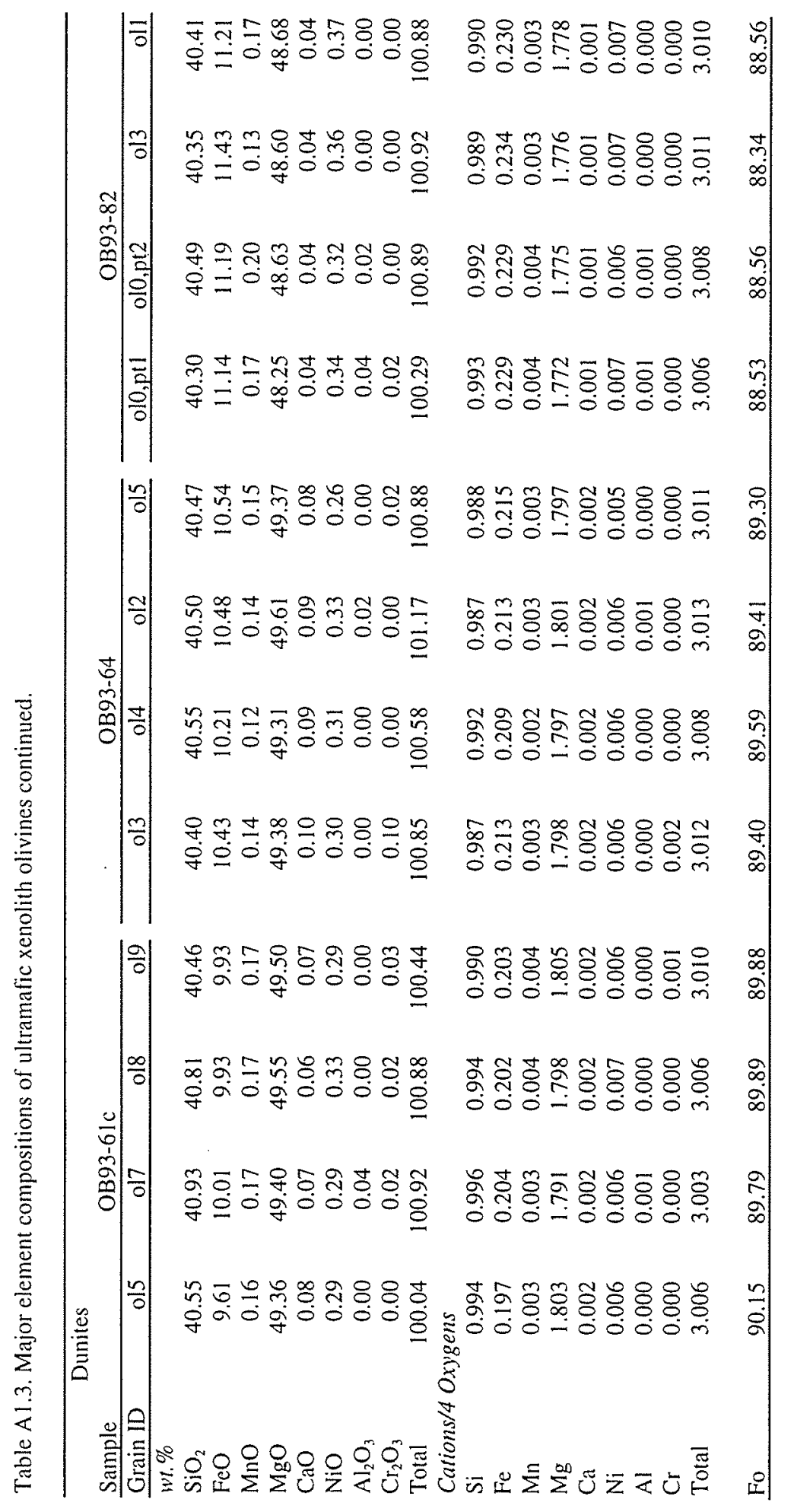




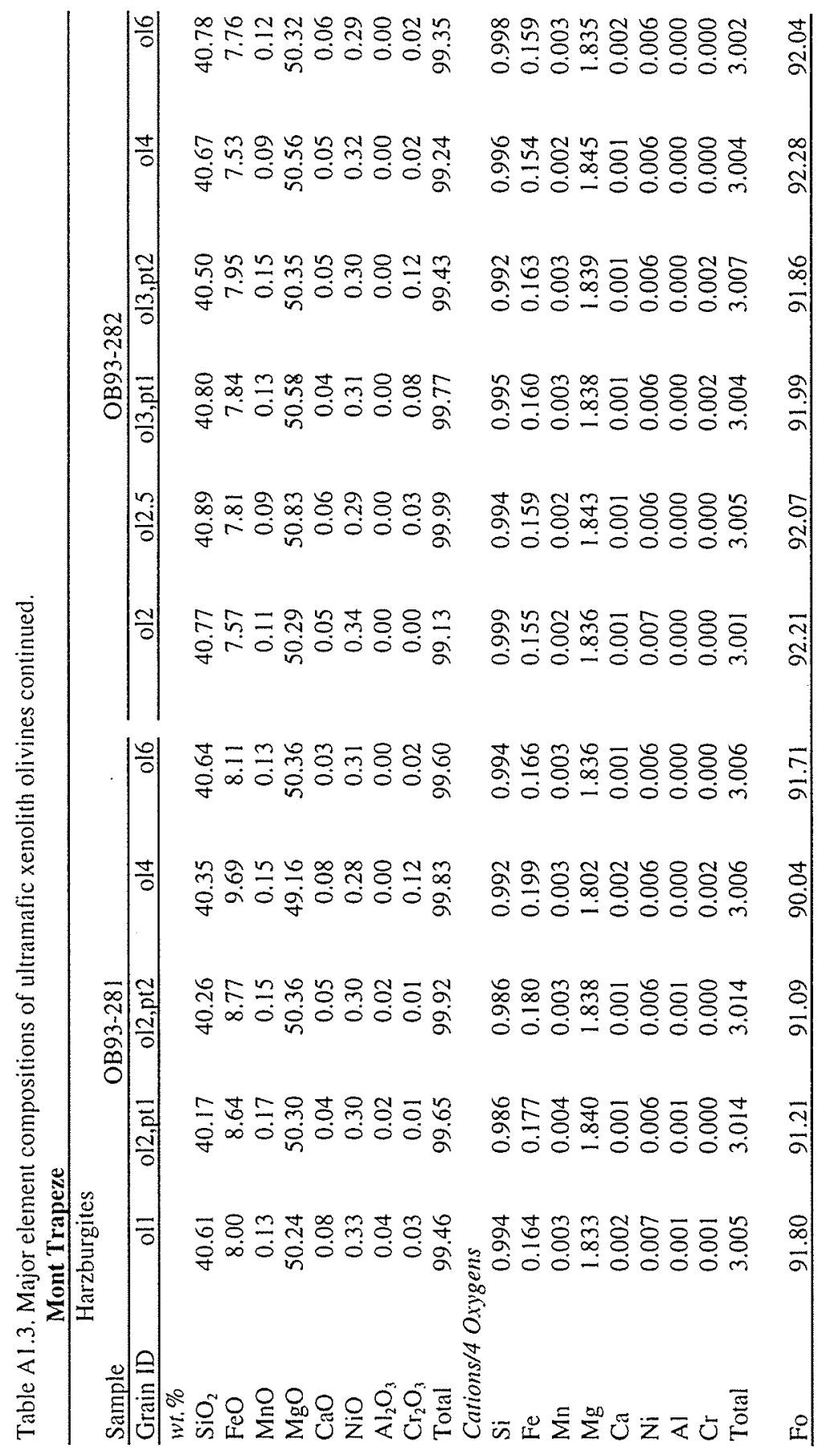




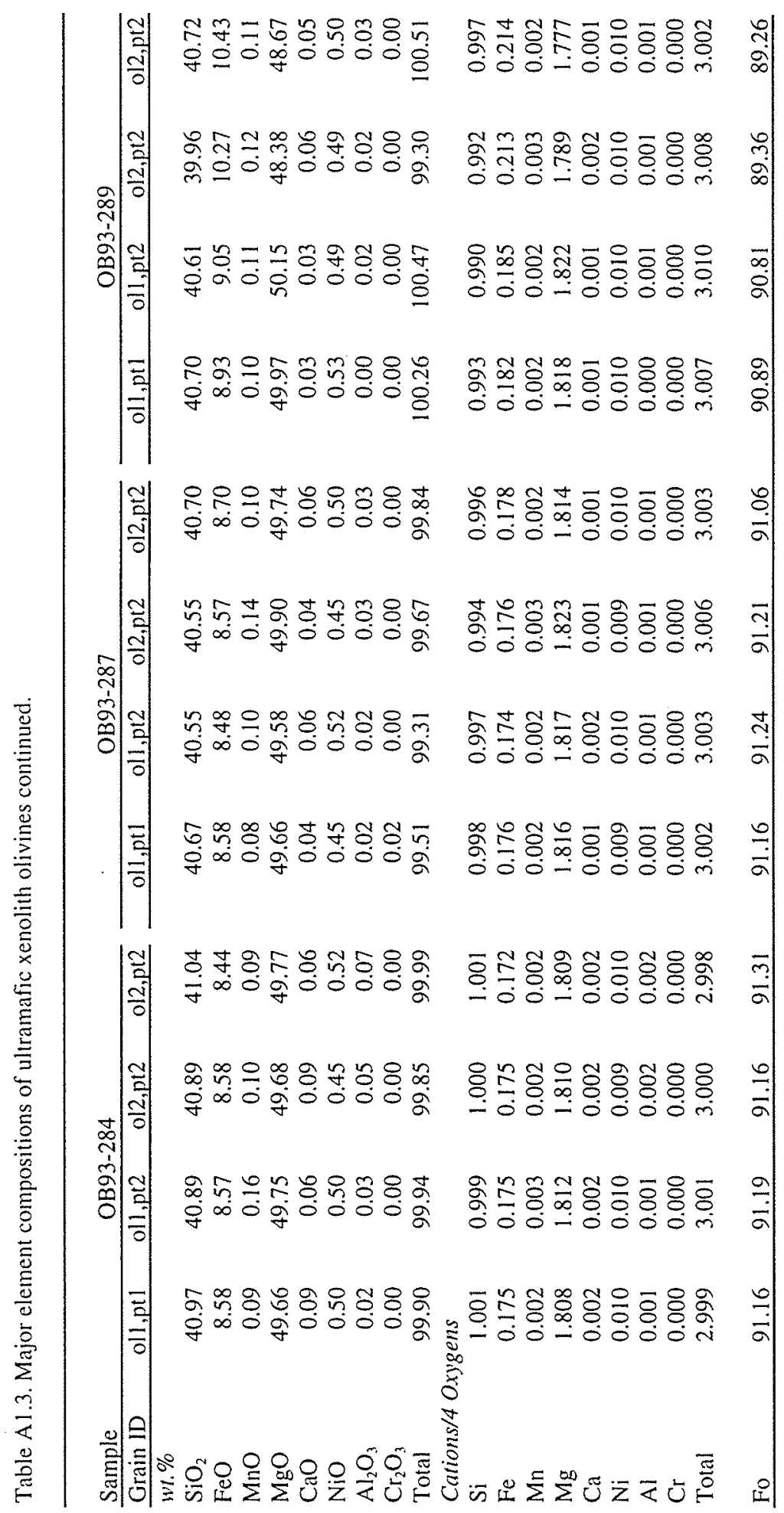




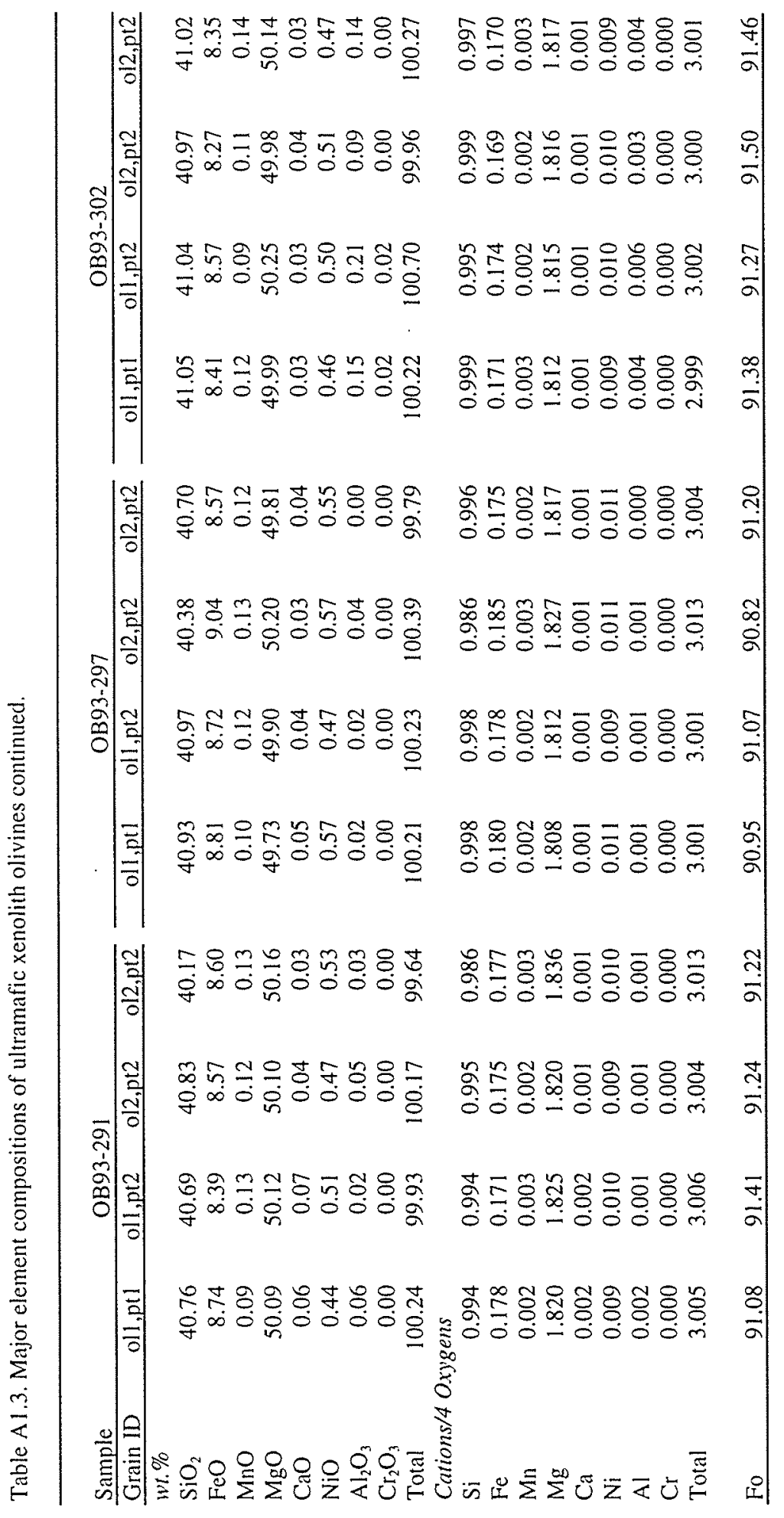




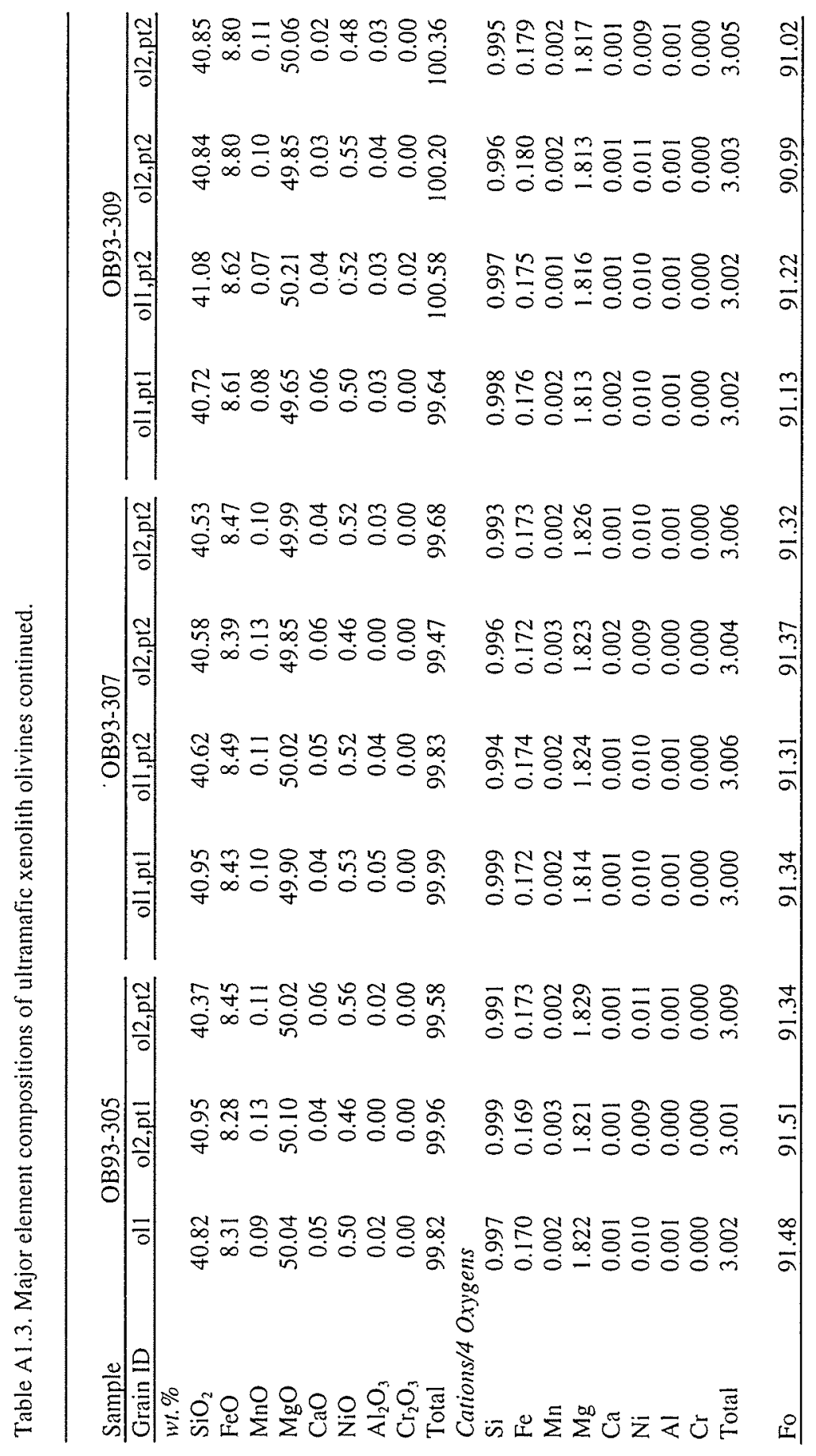




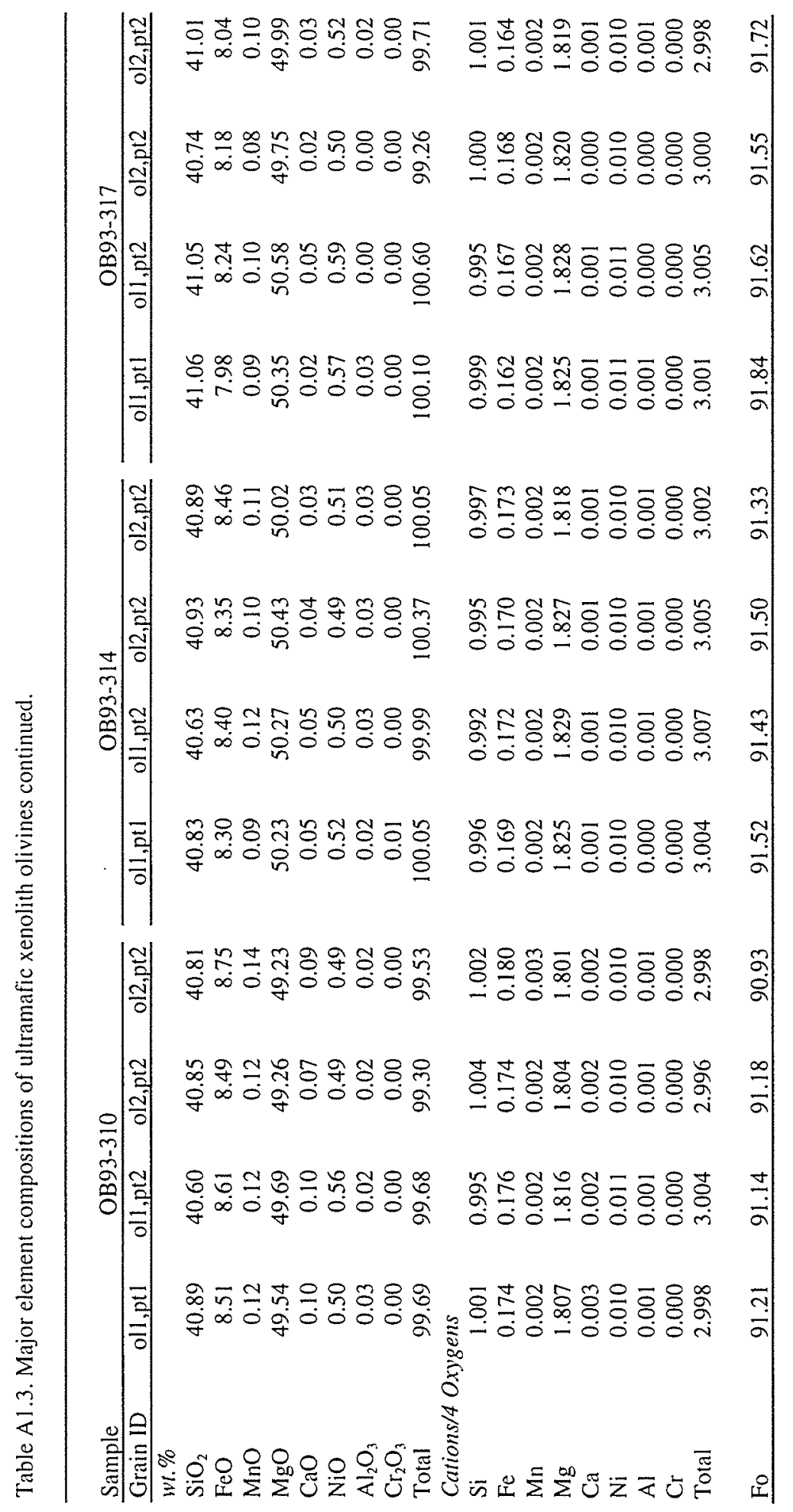




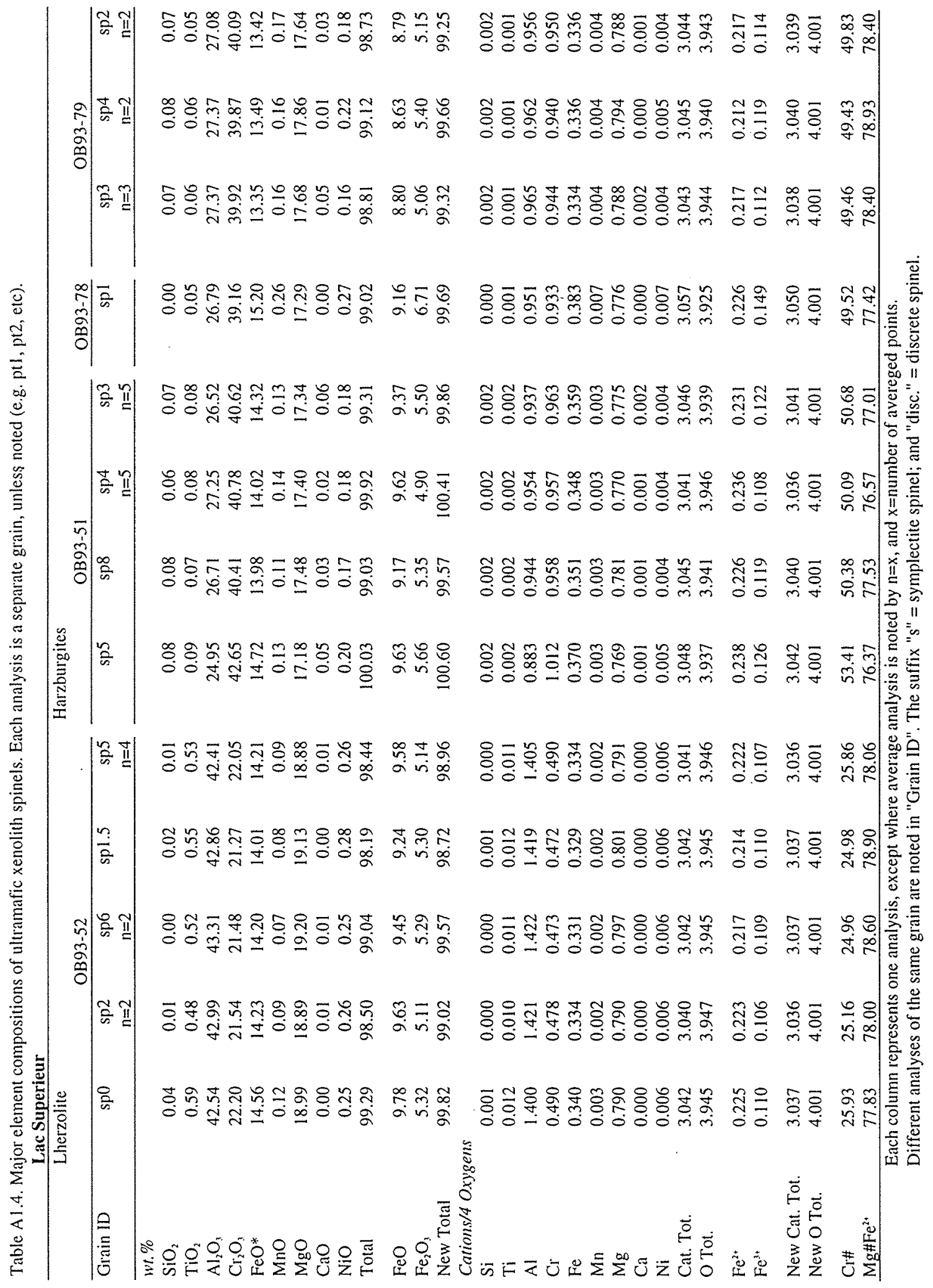




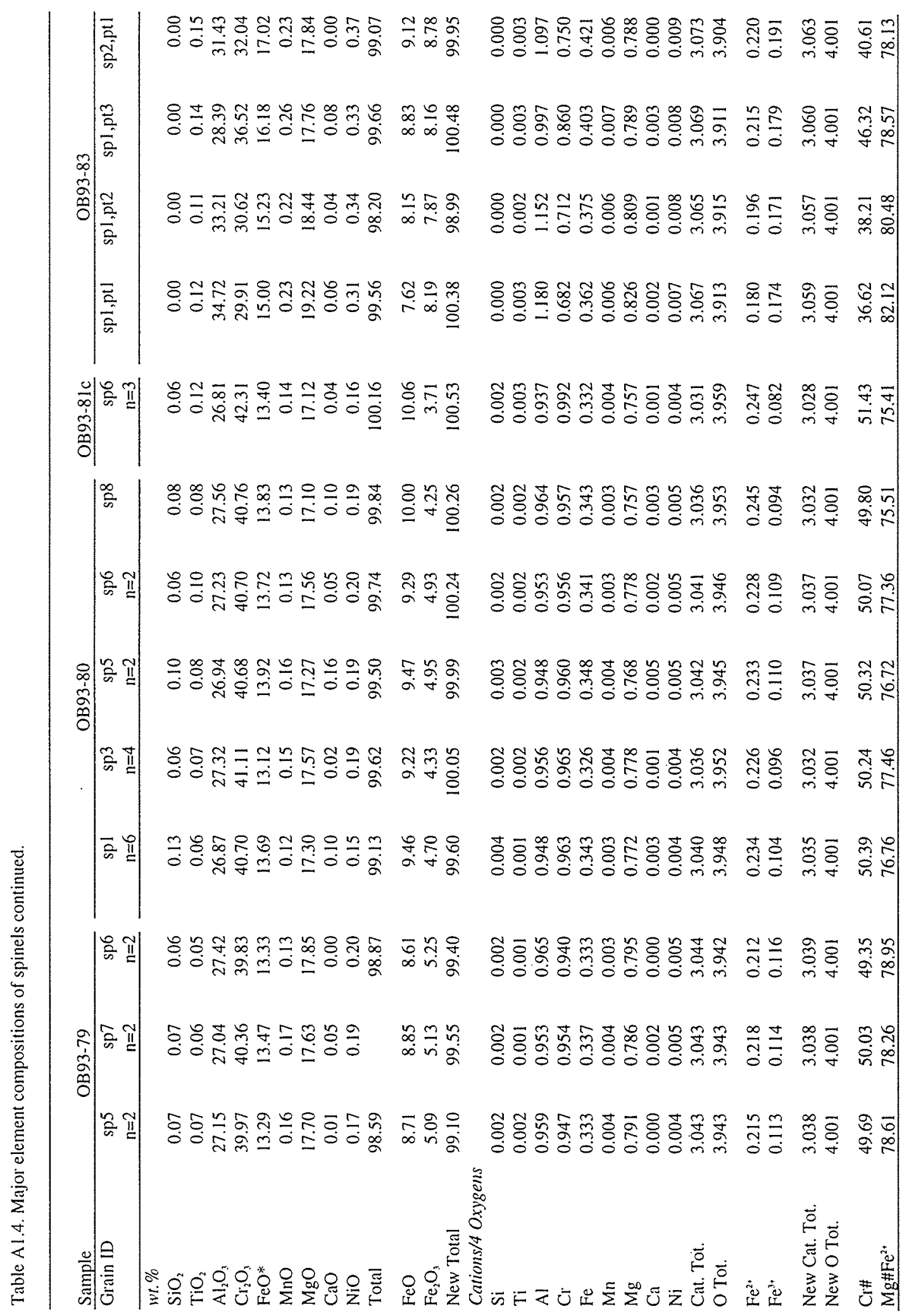




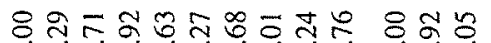

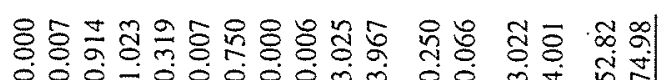

|

为

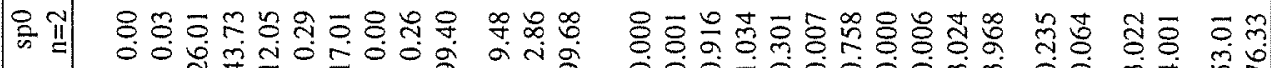
-

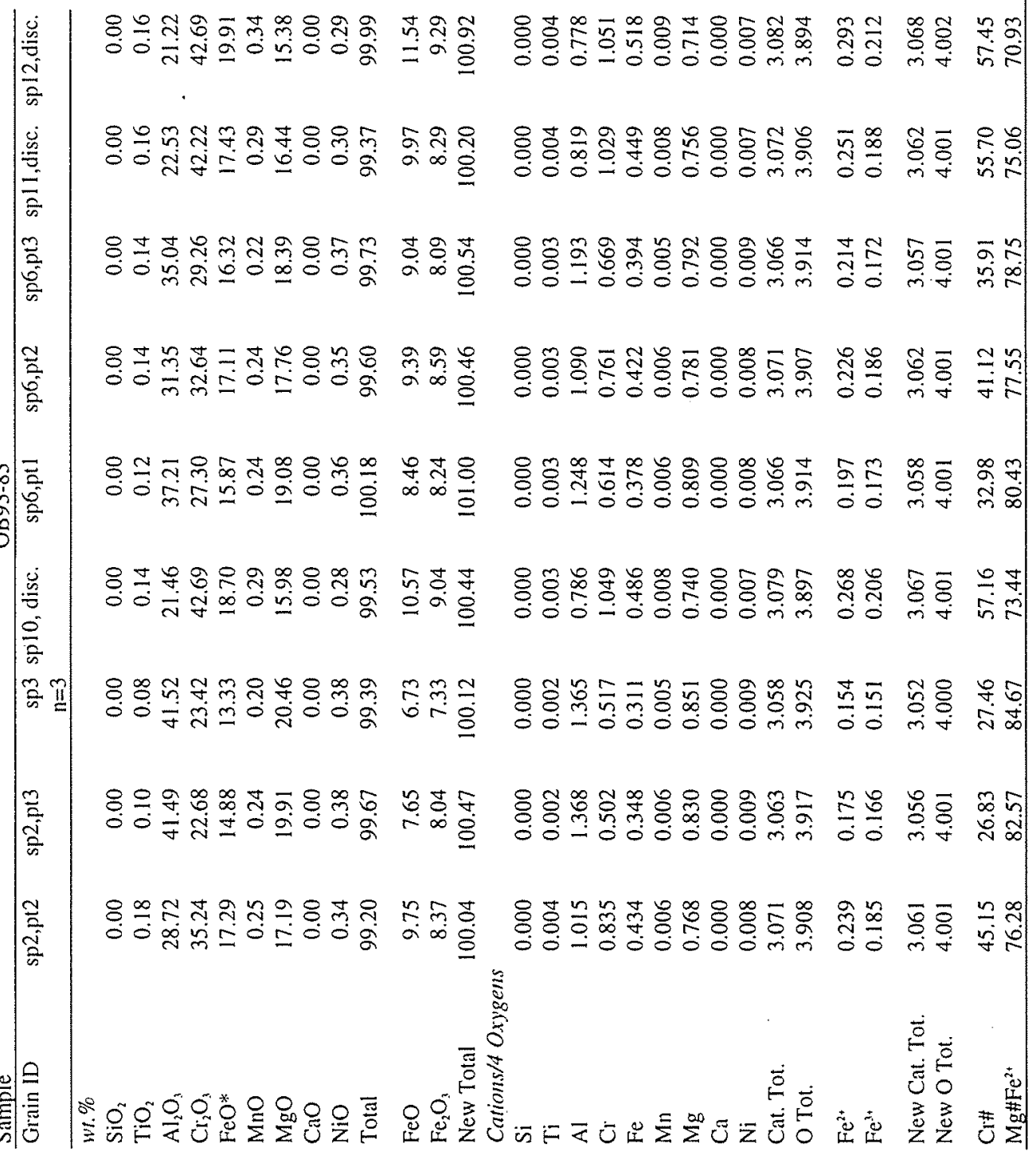




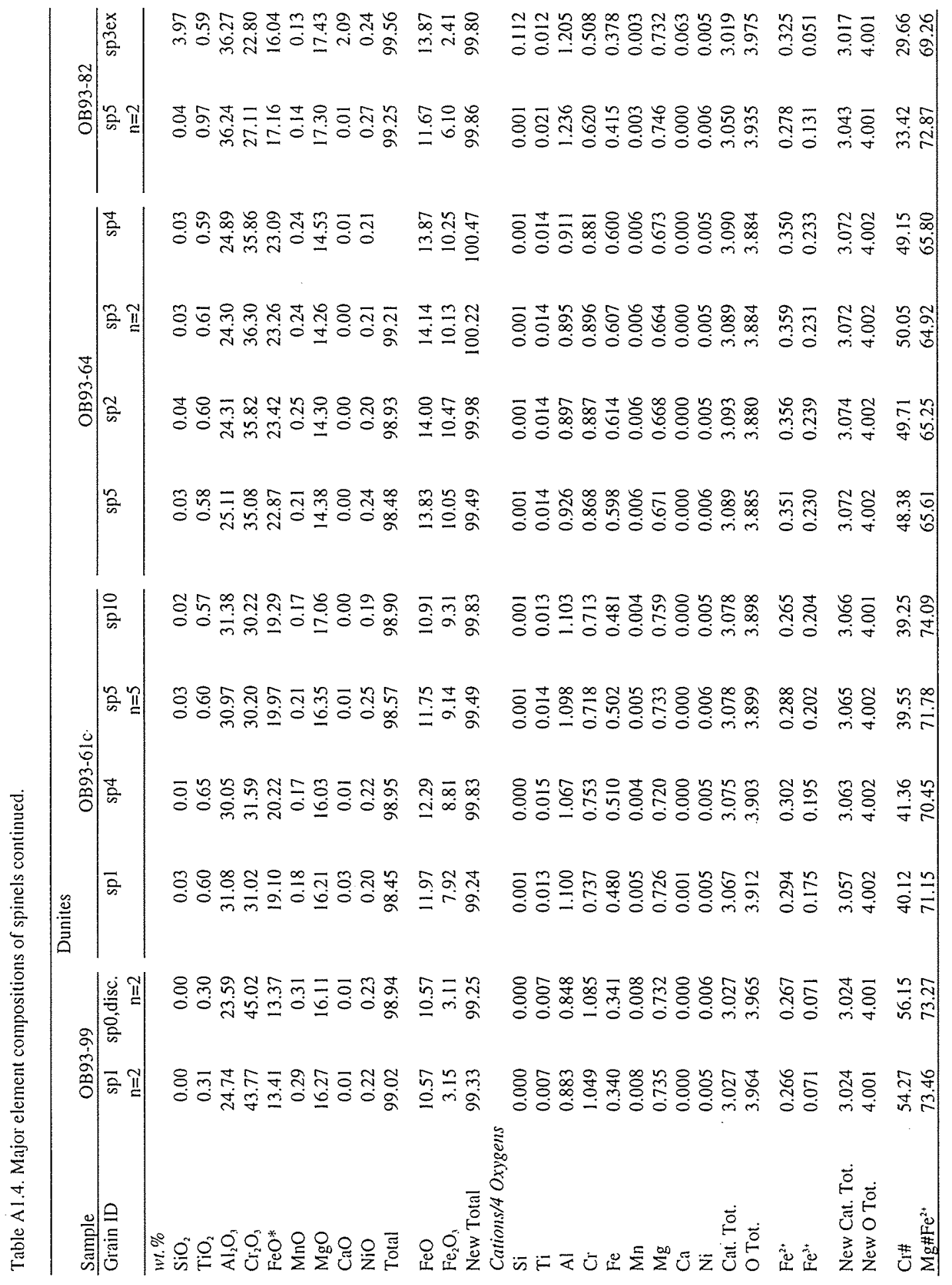




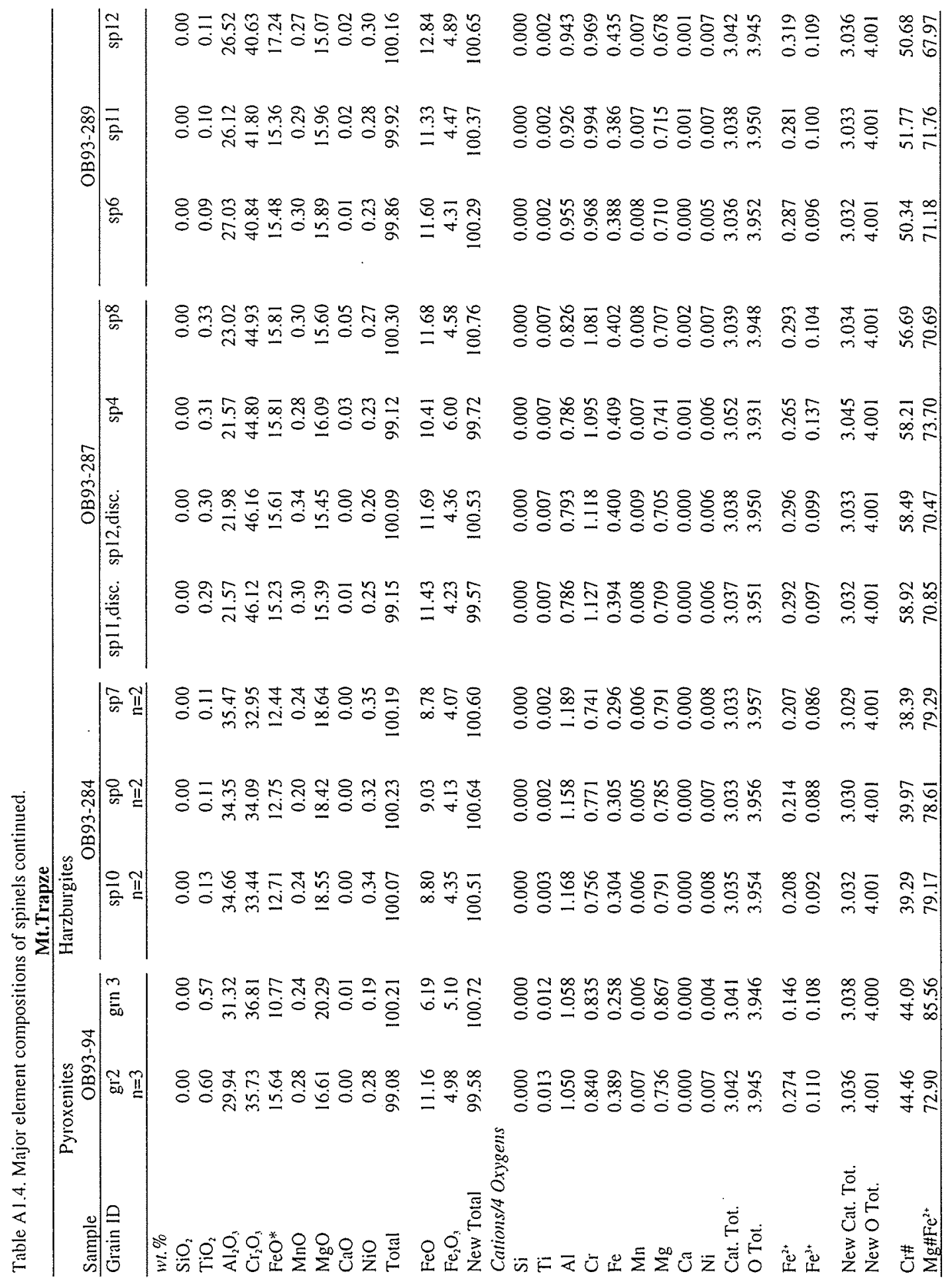




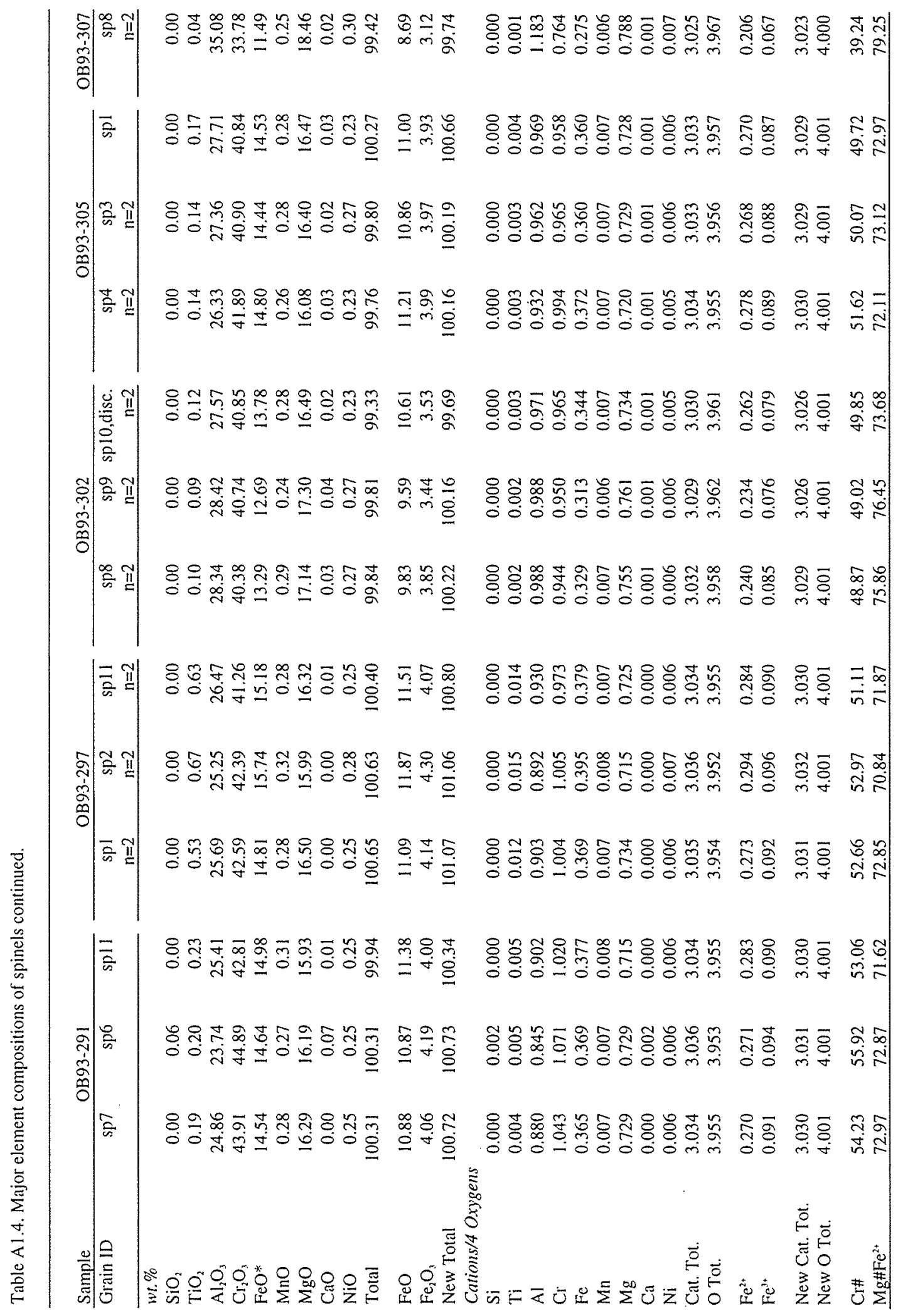




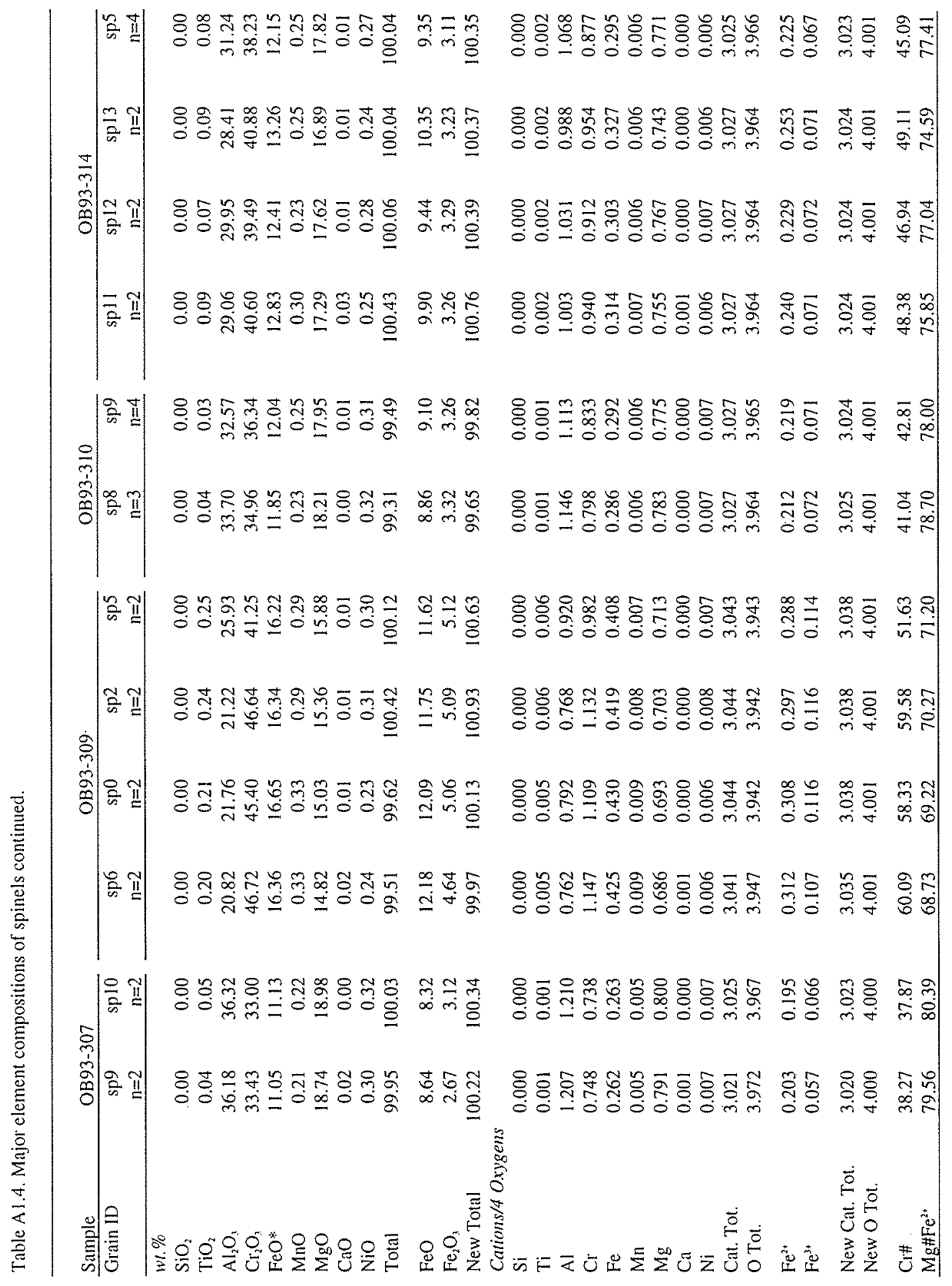




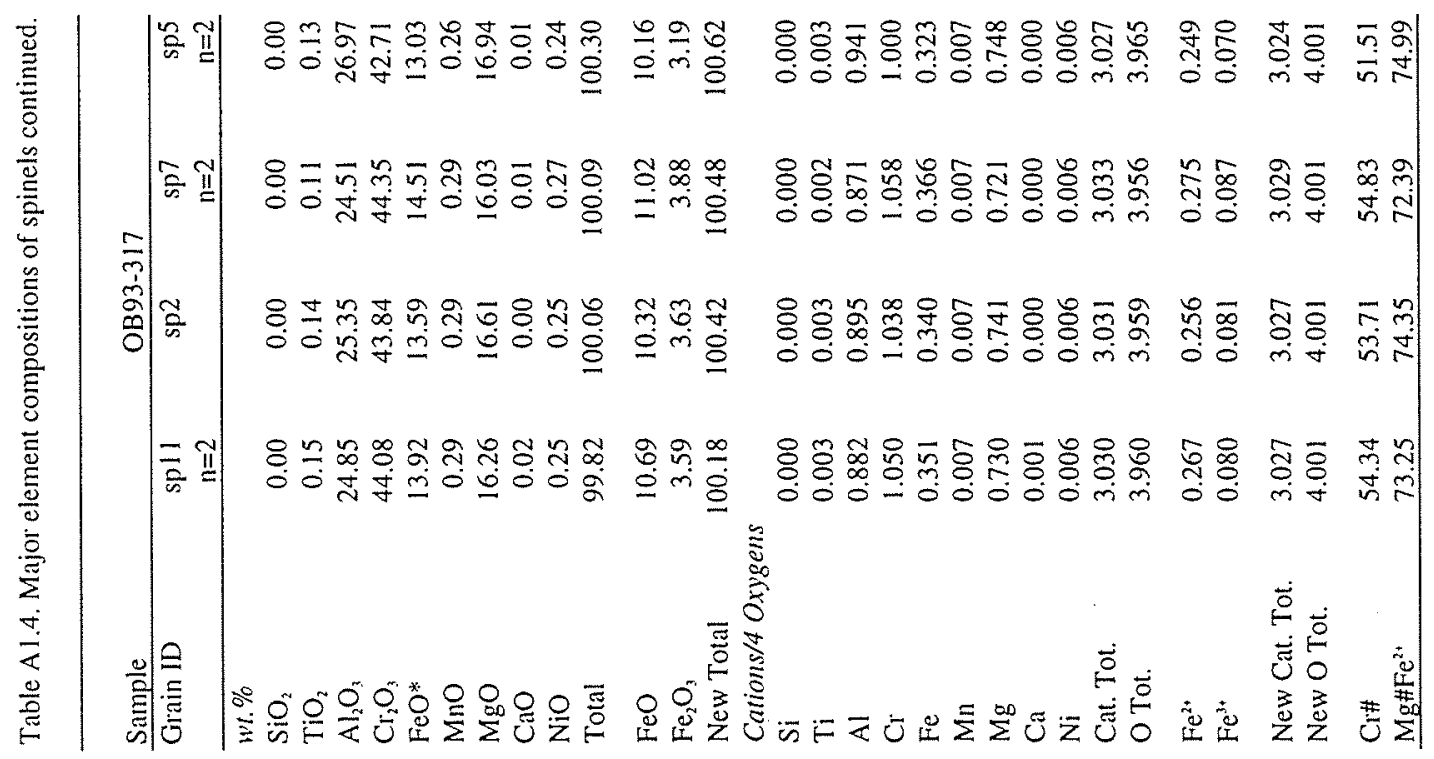




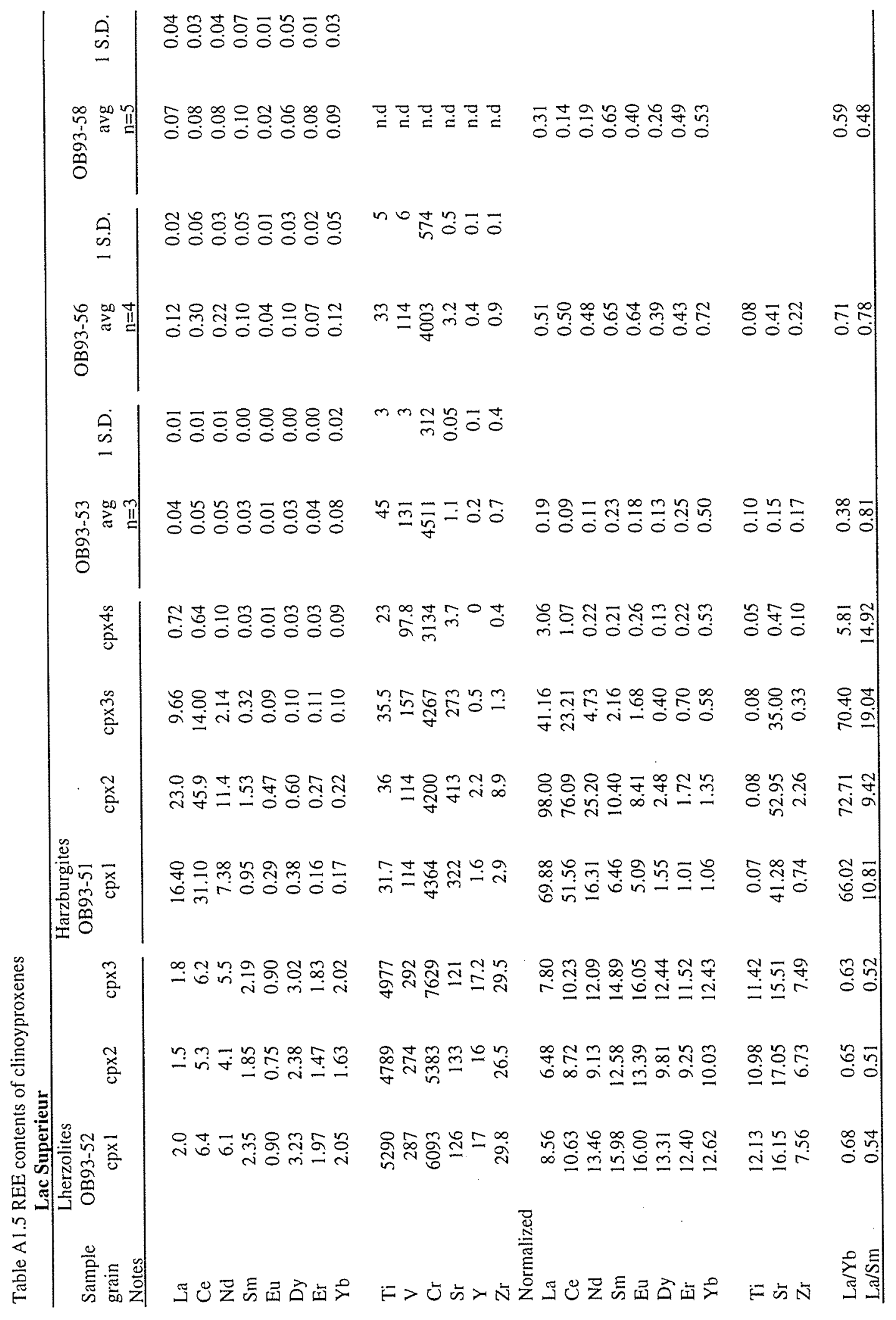




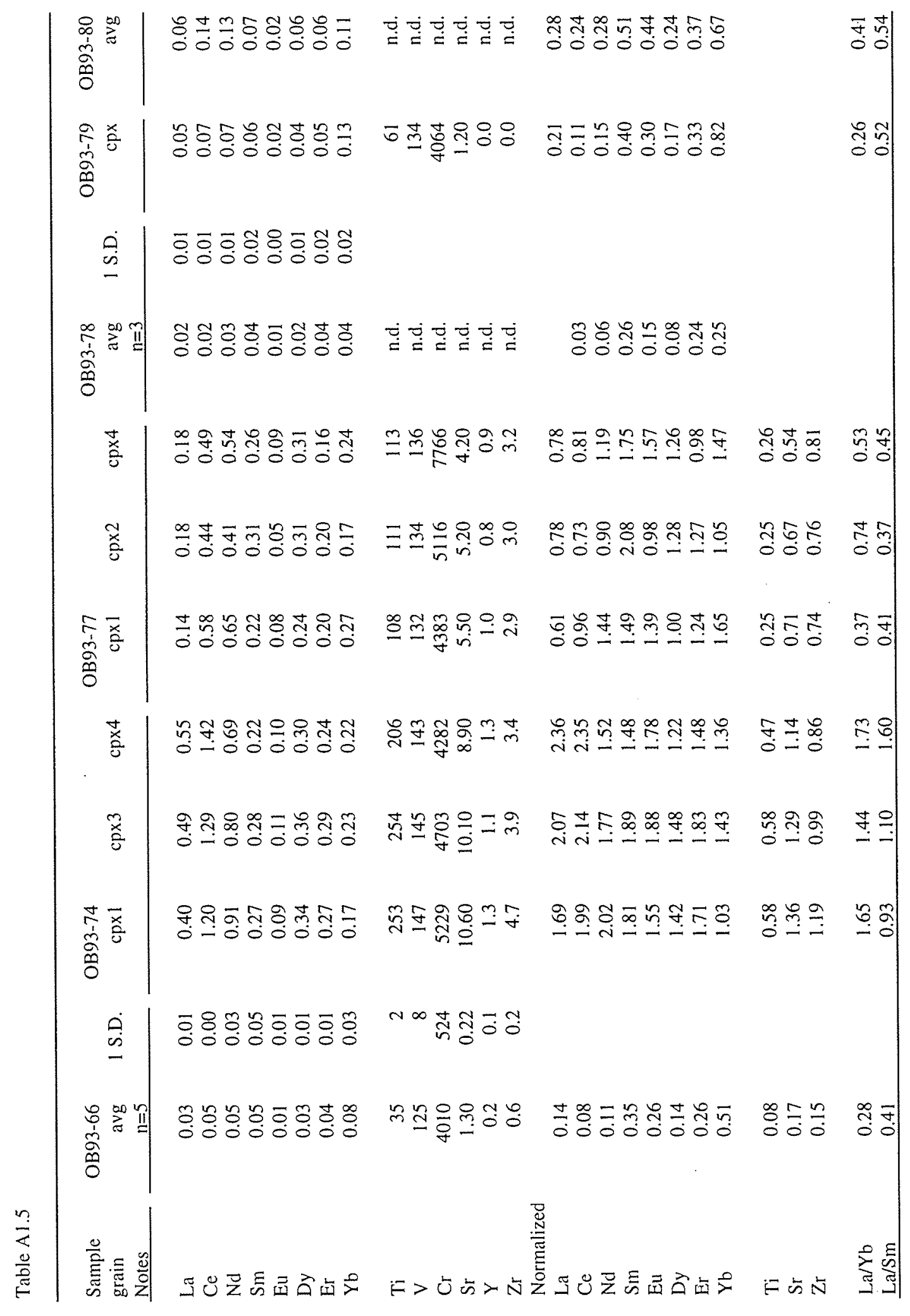




\begin{tabular}{|c|c|c|c|c|c|}
\hline & 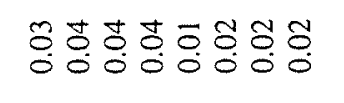 & $\forall r \frac{d}{q}=\overrightarrow{0}$ & & & \\
\hline 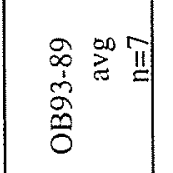 & 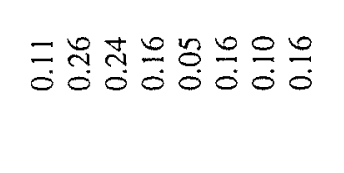 & 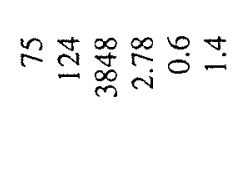 & 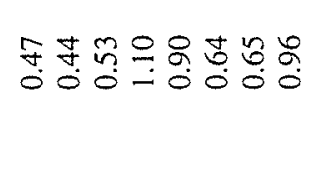 & 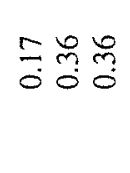 & fò \\
\hline 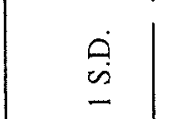 & 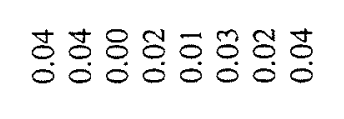 & 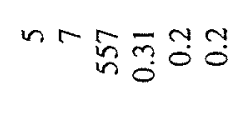 & & & \\
\hline 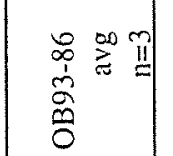 & 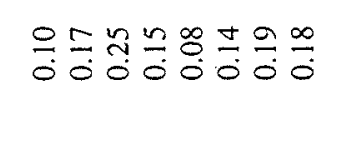 & 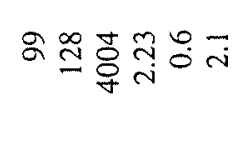 & gơ & & $\tilde{c}$ \\
\hline 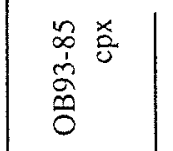 & 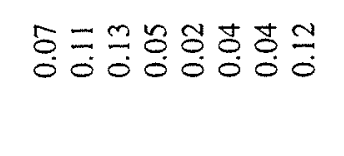 & 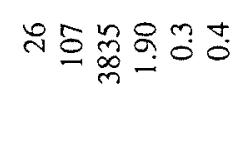 & 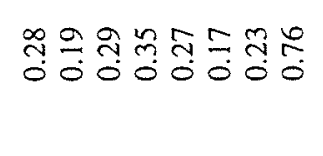 & 영형 & \\
\hline$\frac{\infty}{x}$ & 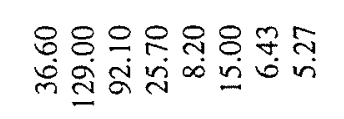 & & 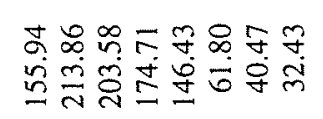 & & \\
\hline 离 & 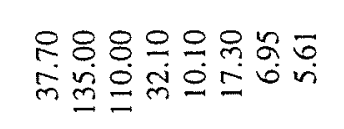 & 염어 & 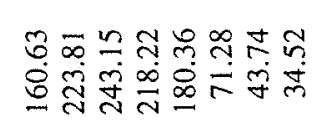 & 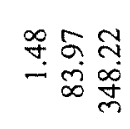 & \\
\hline$\frac{\frac{n}{2}}{\frac{2}{0}}$ & 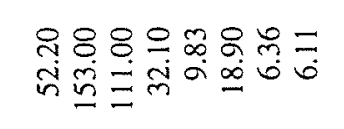 & 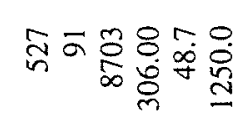 & 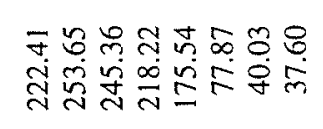 & 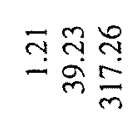 & \\
\hline 芦 & 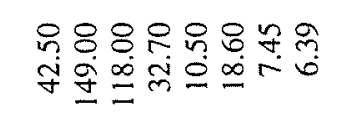 & 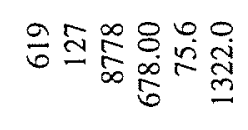 & 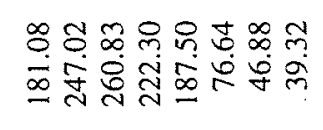 & 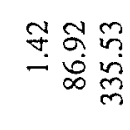 & \\
\hline 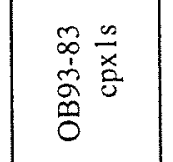 & 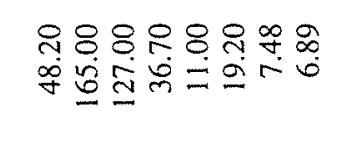 & 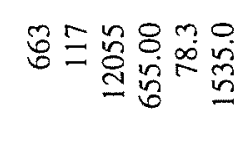 & 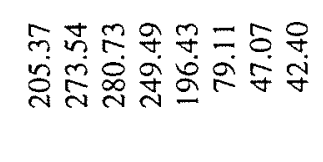 & 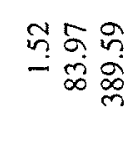 & \\
\hline 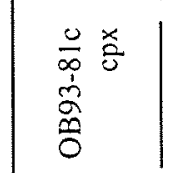 & 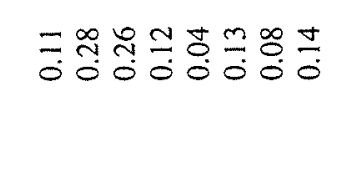 & $\cong \bar{\Xi}$ & 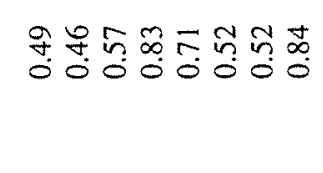 & 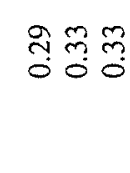 & \\
\hline$\stackrel{\theta}{\Delta}$ & 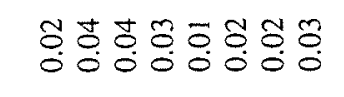 & & & & \\
\hline & & & $t$ & & \\
\hline
\end{tabular}




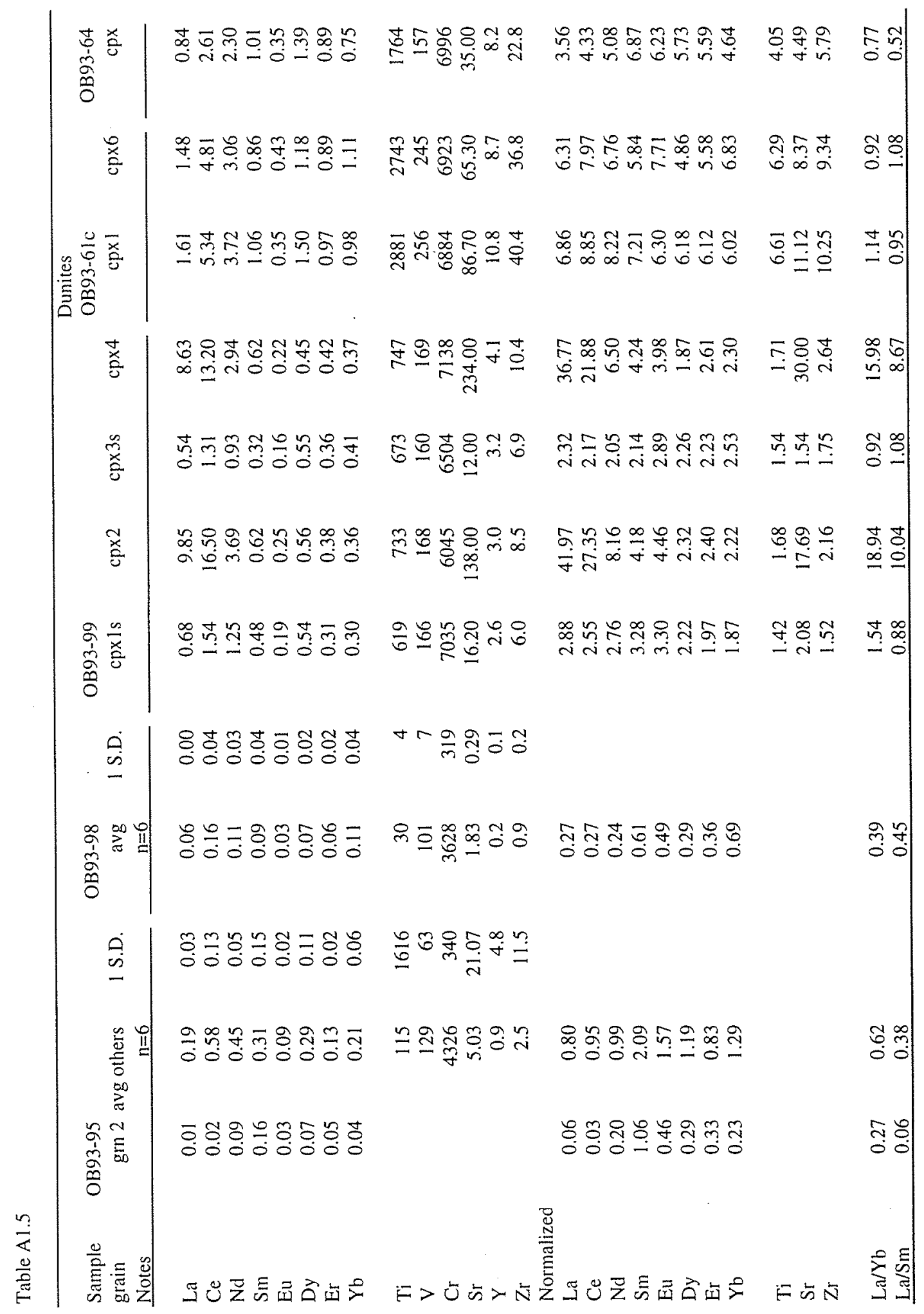




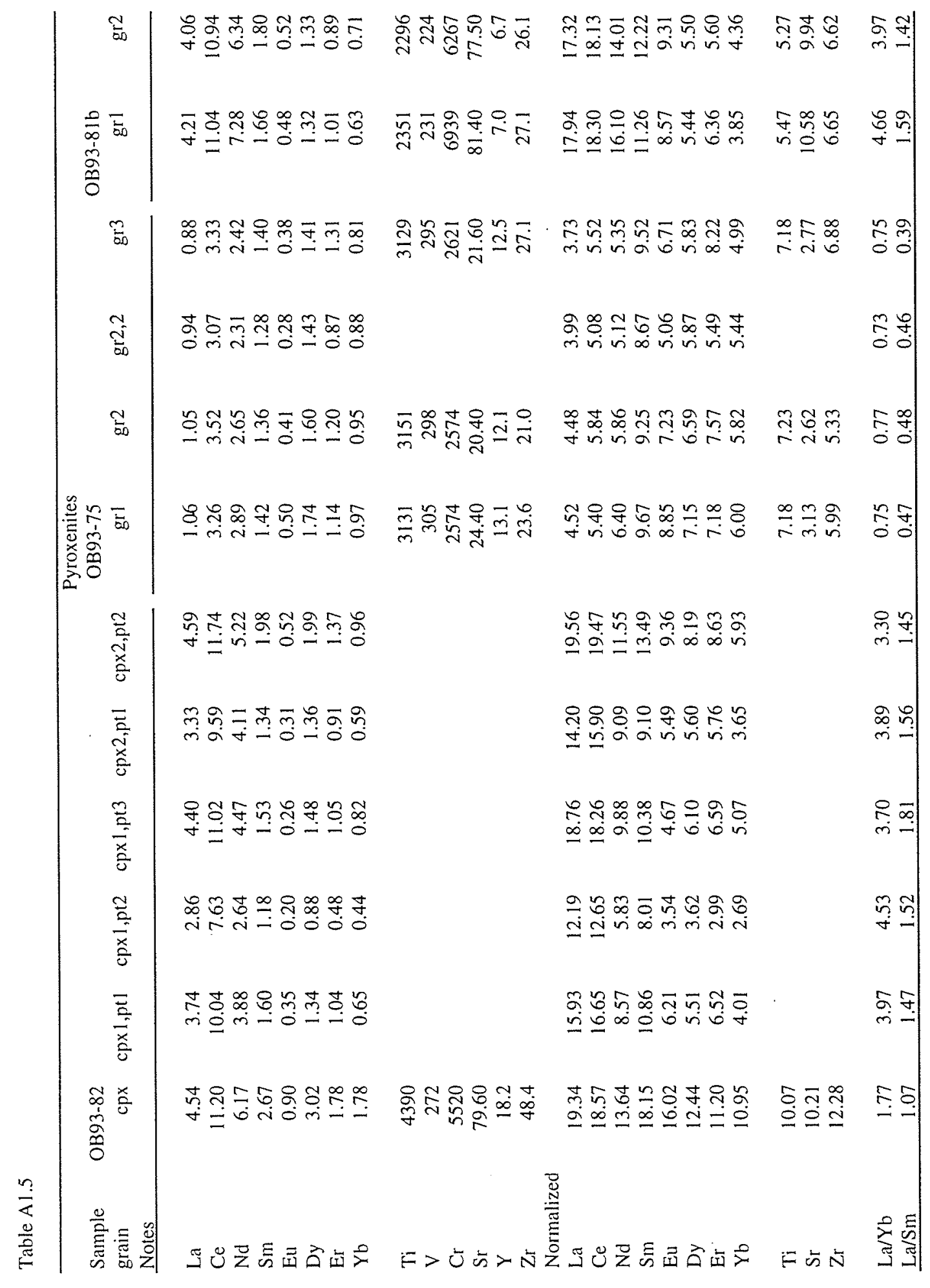




\begin{tabular}{|c|c|c|c|c|c|}
\hline 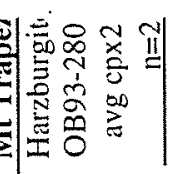 & 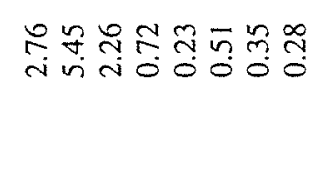 & & 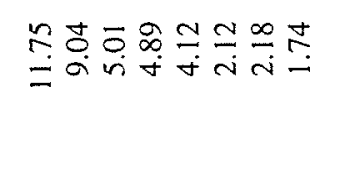 & & n̊용 \\
\hline শิㅡㅁ & 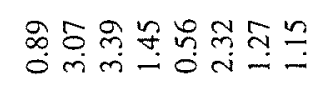 & 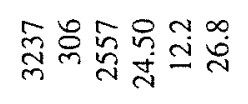 & 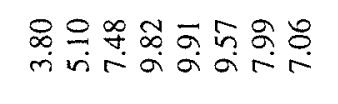 & 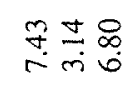 & से \\
\hline 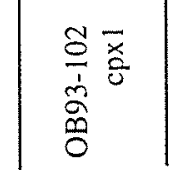 & 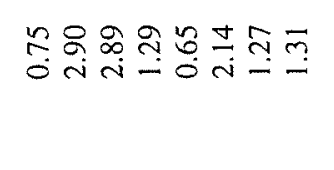 & 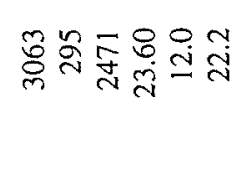 & 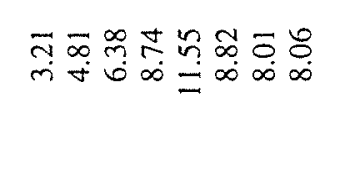 & 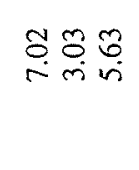 & 웡 \\
\hline ָัญ & 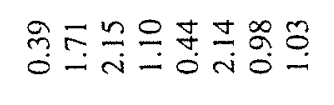 & 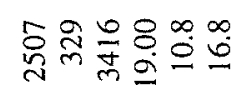 & 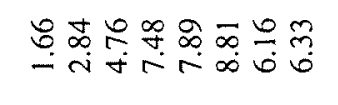 & 忩莳芦 & ్ㅠ đ̊ \\
\hline $\begin{array}{l}\text { 음 } \\
\text { 合 } \\
\text { 。ै }\end{array}$ & 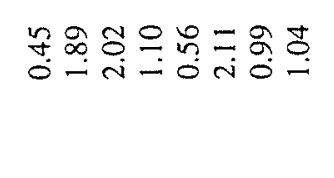 & 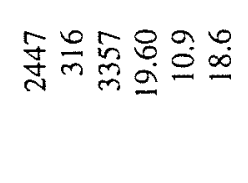 & 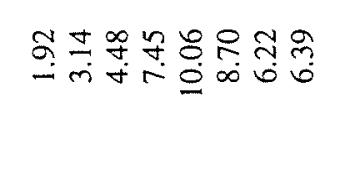 & 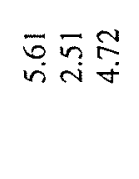 & 3 \\
\hline$\frac{\pi}{0}$ & 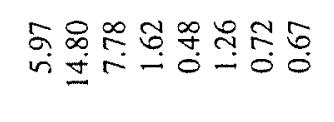 & 홍 & 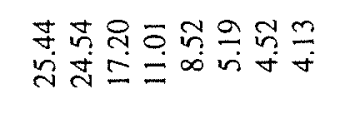 & 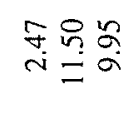 & $\frac{0}{m}$ \\
\hline 즙 & 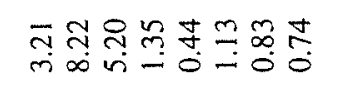 & 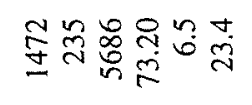 & 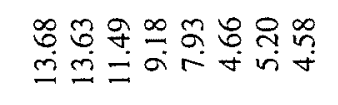 & mi & S. \\
\hline 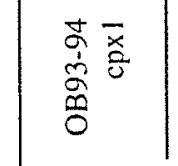 & 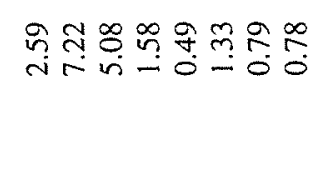 & 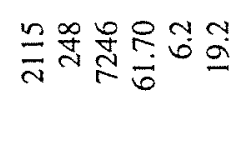 & 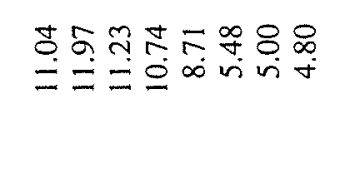 & 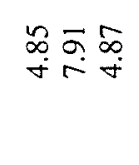 & ק్ \\
\hline 落 & 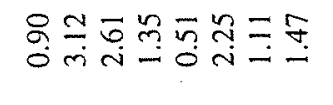 & 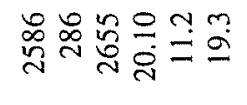 & 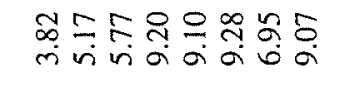 & 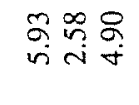 & \\
\hline$\widetilde{E}_{0}$ & 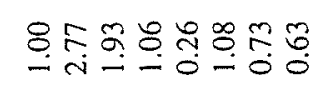 & 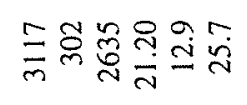 & 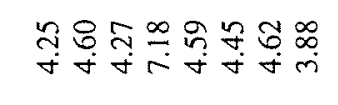 & $\stackrel{2}{\sim} \underset{i}{*}$ & 3 \\
\hline 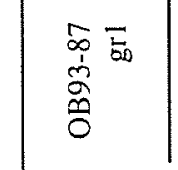 & $\begin{array}{l}0 \\
0 \\
0\end{array}$ & 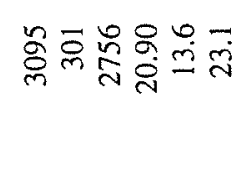 & 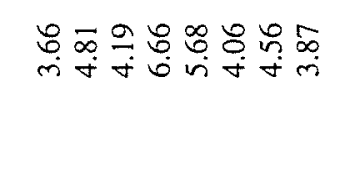 & 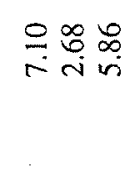 & g \\
\hline$\tilde{\tilde{I}}$ & 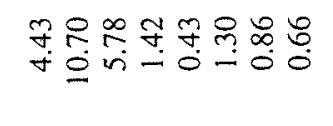 & 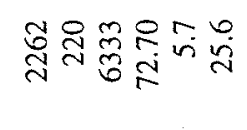 & 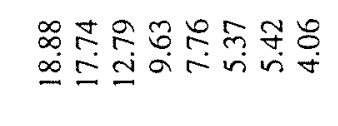 & 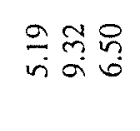 & \\
\hline 言 & 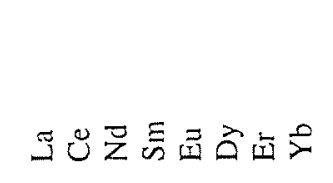 & L & $\geqslant$ & is & 5 \\
\hline
\end{tabular}




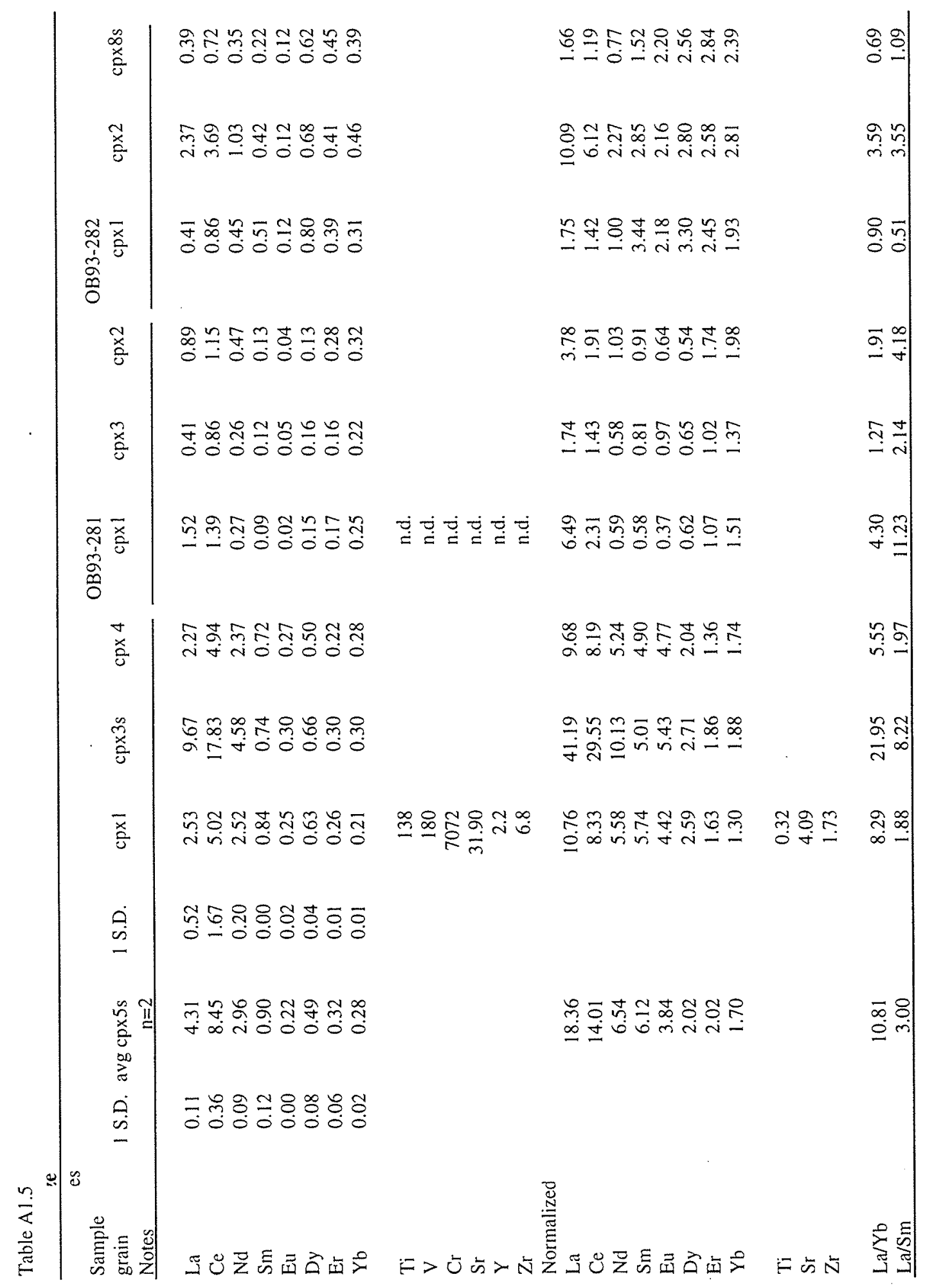




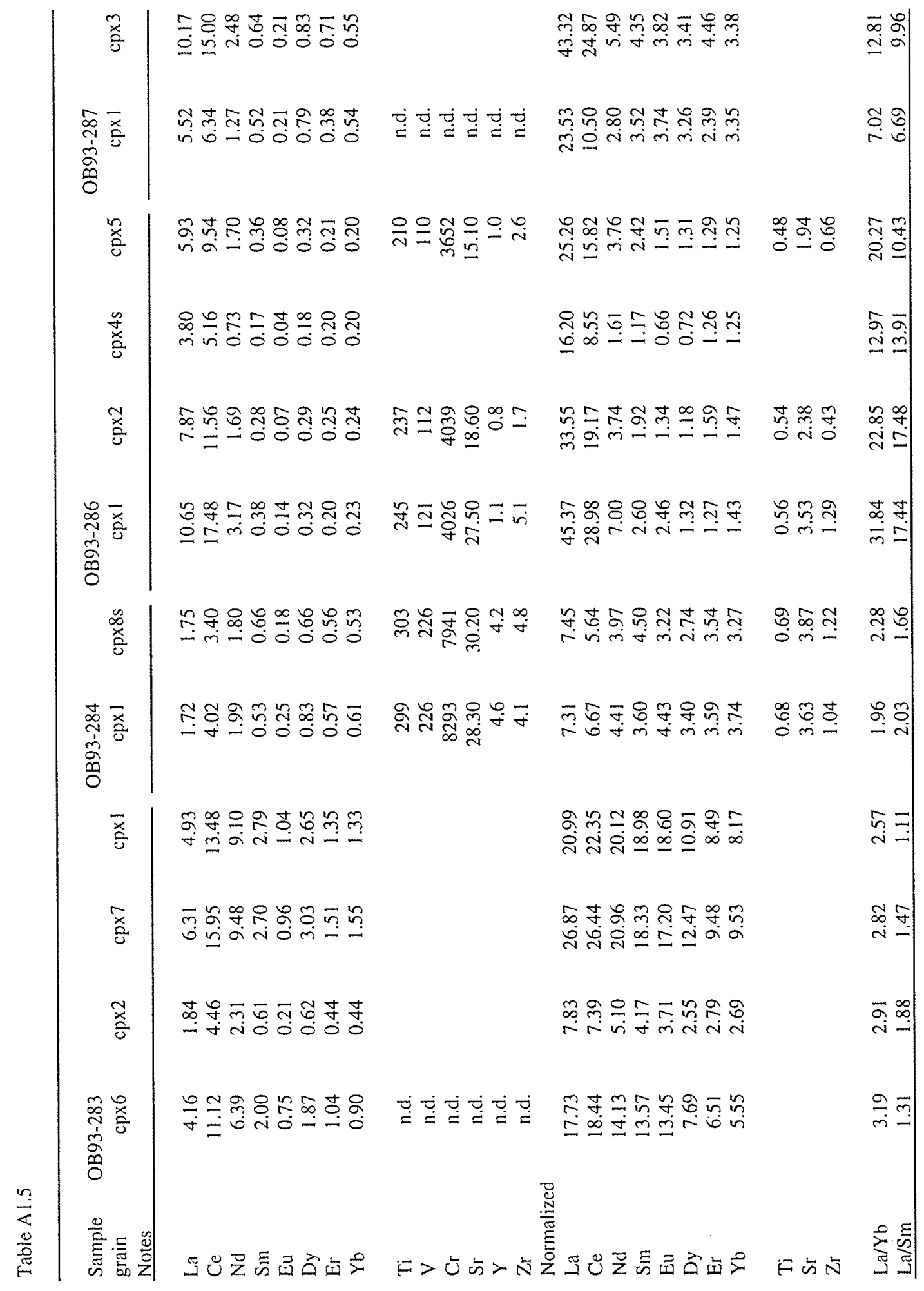




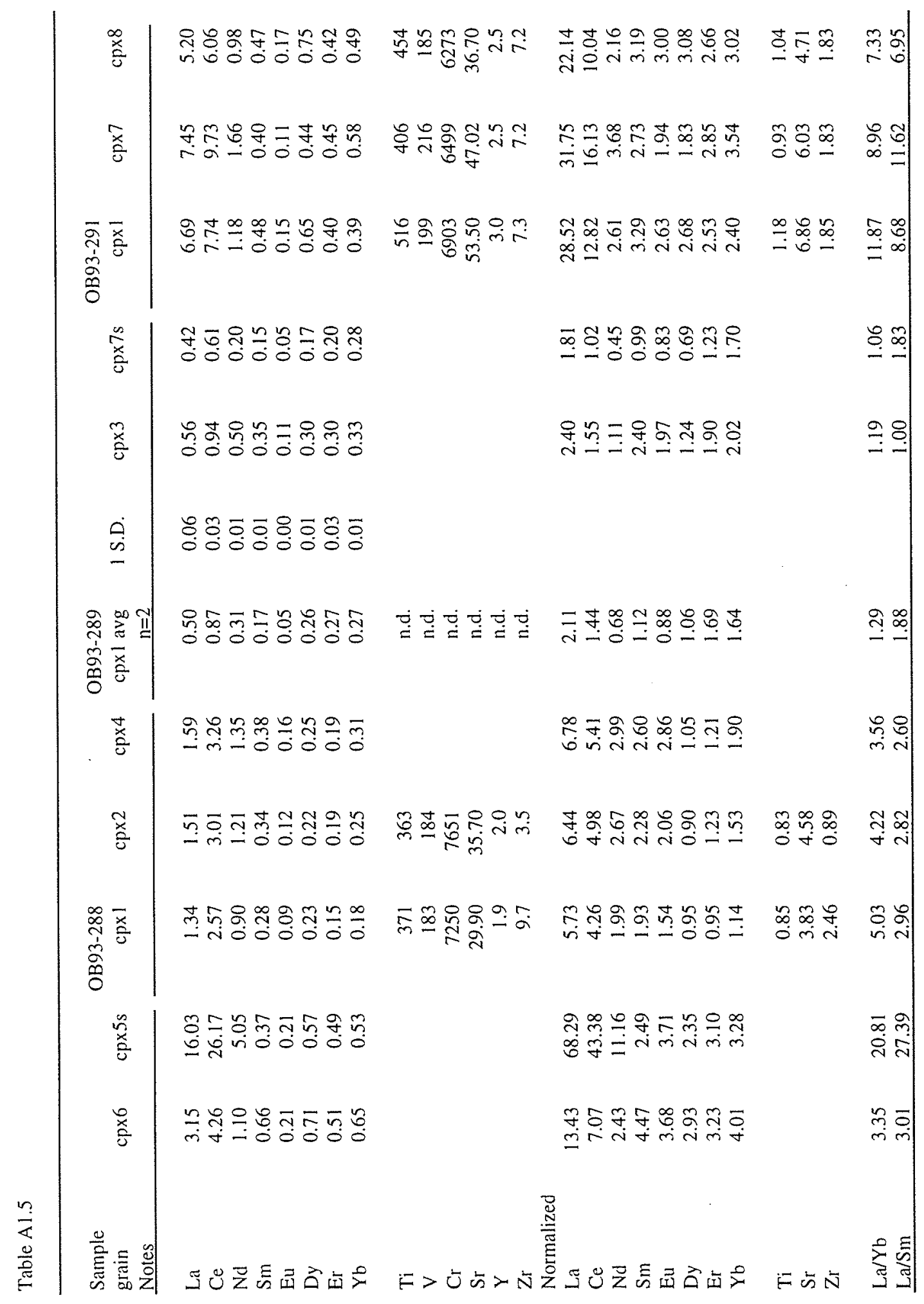




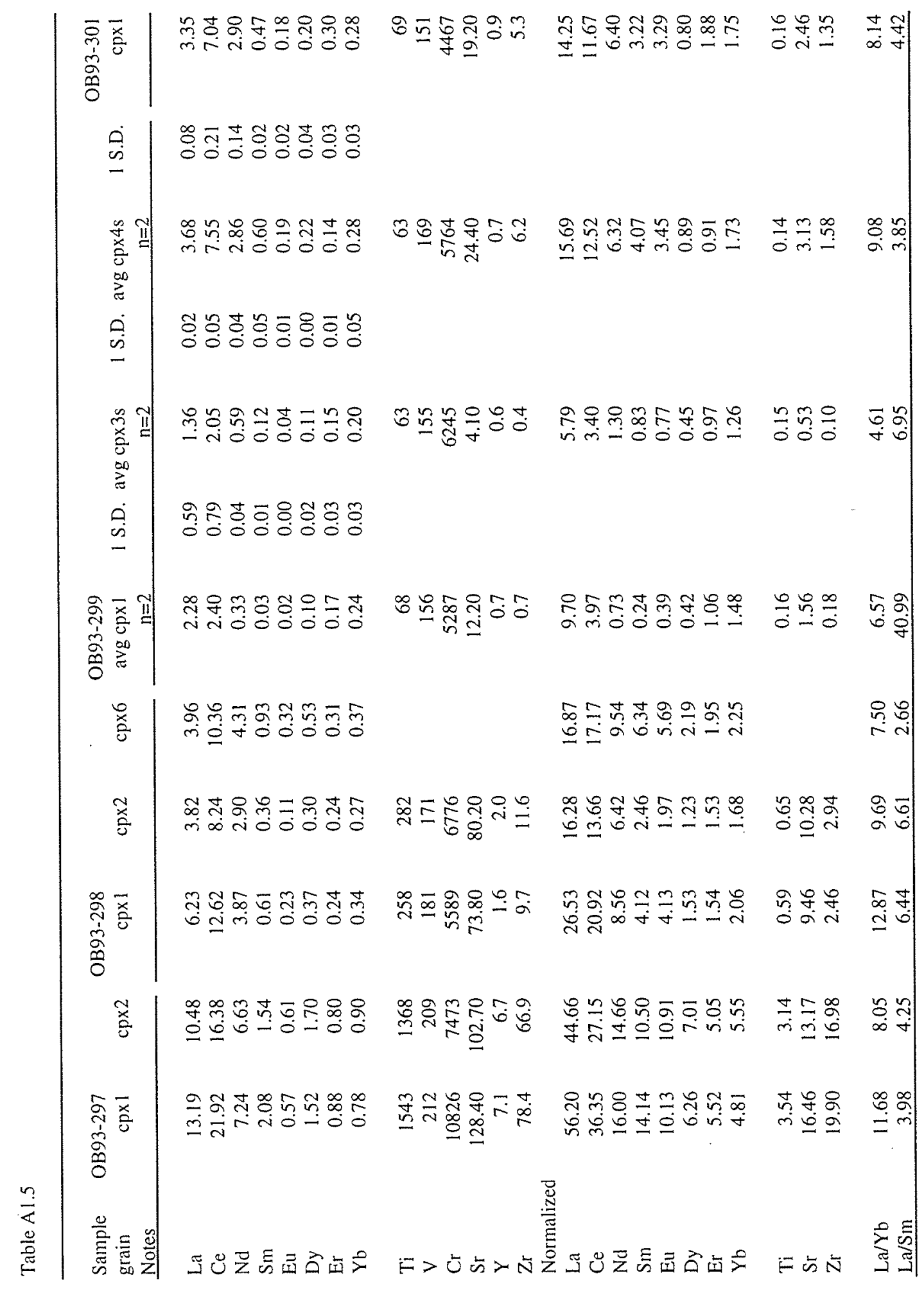




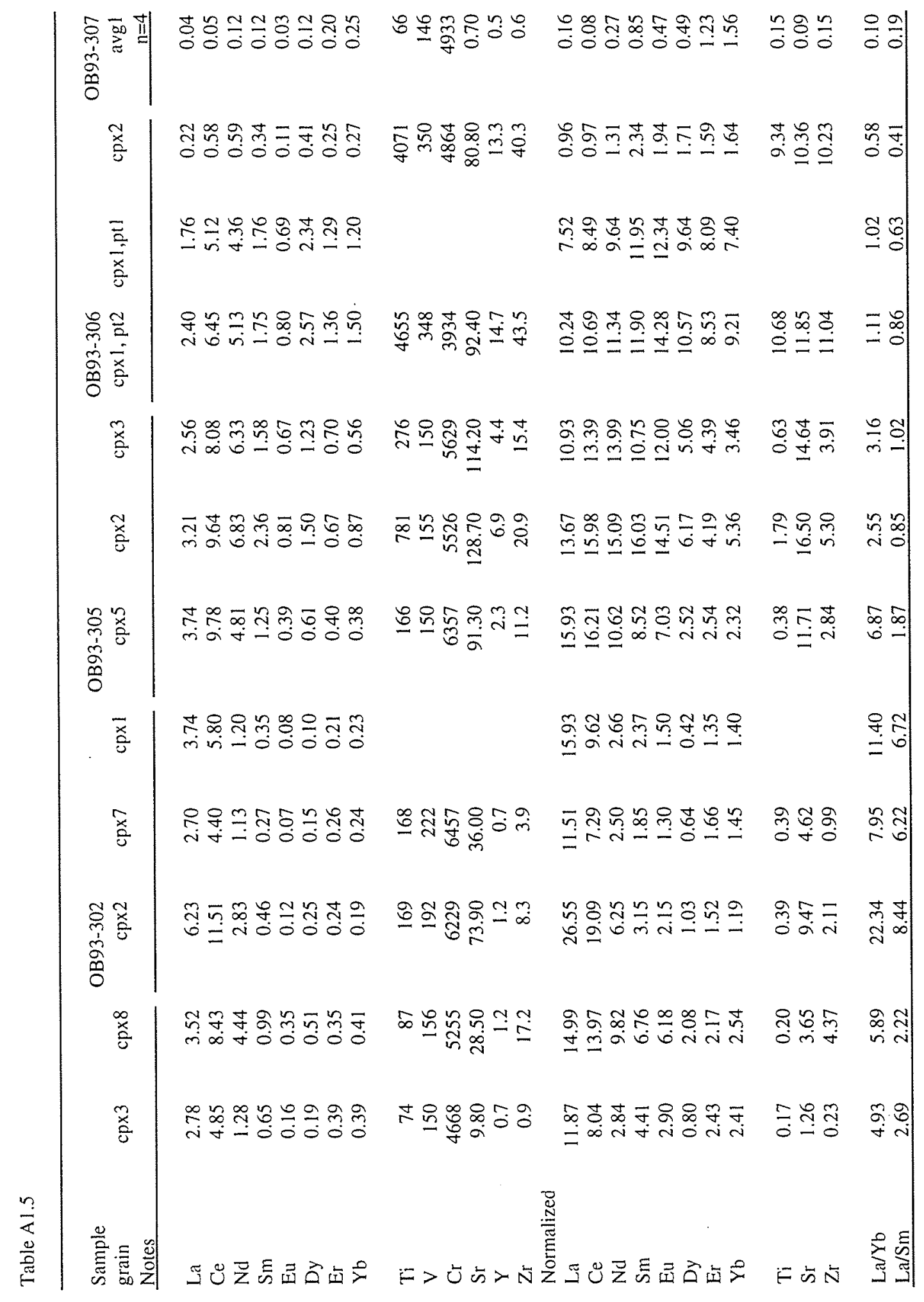




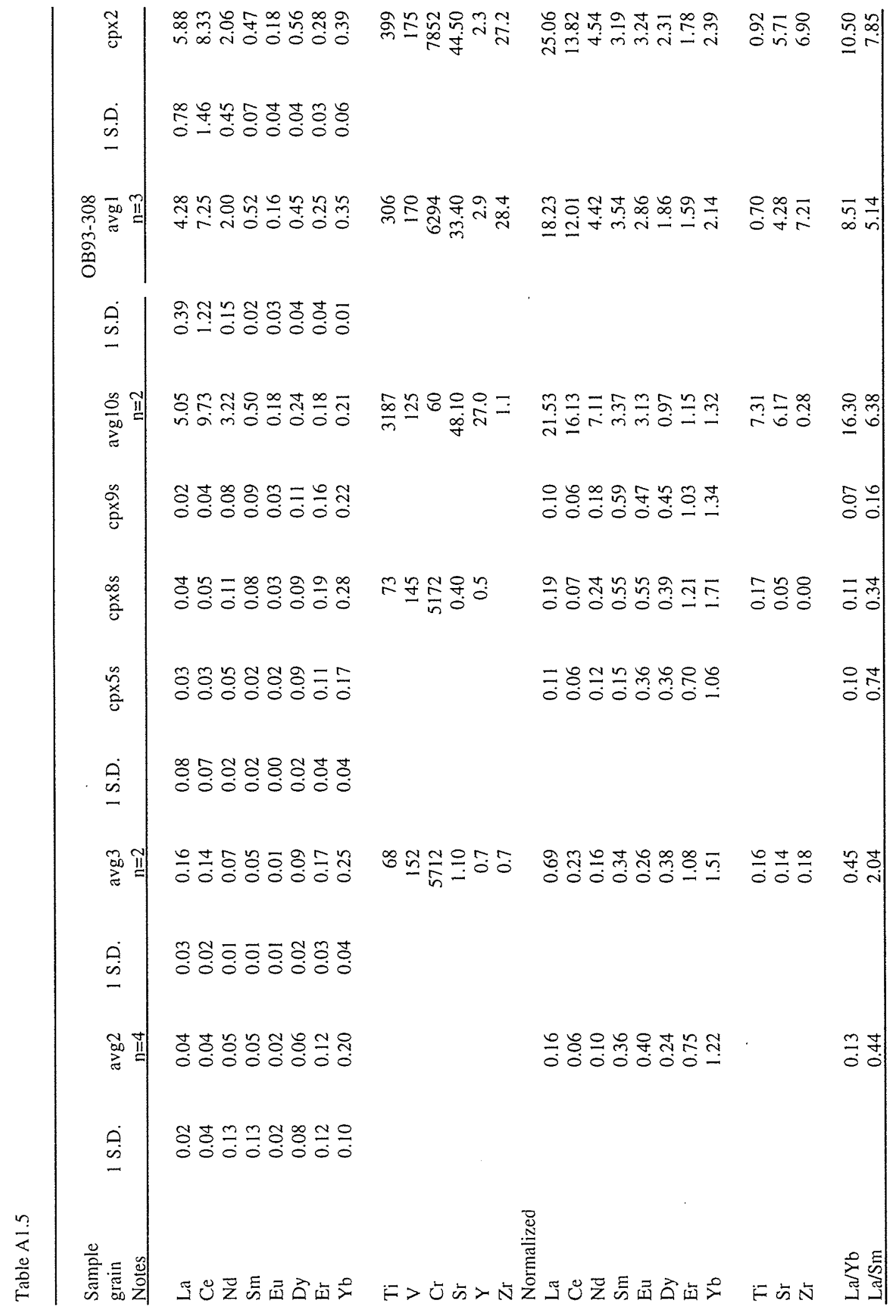




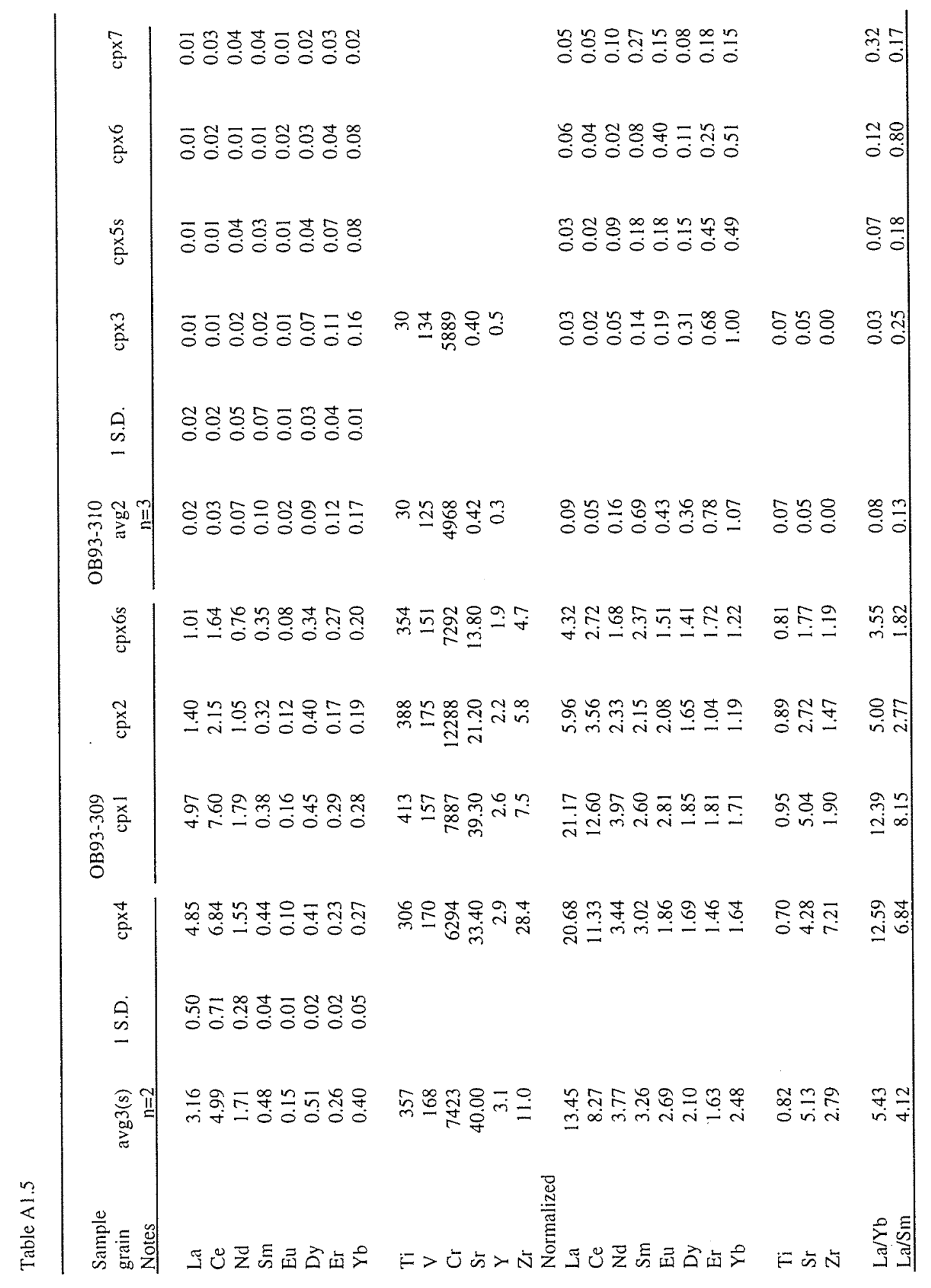




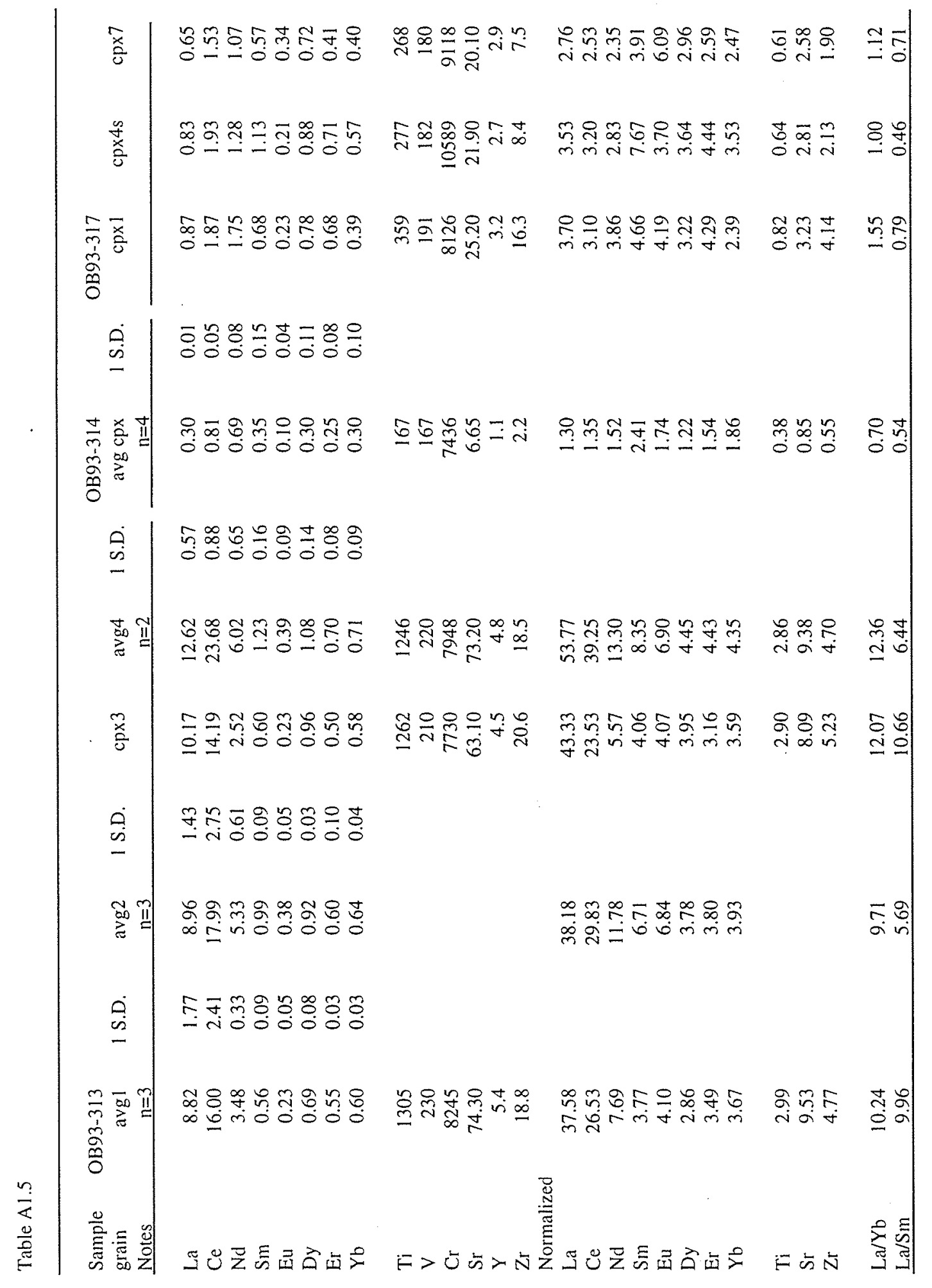




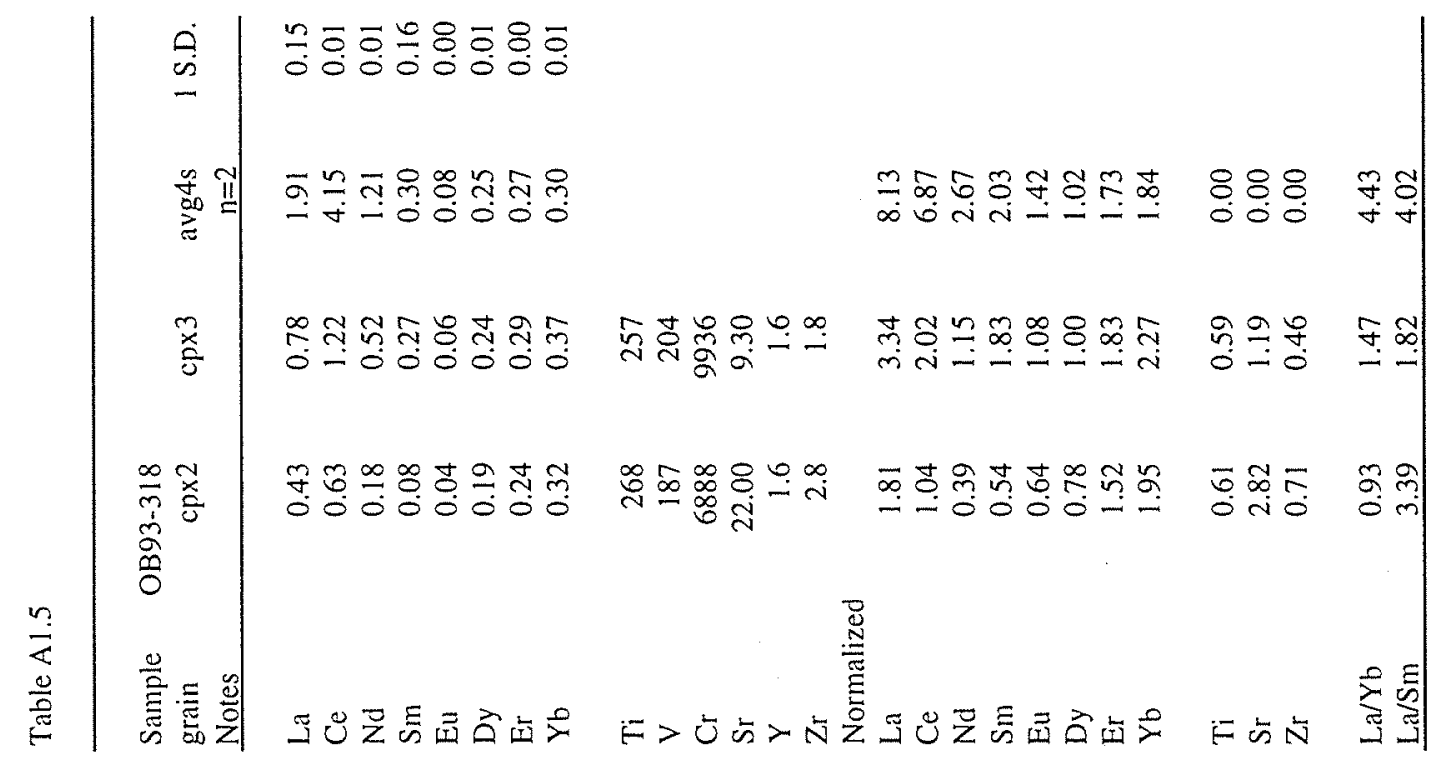


Appendix 2. Complete major and trace element compositions of minerals in the granulites. 


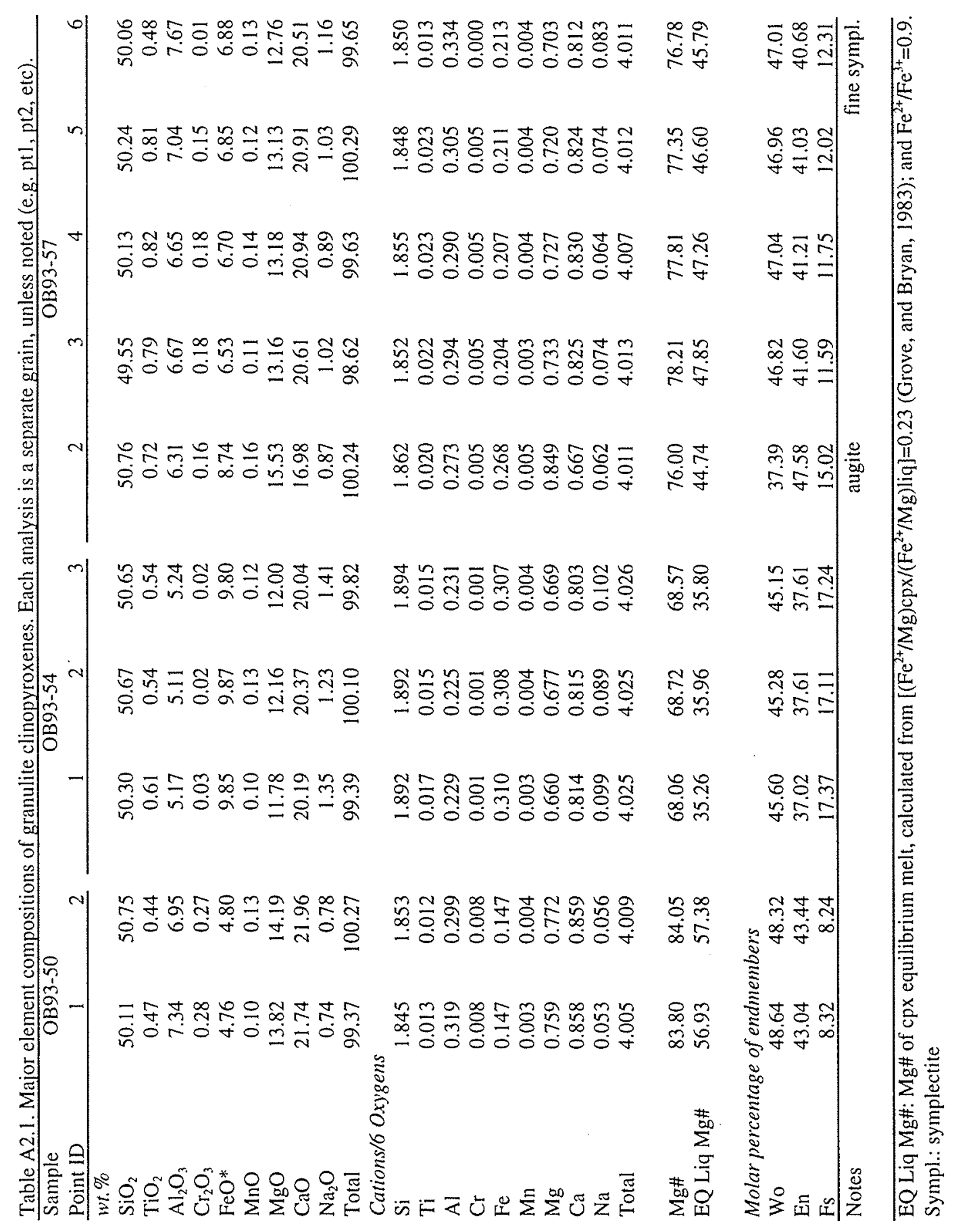




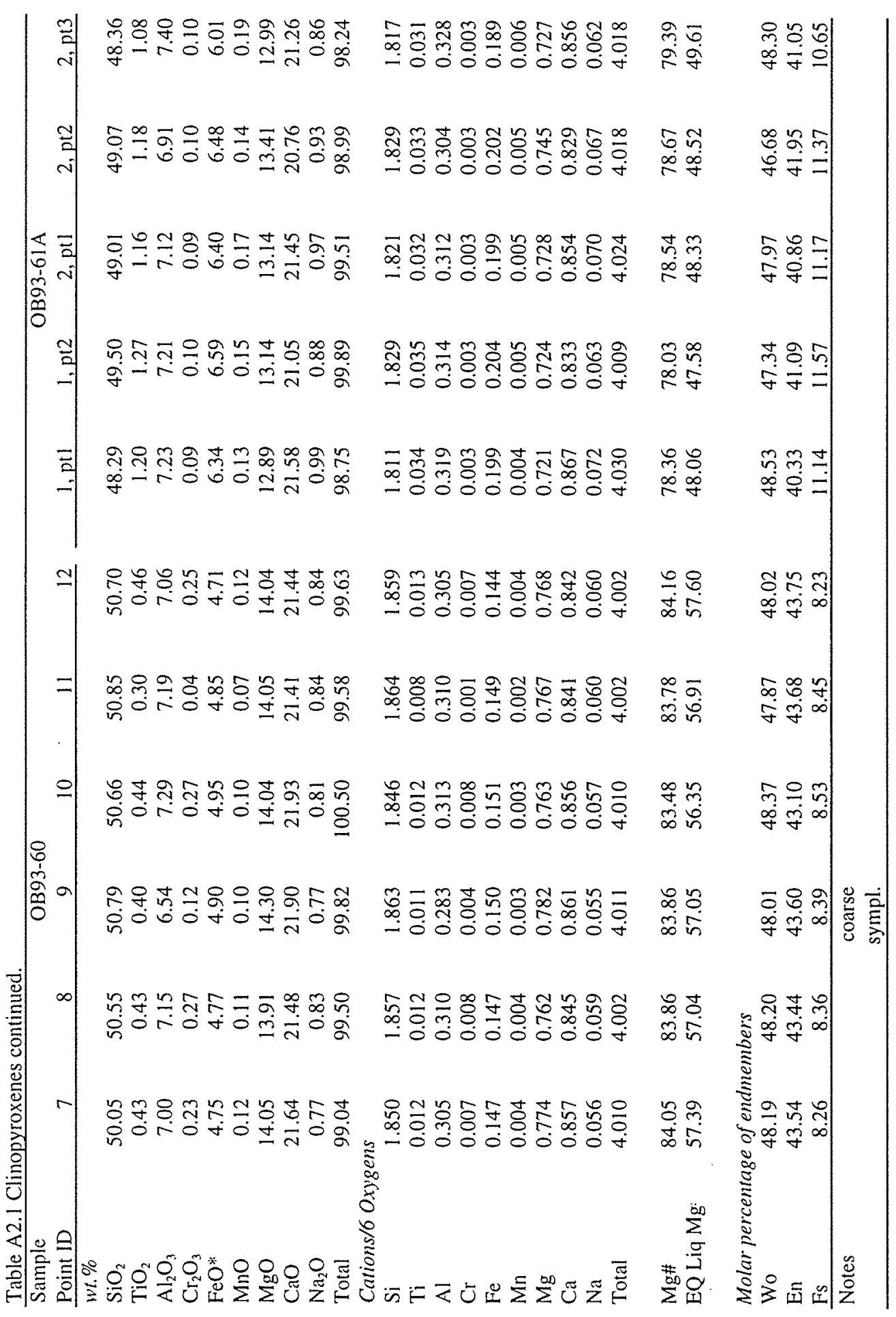




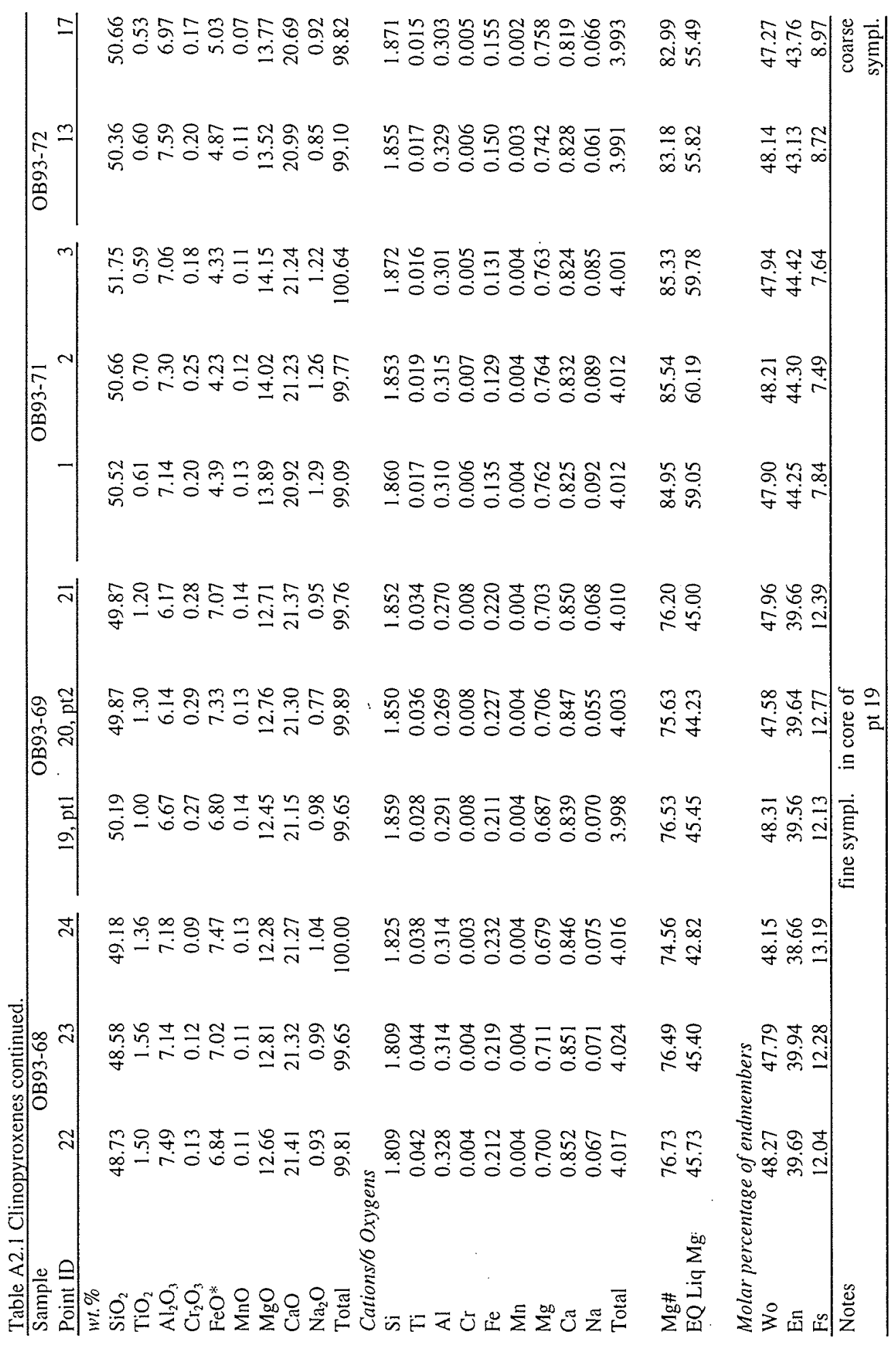




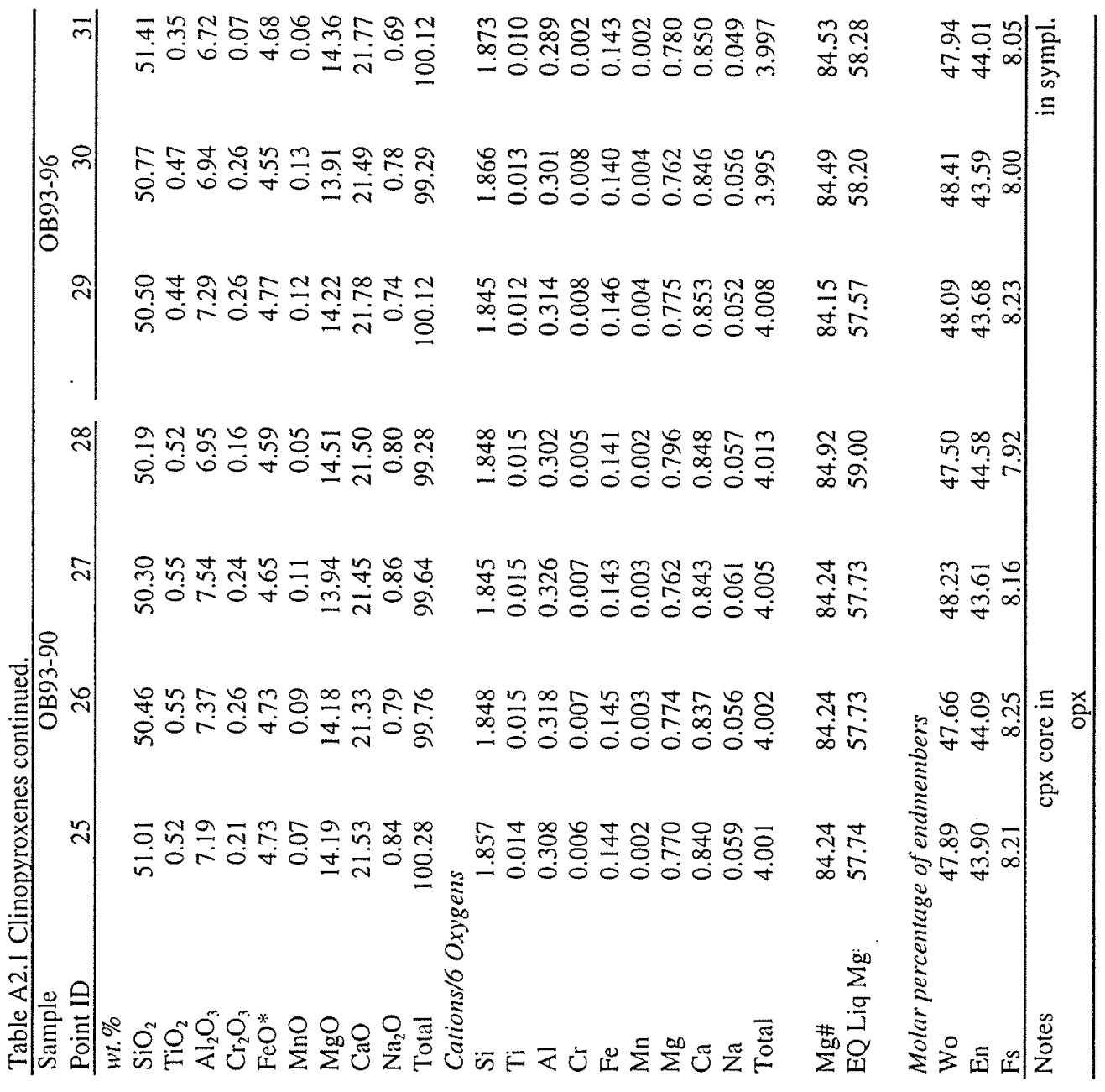




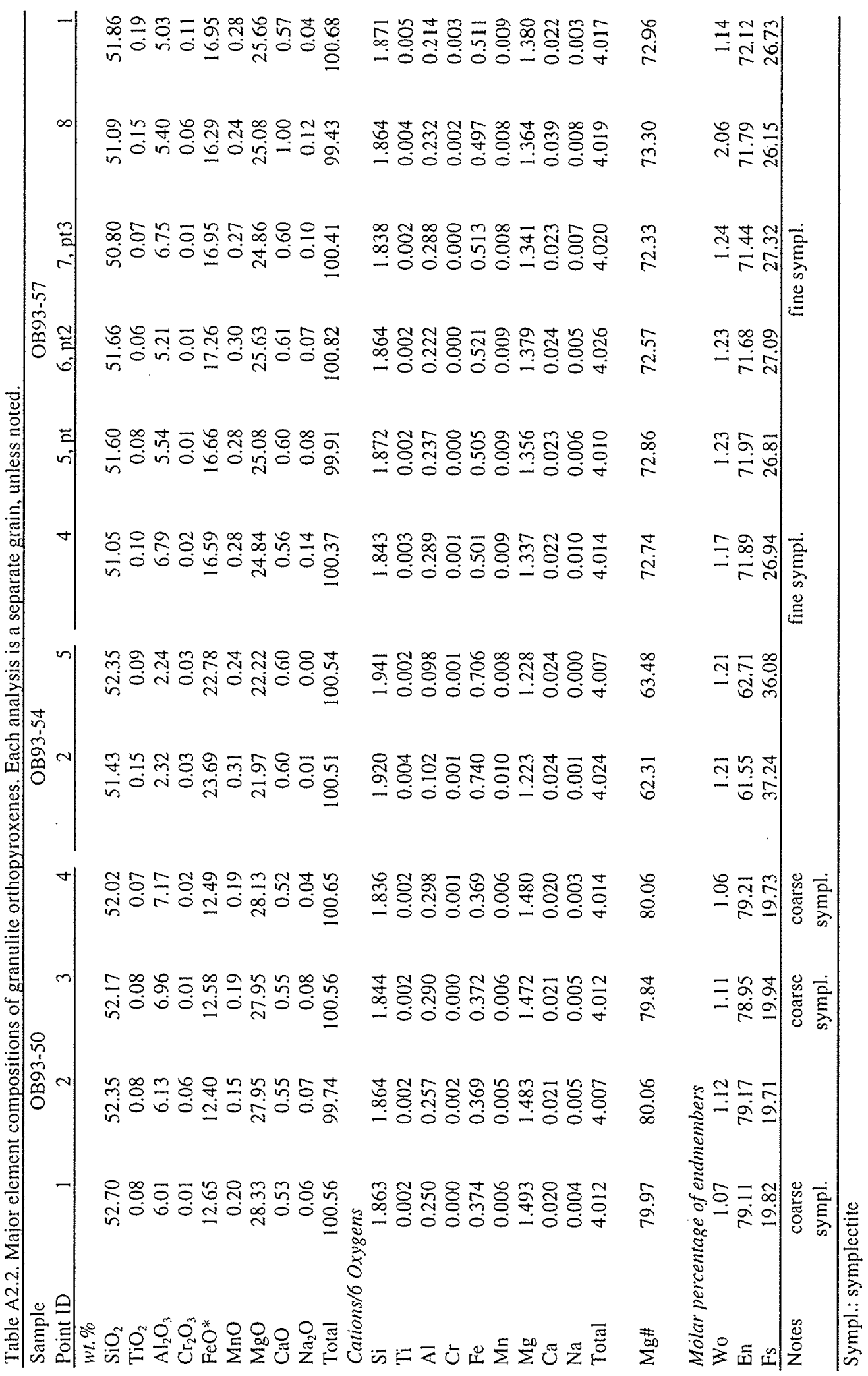




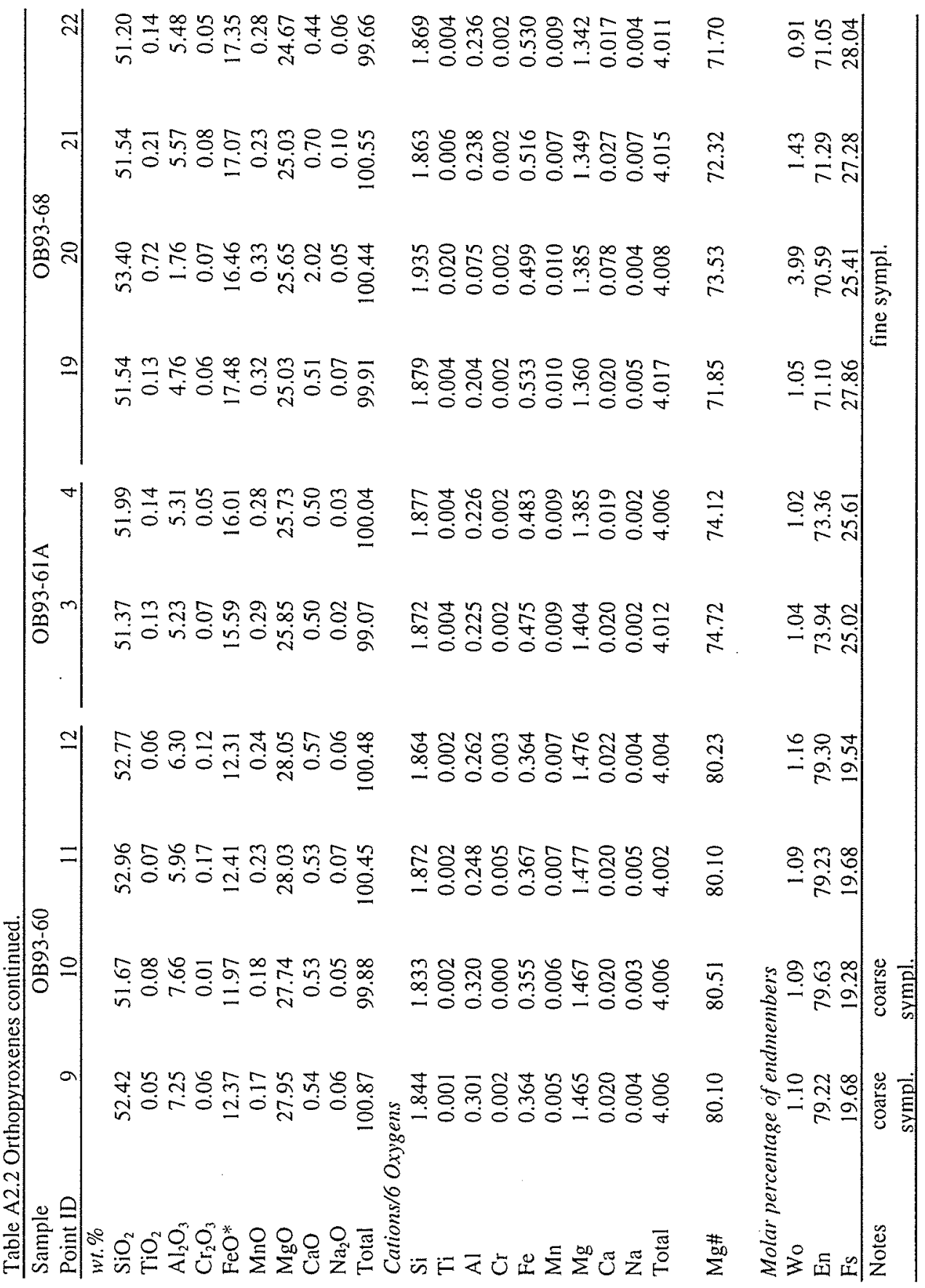




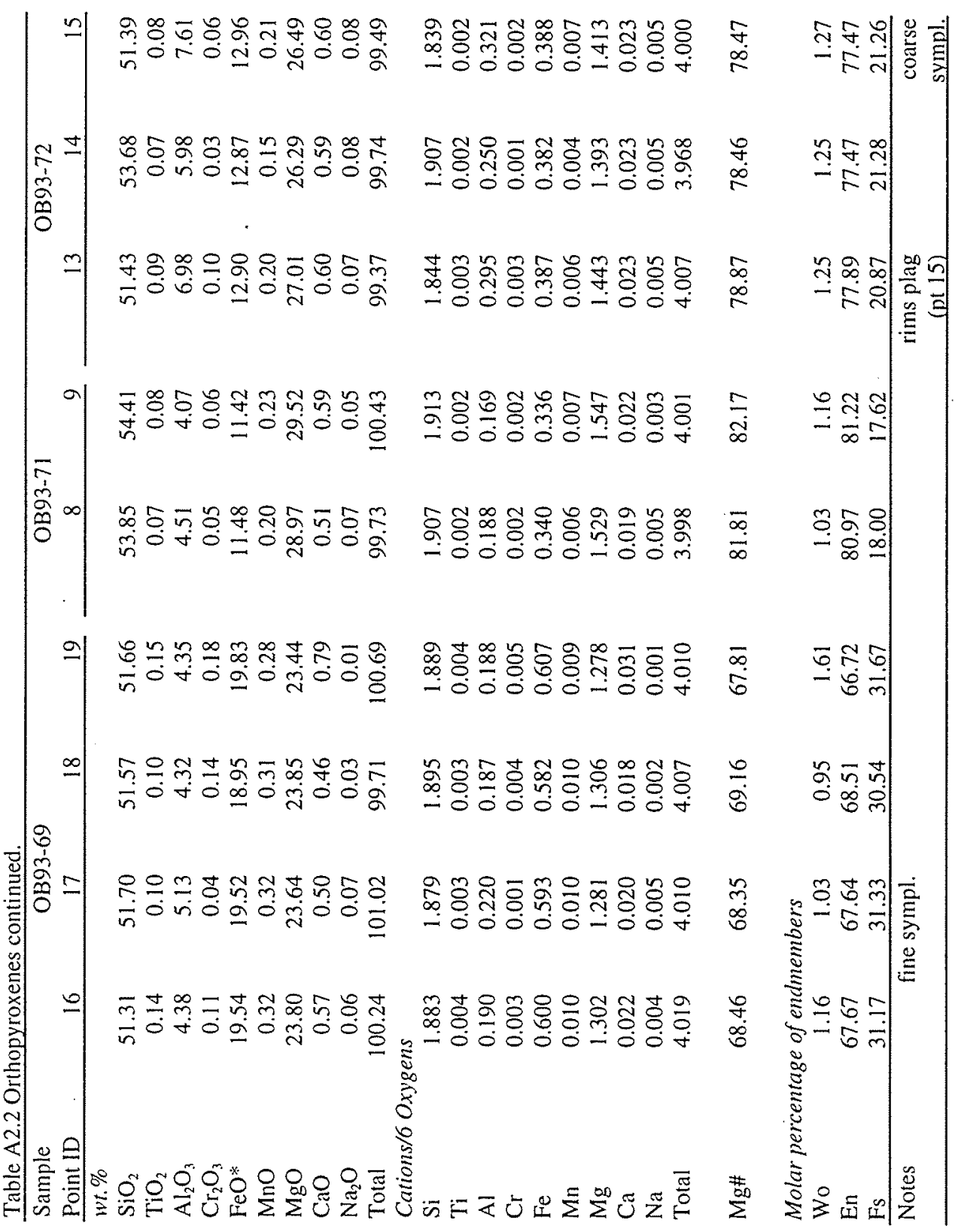




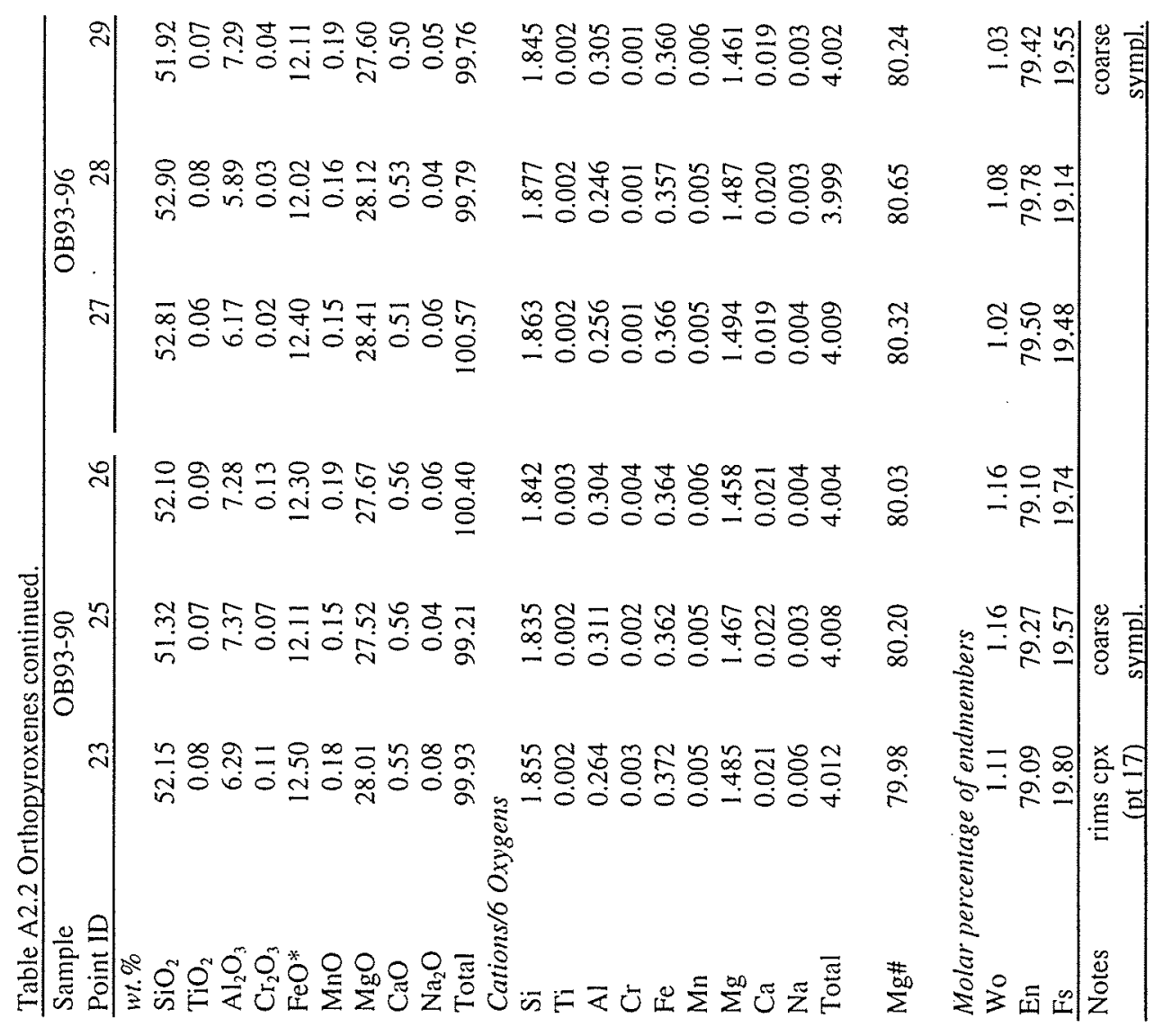




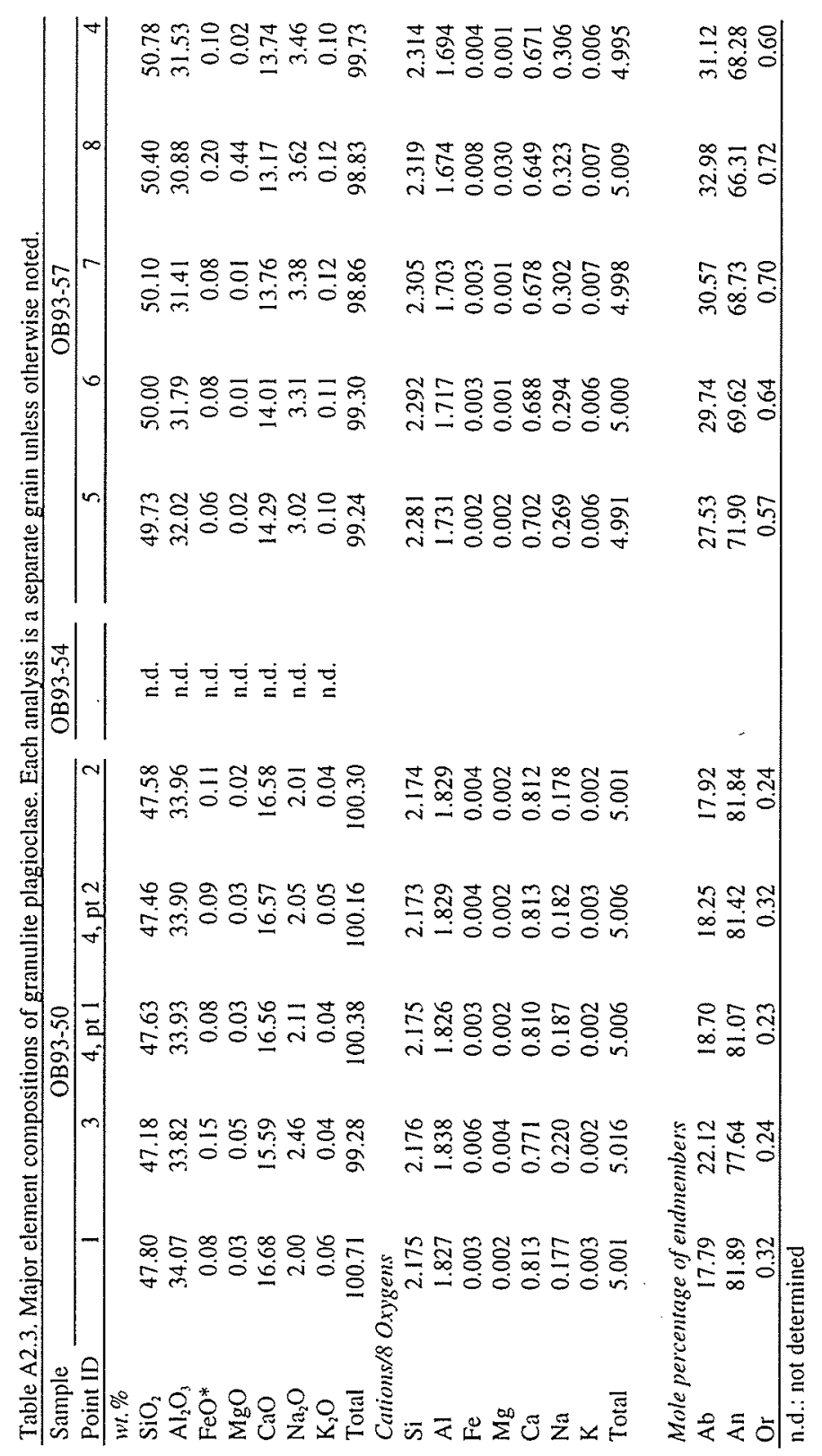




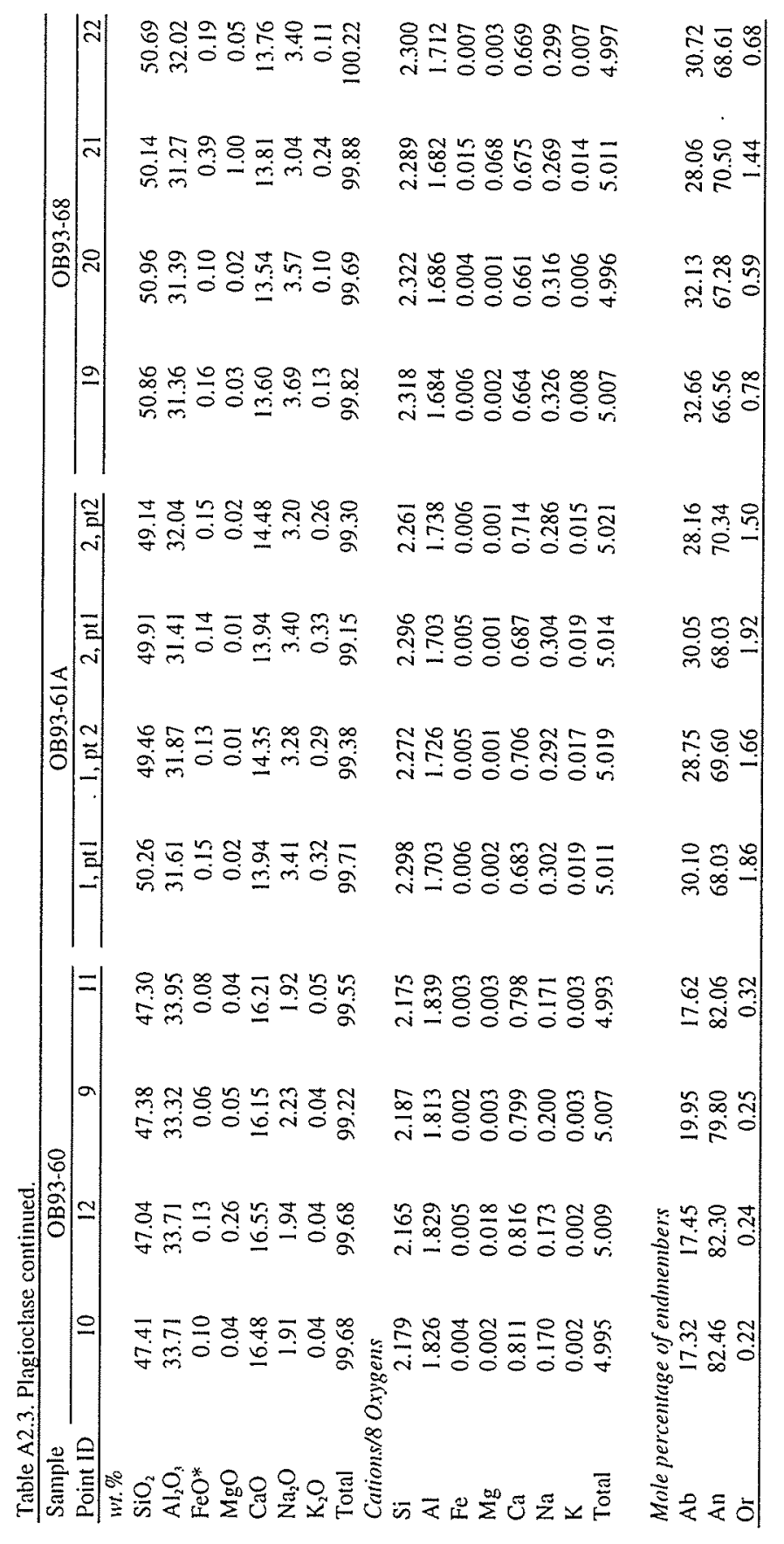




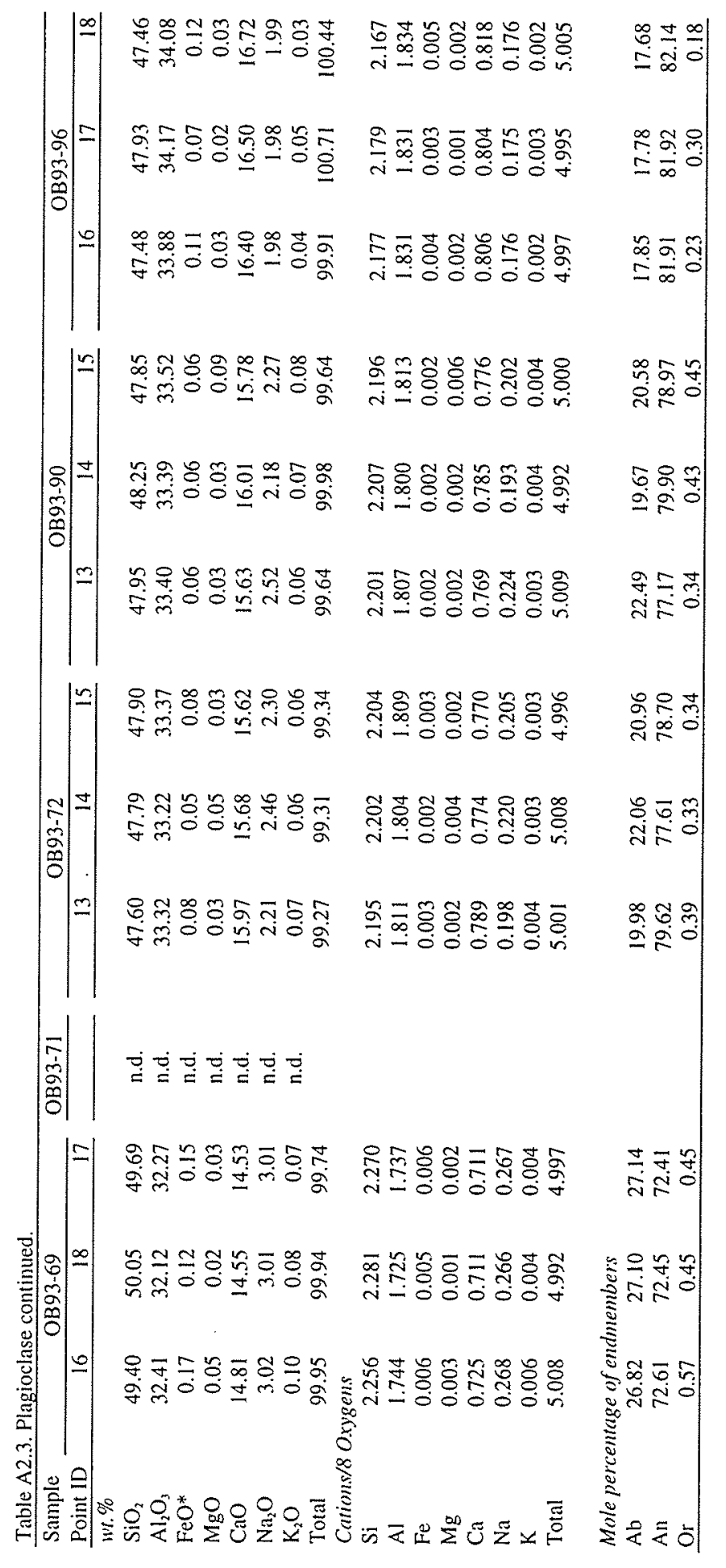




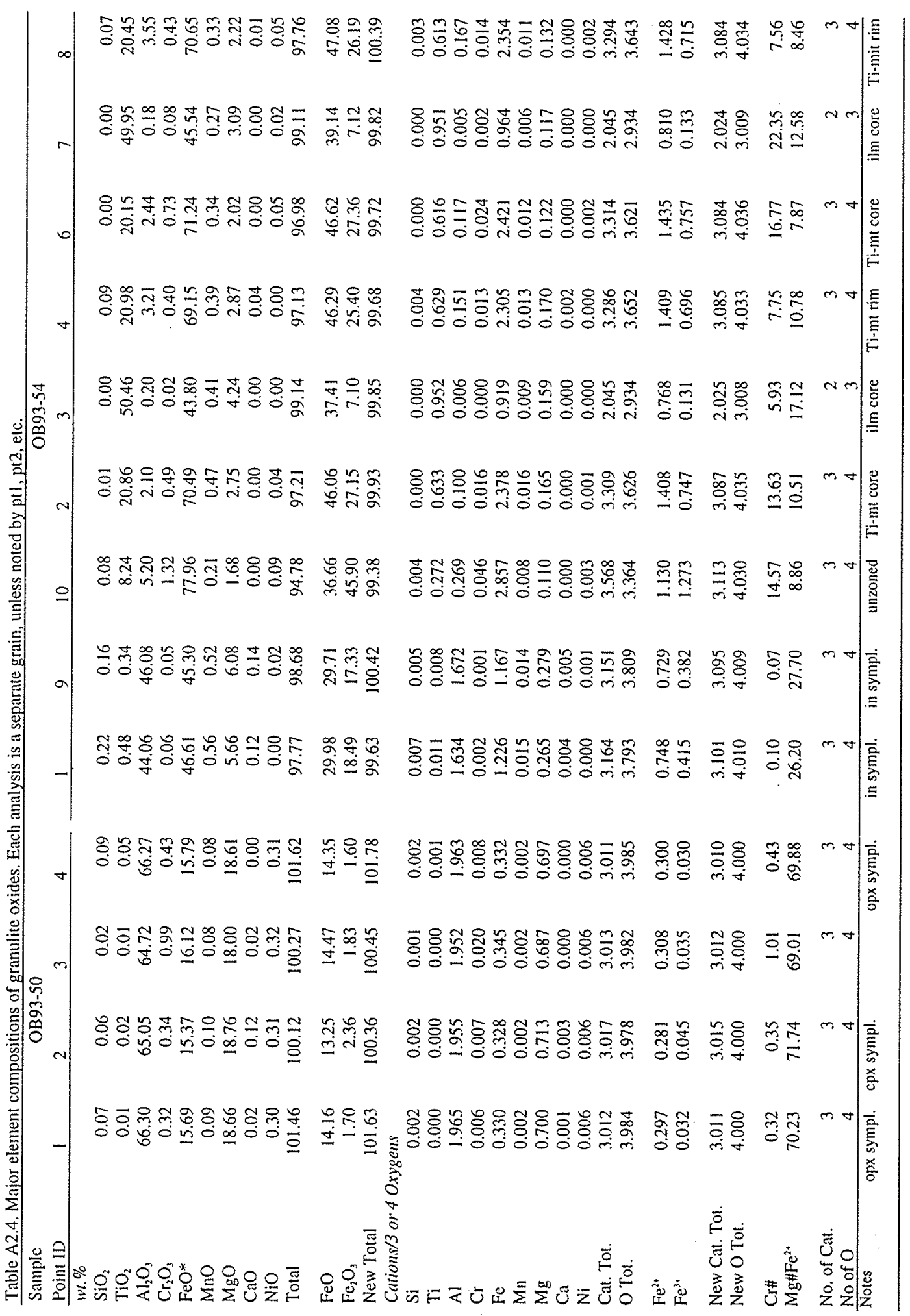




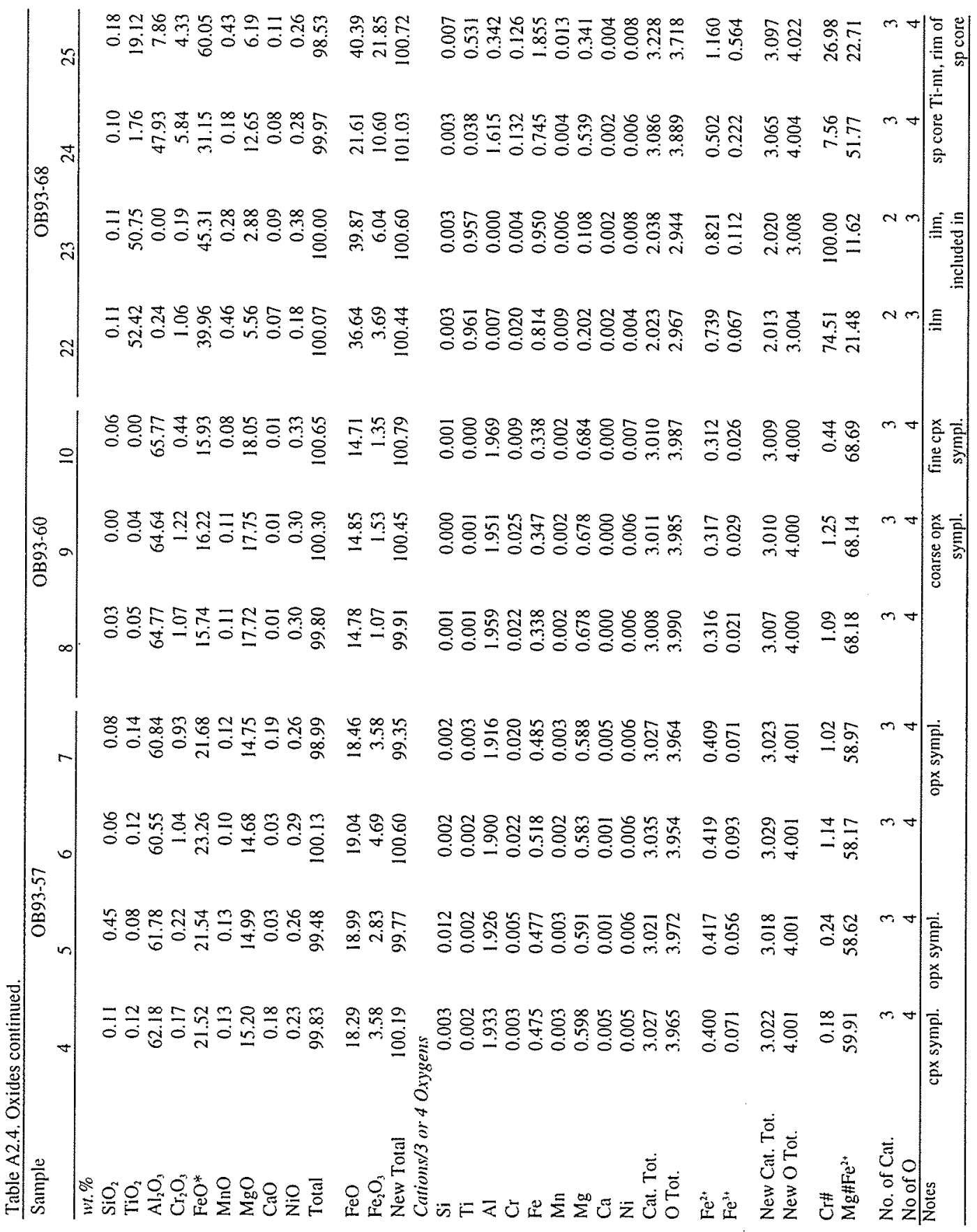




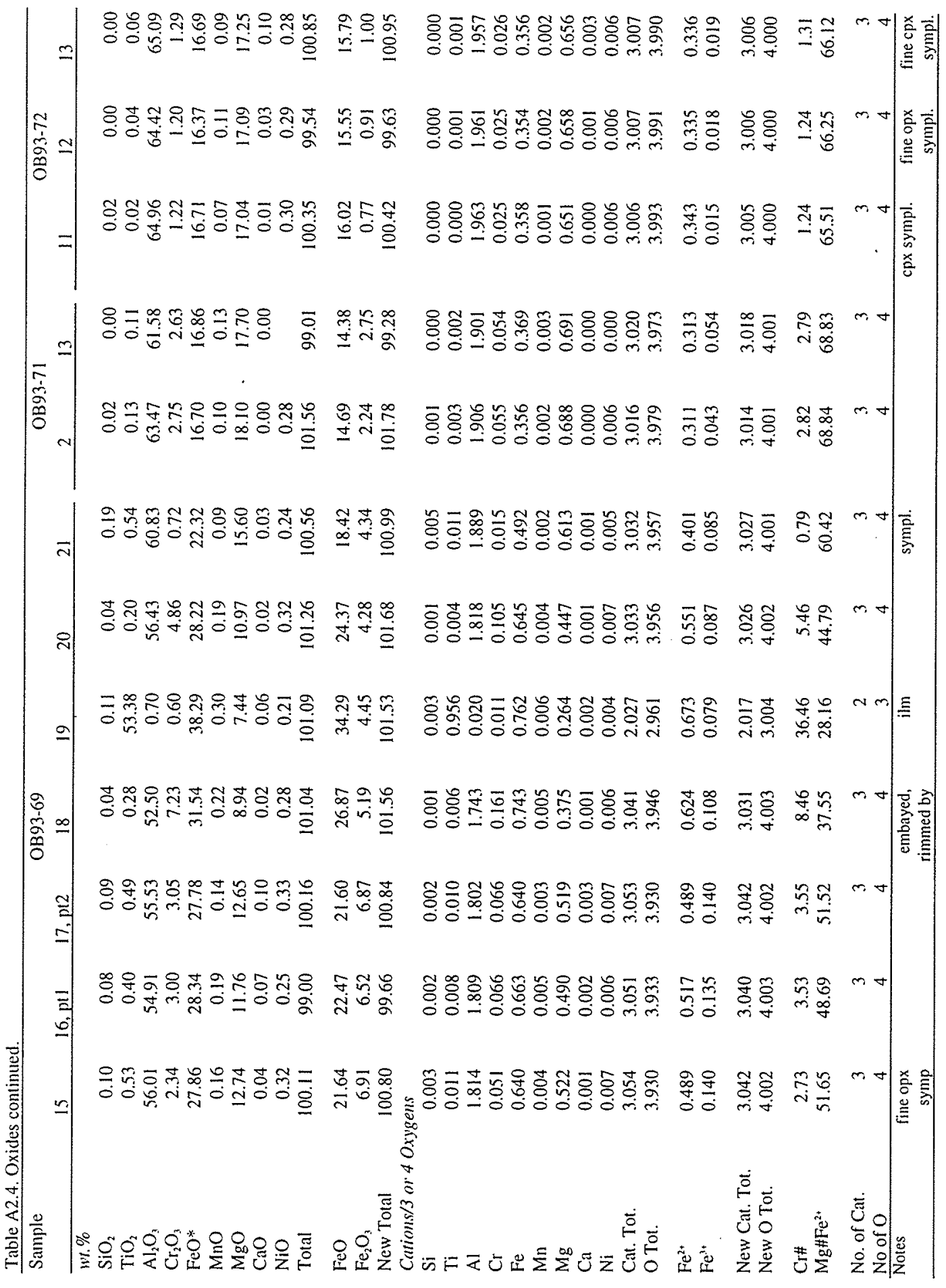




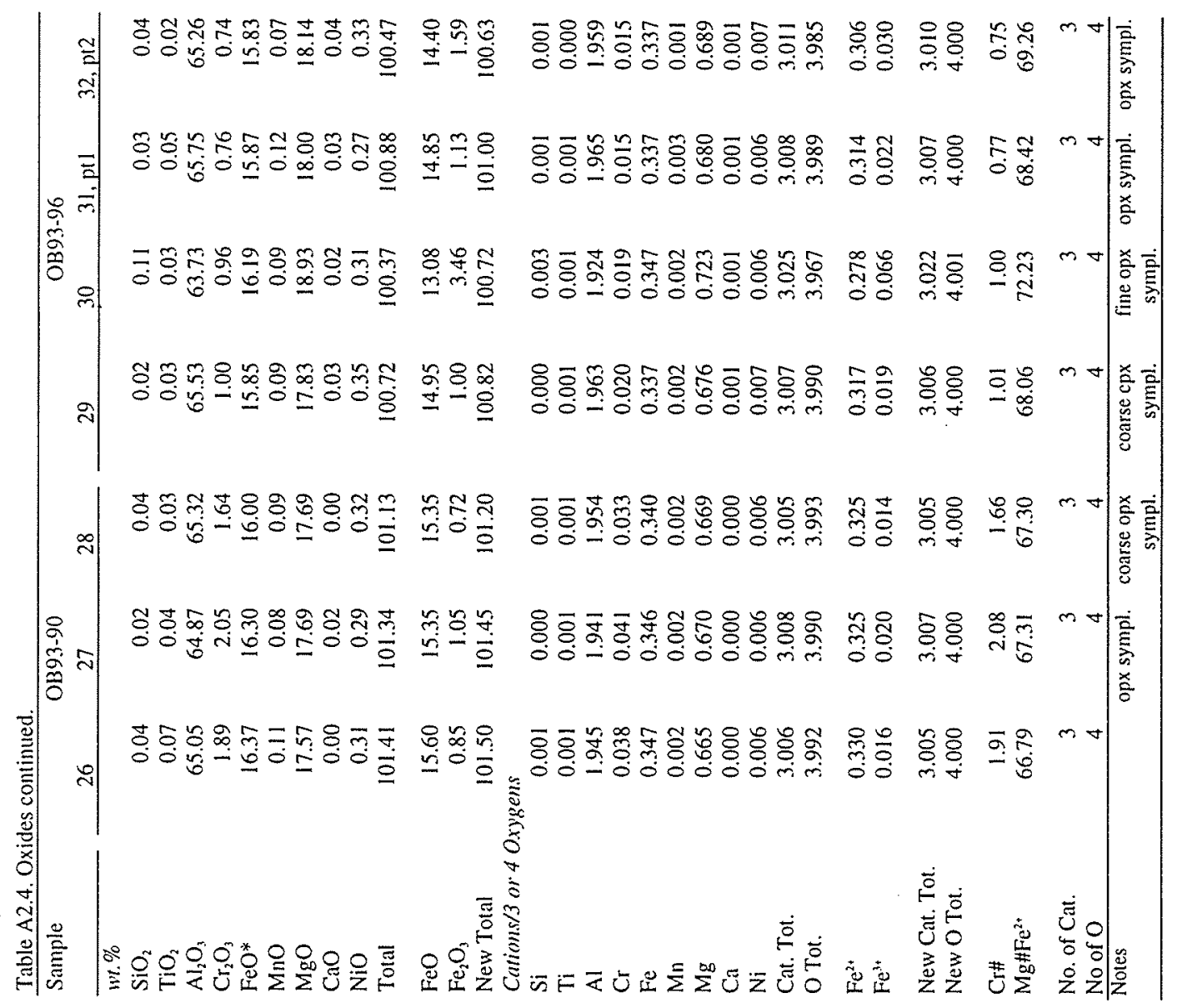




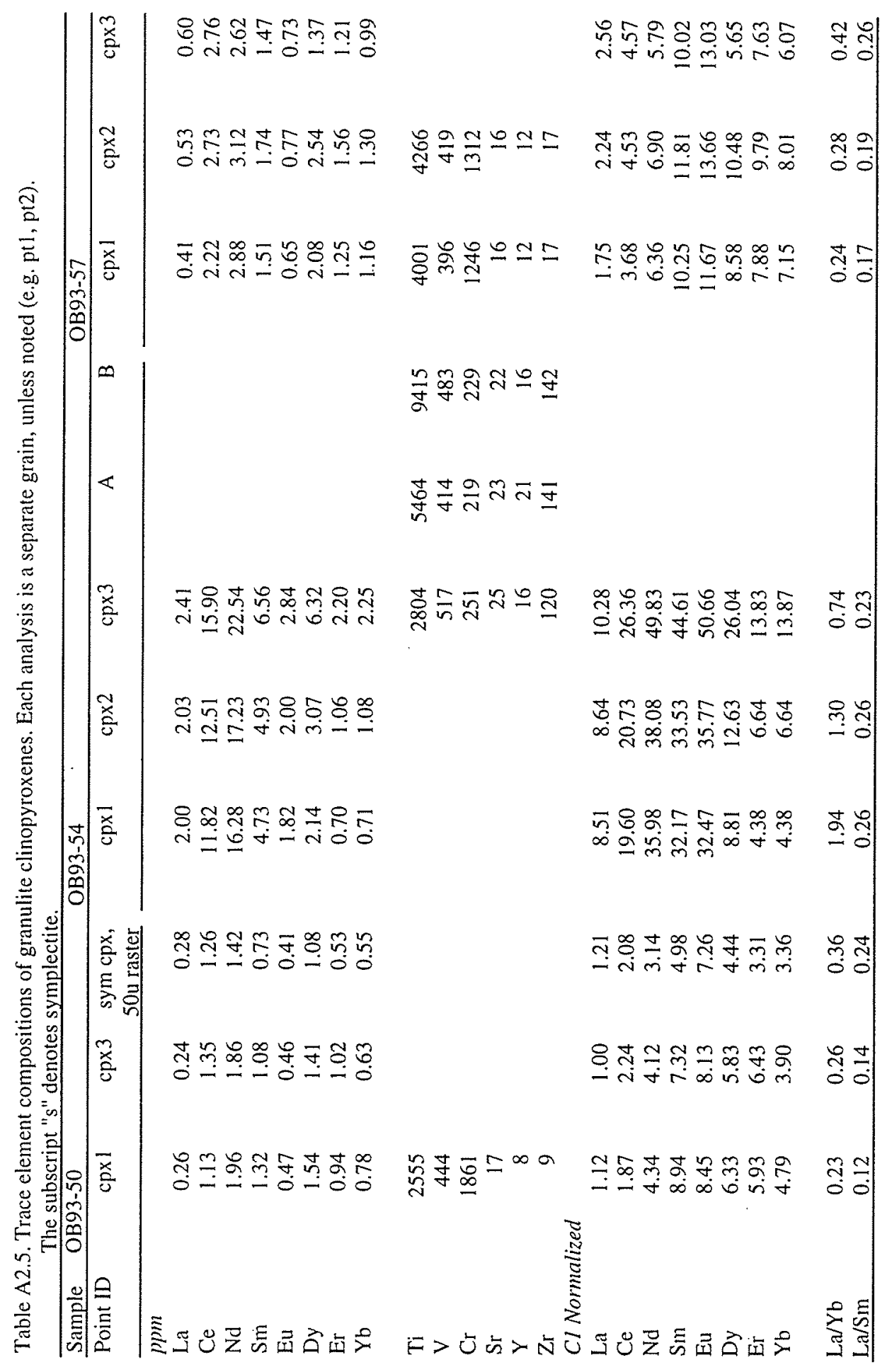




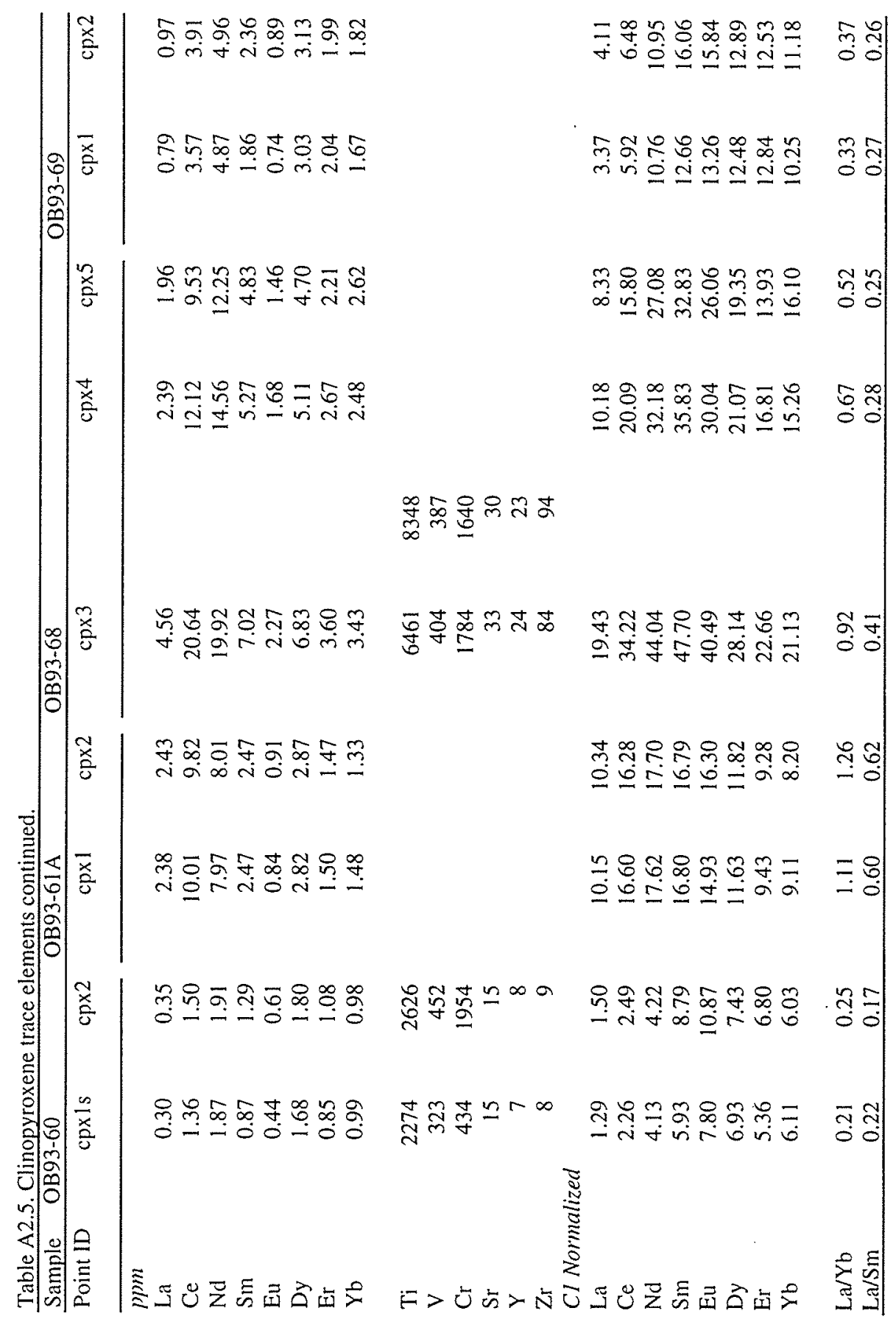




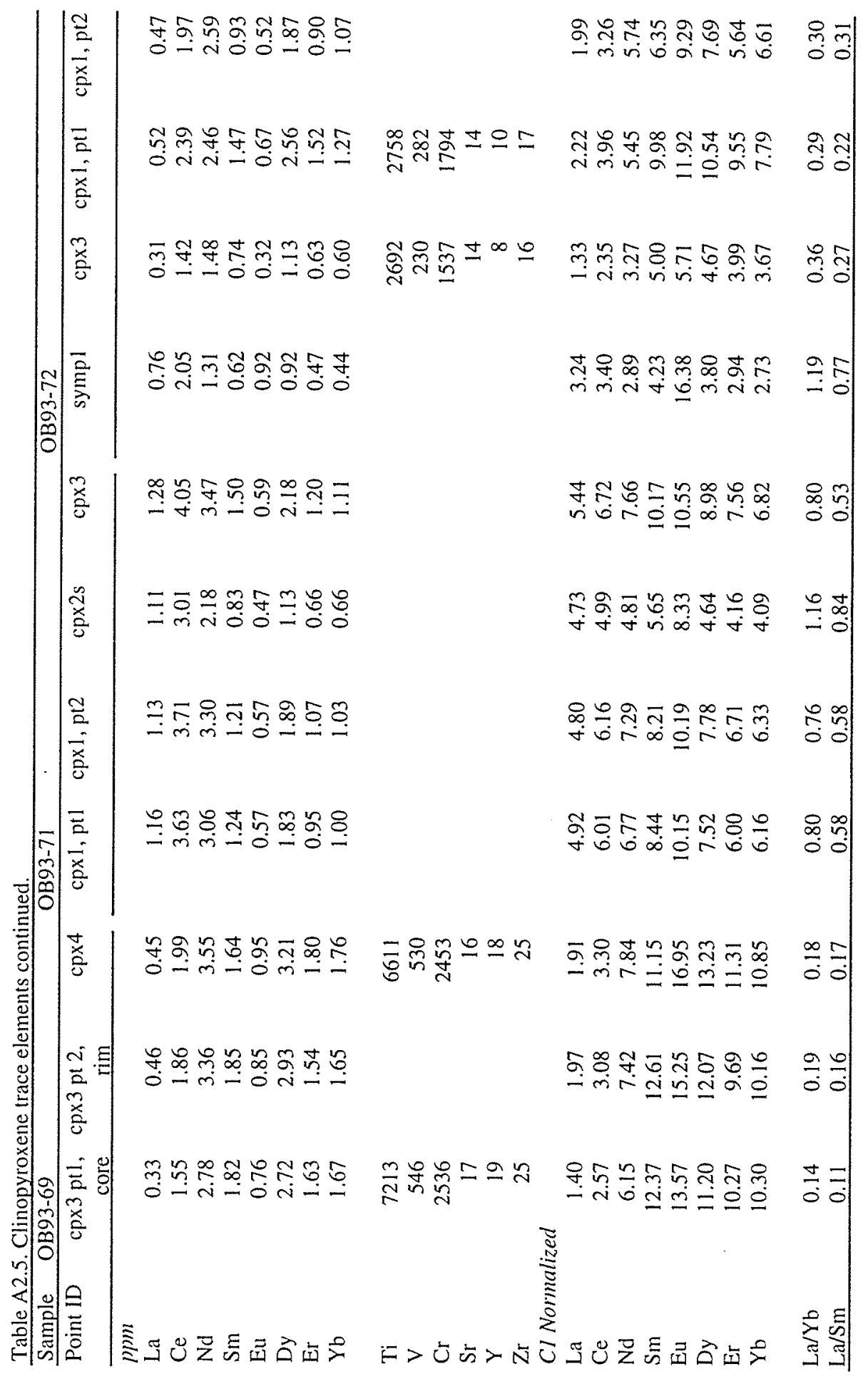




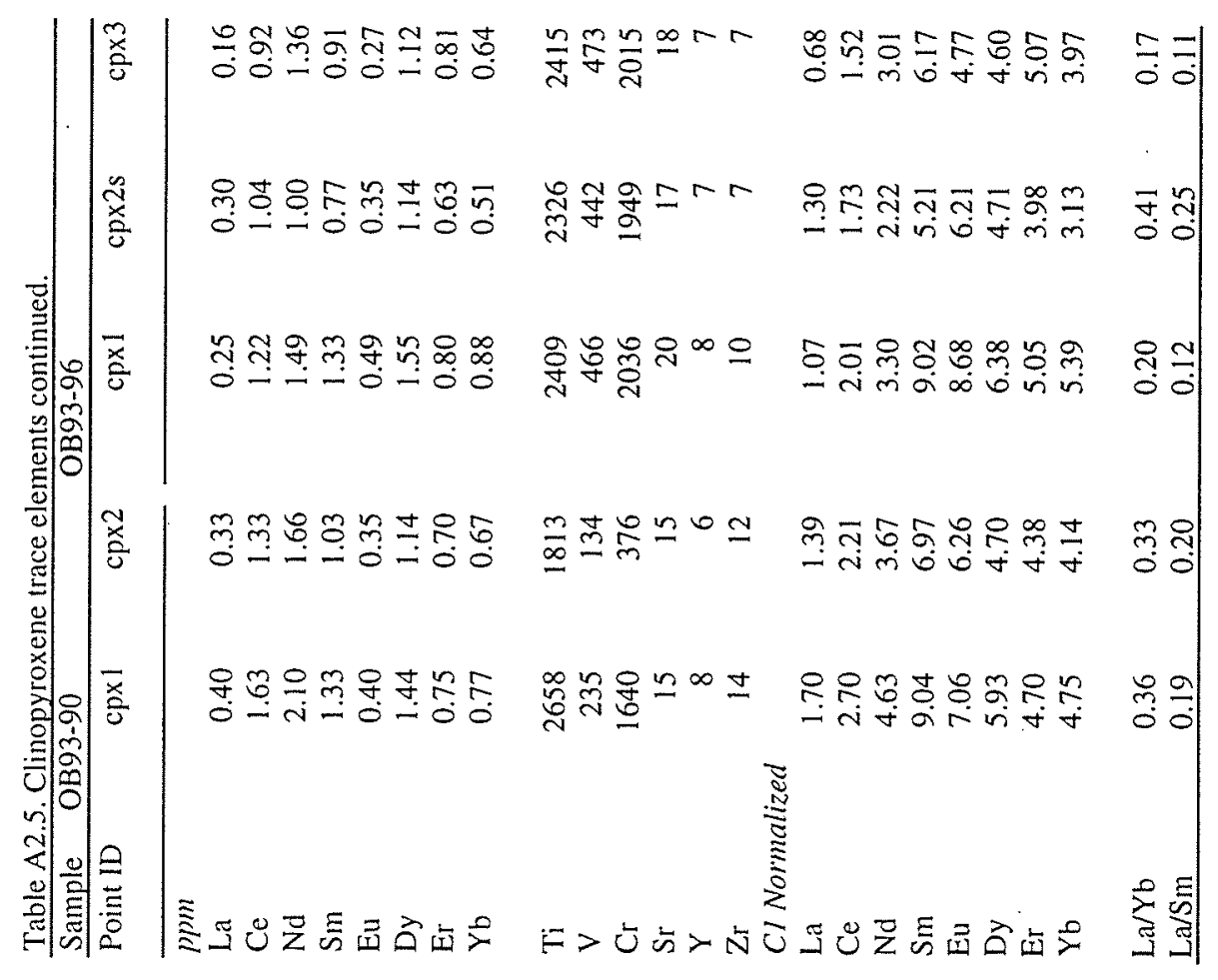




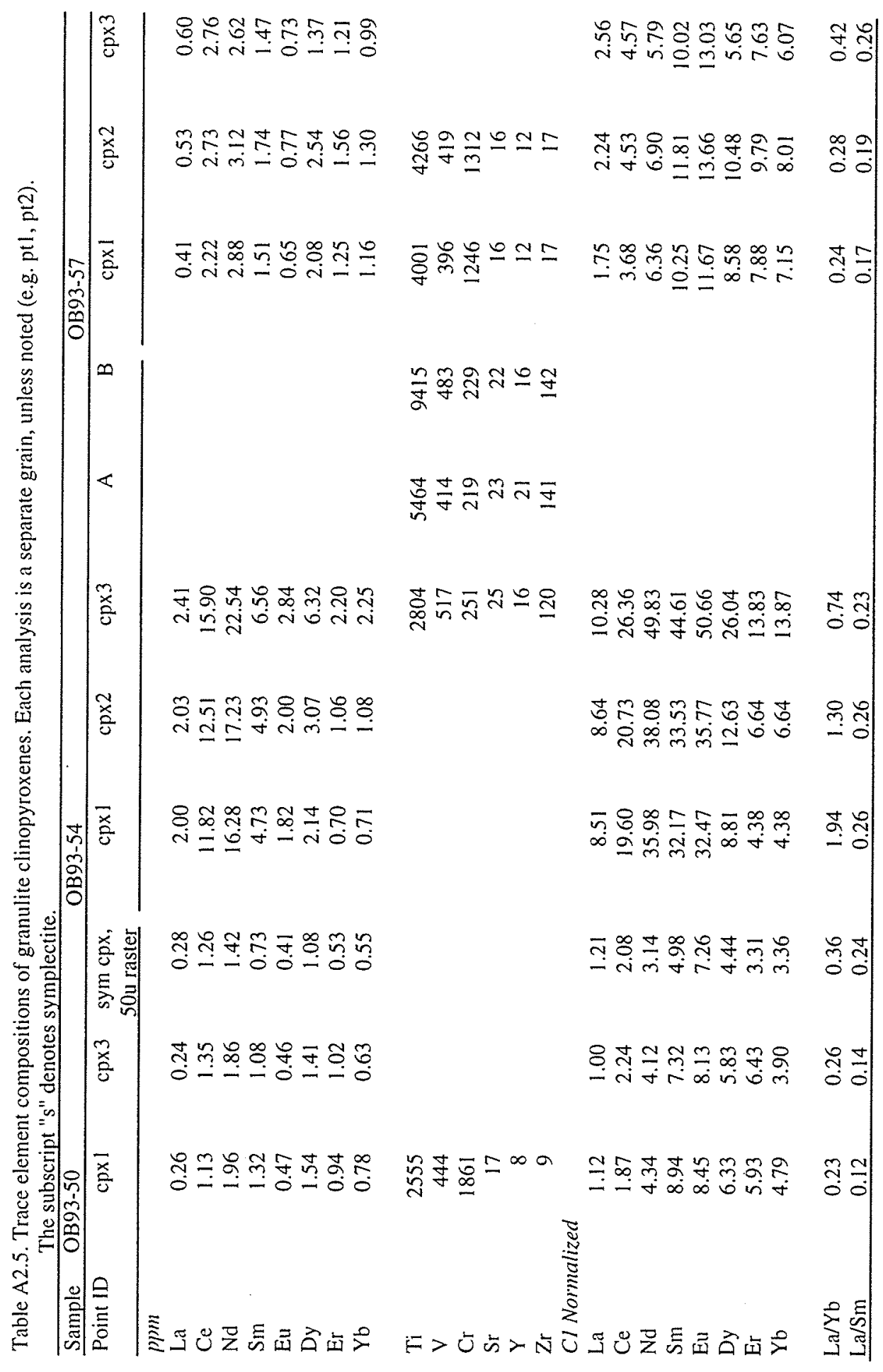




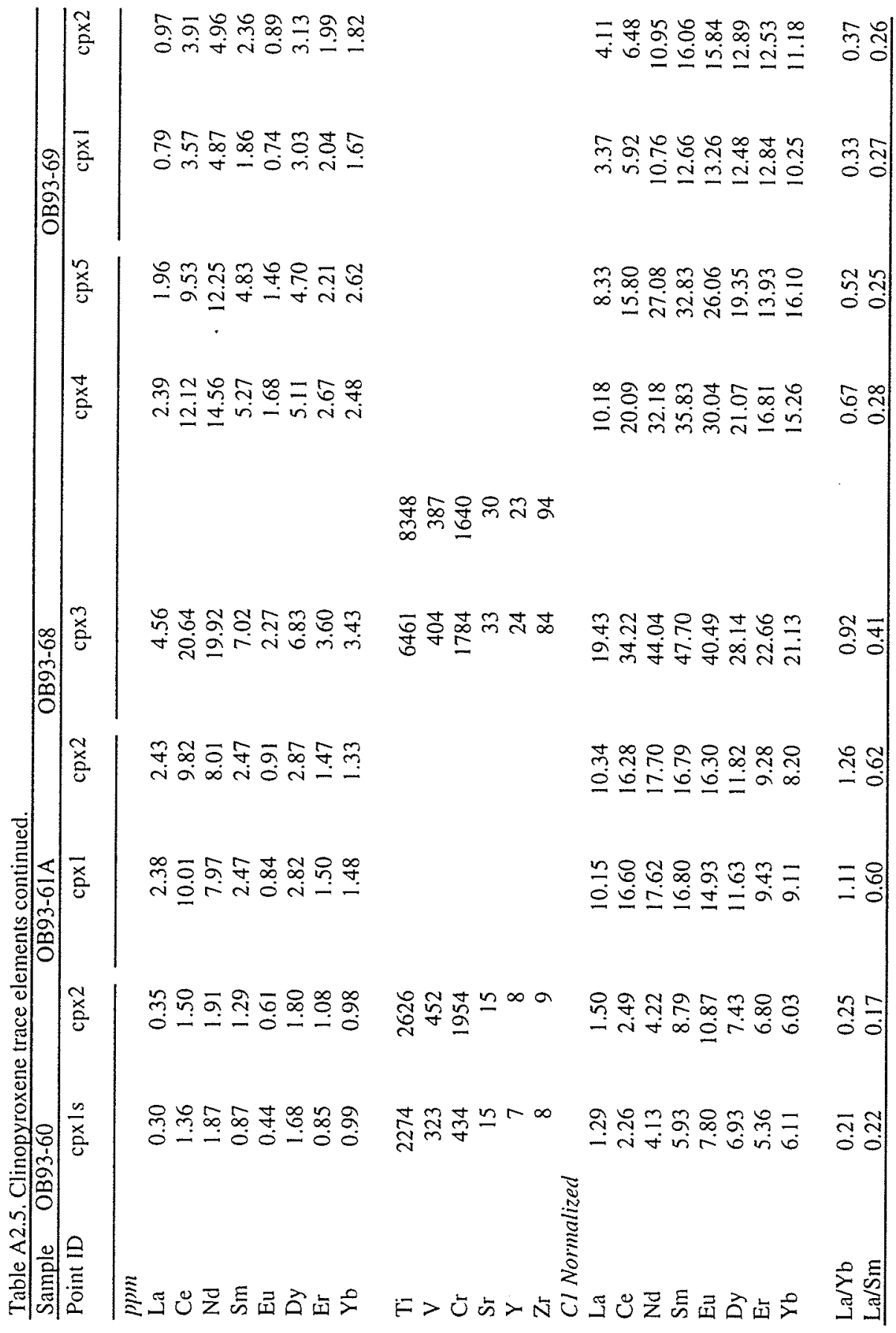




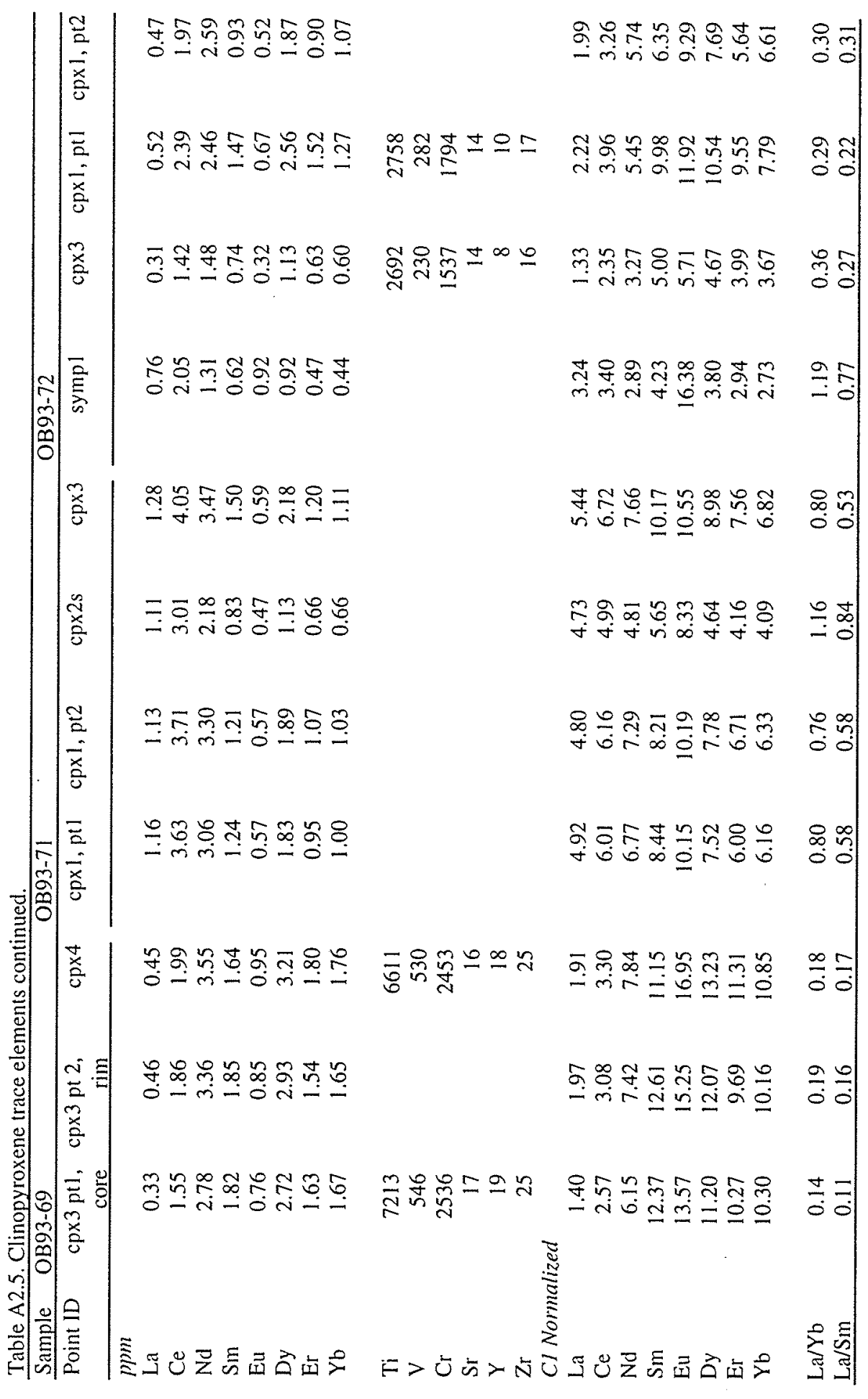




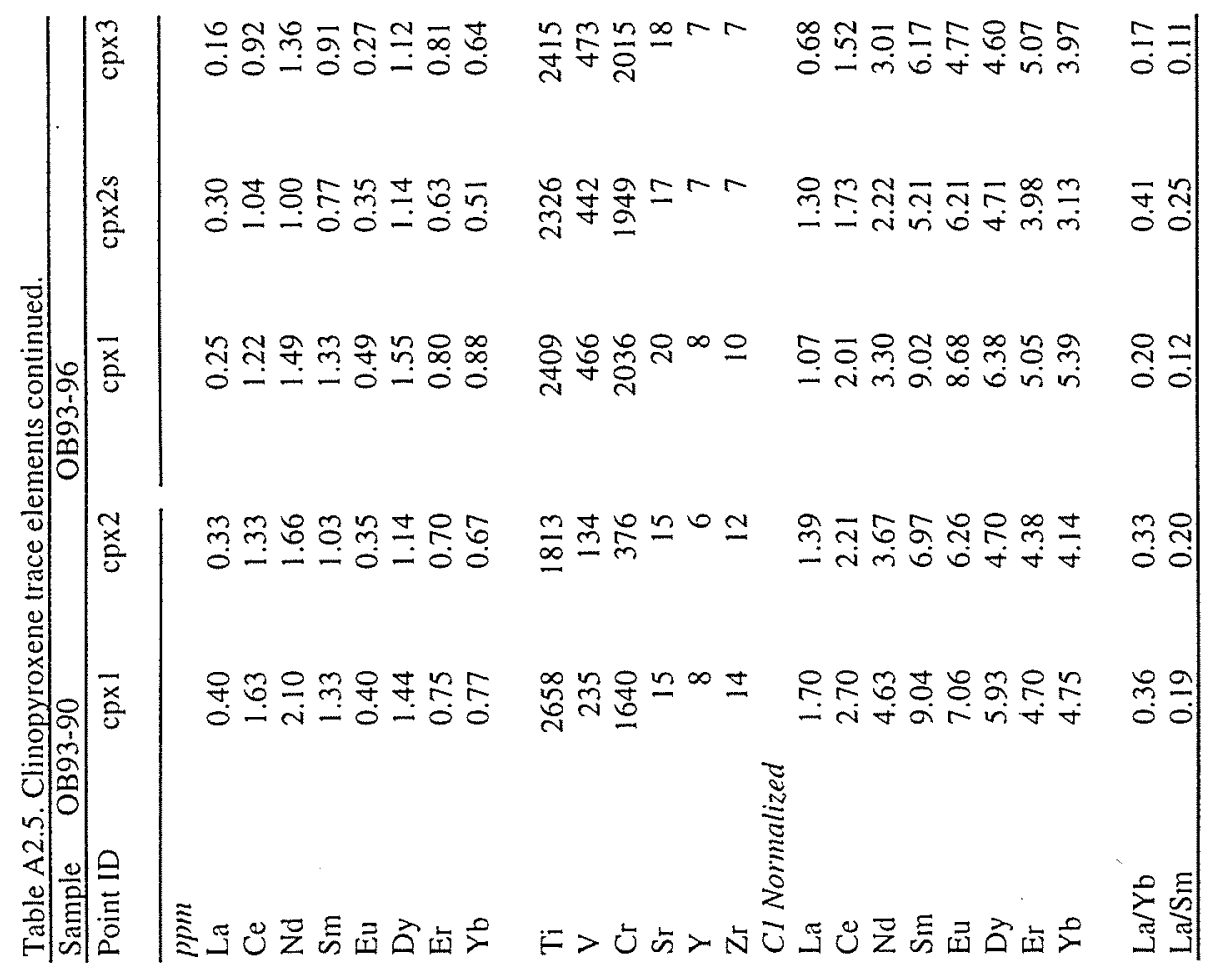

